CONNECTED HISTORIES IN THE EARLY MODERN WORLD 3.

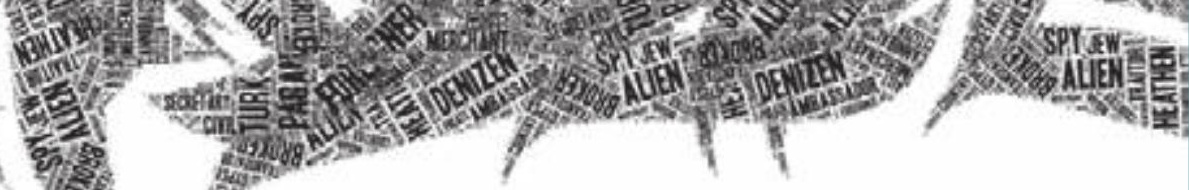

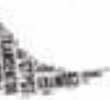

(2) -40

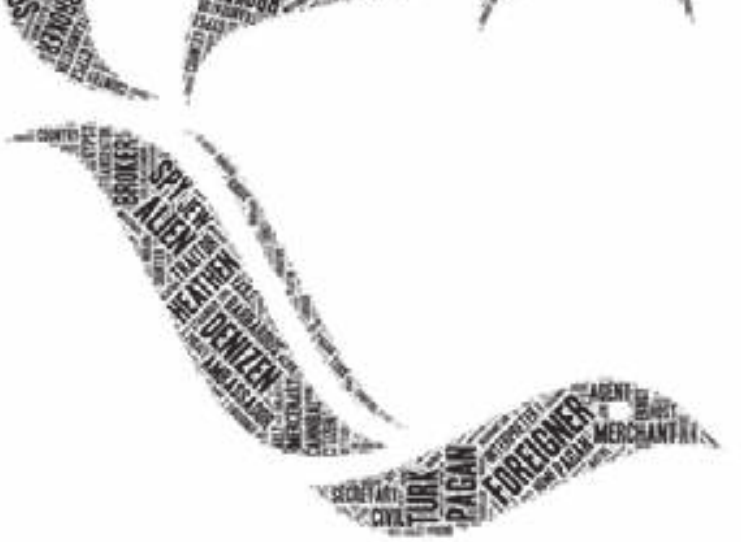

Nandini Das, João Vicente Melo, Haig Z. Smith, and Lauren Working

\title{
Keywords of Identity, Race, and Human Mobility in Early Modern England
}


Keywords of Identity, Race, and Human Mobility in Early Modern England 


\section{Connected Histories in the Early Modern World}

Connected Histories in the Early Modern World contributes to our growing understanding of the connectedness of the world during a period in history when an unprecedented number of people-Africans, Asians, Americans, and Europeans - made transoceanic or other long distance journeys. Inspired by Sanjay Subrahmanyam's innovative approach to early modern historical scholarship, it explores topics that highlight the cultural impact of the movement of people, animals, and objects at a global scale. The series editors welcome proposals for monographs and collections of essays in English from literary critics, art historians, and cultural historians that address the changes and cross-fertilizations of cultural practices of specific societies. General topics may concern, among other possibilities: cultural confluences, objects in motion, appropriations of material cultures, cross-cultural exoticization, transcultural identities, religious practices, translations and mistranslations, cultural impacts of trade, discourses of dislocation, globalism in literary/visual arts, and cultural histories of lesser studied regions (such as the Philippines, Macau, African societies).

Series editors

Christina Lee, Princeton University

Julia Schleck, University of Nebraska, Lincoln

Advisory Board

Serge Gruzinski, CNRS, Paris

Michael Laffan, Princeton University

Ricardo Padron, University of Virginia

Elizabeth Rodini, American Academy in Rome

Kaya Sahin, Indiana University, Bloomington 


\section{Keywords of Identity, Race, and Human Mobility in Early Modern England}

Nandini Das,

João Vicente Melo,

Haig Smith, and

Lauren Working 
Research for this publication was supported by the ERC-TIDE project (www.tideproject.uk). This project has received funding from the European Research Council (ERC) under the European Union's Horizon 2020 research and innovation programme (grant agreement no. 681884).

Cover image by João Vicente Melo for ERC-TIDE.

Cover design: Coördesign, Leiden

Lay-out: Crius Group, Hulshout

$\begin{array}{ll}\text { ISBN } & 978 \text { 94 6372 074 } 8 \\ \text { e-ISBN } & 978 \text { 90 } 48552283 \\ \text { DOI } & 10.5117 / 9789463720748 \\ \text { NUR } & 685\end{array}$

\section{(1) (1) $\Theta \Theta$}

Creative Commons License CC BY NC ND

(http://creativecommons.org/licenses/by-nc-nd/3.o)

@ All authors / Amsterdam University Press B.V., Amsterdam 2021

Some rights reserved. Without limiting the rights under copyright reserved above, any part of this book may be reproduced, stored in or introduced into a retrieval system, or transmitted, in any form or by any means (electronic, mechanical, photocopying, recording or otherwise).

Every effort has been made to obtain permission to use all copyrighted illustrations reproduced in this book. Nonetheless, whosoever believes to have rights to this material is advised to contact the publisher. 


\section{Acknowledgements}

We would like to thank the European Research Council (ERC) for their support, which made this work and the broader research conducted by TIDE possible through the European Union's Horizon 2020 research and innovation programme (grant agreement no. 681884).

Individually and as a project, we are indebted to many colleagues and friends over the years, and we thank you all for your encouragement and insights.

In particular, the TIDE team would like to thank all our colleagues at both the University of Oxford and the University of Liverpool. We are grateful to Roger Christofides, Harald Braun, Peter Davidson, Victorina Gonzalez-Diaz, Caterina Guardamagna, Ursula Kania, and Jyotsna Singh for their support and generous sharing of expertise. Furthermore, we would like to thank Sylvia Adamson, Matthew Dimmock, Derek Dunne, John Gallagher, Claire Jowitt, Sarah Knight and Edmond Smith for their help and feedback. Lorna Hutson, Preti Taneja and Kim F. Hall offered crucial encouragement at various stages of our work, as did Eoin Price and Amrita Dhar.

For their enthusiasm and refusal to settle for easy answers, we owe our thanks also to the doctoral researchers on the TIDE project, Tom Roberts and Emily Stevenson. Without Tom's contribution as primary author for the essay on 'Translator', and Emily's scrupulous attention to detail, this volume would be the poorer. We also owe our thanks to Cheryl Birdseye and Sara Ayers for their help with the preparation of the volume, and EmmaLouise Whitehead's meticulous proof-reading in the final stages.

Paul Simpson, Ros Ballaster, Sadie Slater, and Richard Trainor ensured our access to crucial institutional resources with exemplary kindness and patience. At Amsterdam University Press, thanks are due to the series editors, and to the incomparable Erika Gaffney for her editorial guidance and willingness to see this project through to print. 



\section{Table of Contents}

Acknowledgements $\quad 5$

$\begin{array}{lr}\text { Introduction } & 9\end{array}$

Alien/Stranger $\quad 20$

Ambassador 30

Blackamoor/Moor 40

Broker $\quad 5^{1}$

$\begin{array}{ll}\text { Cannibal } & 57\end{array}$

$\begin{array}{ll}\text { Citizen } & 63\end{array}$

$\begin{array}{ll}\text { Convert } & 70\end{array}$

$\begin{array}{lr}\text { Courtier } & 80\end{array}$

$\begin{array}{ll}\text { Denizen } & 88\end{array}$

$\begin{array}{ll}\text { Envoy } & 95\end{array}$

$\begin{array}{lr}\text { Exile } & 101\end{array}$

$\begin{array}{ll}\text { Foreigner } & 109\end{array}$

Friend/Ally $\quad 116$

$\begin{array}{ll}\text { Gypsy } & 125\end{array}$

$\begin{array}{ll}\text { Heathen } & 131\end{array}$

$\begin{array}{lr}\text { Host } & 137\end{array}$

Indian $\quad 143$

$\begin{array}{lr}\text { Interpreter } & 148\end{array}$

$\begin{array}{ll}\text { Jew } & 157\end{array}$

$\begin{array}{ll}\text { Mahometan } & 167\end{array}$

$\begin{array}{ll}\text { Mercenary } & 174\end{array}$

$\begin{array}{ll}\text { Merchant } & 180\end{array}$

$\begin{array}{lr}\text { Native } & 189\end{array}$

$\begin{array}{lr}\text { Pagan } & 196\end{array}$

$\begin{array}{ll}\text { Pirate } & 202\end{array}$

Rogue $\quad 211$

$\begin{array}{ll}\text { Savage/Barbarian } & 217\end{array}$

$\begin{array}{ll}\text { Secretary } & 224\end{array}$

Settler $\quad 231$

Spy $\quad 236$

$\begin{array}{ll}\text { Subject } & 245\end{array}$

Traitor $\quad 251$

Translator $\quad 258$

$\begin{array}{lr}\text { Traveller } & 267\end{array}$

$\begin{array}{ll}\text { Turk } & 276\end{array}$ 
Vagrant/Vagabond

284

Bibliography

291

Index 


\section{Introduction}

'Where shall I find you about twelve a clocke?' asks a speaker in John Eliot's French-English manual, the Ortho-epia Gallica (1593). 'I will be below in the Change', is the proffered reply, 'either walking among the Italians, or truking with the French, or pratling amongst our English, or carousing with the Flemings at the Cardinal's Hat'. 'The conversation directs the reader's attention to the buzz of the Royal Exchange, opened in 1571, whose novelty as England's first major commercial centre and multi-cultural trading bourse had not yet faded. The space that it signals is elusively mobile, and almost disconcertingly multicultural and multilingual. It is exaggerated, as one might expect from a semi-satiric bilingual manual, but not entirely unfounded. The radically transformative impact of human mobility and displacement on virtually all aspects of life and society in sixteenth- and seventeenth-century Europe - from politics and economy to everyday practices of consumption and habit - is well established. Nowhere was its transformative effect felt as substantially in the shaping of the nation as among the English, deeply conscious of their identity as an island nation, 'penitus toto divisos orbe' ('quite sundered from the rest of the world', Virgil, Eclogue 1, 67).

What did it mean to be a stranger in sixteenth- and seventeenth-century England? How were other nations, cultures, and religions perceived? And what happened when individuals moved between languages, countries, religions, and spaces? The primary aim of the essays in this volume is to examine certain terms which repeatedly illuminated points of tension, debate, and change around issues of identity, race, and belonging throughout this period. The words chosen for this volume featured centrally in English debates about migration and empire. They span a period that stretches from the arrival of Huguenots and other religious exiles from Europe, to the rise of settler colonialism, from the first voyage of the East India Company in 1601, to the 1660 chartering of the Royal African Company and the development of institutionalised slavery in British America.

Writing at the end of the sixteenth century, Richard Hakluyt argued that it was through the 'prosperous and speedy discovery of many rich lands and territories of heathens and gentiles' and the 'honest employment of many thousands of our idle people' that trade and navigation could ensure 'the

1 John Eliot, Ortho-epia Gallica, Eliots fruits for the French: enterlaced with a double new invention, which teacheth to speake truely, speedily and volubly the French-tongue (London, 1593; STC 7574), p. 26. 
infinite wealth and honour of our Countrey'. ${ }^{2}$ Hakluyt's optimism grew against the backdrop of England's success against the Spanish Armada and a growing acknowledgment of England's belated entry, in comparison to its Iberian and Dutch competitors, into a global network of trade and colonisation. Towards the end of the time frame covered in this book, Josiah Child, governor of the East India Company, similarly declared that the 'thing being to be prized above Gold' was that which 'encreaseth the Navigation of any Country, especially that of this Island of England'. ${ }^{3}$ According to Child, the 'medium of mutual commerce' not only benefited 'infinite numbers of Families at home', but when 'transported to the remotest parts of the habitable known World', it also 'tends to the civilising [of] the unsociable Tempers of many barbarous People'. ${ }^{4}$ For Hakluyt, Child, and innumerable other exponents of English travel and trade, encounters with other cultures not only benefited English subjects in terms of wealth, but also helped the nation develop an international identity based on its global aims.

That vision, however, is only part of the story. Economic prosperity, though often couched in the language of 'improving' the lives of others, often depended on exploitation and dispossession at home and abroad, as the English began to establish their colonies in America and their factories across South and South East Asia. Early modern critical race studies have worked to illuminate the ways in which articulations of civility, faith, and identity were often infused with assumptions based fundamentally on race, ethnography, and colour. Kim F. Hall's Things of Darkness (1995) and Imtiaz Habib's Black Lives in the English Archives (2008) come to mind as foundational inquiries in the field, recovering traces of lived and imagined black presence. ${ }^{5}$ That work prepared the ground for a new wave of scholarship that has begun to show how normative assumptions about whiteness were often shaped by the representation of blackness and black lives in the period. Ania Loomba and Jonathan Burton's Race in Early Modern England: A Documentary Companion (2007) not only brought together a superb selection of primary texts, but also provided an articulation of the reasons why matters of race and racial difference needed to be acknowledged in early modern studies, despite the often-proffered counterargument that 'race' arguably

2 Richard Hakluyt, The principal navigations, voyages, traffiques and discoveries of the English nation (London, 1599-1600; STC 12626a), p. 4.

3 Josiah Child, A discourse about trade (London, 169o; Wing C3853), p. 3.

4 Ibid., p. 11.

5 Kim F. Hall, Things of Darkness: Economies of Race and Gender in Early Modern England (Ithaca, NY: Cornell University Press, 1995); Imtiaz Habib, Black Lives in the English Archives, 1500-1677: Imprints of the Invisible, 2nd edn (Abingdon: Routledge, 2016). 
may not have carried the same meanings as it does now. As they noted, " $\mathrm{a}] \mathrm{s}$ is the case in the modern world, when we examine early modern notions of racial difference we must consider not only those divisions of humanity that were putatively based on distinctive combinations of physical traits and transmitted through a line of descent, but also the eclectic range of cultural differences that are used to explain, manage, or reorganize relations of power. ${ }^{6}$ Those same relations of power meant that matters of race and racial identity were linked intrinsically to matters of identity and belonging.

At the same time, throughout the sixteenth and seventeenth centuries, English responses to the influx of 'strangers' and 'aliens' whose difference was not marked through quasi-biological, physical features also returned repeatedly to anxieties about their influence and agency. In 1530, Parliament expressed its concern that foreign merchants had been sending goods back to 'their own country to the detriment of England' and passed an 'Acte for Denyzens to paye Straungers'? This act sought to deal with these accusations by preventing foreign-born 'denizens' from employing 'strangers', and by doing so authorities also hoped it would combat social anxiety surrounding the numbers of migrants arriving in London. The Act defined the individual's own country as where the foreign merchant had 'been naturally born. ${ }^{8}$ Yet it is evident that any easy binaries of differentiation between those who belonged and those who did not - whether due to race, colour, language, religion, or birth - were complicated constantly by conflicting affiliations, such as those based on shared faith or shared craft, and by practical conditions of living and working in close proximity. ${ }^{9}$

Beyond English shores, equally thorny questions of rights and allegiance were opened up by figures who operated across national, political, and linguistic borders, from the thousands of English-born who ventured abroad as travellers, merchants, settlers, and colonisers, to envoys and ambassadors, pirates, and religious exiles. When the Marian reformer, John Bradford, wrote shortly before his execution, 'Thynke som[e] thing how we ar[e] strangers

6 Race in Early Modern England: A Documentary Companion, ed. by Ania Loomba and Jonathan Burton (London: Palgrave Macmillan, 2007), p. 2. See also Peter Erickson and Kim F. Hall, "A New Scholarly Song”: Rereading Early Modern Race', Shakespeare Quarterly, 67 (2016), 1-13; Urvashi Chakravarty, 'The Renaissance of Race and the Future of Early Modern Race Studies', English Literary Renaissance, 50:1 (2020), 17-24.

7 'Acte for Denyzens to paye Straungers', 1530, 22 Hen. VIII c. 8.

8 Ibid.

9 See, for instance, Andrew Pettegree, Foreign Protestant Communities in Sixteenth Century London (Oxford: Clarendon Press, 1986); Douglas Catterall, Community without Borders: Scots Migrants and the Changing Face of Power in the Dutch Republic, c. 1600-1700 (Leiden: Brill, 2002). 
from our contry from our home, from our original', he was drawing on the competing claims of national and spiritual allegiance that threatened to split the idea of the country as 'home' from the inside, estranging English subjects both from themselves and from their covenant with God. ${ }^{10}$ While some terms were forged during domestic upheavals including the Reformation or the civil wars, other terms, such as 'native', took on new or altered meanings through colonisation, as English communities in Ireland or New England refashioned ideas of 'native' rights while seeking to sever the ties between invaded peoples and their ancestral homelands.

Tracing these terms is challenging, precisely because of the shifting and ambiguous nature of the descriptors. The difference between a 'stranger' and a 'foreigner', for instance, could depend on the perspective from which such identities were being evaluated, and would be inflected both by changing civic law and economic measures. In early modern London, the term 'foreigner' would usually denote someone from another city: by that definition, playwrights such as Christopher Marlowe (born in Canterbury) and William Shakespeare (born in Stratford-upon-Avon) were both 'foreigners' in London. English law and taxation practices distinguished them from 'citizens' on the basis of place of origin at a fundamental level, just like travellers from other nations who were identified as 'strangers' and 'aliens', even as other factors such as national allegiance, language, and faith nuanced the legal, economic, and cultural expression of such difference. In Robert Wilson's late-Elizabethan comedy, The Three Lords and Three Ladies of London (1590), for instance, it seems safe to predict that the 'Three Lords' have a better chance of winning the hands of the 'Three Ladies of London' than their three Spanish rivals. It takes an explanation from the judicial character within the play, Judge Nemo, however, to establish why their claim on the ladies as 'their countrimen, in London bred as they', is stronger than that of the competing 'Three Lords of Lincoln'."

Even among 'strangers' themselves, distinctions cut across boundaries as frequently as they created new ones. In $155^{\circ}$, in a proclamation from the reign of Edward VI against idle persons, the Crown ordered individuals to leave London and return to 'their native Countreyes where they were borne'. ${ }^{12}$ On the surface this might seem similar to the multiple

10 John Bradford, A godlye medytacyon composed by the faithfull...I.B. latlye burnte in Smytfelde (London, 1559; STC 3483), Cir.

11 Robert Wilson, The pleasant and stately morall, of the three lordes and three ladies of London (London, 1590; STC 25783), sig. N4v.

12 Edward VI, A proclamacion set furth by thee Kynges Maiesty (London, 1550; STC 7831). 
proclamations aiming to control the movements and trade of 'strangers' that had been issued before. Yet early modern ideas of foreignness meant that the instruction to return to 'native Countreyes' in the $155^{\circ}$ proclamation not only referred to national origin, but could also mean the domestic county where a person had been born. Although not technically against merchants, the proclamation also stipulated that they should return to 'the places within the realme where they last dwelt by the space of three yeres': in other words, a home city, town, or parish in England..$^{13}$ The clause meant that migrants born outside of England, such as Huguenots and other religious refugees, could identify a geographic space as a legal home in England through residency. In doing so, English authorities had established a form of early modern residency where foreign merchants and migrants could establish a legal home in England. Yet there were distinctions there too. Those who permanently settled in the city and negotiated rights to escape alien custom duties and taxes ('denizens') were habitually distinguished both from people who had freedom of the City in addition to, or instead of, a letter of denization ('free denizens'), as well as from others of their own nations simply passing through - merchants, casual travellers, scholars, spies, or diplomats and their retinue. Subsequent generations further complicated the issue, as did questions of nationhood, race, and ethnicity: the definition and status of 'stranger-born' subjects and 'English-born strangers', as recent scholarship has shown, was hardly consistent even within the period in question. ${ }^{14}$

Much in terms of expectation and generalisation around issues of race and identity was nuanced significantly and constantly on the basis of such labelling. Judge Nemo's decision in Wilson's play, for instance, gains an added dimension when we juxtapose it with the humanist Thomas Wilson's Arte of Rhetorique (1553), where origin was linked to fundamental qualities such as civility. 'The realme declares the nature of the people', wrote Wilson, so that towns 'helpeth somewhat, towardes the encrease of honour: As it is much better, to be borne [...] in London, then in Lincolne. For that [...] the people [are] more civil'. ${ }^{15}$ That understanding of civility as progress contained profound implications for colonists who travelled to Ireland or

13 Ibid.

14 See Lien Luu, 'Natural-Born versus Stranger-Born Subjects: Aliens and Their Status in Elizabethan London', in Immigrants in Tudor and Early Stuart England, ed. by Nigel Goose and Lien Luu (Brighton: Sussex Academic Press, 2005), pp. 57-75; Jacob Selwood, “'English-Born Reputed Strangers": Birth and Descent in Seventeenth Century London',Journal of British Studies, 44 (2005), 728-753.

15 Thomas Wilson, The Arte of Rhetorique (London: 1553; STC 25799), sig. B3v. 
America, seeking to valorise both their identities and their actions through the desire to 'civilize'. ${ }^{16}$ Andrew Trollope wrote from Ireland in 1581 that the Irish living outside of walled towns were 'not christyans, cyvell, or humane creatours, but [...] savage, and brute bestes', while Thomas Hariot, though depicting a nuanced account of Native American life based on his first-hand observations in the 1580 s, nonetheless promoted the need to transform Algonquians into English subjects: 'Whereby may be hoped if meanes of good government bee used, that they may in short time be brought to civilitie, and the imbracing of true religioun. ${ }^{17}$ Ridiculing the uncivil also played a social and gendered role within England by placing the unlearned or inexperienced English individual outside the refined spheres occupied by their social superiors. In his thundering invective against long hair and other sartorial fashions in 1628, the Puritan William Prynne declared that 'for men to weare long Haire [...] in any Christian, or civill Common-wealth (as ours is)' turned them into 'Barbarous, Uncivill, and Lascivious Pagans.' ${ }^{18}$

The examination of such shifting fields of meaning in Keywords of Identity, Race, and Human Mobility in Early Modern England follows the model of Raymond Williams's Keywords: A Vocabulary of Culture and Society (1976). In the introduction to the first edition of Keywords, Williams argued that the meanings of certain crucial, recurrently used words were 'inextricably bound up with the problems [they] were being used to discuss'. ${ }^{19}$ His twofold definition of such keywords as 'significant, binding words in certain activities and their interpretation' and 'significant, indicative words in certain forms of thought' continues to be a useful framework to interrogate words that sometimes tend to be under-analysed in both popular and academic discussion..$^{20}$ They help to illuminate what Williams had described as 'a history and complexity of meanings; conscious changes, or consciously different uses; innovation, obsolescence, specialisation, extension, overlap, transfer; or changes which are masked by a nominal continuity so that words which

16 Anthony Pagden, The Fall of Natural Man: The American Indian and the Origins of Comparative Ethnology (Cambridge: Cambridge University Press, 1982); Nicholas Canny, The Oxford History of the British Empire, Vol. 1, ed. by Nicholas Canny (Oxford: Oxford University Press, 1998); Nicholas Canny, The Elizabethan Conquest of Ireland (Sussex: Harvester Press, 1976). See also Norbert Elias, The Civilizing Process, trans. by Edmund Jephcott (Oxford: Blackwell, 1978).

17 Andrew Trollope to Francis Walsingham, 12 September 1581, Kew, The National Archives, SP $63 / 85$, f. 96 ; and Thomas Hariot, A briefe and true report of the new found land of Virginia (London, 1588; STC 12785), sig. E2v.

18 William Prynne, The unloveliness of love lockes (London, 1628; STC 20477), sig. B4r.

19 Raymond Williams, Keywords: A Vocabulary of Culture and Society (Glasgow: Fontana, 1976; 1983), p. 15 .

20 Ibid., p. 15. 
seem to have been there for centuries, with continuous general meanings, have come in fact to express radically different or radically variable, yet sometimes hardly noticed, meanings and implications of meaning.. ${ }^{21}$

Williams's own approach has continued to be interrogated and revised. Fundamental to Keywords was the attention it drew to the ways in which both words and vocabularies cohered out of multiple conversations. As Tony Bennett, Lawrence Grossberg, and Meaghan Morris have pointed out, for instance, it highlighted both 'the sharing of a word across differing domains of thought and experience', and 'the ways people group or "bond" them together, making explicit or often implicit connections that help to initiate new ways of seeing their world'. ${ }^{22}$ As editors of New Keywords: A Revised Vocabulary of Culture and Society (2005), the approach adopted by Bennett, Grossberg, and Morris themselves privileged yet further forms of conversation. Their revision of Williams's endeavour is 'a collective rather than individual' effort, justified on the grounds that the 'expansion of resources, and the plurality of perspectives it introduces to the project, are necessary today if proper account is to be taken of the now much greater diversity of the fields of both public and academic debate in which a vocabulary of culture and society is implicated and across which it is no less imperfectly shared'. ${ }^{23}$ It is a model followed also by Keywords for Today: A 21st Century Vocabulary, which substantially revises many of Williams's original entries in addition to supplementing them with new terms, produced through extensive and long-term collaboration among the member contributors from the Keywords Project. ${ }^{24}$

The present volume shares with such initiatives their acknowledgement of the continued utility of engaging with keywords, both as a process of interrogating the historical development of concepts, as well as an examination of our own assumptions about and usage of those concepts within the academy. What did it mean to be 'Indian'? To what extent are our ideas about citizenship or piracy indebted to early modern conversations? Did citizenship mean the same thing for women as it did for men? This volume also shares an acknowledgement of the importance of bringing collaborative attention to bear on our understanding of such concepts. As an interdisciplinary group of editors and authors, we began by identifying

21 Ibid., p. 17.

22 New Keywords: A Revised Vocabulary of Culture and Society, ed. by Tony Bennett, Lawrence Grossberg and Meaghan Morris (Oxford: Blackwell, 2005), pp. xviii-xix.

23 Ibid., pp. xxii; xix.

24 Also seen in other publication series, like the NYUP 'Keywords' series: < https://keywords. nyupress.org > [Accessed 3 January 2021]. 
terms that emerged repeatedly in this period and within our own fields of early modern literature, cultural history, legal history, and histories of trade and diplomacy, among others. Although we drew on extensive searches of digitised print resources, statistical frequency of use was not the only determinant. Large-scale database search 'hits' by themselves do not indicate the kind of tension or process of change that we looked for in a keyword, although along with corpus-based linguistics research they helped us to identify and corroborate changing trends, as well as often revealing often new and unexpected associations. Existing scholarly work and their bibliographies supplemented such findings, extending our frames of reference both in terms of primary resources and critical approaches.

Readers of this volume will find that we have largely excluded words for which definitions of a clear and specific early modern usage are readily available in dictionaries and handbooks. We have also focused principally on terms that were used to describe and categorise the human subjects themselves, rather than abstract concepts such as 'race' or 'nation', which have been the subject of extensive study already. From 'native' and 'stranger', to 'blackamoor' and 'Jew', to 'exile' and 'traitor', the descriptors of identities that we have chosen to explore as keywords surface as often in our classrooms and academic discussions as they did in the usage of the period itself. Along with that frequency of usage comes an assumption of a shared understanding of their meaning, an assumption that was - and continues to be - equally often challenged by dialogues, discourses, and debates in the field, both then and now. Our final selection is indicative rather than exhaustive. It ranges from words which were emerging or whose meanings were changing discernibly in this period (such as 'denizen', 'exile', and 'Mahometan'), to words that were being used in multiple, often contradictory ways (such as 'foreigner' and 'Indian'), as well as words that were taking on additional weight and resonance against the backdrop of travel and debates about identity ('ambassador', 'courtier', 'host', 'interpreter'). As such, while some of the keyword essays discuss at length the etymological roots and contested meanings of the word, other entries focus more productively on the cultural histories of the words in the early modern period, placed within the specific context of travel, displacement, and their implications on conceptions of identity and belonging.

The constantly changing contours of this field, cutting across disciplinary boundaries and frequently connecting to an even wider field of scholarship around global movements and multilingual communities, render any attempt to map it almost immediately incomplete and out of date. Yet engagement with the disjunctions - and often the contradictions - that 
characterise certain terms features in multiple ways in that thriving field of scholarship, bringing the history of ideas together with lived experience. The essays in this volume accordingly draw on an ever-widening body of work. In recent years, the work of scholars such as Andrew Hadfield, Peter Mancall, Miles Ogborn, Andrew Pettegree, Jacob Selwood, Jyotsna Singh, and Laura Hunt Youngblut has explored the impact of migration, movement, cross-cultural networks, and racial and cultural difference in England in ever greater detail. ${ }^{25}$ Such investigations often focus on specific sites (e.g. London in the case of Ian Archer, Joseph Ward, Lien Luu), or specific religious communities and racial identities (e.g. Nigel Goose on the Dutch in Colchester, Bernard Cottret on the Huguenots, Imtiaz Habib on black lives) ${ }^{26}$ Scholars such as Sujata Iyengar, Claire Jowitt, Nabil Matar, Matthew Dimmock, Andreas Höfele and Werner von Koppenfels, James Shapiro, and Sanjay Subrahmanyam have illuminated the interface between literary and intellectual cultures and debates regarding racial, ethnic, and geopolitical differences by drawing attention to specific individuals, communities, genres, and forms. ${ }^{27}$ Others have focused on

25 Andrew Hadfield, Literature, Travel, and Colonial Writing in the English Renaissance, 1545-1625 (Oxford: Clarendon Press, 1998); Peter Mancall, Hakluyt's Promise: An Elizabethan's Obsession for an English America (New Haven, CT: Yale University Press, 2007); Miles Ogborn, Global Lives: Britain and the World, 1550-180o (Cambridge: Cambridge University Press, 2008); Andrew Pettegree, Foreign Protestant Communities in Sixteenth-Century London (Oxford: Clarendon Press, 1986); The Global Renaissance: English Literature and Culture in the Age of Exploration, ed. by Jyotsna Singh (Oxford: Blackwell, 2009); Laura Hunt Yungblut, 'Strangers Settled Here Amongst Us': Policies, Perceptions, and the Presence of Aliens in Elizabethan England (London: Routledge, 1996).

26 Ian W. Archer, The Pursuit of Stability: Social Relations in Elizabethan London (Cambridge: Cambridge University Press, 2002); Joseph Ward, Metropolitan Communities: Trade Guilds, Identity, and Change in Early Modern London (Stanford, CA: Stanford University Press, 1997); Lien Luu, 'Natural-Born versus Stranger-Born Subjects: Aliens and Their Status in Elizabethan London', in Immigrants in Tudor and Early Stuart England, ed. by Nigel Goose and Lien Luu (Brighton: Sussex Academic Press, 2005), pp. 57-75; Nigel Goose, 'The Dutch in Colchester in the 16th and 17th Centuries: Opposition and Integration', in From Strangers to Citizens: the Integration of Immigrant Communities in Britain, Ireland and Colonial America, 1550-1750, ed. by Randolph Vigne and Charles Littleton (Brighton: Sussex Academic Press, 2001), pp. 88-98; Bernard Cottret, The Huguenots in England: Immigration and Settlement c. 1550-1700, trans. by Peregrine and Adriana Stevenson (Cambridge: Cambridge University Press, 1991); Habib, Black Lives in the English Archives.

27 Sujata Iyengar, Shades of Difference: Mythologies of Skin Color in Early Modern England (Philadelphia: University of Pennsylvania Press, 2005); Claire Jowitt, The Culture of Piracy, 1580-1630: English Literature and Seaborne Crime (Burlington, VT: Ashgate, 2010); Nabil Matar, Islam in Britain, 1558-1685 (Cambridge: Cambridge University Press, 1998); Matthew Dimmock, Mythologies of the Prophet Muhammad in Early Modern English Culture (Cambridge: Cambridge University Press, 2013); Renaissance Go-betweens: Cultural Exchange in Early Modern Europe, 
structures and frameworks that facilitated the translation of concepts into practice. ${ }^{28}$

Through its essays, Keywords of Identity, Race, and Human Mobility in Early Modern England offers a resource for continuing to explore global travel and mobility through this interplay between broad change and localised contexts. The selection of words it examines reveal multifaceted histories of usage. In many cases, the concepts, preconceptions, and debates that they embody came to play crucial roles in articulations of identity, rights, and power in subsequent periods. As such, this volume is intended as much for advanced undergraduate and graduate students as for specialist researchers working on early modern England. We also hope that a broader interdisciplinary audience, including those working on earlier or later periods, will find it of interest in their own exploration of diachronic changes in the terms and concepts we have addressed. Our aim is not to settle on a single, definitive description. Instead, what the essays offer are explorations of the concepts in a format that is at once both more detailed than a dictionary definition and more historically focused than a conventional encyclopaedia or 'keyword' entry. They illuminate precisely the complexity, and often the multiplicity, that was inherent in the usage of these terms in early modern English. As descriptors of identities, they are also often interconnected. An author's full meaning is often nuanced by recurring clusters of keywords, or in juxtaposition with other terms of similar or conflicting implications. In some cases, this has demanded paired keyword entries ('alien/stranger', 'blackamoor/Moor'). Even in instances where such pairing has not been necessary, the list of related keywords that conclude most essays indicate possible avenues of connection that can be explored by readers.

Each essay and citation of usage offered here emphasizes the fact that the terms in question share a certain slipperiness, that they are repeatedly altered, revised, and reclaimed by multiple imperatives, and by different speakers. Like language in general, keywords occur as a part of a dense, closely interwoven fabric of changing usage, dependant on social, economic,

ed. by Andreas Höfele and Werner von Koppenfels (Berlin: Walter de Gruyter, 2005); James Shapiro, Shakespeare and the Jews (New York: Columbia University Press, 1996; 2016); Sanjay Subrahmanyam, Three Ways to Be Alien: Travails and Encounters in the Early Modern World (Waltham, MA: Brandeis University Press, 2011).

28 Alison Games, The Web of Empire: English Cosmopolitans in an Age of Expansion, 1560-1660 (Oxford: Oxford University Press, 2008); Henry S. Turner, The Corporate Commonwealth:Pluralism and Political Fictions in England, 1516-1651 (Chicago: University of Chicago Press, 2016); The Corporation as a Protagonist in Global History, c. 1550-1750, ed. by William A. Pettigrew and David Veevers (Leiden: Brill, 2018). 
and cultural forces that shifted and altered over time. We bring them to bear on our literary and historical reading, and our own perceptions and responses are shaped implicitly by their shifting trajectories in time. As our understanding of those forces also continue to evolve, we present this volume both as a point of entry into and a contribution within a thriving, ongoing conversation about ideas of identity, boundary-crossing, and what it means to belong. Its future, we hope, lies in the addition of more terms and more nuance to this starting list, as others join the conversation. 


\section{Alien/Stranger}

In 1771, the English jurist and Tory politician William Blackstone concluded that the people of England could be split into two distinct legal groups: 'Aliens, that is, born out of the Dominions, or Allegiance of the crown of Great Britain; or Natives, that is, born within it'.' Blackstone's mid-eighteenthcentury binary division of natives and foreign-born aliens, also known as 'strangers', had a long tradition dating back to the fourteenth century. This division was based on the difference between a native-born 'natural and perpetual' allegiance to the monarch, and an alien's 'local and temporal' rights and allegiance. ${ }^{2}$ In early modern England, aliens and strangers were defined by their status as foreign-born national residents. Unless endenizened or naturalised, they owed their allegiance to someone other than the English monarch. However, this distinction became increasingly troubled over the course of the sixteenth and seventeenth centuries, as the number of migrants into England increased as English commerce grew and religious groups fled persecution and conflict in France, Germany, and the Low Countries.

First used in the 1380 s, 'alien' is the older of the two words. It defined someone from another family or place, or who owed their allegiance to a foreign country. In his translation of the Vulgate Bible into Middle English, John Wycliffe saw the alien 'other' as a negative influence on the religious life of an individual, translating Genesis 35:2 as an order: 'Do away with alien god'. Likewise, Psalm 18:13 illustrated a believer's desire to 'Make thou me cleene for my privy synnes; and of alien synnes', while in the apocryphal 2 Esdras, Solomon was beguiled to sin by 'alien wymmen'. 3 In 1387, the English chronicler and Benedictine monk Ranulf Higden wrote that 'No man suffer gladly an alien lord'; his observation signalled the word taking on a legal significance, so that by the sixteenth century it largely served to distinguish subjects and non-subjects on legal grounds. ${ }^{4}$

1 William Blackstone, An analysis of the laws of England (London, 1771; ESTC T56692), p. 24.

2 Ibid.; Matthew Lockwood, "Love ye therefore the strangers": Immigration and the Criminal Law in Early Modern England', Continuity and Change, 29 (2014), 349-371 (p. 351).

3 The Earlier Version of the Wycliffite Bible, Vol. 1, ed. by Conrad Lindberg (Stockholm: Stockholm Studies in English, 1959); The Holy Bible, Containing the Old and New Testaments with the Apocryphal Books in the Earliest English Versions made from the Latin Vulgate by John Wycliffe and his Followers, Vol. 2, ed. by Josiah Forshall and Frederic Madden (Oxford: Oxford University Press, 1850), pp. 755, 540.

4 Ranulf Higden, Polychronicon Ranulphi Higden monachi Cestrensis: Together with the English Translation ofJohn Trevisa and of an Unknown Writer of the Fifteenth Century, Vol. III, ed. by Churchill Babington and J. R. Lumby (London: Longman \& Company, 1871), p. 447. 
Similar to 'alien', 'stranger' became used in the middle of the fifteenth century to denote an individual from one country who resided in another, originating from the old French etrangier, an outsider. As one fifteenthcentury Scottish chronicler wrote of St. Machor, 'God mad hym to rest syn in france, in toron, til honouryt be, set pare a strangere was he'. ${ }^{5}$ The word continued to be used in the same manner into the sixteenth and seventeenth centuries, and 'alien' and 'stranger' often functioned interchangeably to denote foreign status. In 1504, Parliament declared that 'no spirituell persone ne straunger aleyn be chargeable' for new taxes upon their land or chattels being raised for the Crown, although unlike naturalised subjects they would continue to pay for 'such goodis and chattles as they be chargeable with to the fifteenths and tenths'. ${ }^{6}$ Quoting St. Augustine, the translators of the 1611 King James Bible wrote: 'A man had rather be with his dog than with a stranger (whose tongue is strange unto him)'. ${ }^{7}$ In 1651 , Thomas Hobbes went one step further, clearly defining the markers of a stranger as being 'not used to live under the same government, nor speaking the same language'. ${ }^{8}$

Alien groups, especially Huguenots from France and the Low Countries, 'became England's first minority of real significance in terms of size', settling in towns and cities across England. ${ }^{9}$ Like other groups, Huguenots received a mixed reception from English authorities and local communities. Protestants celebrated their co-religionists' escape from persecution, but often related migrants' 'alienness' to their perceived threat against domestic economic stability. Many Huguenots were highly trained artisans who brought with them new professional skills that threatened to undercut the trade of city livery companies. Ian Archer has pointed out that aliens and strangers were resented in London for not only competing in 'the same market-place' as English artisans, but for evading 'company regulations', and they were accused of producing 'substandard goods'.10 Anne Kershen describes how once 'industrious and necessitous' migrants settled in England, they eventually

5 Legend of the Saints in the Scottish Dialect of the Fourteenth Century, Vol. II, ed. by W. M. Metcalfe (Edinburgh: William Blackwood and Sons, 1896), p. 1.

6 'Henry VII:January 1504', in Parliament Rolls of Medieval England, ed. by Chris Given-Wilson, Paul Brand, Seymour Phillips, Mark Ormrod, Geoffrey Martin, Anne Curry, and Rosemary Horrox (Woodbridge: Boydell, 2005), British History Online <http://www.british-history.ac.uk/ no-series/parliament-rolls-medieval/january-1504> [Accessed 3 January 2020].

7 The Holy Bible, conteyning the old testament and the new (London, 1611; STC 2216), preface.

8 Thomas Hobbes, Leviathan; or, the matter, form, and power of a common-wealth ecclesiastical and civil (London, 1651), p. 101.

9 C. W. Chitty, 'Aliens in England in the Sixteenth Century', Race, 8:2 (1966/67), 129-145 (p. 130).

10 Ian W. Archer, The Pursuit of Stability: Social Relations in Elizabethan London (Cambridge: Cambridge University Press, 2002), p. 131. 
posed 'an economic threat to the labour market'. ${ }^{11}$ English response to that perceived threat led to the development of a 'xenophobic vocabulary' that conflated economic anxiety with cultural unease about their 'strangeness' in language, religion, dress, and diet. ${ }^{12}$ The mixed reception from local communities in England was mirrored by that of national and local authorities who sought to both protect and regulate against foreign-born individuals. In many cases, the negative response to strangers and aliens was a combination of fear, jealousy, and mistrust, leading to legislative, political, and even physical persecution.

Fleeing the religious conflicts that ravaged continental Europe during the early seventeenth century, strangers and aliens came to England in substantial numbers in the hope of settling peaceably. They were, however, frequently met with hostility. Following the May Day riot in 1517, the humanist Thomas More acknowledged the tension within English society caused by negative perceptions of European migrants. Its continuing presence in collective memory was evident almost a century later in the play-text of The Booke of Sir Thomas More (c. 1603/04), written collaboratively by Anthony Munday and others. In a speech that is widely attributed to William Shakespeare, More chastises the aggressive anti-migrant rioters who wished to 'put down strangers, Kill them, cut their throats, possess their houses'. '[W]ither would you go?' the character of More asks the tumultuous crowd, in a reversal of the usual anti-immigration rhetoric. ${ }^{13}$ Shakespeare's More highlighted the plight of the migrant by inviting the English audience to engage in an act of collective empathy by imagining if they, as strangers, 'would you be pleas'd / To find a nation of such barbarous temper'. ${ }^{14}$ Henry Finch used a similar rhetoric during a parliamentary speech in 1593 where he reminded his fellow MPs of the plight of Protestants who fled England during the reign of Mary I. According to Finch, 'in the days of Queen Mary, when our Cause was as theirs is now' other nations granted English Protestants sanctuary, yet 'now we seek to deny them'.5 Like More, Finch concluded that English people needed to remember that they 'are strangers now, we may be

11 Anne Kershen, Strangers, Aliens and Asians: Huguenots, Jews, and Bangladeshis in Spitalfields 1666-20oo (Abingdon: Routledge, 2004), p. 191.

12 Ibid.

13 'The Booke of Sir Thomas Moore', c. 1590-1604, London, British Library, Harley MS 7368, f. 8 r.

14 Ibid.

15 Quoted in Scott Oldenburg, Alien Albion: Literature and Immigration in Early Modern England (Toronto: University of Toronto Press, 2014), p. 165. See also Nandini Das, 'The Stranger at the Door: Belonging in Shakespeare's Ephesus', Shakespeare Survey, 73 (2020) pp. 10-20. 
strangers hereafter', and so 'let us do as we would be done unto'. ${ }^{6}$ Despite emphatic pleas on the stage, in Parliament, and in print, anti-stranger sentiment founded in economic hardship and an evolving sense of Englishness continued into the seventeenth century. Petitions to the Cromwellian state from 'poore protestant Strangers' echo those delivered almost a century before. Strangers, who 'having no librtye to exercize the Protestant Religion in theyr native Countrye they fled into England', desperately sought state protection so that 'they may be freed from the violence' that many English subjects directed towards them. ${ }^{17}$

The English conceptualised 'alien' and 'stranger' in both temporal and spiritual terms. While an 'alien' was legally a national outsider, a spiritual 'alien' was someone estranged or made foreign to God through their 'erroneous' faith and religious practices. The spiritual stranger, like the spiritual foreigner, was a popular motif throughout the early modern period. This pitted Protestants against non-Protestants, but it also emphasised the Protestant, particularly Calvinist, doctrine that sin made all foreign to God. A spiritual foreigner could only be naturalised through redemption and conversion. Ephesians 2:19 states that '[n] ow ye are no more strangers and foreigners: but citizens with the Saints, and of the household of God', and became a popular verse to illustrate the status of a spiritual stranger, and their transition through conversion into citizens of God. ${ }^{18}$

Jewish people were particularly targeted for being spiritual aliens by English writers, who through contorted theological argument believed they were 'aliens from the common-wealth of Israel'. ${ }^{19}$ Unlike Catholics who were considered 'spiritual foreigners' even when born in England, Jews represented a different perspective that highlighted the merging of national and religious strangeness. The Jewish faith not only represented a religious difference from Protestant/Christian English people, but a national difference, as Jews were thought to constitute their own nation. This blurred line between religious and national allegiance rendered English authorities uneasy about the presence of Jews and Catholics in the nation. Considered

16 Oldenburg, Alien Albion, p. 165.

17 'Petition of the French and Dutch Protestant strangers in or near Hatfield Chace level, in Co[untie]s York, Lincoln, and Notts, to the Protector', ${ }_{5}$ April 1656, Kew, The National Archives, SP 18/126, f. 159 .

18 Thomas Paynall, The piththy [sic] and moost notable sayinges of al scripture, gathered by Thomas Paynel (London, 1550; STC 19494.3), sig. Liv; Robert Bartholomew, A blow for the pope (London, 1615; STC 21096.5), sig. C8r; John Downame, The summe of sacred divinitie briefly \& methodically propounded (London, 1625 ; STC 7148.3), p. 517.

19 Joseph Bentham, The Christian conflict a treatise (London, 1635; STC 1887), p. 101. 
'Strangers to the Covenant' of the nation and the Church, Jews in England faced suspicion and often had their loyalty questioned, frequently leading to persecution. ${ }^{20}$ An 'alien', then, was often a temporal as well as a spiritual stranger. Given the interrelation between Protestantism and the postReformation English state, an individual's foreignness therefore became magnified and refracted in several ways.

Governing officials often perceived strangers and aliens as intruders. Elizabeth I's successor, James VI of Scotland, represented an alien threat to many English officials who saw his succession to the English throne as hazardous to the country's socio-political stability. Robert Persons, an English Jesuit priest, was one of the most vocal critics of James's succession to the English Crown. In a subversive tract concerning issues of succession, Persons critiqued the legal weaknesses of James's claim to the throne, and warned that if the 'alien' Scottish monarch was allowed to take the English throne, England could be thrown into instability, leading to a conflict not dissimilar to the War of the Roses. ${ }^{21}$ According to Persons, James was 'excluded by the common lawes of Ingland from succession to the crowne' for being foreign-born, and the 'said lawes do bar al strangers borne out of the realme, to inherite'. ${ }^{22}$ To Persons, James was legally excluded from inheriting land or property within the country, let alone the throne. However, Persons's claim that James, as a stranger, was barred from claiming the throne was a radical and uncommon position. On the eve of James's coronation, Andrew Willet, a clergyman and controversialist, proclaimed that since James was of 'the same religion', he was 'no forrainer'. Moreover, Willet biblically reinforced James's rights to the English throne, reminding his readers that God had given Israel 'no stranger to reign over them' but 'one of their owne kinred', for the 'Lord hath raised unto us a Soveraigne descended of Davids stocke [...] a prince of the same language, of the Island, of the English royall blood'. ${ }^{23}$ Here, religion and dynastic pedigree outweighed issues of the soil that often played into disputes over foreignness.

The succession of James I to the English Crown sparked a lively debate about the right of an alien Scottish monarch to inherit the English throne, but also wider questions about the status and rights of other aliens and strangers from Scotland and further afield. In the years following James's

21 William Allen and Robert Persons, A conference about the next succession to the crowne of Ingland divided into two partes (Antwerp, 1595; STC 19398), p. 57-107.

22 Ibid., pp. 111-112.

23 Andrew Willet, Ecclesia triumphans (London, 1603; STC 25676). 
coronation, the debate on the rights of aliens and strangers intensified. Often returning to classical or biblical precedents, writers sought to highlight how strangers and aliens had always endangered society. Nathaniel Carpenter declared that 'strangers amongst the Romans' were called 'enemies' whilst the religious radical, John Saltmarsh, used the biblical example of Pharaoh to caution against dealing too 'cruelly with strangers', arguing that 'aliens or forraigners multiply and grow numerous and potent besides you, you may have a vigilant eye upon them.'. ${ }^{24}$ The heightened awareness of strangers and aliens described by Carpenter and Saltmarsh in the 1630 s was in part a reaction to religious migration from Europe, and to Scottish migration following James's arrival into England.

Not everyone agreed with Carpenter and Saltmarsh's sentiments concerning the reception and position of strangers and aliens in England. In a speech to Parliament advocating the naturalisation of Scottish subjects, King James's jurist, Francis Bacon, outlined the various degrees of aliens and their status in England. The first degree contained an 'alien borne under a King, or State, that is enemy', who were offered no protection whilst in the country. ${ }^{25}$ The second degree involved an 'alien that is born under the faith and allegiance of a King or state, that is a friend', and for whom 'the Law doth imparte a great benefit and protection'. ${ }^{26}$ However, Bacon noted that many Scots born after the coronation of James in 1603, also known as postnati, were not 'aliens as the rest'. ${ }^{27}$ The distinction between the subject postnati and the alien status of those born prior to James's coronation, the antinati, was legally enforced following the outcome of what came to be known as 'Calvin's Case' in $1608 .{ }^{28}$

Calvin's Case brought an intense debate over the legal status and rights of individuals in the British Isles, one that had been complicated by the Union of the Crowns in 1603. The case deliberated whether the three-year-old Robert Calvin (actually called James Colville), born in Scotland of Scottish parents, could inherit property in London under English common law. The judges decided that postnati had the legal right under English law to be considered

24 Nathanael Carpenter, Geographie delineated forth in two bookes (London, 1635; STC 4677), p. 207; John Saltmarsh, The practice of policie in a Christian life taught from the Scriptures (London, 1639; STC 21639), p. 52.

25 Francis Bacon, A speech delivered by Sir Francis Bacon, in the lower House of Parliament quinto Iacobi, concerning the article of naturalization of the Scottish nation (London, 1641; Wing B326), p. 17 .

26 Ibid., p. 18.

27 Ibid., p. 17.

28 The Case of the Postnati (1608), 7 Coke Report 1a, 77 ER. 
naturalised English subjects owing their allegiance to both the Scottish and English crowns. The antinati, however, were still considered aliens. At the same time as not sharing that same legal status as English subjects, 'an Alien' was still bound by allegiance to conform 'to the Laws, and an obligation not to attempt anything against the King. ${ }^{29}$ Although still suspicious of aliens and strangers at the end of the seventeenth century, English authorities had attempted to legally bind them in a form of allegiance to the state. By doing so, they reconciled some of the fears that had been raised over the century concerning the presence of aliens and strangers and the threat they posed to the stability of English society.

In essence, English authorities attempted to bind aliens and strangers in allegiance by either naturalising or conferring the status of 'denizen' upon them. The immediate distinction between the two statuses was that an act of naturalisation was passed and granted by Parliament, whereas denization was granted to individual - and occasionally groups of - migrants by the Crown. As today, naturalisation comprehensively provided a migrant with a full set of rights as an English subject. On the other hand, the rights bestowed through denization were limited to enjoying 'al priviledges as an Englishman', while still having to 'paye customes and divers other things as aliens doe \& $c^{\prime} 3^{30}$ Although denizens paid homage and swore allegiance to the monarch, they, unlike naturalised strangers and aliens, remained aliens by birth and were prohibited by law from inheriting and bequeathing land to any children born before they were endenizened.

Another factor in the development of English perceptions of alien and stranger identities was the expansion of English global commerce. The difficulties around legally regulating transnational identities are evident in a legal case that baffled several lawyers in London during Cromwell's protectorate. A case from the 1650 s involved the inheritance rights and alien status of the children of a surgeon, David Salter, who had travelled to the island of St. Christopher's (St. Kitt's) in the West Indies, 'an Iland wholie under the government of the late king Charles and now under the States of England and wholie inhabited by English people'.$^{31}$ Whilst there, David Salter married an Englishwoman from Gloucestershire. The couple had a daughter, Elizabeth, on the island, but also a son (David) on their return

29 Theophilius Downes, A discourse concerning the signification of allegiance, as it is to be understood in the new oath of allegiance (London, 1689; Wing D2082), p. 8.

$3^{0}$ John Rastell, An exposition of certaine difficult and obscure words, trans. by William Rastell (London, 1579; STC 20706.5), p. $5^{8 .}$

$3^{1}$ 'Legal case regarding inheritance of David Salter's heirs', c. 1650s, Washington D.C., Folger Shakespeare Library, MS X.d.564. 
voyage to England. David was born in Holland, where the family stopped 'to make sale of some com[m] dities: and there fore [the son] was an Alien borne'..$^{2}$ In England, the grandfather of Elizabeth and David left Elizabeth the 'land and a legacie in money as freelie as if shee had bin a native and borne in London'.33 To him, Elizabeth's birth in an English colony in the Caribbean made her legally entitled to the rights of an English woman, whereas the younger David, born in Holland, 'was an Alien borne'. ${ }^{4}$ Reviewing the case, the lawyer Orlando Bridgeman concluded that 'neither of the children [...] are Aliens: But if the sonne were an Alien: the Devise is good: and neither the sonne nor the $\operatorname{Com}[\mathrm{m}]$ on wealthe have anie right against the Devises'. ${ }^{35}$ Notes on the case suggest Elizabeth's brother pressed a suit, but the outcome is unknown.

Commercial expansion in this period also brought substantial numbers of non-English merchants into England. Like other alien communities, 'merchant strangers' were perceived as having negative and positive influences on English society, some suggesting they deprived England of trade and others claiming such commerce encouraged lucrative growth. ${ }^{6}$ In 1689 the East India Company merchant, governor, and politician Josiah Child advocated the extension of greater freedoms to merchant strangers. Child proposed following Dutch trading practices towards aliens and foreigners as a means of encouraging English trade: 'if all Strangers had free Liberty to enter into any of our Incorporated foreign trades' like the Dutch, 'it would greatly increase our Trade, and improve the value of the Land'. ${ }^{37}$ Child was not the first to advocate the adoption of Dutch commercial practices. Some 27 years earlier, an anonymous author praised Holland for offering 'great freedom [...] to all strangers', relating this to how the Dutch had grown 'so potent in Trade and Wealth beyond other Nations' ${ }^{3}$

The political writer Roger Coke noted how the lack of liberty afforded to merchant strangers or aliens placed undue constraint on trade, highlighting that Parliament had attempted to rectify this by giving 'Liberty to bring in a Bill for a General Naturalization of all Alien Protestants, and allowing

36 Ephemeris parliamentaria (London, 1654; Wing F2422), p. 142.

37 Josiah Child, A discourse concerning trade (London, 1689; Wing D159o), p. 5 .

38 Short notes and observations drawn from the present decaying condition of this kingdom in point of trade, laid down in twelve particulars (London, 1662; Wing S3608A), p. 5 . 
them Liberty to Exercise their Trades in all Corporations' ${ }^{39}$ Many advocated 'naturalising Aliens' in order to encourage merchants 'to come hither, to bring their Stocks, their Wealth, their Trading, their Manufactures hither'. ${ }^{\circ}$ English manufacturers often aggressively opposed this position. If English manufacturing was 'delivered ever to Aliens', this would leave the 'English impoverish'd' and their jobs given to 'Strangers' who had beaten Englishmen and women 'out of their Trade, and eaten them out of their Country'. ${ }^{41}$ Lawmakers were so concerned that alien commodities were undermining the economy that during the Interregnum, they sought aggressively to curtail aliens from importing commodities into the country. The Navigation Acts increasingly narrowed the definition of 'Alien's Goods', eventually specifying that any ship that did not belong to 'England, Ireland, Wales or Town of Berwick upon Tweed' and 'navigated with mariners thereof' would 'pay all Customs and dutyes' to the Crown and the town and port. ${ }^{42}$ It was also argued that the primary reason against establishing a bank for the naturalisation and denization of aliens and strangers was that 'the advancing Aliens in Riches and Honour' led to 'impoverishing the native Subjects'. 43 Debates concerning the rights afforded to stranger and alien commercial communities continued well into the eighteenth century. By this point, however, the place of commerce in English society was firmly established, as was the role of merchants and aliens in its continued growth. This came to be accepted as a response to the English appetite for foreign goods. In an almost defeatist tone, the merchant and politician John Pread observed in 1695 how 'Alien Impositions are so much greater than ours on Exportation' because 'to our unnatural shame', the English were 'more inclined to Alien Commodities, than Aliens are to ours'. ${ }^{44}$

The growing reputation of England as a destination for religious migrants made aliens and strangers increasingly common in Tudor and Stuart society. As the numbers of aliens and strangers migrating into England increased over the sixteenth and seventeenth centuries, English authorities had a mixed

39 Roger Coke, Reflections upon the East-Indy and Royal African Companies with animadversions, concerning the naturalizing offoreigners (London, 1695; Wing C4980), p. 16.

40 Sundry considerations touching naturalization of aliens (London, 1695; Wing S6178), p. 3.

41 Ibid., p. 9.

42 'Act for the Encourageing and increasing of Shipping and Navigation', 166o, 12 Car. II c. 18.

43 Reasons humbly offered against the clause intended in the act for the establishing the land-bank for denizing or naturalizing of all aliens that shall subscribe 500 l. to the said bank (London, 1695; Wing R527) [single sheet].

44 John Praed, An essay on the coin and commerce of the kingdom trade and treasure (which are twins) being the only supporters thereof next to religion and justice (London, ${ }_{1695}$; Wing $\left.\mathrm{P}_{316}{ }_{3} \mathrm{~A}\right)$, p. 20. 
response to their presence. Their status as foreign-born nationals raised serious questions about allegiance. Unless made a denizen or naturalised, English officials often felt threatened by their presence. Similarly, national and parish authorities, conscious of local opinion, often legislated to regulate foreign-born individuals in certain professions. Migrant women in particular faced the hurdle of being neither 'native' nor male, their citizenship or sense of belonging usually occurring through their association with their husbands or male kin. While English men and women often expressed sympathy for the plights of Protestant strangers and aliens, they also responded to the presence of migrants with fear, jealousy, and xenophobia, resulting in inconsistent social, legal, and political responses to strangers throughout the early modern period.

Related keywords: denizen, foreigner, merchant, native, subject 


\section{Ambassador}

The word 'ambassador' (from the Latin ambaxiator or ambasciator, a synonym of 'envoy') was in recorded use in northern Italy since the early twelfth century. ${ }^{1}$ The functions associated with 'ambassador', as in the case of 'envoy', were often confounded with the tasks performed by other diplomatic agents appointed with titles derived from classical and medieval diplomatic terminology such as nuntius, orator, procurator, legatus, or missus. ${ }^{2}$ The first recorded use in England appears to be in Geoffrey Chaucer's Troilus and Criseyde, written around 1374 and first printed by William Caxton in 1477: in the fourth of book of Chaucer's poem, there are two stanzas describing the mission of Greek '[a]mbassatours' to Troy. ${ }^{3}$

By the middle of the fifteenth century, the traditional system of ad hoc diplomatic communication and negotiation that predominated in the medieval period began to change. The intensification of European and particularly Italian diplomatic activity instigated the development of new practices and structures of representations that paved the way to the emergence and consolidation of the figure of the resident ambassador. ${ }^{4}$ The Duke of Milan Ludovico Sforza's decision to send a resident ambassador to the court of Henry VII in 1490 increased the growing influence of Italian diplomatic practices and theory in Tudor England. In 1505, Henry VII instructed John Stile, initially appointed as an envoy in a special mission to Spain, to remain there as a resident ambassador. During the 1520 s, under the direction of Thomas Wolsey, Henry VIII had resident embassies in France, Venice, and Spain.

1 José Calvet de Magalhães, The Pure Concept of Diplomacy (New York: Greenwood Press, 1998), p. 31; Donald E. Queller, Office of the Ambassador (Princeton, NJ: Princeton University Press, 1967), p. 62.

2 For the evolution of early modern diplomatic terminology see, for example, Dante Fedele, Naissance de la diplomatie moderne (XIIIe-XVIIe siècles): L'ambassadeur au croisement du droit, de l'éthique et de la politique (Baden-Baden: Nomos Verlag, 2017), pp. 191-280, 527-564.

3 'Ambassador, n.', Oxford English Dictionary; Geoffrey Chaucer, Troilus and Criseyde (Westminster, 1483; STC 5094), unpaginated.

4 For an overview of these changes see: Timothy Hampton, Fictions of Embassy: Literature and Diplomacy in Early Modern Europe (Ithaca, NY: Cornell University Press, 2009), p. 3; Dante Fedele, 'The Renewal of Early-Modern Scholarship on the Ambassador: Pierre Ayrault on Diplomatic Immunity', Journal of the History of International Law, 18 (2006), 449-468; John Watkins, 'Toward a New Diplomatic History of Medieval and Early Modern Europe',Journal of Medieval and Early Modern Studies, 38:1 (2008), 1-13. 
The turbulent years following the Henrician Reformation and the reign of Mary I slowed the formalisation of English diplomacy, until Elizabeth I invested in a gradual professionalisation of her diplomatic corps, appointing individuals as ambassadors and envoys who had reputable experience or expertise in political, diplomatic and administrative affairs. However, the office of the ambassador changed most profoundly under the Stuarts, when James I established permanent embassies in Paris, Madrid, Venice, and the Hague. ${ }^{5}$ Notwithstanding the political vicissitudes of the Tudor and Stuart periods, or perhaps because of them, English diplomats, jurists, and scholars were heavily involved in the theoretical and juridical debates surrounding the office of the ambassador. The laws and treatises around ambassadors were also influenced by foreign exiles based in the universities of Oxford and Cambridge, such as the Italian lawyer Alberico Gentili.

The ambassador was a figure caught in between, thrown into the fraught political environments of other regimes while charged with serving the interests of his own monarch. In De legationibus libri tres (1585), Gentili defined the ambassador as a diplomatic agent (legatus), 'not only appointed by the state, but also in the name of the state, and as the representative of the state' (Vt legatus is fit qui non modò public, sed public etiam nomine $\&$ publica indutus persona $).{ }^{6}$ In other words, ambassadors were true representatives of sovereignty, embodying and acting in the name of a state or a prince. Ambassadors had to develop a specific persona or character which would enable them to act and speak on behalf of their prince without losing their own autonomous self. This function of double representation forced an ambassador to construct a performative self which allowed him to manipulate his two personae according to circumstance. The Oxford graduate and French ambassador Jean Hotman, for example, made an analogy with theatre to explain the limits of the representative function of ambassadorship. An '[a]mbassage and a Comedie are different things' since ambassadors were not able to 'play diverse partes under diverse garments'?

Even though an ambassador facilitated the communication between different princes, he only represented one of them, and his legitimacy and

5 Mark Netzloff, 'The Ambassador's Household: Sir Henry Wotton, Domesticity and Diplomatic Writing', in Diplomacy and Early Modern Culture, ed. by Robyn Adams and Rosanna Cox (London: Palgrave Macmillan, 2011), p. 158; F. Jeffrey Platt, 'The Elizabethan Foreign Office', The Historian, 56 (1994), 725-740.

6 Alberico Gentili, De legationibus libre tres (London, 1585; STC 11737), p. 6. A brief but thorough analysis of Gentili's theorisation of ambassadors and embassies is provided by Joanna Craigwood, 'Sidney, Gentili, and the Poetics of Embassy', in Diplomacy and Early Modern Culture, pp. 88-92. 7 Jean Hotman, The ambassador (London, 1603; STC 13848), sig. F7r. 
dignity relied on this close bond between himself and his prince. If an ambassador represented multiple rulers, he would no longer be a representative of sovereignty, but a mere messenger. The career of Robert Sherley, the Englishman employed by Shah Abbas of Persia as his ambassador to the European courts, faced several problems due to the frequent doubts concerning his true political allegiances. Observing his behaviour as he travelled across Portugual, Spain, and the Netherlands, Iberian agents commented on the way Sherley acted on behalf of English interests. At the same time, English authorities were wary of Sherley's close friendship with Shah Abbas. During his first audience with James I, Sherley asked to be forgiven for being at the service of the shah. Although he was pardoned, James expressed displeasure at seeing one of his subjects dressed as a Safavid courtier and asked Sherley to return to English fashion. ${ }^{8}$

Such a precise function stressed the importance of the personal qualities of the holder of an ambassadorial post. Treatises on the office of the ambassador highlighted the importance of appointing virtuous individuals whose physical appearance, intellectual abilities, aristocratic background, and moral integrity could reflect and enhance the reputation of the prince. This rendered the Renaissance concept of civility essential to the political and personal relationships between different cultures. This type contained some parallels with Renaissance discussions of the ideal courtier, often presented as well-educated, politically savvy, gracious, and - more controversially adept at dissimulation. ${ }^{9}$ As mediators between different rulers of states, ambassadors were required to have the capacity to operate within different societies and courtly environments. They needed to be able to manipulate languages, bureaucratic systems, and rituals that shaped a range of foreign polities. These transcultural skills highlighted the importance of crosscultural knowledge and experience. Diplomatic practices and processes became not only a realm for well-read and politically savvy aristocrats, but increasingly required the collaboration of a myriad of agents such as interpreters, secretaries, scholars, or merchants, individuals who had the ability to navigate between different political and cultural systems. ${ }^{10}$

8 Samuel C. Chew, The Crescent and the Rose: Islam and England during the Renaissance (Oxford: Oxford University Press, 1937), pp. 311-312.

9 Douglas Biow, 'Castiglione and the Art of Being Inconspicuously Conspicuous', Journal of Medieval and Early Modern Studies, 38 (2008), 35-55 (pp. 45-50); Daniela Frigo, 'Prudence and Experience: Ambassadors and Political Culture in Early Modern Italy',Journal of Medieval and Early Modern Studies, 38 (2008), 15-34 (pp. 25-30).

10 Cross-Confessional Diplomacy and Diplomatic Intermediaries in the Early Modern Mediterranean, special issue, Journal of Early Modern History, ed. by Martje van Gelder and Tijana 
Henry Wotton, who served as English resident ambassador in Venice in three different missions between 1604 and 1623 , famously quipped that an ambassador was 'an honest man sent abroad to lie for the good of his country'. ${ }^{11}$ Wotton's witticism played both with the extraterritorial dimension of ambassadorship and with the widespread perception of the resident ambassador as an 'honest (or licensed) spy', an ambiguous figure responsible for collecting intelligence from his host, interfering in local affairs, and participating in courtly intrigue. ${ }^{12}$ The need for intelligence and news made diplomats essential gatherers of all sorts of information, from court gossip to suspicious military movements. ${ }^{13}$ As Robert Cecil reminded William Trumbull, the English ambassador at Brussels between 1609 and 1625 , in a letter from 1610, the main function of an ambassador was to 'observe and advertise' so that Cecil could 'make use for the best of His Majesty's service of what I receive from you'. ${ }^{14}$ This knowledge-gathering function of ambassadors often blurred the distinction between diplomacy and espionage. The salary of Thomas Edmondes, the English resident ambassador in France (1610-1616), covered, for example, his 'diet and intelligence.'. ${ }^{15}$

The thin line separating diplomacy from espionage triggered anxieties concerning the activities of foreign ambassadors residing in England. One of the figures who epitomised the dangerous presence of the foreign resident ambassador for Jacobean observers was Diego Sarmiento de Acuña, count

Krstić, 19:2-3 (2015); Practices of Diplomacy in the Early Modern World c. 1410-180o, ed. by Tracey A. Sowerby and Jan Hennings (London: Routledge, 2017).

11 Henry Wotton, Reliquiae Wottoniae or a Collection of Lives, Letters, Poems, with Characters of Sundry Personages, and Other Incomparable Pieces of Language and Art (London, 1651; Wing 3648), sig. Civ.

12 Dominique Goy-Blanquet, “Ces petits livres en françois de Messieurs les Hotmans": Peacemaking in a/the European Family', in Early Modern Diplomacy, Theatre and Soft Power: The Making of Peace, ed. by Nathalie Rivère de Carles (London: Palgrave Macmillan, 2016), pp. 47-67 (pp. 54-56); Richard Langhorne, 'Alberico Gentili on Diplomacy', The Hague Journal of Diplomacy, 4 (2009), 307-318 (pp. 312-314).

13 András Kiséry, 'Diplomatic Knowledge on Display: Foreign Affairs in the Early Modern English Public Sphere', in Cultures of Diplomacy and Literary Writing in the Early Modern World, ed. by Tracey A. Sowerby and Joanna Craigwood (Oxford: Oxford University Press, 2019), pp. 147-160; Noah Millstone, 'Seeing Like a Statesman in Early Stuart England', Past \& Present, 223 (2014), 77-127.

14 Robert, Earl of Salisbury to William Trumbull, 1 February 1610, in Report on the Manuscripts of the Marquess of Downshire, Paper of William Trumbull the Elder, Vol. 2:1605-1610, ed. by F. K. Purnell and A. B. Hinds (London: His Majesty's Stationery Office, 1936), p. 229.

15 'Estimate of moneys due to Sir Thos. Edmondes, October 1615', in Calendar of State Papers, Domestic, of the reign ofJames I, 1611-1618, preserved in the State Paper Department of her Majesty's Public Record Office, Vol. 2, ed. by Mary Anne Everett Green (London: Her Majesty's Record Office, 1858$)$, p. 324 . 
of Gondomar and Spanish ambassador to England from 1613 to 1622. Indeed, Gondomar regularly complained to Philip IV's court in Madrid that his duty to obtain valuable information on English politics through all possible means, including bribery and espionage, made ambassadorship 'a nasty job [...] since one has to be mixed up in business like this. ${ }^{16}$ The emergence of the resident ambassador as an integral part of early modern statecraft at home and abroad led to literary reflections that explored many of the issues raised by diplomatic and legal treatises. The allegorical and satirical character of the Black Knight in Thomas Middleton's immensely popular and controversial play, The Game at Chess (1624), was largely inspired by Gondomar and explored the anxieties and suspicions raised by the presence of foreign ambassadors.

Although women were excluded from formal diplomatic service, ambassadors' wives often operated as informal agents. As such, they became important nodes in correspondence networks and the gathering of state intelligence. Jean Hotman strongly favoured the appointment of married men to ambassadorial posts and advised ambassadors to bring their wives, not only for the moral virtues associated with marriage, but for the need to have a trustworthy person who could manage the ambassadorial household. ${ }^{17}$ Apart from running the logistic and domestic affairs of an embassy, ambassadresses were able to explore local (and predominantly female) sociability networks that allowed them to lobby and cultivate friendships with politically influential women. ${ }^{18}$ The involvement with local gendered social networks also made it possible to gather relevant information through channels which were usually restricted to their husbands. In her memoirs, Ann Fanshawe, the wife of Richard Fanshawe, the English ambassador in Madrid between 1664 and 1666, mentioned visits from many ladies of the Spanish court and noted her proximity to Queen Mariana. This privileged access to relevant female figures of the court allowed Lady Fanshawe to pass sensitive diplomatic intelligence to her husband, especially during his

16 Quoted in Garett Mattingly, Renaissance Diplomacy (London: Jonathan Cape, 1963), pp. 261-262.

17 Jean Hotman, The Ambassador (London, 1603; STC 13848), sig. D6r.

18 Florian Kühnel, “'Minister-like cleverness, understanding, and influence on affairs”: Ambassadresses in everyday business and courtly ceremonies at the turn of the eighteenth century', in Practices of Diplomacy in the Early Modern World c. 1410-180o, ed. by Tracey A. Sowerby and Jan Hennings (London: Routledge, 2017), pp. 130-146; Gemma Allen, 'The Rise of the Ambassadress: English Ambassadorial Wives and Early Modern Diplomatic Culture', The HistoricalJournal, 62:3 (2019), 617-638; Amanda Herbert, Female Alliances: Gender, Identity, and Friendship in Early Modern Britain (New Haven, CT: Yale University Press, 2014). 
involvement in the negotiations that would lead to the 1668 peace treaty between Portugal and Spain. ${ }^{19}$

Spouses also played an important role in the performance of diplomatic rituals. The presence of an ambassador's wife was often used to bypass protocol obstacles, especially those involving gift-exchange practices. The offers of gifts to diplomatic representatives by their hosts were usually perceived as threats that could corrupt or distract an ambassador. ${ }^{20}$ However, the ambassador's wife, since she was not a formal diplomatic agent, was able to receive gifts and to participate in gift-exchange practices that served to facilitate communication and express cordiality. ${ }^{21}$

The high mobility of ambassadors and their close association with their home and host royal courts often made them important introducers of foreign literary works, new cultural tastes, and consumption habits. Henry Wotton and Dudley Carleton, during their time as ambassadors in Venice, were often asked by English art collectors such as Thomas Howard, Earl of Arundel, to obtain Greco-Roman art pieces and inform them of all the novelties of the Italian art scene. ${ }^{22}$ If Wotton and Carleton operated as cultural or artistic brokers, other diplomats like Richard Fanshawe, who served as ambassador in Lisbon (1661, 1662-1665) and Madrid (1664-1666), became textual or literary intermediaries. A specialist in Iberian affairs since his time as secretary of the English embassy in Spain (1635-1638), Fanshawe was the author of the first English translations of Luís Vaz de Camões's sonnets and Os Lusíadas (1572). His translation of Camões's epic poem, first published in 1655, is considered to have influenced John Milton's Paradise Lost (1667) and is mentioned by John Dryden. ${ }^{23}$ During his stint as English ambassador to the Sublime Porte (1621-1628), Thomas Roe was

19 Ann Fanshawe, The Memoirs of Ann, Lady Fanshawe, ed. by Herbert Charles Fanshawe (London: John Lane, 1907), pp. 235-251.

20 Maija Jansson, 'Measured Reciprocity: English Ambassadorial Gift Exchange in the 17th and 18th Centuries', Journal of Early Modern History, 9:3 (2005), 348-37o (pp. 368-369).

21 Allen, 'The Rise of the Ambassadress', pp. 625-627.

22 See for example, Marika Keblusek, 'The Embassy of Art: Diplomats as Cultural Brokers', in Double Agents: Cultural and Political Brokerage in Early Modern Europe, ed. by Marika Keblusek and Badeloch Vera Noldus (Leiden: Brill, 2011), pp. 11-26; Robert Hill, 'Art and Patronage: Sir Henry Wotton and the Venetian Embassy, 1604-1624', in Double Agents: Cultural and Political Brokerage in Early Modern Europe, pp. 27-58.

23 Luís Vaz de Camões, The Lusiad, or, Portugals historicall poem, trans. by Richard Fanshawe (London, 1655; Wing C397); John T. Shawcross, 'John Milton and His Spanish and Portuguese Presence', Milton Quarterly, 322 (1998), 41-52; Catarina Fouto, 'The Lusiads and European Diplomacy (1580-1664)', in Cultures of Diplomacy and Literary Writing in the Early Modern World), pp. 101-115; John Dryden, The state of innocence and fall of man (London, 1677; Wing D2372), sig. C2v. 
actively engaged in gathering rare and curious objects from the Ottoman territories. One of the pieces he acquired and gifted to Charles I, the Codex Alexandrinus, was a rare collection of early Christian texts, which instigated a renewed interest in Eastern Christianity and its textual production. ${ }^{24}$ The fashion for global consumption and gifts, including drinking vessels for drinking chocolate or tea, also meant that the habits that ambassadors and ambassadresses picked up abroad could influence elite tastes in England, as when Edward Montagu, Earl of Sandwich, became an enthusiastic supporter of chocolate-drinking during his time as ambassador in Madrid in $1666 .{ }^{25}$

While in the sixteenth century there was an emphasis on appointing individuals of the highest social standing to ambassadorial posts, the seventeenth century reflected the increasing bureaucratisation of the early modern state. This served to formalise diplomatic practices, allowing for the emergence of a new professional diplomat. Though many seventeenth-century theorists continued to stress that social status conferred an additional authority and dignity to the office of the ambassador, the emphasis now lay in expertise, merit, and talent. As elsewhere in Europe, the gradual professionalisation of the English diplomatic corps initiated in the late sixteenth and early seventeenth centuries opened the door to the recruitment of well-educated members of the civic and professional classes, who found in diplomatic service an interesting path for social mobility. ${ }^{26}$

The development of a professional English diplomatic service coincided with the regular presence of English diplomats in places such as Mughal India, the Ottoman Empire, or the Barbary Coast. The geographer Richard Hakluyt considered the English diplomatic activities outside Europe to be a remarkable achievement. In his epistle to The Principal Navigations (1589), Hakluyt celebrated the presence of 'an English Ligier', or ambassador, 'in the stately porch of the Grand Signor at Constantinople.'. ${ }^{27}$ Ambassadors sent to the Levant or South Asia, however, faced practical problems regarding their status and functions. While English diplomats in Europe contributed to the development of a professional identity that mixed courtly and bureaucratic elements that granted them a specific political agency and reputation,

24 Scott Mandelbrote, 'English Scholarship and the Greek Text of the Old Testament, 1620-1720: The Impact of Codex Alexandrius', in Scripture and Scholarship in Early Modern England, ed. by Ariel Hessayon and Nicholas Keene (Farham: Ashgate, 2006), pp. 74-93.

25 Kate Loveman, 'The Introduction of Chocolate into England: Retailers, Researchers, and Consumers, 1640-1730', Journal of Social History, 47 (2013), 27-46 (p. 32).

26 Keith Hamilton and Richard Langhorne, The Practice of Diplomacy: Its Evolution, Theory, and Administration (London: Routledge, 2011), p. 38.

27 Richard Hakluyt, The principal navigations (London, 1589; STC 12625), p. 3. 
diplomatic agents of the English trading companies in the Levant and Asia had a more ambiguous status which limited their functions as representatives of sovereignty.

Although the first English ambassador to the Ottoman court, William Harborne, was presented as Elizabeth I's 'true and undoubted Orator, Messenger, Deputy, and Agent' at the Ottoman court, the instructions given to English diplomats sent to the Sublime Porte reminded them that 'the principal part of your employment is to protect our merchants in their lawful trade \& to assist them in the orderly government thereof'. ${ }^{28}$ Appointed by the joint decision of the trading companies and the English Crown, the essential function of these diplomats was to protect and expand English mercantile activities, rather than projecting the authority and power of the English monarch in of itself. Indeed, the use of 'agent' in Harborne's credentials, a term derived from Middle French and Latin to identify the doer of an action, is revealing of how those employed in the joint diplomatic ventures of the English Crown and the trading companies were perceived as someone appointed to perform a set of functions rather than to a specific formal ambassadorial post. Harborne, as well as other company ambassadors, had to carry out a broad range of functions which were more related to the head of a trading factory than to the office of the ambassador. These functions included the supervision of the activities of company factories, the monitoring of English merchants, and the procurement of privileges from the local authorities to English trade, all besides promoting the geopolitical interests of the English Crown. ${ }^{29}$ As servants of both Crown and Company, the nature and extension of the instructions given to these ambassadors were often unclear or flexible enough to allow them to go beyond their original functions and meddle in trading operations, often causing conflicts and tensions..$^{3^{0}}$ Sir Thomas Roe, for example, annoyed the East India Company factors in India with his constant attempts to interfere in their business strategies regarding the Persia trade..$^{31}$

28 Quoted in James Mather, Pashas: Traders and Travellers in the Islamic World (New Haven, CT: Yale University Press, 2009), p. 135.

29 Alfred C. Wood, 'The English Embassy at Constantinople, 166o-1762', The English Historical Review 40 (1925), 533-561 (pp. 534-535).

3o See, for example, Jason Cameron White, 'Royal Authority Versus Corporate Sovereignty: The Levant Company and the Ambiguities of Early Stuart Statecraft', The Seventeenth Century, 32:3 (2017), 231-255.

31 Rupali Mishra, 'Diplomacy at the Edge: Split Interests in the Roe Embassy to the Mughal Court', Journal of British Studies, 53:1 (2014), 5-28 (pp. 20-26). See also R. W. Ferrier, 'An English View of Persian Trade in 1618: Reports from the Merchants Edward Pettus and Thomas Barker', Journal of the Economic and Social History of the Orient, 19:2 (1976), 182-214. 
Company ambassadors often found themselves caught between their own nation and their hosts, and between factions at home. The activities of the ambassadors and other diplomatic representatives of the Levant and East India companies (EIC), for instance, had to balance the aims of the corporations and their members alongside those of the English Crown, and the two were not always the same. During the first English Civil War (1642-1646), the Levant Company became embroiled in a communal dispute with their royalist ambassador, Sir Sackville Crowe, who had attempted to assert the authority of the Crown over the English community in the Levant. ${ }^{32}$ Crowe's regular interferences in the daily life of the company, and his attempt to raise funds for the royalist cause by seizing the property of company merchants, led the General Court of the Levant Company to demand his immediate removal in 1646. The Crown's refusal to recall Crowe forced the company to present a petition to Parliament requesting its intervention. ${ }^{33}$ Following the defeat of royalist forces in 1646, Parliament finally forced Crowe's removal in January 1647 , and Crowe remained imprisoned in the Tower of London between 1648 and $165^{2}$. The incidents involving Crowe are a good illustration of how, whenever the interests of trading companies and the Crown collided, ambassadors could be caught in an uneasy position which weakened their diplomatic status and threatened their career prospects overseas and back home.

The dignity surrounding these ambassadors was another issue. The factors of the EIC frequently warned the company's administrators that 'whosoever should go up to the [Mughal] king under the title of a merchant should not be respected' ${ }^{34}$ There was a clear preference to appoint individuals who had an 'extraordinary countenance and respect', courtiers such as Sir Thomas Roe, the first English ambassador to the Mughal court (1615 and 1619), whom the EIC presented as 'a gentleman of pregnant understanding,

32 Mark Charles Fissel, 'Early Stuart Absolutism and the Strangers Consulage', in Law and Authority in Early Modern England: Essays Presented to Thomas Barnes, ed. by Buchanan Sharp and Mark Charles Fissel (Newark: University of Delaware Press, 2007), pp. 186-224.

33 Subtilty and cruelty: or A true relation of the horrible and unparalleld abuses and intolerable oppressions, exercised by Sir Sackvile Crow His Majesties ambassador at Constantinople (London: Coates, 1657), sigs. A3r-v; Papers of John Ashburnham, c. seventeenth century, London, British Library, Egerton MS 2533, ff. 439r-40v; Daniel Goffman, Britons in the Ottoman Empire 1642-166o (Seattle: University of Washington Press, 1998), pp. 46-49, 131-141, 16o-166; Fissel, 'Early Stuart Absolutism', pp. 203-205.

34 'A Council held the 15 October, consisting of such persons as are underwritten, 18 October 1614', in Letters Received by the East India Company, Vol. 2: 1613-1615, ed. by William Foster (London: Sampson, Low, and Marston, 1897), p. 133. 
well spoken, learned, industrious, [and] of a comely personage'. ${ }^{35}$ This somewhat complicates the picture of a progression from one 'type' of courtly ambassador to a more bureaucratic one in this period, suggesting that company members recognised the courtly attributes that would enhance the prestige of their economic aims.

The problems faced by the diplomatic activities of the Levant and East India companies in many ways reflect the shifting role of the ambassador in the Tudor and Stuart eras. Changing functions of negotiation, mediation, and representation led to the emergence of a new diplomat whose political agency and identity was based less on his proximity to the prince, as advocated by early modern authors, and more on the intellectual, transcultural, and bureaucratic dimensions related to the job. As the seventeenth century closed, diplomacy increasingly became a sphere of formalised actions sustained by a juridical machinery that favoured the development of a cadre of specialists who would shape the so-called 'state systems' until the late nineteenth century.

Related keywords: broker, courtier, envoy, host, spy

35 'Request of Ric[hard] Burrell to have 40 bags of pepper for shipment, 7 September 1614', in Calendar of State Papers, Colonial Series: East Indies, China and Japan, 1513-1616, ed. by W. Nöel Sainsbury (London: Her Majesty's Stationary Office, 1862), p. 318. 


\section{Blackamoor/Moor}

'Moor' and 'blackamoor' are two English words that were highly influenced by Iberian and Italian designations of Northern African peoples. Mouro (Portuguese) and moro (Castilian, Italian) derived from the Latin maurus, an inhabitant of Mauretania, the Roman designation for the region of Maghreb. The lengthy duration of the Iberian Reconquista, the reconquest of Muslim territories by local Christian kingdoms, and the increasing commercial exchanges between Christian Iberia and northern Europe contributed to the dissemination of the word in the Middle Ages, where 'Moor' remained a popular descriptor for the medieval Berber and Arab Muslim conquerors of the Iberian Peninsula and Sicily. The accounts of the late medieval Portuguese travellers, explorers, and merchants often used 'Moor' for Muslim, although distinctions remained: despite such terms as 'Arabian Moors' or 'Turkish Moors', both were usually described as mouros brancos ('white moors'), while Berber and sub-Saharan Muslims were frequently distinguished between mouros da terra (Portuguese for 'moors from the land') or mouros negros ('black moors'). ${ }^{1}$ Mouro and moro also became associated with specific physical features, as the Portuguese and Spanish term moreno (literally 'brunette' or 'swarthy') suggests. 'Morisco', the Iberian category used to identify Christian converts from Islam, was another derivative from mouro/moro which sought to stigmatise and racialise the Arab and Berber descendants from the Muslim communities of Al-Andalus. ${ }^{2}$ This complex relation between ethnicity, geography and religion informed the evolution of 'blackamoor', often used alongside region-inflected words like 'Niger' or 'Ethiop'. ${ }^{3}$ English grammars and dictionaries of the time made similar associations: 'a black More, or a man of Ethiope'; 'The Negro's [sic], which we call the Black-mores'. ${ }^{4}$

Iberian categories, such as 'Morisco', contributed to English ideas about 'moors' and 'blackamoors'. Accounts in Purchas his pilgrims (1625) labelled

1 A.J. R. Russell-Wood, 'Settlement, Colonization and Integration in the Portuguese Influenced World, 1415-1570', Portuguese Studies Review, 15 (2007), 1-35 (p. 26); Linda A. Newson, Conquest and Pestilence in the Early Spanish Philippines (Honolulu: University of Hawaii Press, 2009), p. 32. 2 Francisco Bethencourt, Racisms: From the Crusades to the Twentieth Century (Princeton: Princeton University Press, 2014), p. 143.

3 Ibid., p. 173.

4 'Blackamoor, n., Oxford English Dictionary; Walter Ralegh, The history of the world (London, 1614; STC 20638), sig. L2r. 
Arabic as the 'Morisco tongue'. 5 The original meaning of 'Morisco', however, related to Christian converts from Islam, particularly those descended from the Muslim communities of Al-Andalus. 'Morisco' was thus a designation which stigmatised and racialised groups that, although mostly Christianised, remained religiously and politically suspicious to Europeans due to their Arabic roots. ${ }^{6}$ Successive translations of Portuguese and Spanish works such as António Galvão's Tratado dos Descobrimentos (1601), Miguel de Cervantes's Don Quixote (1612), or Miguel de Faria e Sousa's Asia Portuguesa (1695) contributed to a wide dissemination of the word in England while retaining its discriminatory meaning. ${ }^{7}$ Richard Perceval's Dictionarie in Spanish and English (1599) described a 'Morisco' as a 'blacke Moore made or become a Christian'. ${ }^{8}$ Behind these categorisations lay the perception of the rampant miscegenation of Iberian metropolitan and colonial societies which, in spite of the efforts made by Portuguese and Spanish authorities to enforce religious and ethnic uniformity, separated them from other European nations.

The label 'blackamoor' in England put colour at the heart of identity. In his 1600 translation of the North African humanist scholar Leo Africanus's Description of Africa, John Pory described the 'principall nations' of Africa as 'the Africans or Moores, properly so called; which last are of two kinds, namely white or tawnie Moores, and Negros or black Moores'. 'Tawnie Moores' were North African Muslims, such as the Moroccan ambassador Abd el-Ouahed ben Messaoud, who visited the Elizabethan court in 1600 and whom Pory mentioned in his preface to The Description of Africa. Pory defined ' $[b]$ lack Moores' as the large numbers of individuals who 'are thought to be descended from Cham the cursed son of Noah; except some Arabians of the lineage of Sem, which afterward passed into Africa'. '0 'Moor' could therefore stand on its own, delineating a number of 'tawny' or darker-skinned peoples from the Mediterranean or the Middle East, while containing slightly less derogatory meanings than when prefaced with the word 'black'. In this

5 Samuel Purchas, Purchas his pilgrimes (London, 1625; STC 20509), p. 1340.

6 Francisco Bethencourt, Racisms: From the Crusades to the Twentieth Century (Princeton, NJ: Princeton University Press, 2014), p. 143.

7 António Galvão, The discoveries of the world (London, 1601; STC 11543); Miguel de Cervantes, The history of the valorous and witty knight-errant, Don-Quixote of the Mancha, trans. by Thomas Shelton (London, 1612; STC 4195); Manuel de Faria e Sousa, The Portugues Asia (London, 1695; Wing F428).

8 Richard Perceval, A dictionarie in Spanish and English (London, 1599, STC 19620), p. 169.

9 Leo Africanus, The History and Description of Africa, ed. by Robert Brown and trans. by John Pory (Cambridge: Cambridge University Press, 1896), p. 20.

10 Ibid. 
way, Abraham Hartwell wrote in A reporte of the kingdome of Congo (1597), the inhabitants 'in Congo, are generally and for the most parte blacke, and in India almost white, that is to say, of a middle colour, betweene white and blacke, which the Spaniardes call Mulato, Browne, or Darke-Tawney'. 'Tawny' Moors, in the words of Emily Bartels, appear 'as subjects whose customs and beliefs are more knowable and whose civility [...] is more sure'. ${ }^{12}$ The darkest-skinned Africans, by contrast, supposedly lived 'a brutish and savage life, without any king [...] or knowledge of husbandry'.13

While full-fledged articulations of racial difference did not exist until the institutionalisation of slavery in the late seventeenth century, there were taxonomies in place from classical antiquity that qualified the nature of individuals based on physical characteristics. ${ }^{14}$ People are 'naturally subordinate' to qualities of their 'country of birth', wrote the Greek astrologer and mathematician Ptolemy. One should not call, say, 'the Ethiopian white or straight-haired, and the German or Gaul black-skinned and woollyhaired [...] [or] the Greeks savage of soul and untutored of mind'. ${ }^{15}$ While these classifications acknowledged the humanity of Africans, the rise of Atlantic slavery in the mid- to late seventeenth century drastically changed these perceptions of human difference. Walter Ralegh's assertion in The historie of the worlde (1614) is remarkable, given the shift in perception that followed as Britain became a dominant player in the slave trade: 'if colour [...] made a different Species, then were the Negro's [sic] which wee call the black-mores, non animalia rationalia, not men, but some kinde of strange beastes'. ${ }^{16}$

Africa, Africans, and popular ideas of blackness played an important role in constructions of difference in moral literature. The colour black often represented malignity, death, or wickedness. Witches and dark-skinned figures were associated with the devil, and in a didactic world of contraries

11 Quoted in Kim F. Hall, Things of Darkness: Economies of Race and Gender in Early Modern England (Ithaca, NY: Cornell University Press, 1995), p. 41.

12 Emily C. Bartels, 'Imperialist Beginnings: Richard Hakluyt and the Construction of Africa', Criticism, 34 (1993), 517-538 (p. 529).

13 From John Pory's A geographical historie of Africa, quoted in Hall, Things of Darkness, p. 30.

14 For a review of twenty-first century critical race studies, see Peter Erikson and Kim F. Hall, “'A New Scholarly Song”: Rereading Early Modern Race', Shakespeare Quarterly, 67 (2016), 1-13; Ambereen Dadabhoy, 'Barbarian Moors: Documenting Racial Formation in Early Modern England', in The Cambridge Companion to Shakespeare and Race, ed. by Ayanna Thompson (Cambridge: Cambridge University Press, 2021), pp. 30-46.

15 Ptolemy, Tertrabiblos, trans. by F. E. Robbins (Cambridge, MA: Loeb, 1940), p. 439.

16 Ralegh, The history of the world, sig. L2r. 
and comparisons, blackness stood in opposition to the purity of whiteness. ${ }^{17}$ 'Every vertue is commended by his contrarie', George Whetstone wrote, '[b]lack best setteth foorth White.' ${ }^{18}$ To 'wash the Ethiop white' or 'wash a blackamoor white' was a popular maxim expressing futility, adapted from Jeremiah 13:23 (KJV): 'Can the Ethiopian change his skinne? or the leopard his spots?.' ${ }^{19}$ Such thinking became a way not only to cast 'aspersions of darker-skinned peoples', but a means 'of emphasizing the whiteness, beauty, and virtue of Europeans in general and the English nation in particular'. ${ }^{20} \mathrm{Of}$ all European languages, it was English that used the same word - 'fair' - to denote virtue and light skin. ${ }^{21}$ This relationship between skin colour and moral traits recurred often, not only to condemn blackness but to denounce the sins of English men and women. In 1653, the Puritan Thomas Hall quipped that vain women who primped their hair or wore makeup should be scorched under the sun until they had the 'hue of the Black-moores' to better reflect their inner degeneration..$^{22}$ The colour of ivory itself was not incidental: 'the whiteness [...] thought to represent the natural fairenesse of mans skinne'. ${ }^{23}$ Ivory demonstrated the beauty of whiteness, in this case explicitly related to its value as a commodity gained through exploration.

Ideological notions of blackness and whiteness, dark and light, should not distract from the actual African presence in England. It is likely that the metaphorical attributes of blackness were increasingly popular precisely because the English began to encounter African peoples more frequently. Imtiaz Habib found records of 448 individuals in the Tudor and Stuart era who were potentially African, stressing that this is likely not a complete number. ${ }^{24}$ Parish records, and the increasing administrative oversight of

17 Michael Guasco, Slaves and Englishmen: Human Bondage in the Early Modern Atlantic World (Philadelphia: University of Pennsylvania Press, 2011), pp. 106-107; Ania Loomba, Shakespeare, Race, and Colonialism (Oxford: Oxford University Press, 2002).

18 Guasco, Slaves and Englishmen, p. 107.

19 Anu Korhonen, 'Washing the Ethiopian White: Conceptualizing Black Skin in Renaissance England', in Black Africans in Renaissance Europe, ed. by Thomas Foster Earle and Kate J. P. Lowe (Cambridge: Cambridge University Press, 2005), pp. 94-112; in the 1599 Geneva Bible the same verse reads 'Can the black Moor change his skin? or the leopard his spots, then may ye also do good, that are accustomed to do evil?'.

20 Guasco, Slaves and Englishmen, p. 106.

21 Korhonen, 'Washing the Ethiopian White', p. 96.

22 Quoted ibid.

23 Quoted in Hakluyt, The principal navigations (London, 1599-1600; STC 12626a), sig. Bbb4.

24 Imtiaz Habib, Black Lives in the English Archives, 1500-1677: Imprints of the Invisible, 2nd edn (Abingdon: Routledge, 2016), p. 13; Miranda Kaufmann, Black Tudors: The Untold Story (London: Oneworld, 2017). Kaufmann believes an estimated 122 of these may represent non-European peoples, though not necessarily Africans. 
the Tudor Crown, make it possible to trace the births, deaths, and baptisms of dozens of 'blackamoors', particularly in London parishes. One 'Christian Ethiopia[n]' was baptised in London in 1602, and 'Richard a Blakmore' in 16og. Burials included 'Peter a blackmore [...] from Mrs Locksmiths' in 1616, and 'Barbaree, servant to Mr Smith' in $1623 .{ }^{25}$ A Guinean diver testified in an admiralty court case of 1548 , though Italian merchant witnesses complained that his testimony was unlawful because he was a 'slave'. ${ }^{26}$ Africans in England held a range of occupational roles, often as skilled labourers. Henry VIII had a black trumpeter in his retinue, while other Africans served as royal pages, laundresses, maids, or goldsmiths. ${ }^{27}$ Africans and 'Moors' were present in the household of Henry VIII's first wife, Catherine of Aragon, including the 'escalava' Catalina of Motril, and Africans lived and worked in the households of Spanish and Portuguese merchants and traders living in London throughout this period. ${ }^{28}$

Merchants and explorers were largely responsible for the increased number of Africans appearing in Elizabethan England, after the desire for global commodities led to increased exploration in the Atlantic, Indian, and Pacific oceans. Africans arrived mostly 'as a result of England's expeditionary forays into Africa and the Western Atlantic in search of new commodities and markets', where pirates, privateers, and merchants - often with royal backing - recognised that trafficking people could be profitable and enhance one's status. ${ }^{29}$ There were African servants in the household of Lady Ralegh, wife of Sir Walter, in the 1580 s, some of them likely having served under Ralegh as crew members on his Atlantic voyages. ${ }^{30}$ Between $153^{1}$ and 1567 , the English conducted sixteen trips to the West African coast, or stopped in Africa on their way to the Americas. ${ }^{31}$ Amid the search for ivory and gold, human trafficking emerges in small, often offhand references: 'the English in anno 1554 tooke away 5 Negroes' $3^{2}$ A 'fellowe came aboord our (London: Narrative Eye, 2013). See also 'Early Black British History', Oxford Dictionary of National Biography<https://www.oxforddnb.com/applib/newsitem/295/early-black-british-history-andthe-oxford-dnb> [Accessed 20 November 2020].

28 Habib, Black Lives in the English Archives, p. 63; see also Lauren Johnson, 'Catalina of Motril (fl. 1501-1531)', Oxford Dictionary of National Biography <https://doi.org/10.1093/ odnb/9780198614128.013.369157> [Accessed 20 November 2020].

29 Guasco, Slaves and Englishmen, pp. 63-65.

Ibid., p. 67 .

Hakluyt, The principal navigations, sig. Ccc4v. 
shippe without feare, and [...] demaunded, why we had not brought againe their men, which the last yeere we took away [...] we made him answere, that they were in England well used, and were there kept till they could speake the language, and then they should be brought againe to be a helpe to Englishmen in this Countrey'.33

In 1596, Elizabeth I's privy council authorised the merchant Caspar van Senden from Lubeck to transport 'blackamoors' from the realm, proclaiming that 'there are of late divers blackamoores brought into this realme, of which kinde of people there are allready here to $[$ sic $]$ manie', ${ }^{34}$ Five years later, Van Senden complained again to Elizabeth that 'great numbers of Negars and Blackamoors [...] are crept into this realm' and were 'infidels, having no understanding of Christ or his Gospel'.35 Though these complaints made their way to the queen and council, there is no evidence to suggest that Africans were actually deported from England at the time. Van Senden complained to Robert Cecil that merchants and members of the elite refused to part with the Africans in their households. Emily Bartels has suggested that Elizabeth's proclamations had more to do with anxieties over foreigners arriving in London as a result of privateering and war with Spain than with any prejudice based explicitly on skin colour, where 'blackamoors' became bargaining tools in larger issues of trade and commerce. ${ }^{36}$

At the same time, 'blackamoors' were not free from exploitation or manipulation. While some Englishmen did express sympathy towards Africans or Native Americans, it was often 'the supposed cruelty of the Spaniards, not the injustice of slavery' that explained why the English often denounced Atlantic slavery. ${ }^{37}$ The English Jesuit Thomas Gage, who lived in Central America in the late 1620 s and 1630 s, noted that sugar plantations in Mexico were maintained by hundreds of 'blackamoor slaves'. ${ }^{38}$ Although these were owned largely by the Spanish, English merchants and traders to the Americas and Caribbean expressed few qualms in participating in the trafficking of human beings, a practice initiated by Elizabethan

Ibid.

34 'An open warrant to the Lord Mayor of London, 1596', in Acts of the Privy Council, Vol. 26, 1595-1596 (London: Mackie and Co, 1902), pp. 20-21; 'An open letter about 'negroes' brought into England', 1601, The National Archives, PC 2/21, f. 304; Miranda Kaufmann, 'Caspar van Senden, Sir Thomas Sherley and the "Blackamoor” Project', Historical Research, 81 (2008), 366-371.

35 Quoted in Emily C. Bartels, 'Too Many Blackamoors: Deportation, Discrimination, and Elizabeth I', Studies in English Literature, 1500-1900, 46 (2006), 305-322 (p. 305).

36 Ibid., p. 313 .

37 Guasco, Slaves and Englishmen, p. 119 .

38 Ibid., p. 230. 
privateers including John Hawkins and Francis Drake. While he praised Leo Africanus's wit and learning in his Description of Africa, Pory was translating a history of Africa for reasons beyond curiosity or appreciation. Pory's patron was Robert Rich, Earl of Warwick. Warwick sought to use Bermuda as a privateering base for attacking Spanish ships, and had knowingly purchased enslaved Angolans from the Spanish to help with tobacco cultivation in the English colony by the mid-1610s.39 The English were complicit in keeping the status of 'blackamoors' as undefined as possible.

As Jennifer L. Morgan demonstrates in her study of Maria, a 'proper Negro wench' captured by Drake and left pregnant on a remote Indonesian island, African men and women who encountered the English in other spaces were subject to those assumptions and ideologies 'operating in Elizabeth's London'. ${ }^{\circ}$ The context in which individual Africans arrived in England is important for determining how the person may have been treated, and in what capacity. Since Africans were often purchased from the Spanish, who did use enslaved peoples for plantation labour, some scholars subscribe to the idea that all Africans in early modern England were enslaved. ${ }^{41}$ However, until the codification of colonial slavery in English plantations in the 1660 s, which also saw the creation of the Royal African Company in England, the status of Africans in the eyes of the English remained ambiguous and seem to have depended heavily on individual experience, whether as a married man or woman in a rural parish, an interpreter employed in merchant transactions, or an attendant at court.

As letters from the privy council indicated in the late sixteenth century, concerns over African migrants were tied to fears of taking jobs from English men and women, suggesting that English and African labourers worked similar jobs, and were paid for doing them. This should not, however, imply a pervasive equality. On a household or parish level, this may have sometimes been the case, and English trade negotiations with high-status African princes or ambassadors were conducted using the language of amity and

39 Ibid., p. 20o; 'To the right worshypfull, our very good friend, Captaine Nathaniel Butlet, Esquire, Governour of the Sommer Ilands', in Historye of the Bermudaes or Summer Islands. Edited, from a MS in the Sloane Collection, British Museum, ed. by J. Henry Lefroy (London: Hakluyt Society, 1882), p. 211.

40 From a paper by Jennifer L. Morgan cited in Erikson and Hall, 'A N New Scholarly Song”, pp. 11-12.

41 Sujata Iyengar, Mythologies of Skin Color in Early Modern England (Philadelphia: University of Pennsylvania Press, 2005), p. 202. 
friendship..$^{42}$ Nonetheless, to the Crown and the elite, the Africans who arrived in England were often regarded as curiosities or subordinates, often brought into the realm in the households of gentlemen and women who had travelled abroad. 'Blackamoor' figures carved in the Italian or Spanish style, some with chains around their necks or ankles, entered the inventories of country houses at the same time as African men and women were placed in portraits and still life paintings. Whether appearing as types or modelled on real people, they served to enhance the status of white sitters, rather than being depicted as subjects in their own right. ${ }^{43}$ The presence of black individuals, often children, can be seen in the portraits of Peregrine Bertie, Lord Willoughby d'Eresby (date unknown, c. late sixteenth century); Anne of Denmark (1617); Charles I and Henrietta Maria (c. 1630-1632); and Prince Rupert, Count Palatine (c. 163os), among numerous others. In the portrait of Charles II's mistress Louise de Kéroualle, Duchess of Portsmouth (1682), an African girl gestures to the Duchess with a swathe of luxury goods that seem present only to reinforce the wealth and prestige of the sitter. ${ }^{44}$ The disassociation between 'salon' and 'slave port' in elite art was deliberate, but also artificial; by the later seventeenth century, the political economy of slavery is what allowed courtiers continued access to exclusive goods and commodities that fed their expressions of civil refinement. ${ }^{45}$

Though scholars have increasingly sought to uncover the range of experiences that black Tudors and Stuarts might have undergone, the daily experiences of 'blackamoors' in England can be difficult to reconstruct. Often, they appear nameless in the historical record, given only the label 'blackamoor' or 'negro'. Parish records indicate that most Africans living in England had been baptised, meaning the names that do appear for them are usually their baptised name: Peter or Mary, for example, or 'Phyllis [...] [daughter of] a Moroccan basket and a shovel maker' who 'was desyrus to becom a Christian.' ${ }^{46}$ In the mid- to late seventeenth century, poets envisaged Anglo-African sexual encounters, as in Henry Rainolds's 'A Black-moor Maid Wooing a Fair Boy': 'Stay lovely Boy, why fly'st thou mee [...] I'm black 'tis

42 See, for example, Edmund Hogan's ambassadorial mission to Morocco in 1577, recounted in Jerry Brotton, The Sultan and the Queen: The Untold Story of Elizabeth and Islam (New York: Viking, 2016), pp. 67-71.

43 Habib, Black Lives in the English Archives, p. 67.

44 Louise de Kéroualle, Duchess of Portsmouth by Pierre Mignard, 1682, National Portrait Gallery, NPG 497 .

45 Simon Gikandi, Slavery and the Culture of Taste (Princeton, NJ: Princeton University Press, 2011), pp. 3, 100.

46 Habib, Black Lives in the English Archives, p. 91. 
true: why so is Night, / And Love doth in dark Shades delight'.47 The poem plays on light and shadow, and on night as an equalizer in the act of love, blurring distinctions between white and black bodies.

As in poetry, the English stage became a place for white authors to write black voices. 'Moor' characters - Aaron in the early Titus Andronicus, written between 1588 and 1593, and Othello in the play that bears his name, written around 1603 - represent two ends of the spectrum, in terms of their social and moral status. Beyond the sphere of the popular theatre that Shakespeare inhabited, plays and city pageants often equated the figure of the 'tawny moor' and 'blackamoor' with wealth and the allure of global expansion. 'Africana' can be found in Ben Jonson's 'The Masque of Blackness' (1605), the masque of 'Solomon and Sheba' (1606), and in civic pageants like Thomas Middleton's The Triumphs of Truth (1613). ${ }^{4}$ Court masques could be unruly affairs. The ambassador Dudley Carleton expressed little amusement when the ladies of court appeared with blackened skin in 'The Masque of Blackness'. 'Their black faces and hands, which were painted and bare up the elbows', Carleton described, 'was a very loathsome sight and I am sorry that strangers should see our court so strangely disguised'. ${ }^{49}$ It is clear that the shame at the performance was not in the misrepresentation of other peoples, but in maintaining the reputation of the English among other European powers. The French and Spanish ambassadors, Carleton complained, were all present to view this show of incompetence. A sketch of Inigo Jones's costume designs survives for the character of a 'Daughter of Niger', her skin black and wearing robes in hues of blue, yellow, and cream. The figure is a graceful sight, but this is to be expected when embodying a royal and European figure.

Into the seventeenth century, the 'present-absentness', to use Habib's term, of 'blackamoors' in early modern England was intimately and inextricably connected to the burgeoning colonial world and English imperial aspirations..$^{50}$ 'Here we saw a little Turke and negroe which are intended for pages to the two young ladies', the diarist Samuel Pepys recorded in his diary in 1662, making a distinction between the Ottoman 'moor' and 'blackamoor'. ${ }^{1}$ In 1667, Pepys noted that Mingo, Sir William Batten's

47 Poem appears in an appendix of 'poems of blackness' in Hall, Things of Darkness, p. 275.

48 Iyengar, Mythologies of Skin Colour, p. 204.

49 Dudley Carleton to John Chamberlain, 1603-1624, ed. by Maurice Lee (New Brunswick, NJ: Rutgers, 1972), p. 67.

50 Habib, Black Lives in the English Archives, p. 18.

$5^{1}$ '30 May 1662', in The Diary of Samuel Pepys, Vol. 16: May/June 1662, ed. by Henry B. Wheatley (Project Gutenberg ePublication, 2004) < http://www.gutenberg.org/cache/epub/4134/ 
African servant, had appeared in Batten's will. Batten requested that Mingo become lighthouse keeper, retaining the sum of $20 l$ a year. ${ }^{52}$ Mingo's relatively stable position in Batten's household, and Pepys's frequent and not altogether negative depictions of him, were indicative of these structures of power and imperial intervention. The Virginia slave laws in the 1660 s were the beginnings of stricter legislation against Africans based on the need for human labour to produce the vast quantities of tobacco and sugar that North America and Caribbean colonies supplied to Europe. Tobacco advertisements presented intermingling Africans, Native Americans, and English planters in shared moments of sociability, smoking pipes or even, at times, working alongside each other. ${ }^{53}$ Yet these fictions of harmony and cross-racial brotherhood in the seventeenth- and eighteenth-century Atlantic were not indicative of the collapse of a world dependent on African labour, but a sign of its success. Africans were idealised in art or elite fashions as accoutrements to a society that did not perceive Africans as a threat to English sovereignty at home or in the Americas. As Simon Gikandi wrote of the eighteenth century, the 'existence of slavery in absentia [in Britain] would make it difficult to conceptualise or represent slaves as a visual and palpable ingredient of British society, but [...] slavery was part of the political unconscious of Britishness'. ${ }^{54}$

Brief glimpses into interlinked African lives on a parish level or in port cities may suggest, as Habib has posited, a moment in which 'blackness' emerges as an 'English social category' or, in the words of Onyeka Nubia, as 'a black sense of self', ${ }^{55}$ There is as yet little evidence of Africans selfidentifying in this way, but unfortunately, there is little trace of direct African voices at all. It is in the realm of literature and fantasy that the most poignant appeals to the humanity of Africans were often imagined by white authors. The celebration of 'black beauty', though a transgressive poetic trope, envisaged a space where blackness was not a defect: 'What

pg4134-images.html> [Accessed 12 May 2020].

52 'Will of Sir William Batten of London', December 1667, Kew, The National Archives, PROB $11 / 325 / 144$.

53 See, for example, the collection of early modern tobacco papers in the University of Liverpool Special Collections, SPEC Fraser 1566 and SPEC Fraser 1567; Catherine Molyneux, 'Pleasures of the Smoke: "Black Virginians" in Georgian London's Tobacco Shops', The William and Mary Quarterly, 64 (2007), 327-376.

54 Gikandi, Slavery and the Culture of Taste, p. 28.

55 Habib, Black Lives in the English Archives, p. 103; Onyeka Nubia, "Blackamoores" Have Their Own Names in Early Modern England', in Black British History: New Perspectives from the Roman Times to the Present Day, ed. by Adi Hakim (London: ZED Books, 2019), pp. 15-36 (p. 21). 
th'world calls fair is foolish, 'tis allow'd / That you who are so black, be justly proud ${ }^{\prime}{ }^{6}$ Taken in its broader context, however, these poems continued to perpetuate the idea that the 'blackamoor', more so than the 'tawny moor' of 'middle colour', was markedly different.

Related keywords: foreigner, interpreter, merchant, pagan

56 John Collop, 'On an Ethiopian Beauty, M.S.', in Hall, Things of Darkness, p. 279. See also Edward Herbert, 'Sonnet of Black Beauty', Abraham Wright, 'To a Black Gentlewoman', Walton Poole, 'On a Black Gentlewoman', Richard Crashaw, 'On the Baptised Aethiopian', in the same volume. 


\section{Broker}

According to the Oxford English Dictionary, the word 'broker' derives from the Old Northern French brokeor, literally a 'tapster' or a person who serves or sells wine from the tap. ${ }^{1}$ During the Middle Ages, it became synonymous with second-hand dealers, peddlers, or middlemen who facilitated commercial transactions, as well as pawnbrokers and furniture dealers. William Langland's Piers Plowman includes several uses of 'broker'. The figure of Envy, for example, presents itself as 'a broker of backbiting and blaming men's wares / Among merchants all the time especially in London'. ${ }^{2}$ The definition of the broker as a facilitator of commercial exchange also associated it with the functions of a messenger or emissary. William Caxton mentions 'an alien that was called Arnold of Spain that was a brocour [sic] of London', sent as a secret emissary to France. ${ }^{3}$ Peter Levens, in his English-Latin dictionary Manipulus Vocabulorum (1570), associated 'broker' with the Latin word proxeneta, or 'intermediary'. ${ }^{4}$

Besides facilitating commercial transactions, the broker was also a figure who defined the value of goods or identified profitable prospects. This function of the broker as an evaluator of commodities and opportunities was evoked by John Donne to criticise what he considered to be the pernicious effects of money and conspicuous consumption in English society, with 'enquiring eyes' scanning every individual to 'search (and like a needy broker, prize) / the silk and gold he wears'. 5 Those special functions of appraisal and sourcing allowed brokers to have a central role in mercantile arrangements and granted them a considerable degree of autonomy. Tradesmen's resulting dependence on their activities contributed to the perception of the broker as someone motivated not by the interests or needs of their employers, but by their own self-serving desire to make a profit. Comparisons between brokers and morally dubious figures such as prostitutes or usurers abound in early modern English texts, revealing a tension between the independence enjoyed by brokers, and the perceived codes of moral conduct and trust that should regulate commercial exchanges. Thomas Dekker, in The belman of London (1608), compared brokers to prostitutes ('he delivers it either to a

1 'Broker, n.', Oxford English Dictionary.

2 William Langland, William Langland's "Piers Plowman": The C Version, trans. by George

Economou (Philadelphia: University of Pennsylvania Press, 1996), p. 51.

3 William Caxton, The Chronycles of England (London, 1492; STC 9992), sig. III 6r.

4 Peter Levens, Manipulus Vocabulorum (London, 1570; STC 15532), sig. Fiii.

5 John Donne, Poems (London, 1633; STC 7045), p. 326. 
Broker or some bawd (for they all are of one feather), of which Receivers they have as present money for it, as if they traded with merchants'), and criticised the conspicuous consumption and social ambitions of wealthy and successful brokers. His allegorical figure of Lady Avarice is bizarrely and lavishly dressed, 'attired like a Brokers wife, for her apparel is made of several parcells, which by violence she hath torne from sundrie backes' ${ }^{6}$ Lady Avarice's bizarre apparel made of 'several parcells' evoked, at the same time, the importance of brokers in connecting London and other English cities with foreign markets. ${ }^{7}$

As English merchants expanded their activities into continental Europe in the fifteenth century, the word 'broker' became associated with foreign intermediaries who represented the interests of English traders abroad, or of European merchants in England. A different cluster of assumptions and expectations can be identified around such figures, which privilege professional integrity or objectivity over national identity. Around 1562, Thomas Ferrers, mentioning the experiences of English tradesmen in Germany, France and Iberia, observed that 'a certain brokerage is allowed, and if any buy or sell without broker [...] goods become forfeit'. ${ }^{8}$ Ferrers presented the figure of the broker as 'an indifferent person between the buyer and the seller, and keep books thereof'. ${ }^{9}$ The importance of this intermediary figure in other European markets led Ferrers to propose the establishment of a 'chief broker for strangers' to regulate the commercial transactions involving English and foreign merchants in London. ${ }^{10}$ Brokers were indeed regarded as useful figures in commercial transactions in foreign countries. Ralph Fitch's account of his travels across the Indian Ocean between 1583 and 1591 reveals the importance of these individuals in Pegu, where there were 'eight Brokers, whom they call Tareghe, which are bound to sell your goods at the price which they be worth, and you give them for their labour two in the hundred: and they be bound to make your debt good, because you sell your marchandises upon their word'.11

6 Thomas Dekker, The belman of London (London, 16o8; STC 6482), sigs. Br, G2v.

7 Ibid.

8 'Project by Thos. Ferrer, for preventing the export of coin and bullion, and the better observance of the laws respecting the trade of merchants strangers, [1562?]', in Calendar of State Papers, Domestic, 1601-1603, with Addenda, 1547-1565, ed. by Mary Anne Everett Green (London: Her Majesty's Stationery Office, 1860), p. 531.

9 Ibid.

10 Ibid.

11 Ralph Fitch, 'The Voyage of M. Ralph Fitch', in Richard Hakluyt, The principal navigations, voyages, traffiques and discoveries of the English nation (London, 1599-1600; STC 12626a), p. 260. 
Such brokers were also mediators, playing an essential role in introducing English or foreign merchants to the local norms that regulated commercial transactions, from matters of etiquette to methods of payment. On $19 \mathrm{Au}-$ gust 1625 , a consultation of the East India Company (EIC) factory at Surat mentioned that, following the indications of 'Moore brokers', the company decided to adopt 'the practice of the Moore marchants, the house-brokers now take 2 per cent, for brokerage on the calicoes bought in the factory, whereas they formerly took but one, it is ordered that in future they shall take the 2 per cent, but shall pay half of it into the Company's account, insomuch as one of those taken by the Moore brokers is by them paid into the Custom house'. ${ }^{12}$ These English concessions to 'Moors' in the pragmatic realm of trade and negotiation offer a strikingly different insight into cross-cultural relations than those understood in cheap print or plays in England.

Brokers were present in almost all markets where English tradesmen operated, but these intermediaries were particularly relevant for the activities of the English trading companies operating in the Levant and Asia. The middlemen employed by the EIC or the Levant Company often played a pivotal role in the transactions and organisation of the commercial structures developed by English merchants in the Mediterranean and Indian Ocean. The rich documentation of these two companies offers numerous illustrations of English perceptions of the broker and the dealings of local intermediaries who facilitated the penetration of English trade across the Ottoman Empire, Mughal India, Persia or Southeast Asia.

As the 1625 consultation from the EIC factory at Surat mentioned above reveals, brokers helped English merchants operate in foreign markets in ways that enabled them to gain an advantageous position. Although Ferrers idealised the broker as an 'indifferent person', the records of the English factory at Surat are rich in complaints about the untrustworthiness or ambiguous behaviour of local brokers. The fact that most brokers were autonomous merchants who momentarily shared commercial interests with the English companies, and could eventually change their strategies and collaborate with other more profitable or advantageous partners according to their own self-interest, often led to conflicts of interest and suspicions and confusions about a broker's true loyalty or allegiance. Indeed, the relation between a merchant and broker was often defined by a difficult balance between trust and profit. On 17 February 1628, EIC merchants at

12 'Consultation held in Surat by President Kerridge and Messrs. Wylde, Hoare, and Page, 19 August 1625', in The English Factories in India, Vol. III, ed. by William Foster (Oxford: Clarendon Press, 1909), p. 92. 
Agra complained they were 'in great want of an honest broker' since those who previously served them had been 'very knaves and traitors'. ${ }^{13}$ When 'choosing commodities', the employees of the Khambhat (Cambay) factory were advised to 'put little confidence in their brokers, who are ever falsest where they discern most negligence.'. ${ }^{14}$ On 26 November 1630, the EIC factory at Baroda was informed that its 'broker will be called to account later for his neglect of their business and his underhand devotion to the Dutch'..5

These remarks indicate a perception of brokers as hybrid figures, individuals who were able to navigate diverse cultural worlds, political structures, and economic systems. This ability to connect different diplomatic and commercial networks also suggested a capacity to change allegiances according to specific circumstances or private interests. The alleged 'untrustworthiness' of brokers derived much from their autonomy and capacity to mould their identity. One example is the case of Samuel Baron, the man who brokered the agreement to establish English factories in Tonkin and Taiwan in 1672 . The son of a Dutch factor and a Tonkinese woman, Baron sought to dissipate doubts on his ethnicity and political allegiances. His initial contacts with the EIC stressed his Protestantism, loyalty to Charles II, and evoked a supposed proximity to England through his paternal Scottish ancestry, as well as an authentic European background due to his mother's alleged Portuguese origins. As Anna Winterbottom has noted, Baron's self-fashioning strategy persuaded the EIC to promote his naturalisation. ${ }^{16}$ Although a 'naturalised Englishman', Baron also exploited his Tonkin heritage to forge political and commercial partnerships with key actors in Vietnam and Siam, articulating simultaneously his own agenda as a private merchant and his role as a promoter of the interests of the EIC in the region. ${ }^{17}$

The growing influence of local middlemen in the Levant and Asia, and the often antagonistic interests between English trading companies and local brokers, led these companies to invest in the placement of their own intermediary agents in the main commercial hubs of the Ottoman Empire

13 'Gregory Clement, John Bangham, Robert Clitherow, Ralph Cartwright, and John Goodwin at Agra to the Same, 17 February 1628', in The English Factories in India, Vol. III, pp. 240-241.

14 'To [Thomas] Robinson and other Factors at Cambay, December 5, 1630', in The English Factories in India, Vol. IV, ed. by William Foster (Oxford: Clarendon Press, 1910), p. 110.

15 'To the Factors at Baroda, November 26, 1630', 'Consultation held at Surat by President Hopkinson, Nathaniel Mountney, and Roger Giffard, 26 November 163o', in The English Factories in India, Vol. IV, p. 103.

16 Anna Winterbottom, Hybrid knowledge in the Early East India Company World (Basingstoke: Palgrave, 2016), pp. 30-33.

17 Ibid., pp. 34-38. 
and the Indian Ocean. The company 'agent' was deployed to be a counterweight to non-European mediators, an integral part of a strategy that aimed to use experienced English resident merchants to supplant non-English brokers or middlemen. These company agents were often experienced individuals with the necessary linguistic skills to operate in local markets and infiltrate into local social and political structures. Some EIC agents, for example, were involved in private trading activities that allowed the company to penetrate the South Asian 'country trade.. ${ }^{18}$

Although women tended to not be officially acknowledged as brokers or agents, they were often employed as 'go-betweens', 'third-parties' or discreet facilitators of contacts, especially in interactions with non-European societies. One of the most illuminating cases is that of Malintzin, alias La Malinche, a Nahua woman who became Hernán Cortés's interpreter, counsellor, envoy, and ultimately mistress during the Spanish conquest of Mexico. ${ }^{19}$ In her study of the early contacts between Portuguese colonisers and Amerindians in Brazil, Alida Metcalf highlighted the role of Margarida, the Christian name of an enslaved Aimoré woman who brokered the negotiations that led to the incorporation of the Aimoré into the Portuguese colonial apparatus in Bahia in $1602 .{ }^{20}$ The cases of La Malinche and Margarida are very similar to that of Pocahontas, a pivotal interpreter and mediator in the interactions between the English colony of Jamestown and the Algonquian region of Tsenacommacah. ${ }^{21}$ The experiences of La Malinche, Margarida and Pocahontas reveal how non-European women linked to European men through sexual/marital partnerships or enslavement used their knowledge of local societies to reshape their gendered functions by developing an ability to intermediate different cultural worlds. In the same way in Europe, the ability of women to discreetly navigate between the domestic and public spheres, and especially their role in cementing strategic partnerships through marriage, also encouraged their role as discreet mediators or brokers. The biography of Lucy Harington, the wife of Edward Russell, third Earl of

18 Emily Erikson, Between Monopoly and Free Trade: The English East India Company, 160o-1757 (Princeton, NJ: Princeton University Press, 2014), pp. 14, 20.

19 María Laura Spoturno, 'Revisiting Malinche: A Study of Her Role as an Interpreter', in Translators, Interpreters and Cultural Negotiators: Mediating and Communicating Power from the Middle Ages to the Modern Era, ed. by Federico M. Federici and Dario Tessicini (London: Palgrave Macmillan, 2014), pp. 121-135.

20 Alida C. Metcalf, Go-betweens and the Colonization of Brazil, 1500-160o (Austin: University of Texas Press, 2005), pp. 270-272.

21 See Rebecca Kay Jager, Malinche, Pocahontas, and Sacagawea: Indian Women as Cultural Intermediaries and National Symbols (Norman: University of Oklahoma Press, 2015). 
Bedford, offers an interesting case study of how aristocratic women could use their marriages to become 'political brokers' at the service of the interests of their families. ${ }^{22}$

With the rise of connoisseurship and art collecting in seventeenth-century England, agents and brokers were not just in the employ of trading companies but of individual patrons who sought go-betweens who could access global markets. Wealthy patrons like the Duke of Buckingham, the Earl of Salisbury, and the Countess of Arundel commissioned agents such as William Petty and Thomas Roe to broker for statues, art, coral, and coins in their travels to the Levant. The agents charged with bringing coveted Greco-Roman art and sculpture to England at the behest of their patrons drew on the same set of skills that company agents used, and often became involved in their own underhand mercantile activity. The 'saucy' Petty spent five years in Italy, Rhodes, and Athens in the Arundels' service, crossing mountains and surviving storms at sea in the pursuit of objets d'art that might please his patrons. ${ }^{23}$ 'There was never man so fitted for employment', Roe observed of Petty, 'that encounters accidents [...] eates with Greeks on their worst days, lies on planks with fishermen at the best, is all things to all men, that he may obtain his ends'. ${ }^{24}$ Anthony van Dyck's painting, 'George Gage and Two Attendants' (c. 1620s), aptly captures such mediation. Van Dyck portrays Gage, a Catholic agent of the Arundels, in the midst of negotiating for a marble statue of Aphrodite, flanked by two attendants including an African man who may have been in the household of the Countess of Arundel. ${ }^{25}$ The painting conveys a spirited confidence in the English capacity for lucrative brokering, but also the role of cross-cultural mediation and the presence of non-European peoples in the lives of agents, and in the circulation of knowledge and goods in and beyond England.

Related keywords: alien/stranger, envoy, interpreter, merchant, translator

22 Margaret Maurer, 'The Real Presence of Lucy Russell, Countess of Bedford, and the Terms of John Donne's “Honour is So Sublime Perfection"', ELH: A Journal of English Literary History, 47:2 (1980), 205-234; Nadine Akkerman, 'The Goddess of the Household: The Masquing Politics of Lucy Harington-Russell, Countess of Bedford', in The Politics of Female Households: Ladies-in-waiting across Early Modern Europe (Leiden: Brill, 2014), pp. 287-310.

23 David Howarth, Lord Arundel and his Circle (New Haven, CT: Yale University Press, 1985), p. 146. 24 Quoted in Adolf Michaelis, Ancient Marbles in Great Britain, trans. by C. A. M. Fennell (Cambridge: Cambridge University Press, 1889), p. 12.

25 Howarth, Lord Arundel and his Circle, p. 158; Ernest B. Gilman, 'Madagascar on the Mind: The Earl of Arundel and the Arts of Colonization', in Early Modern Visual Culture: Representation, Race, and Empire in Renaissance England, ed. by Peter Erickson and Clark Hulse (Philadelphia: University of Pennsylvania Press), pp. 284-314. 


\section{Cannibal}

The Greek author Herodotus, writing in the fifth century BC, was one of the earliest chroniclers of man-eating. 'Beyond the desert the androphagi dwell', he wrote. 'The androphagi have the most savage customs of all men: they pay no regard to justice, nor make use of any established law. They are nomads and wear a dress like a Scythian [...] and of these nations, are the only people that eat human flesh'. ${ }^{1}$ Their willingness to consume human beings was the trait that most characterised the world's most 'savage' inhabitants. The essence of the man-eater lay in his or her name: anthropo, meaning human, and pophagy, feeding on or consumption. ${ }^{2}$ Invoked in philosophical treatises, travel narratives, epic poetry, and political works by Aristotle, Pliny, and Juvenal, man-eating described those who lived on the margins of civil, and therefore political, societies. ${ }^{3}$

The recurrent associations between cannibalism and savagery appeared almost universally in subsequent usages. While notions of man-eating had a wide geographic reach prior to European intervention in the Atlantic, appearing in accounts about Russia or Scythia, the word 'cannibal' itself was a product of European encounters with Indigenous Americans. The linguistic base from which canibe or cannibal derived likely came from Columbus's term for the Caribs he encountered in the West Indies. ${ }^{4}$ As with terms such as 'Indian', this injected novel associations into older concepts of cultural difference. Cartographers visually rendered these associational connections in the new world maps in the early sixteenth century, where 'cannibal iconography' encouraged viewers to see the 'conceptual proximity of the Far East and the New World'. 5 The presence of non-European peoples depicted with dismembered body parts on maps and in cosmographies reinforced ancient and medieval lore about monsters and marvels in faraway places while placing them distinctly within the present moment of exploration

\footnotetext{
$1 \quad$ Quoted in William Arens, The Man-Eating Myth: Anthropology and Anthropophagy (New York: Oxford University Press, 1979), p. 10.

2 'Cannibal, $n$.', Oxford English Dictionary.

3 Andrew McGowan, 'Eating People: Accusations of Cannibalism Against Christians in the Second Century', Second-Century Journal of Early Christian Studies, 2:4 (1994), 413-442 (p. 426). 4 Christopher Columbus, The Four Voyages of Christopher Columbus, ed. and trans. by J. M. Cohen (London: Penguin, 1969), pp. 17, 215; Arens, The Man-Eating Myth, p. 44. Shakespeare's Caliban in The Tempest (1611) is an anagram of this.

5 Surekha Davies, Renaissance Ethnography and the Invention of the Human: New Worlds, Maps, and Monsters (Cambridge: Cambridge University Press, 2016), p. 98.
} 
and expansion. Cannibal figures became 'markers' that fuelled mercantile desires: they embodied recognisable enemies who confirmed expectations about unknown territories, pointing the way to the spices and exotic flora and fauna that might be obtained beyond. ${ }^{6}$

In the late sixteenth and seventeenth centuries, English authors began to use 'cannibal' to denote a wide range of social, religious, and political transgressors. If the writings of polemicists were taken literally, then cannibals were to be found in parish communities, Catholic churches, and the royal court itself, where metaphors of ripping bodies apart resonated with deep social and economic change in England. Discussions of cannibal behaviour became related to discourses about citizenship and society - about the bounds of civil society, and who might live within it. This complicates postcolonial scholarship on the cannibal as the ultimate 'other', which maintains that cannibals are understood purely in terms of European dominance and power. A distinct relationship certainly existed between the conquest of other territories and peoples, and the (supposed) proliferation of cannibals in those regions, as scholars such as Stephen Greenblatt and the anthropologist William Arens have argued. ${ }^{7}$ George Peckham, while promoting English activity in North America in 1578, professed that 'Christians may [...] justly and lawfully ayde the Savages against the Canniballs. ${ }^{8}$ Meanwhile, cases of English colonists resorting to eating human flesh during the Starving Time of 1609-1610 in Jamestown, reported by John Smith and the governor George Percy, broke down neat dichotomies of 'civil' Englishmen and 'savage' others. ${ }^{9}$ The English called it 'spitefull dealing' when they found out that the Portuguese had told a group of 'Moores' that they were the 'cruell people and men-eaters'. ${ }^{10}$

In England, Protestant writers frequently used 'cannibal' to describe the Catholic belief in transubstantiation, in which the bread and wine of the Eucharist became the body and blood of Christ. 'If the Canibals are to be

6 Ibid., p. 101.

7 Arens, The Man-Eating Myth; Stephen Greenblatt, Marvellous Possessions: The Wonder of the New World (Oxford: Clarendon, 1991); Peter Hulme, Colonial Encounters: Europe and the Native Caribbean, 1492-1797 (London: Methuen, 1986); Cannibalism and the Colonial World, ed. by Francis Barker, Peter Hulme and Margaret Iversen (Cambridge: Cambridge University Press, 1998); Kelly L. Watson, Insatiable Appetites: Imperial Encounters with Cannibals in the North Atlantic World (New York: NYU Press, 2015).

8 George Peckham, A true report, of the late discoveries (London, 1583; STC 19523), sig. C3v.

9 Rachel B. Herrmann, 'The "tragicall historie": Cannibalism and Abundance in Colonial Jamestown', The William and Mary Quarterly, 68 (2011), 47-74.

10 Quoted in Emily C. Bartels, 'Imperial Beginnings: Richard Hakluyt and the Construction of Africa', Criticism, 34 (1993), 517-538 (p. 534). 
abhorred, because they devour and eate mans flesh, their enimies whome they take in the warres', wrote Thomas Lupton, 'are not you then much more to be detested, that are not ashamed to eate and devoure [...] the very bodie of Christ your great \& high friend? ${ }^{\prime 11}$ Faithful Christians eschewed violence in favour of love, wrote Thomas Sanderson in 1611, rejecting the 'mysticall and spiritual kind of murder and mangling' that came from 'a corporall feeding [...] [like] brutish Cannibals'. ${ }^{12}$

In other contexts, the 'cannibal' described larger societal divisions caused by the Reformation and the expansion of the early modern state. Those who practised enclosure and closed off public land, wrote the cartographer and surveyor John Norden in a popular devotional work, 'were as good to say, hee would eate his flesh like a Canniball [...] Alas, what will a poore mans carkasse profit you?'13 Ben Jonson's plays, in which he lampoons the lust for wealth seizing English subjects, includes an instance in The Case is Altered (published 1609) in which the miser Jacques cries to his daughter, 'Wher's my gold? / [...] O thou theevish Canibal, / Thou eatest my flesh in stealing of my gold'. ${ }^{14}$ In Jonson's The Staple of News, performed in 1625 , the Puritan projector Lickfinger expresses his belief that for the English to consume their own out of greed made them more corrupt than Indigenous peoples who consumed strangers. It was 'our Caniball-Christians' rather than the American '[s]avages', Lickfinger suggests, who had to learn to '[f]orbeare the mutuall eating one another, / Which they doe doe [sic], more cunningly, then the wilde / Anthropophogi; that snatch onely strangers'. ${ }^{15}$

Indeed, most English accounts of Indigenous cannibalism focused on the violence more than the act of human incorporation. In An houre-glasse of Indian newes (1607), John Nicholl recalled being shipwrecked off the island of St. Lucia in 1605, where the crew came into conflict with Carib Indians. Nicholl lamented being left 'onely with a companie of most cruell Caniballs', yet he did not purport to witness any man-eating ceremony himself. ${ }^{16}$ Rather, it was Carib 'tyranny' in killing the shipwrecked English that most haunted him. Nicholl's pamphlet served a didactic function not unlike early seventeenth-century writings on English captivity in the Ottoman Empire. The experience reinforced the Christian, usually Protestant, fidelity that

13 John Norden, A pathway to patience (London, 1626; STC 18615), sig. L7v.

14 Ben Jonson, The Case is alterd (London, 1609; STC 14757), sig. H3r.

15 Ben Jonson, The staple of newes (London, 1631; STC 14753.5), sig. F2v.

16

Thomas Lupton, A persuasion from papistrie (London, 1581; STC 16950), sig. Gg3r.

John Nicholl, An houre glasse of Indian newes (London, 1607; STC 18532), sigs. D2v, B3r.

Thomas Sanderson, Of romanizing recusants, and dissembling Catholicks (London, 1611; STC 
brought deliverance in the face of hardship. '[L]et the Christian Reader judge', Nicholl wrote, 'in what a perplexed state we were plunged [...] without hope of ever having any meanes to recover the sight of our native and deare countrey', until, through divine aid, friendlier peoples on the island provided succour. ${ }^{17}$

Instances of more nuanced representation also existed. The Elizabethan traveller Anthony Knivet lived among Tupi groups in Brazil in the $1590 s$. His account contained detailed descriptions of the habits and fashions of different Indigenous groups across South America, where he 'went naked as the Cannibals did'. ${ }^{18}$ Knivet liberally and interchangeably referred to many Indigenous groups as 'savages' and 'cannibals', which seems to confirm European standards of civility against the supposed generalised savagery of Native peoples. However, his willingness to use specific names for places and individuals - such as the Tapuia-speaking 'Pories' (Purí) and the 'Wataquazes' (Waitaká) - also demonstrates an awareness of the differences in Indigenous identities. Knivet's seeming interest in discussing Indigenous groups served a practical purpose, providing detailed intelligence that enabled him to participate in the capture and enslavement of Native peoples for the Portuguese. ${ }^{19}$ But he also recorded personal connections, such as his travels with a man named Quarasipsinca, 'the yellow Sunne': '[n]ever man found truer friendship of any then I did of him. ${ }^{20}$

Back in Europe, the use of cannibalism as a means of self-reflection was evident in the French essayist Michel de Montaigne's essay 'Des Cannibales' (c. 1580). Montaigne famously used Brazilian Tupis to critique his own society's mores, specifically in the context of religious violence. '[A]s farre as I have been informed', Montaigne posited, in the translation of his essays into English by John Florio in 1603, 'there is nothing [in Brazil] that is either barbarous or savage, unlesse men call that barbarisme, which is not common to them'. ${ }^{21}$ Montaigne juxtaposed the supposed 'barbarous horror'

17 Ibid., sig. D2v.

18 Samuel Purchas, Purchas his pilgrimes (London, 1625; STC 20509), sig. Iiiii5r.

19 On the Portuguese slave trade and plantation labour in Brazil, see John M. Monteiro, 'The Crises and Transformations of Invaded Societies: Coastal Brazil in the Sixteenth Century', in The Cambridge History of the Native Peoples of the Americas: Vol. 3: South America, ed. by Frank Salomon and Stuart B. Schwartz (Cambridge: Cambridge University Press, 1999), pp. 973-1024; The Admirable Adventures and Strange Fortunes of Master Anthony Knivet: An English Pirate in Sixteenth-Century Brazil, ed. by Vivien Kogut Lessa de Sá (Cambridge: Cambridge University Press, 2015).

20 Purchas, Purchas his pilgrimes, sig. Iiiii5r.

21 The essayes or morall, politike and millitarie discourses of Lo: Michaell de Montaigne, trans. by John Florio (London, 1603; STC 18041), sig. K3v. 
of cannibalism to the French wars of religion, where 'I think there is more barbarisme in eating men alive, then to feede upon them being dead; to mangle by tortures [...] a body full of lively sense, to roast him in peeces [...] as we have not only read, but seene very lately, yea and in our own memorie, not amongst anciente enemies but our neighbours and fellow-citizens; and, which is worse, under the pretence of piety.'.2

Within the English context, Shakespeare's Caliban in The Tempest, whose name may be a play on 'cannibal' or its many variants, has generated much discussion. Written around 1610-1611, The Tempest is a product of a culture that avidly consumed travel accounts, such as one of its possible sources, William Strachey's 'True Reportory' (c. 1610), about the wreck of the Sea Venture in Bermuda in 16og. There is a telling ambivalence in its representation of Caliban as strange and other, yet 'familiar' and revelatory in the raking light he helps throw on the 'civilised' European people who find themselves on the island. This provides the backbone of the social and moral negotiations in the play. Caliban's characterisation shifts among multiple points. He is both new (a 'strange fish', II.ii) and old (his mother is the witch Sycorax of Algiers, I.ii). His actions move from savagery (he is accused by Prospero of attempting to rape Miranda, I.ii), and gullibility ('[a] most poor credulous monster', Trinculo calls him in II.ii), to striking lyricism ('the isle is full of noises, / Sounds and sweet airs, that give delight and hurt not', III.ii). Prospero's words about him in the final scene of the play (" $[\mathrm{t}] \mathrm{his}$ thing of darkness I acknowledge mine', V.i) has been the focus of a significant body of scholarship that reads him as a part of an emergent colonial discourse. ${ }^{23}$

Scholarship has examined cannibalism through the lens of medical history, proto-capitalism, and religious confessional differences, but the physicality of cannibal behaviour emerges most strongly in many sixteenth- and seventeenth-century usages. ${ }^{24}$ It was the visceral embodiment of degeneration and the breakdown of civil society that seemed to haunt English writers most, where communal acts of tearing apart other human beings (committed by men and women alike) seemed to represent the frightening promise of chaos and war. This vision of bloodshed must have

22 Ibid., sig. K4v.

23 For a useful review of such scholarship, see Alden T. Vaughan and Virginia Mason Vaughan, Shakespeare's Caliban: A Cultural History (Cambridge: Cambridge University Press, 1991).

24 Cătălin Avramescu, An Intellectual History of Cannibalism, trans. by Alistair Ian Blyth (Princeton, NJ: Princeton University Press, 2009); Neil Whitehead, 'Hans Staden and the Cultural Politics of Cannibalism', The Hispanic American Historical Review, 80:4 (2000), 721-751; Watson, Insatiable Appetites; Richard Sugg, "'Good Physic but Bad Food”: Early Modern Attitudes to Medicinal Cannibalism and its Suppliers', Social History of Medicine, 19:2 (2006), 225-240. 
appeared particularly terrifying to the English as they watched the wars of religion ravaging the Continent in the decades between the French wars of religion and the Thirty Years' War. In 1624, George Goodwin's satires attacked transubstantiation in the context of Rome's imperial supremacy, for what was the '[f]lesh-feeder' but a 'Popish Canniball', sowing widespread violence? ${ }^{25}$ While scholars should approach early modern sources purporting to witness cannibalism with caution, anthropologists and select Indigenous groups have acknowledged the importance of human consumption as a cultural system in specific moments in time, in acts of warfare or commemoration. ${ }^{26}$ The word 'cannibal' thus operated at a crossroads, relying on its associations, however tenuous or fabricated, to the lifeways of Indigenous peoples while functioning as means for the English to reflect on their own capacity for violence, and their anxieties about the collapse of civil society.

Related keywords: alien/stranger, citizen, native, savage/barbarian

25 George Goodwin, Babels balm (London, 1624; STC 12030), sig. Lir.

26 Lauren Working, The Making of an Imperial Polity: Civility and America in the Jacobean Metropolis (Cambridge: Cambridge University Press, 2020), pp. 106-108; The Taking and Displaying of Human Body Parts as Trophies by Amerindians, ed. by Richard J. Chacon and David H. Dye (New York: Springer, 2007); Peggy Reeves Sanday, Divine Hunger: Cannibalism as a Cultural System (Cambridge: Cambridge University Press, 1986); Carlos Fausto, Warfare and Shamanism in Amazonia (Cambridge: Cambridge University Press, 2012); Beth A. Conklin, Consuming Grief: Compassionate Cannibalism in an Amazonian Society (Austin: University of Texas Press, 2001). 


\section{Citizen}

The word 'citizen' was used in England from the Middle Ages to describe the inhabitant of a city or town, or the subject of a larger polity who possessed various rights and privileges. ${ }^{1}$ In 1275 , the Statutes of Westminster granted 'des Citieins \& de Burghes' the right to collect 'murage', a toll for building and repairing city walls. ${ }^{2}$ This view of citizen status is seen in Henry VIII's acknowledgment of the rights of 'citizens and inhabitaunt of the seid Cities and Townes', their status underlined by the fact that taxes would need to be collected from those 'Citezens of Cities and Burgeys of boroughes and Townes'. ${ }^{3}$ However, early modern ideas of citizenship were heavily influenced by the recovery of the conceptual vocabulary of classical Greek and Roman civitas. The rediscovery of Aristotle's Politics favoured the emergence of a humanist ideal of civic self-government, sustained by the citizen as an honest, virtuous, politically educated individual who worked for the common good. ${ }^{4}$ Furthermore, the idea of civitas implied a social contract that bound together or excluded individuals from collective bodies or organisations such as guilds, corporations, and cities.

The long-established civic traditions associated with the great guilds that had governed commercial and City life during the Middle Ages played a formative role in subsequent English conceptions of the citizen, civitas, and citizenship. Thus in 1642, Thomas Hobbes could argue that 'every City be a civill Person' and within the city 'many Citizens, by the permission of the City, may joyne together in one Person, for the doing of certain thing. ${ }^{5}$ However, Hobbes also noted how the expansion of trade, urban life and England's global presence over the sixteenth and seventeenth centuries complicated the traditional legal and social

1 'Citizen, $n$. and adj.', Oxford English Dictionary.

2 'Statute for tolls in markets and murage', 1275, 3 Edw. I c. 31.

3 'Act concerning Ministration of Justice in the City of Turneye', 1513, 5 Hen. VIII. c. 1; 'Taxation Act', 1545, 37 Hen. VIII c. 25 .

4 Aristotle, The Politics, trans. by T. A. Sinclair, revised by Trevor J. Saunders (London: Penguin, 1981), pp. 179-183: 'the task of all the citizens, however different they may be, is the stability of the association, that is, the constitution. Therefore the virtue of the citizen must be in relation to the constitution [...] men praise the ability to rule and to be ruled, and the virtue of a citizen of repute seems to be just this - to be able to rule and be ruled well [...] That is what we mean by the virtue of a citizen - understanding the governing of free men from both points of view'. 5 De Cive (1642) was published in Latin from Paris. The English translation under the title Philosophicall rudiments concerning government and society appeared in 1651. Thomas Hobbes, De Cive: The English Version (Oxford: Clarendon Press, 1983), p. 89. 
interpretations of such terms. According to Hobbes, these groups of 'civil persons' could band together to make 'companies of Merchants, and many other Convents' but they were not a city themselves because 'they have not submitted themselves to the will of the company simply, and in all things, but in certain things onely determined by the City'. ${ }^{6}$ Although these companies developed as quasi-independent authorities with their own jurisdictions and legal rights over the sixteenth and seventeenth centuries, they and their members remained 'civill Persons subordinate to the City' and state mechanisms of governance. ${ }^{7}$ Nevertheless, the figure of the citizen can be linked to the various forms of corporate communities that inhabited, governed, and structured the developing English cosmopolitan cities. ${ }^{8}$

The concept of civic citizenship also related to prevailing religious ideas in post-Reformation England around Christian humanism, Protestant unity, and the role of the reformed faiths in Europe and the wider world. ${ }^{9}$ As Francis Bacon asserted when calling for union between the English and Scottish nations, Protestantism connected people across nations religiously and legally as 'fellow citizens.'.$^{10}$ The privilege of citizenship in the Church with individuals as 'Naturalizants of the heavenly Jerusalem' could be shared by 'all people, of all languages, and Linages' so long as they were 'common of Saints'. ${ }^{11}$ Numerous early modern authors adopted a pan-Christian model of citizenship, describing themselves, in the words of the apostle Paul, as 'fellow-Citizens of the Saints' (Ephesians 2:19). ${ }^{12}$ Robert Abbot argued that shared citizenship through Christ marked ideas of

6 Ibid.

7 Ibid.

8 Phil Withington, The Politics of Commonwealth: Citizens and Freemen in Early Modern England (Cambridge: Cambridge University Press, 2005), p. 10; Withington, Society in Early Modern England: The Vernacular Origins of Some Powerful Ideas (Cambridge: Polity Press, 2010), pp. 114-118; Henry S. Turner, The Corporate Commonwealth: Pluralism and Political Fictions in England, 1516-1651 (Chicago: University of Chicago Press, 2016).

9 Margo Todd, Christian Humanism and the Puritan Social Order (Cambridge: Cambridge University Press, 1987).

10 Francis Bacon, A speech delivered by Sir Francis Bacon in the lower house of Parliament (London, 1641; Wing B326), pp. 13-14.

11 Ibid.

12 Benjamin Austin, Scripture manifestation of the equality of the Father, Sonne, and Holy-Ghost (London, 1650; Wing A4242), sigs. M7r-M8v; John Abernethy, The dignity and duty of a Christian (London, 1620; STC 76), p. 45; 'An Epistle to the King', in Henry Adis, A fannaticks mite cast into the Kings treasury being a sermon printed to the King because not preach'd before the King (London, 1660; Wing A581), p. 27; Robert Abbot, The second part of the Defence of the Reformed Catholicke (London, 1607; STC 49), p. 645. 
belonging and inclusion, since the love of God maketh Hierusalem and the citizens thereof' ${ }^{13}$ However, the relationship between religious conformity and the rights of citizenship was a complicated and at times contradictory one. In the context of colonial and commercial expansion, differences in attitudes to religious governance and confessional practices in places as diverse as Massachusetts Bay, Maryland, or the South Sea illuminate the practical variances that inflected the language of universal Protestantism on the ground.

Even beyond its biblical application, citizenship - steeped in ideas of civic humanism - was, in theory if not always in practice, blind to national identity. Its best-known expression is possibly Desiderius Erasmus's oftenquoted refusal of burghership of Zurich, where he describes himself as a 'citizen of the world', and hopeful of entry into the city of heaven. ${ }^{14}$ In economic and political domains, entry into guilds, companies, and broader corporate entities, and the oath to the Crown that accompanied incorporation, equally challenged perceptions of nationality as an unchanging, singular characteristic, and ensured that individuals were legally viewed 'no more [as] strangers and foreigners.' ${ }^{15}$ The early modern antiquarian John Stow wrote that 'the estate of London, in the persons of the Citizens' was comprised of 'merchants, handicrafts men, and labourers', so that citizens were 'by birth for the most part a mixture of all countries' ${ }^{16}$ Furthermore, he argued, it was in 'the persons of the Citizens' that London society was 'so friendly interlaced', so that the people were 'knit in league with the rest of the realme.. 17

Between $155^{\circ}$ and 1700, commercial and urban expansion and migration provoked by the religious wars in continental Europe contributed to the growth of many English cities, particularly London. Stow described London as being 'but a citizen' itself, becoming the focus of large-scale migration as people sought to take advantage of its developing trading and commercial networks. ${ }^{18}$ English towns like Norwich, Canterbury, York, and Colchester

14 'Ego mundi civis esse cupio, communis omnium vel peregrinus magis. Utiam contingat asscribi civitati coelesti', letter to Ulrich Zwingli, September 1522, quoted in George Hoffman, Reforming French Culture: Satire, Spiritual Alienation, and Connection to Strangers (Oxford: Oxford University Press, 2017), p. 123.

15 Abernethy, The dignity and duty, p. 45.

16 John Stow, A survay of London Contayning the originall, antiquity, increase, moderne estate, and description of that citie (London, 1598; STC 23342), p. 479.

17 Ibid.

18 Ibid., p. 557 . 
were also commonly associated with large migrant populations. ${ }^{19}$ These cities became centres for French, Dutch, and German artisans fleeing confessional conflicts, and gradually functioned as hubs for merchants and traders from Europe and further afield in Asia and Africa. ${ }^{20}$ Although the relationship between foreign and English merchants and artisans was at times fraught, coexistence between different cultures and faiths was commonplace in daily life. With an eye on bolstering their trade networks and technical skills, urban authorities, institutions, and guilds often promoted the incorporation of migrants into the world of civic citizenship. ${ }^{21}$ In Norwich in the sixteenth and seventeenth centuries, wealthy Dutch and Walloon merchants were able to purchase their citizenship, often using their commercial wealth and power to secure coveted positions as city administrators. ${ }^{22}$ In London, however, guild incorporation was strictly governed and guarded, meaning that European artisans were less guaranteed incorporation. For example, the Goldsmiths and Weavers companies accepted Dutch apprentices, whereas the Merchant Taylors did not. ${ }^{23}$ This presented problems for many migrants, since apprenticeships and membership to the London guilds was legally required for citizenship. Nonetheless, whether through purchasing citizenship or acquiring it through an apprenticeship, European migrants seeking to work as artisans and traders were regularly able to enjoy the same civic rights and protections as English citizens, holding public office as well as securing legal and economic protection. ${ }^{24}$

As active members of these organisations, citizens often proudly fashioned themselves according to Renaissance Italian ideals of 'public service, participation, and activity'. ${ }^{25}$ This enabled them to seek their own preferment while also financially and culturally enriching the 'corporate stock' of their cities, towns, and nation. ${ }^{26}$ In 1637 , the Levantine merchant Lewes Roberts connected commerce with patriotism. Civic participation

19 Raingard Esser, 'Citizenship and Immigration in 16th and 17th Century England', in Citizenship in Historical Perspective, ed. by Steven G. Ellis, Guðmundur Hálfdanarson, and Ann Katherine Isaacs (Pisa: Pisa University Press, 2006), pp. 237-252; C. W. Chitty, 'Aliens in England in the Sixteenth Century', Race, 8:2 (1966/1967), 129-146.

20 Lewes Roberts, The merchants map of commerce (London, 1638; STC 21094), p. 309.

21 Scott Oldenburg, Alien Albion: Literature and Immigration in Early Modern England (Toronto: University of Toronto Press, 2014).

22 Raingard Esser, 'Citizenship and Immigration', p. 243.

23 Ibid., p. 245.

24 The honour of London apprentices (London, 1647; Wing H2596), sig. AD 3 r.

25 Phil Withington, 'Public Discourse, Corporate Citizenship, and State Formation in Early Modern England', The American Historical Review, 112 (2007), 1016-1038 (p. 1017).

26 Withington, Society in Early Modern England, p. 118. 
was the essential duty of a 'Patriot and Citizen [...] for his Traffick is seen to improve the Countries Commodities.' ${ }^{27}$ Trade and merchants, he asserted, 'wonderfully inriched the City, and increased the power of the Citizens'. ${ }^{28}$ While merchants were not significantly comprised of the citizen class, they were a significant group that consciously constructed their identity to their trades, so much so that the late seventeenth-century economist Nicholas Barbon described 'Citizens estates' as 'Trade and Goods.' ${ }^{29}$

Barbon's comments on the link between citizens and trade also highlights the complex connections that tied political citizenship to rights of property. The socio-political affiliations of those who identified as 'citizens' and City merchants implicated the vested interests of Members of Parliament and policymakers as well as the 'middling' sort and their connections to other countries and trade networks, which did not always perfectly align to the interests or authority of the Crown. During the Middle Ages, property was a marker that delineated the privileges of individuals to political representation in England. However, as early modern England underwent radical changes that saw the expansion of commerce and rapid urbanisation, property and its protection became increasingly linked to the idea of incorporation and citizenship. Key to the privilege of citizenship was the idea of incorporation into a corporate body, whether civic or commercial. Through incorporation, individuals and their property obtained the important civic privilege which allowed them to be 'represented both at law and in Parliament'. $3^{0}$ Furthermore, citizenship acquired through incorporation came with other benefits including access to trade in certain goods, and the right to own and inherit property. Although birth was one route to obtaining these advantages, the incorporation of individuals as citizens provided a mechanism to broaden and tighten access to these civic rights.

The articulation of the complexities inherent in citizen identity left its mark on the English imagination on stage and print as well. In plays such as Robert Wilson's Three Ladies of London (1584) and William Haughton's Englishmen for my Money (1598), a mixture of English, foreign, and naturalised characters of foreign descent or ancestry engage in the transactions that make up the fabric of civic life in their contemporaneous London.

29 Nicholas Barbon, An apology for the builder, or, A discourse shewing the cause and effects of the increase of building (London, 1685; Wing B704), p. 33.

30 Withington, 'Public Discourse', p. 1027. 
The popular sub-genre of the 'city comedy' or 'citizen comedy' which playwrights such as Thomas Dekker, Thomas Middleton, Ben Jonson, Francis Beaumont, and others subsequently developed, often tread a thin line between the celebratory and the satiric, playing with multiple claims on the citizen's identity and loyalty. Similarly, from the early citizen romances and prose fiction of Robert Greene, Thomas Nashe, and others in the 159os, to Francis Kirkman's semi-autobiographical The Unlucky Citizen (1673), the citizen figure is regularly identified as a non-aristocratic member of the middling classes, whose ambivalent relationship with social hierarchy, trade, and a developing 'English' identity is at once ridiculed and celebrated.

Although women were publicly excluded from the public realm of politics, they featured significantly in sixteenth- and seventeenth-century citizen plays, as in the realm's actual labour economy. Female characters banded together to socially advance or dupe their husbands; they were avid consumers of global goods that served to augment their position in society; and they invested or became involved in crafts, industries, and financial projects..$^{31}$ Thomas Dekker and John Webster's Westward Ho (performed 1604) for instance, opens with the bawd, Mistress Birdlime, talking about a stranger woman in the city, 'Master Justiniano's wife, the Italian merchant': 'The young gentlewoman hath a good city wit, I can tell you. She hath read in the Italian Courtier that it is a special ornament to gentlewomen to have skill in painting'.32 But Birdlime's conversation soon erases national boundaries to praise the collective power of citizens' wives, who could 'awe their Husbands [...] control their husbands', using their status and access to goods to reach certain levels of autonomy and self-assertion in public and private spaces. ${ }^{33}$ On the other hand, in his 1635 biblical commentary, Richard Chapman translated the worldly and independent-minded 'woman of the city' (Luke $7: 37)$ to the 'sinne-sunke citizen woman'. ${ }^{34}$ However, women, like men, did

31 Maids and Mistresses, Cousins and Queens: Women's Alliances in Early Modern England, ed. by Susan Frye and Karen Robertson (Oxford: Oxford University Press, 1999); Mark Hailwood and Jane Whittle, 'Women's Work in Rural England, 1500-1700: a New Methodological Approach', Local Population Studies, 96 (2016), 66-71; Adriane Schmidt, 'Women \& Guilds: Corporations and Female Labour Market Participation in Early Modern Holland', Gender \& History, 21 (2009), 170-189; Charlie Taverner, 'Consider the Oyster Seller: Street Hawkers and Gendered Stereotypes in Early Modern London', History Workshop Journal, 88 (2019), 1-23; Amy M. Froide, Silent Partners: Women as Public Investors During Britain's Financial Revolution, 1690-1750 (Oxford: Oxford University Press, 2017).

32 The Works ofJohn Webster, ed. by Alexander Dyce (London: George Routledge, 1877), p. 209.

33 Ibid.

34 Richard Chapman, Hallelu-jah (London, 1635; STC 4998), p. 8 o. 
express their sense of belonging through their spiritual understanding of citizenship: in their piety, they too were 'cytizen[s] of heaven'. ${ }^{5}$

Ideas surrounding the identity of the citizen in early modern England developed in response to the political, social, and legal pressures that rapid commercial and urban expansion had on English society. As middling classes emerged, their position in English society, whether imagined, political, or legal, was defined by their incorporation as citizens of England. The concept of the citizen became a civic identity that not only benefited the nation but was also a means of policing the entry of foreign entities and influencing urban and commercial spaces. By encouraging, forcing, or prohibiting foreign artisans and merchants from establishing their trades or from seeking apprenticeships and therefore entering civic life in a way that would enable them to offer their civic duties to the state, early modern authorities created a means to regulate foreign incorporation. These regulations were largely aimed at men, since men were responsible for the women in their households; but women also gained status by being the wife of a citizen, both through associations with civil virtue as well as the cosmopolitanism that came with living in cities and accessing new goods and spaces of consumption. Further, behind migrant labour and merchant activity were the hands and skills of women as well as men. The array of surviving material culture in middling households across England, from tapestries using Italian weaving techniques to silk dyes pioneered by Huguenot refugees in Spitalfields, testify to the entangled role played by foreign and domestic artisans and merchants on shaping the cultural life of corporations and civic participation. ${ }^{6}$

Related keywords: alien/stranger, denizen, merchant, settler, subject

35 Marguerite, Queen consort of Henry II, A godly medytacyon of the christen sowle (London, 1548; STC 17320), sig. A6v; The first examinacio [ $n]$ of Anne Askewe latelye martired in Smythfelde (London, 1547; STC 851), sig. O2r.

36 On citizenship, craft, and material culture, see Tara Hamling and Catherine Richardson, A Day at Home in Early Modern England: Material Culture and Domestic Life, 1500-1700 (New Haven, CT: Yale University Press, 2018); Everyday Objects: Medieval and Early Modern Material Culture and its Meanings, ed. by Tara Hamling and Catherine Richardson (Farnham: Ashgate, 2010); Making Knowledge in Early Modern Europe: Practices, Objects, and Texts, 1400-180o, ed. by Pamela H. Smith and Benjamin Schmidt (Chicago: University of Chicago Press, 2007). 


\section{Convert}

Steeped in religious language, the 'convert' was a figure of intrigue and fear in the early modern era. The related verb 'to convert' applied this idea of change to a range of contexts at a time that saw drastic changes in medicine and natural philosophy. 'Convert' and 'conversion' related to transformation and alteration, but the confessional split caused by the Reformation, and more frequent English encounters with peoples and polities beyond Europe, meant the 'convert' became an important figure in English definitions of their own identities. ${ }^{1}$ For the English, encountering other people was a double-edged sword. On one side, these exchanges provided the opportunity for many to fulfil what they saw as their biblically ordained evangelical responsibility to convert peoples and environments for both the Protestant faith and English state. On the other hand, cross-cultural encounters also placed the English at risk of conversion to other faiths and cultures.

The use of 'convert' as a noun first occurs in English in the middle of the sixteenth century, where it described an individual who had been encouraged to embrace and profess a different faith. In 1561, John Calvin criticised the Anabaptists and Jesuits who 'appoint certaine days to their newe convertes, during which they must exercise themselves in penance' to enter communion. ${ }^{2}$ Similarly, Biblical translations described various forms of converts. In the 1599 Geneva Bible, God punishes Israel 'because they refused to convert', while in the 1611 King James Version, Isaiah prophesied that 'Zion shall be redeemed with judgement, and her converts with righteousnesse.' ${ }^{3}$ By the middle of the seventeenth century, 'convert' was not only used to describe and identify individuals who had changed religions but also someone who had shifted their political, legal, or even cultural allegiance. The lawyer and MP William Hakewell wrote in 1641 how he considered his 'former opinion as erroneous' and did 'embrace the contrary', so that he had 'become a convert'. ${ }^{4}$

1 'Convert, $n$. and adj., Oxford English Dictionary.

2 John Calvin, The Institution of Christian Religion, trans. by Thomas Norton (London, 1561; STC 4415), p. 276.

3 The Bible and Holy Scriptures (Geneva, 1560; STC 2093), Hosea 11:5; The Holy Bible, conteyning the old testament and the new (London, 1611; STC 2216), Isaiah 1:27.

4 William Hakewill, The libertie of the subject: against the pretended power of impositions (London, 1641; H210), p. 3. 
After the Reformation, Protestant fears of conversion back to Catholicism, and away from the 'true doctrine' of the reformed faith, could happen within the realm as much as beyond it. Because Henry VIII's break from Rome had placed the English monarch at the head of both Church and state, conversion was a political as well as a spiritual issue, becoming a concern for policymakers and churchmen alike. ${ }^{5}$ Spanish agents of the Iberian Counter-Reformation, as well as English Catholics who fostered ties with the Jesuit colleges in Europe, sought to claim converts in their attempt to return England to the fold of the papacy. 'I hope that Our Lord will blind [the Protestants] and temper the situation', wrote the Spanish woman Luisa de Carvajal y Mendoza from London in 1606, 'otherwise soon there will be no Catholics left'. ${ }^{6}$ The conversion of individuals could have implications on a national or international scale. Carvajal expressed sympathy for King James, 'for he had been left a child without his saintly Catholic mother and in the puritans' hands'. ${ }^{7}$ In response to Catholic attempts to draw converts, Protestants proclaimed the authority of their doctrines from print and pulpit, often offering staged conversions to reinforce the providentialism of the Protestant order. ${ }^{8}$ Once such example is evidenced in the sermon by Anthony Tyrell. A renegade priest and spy, Tyrell converted and reverted at least six times from Protestantism and Catholicism during the 1580 s. His sermon in 1589 aimed to 'publish unto the world yet once againe the constancie of my faith', declaring that 'I do from my hart [...] relinquish and abandon the Pope and the sea of Rome so far forth as it mainteineth Idolatrie, favoureth superstition, nourisheth schisme and devision, teacheth disobedience both to God and Princes'. ' 'I wyll not the death of a sinner', the Swiss reformer Theodore Beza wrote, in

5 Michael Question, Conversion, Politics, and Religion in England, 1580-1625 (Cambridge: Cambridge University Press, 1996); Catholicism and Anti-Catholicism in Early Modern English Texts, ed. by Arthur F. Marotti (Basingstoke: Palgrave, 1999); Torrance Kirby, Persuasion and Conversion: Essays on Religion, Politics, and the Public Sphere in Early Modern England (Leiden: Brill, 2013).

6 Luisa de Carvajal to Magdalena de San Jeronimo, 3 July 16o6, in The Life and Writings of Luisa de Carvajal y Mendoza, ed. by Anne J. Cruz (Toronto: Centre for Reformation and Renaissance Studies, 2014), p. 225.

7 Luisa de Carvajal to Father Joseph Creswell, 29 June 1608, ibid., p. 244.

8 John Foxe, Actes and monuments (London, 1563; STC 11222); Kirby, Persuasion and Conversion, pp. 99-113; Matthew Dimmock, 'Converting and Not Converting "Strangers" in Early Modern London', Journal of Early Modern History, 17 (2013), 457-478.

9 Anthony Tyrell, A fruitfull sermon preached in Christs-Church (London, 1589; STC 24474), sigs. Aiir-v. 
a translation by John Stockwood, 'but I wyl rather than the sinner convert, repent and lyve'. ${ }^{10}$

As Carla Pestana argues in Protestant Empire, much of the English zeal to convert came as a result of their desire to compete with the conversion efforts of Catholic Spain in the Atlantic. ${ }^{11}$ Early European travels in the Atlantic and Indian oceans were dominated by the Spanish and Portuguese. In 1588, the Spanish Jesuit missionary José de Acosta argued that the reason for the success of the Iberian nations was that 'in the holy Scripture it was foretold long before, that this new worlde should be converted to Jesus Christ by the Spanish nation.' ${ }^{2}$ Like many other Europeans, Acosta believed that it was not only the duty of the Iberian crowns but also all Catholics to 'convert many Nations unto the Lorde.' ${ }^{13}$ Awareness of Iberian attempts to convert the people of America, and of the wealth they had acquired through their commercial expansion, shaped similar English attempts to legitimise English global expansion. This created a fundamental relationship between the conversion of souls and the conversion of landscapes. In 'A Discourse Concerning Western Planting' (1584), Richard Hakluyt proclaimed that the first aim of western plantation 'will be greatly for the inlargement of the gospel of Christe, whereunto the princes of the refourmed religion are chefely bounde', but this document was also profoundly influenced by commercial competition with Spain. ${ }^{14}$

Diplomatic and commercial contacts with the Iberian Peninsula, and the translation of works related to the Iberian overseas expansion, the history of the Peninsular kingdoms or picaresque novels, instigated an interest in England in the status of the Jewish, Muslim, and other non-Christian communities who converted to Catholicism under the auspices of the Iberian crowns. Terms such as Marrano, Morisco, converso, or 'New Christian' (Por. Cristão novo; Sp. Cristiano nuevo) became increasingly familiar to readers of Spanish or Portuguese works. The awareness of the existence of Iberian socioreligious groups formed by converts from Islam (Moriscos) and Judaism (Marranos, conversos) derived not only from an interest on the domestic

10 Theodore Beza, The treasure of trueth [with additions by John Foxe] (London, 1576; STC 2049), sig. Q6v.

11 Carla Gardina Pestana, Protestant Empire: Religion and the Making of the Atlantic World (Philadelphia: University of Pennsylvania Press, 2009).

12 José de Acosta, The naturall and morall historie of the East and West Indies (London, 1604;

STC 94), p. $5^{\text {o. }}$

13 Ibid., p. $5^{2}$.

14 Richard Hakluyt, A Discourse Concerning Western Planting (1584), ed. by Charles Deane (Cambridge: Wilson \& Son, 1887), p. 3. 
situation of rival powers such as Portugal and Spain, but on the perception that the Morisco and converso communities, like the Catholic populations of England, represented an 'enemy within', a disruptive element which posed a serious threat to social and political unity. ${ }^{15}$ Francis Bacon, for example, suggested that the Moriscos, even after their expulsion from Spain in 1609, still 'hang as a Cloud or Storme over Spain' due to their religious affinities with the Ottoman Empire or the Sultanate of Morocco. ${ }^{16}$ Bacon's perception of the Moriscos has echoes of Matthew Sutcliffe's diatribes against the 'obstinate recusants' who were depicted as 'domesticall malcontents', a feared internal threat 'secretly reconciled to the pope, and adhere to her enemies'. ${ }^{17}$ These assertions of similarities between Moriscos, conversos, and recusants are also evident, as Gary K. Waite notes, in the translation into English of Philip III's 1609 edict decreeting the expulsion of the Moriscos from Spain, a piece of Spanish legislation which was 'English'd' to warn 'the danger that Moriscos presented to Spain, and potentially to England, should any be allowed to settle there'. ${ }^{18}$

The ambiguous religious and political identity of Moriscos and conversos was also perceived in England as an example of the predisposition of Iberian societies towards racial hybridity. Richard Perceval's A dictionarie in Spanish and English (1599) presented 'mestizo' as the 'sprung of a mixture of two kinds, as a blacke-Moore and a Christian', and 'mulato(a)' as the son or daughter of 'a blackmoore, and one of another nation.' ${ }^{19}$ Perceval's definition of these Iberian racial categories suggested a perception that religious conversion encouraged or fomented miscegenation. This idea is also present on English and European accounts of Iberian overseas territories. The English translation of Jan Huyghen von Linschoten's Itinerario (1598), for example, noted that the Christian population of Goa included a considerable and influential number of mestiços, the offspring of marriages between

15 Jesús López-Peláez Casellas, “Paradoxing” the Alien: The Morisco in Early Modern English Texts', Miscelánea: A Journal of English and America Studies, 46 (2012), 34-36 (pp. 29-52).

16 Francis Bacon, Certain miscellany works of the Right Honorable Francis Lo. Verulam, Viscount S. Alban (London, 1629: STC 1124), p. 75.

17 Matthew Sutcliffe, A briefe replie to a certaine odious and slanderous libel (London, 160o; STC 23453), sig. R2v.

18 W. I., Newes from Spaine The king of Spaines edict, for the expulsion \& banishment of more then nine hundred thousand Moores out of his kingdome (London, 1611; STC 22992.7). Gary K. Waite, 'Empathy for the Persecuted or Polemical Posturing? The 1609 Spanish Expulsion of the Moriscos as Seen in English and Netherlandic Pamphlets', Journal of Early Modern History, 17:2 (2013), 111-112 (pp. 95-123).

19 Richard Perceval, A dictionarie in Spanish and English (London 1599; STC 19620), pp. 169, 173 . 
Portuguese and Indian women converted to Christianity. ${ }^{20}$ Thomas Gage's account of Spanish America also noted that the Christianisation of the New World encouraged cultural and racial hybridisations reflected in a series of racial categories - 'Mestizos', 'Mulattos', 'Criolios', and 'Black-Moors'. ${ }^{21}$ Both Linschoten and Gage highlighted that the racial diversity of Iberian colonial societies was accompanied by the efforts of the inquisitorial courts to impose religious orthodoxy and erase the memory of the 'heathen' practices of the converted Indigenous populations.

The word 'convert' appeared in the directions given to the Virginia Company in 1609 for 'the conversion and reduccion of the people in those partes unto the true worshipp of God and Christian religion.' ${ }^{22}$ The 1620 charter of the New England Company similarly required that the company 'tendeth to the reducing and Conversion of such Savages as remaine wandering in Desolacion and Distress, to Civil Societie and Christian Religion'. ${ }^{23}$ Early expansion and the perceived paganism of 'savages' presented the English with the opportunity to convert Native Americans to Christianity, fulfilling their God-given responsibility whilst preventing Spanish expansion. The Algonquian woman Pocahontas was one of the best-known conversions of the period, used by many in England as a justification for colonising Virginia and for advertising expansion more broadly. Pocahontas's conversion, her subsequent marriage to the planter John Rolfe, and the birth of her son Thomas induced the Virginia Company to request that Pocahontas and her family visit England in 1616. In the lead-up to her voyage to England, John Smith wrote to Queen Anne suggesting it would be crucial for the queen to meet Pocahontas, as Pocahontas was the 'first Christian ever of that Nation, the first Virginian ever spake English, or had a childe in marriage by an Englishman' and as such God had made 'her his instrument'. ${ }^{24}$ For Smith, any refusal to meet her would be detrimental to the fate of the English mission in Virginia, as 'her present love to us and Christiantie, might turne to such scorne and furie, as to divert all this good to the worst of evill'. ${ }^{25}$ Smith's plan

20 Jan Huyghen van Linschoten, John Huighen van Linschoten. His discours of voyages into the Easte \& West Indies (London, 1598; STC 15691), p. 53.

21 Thomas Gage, The English-American, his travail by sea and land (London, 1648; Wing G109).

22 'Second Charter of the Virginia Company (1609)', in Francis Newton Thorpe, Federal and State Constitution, Colonial Charters, and other Organic Laws of the States, Territories and Colonies Now or Heretofore Forming the United States of America, Vol. I (Washington, D.C.: Government Printing Office, 1909), p. 3800.

23 The Charter of New England (1620), ibid., Vol. III, p. 1839.

24 Captain John Smith: A Select Edition of His Writings, ed. by Karen Ordahl Kupperman (Chapel Hill: University of North Carolina Press, 1988), pp. 69-71.

25 Ibid., p. 71. 
to use Pocahontas to promote the Christian conversion of Virginia never came to fruition. Pocahontas fell ill and died in Gravesend in $1617 .{ }^{26} \mathrm{Her}$ story is illustrative of the much wider policy of conversion that the English adopted in Virginia, where Algonquian children were taken, often against their will, from their parents and instructed in English customs and religion. ${ }^{27}$

As with Native Americans in the Atlantic, English commercial expansion in the Mediterranean and Indian oceans increased the number of encounters with Muslim, Jewish, and Hindu peoples. For many in England, the role of the commercial companies that operated in the East was conversion alongside commerce. One influential East India Company (EIC) chaplain, Patrick Copland, is mostly remembered for instigating the first company conversion of an Indian boy in 1614. Returning from India that year with the converted boy, Copland managed to arrange for the company to provide a stipend for the boy to attend school in London to be 'taught and instructed in religion' so that God would be 'soe pleased to make him an Instrument in roundinge some of his nation'. ${ }^{28}$ One year later, Copland reported on the success of the boy's education. Since the boy had 'profited in the knowledge of the Christian religion', it would benefit the company to hold a baptism 'publiqielie' to celebrate the conversion of the 'first fruites of India'. ${ }^{29}$ However, the conversion of 'Peter Pope' did not lead to large-scale change. Edward Terry, chaplain to Thomas Roe in India, bemoaned the inability of the English to convert compared to the success of the Jesuits, writing that only they 'have liberty to convert, any they can work upon, unto Christianity'. ${ }^{\circ}$ Another EIC chaplain, Henry Lord, wrote about the Hindu and Parsi faiths he encountered in the 1630s. One of the aims of his work was to ensure that 'good Christians in England' were able to learn 'to convert the Heresies of the Heathen' ${ }^{31}$

Converting the souls of non-European peoples was complex and fraught with not only spiritual but also diplomatic dilemmas. In 1669 the Deputy Governor of Bombay, Henry Young, expressed concerns that Portuguese

26 Karen Ordahl Kupperman, Indians and English: Facing Off in Early America (Ithaca, NY: Cornell University Press, 200o), pp. 199-203.

27 Karen Ordahl Kupperman, Pocahontas and the English Boys: Caught Between Cultures in Early Virginia (New York: New York University Press, 2019).

2819 August 1614, London, British Library, IOR B/5; Edward Duffield Neill, Memoir of Rev. Patrick Copland: Rector elect of the first projected college in the United States: A chapter of the English colonization of America (New York: Scribner, 1871), pp. 13-14.

2918 July 1615 , London, British Library, IOR B/5.

30 Edward Terry, A Voyage to East-India (London, 1655, Wing T782), p. 446.

31 Henry Lord, A display of two forraigne sects in the East Indies (London, 1630; STC 16825), sig. P3r. 
ministers had demanded that they be permitted to continue to 'use compulsion' in converting local Indians. ${ }^{32} \mathrm{~A}$ month later Young and some associates continued to complain about the effects of Catholic evangelical practices in Bombay, suggesting that they were forcibly baptising Indians. ${ }^{33}$ Young questioned the conversion, arguing that 'noe Christian', Protestant or Catholic, found spiritual salvation through being 'forcibly (mocke) baptised' as such an act did not include the necessary 'confession of faith [...] or profession to forsake the Divell [...] or to fight under [the] Christian banner'.34 In response to the actions of the Catholic priests Young ordered that they cease, pointing out that it was damaging relations with the local Indian population whilst commanding that they were 'not to christen nor punish' any 'Gentiles without a licence'. ${ }^{35}$ However, problems relating to conversion did not stop there: in many cases English travellers and officials in India wrote of their fascination and frustration at the doctrinal malleability of local peoples, as they were able to assimilate certain Christian practices and teaching into their wider faith. This doctrinal flexibility was not seen as true conversion. Perceived by company officials as pretending 'to have become a voluntary Christian', those who 'relapsed' to their old faiths posed a troublesome threat to the company's religious governance. ${ }^{36}$

Conversion worked in the opposite direction as well. As English subjects ventured further afield, English authorities became increasingly concerned with apostasy or, in the case of encounters with Ottomans, 'turning Turk'. Regardless of attempts to prevent the conversion of English subjects, it was often the case that English authorities only had the power to address apostacy after it had happened. One such case took place in the spring of 1649, when EIC agent Thomas Breton wrote of his grief to 'imparte unto you a sad story' of how one man's conversion to Islam had brought both 'dishonour to our nation, and (which is incomparably worse), of our Christian profession'. ${ }^{37}$ According to Breton, Joshua Blackwell, a company employee at Agra, had converted to Islam and in doing so had been 'irrecoverably lost' ${ }^{3}$

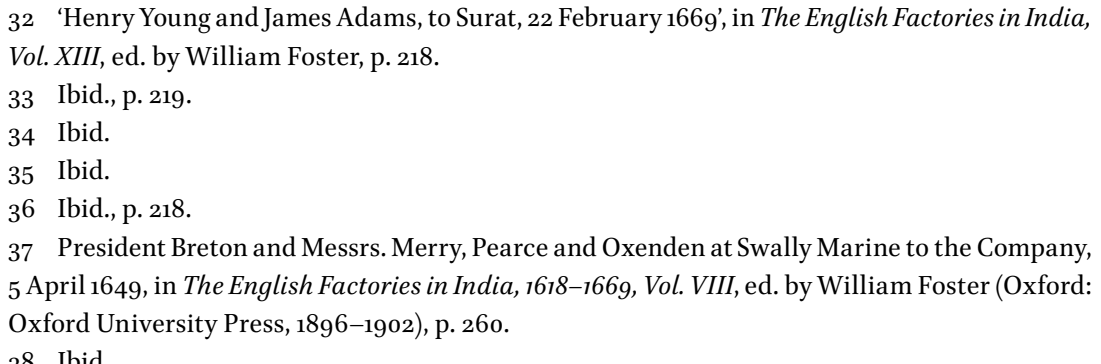
$3^{8}$ Ibid. 
Breton's surety that Blackwell was beyond reformation was an acknowledgment of Mughal legal acts, or farmans, which prevented any interaction that would lead to the reconversion of an individual who had become Muslim. Yet despite Breton's assertion that he was beyond 'redemption', Blackwell initiated a series of correspondences in following months that lead to Blackwell's readmittance into the Company, and to the Protestant community it represented. ${ }^{39}$ Even 'upon the acknowledgment of his sin and promise of perseverance in his Christian profession', Blackwell still faced problems that would lead to him being sent back to England, as he would be 'subject to the abuse of every Mahometan that knowes your condition'. ${ }^{40}$ When it came to apostasy, English authorities abroad provided two services: first to prevent apostasy, and second to clean up after it.

Conversion affected places and spaces as well as souls. Many English travellers lamented the loss or destruction of Christian religious spaces by an invading force or faith. These narratives emphasised the role of external, 'foreign' forces in the conversion of sacred places. As with cases of apostasy, Muslims and Catholics were often perceived to be antagonists in accounts where churches were converted to other uses. In one English account of the Ottoman attacks of the Hungarian city of Buda in 1541, the 'Christian Religion was now by sufferance', with the 'Churches [...] converted to Mosques'. ${ }^{41}$ To Christian observers, one of the most horrific repercussions of the siege was the transferral of Christian spaces into Muslim ones, something that occurred with increasing frequency as the Ottoman empire expanded its bounds into Europe and the Mediterranean. Even within the Christian faith, 'false' conversions might abound. In the 1690s, an English traveller lamented the condition of Protestants in the Palatinate, where Protestant churches were converted to Catholic ones: 'at Creutznach the Church that stands upon the Egg Market, they [Catholics] converted to their own use with the Latin Schools', the money found in the church 'to pay Popish School-masters, and for Popish uses'. ${ }^{42}$ For the author, the conversion of the Protestant church to a Catholic school was doubly troubling. Not only did the loss of

39 Joshua Blackwell at Agra to the President and Council at Surat, 14 February 1650, in ibid., p. 299 .

40 'Instruction for President and Council at Surat to Richard Davidge, Proceeding to Court, 7 March 1650', and 'The Rev. William Isaacson at Surat to Joshua Blackwell [at Agra], 7 March 165o', in ibid., pp. 302-304.

41 A. B., A letter to a friend being an historical account of the affairs of Hungary (London, 1684; Wing B17), p. 2.

42 An Account of the present condition of the Protestants in the Palatinate in two letters to an English gentleman (London, 1699; Wing A336), p. 10. 
the space signify a loss to Protestant advancement, but its conversion to a centre of Catholic education lay the foundations for the future flourishing of Catholicism. These instances highlight the role of the visual, and the built environment, in marking the successes of forms of conversion. This had been underway in the British Isles since the second half of the sixteenth century, as Protestants established regional ascendancy through the dissolution of monasteries, where the building of reformed spaces of worship created a radical reconfiguring of the landscape. To Protestants, the 'reformation of the landscape' was acceptable and necessary for the furthering of their doctrines. ${ }^{43}$

Conversion not only meant a switch in faith, but often also signified a change in national identity and allegiance. The legal implications of conversion or possible conversion affected the status of numerous people across the early modern English world. In Britain, several acts, such as the Test Act, Corporation Act, and the Clarendon codes (four Acts introduced by Charles II's chief minister, Edward Hyde, Earl of Clarendon) imposed harsh legal penalties on recusants and dissenters, discouraging conversion from the state faith. Passed in 1661, the Corporation Act forbade anyone from taking public office who refused to take 'the sacrament of the Lord's Supper according to the rites of the Church of England'. ${ }^{44}$ Reinforced again in the Test Act (1672), these acts effectively barred Catholic converts or dissenting Protestant groups, such as Quakers and Baptists, from state offices even if they were English-born. ${ }^{45}$ In London and other English towns and cities, this could even prevent individuals from becoming citizens. ${ }^{46}$

In the Atlantic world, authorities also attempted to curtail the legal freedoms that religious conversion had traditionally offered non-Europeans, particularly enslaved Africans. For the enslaved, conversion and baptism had been traditionally seen as a form of manumission, allowing them to legally obtain their freedom and the rights and privileges that came with it. However, during the seventeenth century, a number of English colonies attempted to prevent enslaved men and women from obtaining their freedom through conversion. The Virginia Assembly was the first body in America to legislate this in 1667 , declaring that ' $[\mathrm{b}]$ aptisme doth not alter the condition

43 Alexandra Walsham, The Reformation of the Landscape: Religion, Identity, and Memory in Early Modern Britain and Ireland (Oxford: Oxford University Press, 2011).

44 'Corporation Act', 1661, 13 Car. II st.2 c. 1.

45 'Act for preventing Dangers which may happen from Popish Recusants', 1672, 21 Car. II c. 2.

46 Alexandra Walsham, Charitable Hatred: Tolerance and Intolerance in England, 1500-1700 (Manchester: Manchester University Press, 2006), pp. 86-88. 
of a person as to his bondage or freedom'. ${ }^{47}$ Officials in Maryland followed Virginia's lead, passing the 'Act for the Encouraging of the Importation of Negroes and Slaves' (1671) which also declared that baptism and conversion did not mean manumission. ${ }^{48}$ English authorities at home and abroad thus sought to prevent conversion away from Protestantism, but also to restrict the transmission of legal privileges through conversion.

The Reformation, global intervention, and the rise of empirical methods of medical or 'scientific' research imbued 'convert' with ideas of cultural difference, the transferral of properties, and the potential for transformation. Poets were compared to alchemists in their ability to transform and perfect language. 'All minerals [...] thou couldst convert to gold', acclaimed Arthur Wilson in his commendatory verses to the metaphysical poet John Donne, 'And with thy flaming raptures so refine, / That it was much more pure then $[s i c]$ in the Mine'. ${ }^{49}$ As an alchemical term, natural philosophers and doctors noted that conversion involved continual change. The results might be welcome - the conversion of an Indian boy to Christianity, or the earth's conversion of rocks into precious stones - but it might also bring deception or religious degeneration. Alongside spiritual or mental conversion, early modern individuals conceived of conversion as physical, involving invisible and visible changes in character and appearance. As such, a 'convert' was a person who underwent profound changes, triumphing over or failing to combat the forces of sin and evil in the process.

Related keywords: exile, Jew, Mahometan, subject, traitor

47 'An Act declaring that baptisme of slaves doth not exempt them from bondage (1667)', in The Statutes at Large: Being a Collection of all the Laws of Virginia, from the First Session of the Legislature in the Year 16rg, Vol. 2, ed. by William Waller Hening (New York: R \& W Bartow, 1823), p. 260 .

48 Jeffrey K. Sawyer, 'English Law and the "Rights of Persons" in Early Maryland', in Order and Civility in the Early Modern Chesapeake, ed. by Debra Meyers and Melanie Perreault (Lanham: Lexington, 2014), pp. 71-9o (p. 89).

49 Poems, byJ[ohn] D[onne] (London, 1633; STC 7045), p. 398. 


\section{Courtier}

Derived from the Anglo-Norman 'corteiour' and the Old French 'cortoyeur', the word 'courtier' identified those who frequented a sovereign's court, princely residence, or household. ${ }^{1}$ Although the seat of English political power and national sovereignty, the court was often perceived as a separate space from the rest of the country. ${ }^{2}$ As a governmental, scholarly and artistic centre, as well as a hub of conspicuous consumption, the court functioned as a contact zone, a meeting point which fomented a regular interaction between different English and foreign political and cultural actors. ${ }^{3}$ These included not only foreign ambassadors, but also the entourages of foreign queens such as Anne of Denmark, Henrietta Maria, and Catherine of Braganza, as well as the foreign artists and scholars serving at the court. ${ }^{4}$ All these actors tended to share similar cultural and intellectual references, as well as an aristocratic or courtly habitus which reinforced the links between the English court and other European courtly centres.

These connections are well patent in the influence of continental books of courtly manners such as Baldassare Castiglione's seminal Il Cortegiano (1528), translated into English by Thomas Hoby in 1561. One of the aims of Il Cortegiano and other influential Italian works like Giovanni della Casa's Galateo (1558), 'English'd' by Robert Peterson in 1576, was to establish a code of civil conduct that could be shared by the variety of individuals who frequented the court, and smooth the often vicious behaviour caused by the competition for posts, prestige and notoriety between courtiers. At the same time, it helped to establish, at least in theory, a shared pan-European perception of certain frameworks of courtly

1 'Courtier, $n$.', Oxford English Dictionary.

2 Malcolm Smuts, Court Culture and the Origins of a Royalist Tradition in Early Stuart England (Philadelphia: University of Pennsylvania Press), p. 2.

3 On the role of courts as contact zones see, for example, Jeroen Duindam, 'The Court as a Meeting Point: Cohesion, Competition, Control', in Prince, Pen, and Sword: Eurasian Perspectives, ed. by Maaike van Berkel and Jeroen Duindam (Leiden: Brill, 2018), pp. 32-128.

4 See for example, Anna-Marie Linnell, 'Greeting the Stuart Queens Consort: Cultural Exchange and the Nuptial Texts for Henrietta Maria of France and Catherine of Braganza, Queens of Britain', in Queens Consort, Cultural Transfer and European Politics, c. 1500-1800, ed. by Helen Watanabe-O'Kelly and Adam Morton (London: Routledge, 2017), pp. 153-171; and Adam Morton, 'Sanctity and Suspicion: Catholicism, Conspiracy and the Representation of Henrietta Maria of France and Catherine of Braganza, Queens of Britain', in Queens Consort, Cultural Transfer and European Politics, pp. 172-201. 
behaviour that were communicated and emulated across national and linguistic boundaries.

Essential for the archetypical courtier proposed by Castiglione was the concept of sprezzatura, the ability of making graceful, sophisticated conduct look effortless. In Hoby's translation, sprezzatura consisted in an '[a]ffectation or curiosity \& (to speak a new word) to use in every thyng a certain Reckelesness, to cover art withall, \& seeme whatsoever he doth \& sayeth to do it without pain, \& (as it were) not minding it'.5 Translated by Hoby as 'recklessness', sprezzatura was a skill that all courtiers were expected to develop in order to achieve their aims and become recognised members of a courtly elite. ${ }^{6}$ That characteristic mediation between calculated effort and effortless style required both a good deal of cultural sophistication and political shrewdness. To gain the prince's favour and the admiration and respect of the rest of the court, Castiglione's ideal courtier needed to be adept at dissimulation and construct a specific identity that would made him able to act according to different circumstances without breaching the limits imposed by relations of power and cultural norms. ${ }^{7}$ An accomplished courtier never revealed his intentions or feelings, and always behaved in a polite and cautious way so as not to undermine his prospects at the court. This required the courtier to develop a specific persona and invest in a process of 'self-fashioning' based on elements from the political, literary, visual, and material culture that influenced the court. ${ }^{8}$ It also inevitably resulted in the figure of the courtier being associated increasingly with political corruption and amoral or artificial behaviour. In $A$ discourse of civil life (1606), the poet Lodowick Bryskett, who read Castiglione and was well acquainted with Italian courtly literature, criticised the means used by ambitious men 'to purchase reputation and credit, or profit' which made them 'plaine hypocrites'. ${ }^{9}$ From Shakespeare's history plays to Tudor and Jacobean revenge tragedies, English drama demonstrates the continuing influence that such anxieties had on cultural perceptions of courtly life. Thomas

5 Ibid.

6 Baldassare Castiglione and Thomas Hoby, The courtier of Count Baldessar Castilio (London, 1561; STC 4778), sig. E2r.

7 Jon Snyder, Dissimulation and the Culture of Secrecy in Early Modern Europe (Los Angeles: University of California Press, 2009), pp. 70-81; Jennifer Richards, Rhetoric and Courtliness in Early Modern Literature (Cambridge: Cambridge University Press, 2003), pp. 48-55; Anna Bryson, From Courtesy to Civility: Changing Codes of Conduct in Early Modern England (Cambridge: Cambridge University Press, 1998).

8 The term 'self-fashioning' first appeared in Stephen Greenblatt, Renaissance Self-Fashioning: From More to Greenblatt (Berkeley, CA: Stanford University Press, 1980).

9 Lodowick Bryskett, A discourse of civill life (London, 1606; STC 3958), p. 242. 
Dekker's The pleasant comedie of old Fortunatus (1600), for example, mocked the efforts of the '[s]pruce silken faced Courtier, that stands every morning two or three hours learning how to look by his Glasse, how to speak by his Glasse, how to sigh by his glasse, how to court his Mistress by his Glasse'.10

In their pursuit of sprezzatura, English courtiers developed different strategies of social distinction that often involved the adoption of elements from foreign material and intellectual cultures. The intensification of English trade and diplomatic exchanges with continental Europe facilitated the dissemination of new literary and artistic styles, as well as consumption habits and fashions. Patronage of Elizabethan courtiers such as William Cecil, Thomas Sackville, or Francis Walsingham helped to further courtly and intellectual models inspired by the models of conduct proposed by Italian humanism, which in turn had been influenced by Greco-Roman ideals of virtue, scholarly excellence, and public service. ${ }^{11}$ Sackville, for example, wrote a commendation for Hoby's translations of Il Cortegiano, praising the book and the translation for explaining 'what in Court a Courtier ought to be..' ${ }^{2}$

Genealogy was another key element. Besides the Renaissance interest in antiquarianism, genealogy was an instrument to validate an aristocratic pedigree or corroborate one's suitability to courtly status. The courtly and political career of Robert Devereaux, second Earl of Essex, for example, relied on the investment of a public image which highlighted, as William Camden put it, a 'Genealogy ancient and very noble'. A long and impeccable aristocratic lineage suggested the possession or inheritance of innate virtuous qualities that made one naturally distinct and apt to be a part of the upper echelons of the social order. The capacity to exhibit a solid and long ancestry was an important marker of distinction. Indeed, genealogy was often a weapon used by courtiers in the competition for the posts and rewards (symbolic and material) distributed by the Crown. Lord Burghley's interest in the genealogical past of his and other English and European aristocratic families, more than an exercise of Renaissance antiquarianism, was part of a strategy to cement his status within the English elite. ${ }^{13}$ Genealogy, as Jean Feerick has noted, was a key instrument which structured

\footnotetext{
10 Thomas Dekker, The pleasant comedie of old Fortunatus (London, 160o; STC 6517), sig. F3r.

11 Mary Partridge, 'Lord Burghley and Il Cortegiano: Civil and Martial Models of Courtliness in Elizabethan England', Transactions of the Royal Historical Society, 19 (2009), 95-116 (p. 115).

12 Castoglione and Hoby, The courtyer, sigs. Aiir-v.

13 Lawrence Stone, The Crisis of the Aristocracy, 1558-1641 (Oxford: Clarendon Press, 1965), pp. $23-24$.
} 
a social hierarchy defined by blood lineages. ${ }^{14}$ This articulation between lineage and rank in early modern English usage became, as it happened with similar coeval Iberian or French notions of purity of blood, an integral part of emerging racial discourses which recurred to notions of genealogical impurity to restrict the political, economic, and religious agency of domestic minorities or colonial populations. ${ }^{15}$ The pursuit or willingness to present an impeccable or solid genealogy sought thus to certify that the members of the English aristocracy were fully embedded in an English familial and social nexus, untainted by potentially corrupt or foreign elements.

Indeed, the perception of the court as space that stood apart from the rest of the country's social fabric often prompted questions about the Englishness of courtiers. Around 1612, the poet Josuah Sylvester expressed the commonplace belief that lavishness of the court and the increasing influence of continental fashion posed a risk to the character of national governance: 'Wee Courtiers next, who French-Italianate, / Fashion our Faith after the forme of State'. ${ }^{16}$ Two years later, in 1614, Sylvester revisited these lines and associated the regular adoptions of new fashions at the court with the inconstancy of the character of the courtier: 'Wee Courtiers, next, who French-Italianate, Change (with the Moon) our Fashion, Faith, \& Fate.. ${ }^{17}$ This association between the changes of the moon and the character of the courtier suggested a moral ambiguity that other authors also evoked. John Donne perceived the court as a place for intrigue and opportunism, so that 'vertue in Courtiers hearts / Suffers an Ostracisme, and departs.' ${ }^{18}$

The changing fashions and the competition between different factions made the English court, as Henry Wotton observed, a 'market of noise and novelties'. ${ }^{19}$ Wotton's witty remark expresses a perception of the English courtly milieu as a space which received and produced new social and

14 Jean E. Feerick, Strangers in Blood:Relocating Race in the Renaissance (Toronto: University of Toronto Press, 2010).

15 For an overview of the evolution of the usage of the Iberian notions of purity of blood in the Iberian monarchies and their colonial systems see, for example, Race and Blood in the Iberian World, ed. by Max S. Hering Torres, María Elena Martínez and David Nirenberg (Münster: Lit Verlag, 2012); on the French case, see, for example, Ellery Schalk, From Valor to Pedigree: Ideas of Nobility in France in the Sixteenth and Seventeenth Centuries (Princeton, NJ: Princeton University Press, 1986) and Guillaume Aubert, "The Blood of France": Race and Purity of Blood in the French Atlantic World', The William and Mary Quarterly, 61: 3 (2004), 439-478.

16 Josuah Sylvester, Lachrimae lachrimarum (London, 1612; STC 23576), sig. Bir.

17 Josuah Sylvester, The parliament of vertues royal (London, 1614; STC 23581), sig. X4v.

18 John Donne, Poems (London, 1633; STC 7045), p. 85.

19 To Sir Thomas Edmondes, 28 March 1612, in The Life and Letters of Sir Henry Wotton, Vol. 2 (London: Clarendon Press, 1907), p. 1. 
cultural trends. Throughout the seventeenth century, efforts made by James I and his successors, Charles I and Charles II, to restore diplomatic relations with Catholic Europe further exposed Stuart courtiers to foreign tastes and practices that had a profound impact on the English cultural landscape. Lady Anne Clifford, for example, commented that during the early days of the Jacobean court there was 'a great change between the fashion of the Court as it is now and of that in the queen's time', alluding to James's adhesion to foreign cultural models and fashions, as well as the rapid promotion of a group of the king's Scottish favourites. ${ }^{20}$

Royal consorts often offered the natural centre for the development of such courtly coteries. Tudor and Stuart queens from Spain, France, Denmark, and Portugal brought with them their own servants, advisors, tailors, priests, and clergymen who altered the social fabric of daily life in the heart of the political realm. Anne of Denmark showed herself to be politically savvy at the Scottish court ('always the Queen knows all', Robert Cecil commented in 1598), and after her arrival in England set up her own courts at Somerset House and Greenwich, where she oversaw major building works and played an important role in bringing court masques and Italian fashions to the English court. ${ }^{21}$ Charles I's French wife, Henrietta Maria, commissioned masques that celebrated the Marian cult of devotion she fostered at the court. The queen's Catholicism and harbouring of Jesuits came under attack in the parliamentary publication, The King's cabinet opened (1644), which also condemned the queen for the political advice she regularly gave the king. ${ }^{22}$

Foreign embassies were another important channel for the diffusion of continental novelties. Indeed, the presence of Spanish, French and Italian ambassadors and their regular - and at times intimate - contacts with royal officials and courtiers generated a new interest in the cultural and

20 Lady Anne Clifford, Countess of Dorset, Pembroke \& Montgomery: 1590-1676. Her Life, Letters, and Works, ed. by George Charles Williamson (Kendal: Titus Wilson \& Son, 1922), p. 68.

21 Leeds Barroll, Anna of Denmark, Queen of England: A Cultural Biography (Philadelphia, PA: University of Pennsylvania Press, 2001), pp. 25-26; Barbara Ravelhofer, The Early Stuart Masque: Dance, Costume, and Music (Oxford: Oxford University Press, 2006); Susan Dunn-Hensley, Anna of Denmark and Henrietta Maria: Virgins, Witches, and Catholic Queens (Basingstoke: Palgrave, 2017).

22 'I have received your Proclamation or Declaration, which I wish had not bin made, being extreamly disadvantagious for you, for you shew too much fear'. 'Henrietta Maria to Charles Stuart, 27 June 1643', in The Kings cabinet opened (London, 1645; Wing C2358), sig. Fr; see also Women's Worlds in Seventeenth-Century England: A Sourcebook, ed. by Patricia Crawford and Laura Gowing (London: Routledge, 2000), p. 251; Karen Britland, Drama in the Courts of Queen Henrietta Maria (Cambridge: Cambridge University Press, 20o6). 
intellectual life of the continental courts. ${ }^{23}$ The musical performances offered by the chapels of the Portuguese, Spanish or French embassies, for example, often attracted courtiers interested in the musical novelties from the continent. ${ }^{24}$ English embassies in European capitals such as Madrid, Venice, or Paris also served as platforms for the diffusion of foreign novelties and offered to some courtiers a rare experience of courtly access abroad. ${ }^{25}$ Influential Stuart courtiers such as Robert Cecil, Earl of Salisbury, and George Villiers, Duke of Buckingham, regularly commissioned English diplomats and agents stationed in the Low Countries or the Italian peninsula to acquire artwork and ancient manuscripts to promote their own political positions at home and abroad. These practices of patronage aimed not only to enhance the status of leading courtiers, but to position the English court within international artistic and intellectual centres. This had begun with Henry VIII and the humanist statesmen at his court, such as Thomas More, who had encouraged the Augsburg-born artist Hans Holbein's endeavours in London, and who sat for portraits themselves. Writing about his experience in England in the 1630s, the artist Peter Paul Rubens commented that 'this island [...] seems to me to be a spectacle worthy of the interest of every gentleman [...] not only for the splendor of the outward culture, which seems to be extreme, as of a people rich and happy in the lap of peace, but also for the incredible quality of excellent pictures, statues and ancient inscriptions which are to be found in this court'. ${ }^{26}$

The early Stuart courtier therefore became a privileged agent for the introduction of foreign novelties, increasingly associated with cosmopolitan

23 For an overview of the influence of foreign embassies in London see Roberta Anderson, 'Catholic ambassadors in a Protestant court: London, 1603-1625', in Confessional Diplomacy in Early Modern Europe, ed. by Roberta Anderson and Charlotte Backerra (London: Routledge, 2020), pp. 141-159; Cristina Bravo Lozano, 'Popular Protests, the Public Sphere and Court Catholicism. The Insults to the Chapel of the Spanish Embassy in London, 1685-1688', Culture \& History Digital Journal, 6:1 (2017) <http://cultureandhistory.revistas.csic.es/index.php/cultureandhistory/article/ view/115> [Accessed 1 February 2021].

24 See, for example, Ester Lebedinski, "'Obtained by peculiar favour, \& much difficulty of the Singer": Vincenzo Albrici and the Function of Charles II's Italian Ensemble at the English Restoration Court', Journal of the Royal Musical Association, 143:2 (2018), 325-359; Peter Leech, 'Musicians in the Catholic chapel of Catherine of Braganza, 1662-1692', Early Music, 29:4 (2001), 571-587; Margaret Mabbett, 'Italian Musicians in Restoration England (1660-1690)', Music \& Letters, 67:3 (1986), 237-247; Ian Spink, 'The Musicians of Queen Henrietta-Maria: Some Notes and References in the English State Papers', Acta Musicologica 36:2-3 (1964), 177-182.

25 Smuts, Court Culture, p. 186.

26 Peter Paul Rubens to Pierre Dupuy, 8 August 1629, in The Letters of Peter Paul Rubens, ed. by Ruth Magurn (Cambridge, MA: Harvard University Press, 1955), p. 320; Smuts, Court Culture, p. 186. 
sophistication. Young Jacobean and Caroline aristocrats with courtly ambitions invested in travel as part of their education, and visits to foreign courts and continental aristocratic households were considered useful for obtaining relevant posts in the royal administration or diplomatic service when they returned home. Endymion Porter spent most of his formative years at the household of Gaspar de Guzmán, Count Duke of Olivares and valido (favourite) of Philip IV of Spain, and the lord treasurer Francis Cottington lived for more than a decade at the Spanish royal court. ${ }^{27}$ Other relevant Caroline courtiers like Kenelm Digby and Thomas Howard, Earl of Arundel, embarked on several 'grand tours' of Europe and were fluent in Italian and French. ${ }^{28}$ The Earl of Arundel's wife, Aletheia Howard, accompanied him on his trip in the 1610 s, taking part in diplomatic activity and developing her own networks with Italian doges and court painters. ${ }^{29}$

The figure of the courtier became thus increasingly associated with a wider cosmopolitan arena and to the possibility of a transnational identity based on a shared social and cultural habitus that surpassed national or confessional boundaries. The openness to foreign (often Catholic) influences and cultural trends was deemed as a threat to English social and religious harmony. Puritan and parliamentary propaganda during the civil wars and Cromwell's protectorate often explored this perception, presenting courtiers as corrupted individuals who acted against the interests of the commonwealth. One anonymous pamphlet from the 1650 os reminded Parliament that 'the corrupt Courtier' was to be grouped with those who 'are the taile of the Beast, and sting the poor labouring man'.30

The courtier, due to his social status, proximity to political power, and access to foreign novelties, became a stereotypical figure associated with alternative values or practices that were considered to be remote from English traditions or the daily life of other English men and women. Aristocrats and courtiers seemed to share this belief that they possessed a distinct and privileged position in the English social landscape, albeit separated from

27 J. N. Hillgarth, The Mirror of Spain, 1500-1700: The Formation of a Myth (Ann Arbor: University of Michigan Press, 200o), pp. 26-279; José Ramón Fernández Suárez, 'Francis Cottington: su correspondencia inédita con el Conde de Gondomar (1616-1619)', ES: Revista de filología inglesa, 7 (1977), 69-116; Gervas Huxley, Endymion Porter: The Life of a Courtier 1587-1649 (London: Chatto and Windus, 1959), p. 24.

28 Vittorio Gabrieli, Sir Kenelm Digby: Un inglese italianato nell'età della controriforma (Rome: Edizione di Storia e Letteratura, 1957); Mary F. S. Hervey, The Life, Correspondence \& Collections of Thomas Howard, Earl of Arundel (Cambridge: Cambridge University Press, 1921), pp. 6o-88.

29 See, for example, David Howarth, 'The Patronage and Collecting of Aletheia, Countess of Arundel, 16o6-1654', Journal of the History of Collections, 10:2 (1998), 125-137.

30 J. R., Proposals in behalfe of the poore of this nation (London, 1653; Wing R29), p. 4. 
the rest of the population. Margaret Cavendish, Duchess of Newcastle, though with some playfulness or irony, argued under the guise of an epistle that different social groups 'should be apart by themselves, like several Commonwealths, Courtiers should only Converse with Courtiers, or Courtly Persons, and Country Gentlemen with Country Gentlemen, Citizens with Citizens, Farmers with Farmers'. ${ }^{31}$ Although perhaps not meant to be taken purely in earnest, such sentiments raised attention to the distinct world of the courtier, and the impossibility of understanding the rights, values, and idioms of those whose lived experiences could be so different to one's own.

Related keywords: ambassador, citizen, host, merchant, secretary 


\section{Denizen}

Unlike many of the other keywords in this volume, 'denizen' is not commonly used in modern-day vernacular. However, in sixteenth- and seventeenthcentury England, 'denizen' served as a specific and widely used legal term in English. 'Denizen' ('born within') originates from the Anglo-Norman for someone who dwells within a country as opposed to outside of it. ${ }^{1}$ Yet by the thirteenth century, it had come to identify figures who were distinctly external in their origins: migrants who had been granted certain rights to settle in the country. Unlike acts of naturalisation passed by Parliament, denization was granted by the Crown. Whereas naturalisation provided a migrant with a full set of rights as an English subject, denization offered a limited set of privileges to the recipient individual or group. In his Expositiones terminorum legume Angliea (1579), John Rastell defined how a migrant became a denizen, and the limitations of this status. ${ }^{2}$ According to Rastell, a 'denizen' was an alien who had 'becommeth the Quéenes subject and obteyneth her letters patentes to enjoye al priviledges as an Englishman', though 'not with standinge, he shall paye customes and divers other things as aliens doe \&c'. ${ }^{3}$ Over half a century later, Francis Bacon similarly defined denizens as the third of four degrees of legal subjecthood. ${ }^{4}$ Like Rastell, Bacon highlighted how denization 'doth imparte, yet more ample benefit, for it gives him power to purchase freehold and inheritance to his owne use' and allows his children to also do so, yet they could not 'make title' as the '[l]aw thinks not good to make him the same degree, with a subject born'. 5 The status of a denizen was inherently precarious, a 'status somewhere between native and stranger. ${ }^{6}$ As Rastell and Bacon pointed out, although they paid homage and swore allegiance to the monarch, denizens remained aliens by birth. This led to the perception that some if

$1 \quad$ 'Denizen, $n$. and adj., Oxford English Dictionary.

2 John Rastell, Expositiones terminorum legume Angliea, trans. by William Rastell (London, 1579; STC 20706.5), p. $5^{8 .}$

3 Ibid.

4 Francis Bacon, A speech delivered by Sir Francis Bacon, in the lower House of Parliament quinto Iacobi, concerning the article of naturalization of the Scottish nation (London, 1641; STC 20706.5).

5 Ibid., p. 19 .

6 Alan Stewart, “Euery Soyle to Mee Is Naturall”: Figuring Denization in William Haughton's Englishmen for My Money', Renaissance Drama, Volume 35 (2006) Embodiment and Environment in Early Modern Drama and Performance, ed. by Mary Floyd-Wilson and Garrett A. Sullivan, Jr (2006), pp. 55-82 (p. 63). 
not all denizens were untrustworthy, as they had rejected the allegiance and country of their birth and might do the same again. ${ }^{7}$ Alan Stewart has highlighted this issue when discussing Portuguese denizens in London: although they received the status in some official documents, they were still always placed on the list of strangers. ${ }^{8}$ As such, they were prohibited by law from inheriting land as well as from bequeathing land to any children born before they became denizens. ${ }^{9}$ Furthermore, they were required to pay customs and taxes as aliens. At the same time, however, they were granted the right to bring lawsuits, children born post-denization could inherit property, and they could request exemption from the customs and tax rates of aliens. ${ }^{10}$

In the earliest records, the distinction between denization and naturalisation was blurred. ${ }^{11}$ Although the records are rather confused, Elyas Daubeny was probably one of the first individuals to be naturalised or granted the status of denizen for his and his family's service to the Crown in 1295, having crossed the Channel in military service for Edward I. It is most likely that Daubeny was endenized, since the grant notes that he was given the right to be heard in all royal courts as an Englishman..$^{12}$ Much like a subject, a denizen had to pay homage or loyalty to the Crown. The act of receiving homage could be delegated by the Crown to officials, which included the Lord Chancellor and borough and local officials. ${ }^{13}$ In $145^{2}$, the Lieutenant of the North, Commander-in-Chief against the Scots and future king Edward III was invested with the power to grant such status to Scots who paid homage to him. ${ }^{14}$ Many of these early denizens formed two distinct groups. The first and rarer was people like Daubeny, who were 'highly favoured individuals', granted, at royal discretion, rights as 'Pure English'. ${ }^{15}$ Not only

7 Ibid., p. 64 .

8 Ibid., p. 62.

9 Ibid., pp. 63-64.

10 Letters of Denization for Aliens in England, Vol. 8:1509-1603, ed. by William Page (Lymington: Huguenot Society of London, 1893), pp. i-ii; Bart Lambert and W. Mark Ormrod, 'Friendly Foreigners: International Warfare, Resident Aliens and the Early History of Denization in England, 1250-1400', English Historical Review, 130 (2015), 1-24 (pp. 2-3).

11 Keechang Kim, Aliens in Medieval Law: The Origins of Modern Citizenship (Cambridge: Cambridge University Press, 200o), pp. 113, 119-120.

12 Rotuli Parliamentorum, Vol. I, ed. by Edward Upham, John Pridden and John Strachey (London: House of Lords, 1832), p. 135 .

13 Jacob Selwood, Diversity and Difference in Early Modern London (Farnham: Ashgate, 2010), p. 45; Clive Parry, British Nationality Law and the History of Naturalization (Milano: Universita di Milano, 1954), pp. 20-21.

14 Rot. Parl., VI, p. 204; Parry, British Nationality Law.

15 Lambert and Ormrod, 'Friendly Foreigners', p. 2. 
did such individuals in the sixteenth century need to have a favourable position with the Crown, they also needed to be financially able to pay anywhere between $6 s 8 d$ (in 156o) and $2 l 12 s 4 d$ (in 1582), well above the means of an ordinary alien. ${ }^{16}$ The second group comprised individuals who were already citizens of English towns and wanted permission from the Crown to pursue interests across the country. ${ }^{17}$ Initiated by the Carta Mercatoria in 1303, which granted protection to foreign merchants and the freedom to trade, demands for rights by aliens increased as privileged groups sought to obtain exemption from the rates and customs duties that foreigners were forced to pay.

The increase in the number of people being endenized can be linked to the arrival of foreign merchants and the granting of concessions by the King concerning tariffs and taxes. ${ }^{18}$ The legal historian Clive Parry has argued that foreign merchants were constricted by two issues. The first was the inability to hold property in common law, and the second, higher custom rates. ${ }^{19}$ In the Middle Ages, the former was not a concern for merchants, as instead they 'frequently sought exemption from aliens' customs', which were granted to individuals from France, Spain, Portugal, Italy, Germany, and the Low Countries. ${ }^{20}$ However, although many denizens obtained exemption from these customs, this was granted as an individual privilege and not automatically granted upon denization. Over the sixteenth century, such cases involving exempting denizens from paying customs duties became less common, as attempts were made to prevent foreign involvement in English trade. In 1529, Parliament ratified a decree made by the Star Chamber which ordered that all foreign strangers, apart from denizens, were prohibited from establishing and maintaining shops. ${ }^{21}$ The following year, Parliament declared that denizens were to pay the same rates as all strangers for 'subsidies, customs, tolls, duties and other sums of money for their ware, merchandises'. ${ }^{22}$ Towards the end of the century, the Court of Common Council, London's primary decision-making body, went further to prevent foreign-born people from

\footnotetext{
16 Lien Bich Luu, Immigrants and the Industries of London 1500-1700 (London: Routledge, 2005), p. 144; Selwood, Diversity and Difference, p. 49.

17 Ibid., pp. 2-3.

18 Parry, British Nationality Law, pp. 32-34.

19 Ibid.

20 Ibid.; Lambert and Ormrod, 'Friendly Foreigners', p. 2.

21 'Act ratifying a Decree made in the Star Chamber, concerning Strangers and Handycraftsmen inhabiting the Realm of England', 1529, 21 Hen. VIII c. 16.

22 'Acte for Denyzens to paye Straungers', 1530, 22 Hen. VIII c. 8.
} 
entering trades, limiting apprenticeships to individuals born in England with an English father. ${ }^{23}$

Between $155^{\circ}$ and 1700 , as local and national authorities sought to restrict apprenticeships, the number of denizens began to decline and naturalisation began to increase. Unlike the status of denizen, granted through a royal patent, naturalisation happened through an act of Parliament. Denization was a prospective response to an individual's descent, whereas an act of naturalisation retrospectively gave an alien the same status as if they had been born a subject. ${ }^{24}$ The growing popularity of naturalisation was in no doubt partially to do with the retrospective status it conferred, but also due to the extensive property and inheritance rights it offered compared to denization. Jacob Selwood has recorded that between $155^{8}$ and 1640 , there were 2778 patents of denization: 1962 of these took place during the reign of Elizabeth I, whilst during the reigns of James and Charles I there were only 530 and 286 respectively. ${ }^{25}$ This was not a permanent decline, and the numbers of denizens increased following the Restoration. This is particularly the case during the reign of James II, who in the mid- to late 168 os granted denizen status to 1714 individuals, mostly foreign-born Catholics. ${ }^{26}$

There were ways in which denizen status was complicated further by place. For instance, by 1593, London had developed its own category of denizen. Of the 1930 strangers listed in a census survey taken that year, 70 individuals were recorded as 'free denizens'. ${ }^{27}$ This ambiguous term likely indicated that individuals had both the freedom of the City of London

23 Selwood, Diversity and Difference, p. 42; Laura Hunt Yungblut, 'Strangers Settled Here Amongst Us': Policies, Perceptions, and the Presence of Aliens in Elizabethan England (London: Routledge, 1996), pp. $105^{-106 .}$

24 A nineteenth-century select committee report defined the difference between the two as follows: 'By obtaining from the Crown letters patent of denization, foreigners are relieved from disabilities [of aliens] so far, that they can hold and transmit all kinds of real and personal property, but they can only transmit real property to such of their children as may have been born subsequent to their denization'. Whereas, 'by obtaining from Parliament an Act of naturalization, foreigners acquire all the privileges of denization, and a slight addition to them. Naturalized foreigners may inherit real property, and may transmit it to any of their children, without distinction as to the time of their birth', see 'Copy of the Report made by a Select Committee of the House of Commons, 2 June, 1843', in George Hansard, A Treatise on the Law Relating to Alien, and Denization and Naturalization (London: V\&R Stevens, 1844), pp. 203-204.

25 Selwood, Diversity and Difference, pp. 49-50; Luu, Immigrants, p. 144.

26 Daniel Statt, Foreigners and Englishmen: The Controversy Over Immigration and Population, 166o-176o (Cranbury: University of Delaware Press, 1995), p. 36, table 2.

27 Selwood, Diversity and Difference, p. 49. 
and actual patents of denization. ${ }^{28}$ In 1628 , the Privy Council accepted a petition from the merchant William Courten to be relieved from customs duties as an alien. Courten not only used his own credentials in the petition, but also those of his Dutch father who had been made a 'free denizen' of London who paid taxes whilst also accruing a substantial fortune. ${ }^{29}$ Courten used his father's position as a 'free denizen' but also drew on his reputation, wealth, and achievements to highlight what he thought made him legitimately English. The Privy Council accepted his petition, stating that the favourable decision should serve as 'an encouragement to him to trade more amply for the King's profit, and his own' ${ }^{30}$ Denizens were therefore tied to the political economy of the realm. Concerns were evidently less about individuals belonging to society and more about the circulation of wealth in the realm. However, as an increasingly unpopular group in the eyes of civic authorities, discontent regarding denizens escalated over the course of the seventeenth century.

Across the Atlantic, the legal foundations of American colonies complicated ideas of denization by connecting them to other legal identities such as 'subject'. In doing so, English authorities were able to manipulate questions of legal status to ensure loyalty to the nation and Crown. Despite domestic unpopularity towards denizens, the Crown used denization to address the colonists' problematic relationship to the English state. In four charters pertaining to America and spanning most of the seventeenth century, 'denizen' continued to ensure the domestic rights of colonists. ${ }^{11}$ Unlike in England, the word 'denizen' acquired a much more nuanced and complicated character when applied abroad which merged ideas surrounding the acquired privileges of foreign-born aliens and the natural rights of English-born subjects. In the first New England and the second Virginian charters, for example, the distinction between 'denizen' and 'subject' is blurred: the language defines the rights of the subjects and the rights of denizens as similar or the same. The earliest recorded cases of the conflation

28 Ibid.; Luu, 'Natural-born Versus Stanger-born Subjects: Aliens and their Status in Elizabethan London', in Immigrants in Tudor and Early Stuart England, ed. by Nigel Goose and Lien Luu (Eastbourne: Sussex Academic Press, 2003), p. 62.

2930 May 1628, Kew, The National Archives, PC 2/38, p. 182.

30 Ibid.; Selwood, Diversity and Difference, p. 110.

31 'Second Charter of Virginia (1609)'; 'Charter of New England (1620)'; 'Charter of Carolina (1663)'; 'Second Charter of Carolina (1665)', in Federal and State Constitutions, Colonial Charters, and Other Organic Laws of the States, Territories and Colonies Now or Heretofore Forming the United States of America, Vol. I, ed. by Francis Newton Thorpe (Washington, D.C.: Government Printing Office, 1909); Christopher Tomlins, Freedom Bound: Law, Labor, and Civic Identity in Colonizing English America, 1580-1865 (Cambridge: Cambridge University Press, 2010), pp. 82-83. 
of both 'denizen' and 'subject' appeared in the charters of the late sixteenth century, granted to Humphrey Gilbert and Walter Ralegh. ${ }^{32}$ In these cases, the individuals, including children, who settled in Newfoundland and North Carolina (then part of Virginia) would 'enjoye all priveleges of free denizens and persons native of England'. 33 The merging of these two legal entities continued into the seventeenth century. The Virginia charter of 1609 declared that 'everie the persons beinge oure subjects' in Virginia were to 'have [and] enjoye all liberties, franchesies and immunities of free denizens and naturall subjects within anie of oure other dominions'. ${ }^{34} \mathrm{~A}$ decade later, the charter for settlement in New England ensured that all children born on the other side of the Atlantic would 'enjoy all Liberties, and franchizes, and Immunities of free Denizens and naturall Subjects within any of our other Dominions' ${ }^{35}$ These charters highlight the legal confusion surrounding the status of children born abroad in the early period of seventeenth-century Atlantic settlement and colonisation. Thus, denizen identity is difficult to examine because the Crown, merchants, traders, and settlers did not have set definitions of their status in this unprecedented historical moment of change. England's new Atlantic territories defied domestic conventions. Settlers viewed themselves as legally English owed allegiance to the English Crown. Many, if not most, of the white settlers in these colonies were English subjects, and as such the status of their children would have been beyond question. Yet any child born in the colonies would technically be born abroad, and traditionally would have been considered a denizen. This confusion meant that in both charters there is no distinction made between the two statuses.

By the second half of the seventeenth century, English policymakers had more experience with colonisation, and a more developed legal apparatus used to justify and govern colonial endeavours. Granted by Charles II soon after the Restoration, the two Carolina charters illustrate how settler status matured after 50 years of colonisation. Unlike previous American charters, the Carolina charters of 1663 and 1665 firmly defined the status of children born to English settlers as denizen. Using identical language, both charters stipulated that the heirs, children, and descendants of individuals

32 See the 'Letters patent to Sir Humphrey Gilbert (1578)' and the 'Charter to Sir Walter Ralegh (1584)', in Federal and State Constitutions, Colonial Charters, and Other Organic Laws of the States, Territories and Colonies Now or Heretofore Forming the United States of America, Vol. I, ed. by Francis Newton Thorpe (Washington, D.C.: Government Printing Office, 1909), pp. 49-59.

33 'Letters Patent to Sir Humphrey Gilbert (1578)', ibid., p. 51.

34 'Second Virginia Charter (16og)', ibid., Vol. VII, p. 3800.

35 'New England Charter (1610)', ibid., Vol. III, p. 1839. 
'transported or to be transported into the said province' were to be 'denizens and lieges of us' ${ }^{36}$ In the same year, the Concessions and Agreements of the Lord Proprietors of the Province of Carolina named 'denizon' status to the residents of each ' $[t]$ ribe or parish' in the colony. ${ }^{37}$ However, unlike the limited privileges afforded to denizens in England, settlers in America used their own legislative bodies to acquire the rights of English subjects. For example, the concessions and agreements in Carolina allowed denizens to elect representatives to the council, something that denizens in England could not do. This right was firmly entrenched in many of the Atlantic settlements by the end of the century; nowhere more so than in Quaker Pennsylvania, where enfranchisement depended on whether individuals were 'free denizens of this government' $3^{8}$ Unlike in England, the status of denizens in English settlements in America adapted to incorporate broader rights that in England would have only been granted by naturalisation. These Atlantic charters, patents, and constitutions illustrate a legal disjuncture that developed between the domestic realm and the periphery, as the English travelled and settled across the world. Unlike earlier documents, the Carolina charters clearly outline the legal status of settlers and their children in the eyes of domestic English authorities. However, this clear definition was not necessarily shared by those who settled in America, and who had developed different ideas of what Englishness was. Despite continuing to use the language of the charters defining their legal persons as 'denizen', their privileges were the rights of natural born English subjects.

Related keywords: alien/stranger, citizen, settler, subject

36 'Carolina Charter (1663)' and 'Second Carolina Charter (1665)', ibid., Vol. V, pp. 2742-2755, $2761-2772,2747$.

37 'Concessions and Agreements of the Lord Proprietors of the Province of Carolina (1665)', ibid., pp. 2756-2761.

38 'Concessions and Agreements \& Frame of Government of Pennsylvania (1696)', ibid., pp. 2758, 3071 . 


\section{Envoy}

Derived from Old French envoy(e) and designating someone or something 'sent forth', 'envoy' and closely related words such as 'emissary' or 'mediator' were often used by early modern diplomats and bureaucrats to designate different types of diplomatic agents charged with temporary missions. ${ }^{1}$ While the appointments of resident ambassadors and the formation of a professional diplomatic corps were gradually adopted across Europe throughout the sixteenth and seventeenth centuries, there were significant financial costs associated with maintaining a permanent embassy in a foreign court. That, along with reasons of political strategy and symbolic communication, led many polities to preserve some of the ad hoc diplomatic practices that predominated between antiquity and the late fifteenth century. Indeed, the diplomatic terminology inherited from Roman and medieval eras persisted in the designation of temporary agents who were regularly identified with titles such as nuntius, orator, procurator, legatus, or missus. ${ }^{2}$ The fact that many of the holders of these titles shared similar functions with resident ambassadors contributed to a terminological confusion which lasted well into the early eighteenth century. François de Callières, the author of the influential De la manière de négocier avec les Souverains (1716), for instance, did not differentiate between envoy and negotiator when describing the function of the ambassador. ${ }^{3}$

In Elizabethan and Stuart diplomatic correspondence, 'envoy' and 'ambassador' were often interchangeable. The persistence of Latin as a diplomatic lingua franca throughout most of the sixteenth and seventeenth centuries favoured the use of words such as 'legatus' or 'orator' to identify a series of English diplomatic agents who were appointed to temporary missions. Nonetheless, the English translations of the summaries of diplomatic credentials and letters produced by Elizabethan and Stuart diplomats and bureaucrats frequently resort to the word 'envoy'. The association between 'envoys' and the transmission of messages is also attested by references in Elizabethan and Jacobean diplomatic correspondence. On 19 February 1569, for example, Christopher Mundt

1 'Envoy, n.', Oxford English Dictionary.

2 For the evolution of early modern diplomatic terminology see, for example, Dante Fedele, Naissance de la diplomatie moderne (XIIIe-XVIIe siècles): L'ambassadeur au croisement du droit, de l'éthique et de la politique (Baden-Baden: Nomos Verlag, 2017), pp. 191-280, 527-564.

3 José Calvet de Magalhães, The Pure Concept of Diplomacy, trans. by Bernardo Futscher Pereira (London: Greenwood, 1988), pp. 29-30, 51. 
wrote from Cologne to William Cecil that 'certain great men would wish her Majesty to send an envoy with congratulatory messages, and so to renew the old amity and confederacy with the Protestant princes'. ${ }^{4}$ In June 1580, Elizabeth I, hoping to impede the acclamation of Philip II of Spain as king of Portugal, planned to send an unnamed envoy to Lisbon to establish contact with the dukes of Braganza, rival claimants to the Portuguese throne, 'because we could by no other means, either from their ambassador resident here, or otherwise, understand certainly the state of their affairs, we resolved for our better satisfaction to send an express messenger to them'. 5

The envoy's role as an extraordinary messenger, as in the instance above, could leave them free to operate in some ways beyond the strictures and formal frameworks of diplomatic hierarchy, largely due to that emphasis on the successful completion of an immediate task - frequently the transmission of crucial information - rather than long-term diplomatic function. Tellingly, this freedom is reflected in the literary form of the 'envoy' which English writers began to exploit from the fourteenth century onwards, when it was popularised by medieval authors including Geoffrey Chaucer. It has been well established that Chaucer and his contemporaries adopted the form of the poetic 'envoi' or 'envoy' from the medieval French tradition of concluding a ballade with a final stanza dedicated to an addressee, often with a moral message. However, in English hands the poetic 'envoy' turned into a significantly more flexible vehicle. In Chaucer's fourteenth-century 'Lenvoy to King Richard', or John Lydgate's moral envoys in The Fall of Princes (1431-1448), the traditional humility topos of sending one's text out in the world was combined frequently with messages of instruction, advice, and sometimes sharp critique directed towards aristocratic addressees. ${ }^{6}$ Later, in a rapidly developing print market, Edmund Spenser's The shepheardes calender (1579) split up the envoy into multiple entities in 'To his booke', dedicating the text to Sir Philip Sidney and sending it forth among a wider, general readership.?

4 Christopher Mundt to Sir William Cecil, 18 February 1570, in Calendar of the Manuscripts of the Most Hon. the Marquis of Salisbury, Preserved at Hatfield House, Hertfordshire, Vol. 1: 1306-1571, ed. by S. R. Scargill-Bird (London: Her Majesty's Stationery Office, 1883), p. 464.

5 'Instructions for an Envoy to Portugal', June 1580, Kew, The National Archives, SP 89/1, f. 105 .

6 On the English poetic envoy, see Bernd Engler, 'Literary Form as Aesthetic Program: The Envoy in English and American Literature', REAL: The Yearbook of Research in English and American Literature, 7 (1990), 61-97.

7 Edmund Spenser, The shepheardes calender (London, 1579; STC 23089). 
Within actual diplomatic practice, professional contact between states often relied on individuals who were involved in transnational trading and intellectual, religious, or artistic networks. Envoys tended often to be individuals engaged in cross-cultural activities outside diplomacy, such as merchants, clergymen, physicians, travellers, interpreters, or factors. Thanks to their language skills, personal networks, and knowledge of local institutional apparatuses, these individuals were able to carry out specific missions as intermediaries. As facilitators of communication, envoys were individuals who had or developed the capacity to move between contexts that were both 'local' and 'global'. It was this element of mobility that allowed envoys to further communicate between different political systems and actors. ${ }^{8}$ Indeed, Tudor and Stuart monarchs often recruited foreigners as envoys or messengers. For example, Matias Becudo, a former Portuguese Franciscan friar and converso, was dispatched by Elizabeth I as an envoy to Marrakech to persuade the Moroccan emperor al-Mansur to grant the English a seaport in Morocco, thanks to his knowledge of Arabic, Portuguese, and Spanish. ${ }^{9}$ The Protestant Swiss refugee Stephen Le Sieur, thanks to his knowledge of French and German, was dispatched as envoy on several diplomatic missions to the German principalities, eventually appointed by James I as resident ambassador to the Holy Roman Empire, Florence, and the German Protestant princedoms, and rewarded with naturalisation in $1620 .^{10}$ In Pocahontas and the English Boys, the scholar Karen Kupperman positioned the Algonquian woman Pocahontas and the English boy-translators in the Chesapeake within this system of official communication, highlighting the role that women and children played within these structures of mediation and negotiation as messengers and valuable linguists. ${ }^{11}$

Foreign diplomatic agents, though not natural subjects of English monarchs, were usually recognised and appreciated as legitimate delegates of the English Crown. The Genoese merchant Horatio Palavicino served Elizabeth I in a variety of special diplomatic missions to Germany and France with the

8 For an introduction to the transcultural role of emissaries and envoys, see Brinda Charry and Gitanjali Shahani, 'Introduction', in Emissaries in Early Modern Literature and Culture: Mediation, Transmission, Traffic, 1550-170o, ed. by Brinda Charry and Gitanjali Shahani (London: Routledge, 2009), pp. 1-23.

9 Pedro de Frias, Crónica del-rei D. António, ed. by Mário Alberto Nunes da Costa (Coimbra: Universidade de Coimbra, 1955), p. 123; Gerald MacLean and Nabil Matar, Britain and the Islamic

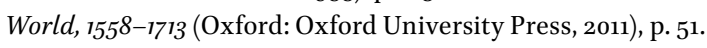

10 E. A. Beller, 'The Negotiations of Sir Stephen Le Sieur, 1584-1613', The English Historical Review, 40 (1925), 22-33.

11 Karen Ordahl Kupperman, Pocahontas and the English Boys: Caught Between Cultures in Early Virginia (New York: New York University Press, 2019). 
title of 'envoy from the Queen of England', and was praised by the Elector of Brandenburg in 1586 as a true representative of Elizabeth's royal dignity for 'diligently' representing 'her benevolent and favourable good-will'. ${ }^{2}$ This acceptance of a foreign messenger as a legitimate representative of an English monarch suggested that envoys and other emissaries could enjoy an honourable status even if they were 'strangers' or 'aliens' in the eyes of the law, and even though they were not vested with the symbolic and political privileges associated with resident ambassadors. In 1688, the author John Northleigh did not make a clear distinction between the functions of 'ambassador' and 'envoy', arguing that the 'Character of an Envoy is the most immediate representation of the King, and every Act of his, but another of the State. ${ }^{13}$

By the end of the seventeenth century, the employment of foreigners as diplomatic agents became more problematic. The development of a professional diplomatic corps, and the sensitivity of those state secrets that diplomats carried, encouraged the perception that diplomatic service should be exclusively in the remit of English subjects. The ascension of William of Orange to the English throne, and apprehension of growing Dutch influence on the English state, led to fears that the king appointing 'a Dutch Man Ambassador or Envoy to any Court in Europe' would lead to '[s]acrificing the Concernments of England, in that Court and Country, to the Pleasure and Profit of the Hollanders'. ${ }^{14}$

Although women tended to be theoretically excluded from formal diplomatic structures, ambassadors' wives, courtiers, servants, and other women who had privileged access to relevant political actors were often employed as informal envoys or messengers. Elizabeth I commissioned Lady Mary Sidney in 1559, for example, to discreetly establish contacts with the Spanish ambassador, Álvaro de la Quadra, regarding a potential marriage with Archduke Karl of Austria. ${ }^{15}$ Wives of English ambassadors stationed in Istanbul were often employed as discreet envoys to the seraglio as part of a strategy to access a key space

\footnotetext{
12 The Elector of Brandenburg to the Queen, 20 June 1586, Kew, The National Archives, SP 81/4/1, f. 144 .

13 John Northleigh, Natural allegiance, and a national protection (London, 1688; Wing N130o), p. 23.

14 Robert Ferguson, A brief account of some of the late incroachments and depredations of the Dutch upon the English (London 1695; Wing F731), p. 18.

15 Helena Graham-Matheson, 'Petticoats and Politics: Elisabeth Parr and Female Agency at the Early Elizabethan Court', in Politics of Female Households: Ladies-in-Waiting Across Early Modern Europe, ed. by Nadine Akkerman and Birgit Houben (Leiden: Brill, 2013), pp. 29-50 (p. 37).
} 
of Ottoman courtly politics, one that male political agents were barred from entering. Katherine Trumbull, wife of William Trumbull, the English ambassador to the Sublime Porte between 1687 and 1691, befriended Sultana Ümmühan, the aunt of Sultan Mehmed IV. As John-Paul Ghobrial has noted, this relationship between the two women allowed the ambassador to explore a new and privileged channel of communication with the Ottoman court. ${ }^{16}$

With the rising commercial interests of the English throughout the seventeenth century, the term 'envoy' was frequently applied to diplomatic agents of non-European polities. The English East India Company (EIC) and the Levant Company encountered highly developed diplomatic systems with their own complex protocols, practices, and conceptual frameworks. While European ambassadors and envoys enjoyed a privileged status inspired by the Roman law of nations in the Ottoman Empire, Morocco, Savafid Persia, or Mughal India, English and other European diplomatic agents found different notions of ambassadorship predominated. ${ }^{17}$ These often granted a limited legal and political status to diplomats. In his account of his travels to Persia and India, John Chardin explained to his readers that 'the Persians make no distinctions between Embassadours, Envoys, Agents, Residents, \&c. but still make use of the word Heltchi, which comprehends all. ${ }^{18}$ The encounter with diplomatic systems based on different notions of ambassadorship, which often required an almost ongoing negotiation with local authorities on the status of English diplomats, generated tension and contributed to a negative depiction of polities outside Europe by the English. Sir Thomas Roe, for example, complained that the Mughal court was a place 'not fit

16 John-Paul Ghobrial, The Whispers of Cities: Information Flows in Istanbul, London, and Paris in the Age of William Trumbull (Oxford: Oxford University Press, 2013), pp. 120-121.

17 For a discussion on the exchanges between European and non-European courtly centres see Sanjay Subrahmanyam, Empires between Islam and Christianity, 1500-180o (Albany, NY: SUNY Press, 2019); Sanjay Subrahmanyam, Courtly Encounters: Translating Courtliness and Violence in Early Modern Eurasia (Cambridge, MA: Harvard University Press, 2012); Joan-Pau Rubiés, 'Political Rationality and Cultural Distance in the European Embassies to Shah Abbas', Journal of Early Modern History, 20:4 (2016), 351-389; Daniel Goffman, 'Negotiating with the Renaissance State: The Ottoman Empire and the New Diplomacy', in The Early Modern Ottomans: Remapping the Empire, ed. by Virginia Aksan and Daniel Goffman (Cambridge: Cambridge University Press, 2007), pp. 61-74; Natalie Rothman, 'Afterword: Intermediaries, Mediation and Cross-Cultural Diplomacy in the Early Modern Mediterranean', Journal of Early Modern History 19:2-3 (2015), 245-259.

18 John Chardin, The travels of Sir John Chardin into Persia and the East-Indies (London, 1681; Wing C2043), p. 73 . 
to keep an Ambassador' and depicted Mughal diplomatic practices as 'affronts and slavish costumes'. ${ }^{19}$

Challenged with different categories of diplomatic agents and with a preference for temporary missions, the English and their European rivals in Asia and Africa frequently used the term 'envoy' as the closest embodiment of the Persian heltchi mentioned by Chardin. John Ovington observed 'a Chinese Madarine, who arrived at Suratt in the quality of an Envoy from Limpo', and Francis Brook transcribed a proclamation signed by William and Mary on an '[o]ffer from the Emperor of $\mathrm{Fez}$ and Morocco, by his Envoy sent hither to Treat about a general Redemption of all the English that are his Slaves'. ${ }^{20}$ As the scholar Jonathan Burton observes, the 'failure to consider how notions of an embassy or an ambassador can be specific to particular cultures' often led to an undervaluation of the diplomatic initiative for non-European polities. ${ }^{21}$ The widespread use of 'envoy', particularly to refer to African or Asian diplomats, suggests a reduction or over-simplification of these societies and their political and intellectual systems.

Related keywords: alien/stranger, ambassador, broker, interpreter, merchant

19 'Roe to Secretary Sir Ralph Winwood [secretary of state], zo November 1616', in The Embassy of Sir Thomas Roe to the Court of the Great Mogul, 1615-1619: As Narrated in his Journal and Correspondence, ed. by William Foster (London: Hakluyt Society, 1899), p. $35^{8}$.

20 John Ovington, A voyage to Suratt in the year 1689 (London, 1696; Wing O701), p. 307; Francis Brooks, Barbarian cruelty, being a true history of the distressed condition of the Christian captives under the tyranny of Mully Ishmael, Emperor of Morocco (London, 1693; Wing B4973), p. xxxiii. 21 Jonathan Burton, 'The Shah's Two Ambassadors: The Travels of the Three Brothers and the Global Early Modern', in Emissaries in Early Modern Literature and Culture, pp. 23-40 (p. 24). 


\section{Exile}

From religious nonconformists to kings and princes, exiles in the early modern period included people from various faiths, professions, and positions in society. The exile was defined by their metaphorical closeness to, and physical distance from, their homeland. Exiles carried with them the etymological memory of classical Latin exilium or exsilium, which signified not only the fact or condition of banishment, but in post-classical Latin stood also for ruin, waste, and destruction. From its earliest uses, the exile's separation from the local and familiar highlighted the precariousness of their identity. ${ }^{1}$ As one fourteenth-century author described, an individual was 'in gret peril / To lese his londes and ben exil'. ${ }^{2}$ Writers recognised that exile involved physical as well as legal and emotional isolation through separation, with the 'solitary place of myn exile' being away from 'native soil' and 'homeland'. 3

The early modern exile often articulated his or her identity through classical references to epic heroes or banished poets, and to biblical stories of Babylonian captivity. The pain of displacement found literary echoes in the works of the Roman poet Ovid, whose poems were widely translated in the seventeenth century. Metamorphoses, where Ovid channels his own anguish at being exiled through the myths and stories of the classical world, sparked the imagination of early modern English audiences. Translations of Metamorphoses highlighted early modern responses to the social implications of exile, describing how when 'Gods exile thee' you become 'most abhord', becoming 'despis'd, and torne'. ${ }^{4}$ Similarly, Puritans in the seventeenth century cherished the history of the Babylonian exile, as it reinforced that all human beings were exiles from Eden and through sin were distanced from God. Such exile carried an element of future restoration into the folds of belonging, for God's dealings with the tribes of

1 Christopher D'Addario, Exile and Journey in Seventeenth-Century Literature (Cambridge: Cambridge University Press, 2007), p. 31.

2 Of Arthour and Merlin, ed. by Osgar Duncan Macrae-Gibson (Oxford: Oxford University Press, 1973), p. 268.

3 Boethius, Boecius de consolacione philosophie (London, 1478; STC 3199), sig. [4]r; D'Addario, Exile and Journey, p. 32; Sharon Ouditt, 'Introduction', in Displaced Persons: Conditions of Exile in European Culture, ed. by Sharon Ouditt (Aldershot: Ashgate, 2002), pp. xii-xix, xii; Peter Burke, Exiles and Expatriates in the History of Knowledge, 1500-1700 (Waltham, MA: Brandeis University Press, 2017).

4 Ovid's metamorphosis englished by G[eorge] S[andys] (London, 1628; STC 18965), pp. 205, 367 . 
Israel during the Babylonian captivity reinforced the belief that he would eventually restore his faithful and return them home. By the seventeenth century this concept had a long history, having first occurred in medieval texts detailing that '[a]lle pe peple of it was in Babiloyne, and for-thy Jerusalem wepte and gretely sorowede her exile'. ${ }^{5}$ Whether volunteered or forced, exile involved painful separation, where a return to one's native soil was not guaranteed.

The boundaries between forced and voluntary exile were blurred during the sixteenth and seventeenth centuries at a time of profound socioeconomic, religious, and political change in Europe. State regimes could swiftly change from Protestant or Catholic and back again depending on the personal preferences or ambitions of a monarch, putting subjects in positions of danger and crisis. At varying points between $155^{\circ}$ and 1700 , English Catholics and Protestants moved to or fled from England, settling in Europe or further afield. The English Catholic cardinal William Allen reported those 'afflicted and banished Catholikes of our nation' who had sought and received shelter from the King of Spain by his 'speciall compassion and Regall munificence principally supported in this their longe exile'. ${ }^{6}$ Even the Calvinist archbishop of Canterbury, George Abbot, acknowledged the 'many Noblemen, and worthy Gentlemen' who were 'most zealous in the Catholique Religion' and had lost their lands to live in 'some exile'. From the 1620s, many Puritans fled to Europe and America, often establishing close-knit communities of 'many faithfull Exiles' in the Netherlands and eastern North America. ${ }^{8}$ As well as the individuals and communities that went into exile beyond England, there were also domestic exiles within England, cast out of their local communities over confessional divides. This included '[m]any godly and sweet Ministers' ejected from their parishes or, as Isaac Ambrose pointed out, more specifically 'exiled from Yorkshire' and other counties by the Act of Uniformity. ${ }^{9}$ Many were subsequently banished by the Five Mile Act (1665), which prevented them from living near

5 Edward Weatherly, Speculum sacerdotale (Oxford: Oxford University Press, 1936), p. 200.

6 William Allen, An admonition to the nobility and people of England and Ireland concerninge the present warres (London, 1588 ; STC 368 ), p. xlix.

7 George Abbot, The supplication of all the papists of England to King James (London, 1642; STC 6189), p. 3. Liesbeth Corens uses the term 'confessional mobility' to explore the forms of religious movement in this period. See Corens, Confessional Mobility and English Catholics in Counter-Reformation Europe (Oxford: Oxford University Press, 2018).

8 Simon Episcopius, The Popish labyrinth (London, 1673; Wing E3163), p. 7.

9 Isaac Ambrose, Media: the middle things, in reference to the first and last things (London, 1649; Wing A2958), p. 72. 
former congregations and parishes. ${ }^{10}$ This could be a profoundly unsettling experience, as much of a person's sense of worth and identity in early modern England came from their parish communities.

Depending on where they placed their confessional and political identities, the difference between 'forced' or 'voluntary' exile was slim. Some were 'forced to forsake their native country, \& live in exile' while others described choosing to 'enter into Monasteries into voluntary exile.." The law seemingly only allowed for an individual to be a voluntary exile. For example, 'no Fréeman' could be 'taken or imprisoned or disseised of his Fréehold or Liberties or Frée Customs, or be Outlawed or exiled. ${ }^{12}$ However, the forced or voluntary status of an exile was often blurred by the language of persecution or regime change. In a sermon to the House of Commons in 1641, the presbyterian Cornelius Burges evoked those ministers who 'underwent voluntary exile' during the 'heat of the Marian persecution.' ${ }^{13}$ Similarly, one anonymous English author, who titled himself 'A Friend to the Protestant Cause', wrote of those Protestants in Spain who had 'escaped the Devils paw' by going into 'voluntary Exile[s]'. ${ }^{14}$ Even following his father's defeat, authors would later call Charles II a 'voluntary exile', ignoring the fact that he and his siblings were effectively ejected by parliamentarian forces during the English civil wars. ${ }^{15}$ In these cases, and many more like them, immense religious, political, and physical persecution and crisis raised the question of how 'voluntary' such exile really was, and according to whom.

Exiles could keep close links with home through private correspondence or friendship/kin networks. The English Protestant community in Amsterdam was well known to Puritans in England. The nonconformist

10 John Coffey, 'Exile and Return in Anglo-American Puritanism', in Early Modern Ethnic and Religious Communities in Exile, ed. by Yosef Kaplan (Cambridge: Cambridge Scholar Publishing, 2017).

11 Henry Ainsworth, The confession offaith of certayn English people living in exile, in the Low countreyes (London, 1607; STC 18435), p. 5; William Wright, A briefe treatise in which, is made playne, that Catholikes living and dying in their profession, may be saved (London, 1623; STC $26044)$, p. 8.

12 A collection of the statutes made in the reigns of King Charles the I and King Charles the II (London, 1667; Wing E898), pp. 14, 4.

13 Cornelius Burges, The first sermon, preached to the Honourable House of Commons (London, 1641; Wing B5671), p. 53 .

14 Clamor sanguinis martyrum, or The bloody inquisition of Spain (London, 1656; Wing C4403), p. 41.

15 Peter Haylin, A short view of the life and reign of King Charles (the second monarch of Great Britain) from his birth to his burial (London, 1658; Wing H1735B), p. 132. 
clergyman and scholar Henry Ainsworth was the 'teacher of the English exiled Church in Amsterdam' whilst in 1649, a Master Woolsey wrote to the 'exiled church' there. ${ }^{16}$ The influential Puritan divine John Cotton wrote in 1648 that allies and enemies alike in England had become 'inquisitive into the cause' of why so many had fled England into 'voluntary exile.' ${ }^{17}$ Some years later Samuel Mather wrote of this connection and support to Congregationalists in England describing those settled in Massachusetts as 'Exiles for the same Cause'..$^{8}$ Similarly, Samuel's brother, Increase Mather wrote how their 'exile' in New England was an opportunity to 'vindicate our selves', highlighting the success of their godly way of life and the 'Congregationalist government' that they had established in Massachusetts to their supporters and detractors in England. ${ }^{19}$

Whether living in north-east America or the cities of northern Europe, exiles found themselves obsessed with the conditions of their exile and their hopes of returning home. Following the failed uprising against Elizabeth I in 1569, the Catholic noble Charles Neville, sixth Earl of Westmorland, first fled to Scotland and then after capture exiled himself to the Low Countries. In the early years of his exile, Neville retained hopes of returning to England, and wrote to his wife from Louvain of his willingness 'to accept of the Mediation' from the Earl of Leicester 'for his return from Exile', going so far as to offer 'to submit to any Pains her Majesty should inflict, saving his Life \& Conscience in point of Religion.' ${ }^{20}$ Westmorland's attempts to return through mediation failed, but he continued to seek to return to England, even using force by commanding a contingent of English fugitives during the Spanish Armada. Despite these attempts, Westmorland died penniless in Europe in 1601. In 1641, the Protestant residents of Antrim, Downe, Tyrone, and Ulster petitioned for religious sanctions to be lifted on their ministers so that they 'may have leave to returne from exile' and be 'freed from the unjust censure

16 Henry Ainsworth, A defence of the Holy Scriptures, worship, and ministerie (London, 1609; STC 235), frontispiece; Francis Johnson, A seasonable treatise for this age occasioned by a letter (London, 1657; Wing S2245), p. 1.

17 John Cotton, The way of Congregational churches cleared in two treatises (London, 1648; Wing C6469), p. 22.

18 Samuel Mather, A testimony from the Scripture against idolatry \& superstition in two sermons (London, 1670; Wing M1283), p. 2.

19 Increase Mather, The first principles of New-England concerning the subject of baptisme \& communion of churches (London, 1675; Wing M1211), p. 35.

20 Charles Earl of Westmorland to his Lady, 9 September 1574, in A Catalogue of the Harleian Manuscripts, in the British Museum: With Indexes of Persons, Places, and Matters, Vol. 3, ed. by Robert Nares, Stebbing Shaw, et. al (London: Record Commission Office, 1808), p. 467. 
imposed on them'. ${ }^{21}$ For the veteran exile Robert Ferguson, the prospects of exiled Protestants returning to England was of vital importance not only to himself but also for the 'Preservation of the Reformed Religion in Britain.' ${ }^{22}$ Ferguson had been ejected from churches in Scotland and England and then forced to escape to the Netherlands following his involvement in the failed Monmouth Rebellion. Aiding William III of Orange in the 'Glorious Revolution' not only offered him the opportunity to return to England, but he hoped it would 'revive the hopes' of many who had similarly fled their homeland by laying 'a foundation for the Redemption and Restauration of persecuted and exiled Protestants'. ${ }^{23}$ Exiles like Ferguson saw their separation as making possible their desire to live the religious life they wished, but it was related to a continual hope to influence the home they departed, so that they might one day return.

Religious difference was not the only impetus. Related to this, political upheavals led to the exile of individuals and families. Over the sixteenth and seventeenth centuries, England hosted multiple exiled nobles, princes, and monarchs, including the Douglas Archibald, Earl of Angus and the Prince and Count Palatine of Rhine, Rupert, both exiled due to conflict and internal political struggles in their own countries. In the case of political exiles, the English court often hosted nobles providing they swore allegiance to the Crown. In harbouring them, English leaders saw an opportunity to undermine the authority of their enemies at home and abroad. After fleeing Scotland in 1529, the Earl of Angus was granted permission to remain at the court as Henry VIII's guest if 'the Earl swear allegiance to him as supreme lord of Scotland, to pay him yearly 10ool. until he has been restored to his lands in Scotland'. ${ }^{24}$ Another illuminating example of the uses of foreign political exiles to further the geopolitical interests of the English Crown is the case of Dom António, the pretender to the Portuguese throne. After the invasion of a Spanish army led by the Duke of Alba to confirm Philip II's acclamation as King of Portugal, Dom António went to exile in 1580 seeking protection at the French and English courts. ${ }^{25}$ Both in Paris and London, Dom

21 The humble petition of the Protestant inhabitants of the counties of Antrium, Downe, Tyrone, $\& c$, part of the province of Ulster, in the kingdome of Ireland (London, 1641; Wing H3573), p. 2. 22 Robert Ferguson, A briefjustification of the Prince of Orange's descent into England (London, 1689; Wing F733), p. 39 .

23 Ibid.

24 Henry VIII to the Earl of Angus, 25 August 1524, in Letters and Papers, Foreign and Domestic, of the Reign of Henry VIII, Vol. 5: 1531-1533, ed. by J. Gardiner (London: Longman, 1880), p. 545.

25 For an overview of the Spanish annexation of Portugal see Rafael Valladares, La conquista de Lisboa: violencia military comunidad política en Portugal, 1578-1583 (Madrid: Marcial, 2008). 
António emerged as potential instrument to disturb Iberian foreign policy and colonial interests. Indeed, most of the attention given by Catherine de Médicis and Elizabeth I to the projects presented by Dom António stemmed from his promises to concede Portuguese colonial territories in exchange for French or English support. For example, the offer of one of the Portuguese fortresses in West Africa persuaded Elizabeth I to approve the 1582 ill-fated Anglo-French expedition to support the pro-Antonine rebels in the Azores. ${ }^{26}$ Between 1585 and 1590, the English authorities used Dom António and his network of supporters to undermine Iberian interests in Europe and beyond. Indeed, the Portuguese claimant's attempts to obtain support from the Moroccan sultan, for example, prompted Elizabeth diplomatic exchanges with al-Mansur, often mediated by two of Dom António's trusted agents - his son Cristovão and the converso Matias Bicudo, an experienced former Portuguese spy who operated in the Levant. ${ }^{27}$ Dom António also used Bicudo and two influential pro-Antonine Portuguese Jews based at the Ottoman court, David Passi and Álvaro Mendes (Salomon Ben Yaesh), to promote his cause at the Sublime Porte. Throughout these exploits, the English authorities often called on Passi and Mendes to further their contacts with the Ottoman sultan. ${ }^{28}$

Unlike these beneficial political exiles from other countries, the English viewed their own political exiles in a somewhat different light. Following the defeat of their father, the future monarchs Charles II and James II were forced to flee, which one contemporary described as being 'exiled as Traytors'. ${ }^{29}$ James II fled to France after a brief reign, living 'in exile, banished his Kingdoms by his own Children and Subjects' following the events of $1688 .^{30} \mathrm{He}$ became known as a 'Prince that would not hear the Counsel of

26 Gordon K. McBride, 'Elizabethan Foreign Policy in Microcosm: The Portuguese Pretender, 1580-1589', Albion: A Quarterly Journal Concerned with British Studies, 5:3 (1973), 193-210 (194). 27 See Nabil Matar, 'Elizabeth through Moroccan Eyes', in The Foreign Relations of Elizabeth $I$ ed. by Charles Beem (Basingstoke: Palgrave Macmillan, 2011), pp. 145-167 (151-153). For an overview of the career of Matias Bicudo see José Alberto Rodrigues da Silva Tavim, 'Portuguese New Christians in the Turkish "Carrefour" Between the Mediterranean and the Indian Ocean in the Sixteenth Century: Decentralization and Conversion', Journal of Early Modern History $17: 5^{-6}$ (2013), $561-584$.

28 On the articulation between these agents, Dom António's exploits and English interests in the Levant see, for example, José Alberto Rodrigues da Silva Tavim, 'Sephardic Intermediaries in the Ottoman Empire', Oriente Moderno, 93 (2013), 454-476.

29 Francis Eglesfield, The life and reigne of our sovereign lord, King Charles the II in a compendious chronicle relating both to His Majesties person and affairs (London, 166o; Wing E237A), p. $5^{8}$.

30 A Short and true relation of intrigues transacted both at home and abroad to restore the late King James (London, 1694; Wing S3557), p. 9. 
the Wise, but embraced the Advice of Fools' and 'expected by his Exile, when he left his People, to return Triumphantly an absolute Monarch'. ${ }^{11}$ James II's case highlighted the possibility of exile as banishment or a permanent state of being. In 1696, one contemporary celebrated the 'universal Joy and Satisfaction throughout the Realm' at the failure of James's '[r]eturn of an Exile. ${ }^{2}$

In America, exile took a different conceptual resonance for settlers, who often saw their migration across the Atlantic as a form of either voluntary or forced exile. The exiled religious communities that moved to America over this period understood and developed their identities in complex, often hybrid, ways, feeling a strong connection to England while also adapting to their new environments. As Christopher D'Addario has suggested, those religious exiles who settled in Massachusetts 'developed and displayed a specific notion of their endeavour in the New World that at once engages with their homeland and their particular relationship with that homeland' 33 Despite relocating themselves across the ocean into 'voluntary exile', the men and women who settled in Massachusetts through familial, legal and cultural ties 'maintained a strong sense of their identity as Englishmen'.34 Furthermore, they perceived almost simultaneously to be both forced and voluntary exiles whose religious beliefs had caused them to set out from England to establish a godly republic for both themselves and for England. ${ }^{35}$ At the same time, as Susan Hardman Moore has demonstrated, many of the English men and women who travelled to New England during the 'Great Migration' of the 1630 s often actively sought to return home, viewing their exile as necessary but impermanent. ${ }^{36}$

From the vantage point of the seventeenth century's religious and political turmoil, literature projected exile as a kind of death, confirming studies that have highlighted that royalists, and not just Puritan supporters of the parliamentarian cause, came to terms with their identities through the lens

32 AJerk for the Jacks, or, All their hopes are lost being an account of the vast and prodigious expectations (London, 1696; Wing J680), p. 9.

33 D'Addario, Exile and Journey, p. 31.

34 John Cotton, The way of Congregational churches cleared in two treatises (Boston: 1649, Wing C6469), p. 22; Increase Mather, David serving his generation, or, A sermon (Boston: 1698, Wing M1195), p. 38; D'Addario, Exile and Journey, p. 94.

35 Michael P. Winship, Godly Republicanism: Puritans, Pilgrims, and a City on a Hill (Cambridge, MA: Harvard University Press, 2012).

36 Susan Harman Moore, Abandoning America: Life-Stories from Early New England (Woodbridge: Boydell, 2015). 
of 'exile' ${ }^{37}$ Settlers who ventured to America used the Virgilian language of being 'expell'd and exil'd' to describe their migration. ${ }^{38}$ 'Admire only you have found me breathing, / After so many years here in Exilement', speaks the Ovid of the cavalier Sir Aston Cockayne, who spent time in exile with Charles II. ${ }^{39}$ 'Ovid weepes English now', wrote the minister Zachary Catlin in 1639, 'I had lost Ovid, and in Extasie / Wept for your Exile, and thought you were here. ${ }^{40}$

In many ways, exile was in the eye of the beholder. To the New England poet Anne Bradstreet, life in Massachusetts brought relief from the blood and turmoil of Old England. Godly exiles had, in essence, exiled themselves from those who had become estranged from redemption as a result of their own sin. In the tumult of the civil wars in her 'wicked land', '[s] ome sin'd, from house \& friends to exile went'. ${ }^{41} \mathrm{~A}$ variety of different and often conflicting facets, therefore, comprised the identity of early modern exiles. From the biblical language of the Babylonian captivity to resonances of Ovid and political exile, the exile, whether a king or yeoman, was defined by their separation and distance from the land they called home. For the traveller and colonist George Sandys, who translated several books of Metamorphoses while in Jamestown in the 1620 s, exile was 'cruell and deplored'. ${ }^{42}$ But despite the language of placelessness and lament, departing from one's homeland did not always mean a complete separation. Rather, exiles developed a complex relationship with their homes, retaining simultaneous identities as both English and exiled. The blurred distinctions between forced and voluntary exile highlight how early modern exiles considered themselves both passive and active agents in their own fate, affected by their own actions as well as events beyond their control. For many, the connection between the exile and his or her homeland operated as a two-way mirror, serving to remind them why they had left, and admonishing those who remained.

Related keywords: settler, subject, traveller

37 Literatures of Exile in the English Revolution and its Aftermath, 1640-169o, ed. by Philip Major (Burlington, VT: Ashgate, 2010).

38 Virgil, The works of Virgil containing his Pastorals, Georgics and Aeneis, trans. by John Dryden (London, 1697; Wing V616) p. 201.

39 Aston Cockayne, The tragedy of Ovid (London, 1669: Wing C49oo), sig. Div.

40 Ovid. De tristibus: or Mournefull elegies in five bookes: composed in his banishment, trans. by Zachary Catlin (London, 1639; STC 18981), sig. A5v.

41 Anne Bradstreet, 'A Dialogue Between Old England and New', in Several poems (Boston, 1678; Wing B4166), sigs. N2r-v.

42 Sandys, Ovid's metamorphosis, sig. A5v. 


\section{Foreigner}

Unlike today, when the word 'foreigner' refers primarily to the status of an individual who originated outside of the country they reside in, its early modern usage embraced three groups. The first group, similar to today's 'foreigner', were outsiders, people entering England from abroad. The first usage cited by the Oxford English Dictionary from the early fifteenth century distinguishes a person as not being from the country they were resident in, 'foreyners, nought of his propre peple'. ${ }^{1}$ However, in this usage 'alien' or 'stranger' was generally preferred. The second group can be defined as spiritual foreigners, people who through their faith were perceived to be biblically alienated from God and salvation. John Calvin used this often in his works to describe the gap in the relationship between God and the sinner, particularly Catholics: 'I am here a foriner and stranger, as all my fathers were'. ${ }^{2}$ Perhaps least expected, the third and most common - category referred to a domestic migrant, who, having moved from one parish or county to another, was considered a foreigner to the locality in which they settled. This wave of domestic migration in early modern England was the result of rapid population growth and the saturation of the agricultural job market. ${ }^{3}$ From parish to parish, county to county, English authorities became increasingly paranoid about the social effects of migration, and attempted to define and regulate those migrants. Those English men and women who migrated within England, leaving their rural homes for emerging towns and cities, were thus perceived to be foreigners by the authorities where they settled, as when local magistrates in Liverpool in 1565 passed an act in which 'men of Bolton, Blackburne or any other places' were to be given the status of 'foreigner'. ${ }^{4}$

Authorities in English commercial towns and cities legislated to protect their trade from domestic and international foreigners. Impelled by a

\footnotetext{
1 'Foreigner, n.', Oxford English Dictionary; The Pylgremage of the Sowle, translated oute of Frensshe into Englysshe, ed. by Katherine Isabella Cust (London; P. M. Pickering, 1859), p. 64.

2 John Calvin, The Institution of Christian Religion, trans. by Thomas Norton, (London, 1561; STC 4415), p. 200.

3 Peter Clark and Paul Slack, English Towns in Transitions, 1500-1700 (Oxford: Oxford University Press, 1976), p. 83; Keith Wrightson and David Levine, Poverty and Piety in an English Village: Terling, 1525-1700 (Oxford: Oxford University Press, 1995), p. 4.

4 City of Liverpool: Selections from the Municipal Archives and Records, From the 13th to the 17th Century Inclusive, Vol. 1 , ed. by James A. Picton (Liverpool: Gilbert G. Walmsley, 1870), p. 75 .
} 
saturated agricultural job market, these individuals travelled to obtain work in the emerging industries of more commercial areas. Migrating merchants or artisans from within England who settled in cities like London and Norfolk were among those classified as foreigners by urban authorities. Popular culture often conflated the threats posed by 'strangers and foreigners'. In the case of London, someone could be labelled a foreigner who had come 'from somewhere within the country, but outside the city of London' and was not a member of a guild, or a non-freeman of the city. ${ }^{5}$ Authorities often treated foreigners and aliens similarly, seeing them as a challenge to the commercial and social stability of the city. However, as Ian Archer has pointed out, the 'foreigner' or 'English non-free' did not face the same level of resentment as aliens, due to 'xenophobia and the ease with which [the aliens] could be identified'. ${ }^{6}$ Similarly, Jacob Selwood has discussed both the shared legal status of foreigners and aliens and the apparent breakdown of regulation in favour of 'Englishborn' foreigners in the city's livery companies. ${ }^{7}$ Likewise, Scots, Irish, and Welshmen, although at times seen as aliens or strangers, were, like the men and women of Bolton and Blackburn, 'subsumed within the larger category of foreigner'. ${ }^{8}$ The identity of people from within the British Isles was further complicated during times of conflict. After the English civil wars, Scots were regarded as both 'being forraigners and strangers' who had invaded England. ${ }^{9}$

This did not mean that 'foreigner' was not used to refer to people from abroad. In an age of rapid commercial and territorial expansion, the English interacted with numerous peoples of varying faiths and cultures. To early modern English men and women, these people and their customs were not only 'strange' or 'alien', but also markedly 'foreign'. Like domestic migrants, they were categorised more by their cultural differences than their similarities, evident in the rising interest, for example, in printed accounts of travel encounters or in the fashion for 'costume books' depicting the different habits and customs of individuals ranging from Scottish widows to Turkish mercenaries.

5 'London Aliens', Map of Early Modern London <https://mapoflondon.uvic.ca/ALIE1.htm> [Accessed 4 July 2019].

6 Ian W. Archer, The Pursuit of Stability: Social Relations in Elizabethan London (Cambridge: Cambridge University Press, 2002), p. 131.

7 Jacob Selwood, Diversity and Difference in Early Modern London (Farnham: Ashgate, 2010), p. 91.

8 Ibid., p. 20.

9 Christopher Love, The whole triall of Mr. Christopher Love (London, 166o; Wing W2065), p. 1. 
As mentioned above, the English conceptualised foreigners in temporal and spiritual terms, the former being an individual who was either locally or nationally an outsider, whilst the latter was someone who through faith and religious practice was made foreign to God. The spiritual foreigner was a popular motif throughout the early modern period, distinguishing between Christians and non-Christians but also between Catholics and Protestants. The Protestant doctrine that sin made all foreign to God, particularly espoused by Calvinists, led to the articulation that a spiritual 'foreigner' could only be naturalised through redemption and conversion. Ephesians 2:19, '[n]ow ye are no more strangers and foreigners: but citizens with the Saints, and of the household of God', became a popular verse to illustrate both the status of a spiritual foreigners and their transition through conversion into citizens of God..$^{10}$ The root of an individual's foreignness in this instance was based on the concept of original sin, that man had in the '[s]eparation from the fellowship of God, as Adam was cast out of Paradise' been 'estranged from the life of God' and as such were made 'forainers [...] farre off from him.." At its most simple, this concept meant that sin ensured that 'every man is a forreiner by birth, and a stranger by life' to God, a problem only rectified through conversion. ${ }^{12}$ Conversion operated much like denization or naturalisation did for a temporal foreigner. It allowed spiritual foreigners to be naturalised into the 'household' or nation of God. Just as Francis Bacon would later point out that '[n] aturalization doth but take out the marks of a Forreiner', conversion removed the mark of a spiritual foreigner. ${ }^{13}$ Further, the lines between the spiritual and the temporal were not easily drawn. For many in England, a spiritual foreigner was akin to a temporal foreigner. Whether Catholic, atheist, or Turk, multiple loyalties were at stake - not just loyalty to God, but to the monarch, who after the Reformation was head of both Church and state.

Fuelled by contemporary political and religious discourse, and antiCatholic rhetoric, the merging of temporal and spiritual foreignness was

10 Thomas Paynall, The piththy [sic] and moost notable sayinges of al scripture, gathered by Thomas Paynel (London, 1550; STC 19494.3), sig. Liv; Robert Bartholomew, A blow for the pope (London, 1625; STC 7148.3), p. 517.

11 John Downame, The summe of sacred divinitie briefly \& methodically propounded (London, 1625; STC 7148.3), p. 246.

12 William Ford, A sermon preached at Constantinople in the Vines of Perah, at the funerall of the vertuous and admired Lady Anne Glover, sometime wife to the honourable Knight Sir Thomas Glover (London, 1616; STC 11176), p. 57.

13 Francis Bacon, A speech delivered by Sir Francis Bacon, in the lower House of Parliament quinto Jacobi, concerning the article of naturalization of the Scottish nation (London, 1641; Wing B326), p. 13 . 
commonplace for many Protestant authors. This complicated how Catholic English subjects identified themselves spiritually and politically. While relatively tolerant to Catholics after ascending the English throne in 1603, King James invoked the dangers of multiple allegiances in his Oath of Allegiance of 16o6, composed in the aftermath of the Gunpowder Treason. All subjects were to renounce the authority of the pope and the power of 'any foreign prince to invade or annoy' the king. ${ }^{14}$ Their supposed allegiance to non-English leaders meant that many Catholics were treated with suspicion, frequently perceived as a threat to social stability and political order. ${ }^{15}$ The evangelical polemicist Thomas Bale described the threats as the 'ravenous desires' of 'unnaturall forainers' which had originally been brought into the country by 'the sleights enticements or traiterous conspiracie, of popish prestes and their adherents. ${ }^{16}$ Catholics like William Allen also described their position in the country as one of 'forreiners' who had 'passed their long banishement in honest povertie; and some in worshipful calling and roomes in universities.' ${ }^{17}$ The government increasingly sought to legislate against Catholics, so that the 'Romish hydra' would be 'by Gods mightie \& mercifull hand bee cut off', protecting themselves against an 'invasion of forreiners' that they thought to be instigated by English Catholics at home and abroad. ${ }^{18}$

In Robert Wilson's play, The Three Lords and Three Ladies of London (printed 159o), a sequel to the popular Three Ladies of London (printed 1584), the lords identified as Policy, Pomp, and Pleasure have to claim their rights to the hands of the ladies of London in competition with two rival groups. The three Spanish 'lords' (Pride, Ambition, and Tyranny) and the three Lords of Lincoln (Desire, Delight, and Devotion) are shown to be equally unsuccessful competitors, with the reigning judge Nemo deciding that London's ladies are best matched by ' $[t]$ heir countrimen, in London bred as they'. ${ }^{19}$ As numbers increased, the governing bodies in commercial

14 'An act for the better discovering and repressing of Popish recusants', 16o6, 3 \& 4 Jac. I c. 4.

15 Francis Bacon, Certaine miscellany works of the Right Honourable Francis Lo. Verulam, Viscount St. Alban (London, 1629; STC 1124), p. 28.

16 John Bale, An excellent and a right learned meditacion, compiled in two prayers most frutefull and necessary to be used and said of al ttue [sic] English men, in these daungerous daies of affliction (London, 1554; STC 17773), sig. Biv.

17 William Allen, A true, sincere and modest defence, of English Catholiques that suffer for their faith both at home and abrode (Rouen, 1584; STC 373), p. 46.

18 Laurence Humphrey, a view of the Romish hydra and monster, traison, against the Lords anointed (London, 1588; STC 13966).

19 Robert Wilson, The pleasant and stately morall, of the three lordes and three ladies of London (London, 1590; STC 25783), sig. D4v. 
cities, paranoid at the presence of 'foreigners' but equally conscious of the wealth they generated through their industrial labour, sought to heavily regulate their lives, keeping them in check whilst benefiting from their skill. In 1604, the Lord Mayor of London ordered that Blackwell Hall be 'appointed Market place and places, for all forreiners', both domestic and international, 'to sell every of the said severall cloth, clothes, wares and commodities'. ${ }^{20}$ In 1605 , Thomas Heywood's play, If you know not me, you know nobody (Part 2), would transpose such regulations abroad when one of its characters warns his runaway apprentice in France, 'thou canst not keepe open shop here, because thou art a forrainer, by the lawes of the Realme', and is reassured, 'Not within the libertie: but I hope the suburbs tollerates any man or woman to occupie for themselves, they may doo't in the Citie too, and they be naturaliz'd once'. ${ }^{21}$

Authorities tried to restrict where certain foreigners could buy and sell their products, and sought to prevent foreign artisans from accessing trade secrets. Two years after foreign cloth merchants were given the right to trade in Blackwell Hall, '[b]asketmakers, Gold-wyerdrawers, and other forraines' were banned from 'using mysteries [trades] within the said Citie'. ${ }^{22}$ Courtiers and MPs like Francis Bacon expressed an awareness that commercial growth rested on encouraging foreign input, for it was 'to be remembred, that for as much as the increase of any Estate, must be upon the Forrainer'. ${ }^{23}$ Nonetheless, Bacon's views were not shared by all, and City and national authorities continued to have a conflicted relationship with foreign merchants throughout the seventeenth century. In 1615, legislation against 'many Forreiners' targeted bakers, whilst the clause in an 1628 oath for freemen prescribed that they were to know no Forraigner to buy or sell any Merchandize, with any other forraigner within this City or franchise thereof', ordering individuals to warn City officials if they did. ${ }^{24}$ At the same time as City legislation acted against foreign merchants and artisans, Parliament declared it was 'very willing' to have '[f]oreigners, and Strangers

20 By the Mayor Orders set downe for Blackewelhall (London, 1604; STC 16719).

21 Thomas Heywood, The second part of, If you know not me, you know no bodie (London, 1605: STC 13336) sig. G3v.

22 By the Mayor An act of Common Councell, prohibiting all strangers borne, and forrainers, to use any trades, or keepe any maner of shops in any sort within this citty, liberties and freedome thereof (London, 1606; STC 16722).

23 Francis Bacon, The essayes or counsels, civill and morall (London, 1625; STC 1148), p. 84.

24 By the Major Whereas divers good acts and ordinances have heeretofore bene made, aswell by publique proclamations, as other waies: for the restraning the great abuses daily committed and used in brewing and uttering of extraordinary strong ale and beere (London, 1615; STC 16725.7); The Oath of every free-man of the citie of London (London, 1628; STC 16764.5). 
[...] receive all encouragement for Trade, and commerce with the City of London and other ports', offering foreigners protection to trade and sell goods across England. ${ }^{25}$

England's commercial and industrial growth forced authorities to move to protect English merchants in the emerging global markets that were being created through English and European territorial expansion. From the late sixteenth century, the English government began to compete beyond the British Isles and Europe, in the Atlantic, Mediterranean, and Indian Oceans, obtaining new commodities that had previously been 'fetcht from hence by forrainers'. ${ }^{26}$ This continued the uneasy relationship between City authorities and 'foreigners' and foreign commodities. To ensure commercial success, English authorities aggressively sought to protect their merchants and commercial outposts by regulating foreign involvement. This occasionally involved diplomacy and commercial treaties with foreign powers. In 1630, Charles I negotiated with Philip IV of Spain, ordering that Spanish merchants, though 'forreiners', were to be treated 'equall and like herein unto naturall Subjects'. ${ }^{27}$ Charles reached the same agreement twelve years later in a treaty negotiated with João IV of Portugal. ${ }^{28}$ Yet more often than not, English protection against foreign merchants was obtained through protectionism and mercantilist policies, epitomised by the first Navigation Act in 1651 .

In line with Parliament, English overseas companies implemented strict rules against foreign merchants from outside London and further afield. Merchants in the Muscovy Company were prevented from selling '[f]orraigners goods'. ${ }^{29}$ Policies such as those adopted by the Muscovy Company were replicated on a national and international level through the Navigation Acts, which prevented England's developing colonies from trading with other nations. This, according to one contemporary, was a 'Forreign Trade driven with Forreign Navigation', where the nation and 'Commodities' remained 'at Home to such Forreigners as come thither to Buy and Export them' $3^{\circ}$

25 An ordinance of the Lords and Commons assembled in Parliament declaring that it shall and may be lawfull for all foreigners and strangers in amity with this kingdome to have free trade and commerce to and from the city of London (London, 1644; E1833), pp. 3-5.

26 Samuel Purchas, Purchas his pilgrimes (London, 1625; STC 20509), p. 896.

27 England and Wales, Articles of peace, entercourse, and commerce concluded in the names of the most high and mighty kings, Charles by the grace of God King of Great Britaine, France and Ireland, defender of the faith (London, 1630; STC 9251.3), sig. D3r.

28 Articles of peace and commerce, between the high and mighty kings, Charles (London, 1642; Wing C2147).

29 Thomas Johnson, A plea for free-mens liberties (London, 1646; Wing J850), sig. A2.

30 William Petyt, Britannia languens: or, A discourse of trade (London, 1689; Wing P1947), p. 19. 
Ensuring that English commodities remained within English jurisdictions would thereby enrich the 'Nation with Treasure more or less, as the Commodities so sold are of greater or lesser quantity and value'..$^{11}$ Although popular amongst those who sought to keep trade out of 'the Forreigners Hands' both at home and abroad, such views also had their detractors. ${ }^{32}$ The Navigation Acts were not always popular amongst colonists in Virginia and Maryland, or merchants who staked a claim in colonial affairs. John Bland, a merchant who trafficked goods between London and Jamestown and spent much of his time in Seville, believed the Navigation Act would 'destroy so many thousands of Your Majesties Subjects'.33 Likewise, a contemporary of Bland bemoaned the imposition of the Navigation Act in Barbados, declaring that the English settlers that become nothing but 'poor English Forrainers'. ${ }^{34}$ Bland further argued that despite people leaving from 'all parts of England, to inhabit and cultivate this New Country', they were now looked upon through the imposition of the Navigation Act as '[f] orrainers and Aliens'.35 Securing England's commercial aims went hand in hand with regulating the involvement of foreigners in overseas trade. In doing so, however, English authorities increasingly alienated many people across the globe from its own commerce. This included the many go-betweens with specialised knowledge that made trade possible on the ground, and English travellers who felt that such acts and regulations made them foreign, or kept them isolated from the benefits of being English subjects.

Related keywords: alien/stranger, citizen, convert, exile, merchant

31 Ibid., p. 19.

32 East India Company, Reasons humbly offered by the Governour, Assistants fellowship of Eastland-Merchants against the giving of a general liberty to all persons whatsoever to export the English woollen-manufacture whither they please (London, 1689; Wing R532), p. 6.

33 John Bland, To the Kings Most Excellent Majesty the humble remonstrance ofJohn Blande of London, merchant, on the behalf of the inhabitants and planters in Virginia and Mariland (London, 1661; Wing B3157).

34 Edward Littleton, The groans of the plantations (London, 1689; Wing L2577), p. 8. 


\section{Friend/Ally}

Early modern English concepts of 'friend' and friendship, as elsewhere in Europe, were heavily influenced by the rediscovery of Aristotle's $\mathrm{Ni}$ comachean Ethics and Cicero's De amicitia, two works that proposed a vision of friendship that exalted virtuous unions between men who shared similar interests and social status. The Anglo-Saxon friund, derived from the Germanic base for 'free', denoted a condition akin to mutual trust and intimacy, or freedom from tribute. 'Friend' shared a similar formation to its antonym, fiend. ${ }^{1}$

Ciceronian views of friendship were particularly popular in Tudor humanist circles. In his translation of De amicitia (1550), John Harrington explained to his readers that his translation of Cicero's 'booke of friendship' aimed to promote 'the goodly rules, the natural order, and civil use of friendship' and demonstrate that only a 'faithfull, a sure, and a trusty friend, must need be a good, a wise, and a virtuous man'. ${ }^{2}$ Richard Hoper mentioned Cicero's work in The instruction of a Christian man, in vertue and honestie (1580) to support his theory that 'friends are to be reverenced and worshipped' in a relationship in which both parties are 'good and Honest', reciprocal, share a similar social status and education. ${ }^{3}$ Opposed to 'mutual love and favor' were 'unlikeness of studies, and diversity of manners' which 'break and departe friendship in sunder. ${ }^{4}$ True friendship, Thomas Churchyard maintained, 'proceeds from virtue, and hath so noble a nature (by a divine motion of goodnesse) that neither vice can corrupt, nor any kind of vanity vanquish'. ${ }^{5}$

Friendship manuals were highly attuned to issues of social status and political loyalty. In A tipe or figure of friendship (1598), Walter Dorke argued along the lines of Cicero that '[f]riendship is a perfect consent and agreement with benevolence \& charity in all things, appertaining as well towards God as men' and only possible 'among good men, and cannot be where virtue is

1 'Friend, $n$. and adj.', Oxford English Dictionary.

2 Marcus Tullius Cicero, The booke offreendeship of Marcus Tullie Cicero, ed. by and trans. by John Harrington (London, 1550; STC 5276), sig. A3r, A7r.

3 Richard Hoper, The instruction of a Christian man, in vertue and honestie (London, 1580; STC 13766.5), pp. 86-88.

4 Ibid.

5 Thomas Churchyard, A sparke offrendship and warme goodwill (London, 1588; STC 5257), sig. B4r. 
not'. ${ }^{6}$ This emphasis on virtue led Dorke to exclude 'the profitable friendship which is among Merchants [...] the pleasant friendship which is among Courtiers [...] [and] the common friendship which is among Clowns' from 'the true, perfect, and unfeigned friendship, which is neither for pleasure partely, nor for profit chiefely, but for vertues sake onely'. Dorke's 'petite pamphlet' was written with the intention to stimulate 'our Anglians to entertain \& embrace Friendship as a mightie co[m]panion and aide to vertues. ${ }^{8}$ The perfect embodiment of friendship, according to Dorke, was possible in England, a 'flourishing Iland' with religious and political stability, due to a Protestantism blessed by God and freed from the 'vices' that plagued other countries. In this way, Dorke defined a specific strain of English friendship by invoking the customs of other geographical spaces as foils. Roman friendships were too covetous, superstitious, and vainglorious, in Turkey 'their Mahomet is too monstrous', India was 'too rude and barbarous', Italy too 'proud and ambitious', Spain 'disdainful, vile and vicious', France 'craftie, fierce and furious', and the faults of German and Danish friendships were that 'they dedicate themselves to Bacchus'. ${ }^{9}$

Dorke's vision of the perfect friend as one who aligns to a Protestant morality was a strong characteristic of Elizabethan friendship books. ${ }^{10}$ Yet at the same time, the Henrician break with Rome through the Reformation, as well as increasing contacts with non-Christians beyond Europe, meant that 'friendship' and 'friend' provided a rhetoric of diplomatic well-wishing that enabled rulers to express the intention to sustain frequent and stable relations with another state or ruler despite religious differences. In many ways, Elizabeth I, as the queen of England, reflected both interpretations of friendship. The queen, according to Dorke, was an example of a true Protestant Christian friend for 'her gracious inclination and readiness in aiding the oppressed $[. .$.$] her godly zeale in planting the Gospel [...] her$ princely care, pitie, and pietie towards her own people and country, it would seem such, and so great, that it might well make all other Princes and Potentates rather amazed to hear it, than apt to imitate it'. ${ }^{11}$ However, the popular Ciceronian notion of friends as individuals engaged in a relationship

6 Walter Dorke, A tipe or figure offriendship Wherein is livelie, and compendiouslie expressed, the right nature and propertie of a perfect and true friend (London, 1598; STC 7060.5), sig. A4v.

7 Ibid., sig. A4r.

8 Ibid., sig. A2v.

9 Ibid., sig. Bir.

10 On masculinity and resistance to prescribed norms, see Alexandra Shepard, Meanings of Manhood in Early Modern England (Oxford: Oxford University Press, 2003).

11 Dorke, A tipe or figure of friendship, sig. Bir. 
of mutual kindness also enabled her to contribute to a developing rhetoric that evoked amity or the prospect of friendship even between hostile states. Elizabeth I could thus address other European rulers, including her arch-rival Philip II of Spain, with the formula 'Brother, cousin and our dearest friend'. ${ }^{12}$ Elizabethan foreign policy in the East was also often expressed in terms of such regal friendship. ${ }^{13}$ In 1601 , for example, Elizabeth raised the utility of diplomatic friendship in a letter addressed to the Sultan of Aceh, in which she suggested that when 'one land may have need of the other', they could 'breed intercourse and exchange of their Merchandise and Fruits, which doe superabound in some Countries, and want in others: but also ingender love and friendship betwixt all men, a thing naturally divine'. ${ }^{14}$

The link between 'friends' and political relationships can be seen in the rhetoric of friendship that guided wider diplomatic language, particularly in dealings with Eastern polities. The ambassador Anthony Jenkinson described his mission to the court of Tahmasp I of Persia as an intent 'to intreat friendship and free passage, and for his safe conduct to be granted unto English merchants to trade into his Seignories, with the like also to be granted to his subjects, when they should come into our countries, to the honour and wealth of both realms, and commodity of both their subjects.' ${ }^{15}$ The relations forged in cross-cultural trade were often used as a vehicle for diplomacy and evoked as a sign of friendship between different states that could expand commercial exchanges. In 1618, Richard Cocks reported to the administration of the East India Company (EIC) that the English factory at Bantam hoped to use their 'China friends', identified as Andre Dittis and Captain Whaw, to translate and send two letters from James I to the Chinese emperor, which included 'one in a friendly sort, and the other some stricter terms' ${ }^{16}$ After reading the two letters, Dittis and Whaw advised the EIC

12 Rayne Allinson, A Monarchy of Letters: Royal Correspondence and English Diplomacy in the Reign of Elizabeth I (Basingstoke: Palgrave Macmillan, 2012), p. 6 o.

13 Matthew Dimmock, Elizabethan Globalism: England, China, and the Rainbow Portrait (New Haven, CT: Yale University Press, 2019); Anthony Arlidge, Shakespeare and the Prince d'Amour: The Feast of Misrule in the Middle Temple (London: Giles de la Mar, 200o).

14 'Elizabeth by the grace of God, Queene of England, France and Ireland, defendresse of the Christian Faith and Religion, January 1601', in Samuel Purchas, Purchas his pilgrimes (London, 1625; STC 20509), p. 154.

15 Anthony Jenkinson, 'A compendious and briefe declaration of the journey of M. Anth. Jenkinson, from the famous citie of London into the land of Persia', in Richard Hakluyt, The principal navigations (London, 1599-16oo; STC 12626a), p. 346.

16 Richard Cocks to the East India Company, 15 February 1618, in Calendar of State Papers Colonial: East Indies, China, Japan, Vol. III: 1617-1621, ed. by W. Noel Sainsbury (London: Longman, 1870), pp. 127-128. 
'not to send the threatening letter, for they are assured there will nothing be done with the King (of China) by force [...] and the English nation worse thought of'. ${ }^{17}$

This association between friendship and alliance consolidated in the second half of the seventeenth century, during which diplomatic relations in Europe became increasingly formalised, even as conflicts between England, France, Spain and the Netherlands escalated. ${ }^{18}$ Words such as 'friend' or 'ally' therefore tended to be used in diplomatic texts and treaties to express an intention to normalise the relation between rival states, or to establish a set of conditions to avoid future conflicts. Rather than an indicative of 'true' friendship, they made communication between competing states possible. For example, the peace treaty signed between the Commonwealth of England and the United Provinces of the Netherlands in 1654 established that 'the two Commonwealths shall remain confederate friends, joined and allied together' and that both parties were 'bound to treat each other on both sides with all Love and Friendship'. ${ }^{19}$

Like 'friend', the word 'ally' (and 'alliance') often described specific types of political relationships. Alliances intended to formalise a set of rules that would secure the mutual kindness between both parties. These usually included the obligation to allow the subjects of each party to travel and trade freely in each territory and to be protected by the same laws; the obligation to include each party in other treaties of friendship and alliance signed with other princes or states; the prohibition to aid each other's enemies; and the obligation to provide military assistance. ${ }^{20}$ The duties imposed by treaties of alliance, however, were fragile and subordinate to reason of state. The religious controversialist Peter Heylyn criticised the pope

17 Ibid.

18 Evgeny Roshchin, Friendship Among Nations (Oxford: Oxford University Press, 2017), p. 128.

19 Articles of peace, union and confederation, concluded and agreed between his Highness Oliver Lord Protector of the common-wealth of England, Scotland \& Ireland, and the dominions thereto belonging (London, 1654; Thomason, E1603[35]), pp. 293, 298.

20 For a general overview of the uses of terms such as friendship and alliance in early modern diplomacy and treaties in Europe and beyond see John Watkins, 'Diplomatic Pathos: Sidney's Brazen Fictions and the Troubled Origins of International Laws', in Cultures of Diplomacy and Literary Writing in the Early Modern World, ed. by Tracey A. Sowerby and Joanna Craigwood (Oxford: Oxford University Press, 2019), pp. 70-84; C. H. Alexandrowicz, The Law of Nations in Global History, ed. by David Armitage and Jennifer Pitts (Oxford: Oxford University Press, 2017); Randall Lessafer, 'Peace Treaties and the Formation of International Law', in The Oxford Handbook of the History of International Law, ed. by Bardo Fassbender and Anne Peters (Oxford: Oxford University Press, 2012), pp. 71-94; Annabel S. Brett, Changes of State: Nature and the Limits of the City in Early Modern Natural Law (Princeton, NJ: Princeton University Press, 2011), pp. 169-194. 
for allowing the breaching of 'the Oaths of Princes, when they conceive themselves induced upon reason of State, to fly off from those Leagues, and break off those Treaties, which have been solemnly made and sworn betwixt them and their Neighbours. ${ }^{21}$ The administrators of the East India Company had a more cynical vision of the mutual obligations determined by these treaties, stating, during a period of conflict with Dutch East India Company in the 168 os, that 'the obligation of protecting an Ally, is but a political artifice.'. ${ }^{22}$

The political artifices of the treaties of 'friendship and alliance', however, framed the legal status of foreigners in England, as well as of English individuals in foreign countries. As Francis Bacon observed in his analysis of the degrees of aliens, those born 'under a King, or State, that is enemy' had no legal protection in England, a situation that translated the absence or breakdown of diplomatic relations. In the same way, the English law granted to those originated from 'friendly' polities 'a great benefit and protection'. ${ }^{23}$ Although these benefits excluded the possession of landed properties or real estate, Common Law allowed these 'alien friends' to be equipped to natural-born English subjects in other matters. As John Rastell noted, those with the status of 'alien friends' had the right 'to have and get within this realm, by gift, trade, or other lawful ways, any treasure or personal goods whatsoever, as well as any Englishman, and may maintain any Action for the same'. ${ }^{24}$ The notion of the 'alien friend' as someone who, albeit his foreign origin, can be integrated into the English commonwealth is patent in a 1653 anonymous pamphlet which, 'in behalfe of the poore of this nation', presented to Parliament presented a set of proposals and complaints regarding the country's economic structures. One of the issues raised was the efforts made by the 'Monopolizing Companies' to regulate and control different sectors of the English economy. The companies were accused not only of posing obstacles to English artisans and merchants, but also of being 'very hot in persecuting of many Alien friends, who have lived many years, married Englishwomen, Children borne here, paid all taxes all the time of the late War here'. 25

22 East India Company, An impartial vindication of the English East-India-Company (London, 1688; Wing I9o), p. 45.

23 Francis Bacon, A speech delivered by Sir Francis Bacon, in the lower House of Parliament quinto Iacobi, concerning the article of naturalization of the Scottish nation (London, 1641; Wing B326), p. 18.

24 John Rastell, Les termes de la ley (London, 1683; Wing R292), p. 41.

25 Proposals in behalfe of the poore of this nation (London, 1653; Wing R29), p. 6. 
Like the aliens living in England, the status English subjects was also defined by the vicissitudes of the evolution of English foreign policy. For example, after the failed ${ }_{1625}$ English expedition against Cádiz, the Spanish authorities at Naples ordered the imprisonment of all English merchants and the seizure of their goods. ${ }^{26}$ In spite of the normalisation of Anglo-Spanish relations in the 1630s, many English merchants based in the Viceroyalty of Naples complained about the hostile behaviour of the local authorities who continued to treat them as de facto enemies. One petition sent to Charles I and Parliament mentioned that English merchants often faced 'imprisoniment without cause, often by quite inferior officers, infringinge our libertie, wronge our Creditt, throwing disgrace upon our Comerce and our reputations.'. ${ }^{27}$ The restoration of the Anglo-Portuguese alliance, following the end of the Iberian Union in 1640, granted to English subjects a series of legal privileges. The treaties of 1642, 1654, and 1661, for example, allowed English residents in Portugal to enjoy freedom of worship and granted special fiscal and judicial conditions similar to the ones enjoyed by natural-born Portuguese subjects. ${ }^{28}$ While the concession of fiscal exemptions sought to enhance English trade, the judicial privileges avoided the full submission of English subjects to foreign laws. Freedom of worship was also a guarantee of preserving English autonomy and protect a national identity based on Protestant traits. The English community of Livorno, with the support of English diplomats, also made a systematic effort to persuade the Tuscan authorities to allow the presence of an English chaplain and the concession of a cemetery for English Protestants. As Lucia Frattarelli Fischer and Stefano Villani have argued, this was more a case of safeguarding social or national prestige than a matter of religion freedom. In the Duchy of Tuscany, as in other Catholic countries, non-Catholics often faced the risk of being buried in open field. The concession of a cemetery allowed thus to establish a space in foreign soil where the social status and national identity of English resident could be simultaneously preserved and affirmed. ${ }^{29}$

26 Helmut Koenigsberger, 'English Merchants in Naples and Sicily in the Seventeenth Century', The English Historical Review, 62:244 (1947), 304-326 (p. 312).

27 Quoted in ibid., p. 313.

28 For an overview of the privileges enjoyed by English merchants in Portugal see, for example, Richard Lodge, 'The English Factory at Lisbon: Some Chapters in Its History', Transactions of the Royal Historical Society, 16 (1933), 211-247.

29 Lucia Frattarelli Fischer and Stefano Villani, "People of every mixture": Immigration, Tolerance and Religious Conflicts in Early Modern Livorno', in Immigration and Emigration in Historical Perspective, ed. by Steven G. Ellis, Guðmundur Hálfdanarson, and Ann Katherine Isaacs (Pisa: Pisa University Press, 2007), pp. 93-107 (pp. 101-102). 
The reciprocal obligations imposed by these treaties echoed the understanding of 'alliance' as it pertained to marriage or to a union between families. Marriages, like peace treaties or political alliances, were theoretically based on mutual or contractual obligations, as when Elizabeth I styled herself as the Virgin Queen, married to her realm. Female bodies were often used to effect this double-pronged understanding of alliance as both marriage and political or diplomatic bond, serving to bring families and states together through their bodies. The justification of a sinner (1650) presented 'the contract of Marriage' as an alliance since 'all Alliances are also Contracts; because an alliance is alligatio partium $[\ldots]$ a binding or tying of parties together each to other'. ${ }^{30}$ Marriage was therefore the basis of 'all natural and legitimate alliance by blood', in which 'man is thereby bound to perform unto his Wife all the offices and duties of a Husband, and reciprocally the woman is bound to all the offices and duties of a Wife; for hence Marriage is called Wedlock, because it lockes and binds the parties wedded' $3^{31}$ Like the conditions determined by treaties of 'peace, friendship and alliance', marriages ought to not be temporary, 'but of perpetuity for ever'. ${ }^{2}$ At the same time, women were often seen as coming between or rupturing the politically and diplomatically loaded bonds of friendship between men. In Thomas Painter's 1567 retelling of the Roman conquest of Africa and the virtuous suicide of the Carthaginian noblewoman Sophonisba, the Roman general Scipio seeks to dissuade his friend Massinissa from losing his territorial conquests at the expense of lust. 'Sophonisba with hir toyes \& flatteries did alienat and withdraw king Syphax from our amitie and friendship', Scipio maintains, and she would do the same with him. ${ }^{33}$ Although the embodiment of civility - a 'passing faire gentlewoman, of flourishing age and comely behaviour, none unto hir within the whole region of Affrica [...] [with] pleasant grace by amiable gesture' - she 'intrapped and tangled [Massinissa] in the nettes of Love', nearly causing him to lose his political identity. ${ }^{34}$

Johann Crell's analogy between a marriage and a treaty of alliance reflected an increasing trend by the mid-seventeenth century to use terms such as 'friend' or 'ally' to describe relationships between family members,

30 Johann Crell, The justification of a sinner being the maine argument of the Epistle to the Galatians (London, 1650; Wing C6878), p. 199.

31 Ibid.

32 Ibid., p. 235.

William Painter, The second tome of the Palace of pleasure (London, 1567; STC 19124), p. 54. 
spouses, or business partners. In Jeremy Taylor's The Measures and Offices of Friendship (1657), discussions of classical, medieval, and Renaissance visions of friendship led to the conclusion that 'friends are meant our acquaintance, or our Kindred, the relatives of our family or our fortune, or our sect'.35 Taylor's universal notion of 'friend' suggested an equality between men and women, an idea that was present in the creation of the Society of Friends, or Quakers, in the mid-seventeenth century, but which collided with the more traditional views proposed by classical and puritan works. ${ }^{36}$

In sum, the uses and pleasures of friendship were celebrated throughout this period as good and necessary for civil society, while notions of friendship were often laced with warnings against false friends and the threat of enmity and deception. As England's global connections developed, discourses of friendship and alliance became increasingly important in providing a framework for contact across religious and cultural divides. At the same time, transatlantic friendships were viewed as a means of maintaining bonds between subjects and settlers that modelled earlier visions of trust and love. Panegyric verses that prefaced travel narratives, like 'Samuel Purchas of his friend Captaine John Smith', lauded those 'friends' who had ventured abroad in service to the state and the project of expansion. ${ }^{37}$ Such verses, set against the supposedly 'savage' or rude fabric of Indigenous societies, continued to place male friendships in particular at the heart of stable civil society. Writing for audiences in New England and London in the 1620 s, the colonist and clergyman Robert Cushman specifically viewed 'the sweetnesse of true friendship' as the means whereby English colonialism and the 'civilising' of Native Americans might be effected. ${ }^{38}$

In the end, then, friendship was valued for the bond it brought between individuals as a kind of virtuous, pragmatic, but also quasi-spiritual and deeply-valued companionship. Since friendship bonded people together, it was inevitably entangled in political and social ideas about civility and the nature of civil society itself. Whoever truly loved solitude and withdrew

35 Jeremy Taylor, The measures and offices offriendship (London, 1657; Wing T350), p. 4. 36 Jordan Landes, London Quakers in the Transatlantic World: The Creation of an Early Modern Community (London: Palgrave Macmillan, 2015); Naomi Pullin, Female Friends and the Making of Transatlantic Quakerism, 1650-1750 (Cambridge: Cambridge University Press, 2018).

37 John Smith, A generall historie of Virginia, New-England, and the Summer Isles (London, 1624; STC 22790). For a discussion of friendship and colonial state-building, see Lauren Working, The Making of an Imperial Polity: Civility and America in the Jacobean Metropolis (Cambridge: Cambridge University Press, 2020), pp. 210-213.

38 Quoted in Working, The Making of an Imperial Polity, p. 211. 
for public life, Francis Bacon maintained in his essay 'On Friendship', was either 'a wilde Beast, or a God'.39 A person's '[a]versation towards Society' made them a '[s]avage Beast', unable to better themselves or the world around them. ${ }^{40}$

Related keywords: alien/stranger, courtier, envoy

39 Francis Bacon, 'Of Frendship', in The essayes or councills, civill and moral (London, 1625; STC 1148), p. 149 .

40 Ibid. 


\section{Gypsy}

Exiles from Egypt, travellers from the East, 'counterfeit Egyptians', strategic performers: Romani people or 'Gypsies' in early modern England evaded easy categorisation. ${ }^{1}$ They were often vilified by policymakers and moral authorities who considered them to exist dangerously beyond the scope of English law and government. 'By name they are called Gypsies, they call themselves Egiptians', reported Thomas Dekker in 16o9. 'They are a people more scattred then $[$ sic $]$ Jewes, and more hated'. ${ }^{2}$ They have 'the bodies of Frantick persons' dictated by influence of the moon, acting like the 'onely base Ronnagants [renegades] upon earth'. 'Foraging' and mobile, carrying their belongings with them as they travelled from town to town or parish to parish, Gypsy communities mingled with English parishioners in the localities while remaining recognisably separate. ${ }^{4}$ Their status, 'culturally different yet legally naturalized', challenged the categories of 'subject', 'stranger', and 'traveller' that authorities sought to impose, instigating broader discussions about vagrancy and social defiance. ${ }^{5}$

The Romani people are now largely recognised to have originated from north-western India. They migrated into Persia, then the Ottoman and Byzantine empires, and were present in Europe from the Middle Ages. ${ }^{6}$ Within Europe, Gypsies settled in the Balkan provinces, north of the Danube in present-day Romania (though the etymologies of 'Romania' and 'Romani' are unrelated), or travelled further west, eventually arriving in England and Scotland. ${ }^{7}$ While present in Germany, France, Switzerland, Italy, Spain, and the Low Countries by the 1420s, Gypsies are not recorded

1 Capitalising 'Gypsy' follows the preference of some Romani activists and academics, who use the term as a proper noun. While the word is here discussed in relation to its early modern usages, it remains contested. For more information on the Romani people and their self-identification, see David Cressy, Gypsies: An English History (Oxford: Oxford University Press, 2018), pp. x-xi; Romani Culture and Gypsy Identity, ed. by Thomas Acton and Gary Mundy (Hatfield: University of Hertfordshire Press, 1999).

2 Thomas Dekker, Lanthorne and candle-light (London, 16o9; STC 6486), sig. Hir.

3 Ibid., sig. Hiv.

4 David Cressy, 'Trouble with Gypsies in Early Modern England', The Historical Journal, 59 (2016), 45-70 (p. 69).

5 Mark Netzloff, “Counterfeit Egyptians” and Imagined Borders: Jonson's “The Gypsies Metamorphosed"', ELH: A Journal of English Literary History, 68:4 (2001), 763-93 (p. 772).

6 Becky Taylor, Another Darkness, Another Dawn: A History of Gypsies, Roma and Travellers (London: Reaktion, 2014), p. 18.

7 Ibid., p. 19. 
in the British Isles until the early sixteenth century. ${ }^{8}$ Since Gypsies moved between towns and geographic spaces, they were viewed as 'a strange and illegitimate hybrid, neither Egyptian nor English, neither black nor white'. ${ }^{9}$ The tendency to identify Gypsies as both domestic vagrants and more exotic, ethnographically-different 'others' is typified in a court masque from 1621, where one character presented the Gypsy children as 'the five princes of Egypt', 'begotten upon several Cleopatras in their several counties. ${ }^{10}$ While presenting them as 'the offspring of Ptolemy' and therefore Egyptian, the reference to 'counties' evoke the parish system of early modern England. ${ }^{11}$

To English observers, mobility remained a key marker of Gypsy identity. According to a tale that some Gypsies also reportedly perpetuated, they had originated from a tribe in Egypt, condemned to wander as exiles for refusing to shelter Mary and Joseph. At the ordinance of the pope, they travelled through Europe on a pilgrimage as penance, one of the few accepted forms of mobility in the medieval period. ${ }^{2}$ Early modern individuals expressed scepticism at this tale; as Andrew Boorde related in 1542, "[t]her be few or none of the Egypcions that doth dwel in Egipt, for Egipt is repleted now with infydele alyons'.13 Gypsies purposely enhanced their origin story, Samuel Rid maintained in 1614, by staining their faces, adopting colourful and patched-up clothing, and imitating nomadic groups from the Mediterranean and the East, but their origins were not easy to verify. ${ }^{14}$

The religious element in ethnographic depictions of Gypsies in early modern England is remarkably muted. While 'Turk' or 'Jew' were terms that did not easily separate religion and ethnicity, sixteenth- and seventeenthcentury writers rarely focused on the religious beliefs of Gypsies. Though their palm-reading at times seemed to evidence superstition, Gypsies were rarely accused of witchcraft and put on trial. Becky Taylor suggests this was because the fear of malevolent magic was generally considered to be a threat within a community, rather than outside of it, which highlights the exclusion of Gypsies in English parishes. ${ }^{15}$

Ibid., pp. 38-39.

9 Quoted in Sujata Iyengar, Shades of Difference: Mythologies of Skin Color in Early Modern England (Philadelphia: University of Pennsylvania Press, 2005), p. 182.

10 Quoted in Netloff, “'Counterfeit Egyptians”, p. 772.

11 Ibid.

12 Taylor, Another Darkness, Another Dawn, pp. 42-43.

13 David Mayall, Gypsy Identities, 1500-200o: From Egipcyans and Moon-men to the Ethnic

Romany (New York: Routledge, 2004), p. 75.

14 Samuel Rid, The art ofjugling or legerdemaine (London, 1614; STC 21028).

15

Taylor, Another Darkness, Another Dawn, p. 49. 
English authors seemed more concerned with the fluidity of Gypsy identities, including 'counterfeit gypsies', or English men and women who joined such communities. Anti-vagrant legislation specifically attempted to limit Gypsies' geographic mobility to better regulate them. ${ }^{16}$ A 1530 act against Gypsies called 'Egyptians' an 'owtlandisshe' people, dangerously mobile and resisting the realm's parish system, travelling instead 'from Shyre to Shyre and place to place' telling fortunes and deceiving 'the people of theyr Money'. ${ }^{17}$ Repeated legislation in $155^{2}$ and 1554 threatened Gypsies with imprisonment and loss of goods. Gypsies could be whipped, mutilated, and even subject to death if charged with repeat offences. The Act for the further punishment of those vagabonds calling themselves Egyptian (1562) included 'counterfeit' Egyptians or those 'vagabonds calling themselves Egytptians' in their legislation, exhibiting concerns with English-born subjects who adopted the manners and lifestyles of Gypsies. ${ }^{18}$ 'Looke what difference there is between a civill cittizen of Dublin \& a wilde Irish Kerne, so much difference there is betweene one of these counterfeit Egiptians and a true English begger', Dekker wrote. ${ }^{19}$

English men and women who assumed Gypsy identification were liable to the same severe punishments as Gypsies themselves. In 1596, all persons pretending to be Egyptians, or 'wandering in the Habite Forme or Attyre of counterfayte Egypcians' were to be punished as felons. This law was significant in that it disregarded previous categories of 'real' and 'counterfeit' Gypsies, suggesting that the identity of the 'genuine' Egyptian no longer existed and that Gypsies and vagrants were viewed as one of the same thing. ${ }^{20}$ Both Gypsies and 'such fellowes as tooke upon them the name of Egiptians above the age of fourteene, or that shal come over and be transported into England, or any other persons, as shal be seene in the company of Vagabonds calling themselves Egipctians, or counterfeiting, transforming, or disguising themselves by their apparel, speach, or other behaviours into Egyptians and so shall continue, either at one, or severall times, by the space of a month they should be adjudged fellons'. ${ }^{21}$ In 1628, John Agglinton, a runaway apprentice, was apprehended 'in the company of certain counterfeit Egyptians that were tried and executed at the last

16 Mark Netzloff, England's Internal Colonies: Class, Capital, and the Literature of Early Modern English Colonialism (Basingstoke: Palgrave, 2003), p. 135.

17 'Egyptians Act', 1530, 22 Hen. VIII, c. 10.

18 'Tillage Act', 1562, 5 Eliz. I c. 2.

19 Dekker, Lanthorne, sig. Hiv.

20 Iyengar, Shades of Difference, p. 177.

21 Rid, The art of jugling, sig. B2r. 
assizes in Suffolk'. ${ }^{22}$ Though not condemned under the Egyptian Act of 1562, Agglinton was sent back to his master and subsequently re-apprenticed to a shipwright. As David Cressy has observed, the apprentice's time among the Gypsies, and his return to settled English society, 'indicates [...] the porosity of the boundaries between migrants and mainstream populations'. ${ }^{23}$ At the same time, the desire to see Gypsies, 'throughe wholsome lawes [...] dispersed, vanished \& the memory of them cleane extynguyshed' did not succeed, even when authorities took measures to assimilate or drive them from the realm. ${ }^{24}$

The severe sentencing against Gypsies suggests a disproportionate fear not of large numbers of the English population actually becoming Gypsies, but of the idea that national character was threatened by those who rejected the centralising state and the vision of Englishness it advanced. ${ }^{25}$ Gypsies were incorporated into concerns of a larger vagrant underworld populated by spies, thieves, Catholics, and other figures of ambiguous loyalties towards the central government, at a time when population increase, food riots, and harvest failures were contributing to a climate of malaise and societal discontent. ${ }^{26}$ It is no coincidence that Dekker compared Gypsies to the 'wilde Irish kerne': kerns were Gaelic soldiers from Ireland, many of whom fought for Gaelic lords or Catholic powers on the Continent, and who represented a threat to Protestant order. ${ }^{27}$ Gypsies were thus portrayed as elusive figures, English and not-English, ever-present, yet able to evade the control of local authorities.

In 1584, William Harborne wrote to Francis Walsingham about his encounter with 'a Rude, Rough, rustical Arabian [horse], Presently putt to sale by a black, base, empti-pursed Egyptian'. Harborne '[p]ittied his povertie, paid his price, \& bettered his beeing. ${ }^{28}$ Whether Harborne's financial offering improved the quality of life of the 'Egyptian', the letter offers insight into the life of a Gypsy man, seen as 'black' and set apart, but who played a role in the circulation of goods and who was a familiar figure occupying the English landscape.

\footnotetext{
22 Quoted in Cressy, 'Trouble with Gypsies', p. 69.

23 Ibid.

24 Thomas Harman, A caveat for commen cursetors vulgarely called vagabones (London, 1567; STC 12787), sig. A3v.

25 Iyengar, Shades of Difference, p. 176; Netzloff, England's Internal Colonies, pp. 135-165.

26 Mayall, Gypsy Identities, p. 61; Iyengar, Shades of Difference, p. 180.

27 Dekker, Lanthorne, sig. Hiv.

28 William Harborne to Francis Walsingham, 11 December 1584, Kew, The National Archives, SP $97 / 1$, f. 81 .
} 
The skill that authorities attributed to Gypsies in creating a place for themselves within those networks of social and economic circulation led to extraordinary accounts of Gypsy self-fashioning. However exaggerated, Gypsies were seen to occupy complex alternate societies, deviously carnivalesque and staunchly in control of their lives and livelihoods. Like actors, they were accused of wearing costumes that changed their appearance and instilled a resistance to conformity. Thomas Harman's 1567 tract against vagabonds, printed three times in the 1560 s and again in 1573 , spent a good deal of ink describing 'Egiptians', who spent their time 'fedinge the rude common people wholy addicted and geven to novelties, joyes, and newe inventions'. ${ }^{29}$ 'Their apparell is od[d], and phantasticke', Dekker wrote, with women dressed 'like one that plaies, the Roague on a Stage'. ${ }^{0}$ Dekker conceded that though Gypsies wore garish scarves and mantles, their undergarments were 'hansome and in fashion'. ${ }^{11}$ Both Harman and Dekker believed Gypsies fell in the category of undeserving poor because they wilfully cozened others, building a strong community for themselves through distinct fashions and habits. They inveigled others with 'the strangeness of the attyre of their heads, and practising paumistrie', through their secret language and riotous, indulgent behaviour. ${ }^{32}$

Aristocratic performances perpetuated such stereotypes. In Ben Jonson's The Gypsies Metamorphosed of 1621, the Duke of Buckingham, after much singing, dancing, and pickpocketing, washed away his darkened face to reveal the graceful courtier underneath. Thomas Middleton and William Rowley's play, The Spanish Gypsy, performed at court in 1623, explicitly linked counterfeit Egyptians - 'Gipsies, but no tann'd ones, no Red-oker rascalls umberd with soot and bacon as the English Gipsies are' - with evasion of the law and the antics of a travelling troupe. ${ }^{33}$ The recognition of their skill cast further ambiguity on Gypsies and their public image, but they remained categorised by visual difference.

In many ways, the difficulties of categorising Gypsies were precisely what made them such a source of fascination. Gypsies continued to be associated with oracles and prophecies, cozening underworlds and vagabondage into the late seventeenth century. A painting of a 'Gipsy Woman with her children' appeared in an auction catalogue in 1690 alongside landscapes,

Harman, A caveat for commen cursetors vulgarely called vagabones, sig. A3v.

Ibid.

Harman, A caveat, sig. A3v.

33 Thomas Middleton and William Rowley, The Spanish gipsie (London, 1653; Wing M1986), sig. C2r. 
shepherdesses, and Mary Magdalenes..$^{34}$ Gypsy tricksters were a regular feature of picaresque tales and ballads of travel and country wanders, and 'coy' Gypsy women often appeared in sexually exploitative tales about seduction and the wiles of women. ${ }^{35}$ 'Like a right Gypsie', Antony laments in Shakespeare's The Tragedie of Antonie, and Cleopatra (1616), she 'fast and loose Beguil'd me' ${ }^{6}$ 'She was a very Gipsie', says one character of his innamorata in James Shirley's Changes, or Love in a maze (1632), 'she us'd me / Basely'. ${ }^{37}$ Such examples disparagingly associated female power with the subversion of tricksters while perpetuating ideas of ethnic difference.

These examples also point to the agency of mobile women, not just in literature but in life. In 1594, Judith Phillips, otherwise known as 'Doll Pope', was imprisoned and examined for cozening a widow out of a gold chain: 'Judith had used this manner of trade of cozenage a long time and had wandered the country in the company of divers persons naming themselves Egyptians' ${ }^{3}{ }^{8}$ Into the late seventeenth and eighteenth centuries, women who aligned themselves with Gypsies continued to be brought to trial for theft and vagabondage. In 1695, one Elizabeth Johnson was accused of 'pretending her self to be an Egyptian, and having familiarity with evil Spirits, and pretending by Magick Arts she could discover where Treasure was hid'. ${ }^{39}$ Seeking to punish unregulated male and female mobility, authorities condemned the wanderer who associated his or herself with Gypsies, punishing them for their 'wicked Lives [...] and sinful Courses': it was a sin 'to pretend'. ${ }^{40}$

Related keywords: rogue, subject, vagrant

34 A collection of paintings, and several other curiosities (London, 1690; Wing C5163), p. 4.

35 To His Excellency General Monck (London, 166o; Wing T1345A); Love in a barn. Or, Right country courtship (London, 1670; Wing L3206); Methinks the poor town has been troubles too long, or, A Collection of the several songs now in mode either at the court or theatres (London, 1673; Wing M1940); Homer alamode, the second part, in English burlesque (London, 1681; Wing S2133); The Fifteen comforts of rash and inconsiderate marriage (London, 1694; Wing F886).

36 William Shakespeare, 'The Tragedie of Anthonie, and Cleopatra', in Mr William Shakespeares comedies, histories, \& tragedies (London, 1623; STC 22273), pp. 340-368 (p. 361).

37 James Shirley, Changes: or, Love in a maze (London, 1632; STC 22437), sig. H2r.

38 Thomas Flemynge to [Robert Cecil?], 10 January 1594/5, The Cecil Papers, CP 24/93.

39 'Elizabeth Johnson brought for grand larceny', 3 July 1695, Proceedings of the Old Bailey, t16950703-8.

40 'Ordinary's Account', 18 September 1695, Proceedings of the Old Bailey, OA16950918. 


\section{Heathen}

Versions of 'heathen' appear in all the Germanic languages to indicate 'non-Christian, pagan' peoples and practices, with its origins often traced back to Gothic haipi ('dweller on the heath'). As such, it is a counterpart of the Latin paganus (originally 'villager', 'rustic', 'rural'), differentiated from the more urban spread of Christianity. A recurrent concept in the Old Testament and in the texts of the early Christian Church, 'heathen' played a central role in English post-Reformation theological debate. English travel and expansion in the sixteenth century added further potency to longstanding associations between heathenism and idolatry or religious error. The word often served as a catch-all to describe those perceived to have strayed from, or who remained ignorant of, the teachings of Christ. Translations of Continental cosmographies from the second half of the sixteenth century, alongside the popular compendia of Richard Hakluyt and Samuel Purchas - both of them Protestant clergymen - served to define and synthesise cultural hierarchies that made clear to readers that 'heathen' beliefs existed throughout the world. ${ }^{1}$ While closely related to 'pagan', 'heathen' focused more on theology, while the latter often featured in discussions about classical literature, objects, and visual art. The Anglican clergyman and future Archbishop of Canterbury, Thomas Tenison, seemed to acknowledge this in his preface to his treatise on idolatry. 'If I have but misspelled the name of some Heathen-god', he wrote, 'I expect severe usage from such Grammarians' and zealous 'Religious men', whereas the imaginative license of poets and orators were the vehicles through which 'Pagan Heroes were Deified'. ${ }^{2}$

The English for the most part applied 'heathen' to individuals or groups whose religious rites and rituals were polytheistic, existing outside the monotheism of the Christian, Jewish, or Muslim faiths. Protestants further likened Catholicism to heathen rites because of the Catholic Church's adoration of saints. Idolatry and heathenism thus became shorthand for the unreformed Church more generally, signifying any who had strayed to corrupt or perverted notions of God. Richard Eden's The history of travayle in the West and East Indies (1577), a compilation of European accounts of America, Africa, and Asia, included descriptions of the rites and ceremonies of the

1 Carina L. Johnson, 'Idolatrous Cultures and the Practice of Religion', Journal of the History of Ideas, 67 (2006), 597-622 (pp. 607-6o8).

2 Thomas Tenison, Of idolatry a discourse (London, 1678; Wing T704), p. 36. 
'heathen prince' of Mexico, the cosmovision of the 'heathen Giapans', and the customs of the Mogorites who were 'in like maner whyte and heathen'. A staunch Protestant with a notorious anti-Catholic zeal, Eden included several marginal annotations in his translation of Ludovico Varthema's Itinerario, in which he exposed the similarities between popery and the 'Idolater' and 'devilish' Malabari religion, often using Catholic terminology to identify heathen practices. ${ }^{4}$ The use of the word in ethnographic writing displayed an awareness of the differences between the inhabitants of the world. In this way, Christians described idolatry as pervading both more 'sophisticated' societies, such as Hindus in India, but also the 'primitive' beliefs of Native Americans, whom colonists often described as having little religion save a belief in the devil.

It was partly through the 'problem' of religious variance that English men and women articulated their beliefs about orthodoxy. The knowledge of differing practices among Greeks, Romans, Egyptians, Indigenous Americans, Russians, and Ottomans, among others, compelled English men and women to vocalise their identities in relation to their exchanges with the world beyond England. When William Biddulph recounted his travels to the East in 1609 , his lengthy title promised that his travel narrative would be 'profitable to the help of travellers, and no lesse delightfull to all persons who take pleasure to heare of the manners, government, religion, and customes of forraine and heathen countries'. 5 This points to the ambiguities towards heathenism: no matter how wary of other global religions, Protestants and Catholics were compelled to acknowledge that heathens were an inevitable component of the world order. Robert Brerewood divided world faiths into four (Christianity, Islam, Judaism, and heathenism), and estimated that Christians occupied only one-sixth of the inhabited world, while heathen 'idolaters' occupied nearly two-thirds. ${ }^{6}$ The knowledge that human beings connected with animals, the elements, and inanimate things to access divinity was both mistrusted and, given the broader cultural influence

3 Richard Eden, The history of travayle in the West and East Indies (London, 1577; STC 649), pp. iii, 250, 464 .

4 Ibid., pp. 387-389. See also Ralf Gelders, 'Genealogy of Colonial Discourse: Hindu Traditions and the Limits of European Representation', Comparative Studies in Society and History, 51:3 (2009), 563-589.

5 William Biddulph, The travels of certaine Englishmen into Africa, Asia, Troy (London, 16o9; STC 3051), frontispiece.

6 Margaret Hodgen, Anthropology in the Sixteenth and Seventeenth Centuries (Philadelphia: University of Pennsylvania Press, 1964), p. 219; Ethan Shagan, The Birth of Modern Belief: Faith and Judgement from the Middle Ages to the Enlightenment (Princeton, NJ: Princeton University Press, 2020). 
of Greco-Roman thought and humanist Neoplatonic scholarship, seen to have been instrumental to human progression towards divine knowledge. ${ }^{7}$

Because of their apocalyptic-mindedness, the more radical Elizabethan and early Stuart Protestants passionately urged their peers and congregations to proclaim the tenets of their faith against those of the heathen. Robert Browne, a zealous reformer who denounced the ecclesiastical hierarchies of the Anglican church as unscriptural, published a tract in 1582 containing tables that enabled readers to compare and contrast their faith to 'Turkes and Papistes and Heathen folke' - those, in other words, who 'take those for gods whiche are no gods', putting 'blessedness in them which vanishe in them selves'. ${ }^{8}$ Protestants advocated lay literacy to equip the godly to meditate on the teachings of God and access his Word first hand, especially when heathenism could be powerfully alluring. False gods, even Catholic superstition, 'have their seducing and wicked spirites'. ${ }^{9}$ In this sense, Protestants in early modern England viewed themselves in a state of inbetweenness, positioned between the terrors of hell and the promise of a new heaven and new earth.

As the religious controversialist John Penry wrote, heathens 'cannot abide the name of Jesus Christ. Be afraide therefore [...] by forsaking the opportunitie of being saved. ${ }^{10}$ Sermons in the sixteenth and seventeenth centuries frequently related superstition to heathenism in order to warn churchgoers of the perils of rejecting salvation. The Elizabethan writer Thomas Nashe used the fall of Jerusalem in the sixth century BC to call for reform: "The Romaines [...] shall conquer thee, and leave thy house desolate unto thee: who being Heathens, and not knowing God, are a degree of indignity inferior to the devill, for he knowes God'." Here, Nashe's humanist, classical learning exposed the tensions inherent in the early modern veneration for Greek and Roman authorities. Like most humanists, Nashe lauded Roman writers for their sophistication, but he tempered his reverence with the awareness that classical writers, as heathens or pagans, lacked knowledge of the 'true'

7 Frances A. Yates, Giordano Bruno and the Hermetic Tradition (New York: Routledge, 1964); The Cambridge Companion to Western Mysticism and Esotericism, ed. by Glenn Alexander Magee (Cambridge: Cambridge University Press, 2016).

8 Robert Browne, A Booke which showeth the life and manners of all true Christians, and howe unlike they are unto Turkes and Papistes, and Heathen folke (Middelburg, 1582; STC 39103), sig. Av.

9 Ibid., sig. A2v.

10 John Penry, An exhortation unto the governours, and people of Hir Majesties countrie of Wales (Aldermanbury [?], 1588; STC 19605.5), p. 4.

11 Thomas Nashe, Christs teares over Jerusalem (London, 1613 ; STC 18368), p. 42. 
God. The classical authorities so admired by humanists remained beyond salvation, their greatness destined for this earthly world alone.

For the English men and women who migrated to North America during the seventeenth century, particularly from the 1630 and during the English civil wars, providentialism and the destruction of heathens were closely related. Victories against Indigenous peoples in the brutal Anglo-Pequot conflicts of the 1630 in New England seemed to confirm God's favour towards his elect. In believing themselves to be ushering a New Jerusalem, Puritan migrants to Massachusetts placed themselves within a narrative in which they were fulfilling biblical prophecies in the heart of a wilderness peopled by enemies of Christ. William Bradford, founder of the Plymouth colony, warned colonists that the forces of sin were stronger in the wilderness, where the devil had more sway: 'Satan hath more power in these heathen lands, as some have thought, than in more Christian nations.' ${ }^{12}$

In places such as South Asia, where the English presence was shaped by commercial interests and relied on the trading and diplomatic privileges granted by much more powerful Muslim and Hindu polities, 'heathens' might be tolerated by business-minded English merchants or diplomats. William Methwold's account of Golconda, originally published by Samuel Purchas in 1626, included a detailed description of the religious practices of the 'gentiles or heathens' of modern-day Andhra Pradesh. ${ }^{13}$ Based on his first seven years as an East India Company (EIC) employee involved in private trade, Methwold described Golconda as a kingdom where heathenism provided the basis of an alternate system of civilisation or a social order that could be compared to ones that predominated in Christendom. Despite the supposedly erroneous beliefs and moral corruption of heathens, the rather secular perspective developed by a commercially-motivated Protestant Christian merchant like Methwold reveals that the interactions between English and non-Christian peoples often involved an element of pragmatism which was essential to facilitate commercial or diplomatic exchanges. ${ }^{14}$ In 1697 , the circumnavigator

12 William Bradford, Of Plymouth Plantation, 1620-1647: The Complete Text (New York: Alfred Knopf, 1952), p. 316.

13 William Methwold, 'Relations of the Kingdome of Golchonda, and other neighbouring nations within the Gulfe of Bengala, Arreccan, Pegu, Tannassery, \&c and the English trade in those parts', in Samuel Purchas, Purchas his pilgrimage (London, 1626; STC 20508.5), pp. 993-1007. 14 Joan-Pau Rubiés, 'Travel-Writing and Ethnography', in The Cambridge Companion to Travel Writing, ed. by Peter Hulme and Tim Youngs (Cambridge: Cambridge University Press, 2002), pp. 244-245; William Methwold, Relations of Golconda in the Early Seventeenth Century, ed. by W. H. Morleand (London: Hakluyt Society, 1931); Methwold, 'Relations of the Kingdome of Goldchonda', in Purchas his pilgrimage, pp. 993-1007. 
William Dampier used 'heathens' to describe trade and diplomatic relations in Africa, and the role of black women as go-betweens and sexual partners in these transactions. In Guinea, 'our Merchants, Factors, and Seamen that reside there, have their black Misses', for it was ' accounted a piece of policy to do it'. ${ }^{15}$ Should 'any difference [arise] about Trade [...] which might provoke the Natives [...] these Dalilahs would certainly declare it to their white friends, and so hinder their Country-mens designs', Dampier noted, for 'these Heathen Nations are very prone' to 'treacherous revenge'. ${ }^{6}$ The language of 'heathens' and conversion was closely tied to trading companies' diplomatic relations with other nations, and to fantasies about converting non-European women to Christianity through marriage.

Although the EIC operated with a certain degree of compromise to ensure commercial success abroad, its leaders, like those in Atlantic companies, did view evangelism as a core part of their identities abroad. In 1610, one official informed a chaplain that securing the fledgling EIC's commercial mission would require obtaining the love and estimation amongst those heathenish people' through conversion to both English government and faith. ${ }^{17}$ The chaplain Henry Lord wrote of his encounters with 'heathen' Hindu and Parsi peoples in an account published in London in 1630, informing English readers of religious practices and stories of these faiths. ${ }^{18}$ The primary aim of this book was to teach future English travellers to the East to convert other peoples, writing that just as 'Physicians in England' had 'learned to make the poisons in foreign Countries medicinable and sovereign in our own', he hoped that '[g]ood Christians in England' would learn 'also to convert the Heresies of the Heathen'. ${ }^{19}$ For many, both inside and outside England, overseas commercial success not only rested on good diplomatic relations with foreign leaders, but also on the expansion of English Protestantism into non-Christian geographies.

In sum, 'heathen' was a word saturated with religious meaning, but it also related to English imperial aspirations in the Atlantic and Indian Oceans, and to early modern systems of ethnographic classification. No single consensus existed among thinkers, religious authorities, and writers on how 'heathens' had codified or developed their systems of belief, meaning that ideas about the world's diversity were almost as diverse as the religions they discussed.

William Dampier, A new voyage round the world (London, 1697; Wing D161), p. 395.

Ibid. p. 396.

Quoted in Daniel O'Connor, The Chaplains of the East India Company 1601-1858 (London:

Bloomsbury Academic, 2012), p. 48.

18 Henry Lord, A display of two forraigne sects in the East Indies (London, 1630: STC 16825). 
While Old Testament writers continually pitted heathen gentiles - those who did not worship Jehovah, the God of the Jews - against reformed Christians, religious dissidents and more radical thinkers also framed the Reformation as a spiritual war on an apocalyptic level. When the Elizabethan bishop Anthony Rudd catalogued how the prophet Jeremiah had 'commanded the House of Israel not to learn the way of the heathen, nor to be afraid of the signs of heaven', his wordplay aptly summarised central beliefs in sixteenth- and seventeenth-century England..$^{20}$ To Rudd and many other English clergymen, the 'heathen' was a living embodiment of ignorance or religious error, signifying God's rejected people, while 'the signs of heaven' pointed to England's chosen place in the world. When Joseph Williamson led a prayer of confession at Queen's College, Oxford, in 1659, he prayed for his own college as well as 'the Church universal' and 'the heathen world'. ${ }^{21}$ In ideas that endured with little change throughout the early modern period, Williamson's words expressed an awareness of the connectedness between the self and the wider 'heathen world', between divine order and one's own small, sometimes imperilled place within it.

Related keywords: convert, Jew, Mahometan, pagan

20 Anthony [Rudd] to Robert Cecil, 9 April 1596, Hatfield House, CP 39/108r.

21 'Fragment of a prayer by Joseph Williamson', undated [1659?], Kew, The National Archives, SP $18 / 205$, f. 14 or. 


\section{Host}

Since at least the early twelfth century, 'host' held its more common association with someone 'who lodges and entertains another in his house' or 'a place of lodging or entertainment.'. 'Host' was also, until the mid-seventeenth century, a noun used to identify those who, in imitation of Jesus Christ, were 'victims for sacrifice'. This usage was greatly influenced by the sacramental bread in Christian liturgy, known as the host (a derivative of the Latin hostia, 'victim'), which symbolizes the body of Christ. ' 'Host' also had the now-archaic meaning of an army or a crowd. ${ }^{4}$ English translations of the Bible, for example, included 'Lord of Hosts' as one of the names of God, a title based on the Hebrew sabaoth (armies) which referred to the divine army of angels who served to exalt the kingship and power of God. 5 The military meanings of 'host' derived from the Latin hostis, a noun used to identify foreign or public enemies. ${ }^{6}$

Hostis was also cognate with the Germanic gaztiz, or guest, and gradually became associated with foreigners, strangers, and notions of hospitality. ${ }^{7}$ This evolution was influenced by two Latin words: hospes, a word that meant both host and guest, and hospit, a fusion of hostis (stranger, guest) and pet (master, lord). The word 'hospitality' thus emerged from the hospit, the master of guests who manages the presence of strangers. ${ }^{8}$ The oxymoronic nature of the etymological roots of 'host' as a derivative from the dual meanings of hostis, the enemy or the guest/stranger, reveals the ambivalent nature of hospitality as an act or gesture that, to paraphrase Jacques Derrida, defined strangers as friends or enemies. ${ }^{9}$ In epics such as The Odyssey, too, first translated into English by George Chapman in 1615, hosts played an important role in the fates and fortunes of travellers. The ancient Greek

1 'Host, n.,' Oxford English Dictionary.

2 Ibid.; 'Host', The Oxford Dictionary of the Christian Church, ed. by F. L. Cross and E. A. Livingstone (Oxford: Oxford University Press, 2005), p. 799.

3 Ibid.

4 Ibid.

5 See, for example, H. G. M. Williamson, Isaiah 6-12: A Critical and Exegetical Commentary (London: Bloomsbury, 2018), pp. 67-68.

6 Robert Sullivan, A Dictionary of Derivations, Or, An Introduction to Etymology (London, 1838), p. 86.

7 Anatoly Liberman, Word Origins ... and How We Know Them: Etymology for Everyone (Oxford: Oxford University Press, 2005), p. 208.

8 Ibid., p. 208.

9 Jacques Derrida, OfHospitality (Stanford, CA: Stanford University Press, 2000), p. 45. 
concept of xenia, or hospitality, bound hosts and their guests together in bonds of duty and aid. In the Iliad, for example, xenia was evoked to reveal the existence of long-term relations, based on affection and mutual obligations, between Trojans and Achaeans. ${ }^{10}$ The bond established by xenia was also theorised by Aristotle as an instrument of ritualised friendship to strangers (philia xenikên) which structured relations with individuals from other social groups and foreigners based on a series of obligations, including acts of hospitality. ${ }^{11}$

Good hospitality was also a demonstration of piety and devotion. In a Treaty of Christian Beneficence (16oo), Robert Allen mentioned that St. Paul, in his Epistle to the Hebrews, instigated Christians to 'not be forgetful to lodge strangers' since the first followers of Christ 'for a fruit and blessing of their hospitality received Angels into their houses at unawares in steede of men'. ${ }^{12}$ A 1615 publication Certaine wholesome observations and rules fo [sic] inne-keepers, and also for their guests evoked Matthew 25:34-36, advising innkeepers that 'in serving and loving your guests, remember you do serve and love God, who takes all as done to himself, which for his sake is done to his'. ${ }^{13}$ The association between Christian virtue and hospitality allowed William Camden to explain Elizabeth I's decision to shelter Dutch Protestant refugees as an act of royal and English magnanimity and piety. According to Camden, the queen, compassionate towards this 'poore miserable people of no note', believed that 'she should commit a great inhumanity, and violate the lawes of Hospitality' had she not extended her sovereign care. ${ }^{14}$

Camden's praise for Elizabeth's hospitality towards the Dutch refugees reveals that the thin line between hospitality and hostility towards strangers tended to be associated with expectations about charity, decorum, and customs along national lines. English writers often praised good hospitality as one of the defining characteristics of the English nation. 'The use and auncient custome of this Realme of England', wrote the anonymous author

10 Christos Tsagalis, 'Epic Space Revisited: Narrative and Intertext in the Episode between Diomedes and Glaucus (Il. 6.119-236)', in Allusion, Authority, and Truth: Critical Perspectives on Greek Poetic and Rhetorical Praxis ed. by Phillip Mitsis and Christos Tsagalis (Berlin: De Gruyter, 2010) pp. 87-114 (103-104).

11 Nicholas Onuf, Making Sense, Making Worlds: Constructivism in Social Theory and International Relations (London: Routledge, 2013), pp. 156-157.

12 Robert Allen, A treatise of christian beneficence (London, 1600 , STC 367 ), p. 56.

13 T. W., Certaine wholesome observations and rules fo [sic] inne-keepers, and also for their guests (London, 1615; STC 24916.7) [single broadsheet].

14 William Camden, Annales the true and royall history of the famous empresse Elizabeth Queene of England (London, 1625; STC 4497), pp. 351-352. 
of Cyvile and uncyvile life (1579), was that 'all Noblemen and Gentlemen [...] from age to age, and from Auncester, to auncesters' offered their hospitality 'which got them great love among their Neighbours, relieved many poor wretches, and wrought also diverse other good effects.' ${ }^{15}$ Country houses, the author maintained, could 'be frequented as honourable hostries.'. ${ }^{16}$ Indeed, as Gervase Markham argued in his $A$ health to the gentlemanly profession of servingmen (1598), hospitality - 'the harbourer of two hopes, prayse, \& prayers' - was a sign of superiority and excellence in a gentleman's household. ${ }^{17}$ Some years earlier, in 1573 , Thomas Tusser associated hospitality with the moral and social reputation of a household: 'What good to get riches, by breaking of sleepe, / but (having the same) a good house for to keep [...] Of all other doings, housekeeping is chiefe, / for daily it helpeth, the poore with relief. / The neighbor, the stranger, \& all that have need, / which causeth thy doings, the better to speede. ${ }^{18}$ The reference to the 'stranger' is telling. Travel did not just involve mobility, but rest, and the figure of the host became an important facilitator in a traveller's geographical advancement and socio-cultural experience. Another important characteristic of a host was trustworthiness. Those who were strangers or guests in unknown places were often unsure of the true intentions of their hosts. While discussing the virtues of charity and wisdom, John Dod, in A plaine and familiar exposition (16o8), provided an example of the doubts surrounding hosts: 'We are not willing to be blindfolded at our meat, nor to eate our supper without a light, especially in strange places where we neither know well the fidelity of our host, nor what dishes are set before us'. ${ }^{19}$

That same idea of hospitality as a precious, if elusive, national characteristic is well patent in Henry Wotton's Elements of Architecture (1624), a treatise that aimed to introduce Italian architectural styles in England. According to Wotton, 'the natural hospitality of England' made the adoption of some Italianate elements somehow difficult. In southern Europe, the service rooms, storerooms, and kitchens were usually hidden or located in the basements. In England, as Wotton observed, 'the Buttery must be more visible; and we need perchance for our Ranges, a more spacious and luminous

Cyvile and uncyvile life (London 1579; STC 15589.5), sig. Biiv.

Ibid., sig. N4r.

17 Gervase Markham, A health to the gentlemanly profession of servingmen (London, 1598; STC 17140), sig. B4r.

18 Thomas Tusser, Five hundreth points of good husbandry united to as many ofgood huswiferie (London, 1573; STC 1717:28), sig. D2r.

19 John Dod, A plaine and familiar exposition of the thirteenth and fourteenth chapters of the Proverbs of Salomon (London, 1608; STC 6959.5), p. 110. 
Kitchen'. ${ }^{20}$ While comparing the quality of the inns he encountered across Europe, the well-travelled Fynes Moryson highlighted the 'the old custom of the English, [to] make our tables plentifully furnished, whereupon other Nations esteem us gluttons and devourers of flesh, yet the English tables are not furnished with many dishes, all for one man's diner, but severally for many mens appetite, and not onely prepared for the family, but for strangers and relief of the poor.'. ${ }^{21}$

Another example of the perception that hospitality towards strangers defined national identities or traits is the well-travelled Jerome Turler's advice to those who wished to travel across Europe. Turler warned his readers that 'towards strangers the Germans are rogue and inhospitable, the Frenchmen gentle, the Spaniards courteous, and the Italians diligent. ${ }^{22}$ Inspired by the success of Thomas Coryate's travel accounts, the London boatman and poet John Taylor travelled to Germany in August 1616 in the hope of publishing an account of his travels between London and Hamburg. Exhausted by the onslaught of new sights and experiences en route, Taylor welcomed the hospitality of the so-called English House of Hamburg, where he found 'a kind Host, an honest hostess, good company, store of meat, more of drink, a true Tapster, and sweet lodging'. ${ }^{23}$

In spite of the different visions of hospitality instigated by religious polemics and geopolitical competition, natural law provided a shared perception of hospitality as necessary and good. According to Christopher Wandesford, the 'Law of Nature' required individuals to be bonded by a 'common Rule of Hospitality' which enforced them 'to Bounty, and all kinds of fair Treatment of Stranger'. ${ }^{24}$ Although hospitality was generally perceived as an essential trait of the English nation, this idea that natural law impelled all individuals to be good hosts or to be inclined to hospitable behaviour influenced English perceptions of foreign societies, especially those beyond Europe and Christendom. By evaluating the hospitality of foreign peoples, one could measure their levels of civility. Sir Thomas Roe, despite his diatribes against Jahangir and his court in

20 Henry Wotton, The elements of architecture, collected by Henry Wotton Knight, from the best authors and examples (London, 1624; STC 26011), sig. I4.

21 Fynes Moryson, An itinerary (London, 1617; STC 18205), p. 151.

22 Jerome Turler, The traveiler ofJerome Turler devided into two books (London, 1575; STC 24336), p. 41.

23 John Taylor, Three weekes, three daies, and three houres observations and travel, from London to Hamburgh in Germanie (London, 1617; STC 23807), sig. B2v.

24 Quoted in Felicity Heal, 'The Idea of Hospitality in Early Modern England', Past \& Present, 102 (1984), 66-93 (p. 73). 
Mughal India, praised the hospitality of Mir Jamal-ud-Din Husain, the governor (subahdar) of Patna. Roe, who frequently complained about the scant courtesy granted to him at Jahangir's court, eulogised the subahdar for possessing 'more understanding and curtesy than all his Countrymen, and to be esteemed hospitable and receiver of strangers'. Mir Jamal-ud-Din Husain received the English ambassador 'with extraordinary familiarity and kindness' which included a gift of a 'leeck [sic] of rupias [sic] and such other Courtesies so great that they beespoke their own refusal. ${ }^{25}$ As Roe told his readers, after his experiences at the Mughal court he 'resolved' that Mir Jamal-ud-Din 'was a good natured and right hearted old man', words that could be used to describe an English civil, magnanimous, and gentlemanly host. ${ }^{26}$

The English employees of the East India Company (EIC) in Japan, for example, used the word 'host' to identify the brokers and mediators who collaborated with the company. The use of the term 'host', instead of others such as 'broker' or 'agent', highlights the function that these Japanese agents had of sheltering EIC men. This practice led John Sarris to believe that Japan was a 'place exceedingly peopled, very Civill and courteous' and inclined to hospitality. ${ }^{27}$ However, the Japanese 'hosts' also had other important roles. Besides offering accommodation and entertainment, they mediated the contacts between English and local merchants, as well as with other members of the population. They also provided essential information regarding local commercial practices or the functioning of the political structures. The Japanese 'hosts' thus operated as cross-cultural guides who oriented their English guests in their contacts with Japanese society. But more than mediating, the role of these 'hosts' was to supervise the activities of the EIC men and ensure they conformed to the interests of the Japanese authorities. This often triggered tensions. Richard Cocks, for example, complained about the interferences of one Japanese official Yasimon Dono, 'an absolute cunning knave', who was accused of hindering English activities and promoting Dutch interests. ${ }^{28}$ Similar accusations were made by Richard Wickham, who mentioned that Yasimon, as well as other

25 Thomas Roe, 'Observations collected out of the Journall of Sir Thomas Roe', in Purchas his pilgrimages, ed. by Samuel Purchas (London 1625; STC 20509), p. 549.

26 Ibid.

27 John Sarris, 'Captaine Saris his Journey to the Court of the Japonian Emperour, and observations there, and by the way', in Purchas his pilgrimages, p. 371.

28 Richard Cocks, Diary of Richard Cocks, cape-merchant in the English factory in Japan, 1615-1622, Vol. 1, ed. by Edward Maude Thompson (London: Hakluyt Society, 1883), p. 27. 
Japanese officials, 'hath made a living of the English'. ${ }^{29}$ This need to accept the demands of local authorities exposes thus how hospitality was not only an act of courtesy, piety, or generosity, but also an instrument to establish relations of dependence or establish a difference of power.

The EIC's dependence on the Japanese authorities is yet another example of how the early stages of English overseas expansion were conditioned by a position of economic and military fragility vis-à-vis the host societies. The success (and failures) of the English company agents relied on their capacity to accommodate to their hosts in many places around the globe. '[A] stranger', as Caleb Dalechamp reminded, 'must be thankful to his public hoste, that is, to the Prince or Magistrate in whose Dominions he sojourns'. ${ }^{30}$

Related keywords: broker, native, stranger, traveller

29 Quoted from James Lewis, “Nifon catange or Japon fation”: A Study of Cultural Interaction in the English Factory in Japan, 1613-1623' (unpublished PhD dissertation, University of Sheffield, 2004), p. 88.

30 Caleb Dalechamp, Christian hospitalitie handled common-place-wise in the chappel of Trinity Colledge in Cambridge (London, 1632; STC 6192), pp. 112-113. 


\section{Indian}

'Indian', when referring to the Indian subcontinent and its inhabitants, derived from the thirteenth-century Anglo-Norman indien. 'Indian' originated from the Greek name for the river Indus, which flows through modern-day Pakistan, and which specifically related India to the geographies of the East until the late fifteenth century. ${ }^{2}$ After 1492, Europeans also used 'Indian' to label the Indigenous peoples of North and South America, from the Iroquois of present-day Canada to the Inca of Peru. ${ }^{3}$ As Jonathan Gil Harris has suggested, Columbus's voyages to America turned 'Indian' into 'the capacious, portable, and problematic term for diverse peoples around the globe', so that Europeans, in many ways, 'invented "Indians"' as a result of global expansion. ${ }^{4}$ Imtiaz Habib notes that the 'predatory impulse' of early modern expansion meant that the descriptor 'Indian' often revealed more about the intent and behaviour of the English than about the societies described. ${ }^{5}$

Examining Shakespeare's A Midsummer Night's Dream (c. 1595), John Fletcher's The Island Princess (1621), and John Dryden's Amboyna (1673), Shankar Raman concluded that 'India' throughout the early modern period was a fluid 'final frontier' representing 'the exotic and the unknowable.' ${ }^{6}$ This mystery and appeal was not new, but formed in large part from the tradition of medieval travel tales, notably the fourteenthcentury Travels of Sir John Mandeville. An ostensible eyewitness account, Mandeville's peregrinations from Europe to India included encounters with green and yellow people, ox-worshippers, Saracens, Tibetans, and cannibals. ${ }^{7}$ The religious, economic, and ethnographic descriptions in medieval texts, which mixed elements of the fantastical with knowledge facilitated by developing trade networks, helped set a template for the

1 'Indian, n.', Oxford English Dictionary.

2 Jonathan Gil Harris, 'Introduction', in Indography: Writing the 'Indian' in Early Modern

England, ed. by Jonathan Gil Harris (Basingstoke: Palgrave, 2012), p. 1.

3 Ibid.

4 Ibid.; Sanjay Subrahmanyam, Three Ways to be Alien: Travails and Encounters in the Early Modern World (Waltham, MA: Brandeis University Press, 2011).

5 Imtiaz Habib, Black Lives in the English Archives, 1500-1677: Imprints of the Invisible, 2nd edn (Abingdon: Routledge, 2016), p. 259.

6 Shankar Raman, Framing 'India': The Colonial Imaginary in Early Modern Culture (Stanford, CA: Stanford University Press, 2001), p. 83.

7 Andrew Fleck, "Here, There, and In Between: Representing Difference in the "Travels" of Sir John Mandeville', Studies in Philology, 97:4 (200o), 379-40o (p. 386). 
way sixteenth- and seventeenth-century travellers 'saw' the places to which they travelled. In 1595, Ralegh purported to have seen monsters and marvels in South America that were 'written of by Maundevile, whose reports was holden for fables many yeres, and yet since the East Indies were discovered, wee finde his relations true of such things as heeretofore were held incredible'. 8

'India' and 'Indians' became discursive spaces for fantastical imaginings in early modern England, operating as a shorthand to describe a vast array of continents, peoples, and commodities. 'India is properly called that great province of Asia, in whiche great Alexander kepte his warres', the Protestant cosmographer Richard Eden wrote in $1577 .^{9}$ As Eden acknowledged, however, European exploration into the Atlantic divided 'India' into two 'Indies'. Columbus could be credited with arriving 'fyrst to the knowledge of the [West] Indies', though Eden faulted him for erroneously believing that he had found a route through the Caribbean to Cathay [China] and India. ${ }^{10}$ The influence of Columbus's writings about the Carib 'Indians' he encountered created a strong association between 'India' and the Caribbean, more so than North America. In deliberating an act of potential piracy in the Atlantic, an anonymous English author raised the fact that 'it must be considered [...] although it is disputeable, whether Virginia be part of the Indias though it be scituate upon the same continent of the West Indies'." When the adventurer William King prepared an expedition to 'West India', he referred to Puerto Rico, St. Domingo, and Honduras. ${ }^{12}$ Edmund Spenser, in The Faerie Queene (1590), referred to 'th'Indian Peru'.13

Whether referring to South America or the Mughal empire, 'Indian' realms signalled the possibilities of wealth and abundance. As physical spaces, these territories were closely related to commodities and their exploitative potential. Writing to Robert Cecil in 1607, the diplomat Hugh Lee reported that 'the late fleet aryved in Spayne fro[m] the West Indyes', the ships laden with '4 Millions of Treasure'.14 In 'The Sunne Rising', the poet John Donne used 'both th'Indias of spice and mine' to evoke separate places,

8 Walter Ralegh, The discoverie of the large, rich, and bewtiful empire of Guiana (London, 1596; STC 20634), p. 70.

9 Richard Eden, The history of travayle in the West and East Indies (London, 1577; STC 649), sig. A3v.

10 Ibid., sigs. A2v, A4r.

11 'Virginia and the Indies', 1606, Hatfield House, CP 119/149r.

12 W[illiam] King to [unknown], [date unknown], Hatfield House, CP 98/137r.

13 Quoted in 'Indian, n.', Oxford English Dictionary.

14 Hugh Lee to the Earl of Salisbury [Robert Cecil], 5 October 1607, Hatfield House, CP 122/129r. 
the spice-rich East and the gold and silver mines of Spanish America, both sites reconciled in his mistress's body. ${ }^{15}$ The element of commodification is further evident in the poetry the amorous Orlando composes in Shakespeare's As You Like It (c. 1599): 'From the east to western Ind, / No jewel is like Rosalind' (III.2.77-8). While 'Indian' wares could refer to products like tobacco and pearls from America, or Eastern spices and silks, these goods were ultimately desirable because they would enrich the domestic realm. This meant discourses of political economy made 'Indian' goods the crux for anxieties over luxury and moral corruption. Luxury, wrote the satirist George Wither, will impoverish the soul and the body, depriving the realm of native trade. 'Our home-made Cloth, is now too course a ware, / For Chyna, and for Indian stuffs we are.'. ${ }^{16}$ To wear 'Indian stuff' risked altering individual and national character.

While 'Indian' related to other geographic spaces and their commodities, the word also described local inhabitants. When Trinculo in Shakespeare's The Tempest (1611) surmised that Caliban is a descendant of 'men of Ind', the distinction is not clear-cut. ${ }^{17}$ 'The undifferentiated Indian', in the words of Rebecca Ann Bach, highlights the ambiguity of European views towards Asian/American geographies and people. ${ }^{18}$ Nonetheless, while the lens of colonial expansion certainly made 'Indian' adaptable and at times indistinct, there were differences in how the English viewed American and eastern Indians, and these differences indicate much about English imperial aspirations. The early colonial experiences of the English in Greater Amazonia, North America, and the Caribbean led to the belief that Native Americans were 'savages': 'rude \& naked Indians in the Westerns parts of the world'. ${ }^{19}$ 'A very faire Iland', the aristocrat George Percy wrote of Dominica in 1606, 'the Trees full of sweet and good smels, [but] inhabited by many Savage Indians'. ${ }^{20}$ On the other hand, a 'Mahumetan, or an Heathen in India', wrote the East India Company chaplain Edward Terry, was often 'excellent in many

15 John Donne, 'The Sunne Rising', in The Collected Poems of John Donne, ed. by Roy Booth (Hertfordshire: Wordsworth Editions, 1994), p. 4.

16 George Wither, 'Book 2, Satire 1', Juvenilia: Poems by George Wither (Manchester: Spenser Society, 1871), p. 221.

17 Quoted in Jonathan Gil Harris, 'Introduction', in Indography, p. 2. For debates over Caliban's origins, see Alden Vaughan and Virginia Vaughan, Shakespeare's Caliban: A Cultural History (Cambridge: Cambridge University Press, 1991).

18 Jonathan Gil Harris, 'Introduction', in Indography, p. 2.

19 Matthew Stoneham, Two sermons of direction for judges and magistrates (London, 1608; STC 23290), sig. B5v.

20 George Percy, 'Observations Gathered Out of a Discourse' (1606), in Purchas his pilgrimes (London, 1625; STC 20509), p. 1685. 
moralities. ${ }^{21}$ Concerned with the behaviour of the English abroad, Terry complained that 'tis sad to behold there [in India], a drunken Christian and a sober Indian [...] [for] It is all one to be a bramble in the wildernesse and a barren tree in Gods Orchard'. ${ }^{22}$ 'Indians' were also brought to London to promote English activity overseas. In 1614, the EIC chaplain Patrick Copland brought a Bengali boy to England and taught him Latin and English. Baptised in London in 1616 as Peter Pope, Copland praised this 'Indian youth, borne in the bay of Bengala' for his aptitude in language-learning. The project to convert, deeply enmeshed as it was with expansion and social order, both collapsed notions of ethnographic difference and amplified alterity. ${ }^{23}$

The 'global turn' in scholarship has revealed some of the shared ideologies and interrelated economic ambitions that underpinned English imperialism in America and the East, despite vast differences on the ground. Rather than interchangeable spaces, the East and West Indies were interlocked in English conceptions of empire. Columbus's naming of the 'West Indies' reflected his desire to seek direct access to trade in India and China. ${ }^{24} \mathrm{At}$ the same time, English desire to access the highly-coveted goods of India and China involved westward plantation, since raw colonial exports would bolster trade and the capital needed to successfully compete in and with Eastern markets. ${ }^{25}$

By the end of the seventeenth century, support for luxury goods from China, India, and Japan came under scrutiny as various merchant and political groups attacked the East India Company's monopoly on trade. An anonymous pamphlet from 1697 criticised the company for having 'debauch'd the Nation with Cobwebs and Cockle-shells, in return for their Gold and Silver. ${ }^{26}$ The ramifications of trade for the '[t]rinkets of the Mogul' were such that the '[l]uxurious and Effeminate are made Indians'. ${ }^{27}$ Two

21 Edward Terry, The merchants and mariners preservation and thanksgiving (London, 1649; Wing T78o), sigs. D3r-4r.

22 Ibid., sig. D4v.

23 Patrick Copland, Virginia's God be thanked (London, 1622; STC 5727).

24 Nabil Matar, Turks, Moors, and Englishmen in the Age of Discovery (New York: Columbia University Press, 1999); Matthew Dimmock, Elizabethan Globalism: England, China, and the Rainbow Portrait (New Haven, CT: Yale University Press, 2019).

25 Jonathan Eacott, Selling Empire: India in the Making of Britain and America, 160o-1830 (Chapel Hill: University of North Carolina Press, 2016); John Brereton, A briefe and true relation of the discoverie of the north part of Virginia (London, 1602; STC 3611 ); John Bonoeil, His Majesties gracious letter to the Earle of South-Hampton (London, 1622; STC 14378), p. 64.

26 An answer to a late tract, entituled, An essay on the East-India trade (London, 1697; Wing A3311), p. 8.

27 Ibid. 
years later, a similar pamphlet described the consumer culture for luxury products as an 'Indian Gangreen', whereby cheap 'Indian Commodities' had destroyed the nations 'Principal Manufactures' ${ }^{28}$ 'Indian' embodied these conflicted, entangled associations between trade and colonialism, situated at the crux of English imperial fantasy and anxieties about cultural difference, the foreign, and the unknown. Perhaps more than any other keyword, 'Indian' in the sixteenth and seventeenth centuries evoked the interconnectedness of global spaces, commodities, and people, collapsing widely disparate geographies under aspirations of empire.

Related keywords: heathen, Mahometan, merchant, native, savage/barbarian

28 England's advocate, Europe's monitor being an intreaty for help in behalf of the English silk-weavers and silk-throsters [...] in a letter to a member of the Honourable House of Commons (London, 1699; Wing N2), pp. 27, 33. 


\section{Interpreter}

'Interpreter' derives from the Latin interpres, a word used to design agents who moved between different parties or individuals who served as intermediaries, translators or explainers, usually in diplomatic activities. ${ }^{1}$ The etymology of interpres is also linked to pretium (price or value). The interpreter was therefore someone who served as a mediator, negotiating terms and prices and often at the centre of a commercial transaction. ${ }^{2}$ The first records of 'interpreter' in English associate the word to the oral translation of dialogues between speakers of different languages, and to the analysis of legal, religious or scholarly documents. Around 1440, the Promptorium Parvulorom (1440), the first bilingual English-Latin dictionary, translated interpres as 'Interpretowre or expownere', relating it to the precise function of explaining or commenting texts or laws. ${ }^{3}$ Miles Coverdale's 1535 translation of the Bible used 'interpreter' in Genesis to mention an oral translation occurring during a dialogue: 'They knew not that Joseph understood it, for he spoke unto them by an interpreter'. ${ }^{4}$ The same year, in A dialogue of comfort against tribulation, the humanist Thomas More used 'enterpretors' to identify Church scholars who commented and analysed the Bible. ${ }^{5}$

The uses of 'interpreter' in these works from the fourteenth to the early sixteenth centuries reveal a perception of the interpreter as someone who facilitated communication and knowledge by deciphering words or translating foreign idioms. In The English dictionarie, or, An interpreter of hard English words (1623), The lexicographer Henry Cockerham evoked 'interpreter' to present a work that aimed to explain and standardise English for a wide audience formed by scholars, clerks, students, women, and foreigners. ${ }^{6}$ This often led to an overlapping of the terms 'interpreter' and 'translator', since both identified individuals who facilitated communication by deciphering

\footnotetext{
1 'Interpreter, n.', Oxford English Dictionary.

2 Dario Tessicini, 'Introduction: Translators, Interpreters, and Cultural Negotiation', in Translators, Interpreters and Cultural Negotiators: Mediating and Communicating Power from the Middle Ages to the Modern Era, ed. by Federico M. Federici and Dario Tessicini (London: Palgrave Macmillan, 2014), pp. 1-9 (pp. 1-2).

3 Anglicus Galfridus, Promptuarium paruulorum clericorum quod apud nos Medulla grammatice appellatur scolasticis (London, 1512; STC 20437), sig. F1.

4 Miles Coverdale, Biblia the Bible (Cologne, 1535; STC 2063.3), sig. Dir.

5 Thomas More, A dialogue of comfort against tribulacion (London, 1553; STC 18082), sig. C3v.

6 Henry Cockerham, The English dictionarie, or, An interpreter of hard English words (London, 1623; STC 5461).
} 
foreign idioms. Nonetheless, while the 'translator' was a linguist or scholarly expert who worked with the written word, the 'interpreter' often identified those who were not necessarily experts but employed to provide oral translations due to their language skills, often in moments that required immediate action.

'Interpreters' therefore served as integral go-betweens in activities that related to commercial and diplomatic exchanges. To Jean Hotman, a member of Sir Amias Paulet's embassy at the French court from 1576 to 1579, the 'interpreter' was one of the 'necessary instruments' of an ambassador for his or her important work in facilitating a dialogue between 'those which speak not the language'. ${ }^{7}$ As Kathryn Vomero Santos noted, works such as Shakespeare's All's Well That Ends Well reveal a perception of a 'trialogic structure of interpreting', a tripartite relation between two monolingual actors and an interpreter who mediates their interaction. This essential task of mediation, however, exposes an unequal balance between the three parties, since the ability of the monolingual elements to communicate relied on a third party who had the power to manipulate what was said. The role of the interpreter encapsulates thus 'the dangerous contingency of the human ability to make and receive meaning'. ${ }^{8}$

The indispensable functions performed by interpreters required an element of trust. In order to guarantee the loyalty of interpreters and the accuracy of their translations, Hotman recommended that ambassadors and princes should include them 'in the accompt of the pensions of that Nation, and receive the ordinary wages of a crown by the day'. ${ }^{9}$ More importantly, interpreters should have 'a certificate or attestation' signed by an ambassador that defined their duties and obligations..$^{10}$ The concern with securing a contractual relation between an ambassador and an interpreter was related to the fact that most interpreters were normally employed on a temporary basis. Interpreters produced an immediate and literal translation orally or in the form of a draft that would be refined later by a translator, or a secretary with some experience with foreign languages. The initial translation could then be polished by the interpreter himself, if he possessed a scholarly background, or by a secretary, clerk, or an official translator. ${ }^{11}$

7 Jean Hotman, The ambassador (London, 1603; STC 13848), sig. D8v.

8 Kathryn Vomero Santos, “Let me be th'interpreter”: Shakespeare and the Tongues of War', Shakespeare Studies, 48 (2020), 66-72 (p. 67).

9 Ibid., sig. K5v.

10 Ibid.

11 Dario Tessicini, 'Introduction', in Translators, Interpreters and Cultural Negotiators, pp. 5-6. 
The expansion of English trade and diplomacy throughout the Elizabethan and Jacobean period introduced new words for the functions of the interpreter. English merchants and diplomats identified the interpreters they employed in the Ottoman Empire as 'dragomans', a word derived from the Greek dragoumanos ( $\delta \rho \alpha \gamma o \mu \alpha$ vos), a variant of the Ottoman Turkish tercüman and the Arabic tarjumān (نامجرت), the interpreter or transcriber of spoken conversations or speeches. The English in the Levant and the Barbary Coast also used 'truchman', another variant of tercüman and tarjumān. ${ }^{12}$ In Southeast Asia, the correspondence of the East India Company has several references to jurebassos, a word borrowed from the Malay-Javanese jurubahāsa (literally, 'language-master') via the Portuguese use of the same word for local interpreters and emissaries. ${ }^{13}$ In India and Persia, interpreters were often identified by East Indian Company (EIC) documents as 'linguists', another borrowing from the Portuguese use of lingua to define South Asian and Persian interpreters, or as 'dubash', from the Hindi 'do-bhasha', one who speaks two languages. ${ }^{14}$

This adoption of different words from European or Asian languages reveals the interpreter as someone with the capacity to live or move between different linguistic, social, cultural, and political worlds. It was this element of mobility and their linguistic skills that made the dragomans, jurebassos, and linguas almost indispensable go-betweens as the English sought trade and expansion abroad. These interpreters not only facilitated communication, but, through their contact networks and knowledge of local practices, aided merchants and diplomats in decoding local cultural or political subtleties that were essential to the success of trading exchanges, diplomatic correspondence, and other forms of cross-cultural communication.

Although useful, the in-betweenness of interpreters generated anxieties about their true intentions. In Ireland, the Elizabethan authorities had serious doubts about the allegiance of their Old English allies. The Old English were Catholic English families who had first settled in Ireland in the twelfth century. Their proximity to Irish society suggested that they could

12 Henry Huyle and A. C. Burnell, Hobson-Jobson: A Glossary of Colloquial Anglo-Indian Words and Phrases, and of Kindred Terms, Etymological, Historical, Geographical and Discursive (London: Kegan Paul, 1903), p. 327.

13 Ibid., pp. 473-474.

14 Ibid., pp. 517-518; Samuli Kaislaniemi, 'Jurebassos and Linguists: The East India Company and Early Modern English Words for "Interpreter"', in Selected Proceedings of the 2008 Symposium on New Approaches in English Historical Lexis, ed. by R. W. McConchie, Alpo Honkapohja, and Jukka Tyrkkö (Sommerville: Cascadilla Proceedings Project, 2009), pp. 6o-73. 
be, as the author and soldier Barnabe Riche scornfully noted, 'English with Irish hearts'. ${ }^{15}$ This widespread perception of degeneration when exposed to other cultures led the diplomat Henry Wotton to complain, whilst serving the Earl of Essex in Ireland in the 159os, that 'whatsoever we have done, or mean to do, we know what will become of it, when it comes amongst our worst enemies, which are interpreters' ${ }^{16}$ Wotton's invective against interpreters echoes the anxieties caused by the capabilities of interpreters which Michel de Montaigne explored in his essay 'Of Cannibals'. The French author lamented that his contact with the Tupinambá Indians brought from Brazil to Rouen for the royal entry of Henry II were undermined by 'so bad an interpreter, and who did so ill apprehend my meaning, and who through his foolishness was so troubled to conceive my imaginations, that I could draw no great matter from him.' ${ }^{17}$

The uneasy trust between mediators was even more acute in places like Japan. William Adams, an English merchant who first served the Barbary Company before joining the Dutch East India Company, became a member of the entourage of shogun Tokugawa Ieyasu in 16oo. Despite maintaining regular contacts with the Dutch East India Company, Adams incited the English East India Company (EIC) merchants based at Bantam to trade with Japan. Although Adams rapidly assumed a pivotal role in the English trading activities in Japan, the correspondence of the first English factor in Japan, John Saris, is full of suspicious remarks on Adam's real intentions and loyalty, even as Sarris recognised Adams's crucial role as an interpreter and broker for the EIC..$^{18}$ The correspondence of EIC employees in Japan also contained abundant complaints about local interpreters. The merchant Richard Cocks complained that the first Japanese interpreter hired by Adams for the EIC, a man named Migell (Miguel), was completely unreliable, being 'stubborn, and loved to runne abroad at his pleasure, leaving me without one that could speak a word'. ${ }^{19}$ Adams replaced Migell with Juan, a Japanese Catholic boy who previously worked in a Spanish household in Manila. Although Cocks recognised the good services of his new interpreter, Juan's Catholicism and

15 'A looking-glass for Her Majesty, May 1599', in Calendar of State Papers Ireland, Vol. 8: 1599-160o, ed. by Ernest George Atkinson (Nendeln: Kraus, 1974), p. 50.

16 'Henry Wotton to John Donne [?], c. 1599', in The Life and Letters of Sir Henry Wotton, Vol. 1, ed. by Logan Pearsall Smith (Oxford: Clarendon Press, 1907), p. 308.

17 Michel de Montaigne, Essays, trans. by John Florio (London, 1613; STC 18042), sig. K3r.

18 Alison Games, Web of Empire: English Cosmopolitans in an Age of Expansion, 156o-166o (Oxford: Oxford University Press, 2008), p. 97.

19 'Relation of Master Richard Cocks', in The Voyage of Captain John Saris to Japan, ed. by Ernest M. Satow (London: Hakluyt Society, 1908), p. 144. 
associations with the Spanish made him an ambiguous figure. ${ }^{20}$ In the Levant, Sir Thomas Roe, during his time as the English ambassador at the Ottoman court, issued oaths of loyalty to the local interpreters who were employed during the negotiations of treaties with the Ottoman authorities, probably as a result of the problems he had previously encountered with his interpreters at the Mughal court. ${ }^{21}$

The recurrent suspicions and doubts on the reliability and integrity of local interpreters led English trading companies to favour English boys as interpreters, which avoided the dependence on non-English individuals. The first English-born interpreter in Virginia, Thomas Savage, began his career around 1608 at the age of thirteen, when the captain Christopher Newport offered the boy as a hostage to the Algonquian chief Opecancanough. Savage remained with the Algonquians, where he learned their language and became a valuable go-between who maintained communication between Opecancanough and English authorities in Jamestown during its fraught early years. The success of Savage's experience as an emissary led John Smith to send another newly arrived teenager, Henry Spelman, to the camp of Parahunt, one of Opecancanough's sons. Savage and Spelman, along with another boy, Robert Poole, found their roles as translators, at a time when few Englishmen knew Algonquian dialects, placed them in positions where they needed to carefully balance English and Algonquian interests. This made them ambivalent figures in both societies. ${ }^{22}$ Surviving letters and official reports from councillors in Virginia indicate that authorities showed little trust in the individual boys as they moved between English and Algonquian spaces, caught between vying interests. 'Captaine Henry Spelman', reported the planter John Rolfe to the MP Edwin Sandys in 1620, had been brought before the council for 'being accused by Rob[er]te Pools (one of the interpreto[u]rs of the Indian language) of many crimes, w[hi]ch might be $\mathrm{p}[\mathrm{re}] \mathrm{iudiciall}$ to the State in general. ${ }^{23}$ At the same time, these interpreters fulfilled an indispensable

20 Games, Web of Empire, p. 99.

21 Sanjay Subrahmanyam, 'Frank Submissions: The Company and the Mughals between Sir Thomas Roe and Sir William Norris', in The Worlds of the East India Company, ed. by H. V. Bowen, Margarette Lincoln, and Nigel Rigby (Woodbridge: Boydell Press, 2002), pp. 69-96; Games, Web of Empire, p. 166.

22 J. Frederick Fausz, 'Middlemen in Peace and War: Virginia's Earliest Indian Interpreters, 1608-1632', The Virginia Magazine of History and Biography, 95:1 (1987), 41-64; Karen Ordahl Kupperman, Pocahontas and the English Boys: Caught Between Cultures in Early Virginia (New York: New York University Press, 2019).

23 John Rolfe to Edwin Sandys, [January 1620?], Ferrar Papers, FP 151, Virginia Company Archives $<$ www.virginiacompanyarchives.amdigital.co.uk $>$ [Accessed 23 September 2016]. 
role in the colony: Spelman was pardoned, Rolfe wrote, and immediately 'employed as interpreto[u]r to Patawamack to trade for corne'. ${ }^{24}$ Spelman died three years later in a failed trading expedition that had escalated into violent conflict.

Foreign interpreters were also present in London, often in merchant households. Coree the Saldanian (d. 1627) was a member of the Khoekhoe people of southern Africa, taken by an EIC merchant and placed in the household of the EIC merchant Sir Thomas Smith. ${ }^{25}$ According to the EIC chaplain Edward Terry, there was 'none ever more desirous to return home to his Countrey than [he]; For when he had learned a little of our Language, he would daily lye upon the ground, and cry very often thus in broken English, Cooree home goe, Souldania goe, home goe. ${ }^{26}$ Having returned to South Africa, however, Coree continued to serve as an interpreter, conducting negotiations between the English and African traders. Several North Americans lived in Walter Ralegh's London household from the 1580s, where they assisted the mathematician Thomas Hariot in compiling his Algonquian dictionary, now lost. ${ }^{27}$ In his voyage to Guiana in 1595 , Ralegh navigated Greater Amazonia 'by my Indian interpreter, which I caried out of England', in order to conduct negotiations with local groups, where his interpreter communicated that 'I [Ralegh] was the servant of a Queene, who was the great Casique [ruler] of the north, and a virgin, and had more Casiques under her then $[s i c]$ there were trees in that Iland'. ${ }^{28}$ 'I confesse', Ralegh wrote, that it was difficult 'to keep the meaner sort from spoile and stealing', and 'I caused my Indian interpreter at every place [...] to know of the losse or wrong. ${ }^{29}$ In this way, the Indigenous interpreter became a mediator between English, Spanish, and Tupi or Carib interests, but also assisted in cases of restitution. This may have been one of the interpreters who returned with Ralegh to London and visited him after Ralegh's imprisonment in the Tower after $1603 \cdot \cdot^{30}$

24 Ibid.

25 Onyeka Nubia, 'Africans in England and Scotland, 1485-1625', Oxford Dictionary of National Biography, <https://doi.org/10.1093/odnb/9780198614128.013.112804> [Accessed 22 November 2020]. 26 Ibid.; Edward Terry, A voyage to East-India (London, 1655 ; Wing T782), sig. C3r.

27 Coll Thrush, Indigenous London: Native Travelers at the Heart of Empire (New Haven, CT: Yale University Press, 2016), pp. 34-36. See also Alden T. Vaughan, Transatlantic Encounters: American Indians in Britain, 1550-1776 (Cambridge: Cambridge University Press, 2006).

28 Walter Ralegh, The discoverie of the large, rich, and bewtiful empire of Guiana (London, 1596; STC 20634), sig. B4r.

29 Ibid., sig. H2v.

30 Vaughan, Transatlantic Encounters, p. 34. 
Non-European women linked through marriage, concubinage, or enslavement to European mercantile and colonial agents were frequently employed as interpreters. One of the most illustrative cases is Malintzin, alias La Malinche, the Nahua interpreter and mistress of Hernán Cortés in Mexico. ${ }^{31}$ Another similar case for the English colonial experience was that of Matoaka or Pocahontas, who was often used by the English as an interpreter in their interactions with the Algonquian tribes of Tsenacommacah. ${ }^{2}$ The knowledge of local societies and languages possessed by these women, as well as their ability to infiltrate and navigate Indigenous spheres often barred or unknown to Europeans, made them extremely valuable in diplomatic and commercial dealings. These cases expose the overlapping functions or multiple roles of the interpreter. Besides facilitating oral communication, interpreters often acted as de facto brokers and go-betweens. By operating in a 'middle ground', to borrow Richard White's words, and possessing a unique linguistic and practical knowledge, interpreters rapidly became crucial intermediaries between different political and cultural worlds, having the ability to initiate or maintain contacts, as well as influence their outcomes. 33

Building on their experiences in the early seventeenth century, trading companies conducted several experiments to end their dependence on foreign interpreters or further the linguistic expertise of English scholars and officials. The factories of the Levant Company often operated as a learning hub where a myriad of individuals with scholarly interests were able to expand their linguistic skills through a direct exposure to Arabic, Turkish, Greek, or Hebrew. ${ }^{34}$ The interpreters at the service of the company, as well as other local scholarly agents, played a key role in these exploits. ${ }^{35}$

31 See, for example, María Laura Spoturno, 'Revisiting Malinche: A Study of Her Role as an Interpreter', in Translators, Interpreters and Cultural Negotiators, pp. 121-135.

32 See, for example, Rebecca Kay Jager, Malinche, Pocahontas, and Sacagawea:Indian Women as Cultural Intermediaries and National Symbols (Norman: University of Oklahoma Press, 2015).

33 Richard White, The Middle Ground:Indians, Empires, and Republics in the Great Lakes Region, 1650-1815 (Cambridge: Cambridge University Press, 2010). For cases specific to the Levant and South America, see Natalie Rothman, Brokering Empire: Trans-Imperial Subjects between Venice and Istanbul (Ithaca, NY: Cornell University Press, 2011); and Alida C. Metcalf, Go-betweens and the Colonization of Brazil, 1500-160o (Austin: University of Texas Press, 2005).

34 Simon Mills, 'Learning Arabic in the Overseas Factories: The Case of the English', in The Teaching and Learning of Arabic in Early Modern Europe ed. by Jan Loop, Alastair Hamilton and Charles Burnett (Leiden: Brill, 2017), pp. 272-293 (p. 274).

35 Simon Mills, 'The English Chaplains at Aleppo: Exploration and Scholarship between England and the Ottoman Empire, 1620-1760', Bulletin for the Council for British Research in the Levant, 6:1 (2011), 13-20. 
During his tenure as the chaplain of the English factory at Aleppo in the 1630s, the Orientalist Edward Pococke expanded his knowledge in Arabic with the help of Ahmad al-Gulshanī, a dervish who provided lessons to Europeans interested in Arabic and Islamic literature. ${ }^{6}$

The EIC encouraged its employees to learn South Asian languages in a controlled environment to minimise the risk of influence from local cultures. These measures included the appointment of teachers, monetary rewards for Englishmen learning local languages, and the forced isolation of young employees from their colleagues in order to guarantee they would rapidly learn a new language. In 1688 , following a similar strategy to the one adopted in Virginia, the EIC sent three fourteen-year-old boys to the Bencoolen factory in Sumatra. ${ }^{37}$ In spite of these efforts, the EIC continued to rely on foreign interpreters who mastered the lingua francas of the Indian Ocean - Persian, Arabic, Malay, and Portuguese. Some of these interpreters became relevant servants of the company. Abraham Navarro, a Sephardic Jew of Portuguese descent, served as an interpreter in China, Siam, and Mughal India between 1683 and 169o, eventually appointed to the office of Pursuer Mariner at Surat. Nonetheless, Navarro's Jewishness impeded him from becoming a member of the Bombay council. The board of the EIC in London barred Navarro's promotion, informing the Bombay council that the inclusion of 'a professed Jew is quite contrary to His Majesty's Charter to the Rt. Honorable Company for Bombay which is to govern the same as near as possible conformable to the laws of England and you know it is against the law that any Jew have any authority in Government'. ${ }^{8}$

As the cases of Adams, Spelman, or Navarro reveal, the roles of interpreters involved a series of activities related to commercial and diplomatic exchanges. This element of mobility forced interpreters to have a peripatetic life and a chameleonic identity which often had to be negotiated or redefined to ensure their employability and their personal safety. Their multiple roles and capacity to cross frontiers made them relevant cultural informants, a function that associated the 'interpreter' not only with language or linguistic skills, but also with the ability to understand and explain cultural or social traits. John Cotgrave's Wits Interpreter (1655), a miscellany of ancient and

$3^{6}$ Mills, 'Learning Arabic', pp. 272-293 (p. 280).

37 Anne Winterbottom, Hybrid Knowledge in the Early East India Company World (London: Palgrave Macmillan, 2015), p. 60.

38 Walter J. Fischel, 'Abraham Navarro: Jewish Interpreter and Diplomat in the Service of the English East India Company (1682-1692)', Proceedings of the American Academy for Jewish Research, 25 (1956), 39-62. 
contemporary quotes, trivia, and epigrams, evoked this specific feature of the interpreter as someone who used language to decipher cultural nuances. ${ }^{39}$ Whether in debates around biblical interpretation or around the translation of meaning across cultures and languages, the status and legitimacy of the interpreter involved issues over authority and power, the balance continually shifting.

Related keywords: broker, envoy, merchant, secretary, translator 


\section{Jew}

The Protestant chaplain for the Levant Company, William Biddulph, described Jews in the early seventeenth century as a people who 'to this day have no king nor country proper to themselves, but are dispersed throughout the whole world'. ${ }^{1}$ Despite this dispersal, Jewish communities retained strong and distinct connections rooted in their biblical heritage. 'They are called by three names', Biddulph wrote, but of Hebrews, Israelites, and Jews, 'the most common name whereby they are called at this day is, the name of the Jewes.' ${ }^{2}$ The shared Abrahamic traditions between Christianity and Judaism compelled Christians to define points of diversion between their faiths. Some Christian theologians saw Christ as fulfilling the prophecies of the Old Testament, rendering Judaic belief a series of empty rituals. ${ }^{3}$ Since Jews were still awaiting their promised saviour, these early modern Christians believed Jews to be falsely interpreting biblical teachings in ways that left them outside salvation. ${ }^{4}$ After the Reformation, Protestants often drew similarities between Jews and Catholics, describing them as living in states of spiritual confusion and superstition. ${ }^{5}$ At the same time, followers of the Jewish faith were seen as a people particularly scorned by other faiths. As Biddulph noted, Jews 'are of more vile account in the sight of Turkes th[a]n Christians [...] And the poore Christians sojourning and dwelling in [Aleppo] doe hate them very uncharitably' ${ }^{6}$

Jewish people had lived in England since the Roman era, welcomed by William the Conqueror as merchant traders. There were perhaps as many as 5000 Jewish people living in medieval England. ${ }^{7}$ The acceptance of Jews as merchants and circulators of economic wealth existed alongside popular views of 'Jews' as enemies of Christ, meaning that Jewish people were often severely persecuted on local, interpersonal levels. Accusations of 'Jews' committing violent crimes including blood sacrifice and ritual murder were

\footnotetext{
1 William Biddulph, The travels of certaine Englishmen into Africa, Asia, Troy (London, 16o9; STC 3051), sig. M4r.

2 Ibid., sig. M3v.

3 Eva Johanna Holmberg, Jews in the Early Modern Imagination: A Scattered Nation (Farnham: Ashgate, 2011), p. 81.

4 Ibid., pp. 54, 6 o.

5 Ibid., p. 55 .

6 Biddulph, The travels of certaine Englishmen, sig. M3v.

7 Eliane Glaser, Judaism without Jews: Philosemitism and Christian Polemic in Early Modern England (Basingstoke: Palgrave, 2007), p. 7.
} 
made in the twelfth and thirteenth centuries in Bristol, Winchester, and London, among other cities and parishes. ${ }^{8}$ In 1290 , all Jews were banished from England under Edward I's Edict of Expulsion. ${ }^{9}$ The Edict has been interpreted as an act of nation-formation, drawing political boundaries in which 'a sense of Englishness' became explicitly 'rooted in anti-Jewishness', a trend that would continue in later periods. ${ }^{10}$

Although officially banned from England, Jewish people reappeared under different statuses and identities in London and other English port cities in the sixteenth century. After the edicts of forced conversion and expulsion of Jews in Spain (1492) and Portugal (1496-1497) many opted to convert and others went into exile, setting up communities in cities such as Bordeaux, Toulouse, Nantes, Antwerp, Venice, Livorno, or Ferrara. These cities were part of trade routes in which Jewish tradesmen played pivotal roles, linked to Iberian hubs such as Lisbon and Seville. ${ }^{11}$ The violent Inquisitorial campaigns against crypto-Judaism in Spain and Portugal encouraged the continuous migration of Iberian Jews and conversos well into the end of the eighteenth century. ${ }^{12}$ London and Bristol were destinations for some Iberian Jews, but due to the 1290 edict these exiles officially entered English soil as Catholics. As Renee Levine Melammed noted, the adoption of a 'Catholic façade' was

8 Robin R. Mundill, England's Jewish Solution: Experiment and Expulsion, 1262-129o (Cambridge: Cambridge University Press, 1998), p. $5^{2}$.

9 Ibid.

10 James Shapiro, Shakespeare and the Jews (New York: Columbia University Press, 1996; 2016), pp. 53, 55. Shapiro's account offers a useful overview of English perceptions of Jews and Judaism.

11 Francesca Trivellato, The Familiarity of Strangers: The Sephardic Diaspora, Livorno, and Cross-Cultural Trade in the Early Modern Period (New Haven, CT: Yale University Press, 2012); Aron Di Leone Leoni, La Nazione Ebraica Spagnola e Portoghese di Ferrara (1492-1559): I suoi rapporti col governo ducale e la popolazione locale e i suoi legami con le Nazioni Portoghesi di Ancona, Pesaro e Venezia (Florence: Leo S. Olschki, 2011); Aron Di Leone Leoni, The Hebrew Portuguese Nations in Antwerp and London at the Time of Charles V and Henry VIII (Jersey City, NJ: KTAV, 2005); Miriam Bodian, Hebrews of the Portuguese Nation: Conversos and Community in Early Modern Amsterdam (Bloomington: Indiana University Press, 1999); Gerard Nahón, 'Les sefarades dans la France modern (XVIe-XVIIIe siècles)', Les Nouveaux Cahiers, 62 (1980), 16-25. 12 For an overview of the Inquisitorial activities against Iberian crypto-Jews and conversos, see Juan Ignacio Pulido Serrano, 'Converso Complicities in an Atlantic Monarchy: Political and Social Conflicts Behind Inquisitorial Persecutions', in The Conversos and Moriscos in Late Medieval Spain and Beyond, Vol. 3: Displaced Persons, ed. by Kevin Ingram and Juan Ignacio Pulido Serrano (Leiden: Brill, 2016), pp. 117-128; Giuseppe Marcocci and José Pedro Paiva, História da Inquisição portuguesa (1536-1821) (Lisbon: Esfera dos Livros, 2013); Francisco Bethencourt, The Inquisition: A Global History, 1478-1834 (Cambridge: Cambridge University Press, 2009); Henry Kamen, The Spanish Inquisition: A Historical Revision (New Haven, CT: Yale University Press, 2008); António José Saraiva, Marrano Factory: The Portuguese Inquisition and its New Christians 1536-1765 (Leiden: Brill, 2001). 
a survival strategy that sought to circumvent the edict of expulsion. To assume a 'Popish' identity allowed such migrants to maintain a familiar and trusted strategy of religious dissimulation. ${ }^{13}$

Those families who converted to Christianity could, on rare occasions, find a place in sixteenth-century England. Dunstan Anes (baptised Gonçalo Anes), a wealthy Portuguese crypto-Jewish merchant based in London, enjoyed commercial success and the ability to attract the interest of the English Crown during the reign of Mary I and then Elizabeth. ${ }^{14}$ In 1568, the College of Arms registered a coat of arms and a genealogy for Anes. In the same year, he became known as 'a Purveyor and Marchant for the Queenes Ma[ies]tyes Grocery'. ${ }^{15}$ Throughout the 158 os and 1590 s, Anes and his sons actively collaborated with the efforts of the Elizabethan espionage system to undermine the union of the Portuguese and Spanish crowns. ${ }^{16}$

The majority of Portuguese and Spanish conversos and crypto-Jews who went to England, however, were considered politically and religiously suspect. Catholic ambassadors in London observed, with some concern, that ostensible Catholics met to observe Jewish feasts such as Passover and Yom Kippur. ${ }^{17}$ Anxieties about marking out Jewish difference often related to fears about immigration more widely, so that anti-Jewish discourse became anti-alien discourse. ${ }^{18}$ The case of Roderigo Lopez, a 'denizened' Portuguese crypto-Jew who converted to Protestantism and was accused of plotting the death of Elizabeth I, exposed many of these fears, as persistent anti-Semitic attitudes intermingled with anti-Hispanic feelings. The scandal over the physician Lopez's ostensible attempt to poison Queen Elizabeth in 1594 brought the distrust of foreigners of privileged status, specifically Jews, to the fore of public debate in London. As the queen's trusted physician, Lopez enjoyed the patronage of the Earl of Leicester and Elizabeth's principal secretary, Francis Walsingham. Although he conformed to the Anglican Church, news and gossip following Lopez's

13 Renee Levine Melammed, A Question of Identity: Iberian Conversos in Historical Perspective (Oxford: Oxford University Press, 2004), pp. 96-97.

14 Edgar Samuel, 'Anes, Dunstan (c. 1520-1594)', Oxford Dictionary of National Biography, $<$ https://doi.org/10.1093/ref:odnb/40770> [Accessed 12 January 2020].

15 Robert Cooke, Visitation of London, 1568, ed. by Joseph Jackson Howard and George J. Armytage (London: Harleian Society, 1869) p. 65.

16 Samuel, 'Anes, Dunstan'.

17 Shapiro, Shakespeare and the Jews, p. 76.

18 Janet Adelman, Blood Relations: Christian and Jew in the Merchant of Venice (Chicago: University of Chicago Press, 2008), p. 8; Scott Oldenberg, Alien Albion: Literature and Immigration in Early Modern England (Toronto: University of Toronto Press, 2014), Part I. 
arrest and trial frequently iterated his converso identity as both a 'Portugal' and 'Jew'. ${ }^{19}$ Lopez's foreignness was an important part of the mistrust levelled against his loyalty. In his notes on the trial, the solicitor general Edward Coke noted that 'many Portuguese living under the Queen's protection were concerned' by a 'Portuguese Jew' serving the Queen of England so closely, suggesting that Lopez's fellow Portuguese were all too willing to distance themselves from him by emphasising the potentially deceptive nature of his religious practices. ${ }^{20}$ Accusations of Lopez's apparent Jewishness undermined his faithful service, and he was hanged, drawn, and quartered on 7 June 1594 .

Many conversos described themselves as men or women of 'the Hebrew nation', or simply as belonging to the 'nation'. Yet, as Lopez's trial suggests, their Portuguese and Spanish origins often surpassed their identification with the 'Hebrew nation'. In places such as Amsterdam, Venice, or even London, most conversos and crypto-Jews were first labelled as 'Portuguese' or 'Spanish'. Many members of these converso communities, in an attempt to stand out from other Jewish communities, continued to present themselves as belonging to the nação portuguesa ('Portuguese nation') or the nación española ('Spanish nation'). Such ambivalent belonging to a 'nation' was thus part of a strategy which allowed the conversos to develop a flexible identity that could be easily adjusted to the demands of Christian societies and other Jewish groups.

Unlike the names Jewish people used for themselves, Iberian conversos and crypto-Jewish exiles were often derogatively denoted Marranos, a Portuguese and Spanish term for 'pig'. A series of royal edicts in Portugal and Castile sought to curb the use of terms such as 'Marrano' by threatening heavy fines and even imprisonment, leading to a gradual decline in its usage, but in turn the term 'Jew' came to serve both as identifier and insult. ${ }^{21}$ Traces of the widespread use of Marrano in the Iberian Peninsula remained in other idioms..$^{22}$ 'Marrano' appears in Edward Blount's 1623 translation of Matias Alemán's Guzmán de Alfarache. ${ }^{23}$ In his Miscellanies of divinitie

19 'Notes [on the trial of Lopez] by Solicitor General [Edward] Coke', March 1594, Kew, The National Archives, SP 12/248, f. 55; see Peter Berek, 'The Jew as Renaissance Man', Renaissance Quarterly, $5^{1}$ (1998), 128-162.

20 David S. Katz, The Jews in the History of England, 1485-1850 (London: Clarendon Press, 1994), p. 56 .

21 António José Saraiva, Marrano Factory, p. xv.

22 Julio Caro Baroja, Los Judíos en la España Moderna y Contemporánea, Vol. I Madrid: Istmo, 2000), p. 405.

23 Mateo Alemán, The Rogue or The Life of Guzmán de Alfarache (London, 1623; STC 289). 
(1635), Edward Kellet related 'Marrano' to a complex evolution of Syriac, Greek, and Latin words about unbelief. ${ }^{24}$

The English abroad often came into direct contact with Jews and Jewish converts. Travellers and merchants in Europe and across the Ottoman Empire were keenly aware that Jewish communities operated vast networks of trade and economic exchange, serving as conduits between 'Constantinople, Aleppo, Damascus, Babylon, Grand Cayro, and every great Citie and place of Marchandise throughout all the Turkes dominions'. ${ }^{25}$ In Coryats crudities (1611), the first English book to include the word 'ghetto', the traveller Thomas Coryate offered his readers rare details about the religious ceremonies, customs, and dress of the early seventeenth-century Venetian Jewish community, as well as observations about the refusal of Jews to convert to Christianity. ${ }^{26}$ When the organ-builder Thomas Dallam travelled to Constantinople to deliver an instrument to Mehmed III at Elizabeth I's behest, he reported lodging ' 3 nyghtes in the house of a Jew, who is by Inglishe men caled the honeste Jew, for he is verrie lovinge unto Inglishe men'. ${ }^{27}$ Travellers noted city quarters where Jews were allowed to live and practice their faith, and expressed curiosity towards Jewish customs including circumcision and the matrilineal nature of Judaism, a concept at odds with the patriarchal hierarchy of early modern England. ${ }^{28}$

On the London stage, Jewish characters were often merchant go-betweens and moneylenders. Robert Wilson's The Three Ladies of London (printed 1584) offers an early and rare positive depiction of a Jewish character in the upright and good-natured moneylender Gerontius. However, the play's personification of Usury is an Englishman of Jewish heritage, embodying anxieties over an unseen or unacknowledged Jewishness difficult to disentangle from English identity. Later plays often emphasise an active differentiation of Jewish subjects and bodies from their Christian and English counterparts. Christopher Marlowe's The Jew of Malta (first performed 1592) drew on the 1565 Ottoman siege of Malta, with Jewish merchants acting 'as commercial

\footnotetext{
24 Edward Kellet, Miscellanies of divinitie (London, 1635; STC 14904), p. 50.

25 Biddulph, The travels of certaine Englishmen, sig. M3v.

26 Thomas Coryate, Coryats crudities (London, 1611; STC 5808).

27 'The diary of Master Thomas Dallam, 1599-1600', in Early Voyages and Travels in the Levant, ed. by James Theodore Bent (London: Hakluyt Society, 1893), p. 84.

28 Biddulph, The travels of certaine Englishmen; Fynes Moryson, An itinerary (London 1617; STC 18205); John Taylor, Three weekes, three daies, and three houres observations and travel, from London to Hamburgh in Germanie (London, 1617; STC 23807); James Howell, Instructions for forreigne travell (London, 1642; Wing H3082); William Mountague, The delights of Holland (London, 1696; Wing M2477); T. C., The New Atlas (London, 1698; Wing C139).
} 
intermediaries' moving between Christian and Islamic worlds. ${ }^{29}$ Like Shylock in Shakespeare's Merchant of Venice (c. 1597), Marlowe's Barabas offers a famous example of the pejorative depiction of Jewish men in early modern drama. Conniving and brutally murderous, Barabas is publicly punished on stage, his death a violent redress against the supposedly merciless Jew. These literary retributions are most viciously exemplified by Thomas Nashe's picaresque prose fiction, The Unfortunate Traveller (1594), where the Italian Jew Zadok suffers an extraordinary and lengthy torture and execution. In Robert Daborne's play, A Christian Turn'd Turk (1612), the double-dealing, slave-trading Benwash and his assistant Rabshake are converts to Islam for economic reasons, counterpointing the pirate John Ward's conversion for love. Yet as Aaron Kitch points out in his analysis of the Jewish figure in Thomas Middleton's City pageant, 'Triumph of Honour and Industry' (1617), more positive depictions of Jews could acknowledge their important place in the early modern political economy. $3^{0}$

Jewish women often became subjects of attention. Some accounts, including that of George Sandys, took pains to record their 'sluttish corpulency' with a misogynistic vehemence closely linked to derogatory comments about Jewish physical features usually directed at men. ${ }^{31}$ Others, like Coryate, insisted that the Jewish women he met were 'as beautiful as ever I saw', and admired their lavish 'apparel, jewels, chains of gold, and rings adorned with precious stones' which to him surpassed the wealth and elegance of 'English countesses' $3^{2}$ Coryate used the opulence and beauty of Jewish women to play with anti-Semitic stereotypes relating to the supposed material well-being of Jews, but also to suggest the physical attractiveness of Jewish women. ${ }^{33}$ Those perceptions are still present in the observations made by John Evelyn, another English visitor of the Venetian ghetto, in 1646. In his diary, Evelyn described attending a lavish Jewish wedding with a 'fine banquet' and 'divers very beautiful Portuguese Jewesses with whom we had some conversation'.34 This fascination was echoed in popular theatre of the period. Both Shakespeare's Jessica in The Merchant of Venice and Christopher Marlowe's Abigail in The Jew of Malta (first performed in 1592) demonstrate

29 Jerry Brotton, The Sultan and the Queen: The Untold Story of Elizabeth and Islam (New York: Viking, 2016), p. 175 .

30 Aaron Kitch, 'Shylock's Sacred Nation', Shakespeare Quarterly, 59 (2008), 131-155 (p. 133).

31 Holmberg, Jews in the Early Modern English Imagination, p. 122.

32 Coryate, Coryats crudities, p. 233.

33 Holmberg, Jews in the Early Modern English Imagination, p. 113; Richard I. Cohen, Jewish Icons: Art and Society in Modern Europe (Berkeley: University of California Press, 1998), pp. 11-12. 34 The Diary ofJohn Evelyn, ed. by William Bray (London: M. W. Dunne, 1901), p. 215. 
the ways in which women were often perceived to be easier to convert, as they were less obviously associated with external markers of Jewish identity (such as wearing a kippah and being circumcised) than men. ${ }^{35}$

Positive English representations of female Jewish beauty gesture not only to an implicit acknowledgement of Jewish economic power, but also to the place which the Hebraic tradition occupied within cultural and Christian religious beliefs. To view Jews as mere 'others' in seventeenthcentury England, as Achsah Guibbory argues, prevents an understanding of 'certain kinds of continuity and identity' that the English held towards ancient Jews. ${ }^{36}$ That continuity was often articulated through the figures of Jewish women from the Old Testament: Deborah, Judith, Hester, and Mariam often appeared as counterparts and exemplars to the virtues of Christian women such as Elizabeth I. ${ }^{37}$ Issues of virtue, duty, gender, and racial identity were present in Elizabeth Cary's The tragedie of Mariam (1613), the first known female-authored play to be published in England. ${ }^{8}$ In Cary's play, the distinction between the 'fair' proto-Christian Mariam and 'blackamoor' Salome (IV.vii.462) creates a distinction between Edomites and Israelites that plays out as much in terms of race and colour as religion. ${ }^{39}$

As Cary had done with the sources for The tragedie of Mariam, postReformation English theologians revisited the Hebraic/Jewish past in attempts to inform their historical understandings of nationhood and Englishness. ${ }^{40}$ Protestants aligned themselves with what they viewed as 'positive' aspects of Jewishness, including being God's chosen people, while accusing their opponents of its perceived negative aspects, such as legalism or heresy. ${ }^{41}$ Puritans who sought to establish a 'New Jerusalem' in New

35 M. Lindsay Kaplan, 'Jessica's Mother: Medieval Constructions of Jewish Race and Gender in "The Merchant of Venice"', Shakespeare Quarterly, 58 (2007), 1-30; Dympna Callaghan, 'Re-Reading Elizabeth Cary's The Tragedy of Miriam, Faire Queene ofJewry', in Women, 'Race', and Writing in the Early Modern Period, ed. by Margo Hendricks and Patricia Parker (Abingdon: Routledge, 1994), pp. 163-177; Ania Loomba, "Delicious traffic": Racial and Religious Difference on Early Modern Stages', in Shakespeare and Race, ed. by Catherine M. S. Alexander and Stanley Wells (New York: Cambridge University Press, 2000), pp. 203-224.

36 Achsah Guibbory, Christian Identity, Jews, and Israel in Seventeenth Century England (Oxford: Oxford University Press, 2013), p. 3.

37 John King, 'The Godly Woman in Elizabethan Iconography', Renaissance Quarterly, 38 (1985), 41-84; Susan Doran, 'Elizabeth I: An Old Testament King', in Tudor Queenship, ed. by Alice Hunt and Anna Whitelock (New York: Palgrave Macmillan, 2010), pp. 95-110.

38 Elizabeth Cary, The tragedie of Mariam, the faire queene of Jewry (London, 1613; STC 4613).

39 Kim F. Hall, Things of Darkness: Economies of Race and Gender in Early Modern England (Ithaca, NY: Cornell University Press, 1995), p. 185.

40 Guibbory, Christian Identity, Jews, and Israel, pp. 7-8.

41 Glaser,Judaism withoutJews, p. 33. 
England by converting 'heathens' sought answers to enduring questions about the dispersed twelve tribes of Israel as a signal of the end times. ${ }^{42}$ Reformation scholars in Holland and Geneva retained close networks with English Puritans and sympathised with their zeal for uncovering Hebraic truths. The Calvinist minister Franciscus Junius dedicated his Grammatica Hebraeae Linguae (1580) to Philip Sidney, writing that

the reason, obviously, why I like to offer [this book] to your country, is that I conclude from long conversations which I used to have with some of your fellow countrymen that they particularly were friends of art and friends of Hebrew; that their souls breathed only Hebraic flowers [...] that their houses seemed to be all decorated with Hebrew letters and their table-talk never without them. ${ }^{43}$

This is not to say that Puritans did not share anti-Jewish prejudices, but that many Protestant scholars and theologians engaged with Judaism. A shared textual heritage ensured an intellectual engagement with Jewishness that the English were less inclined to extend to Islam. ${ }^{44}$

As the seventeenth century progressed, English merchants, churchmen, and policymakers weighed questions of assimilation and tolerance with economic necessity. Doubtlessly influenced by encountering Jewish people abroad, the gentleman traveller Thomas Sherley the younger returned to England from Constantinople in 1607 and penned a proposal arguing for the importance of Jews to the English rise to global power. Enticing Jewish people to England, Sherley maintained, would induce them to leave Portugal and thus bring their trade with Brazil to English ports. Throughout, Sherley remained pragmatic. 'Daily occasions will be offered to make greater commodities out of them if once you have hold of their person and goods', he promised. 'But at first [the Jewes] must be tenderly used, for there is a great difference in alluring wild birds and handling them when they are caught'. 45

Sherley's project, though it did not come to fruition, demonstrates how politically minded Englishmen in the seventeenth century sought to benefit from Jewish networks of trade. This idea of Jews as global circulators of wealth sat alongside the apocalyptic-mindedness of the more militant or

42 Andrew Crome, 'The Restoration of the Jews in Transatlantic Context, 1600-1680', in Prophecy and Eschatology in the Transatlantic World, 1550-180o (Basingstoke: Palgrave, 2016), p. 140.

43 Ibid., p. 44.

44 Ibid., p. 63; Guibbory, Christian Identity, Jews, and Israel, pp. 1-23.

'Thomas Sherley's project', [early seventeenth century], Hatfield House, CP 124/152. 
radical religious dissenters of the Stuart period. The puritan belief that Jews might be converted before the end times, and thus be used by God as a scourge against the Ottomans to usher a godly Protestant kingdom in Palestine, fed into enduring fantasies about 'repossessing' the East. The political potential of this fantasy had been apparent in the West since the Crusades, but it increasingly became situated within a worldview which increasingly also looked to the Atlantic as a place of salvation. ${ }^{6}$ In 1654 , keen to bolster English mercantile activity, the Committee of Trade and Plantations issued a charter for 'Privileges granted to the People of the Hebrew Nation that are to go into the Willde' rainforests of South America and establish a Jewish colony for the English in Suriname. ${ }^{47}$ Although this colony failed, English officials revived the project in 1665 , when the governor of Surinam offered Jewish people the opportunity to become 'true subjects of our Sovereign Lord the King of England' in the colony. ${ }^{4}$

Over $35^{\circ}$ years after their expulsion, Oliver Cromwell sought to formally readmit Jews into the country after repeated petitions and requests from Jewish leaders in Europe, particularly the rabbi Menasseh ben Israel. Born in Portugal and baptised as Manuel Dias Soeiro, Menasseh and his family were conversos who settled in Amsterdam around 1610 after fleeing from the Portuguese Inquisition. ${ }^{49}$ His interest in Jewish readmission to England was sparked after the visit of an English trade delegation to his synagogue in 1650, where the English discussed the possibility of drawing trade to England by offering Jewish people the same rights that they enjoyed in Amsterdam..$^{\circ}$ In 1655 , Menasseh left for England with his family and a small group from his community to argue for the formal recognition of Jewish settlement. In an open letter to Cromwell, Manasseh wrote that '[p]agans of old' had often 'granted most willingly free liberty, even to apostate Jewes', and that 'we, that are not Apostate or runagate Jewes' hoped for much the same reception from Cromwell, since we 'adore the same one onely God of

46 Summarized by Gerald MacLean in Looking East: English Writing and the Ottoman Empire Before 1800 (Basingstoke: Palgrave, 2007), p. 16.

47 'Privileges granted to the People of the Hebrew Nation that are to go into the Wilde', 1654, London, British Library, Egerton MS 2385, f. 456.

48 'Grant of Privileges by the Governor, Council, and Assembly of Surinam, to Jews in Surinam, 17 August 1665', in Samuel Oppenheim, 'An Early Jewish Colony in Western Guiana, 1658-1666: And its relation to the Jews in Surinam, Cayenne and Tobago', Publications of the American Jewish Historical Society, 16 (1907), 179-180.

49 See David S. Katz, 'Menasseh Ben Israel (1604-1657)', Oxford Dictionary of National Biography $<$ https://doi.org/10.1093/ref:odnb/17916> [Accessed 15 November 2020].

50 Menasseh Ben Israel's Mission to Oliver Cromwell, ed. by Lucien Wolf (London:Jewish Historical Society of England, 1901), pp. $\mathrm{xxx}-\mathrm{xxxi}$. 
Israel, together'. ${ }^{51}$ However, Menasseh was not favourably disposed towards all Jewish communities and tried to distinguish between the Sephardic and Ashkenazi communities, favouring the latter over the former. Despite the council's encouraging response to Jewish readmission the results were inconclusive, and the official acceptance of Jews in England with royal protection only began in 1664, seven years after Menasseh's death.

The readmission of Jews in England coincided with the presence of converso communities in the English Caribbean, formed by Portuguese conversos following the ill-fated Dutch attempt to invade north-west Brazil. After the Portuguese recapture of Pernambuco in 1654, many Jewish people opted to resettle in the Caribbean, including in the English-held island of Jamaica and Barbados..$^{2}$ Although English authorities encouraged their settlement, these descendants of Portuguese conversos had discriminatory status in the English Caribbean. In Barbados, their testimony in courts had no validity and they faced restrictions in their possession of enslaved peoples. Those who migrated to Jamaica were not allowed to vote or be elected to civic institutions, and the colonies established a 'Jew Tax' in 1692. ${ }^{53}$ Most of these restrictions echoed the legislation which had been created to regulate the Jewish presence in England from 1656.54 Jewish people were prevented from entering the Levant Company or becoming board members of the West or East India Companies. 55 Though tolerated and readmitted for their economic utility, they continued to face restrictions that sought to hinder their participation both in English overseas trade and in the economic and financial expansion of London's activities.

Related keywords: broker, convert, merchant

$5^{1}$ Menasseh ben Israel, To His Highnesse the Lord Protector of the Common-Wealth of England, Scotland, and Ireland (1655), in Menasseh Ben Israel's Mission, pp. 76-77.

52 Erik R. Seeman, 'Jews in the Early Modern Atlantic', in The Atlantic in Global History: 150o-20oo, ed. by Jorge Cañizares-Esguerra and Erik R. Seeman (London: Routledge, 2016), pp. 41-62 (p. 45).

53 Ibid.

54 Francesca Trivellato, 'Sephardic Merchants in the Early Modern Atlantic and Beyond: Toward a Comparative Historical Approach to Business Cooperation', in Atlantic Diasporas: Jews, Conversos, and Crypto-Jews in the Age of Mercantilism, 1500-180o, ed. by Richard Kagan and Philip Morgan (Baltimore, MD: Johns Hopkins University Press, 2009), pp. 99-120 (p. 113). 55 Ibid., p. 114. 


\section{Mahometan}

'Mahometan', and to a lesser extent 'Musselman', were terms for followers of Islam at a time before 'Islam' and 'Muslim' were in use. 'The postclassical Mahometanus was a rendering of the Arabic name for Muhammad (d. 632), the founder of Islam. Islam, along with Judaism and Christianity, was an Abrahamic religion. ${ }^{2}$ Prolonged English encounters with Islam stretched back to pilgrimage and crusading in the early Middle Ages, while the Spanish conquest of Muslim-occupied Spain into the fifteenth century linked Arabic and Iberian cultures together in the English imaginary through terms such as 'Moor' and 'Morisco'. The collapse of the Christian Byzantine empire following the Ottoman conquest of Constantinople in 1453 shifted international political power, and ongoing Ottoman expansion 'propelled Mahomet into a wider Christian consciousness'. ${ }^{3}$ While 'Moors' often referred to North African Muslims, who were sometimes also categorised as 'blackamoors', 'Mahometans' often referenced Ottoman imperial might: thus in 1529, Thomas More described the 'Machometanys' as 'a sensual sect [that] dyd in a fewe yeres draw the great part of the world unto it'. ${ }^{4}$

In their desire to establish conformity to the Church of England, Protestant authorities in post-Reformation England sought to dispel parallels drawn between Christians and Mahometans deriving from their shared Abrahamic roots. ${ }^{5}$ Elizabethan and Jacobean travellers and writers projected the idea of 'Mahomet' as a false prophet who relied on tricks and deception to gain followers. Tales circulated that he had invented the Quran with the assistance of a renegade monk named Sergius, in a narrative which enmeshed Islamic prophecy with Catholic superstition. Giles Fletcher in The policy of the Turkish empire (1597) relayed that 'Mahomet' and the 'fugitive Monke' decided to 'coyne' a new religion that was 'neyther perfect Jew nor perfect Christian', but a patchwork of several pre-existing religions. ${ }^{6}$ Protestants must reject 'Mahomet, that cozening Arabian', Joseph Hall urged in 1625

1 'Mahometan, $n$. and adj.', Oxford English Dictionary.

2 Ibid.

3 Matthew Dimmock, Mythologies of the Prophet Muhammad in Early Modern English Culture

(Cambridge: Cambridge University Press, 2013), p. 10.

4 Ibid.

5 Ibid.

6 Giles Fletcher, The policy of the Turkish empire (London, 1597; STC 24335), sigs. B2r, D4v. 
whose 'rude ignorance', 'palpable imposture', and 'barbarous fictions [...] a wise Christian will scorne'?

Portrayals of Mahometans by English eyewitnesses tended to describe Islamic societies as corrupt or 'counterfeit'. Visiting the Ottoman Empire in the early 1610s, George Sandys lamented the circumcision of children, who were taken into mosques in white turbans where 'they dream that they shall all be assumed by Mahomet into Paradise'. ${ }^{8}$ Sandys critiqued the imperatives of survival that drove Christians to publicly convert to Islam, but reserved his greatest criticism for what he characterised as Islamic 'fables' and superstitions. The afterlife, based on 'the impious saying of Mahomet' was to be a world of 'sensuall felicities', of 'fragrant shades' with 'amorous virgins'. ${ }^{9}$ This, Sandys insisted, was 'rude and vulgar', a trick to ensure conversion through 'sensuall doctrine'. ${ }^{10}$ At the same time, as the translator and traveller John Pory acknowledged in 'Of Mahumet, and of his accursed religion in generall' in A geographical historie of Africa (1600), 'Mahumet his law', though 'it embraceth circumcision', also 'looseth the bridle of the flesh, which is a thinge acceptable to the greatest part of men.. ${ }^{11}$ It was perhaps this awareness of its attraction that compelled Protestant writers to seek to discredit Islam by emphasising that the Prophet Muhammad had been a man, marked by bodily dissolution and death. ${ }^{12}$

English descriptions of Islam also encompassed ideas about social order and political organisation, which invited the English to think about and articulate their own hierarchical norms. Muhammad's role as prophet was related to territorial gain, as Fletcher described in The policy of the Turkish empire. 'In this manner did MAHOMET erect a new Religion and kingdome amongest the Sarracens in the yeare of grace 623', Fletcher wrote, 'making Siria the seate of his Empire'.13 Mahomet 'was then grown to be a great power and estimation by reason of his wealth and the opinion of his Religion', which rendered him 'highly adored, both of the Arabians and the Egyptians.' ${ }^{14}$ Having spent several years in captivity in Constantinople, Thomas Sherley returned to England in 1606 and wrote his 'Discours of the

7 Joseph Hall, The works of Joseph Hall Doctor in Divinitie (London, 1625; STC 12635b), sig. Ee4v.

8 George Sandys, 'The Mahometan Religion', in Sandys travailes containing a history of the originall and present state of the Turkish empire (London, 1652; Wing S677), p. 44.

9 Ibid., p. 46.

10 Ibid.

11 John Pory, A geographical historie of Africa (London, 160o; STC 15481), p. 381.

12 Fletcher, The policy of the Turkish empire, sig. Civ.

13 Ibid., sig. Cir.

14 Ibid. 
Turkes', describing the arrival of the Ottomans in Asia Minor as responsible for 'the erronious \& devilishe sect of Mehemett'. ${ }^{15}$ Sherley discussed sodomy in order to relate deviant religion to destabilising social order: 'Theyre manner of living in private \& in generalle is moste uncivil and vicious [...] for theyre Sodommerye they use it soe publiquelye \& imprudentelye as an honest Christian would shame to companye with his wyffe as they doe with theyre buggeringe boyes'. ${ }^{16}$ Since private acts in domestic settings subverted the patriarchal order so integral to early modern English stability, the perceived threat of Islam did not just imperil the individual soul but the entire fabric of the commonwealth.

The English were also wary of how Islam absorbed, even welcomed, converts. A deep, implicit unease that Islam might prove stronger than Christianity ran alongside these vehement attacks against 'Mahometans'. ${ }^{17}$ This helps explain the invectives against Englishmen who 'turned Turk', such as the pirate John Ward in the 1610s. It also framed the public conversions of Muslims to Christianity celebrated by the Anglican Church. When Meredith Hanmer celebrated the 'Turk' who had rejected 'the superstitious lawe of Mahomet' and now embraced 'his true faith in Jesus Christ, received into the congregation of the faithful', it was important to publish the news. ${ }^{18}$

The English encountered Muslims beyond the Ottoman Empire. The ascension of the Safavids in Persia around 1501 established a Shi'a polity which directly challenged and competed with the Ottoman Sunni caliphate. At times, the English sought alliances with the Safavids against Ottomans for their mutual interests. The Persian empire fascinated English humanists who sought imperial templates and were drawn to Persia's classical heroes. English attitudes to Persia were 'markedly different to [their] fearful attitudes to the Ottomans', where 'Safavid ideology held a place for exemplary figures from Persian antiquity, including both Cyrus and Alexander'. ${ }^{19}$ Philip Sidney hailed the conqueror Cyrus and the Persian empire as the 'portraiture of just empire' in the early 1580 s, and the English continued to frame their own political aspirations in relation to Persia at various points in the seventeenth

15 Quoted in Ian Smith, 'The Queer Moor: Bodies, Borders, and Barbary Inns', in A Companion to the Global Renaissance: English Literature and Culture in the Era of Expansion, ed. by Jyotsna G. Singh (Chichester: Blackwell, 2009), pp. 190-204 (p. 197).

16 Ibid.

17 Gerald MacLean and Nabil Matar, Britain and the Islamic World, 1558-1713 (Oxford: Oxford University Press, 2011), p. 137 .

18 Meredith Hanmer, The baptizing of a Turke (London, 1586; STC 12744), sig. A2v.

19 Jane Grogan, The Persian Empire in English Renaissance Writing, 1549-1622 (Basingstoke: Palgrave, 2014), pp. 8-9. 
century. ${ }^{20}$ Tellingly, discussions of 'Mahomet' tended to be absent in these more positive appraisals of Islamic power by highlighting Cyrus's religious toleration prior to the Ottoman conquest.

The brothers Anthony and Robert Sherley travelled to Persia in 1599, where the Shah welcomed them at court. Ever an opportunist, Anthony received the title of mirza, an honour usually reserved for Muslim princes, and became close to Shah Abbas, with whom he could be seen walking arm in arm down the city streets. ${ }^{21}$ Anthony acknowledged that Persian attitudes towards religion were politically strategic. The Shah was 'exceeding curious and vigilant to suppress through all his dominions, that religion of Mahomet which followeth the interpretation of Ussen', referring to the Shah's Shi'a beliefs and his desire to suppress Sunni followers. ${ }^{22}$ While Anthony spent less than a year in Persia, his younger brother Robert lived there eight years. Through pressured to convert to Islam, Robert converted to Catholicism and married a baptised Circassian woman, Theresia. ${ }^{23}$ The poet Thomas Middleton celebrated Robert as 'this famous English Persian', but also praised him for seeking 'Christian confederacie against Mahomet \& his Adherents'. ${ }^{24}$

The dramatisation of the adventures of the three Sherley brothers in the play by John Day, William Rowley, and George Wilkins, The Travels of the Three English Brothers (1607), is illustrative of long-standing traditional ways of representing Islam and 'Mahometans' in the popular and literary culture of the period. ${ }^{25}$ Within the wider narrative tradition, Muslim characters appeared frequently in medieval crusading romances. The Sowdone of Babylone (c. 1400), for instance, involves the invasion of Rome by a sultan and his son Ferumbras, who eventually converts to

20 Ibid., pp. 8, 43-44. Philemon Holland's translation, Cyrupaedia (1632), included the Persian king Cyrus occupying one side of the image with King Charles on the other, wearing a closed imperial crown. See also Ladan Niayesh, 'Shakespeare's Persians', Shakespeare, 4:2 (2008), $127-136$.

21 Jerry Brotton, The Sultan and the Queen: The Untold Story of Elizabeth and Islam (New York: Viking, 2016), p. 240.

22 Ibid., pp. 241-242.

23 Bernadette Andrea, 'Lady Sherley: The First Persian in England?', The Muslim World, 95 (2005), 279-295.

24 Thomas Middleton, Sir Robert Sherley, sent ambassadour in the name of the King of Persia (London, 1609; STC 17894.5), sigs. C3v, C4r.

25 Dimmock, Mythologies of the Prophet Muhammad; Matthew Dimmock, New Turkes:Dramatizing Islam and the Ottomans in Early Modern England (Aldershot: Ashgate, 2005); Jonathan Burton, Traffic and Turning: Islam and English Drama, 1579-1624 (Newark: University of Delaware Press, 2005). 
Christianity, along with his sister, Floripas. Apart from the ever-present issues of conversion and temptation (often represented by the figure of a Muslim woman), the 'Mahometan' in such texts could function as a figure against and in response to whom Christian chivalric ideals could be explored. Within European literary tradition, the representation of adherents to Islam - 'Saracens' - was shaped through hugely influential Italian chivalric narrative poems like Matteo Boiardo's Inamoramento de Orlando (1483) and Ludovico Ariosto's Orlando furioso (1516). In England, Edmund Spenser's Redcrosse knight battled Saracens and an evil dragon from 'Tartary' in Book I of The Faerie Queene (1590). In such sources, it is difficult to ascribe a single conceptualisation of religious or cultural difference or a single idea of 'otherness' to such a range of texts. Instead, as Jonathan Burton argues, 'Islam functions as a discursive site upon which contesting versions of Englishness, Christianity, masculinity, femininity, and nobility are elaborated and proffered', leading to 'a representative practice, particularly apparent in English drama, which accommodates the solicitous, peaceful Turk and the bloody miscreant Turk, the convert and the temptress, the saint and the tyrant'. ${ }^{26}$

Insufficient or faulty knowledge informed English views towards Muslims along with superstition or prejudice, coupled with preconceptions about the inherent state of damnation shared by any who did not practice Protestantism. Prior to the English translation of the Quran in the midseventeenth-century, many scholars had relied on an error-ridden medieval Latin translation that exhibited little effort to convey the stylistic features of the original text. ${ }^{27}$ William Bedwell's Mehammedis Imposturae (1615) engaged with an anonymous Arabic text and contained three dialogues between two pilgrims returned from Mecca. One became Christian, while the other was a Muslim who sought to learn the true nature of salvation, asking for essential points of the faith as they were understood by both the Quran and the Gospels. The book concluded with the converted Sheich Sinan converting Doctor Ahmed to Christianity, but the text nonetheless displayed an interest in cross-religious exchange and understanding, even if it ultimately ended with an expression of Christian superiority. ${ }^{28}$ Bedwell was a well-respected Arabic scholar who worked on an Arabic-Latin dictionary

26 Burton, Traffic and Turning, p. 28.

27 Samuel C. Chew, The Crescent and the Rose: Islam and England during the Renaissance (New York: Oxford University Press, 1937), p. 434; Mordechai Feingold, 'Learning Arabic in Early Modern England', in The Teaching and Learning of Arabic in Early Modern Europe, ed. by Jan Loop, Alastair Hamilton, Charles Burnett (Leiden: Brill, 2017), pp. 33-56.

28 Chew, The Crescent and the Rose, pp. 436-437. 
and served as an interpreter to the Moroccan ambassador at court in 1600 . Several of his publications included an index of the chapters of the Quran and 'Arabicke termes used by Historians'. ${ }^{29}$ The first English translation of the Quran, The Alcoran of Mahomet, appeared in 1649, based on a French translation. Henry Stubbe, writing in the later seventeenth century, sought to combat the misinformation that had circulated as a result of faulty copies and translations. 'We have so many fabulous and ridiculous Accounts, both of Mahomet and his Imposture', Stubbe maintained, 'a great deal of fabulous, ridiculous trash, with which most of the Christian Narratives of him are stuff'd'.$^{30}$

Converts to Islam became a growing concern for English secular and religious leaders as commercial activities placed English men and women in increasing contact with Muslims. The Archbishop of Canterbury William Laud published $A$ Form of Penance and Reconciliation of a Renegado or Apostate from the Christian Religion to Turkism (1637), providing a liturgical way to formally reintroduce English converts to Islam back into the Protestant Church and English society. ${ }^{31}$ Outlining the process of recovery and reconciliation, Laud ordered that the individual should come to the Church 'in a penitent fashion in a white sheet and white wand in his hand, head uncovered' to beg the congregation to 'remember in your prayers a poor, wretched apostate or renegade'. $3^{2}$ The penitent had to repeat these actions for four weeks until they could 'penitently confess that I have grievously offended the majesty of God and deeply wounded my own soul'.33 Upon doing so the individual would not only be accepted back into the Church, but would in the eyes of the English be considered a subject of the Crown once again. One such case took place in the spring of 1649, when East India Company agent Thomas Breton wrote of his grief to 'imparte unto you a sad story' of Joshua Blackwell, a company employee at Agra, who was 'irrecoverably

29 William Bedwell, Mohammedis imposturae: that is, A discovery of the manifold forgeries, falshoods, and horrible impieties of the blasphemous seducer Mohammed with a demonstration of the insufficiencie of his law (London, 1615; STC 17995); William Bedwell, Mahomet unmasked (London, 1624; STC 17995.5).

30 Quoted in Dimmock, Mythologies of the Prophet Muhammad, p. 18.

31 William Laud, A Form of Penance and Reconciliation of a Renegado or Apostate from the Christian Religion to Turkism (1637), in Piracy, Slavery and Redemption: Barbary Captivity Narratives from Early Modern England, ed. by Daniel J. Viktus (New York: Columbia University Press, 2001), pp. 361-366.

32 Ibid., p. 362 .

33 Ibid., p. 363 . 
lost' after becoming a Muslim..$^{34}$ Breton believed that Blackwell was beyond reformation, citing Mughal legal acts that prevented any interaction that would lead to the reconversion of an individual. Against Breton's fears, Blackwell initiated a series of correspondences that led to his readmittance into the Protestant community, but which forced him to return to England to avoid being 'subject to the abuse of every Mahometan that knowes your condition'. 35

Increased trade routes and diplomatic exchanges in the later seventeenth century broadened existing English knowledge about Muslims, but the belief persisted that 'the Mahometists [...] doo erre and wander in the Labyrinth of straunge superstitions' ${ }^{3}{ }^{6}$ As the eighteenth century dawned, London feared 'turning Turk' once again, less through conversion than through altered bodies with the arrival of coffee from the Levant. 'Coffee-politicians', complained one anonymous writer in 1679 , were 'Turky News mongers, who with their Pipes and Dishes look as learnedly, as the Mahometan in the Sign'. ${ }^{37}$ Detractors celebrated imbibing alcohol as an act that socially differentiated English and Ottoman consumers: 'To drink is a Christian Diversion, / Unknown to the Turk and the Persian: / Let Mahometan Fools / Live by Heathenish Rules, / And be damn'd over Tea-Cups and Coffee' ${ }^{3}{ }^{8}$ Yet coffeehouses, their intoxicants, and their material cultures signalled one instance in which Ottoman practices and habits influenced English sociability.

Related keywords: blackamoor/Moor, convert, Turk

34 'President Breton and Messrs. Merry, Pearce and Oxenden at Swally Marine to the Company, 5 April 1649', in The English Factories in India, 1618-1669, Vol. VIII, ed. by William Foster (Oxford: Clarendon Press, 1906), p. 260.

35 Joshua Blackwell at Agra to the President and Council at Surat, 14 February 1650, in ibid., p. 299; Instruction for President and Council at Surat to Richard Davidge, 7 March 1650, in ibid., p. 302; William Isaacson at Surat to Joshua Blackwell [at Agra], 7 March 1650, in ibid., p. 304.

36 Fletcher, The policy of the Turkish empire, sig. Yv.

37 Observations on the last Dutch wars, in the years 1672 and 1673 (London, 1679; Wing O104), p. 6.

$3^{8}$ William Congreave, The way of the world a comedy (London, 1700; Wing C5878), p. 64. 


\section{Mercenary}

The English word 'mercenary' is derived from the Latin mercenarius, a hireling or someone who is paid for work. The original etymology of the mercenarius is rooted in two other Latin words: mercari, to trade or exchange, and merx, commodity or merchandise. That wider meaning was frequently associated in general usage with faithlessness and greed or desire, as when the Earl of Essex, writing to Elizabeth I, professed that 'the two ends of my life have been, the one to please you, the other to serve you', positioning these aspirations against 'mercenary or self-loving respect'. The pejorative dimension of 'mercenary' made the word a recurrent rhetorical weapon to attack the loyalty, legitimacy or credibility of political rivals or religious groups. ${ }^{2}$ The civil lawyer Walter Haddon attacked the 'mercenary ear confession' of the Counter-Reformation Portuguese humanist Jerónimo Osório's letter to Elizabeth I. ${ }^{3}$ The Puritan Henry Barrow, in his $A$ brief discoverie of the false church (1591), accused the Church of England of being formed by 'hireling Lecturers, vagrant \& mercenary Preachers' who, for preserving 'Romish brawling bawdy court, with all their popish canons, customs', were nothing more than 'mercenary Romish Doctors, pleaders, proctors \&c. which are to couller \& plead the most vile hateful causes which a Christian's ear abhorred to hear of, or by such wicked blasphemous customs, othes, purgations \& $c^{\prime} .{ }^{4}$ Similarly, the idea of writing for hire - the 'mercenary pen', '[t]hese mercinary pen-men of the Stage' - reduced the dignity of authorship to a base desire to benefit from the marketplace of print. ${ }^{5}$ It is an association that would later surface repeatedly during the English Civil War, due to the increased use of printed polemic to bolster both royalist and parliamentary causes. The equating of 'mercenary' with trade or exchange, as well as self-serving covetousness, was not always gender specific. 'A whore that is mercenary', wrote Thomas Gainsford,

\footnotetext{
1 The Earl of Essex to the Queen, 1595 [?], Hatfield House, CP 58/2or.

2 Sarah Percy, Mercenaries: The History of a Norm in International Relations (Oxford: Oxford University Press, 2007), p. 51.

3 Walter Haddon, Against Jerome Osorius Byshopp of Silvane in Portingall and against his slaunderous invectives (London, 1581; STC 12594), p. $5^{0 .}$

4 Harry Barrow, A brief discoverie of the false church (London [?], 1591; STC 1517), pp. 46, 230.

5 A prefatory discourse (London, 1681; Wing A3032), p. 18; George Wither, The great assises holded in Parnassus (London, 1645; Wing W316o), sig. E3r; Richard Brathwaite, An excellent piece of conceipted poesy (London, 1658; Wing B4263); Vincent Alsop, Melius inquirendum (London, 1678; Wing A2914), p. 12.
} 
'will hardly be drawn from her filthy life, she is so fast linked to the love of money'. ${ }^{6}$ And a '[m]ercenary Woman', warned the satirical writer Ned Ward in Female policy detected (1695), would 'submit to your Pleasure' for 'a splendid Maintenance' of silk and satin, only to build 'a Provision for her self out of the Ruins of your Fortune'?

The association between mercenary activity and military service, however, indicated a particularly dominant usage of the word. As professional soldiers who fought for pay rather than their prince, mercenaries became increasingly perceived as the antithesis of the sixteenth- and seventeenthcentury archetype of the military profession. Walter Ralegh, who served under the French Huguenot leader, Gaspar de Coligny, presented mercenaries as men who were not motivated 'by any love to the State, but to mere desire of gain, that made them fight', selling their soldiering skills to the best offer. $^{8}$ The services provided by mercenaries were thus less motivated by a political allegiance to a ruler or state than by an economic transaction. Mercenaries tended to show little interest in the cause for which they fought, being primarily motivated by their own private benefit. This element of free agency allowed mercenaries to choose their employers, and even change sides, contributing to their widespread negative image. ${ }^{9}$

In the confessional, dynastic upheavals that accompanied the Reformation and its aftermath, many English military men became itinerant soldiers in the service of the Protestant cause in France or the Low Countries. Professional or voluntary soldiers sought to distance themselves from the negative connotations associated with 'mercenary'. Soldiers in service to a foreign power could not only justify their actions but also enhance their prestige if that service was related to the alliances and aims established by their natural prince. In 1593, Thomas Churchyard praised those who, like him, were '[s] oldiers, whose venter and valiance hath been great, service and labor not little, and daily defended with the hazard of their lives, the liberty of the Country', complaining that 'it may be thought that every mercenary man, and common hireling (taken up for a while, or serving a small season) is a soldier fit to be registered, or honored among the renowned sort of warlike people. ${ }^{10}$ Another English veteran of the Low Countries, Thomas Digges,

6 T[homas] G[ainsford], The rich cabinet (London, 1616; STC 11522). p. 166.

7 Edward [Ned] Ward, Female policy detected (London, 1695; Wing W734), sig. Fiv.

8 Walter Ralegh, The history of the world (London, 1617; STC 20638), p. 379.

9 Percy, Mercenaries, p. 51; Frank Tallet, 'Soldiers in Western Europe, c. 1500-179o', in Fighting for a Living: A Comparative History of Military Labour, 1500-200o, ed. by Erik-Jan Zurcher (Amsterdam: Amsterdam University Press, 2013), pp. 163-164.

10 Thomas Churchyard, Chuchyards challenge (London, 1593; STC 5220), p. 85. 
presented himself as a part of a group of soldiers who were 'not mercenarie[s] for pay of strangers' but who fought abroad under a foreign flag at the service of 'our natural Prince and Country, (to whom we owe our bodies and lives).' The English who served with Dutch and French Huguenot troops against Spain and the Catholic League were rarely perceived as mercenaries, but rather as military men who served the realm by protecting the integrity of Protestantism both at home and abroad.

The experience of gentlemen serving the Crown in religious wars abroad contributed to the perception that a staunch adherence to Protestantism was an essential element of English identity and national allegiance. In The defense of the militaire profession (1579), Geffrey Gates considered the 'exercise of Arms' in defence of England and Protestantism as an essential duty for 'every citizen \& rural man, gentle or ungentle, noble or unnoble $[s i c]$, rich or poor, that meant to prove himself a good Christian, a faithful Englishman, zealous toward the state public of his country, of commendable integrity toward his prince and fervent in the love and maintenance of God's kingdom and glory upon earth.' ${ }^{12}$ In 1626 , for example, the clergyman Thomas Barnes praised those faithful English Protestants who went abroad to fight against Catholic powers, appealing to the 'meaner and vulgar sort' to join these wars in a call to arms. ${ }^{13}$

English Catholics also developed a similar rhetorical strategy which associated Catholicism with an English identity upheld by those who went abroad to fight for country and religion. A good example is the justification made by Cardinal William Allen to the actions of Sir William Stanley, a Catholic officer sent by Elizabeth I to Flanders. In 1587, Stanley surrendered his garrison to the Spanish army and entered the service of Philip II of Spain. What seemed to be an act of treason, was praised by Allen as a demonstration of 'Christian knighthood, \& an act much renowned' of a true Englishman who decided to defend the 'honor, conscience, and Religion, of our country' against Elizabeth I, a 'usurper, \& Heretical Queen'. ${ }^{14}$ This was not the case of a Catholic traitor and mercenary, but of someone who consciously acted to protect the quintessential Catholic traits of English identity from the damages inflicted by an illegitimate monarch who had undermined the true faith at home and abroad.

11 Thomas Digges, Foure paradoxes, or politique discourses, ed. by Dudley Digges (London, 1604; STC 6872), p. 69.

12 Geffrey Gates, The defense of the militarie profession (London, 1579; STC 11683), sig. G2r.

13 Thomas Barnes, Vox Belli: or, an Alarum to Warre (London, 1626; STC 1478), p. 40.

14 William Allen, The copie of a letter written by M. Doctor Allen (London, 1587 ; STC 370), sigs. $\mathrm{B}_{3} \mathrm{r}-\mathrm{v}$. 
The crusading spirit that justified war against Catholics also made acceptable the involvement of Protestant Englishmen in campaigns against 'pagan' or 'heathen' nations in Eastern Europe and the Mediterranean, even when these campaigns occasionally involved alliances with Catholics. Thomas Churchyard praised English private soldiers who served in Spanish armies against the 'Great Turk' for impeding the expansion of the Ottoman Empire and the spread of Islam. Among these was John Smythe who was 'so honorable that he advanced the fame of his country by the nobleness of his mind'. ${ }^{15}$ Despite being accused of treason for his Catholicism and allegiance to Rome and Philip II of Spain, the life of Thomas Stukeley, who fought under the Spanish flag in Lepanto and died serving Sebastian I of Portugal at the Battle of Alcazar, was celebrated as an example of English commitment in the defence of Christendom against Islamic expansion in George Peele's play The battell of Alcazar (1594), and popular ballads and poems such as The famous historye of the life and death of Captaine Thomas Stukeley (1605). ${ }^{16}$

If English private soldiers fighting against Islamic powers in the Tudor and early Stuart eras evoked an honourable crusading and chivalric spirit which made it acceptable to serve a Catholic prince in the defence of Christendom, fighting for non-Christian rulers was more difficult to justify. Englishmen who served the Ottoman sultan or the Mughal emperor were presented as mercenaries or renegades. In South Asia, the East India Company was frequently troubled by desertions of military men who opted to join local potentates or serve the Dutch East India Company or the Portuguese Estado da Índia. Although his brother Anthony served the ruler of Morocco in 1606, Sir Thomas Sherley, for example, complained that Europeans and Englishmen who served the Great Turk were 'for the most part rogues, \& the scum of people, which being villains and atheists, unable to Hue [sic] in Christendom, are fled to the Turk for succor \& relief'. ${ }^{17}$

Whether employed to fight for Protestant armies in Ireland or Catholic armies in the Ottoman Empire, mercenaries tended to be portrayed as marginal and roving individuals who did not belong to the established social order for a range of economic, political, or religious reasons. This perception was often motivated by the frequent recourse to the forced

15 Thomas Churchyard, A generall rehearsall of warres (London, 1579; STC 5235.2), sig. D4r.

16 George Peel, The battell of Alcazar (London, 1594; STC 19531); The famous historye of the life and death of Captaine Thomas Stukeley (London, 1605; STC 23405).

17 'Discours of the Turkes by Sir Thomas Sherley', in Camden Miscellany, Vol. XVI, ed. by E. Denison Ross (London: Offices of the Society, 1936), p. 4. 
conscription of convicted criminals, vagrants, and unemployed men in Tudor and Stuart armies, especially in the expeditionary forces sent to Ireland. The background of these recruits led Thomas Churchyard to criticise the 'mercenary multitude of troops' led by the Earl of Essex in Ireland. ${ }^{18}$ 'Mercenary' was thus a word that could be applied not only to a group of professional hired soldiers, but also to disliked volunteer soldiers whose behaviour or social origins clashed with the aristocratic martial ethos.

Mercenary armies had long been comprised of diverse nationalities. During the English civil wars, the employment of foreign soldiers became a particular issue of contention. The high number of desertion and defections among foreign soldiers serving both royalists and parliamentarians contributed to a widespread distrust on the reliability of 'outlanders'. Foreign soldiers of fortune, such as the Croatian Carlo Fantom, became notorious for treacherous behaviour. Described by the antiquarian John Aubrey as 'very quarrelsome and a great Ravisher', Fantom initially served the parliamentary forces and then changed sides for the royalist camp. ${ }^{19}$ According to Aubrey, Fantom assumed his mercenary condition, having declared: 'I care not for your Cause: I come to fight for your half-crown, and your handsome women: my father was a R[oman] Catholic; and so was my grandfather. I have fought for the Christians against the Turks; and for the Turks against the Christians'. ${ }^{20}$ Aubrey's short biographical notes on Fantom present this peripatetic Croatian who 'spoke 13 languages' as a true personification of the villainy associated with the mercenary. ${ }^{21}$ Aubrey's account of Fantom offered an extreme example of the untrustworthiness of foreign mercenaries. The soldier's pillaging, Catholic sympathies, and performing past services for the Ottoman Empire embodied the dangers of employing foreign soldiers. The violence and devastating impact of the English civil wars, and the significant presence of foreign soldiers fighting for both sides, reinforced rising xenophobic feelings, especially among Parliament's staunch Protestants. Rumours that Charles I planned to recruit foreign mercenaries from across Europe allowed parliamentarian

18 Thomas Churchyard, "The Fortunate Farewell to the most forward and Noble Earl of Essex [London: 1599]', in The Progresses and Public Progressions of Queen Elizabeth, Vol. III, ed. by John Nichols (London: J. Nichols and Sons, 1823), p. 433.

19 John Aubrey, Aubrey's BriefLives, ed. by Oliver Lawson Dick (London: Secker and Warburg, 1950), p. 105 .

20 Ibid., p. 105.

21 Ibid. 
propaganda to present the New Model Army as a truly English army, void of foreign corruption. ${ }^{22}$

If an English mercenary abroad was a potential traitor, a foreign mercenary in England threatened domestic harmony. The dangers posed by mercenaries constituted thus a threat to national identity. As Daniel Vitkus rightly noted, these were 'rogue cosmopolitans', highly mobile individuals who easily crossed physical, political, and religious borders. ${ }^{23}$ This border-crossing ability contributed to a perception of mercenaries as outsiders who did not belong to the established social order due to a range of socio-economic, political, and religious reasons. Their unstable identities and willingness to simply follow their self-interest questioned not only the parameters which defined the still tenuous conceptions of national identity, but also the authority of the state and its capacity to control the movements and behaviour of its populations. Indeed, the accusations or praise of mercenaries echoed the growing tensions between an idealised English identity and the more nuanced realities imposed by a geopolitical scenario shaped by the post-Reformation and overseas expansion.

Related keywords: alien/stranger, foreigner, rogue, traitor

22 Matthew Hoppe, Turncoats and Renegadoes: Changing Sides during the English Civil Wars (Oxford: Oxford University Press, 2012), pp. 69-72; Mark Stoyle, Soldiers and Strangers: An Ethnic History of the English Civil War (New Haven, CT: Yale University Press, 2005), pp. 102-110, 149, 204 .

23 Daniel Vitkus, 'Rogue Cosmopolitans on the Early Modern Stage:John Ward, Thomas Stukeley, and the Sherley Brothers', in Travel and Drama in Early Modern England: The Journeying Play, ed. by Claire Jowitt and David McInnis (Cambridge: Cambridge University Press, 2018), pp. 128-149. 


\section{Merchant}

Derived from Old French merchand and its variants, and used to designate a person who earned a living by purchasing and selling goods that were manufactured or produced by someone else, 'merchant' was an ambiguous word in the early modern period, used not only to describe those involved in commercial transactions but also to criticise individuals whose background and behaviour questioned notions of status or political allegiance. As individuals who dealt with money and were motivated by profit, merchants could be associated with serving lowly or dishonourable functions. Late medieval and Tudor authors often presented the figure of the merchant as a dubious character, usually in the form of a self-seeking fraudster or usurer who tricked his business partners and clients. In Newes from the north (1579), a work inspired by Piers Plowman, the author complained that 'it is as hard for a Merchant to be no Liar and for a Taverner or Inholder to be no drunkard'.

The widespread notion that landed wealth was the quintessential marker of nobility, distinguishing the aristocrat from those who had to labour to earn money, contributed to negative perceptions of merchants as an emergent class with unconventional pretensions to status. William Harrison's Description of England (1577) divided Elizabethan society into four groups: gentlemen, 'citizens or burgesses', yeomen, and 'artificers or laboures.' ${ }^{2}$ Harrison placed merchants 'amongst the citizens', a group of individuals who 'have next place to gentlemen' and who enjoyed the privileges of being 'free within the cities, and are of some likely substance to beare office'. ${ }^{3}$ Their wealth allowed them to have the political status of 'citizen' and enjoy a proximity to gentlemen, since citizens 'often change estate with gentlemen, as gentlemen do with them, by a mutual conversion of the one into the other'. ${ }^{4}$ However, implicit in that acknowledgement of proximity was a mistrusted fluidity between the place of merchants and gentlemen in the Elizabethan commonwealth. In 1581, the schoolteacher and author Richard Mulcaster divided English society into two main groups: gentlemen and the commons. The latter were formed by 'marchauntes and

1 F. T. [Francis Thyme?], Newes from the north (London, 1579; STC 24062), sig. A2v.

2 William Harrison, 'The Description of England', in The first and second volumes of Chronicles comprising the description and historie of England, ed. by Raphael Holinshed (London, $15^{8} 7$; STC 13569), p. 163 .

3 Ibid.

4 Ibid., p. 62. 


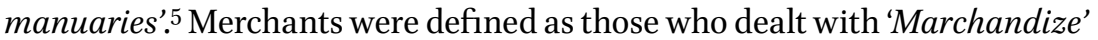
and included 'all those which live any way by buying or selling', related, therefore, less to the elite than with the 'manuaries' were 'those whose handyworke is their ware, and labour their living. ${ }^{6}$ Mulcaster and Harrison's observations reflected how the circulation of wealth within and out of the realm allowed individuals to aspire to social betterment and, in the case of merchants, to enjoy the lifestyle and civic activities traditionally associated with gentlemen.

Merchants themselves were particularly zealous about their own identifications. The members of the Spanish Company, for example, refused access to anyone who was not a 'mere merchant', thus excluding shopkeepers, retailers, and manufacturers. 7 The Company of Merchants Adventurers of York, established in 1581, only accepted individuals who had been merchants for a minimum of ten years or who had served as apprentices for a period of seven years, rejecting anyone who worked as 'artificers and handicraftsmen'. 8 These restrictions aimed to regulate a specific profession, and to protect and enhance the status of its members, who were aware of the ambivalent terms used to identify them.

As 'strangers', the status of foreign merchants in England was extremely complex and often involved intricate and contradictory interpretations of statutory law, common law, law merchant, and a series of local regulations. Alessandro Magno, a Venetian merchant who travelled to England in 1562 , recounted some of the restrictions faced by foreign merchants during Elizabeth I's reign. 'No one', he wrote, 'can set up shop or buy anything from foreign merchants if he has not served a seven-year apprenticeship; and if it is discovered that goods have been bought from foreign merchants rather than from an Englishman who has served the required time, the goods are forfeited'. ${ }^{9}$ The practical problems posed by the restrictions imposed on 'stranger' and 'alien' merchants led Roger Coke, who considered them to be a 'defect', to propose that Parliament should 'bring in a Bill for a General Naturalization of all Alien Protestants, and allowing them Liberty

5 Richard Mulcaster, Positions wherein those primitive circumstances be examined, which are necessary for the training up of children (London, 1581; STC 18253), p. 198.

6 Ibid., p. 198.

7 See for example: Pauline Croft, 'Introduction', in The Spanish Company, ed. by Pauline Croft (London: London Record Society, 1973), pp. x-xxix.

8 David M. Smith, The Company of Merchant Adventurers in the City of York: Register of Admissions 1581-1835 (York: Borthwick Publications, 1996), p. i.

9 Quoted in Michael Wyatt, The Italian Encounter with Tudor England: A Cultural Politics of Translation (Cambridge: Cambridge University Press, 2005), p. 139. 
to Exercise their Trades in all Corporations'. ${ }^{10}$ The debate on the status of foreign merchants would continue well into the eighteenth century, heavily influenced by changes in English foreign policy.

Nonetheless, the Crown often relied on London's merchant strangers and financiers as a source of revenue in times of need. In return for lucrative monopolies, lands, and titles, strangers leant large sums to finance both domestic affairs and military campaigns abroad. The Genoese alum exporter Horatio Palavicino first came to England in 1578 after lending $£_{30,000}$ worth of alum stock to the States General of the Low Countries in order to support the war effort against Spain. ${ }^{11}$ Elizabeth had underwritten the loan which, while never repaid, by 1593 had accrued Palavicino $£ 45,47911 s 11 d$ in interest payments. In 1588 an enforced loan from the City's merchant strangers to fund the Armada effort accrued $£ 4900$. Palavicino, knighted the year before for services to the Crown, contributed $£_{300}{ }^{12}$

The expansion of English overseas trade during the Elizabethan and Stuart eras stimulated the social and political ascension of merchants. As Richard Brenner observed, the socio-economic structures of early modern England underwent profound changes between 1570 and $1660 .{ }^{13}$ During Elizabeth's rule English commercial and diplomatic exchanges with Catholic Europe, especially with Iberian powers, were severely damaged. Without direct access to the Asian, African, and American commodities sold in Lisbon and Seville, the English Crown supported projects that sought to exploit new markets and trade routes such as the Turkey Company (1581), the Barbary Company (1585), the Levant Company (1592), or the East India Company (160o). The royal charters issued for these and other trading companies forged a complex web of interdependence between the Crown and the leading members of mercantile groups. ${ }^{14}$ Even as English monarchs used the chartered companies as an instrument to increase their revenues,

10 Roger Coke, Reflections upon the East-Indy and Royal African Companies with animadversions, concerning the naturalizing offoreigners (London, 1695; Wing C489o), p. 16.

11 Ian W. Archer, 'Palavicino, Sir Horatio (c. 1540-160o), merchant and diplomat', Oxford Dictionary of National Biography<https://doi.org/10.1093/ref:odnb/21153> [Accessed 13 May 2020]. 12 Returns of Aliens Dwelling in the City and Suburbs of London from the Reign of Henry VIII to that ofJames I, Vol. 2, ed. by R. E. G Kirk and Ernest F. Kirk (Aberdeen: Aberdeen University Press, 1900-1908), pp. 414-415.

13 Richard Brenner, 'The Social Basis of English Commercial Expansion, 1550-1650', The Journal of Economic History, 32:1 (1972), 361-384.

14 William A. Pettigrew, 'Corporate constitutionalism and the dialogue between the global and the local in seventeenth-century English history', Itinerario, 39:3 (2015), 487-501; Henry S. Turner, The Corporate Commonwealth: Pluralism and Political Fictions in England, 1516-1651 (Chicago: University of Chicago Press, 2016), pp. 118-144. 
the joint-stock nature of these corporations enabled the development of new and complicated ideas of governance and political authority. This allowed the formation of a politically influential mercantile elite who were able to claim superior social status and help shape the direction of English diplomatic, colonial, and economic policies. ${ }^{15}$

Women from the aristocracy and affluent merchant families were investors and financiers in overseas trade. Their involvement connected them to ports such as London and Amsterdam, but they were also important links between families and patrons who brought a range of trade and colonial projects together. Katherine Hueriblock and Rebecca Romney are two such examples. ${ }^{16}$ The first was the daughter of a Dutch merchant who migrated to London in the 1550 s. Her first two marriages were to two freemen of the Grocers' Company, John West and Richard Fust respectively. A third marriage made her the wife of Sir Edward Conway, a member of the Privy Council and a secretary of state. The pattern of Hueriblock's marriages is revealing, not only of the ways in which the riches offered by marriages with women from merchant families attracted individuals with political aspirations, but also of her ability to accumulate wealth through her own independent investments. ${ }^{17}$ Rebecca Romney was the sole heir of Robert Taylor, a wealthy mercer and freeman of the Haberdashers' Company. She had received a thorough education and was well acquainted with London merchant networks. Her union with William Romney was largely a business partnership. Romney made a series of profitable independent investments in the Virginia Company (1609), the Hudson voyages (1610), and the NorthWest Passage Company (1612), and through her husband and after his death became involved with the Spanish Company, the East India Company, and the Levant Company. These two cases of early modern businesswomen who constructed global investment portfolios while integrating their social and commercial networks of influence are illuminating examples of how women were able to intervene in overseas ventures, something which only escalated through the seventeenth century. ${ }^{18}$

As an integral part of English overseas expansion, merchants and their exploits abroad were celebrated as triumphs of the English nation. In The

15 See, for example, Edmond Smith, 'The global interests of London's commercial community, 1599-1625: Investment in the East India Company', Economic History Review, 71:4 (2018), 1118-1146. 16 Misha Ewen, 'Women Investors and the Virginia Company in the Early Seventeenth Century', Historical Journal, 62:4 (2019), 853-874.

17 Ibid.

18 Ibid.; Amy Froide, Silent Partners: Women as Public Investors during Britain's Financial Revolution, 1690-1750 (Oxford: Oxford University Press, 2016). 
principal navigations (1589), the geographer and editor Richard Hakluyt enthusiastically hailed the tradesmen who 'through the special assistance, and blessing of God, in searching the most opposite corners and quarters of the world, and to speak plainly, in compassing the vaste globe of the earth more than once, have excelled all the nations and peoples of the earth'.19 Hakluyt's successor, Samuel Purchas, praised merchants for bringing 'profit to our Nation, to vent Clothes, Iron, Lead, and other Commodities', and 'set[ting] on work so many of all Trades and Professions [...] to enrich the Kings Coffers and public Treasury, in Customs, Imposts, and other Duties'. ${ }^{20}$

Meanwhile, their presence in foreign lands offered English merchants many opportunities to behave outside the social, religious, and moral norms that regulated sixteenth- and seventeenth-century English life. John Sanderson, writing from Pera in 1600 , complained about the loose behaviour of his fellow Levant merchants ('a set of divers devils, fools, madmen, antiques, monsters, beast, whoremongers') during a dinner where a 'whore should have been at it in mans apparel, but was sent out of the room because a cuckold of this damned crew could not brooke her company'. ${ }^{21}$ The English consul in Lisbon, Hugh Lee, regularly reported his fears that the young English merchants and apprentices who were sent to the Portuguese capital to live with the families of local merchants would eventually convert to Catholicism. ${ }^{22}$

It was not uncommon for merchants with families in England to marry abroad, despite harsh punishments for bigamy. Overseas companies imposed several obstacles to merchants travelling with their families, creating a situation in which many merchants established informal unions with local women. William Adams, the EIC merchant and agent in Japan, had a wife and children in England and another wife and two children in Japan. ${ }^{23}$ The status of the children of English merchants born overseas was difficult to establish, especially if they were the offspring of mixed marriages. According to the De Natis statute of 1351, offspring of English subjects could inherit

19 'To the right honorable Sir Francis Walsingham Knight', in Richard Hakluyt, The principal navigations, voyages, traffiques and discoveries of the English nation (London, 1589; STC 12625), sig. ${ }^{*} 2 \mathrm{v}$.

20 Samuel Purchas, Purchas his pilgrimage (London, 1626; STC 20508.5), p. 484.

21 John Sanderson, The Travels of John Sanderson in the Levant, 1584-1602, ed. by William Foster (London: Hakluyt Society, 1931), p. 197.

22 Alison Games, The Web of Empire: English Cosmopolitans in an Age of Expansion, 1560-1660 (Oxford: Oxford University Press, 2008), p. 98.

23 'William Adams to Augustine Spalding, 12 January 1613', in Letters Received by the East India Company, 1602-1613: Vol. 1 , ed. by Frederick Charles Danvers (London: Sampson Low, Marston \& Company, 1896), p. 209. 
property in England if both parents were English. However, if these children had an alien mother, they were not allowed to inherit the property of their father as the De Natis stated that an alien mother eliminated the father's English nationality. The rationale behind this argument was that national or political allegiance was tied to place. Thus, the marriage between an alien woman and an Englishman did not change her allegiance and their offspring, being born on foreign soil, were not entitled to the privileges enjoyed by English subjects.

As English trade expanded and English merchants abroad constituted families with foreign women, the principles established by the De Natis became increasingly problematic. King $v$. Eaton (1627), a case concerning the inheritance rights of Richard Stephenson, the son of an English merchant in the Eastland Company and a Polish mother, would initiate a gradual transformation of English legislation. The judges established that in similar cases the application of the principles of the De Natis should include offspring with only one English parent. More importantly, the sentence also established the principle partus sequitur patrem (the offspring follows the condition of the father), confirming that the nationality of an English father was directly transmitted to his children. ${ }^{24}$ King $v$. Bacon (1640), a case involving the inheritance rights of Gertrude Bacon, the daughter of another merchant based in Poland, confirmed the verdict of 1627 and stated that the child of an English merchant based in a foreign country should be considered a denizen and heir. ${ }^{25}$ These two cases offered a viable solution based on an idea of superiority of English nationality transmitted via a paternal line.

Throughout the period, merchants were indispensable intelligencers. Much of the Elizabethan and Jacobean knowledge of African, American, and Asian geography, and of the colonial projects of other European powers, was provided by the translations of Iberian or Italian works made by merchants such as John Frampton or Thomas Nicholas. Through merchants, English scholars and armchair travellers too obtained valuable manuscripts and objects to enlarge libraries and cabinets of curiosities. Though Francis Bacon disdained the political pretensions of merchants, he praised the '[m]erchants

24 Jacob Selwood, Diversity and Difference in Early Modern London (Farnham: Ashgate, 2010), pp. 90-98.

25 For an overview of these cases see Barbara J. Todd, 'Written in Her Heart: Married Women's Separate Allegiance in English Law', in Married Women and the Law: Coverture in England and the Common Law World, ed. by Tim Stretton and Krista J. Kesselring (Montreal: McGill-Queen's University Press, 2013), pp. 163-199 (pp. 163-177). 
of Light' who '[s]ayle into Forraine Countries [...] [and] bring us the Books, and Abstracts, and Patterns of Experiments of all other Parts. ${ }^{26}$

The movement of goods and people linking England with the Atlantic, Mediterranean, and Indian oceans had a profound impact on English consumption and social habits. Authors attributed the popularity of coffee and tobacco in seventeenth-century England to 'smoakie Merchants' or 'Smoak Merchants [...] TOBACCO-Mongers' who promoted the adoption of alien commodities that contained the potential to corrupt English virtues and national character. ${ }^{27}$ Tobacco became the first non-European commodity of mass consumption in England, smoked by men and women of all social statuses. Words usually associated with merchant activities and overseas commercial exchanges, such as 'assurance', 'premium', 'credit', or 'risk', became common usage in the seventeenth century. ${ }^{28}$ Merchants, especially those who operated in multilingual contexts in the Mediterranean and Asia, also developed a specific jargon based on local words such as 'bazaar' (from the Persian $b \bar{a} z \bar{a} r$ ) or 'bank' (from the Italian banca). Other loanwords entered English as commodities: tobacco (from the Portuguese and Spanish tabaco), tea (from the Chinese te), or coffee (from the Turkish kahveh, and the Dutch koffie). The novelties introduced by English merchants and their influence on consumption and social practices could be perceived as a risk, but they were also celebrated as a symbol of English power and wealth. ${ }^{29}$

Throughout the period, merchants were often evoked in literature and visual culture as a recognisable, if envied or critiqued, part of the social fabric, responsible for the circulation of wealth and goods. Poets contrasted merchant wealth to true beauty and virtue as a literary conceit, as in Edmund Spenser's 'Amoretti VI: Ye tradefull Merchants that with weary toyle' or Fulke Greville's 'Sonnet LVIII' ${ }^{30}$ Such poems exposed the uneasy counterpoise between desire and humanist conceptions of moderate virtue, further complicated by metaphors that drew on the physical to explain

26 Francis Bacon, Sylva sylvarum (London, 1627; STC 1168), p. 43.

27 Blasius Multibibus, A solemne joviall disputation (London, 1617; STC 3585), sig. G4r; Josuah [Joshua] Sylvester, Tobacco battered, \& the pipes shattered (London, 1616; STC 23582a), p. 115.

28 For an evolution these terms see, for example, Christopher Ebert, 'Early Modern Atlantic Trade and the Development of Maritime Insurance to 1630', Past \& Present, 213:1 (2011), 87-114. 29 Mercantilism Reimagined: Political Economy in Early Modern Britain and its Empire, ed. by Philip J. Stern and Carl Wennerlind (Oxford: Oxford University Press, 2013); Global Traffic: Discourses and Practices of Trade in English Literature and Culture from 1550 to 1700 , ed. by Barbara Sebek and Stephen Deng (New York: Palgrave, 2008).

30 Edmund Spenser, Amoretti and Epithalamion (London, 1595; STC 23076), sig. B4r; Fulke Greville, Certaine learned and elegant workes [...] written in his youth, and familiar exercise with Sir Philip Sidney (London, 1633; STC 12361), sig. Ff2r. 
the metaphysical. ${ }^{31}$ In city comedies, as in the sixteenth- and seventeenthcentury economy, the wives and daughters of merchants became important nodes linking trading companies and merchant families together.

This role of merchants in overseas expansionism, Tudor and Stuart intellectual life, and the circulation of goods - in being responsible, in many ways, for creating a culture of global consumption in England, from plants to spices to ceramics - contributed to a re-appreciation of the political and social status of merchants from the mid-seventeenth-century. The traveller and dramatist Richard Flecknoe presented the English overseas tradesman as 'the honour of his Nation abroad, and therefore his Nation should be very dishonourable and unworthy, should it not always honour him. $3^{22}$ Flecknoe's description of the lifestyle and moral behaviour of merchants differed greatly from the entrenched image of the usurer or amoral businessman. Those who knew the households and restrained lifestyles of wealthy overseas merchants, Flecknoe remarked, would find 'him a noble and gallant minded Gentleman'.33 Merchants strongly identified with their role in advancing the good of the nation through 'weary toyle' and merchandising. In his 1544 portrait the mercer and merchant adventurer Thomas Gresham, founder of the Royal Exchange, chose to be portrayed in full length, his image rivalling the size of those painted for Tudor monarchs. The portrait commemorated Gresham's marriage to Anne Ferneley through their interlocked initials, but it also included his merchant's mark and a skull, popular in the vanitas genre. Merchants were the invisible presence behind the still life genre that effloresced as a result of global exploration. The luxurious and exotic commodities brought by English merchants were often understood to be a demonstration of English superiority and their ability to 'subdue and convert the whole world' ${ }^{34}$

As the seventeenth century drew to a close, merchant elites consolidated their position and celebrated their success. According to Kirti Chaudhuri, the EIC registered profit rates of more than 100 per cent between 1608 and 1612. The company's fifth voyage (16o8), for example, yielded a profit of 234 per cent. ${ }^{35}$ In 1690, Josiah Child, who served in different high-ranking

31 Philip Edwards, Sea-Mark: The Metaphorical Voyage, Spenser to Milton (Liverpool: Liverpool University Press, 1997), pp. 8-9.

32 Richard Flecknoe, A relation of ten years in Europe, Asia, Affrique, and America (London, 1656; Wing F1232), p. 89.

33 Ibid., p. 90.

34 John Donne, Fiftie sermons (London, 1649; Wing D1862), p. 449.

35 K. N. Chaudhuri, The English East India Company: The Study of an Early Joint-stock Company, 160o-164o (London: Routledge, 1965), p. 209. 
administrative posts of the EIC throughout the 1670 os and 168 os, praised the perseverance of tradesmen and social ascension: 'We that are merchants, can so easily turn Gentlemen by buying Lands for less than twenty Years purchase, let no Man expect that if we thrive, we will drudge all our days in Trade; or if we would, to be sure our Sons will not'. ${ }^{6}$ Child's discourse, like other works written by tradesmen, revealed a self-awareness of merchants as dutiful and important members of the polity, well poised to serve the interests of the realm, at a time when longstanding ideas of the commonwealth were being replaced by 'more flexible notions of public interest and the public good', ${ }^{37}$ New commodities and consumption habits played a role in these changes to the traditional order of early modern England. Still lifes demonstrated the sheer range of goods that merchants brought into the realm - not just tea, tobacco, and coffee but pepper, ginger, Chinese ceramics, Ottoman tulips, chocolate, pineapples. In 1685, the author Edward Philips remarked that civility gave 'proper grace to a Courtier' but 'would cause derision if presented by a Merchant or a Factor' $3^{8}$ Yet elite criticisms of merchants existed alongside the Crown and court's dependence on merchants for capital and for luxury goods that enhanced their own status. By the early eighteenth century, ideas of luxury, politeness, and honour had shifted the place merchants held in the realm. ${ }^{39}$ The world of courtiers and merchants, of court, commerce, and the bustling world of street sellers and shopkeepers, overlapped and were inextricably connected.

Related keywords: alien/stranger, broker, citizen, denizen

36 Josiah Child, A discourse about trade (London, 169o; Wing C3853), pp. 158-159.

37 Paul Slack, The Invention of Improvement:Information and Material Progress in SeventeenthCentury England (Oxford: Oxford University Press, 2014), p. 54.

38 Quoted in Markku Peltonen, The Duel in Early Modern England: Civility, Politeness, and Honour (Cambridge: Cambridge University Press, 2003), p. 300.

39 Ibid. 


\section{Native}

The early modern English concept of 'native', derived from post-classical Latin nativus, arose in part from long standing legal perceptions surrounding a person's status from birth, either as an individual born into bondage, servants, or one inheriting a status. In Scotland, the word dates back as early as 1381, but first appeared in English language in the fifteenth century to denote the particular status of local people as being either 'bondmen or natifis.' 'Native' not only related to local and national geography, but to the status of an individual's parents. That status was an inheritable right. It entitled an individual, through feudal ideas of fealty and allegiance to the Crown, to certain rights and privileges that were withheld from others. ${ }^{2}$ Calais was lost in $155^{8}$ and Wales had been under English control since Edward I. Following the accession of James VI to the throne of England in 1603 , Scotland and England became the focal point of debates on legal natives.

In the early seventeenth century, a particularly crucial legal nuance was introduced. The 1608 legislation now known as Calvin's Case decided that Scottish children, known as the postnati (born after the Scottish King James VI inherited the throne of England in 1603), had the legal right under English law to be considered native English subjects, whilst also clearly outlining who would be excluded from obtaining and inheriting the rights and privileges of native English subjects. ${ }^{3}$ This ruling affirmed ideas of $j u s$ soli, based around an enduring and personal bond between subjects and the monarch, in which children of immigrants were granted, as a natural birthright, the privileges of natives through their connection to the same monarch. If a child born in Scotland after the union pledged allegiance to the Scottish Crown, then they also pledged allegiance to the English crown by proxy. The decision blurred the boundary between 'status and place of origin', and meant that within the British Isles, the status of 'native'

1 The English register of Godstow Nunnery, near Oxford, written about 1450, ed. by Andrew Clark (London: Early English Text Society, 1906), p. 13o; Douglas Book, Vol. 3, ed. by William Fraser (Edinburgh: Edinburgh University Press, 1885), p. 29; For more information on Calvin's Case see the 'Subject' keyword.

2 Polly J. Price, 'Natural Law and Birthright Citizenship in Calvin's Case (16o8)', Yale Journal of Law and Humanities, 9 (1997) pp. 73-145 (p. 92).

3 The Case of the Postnati (1608), 7 Coke Report 1a, 77 ER, pp. 403-404; Jacob Selwood, Diversity and Difference in Early Modern London (Farnham: Ashgate, 2010), p. 91. 
became fully portable between England and Scotland. ${ }^{4}$ Although Calvin's Case settled some of the concerns around who was entitled to the status of 'native' in early Stuart England, a substantial group were still excluded from native rights, in particular those who were born, or whose parents were born, outside of the British Isles.

Only through naturalisation or denization could an alien 'do as the King's native subjects do', which included being allowed to 'purchase, and to possess lands' as well as 'be capable of any office or dignity'. ${ }^{5}$ However, foreign-born aliens, even once naturalised or made denizens, could not call themselves 'native-born', and nor could their children. Even individuals born in England, despite inheriting the privileges from their naturalised or denizen parents, were not always considered native-born. In 1628, William Courten, the English-born son of a Dutch merchant, petitioned the Privy Council to be relieved from customs duties as an alien. In his petition, Courten drew on his reputation, wealth, and achievements, but also those of his Dutch father who had been made a 'free denizen' of London. ${ }^{6}$ Courten had been born in England and therefore believed himself to be legitimately English. ${ }^{7}$ Although successful, Courten's petition highlights the complexities of the status of 'native', one that could be granted through either, both, or neither inheritance or location of birth.

Despite its complexities in assigning status to individuals, the word 'native' also served to appeal to commonalities, such as a shared loyalty to the monarch and to England as a nation. In the pitch of fervour for Queen Elizabeth in the preparations leading to the Spanish Armada of 1588 , subjects related the 'defence of Queene Elizabeth' to a love of one's 'native country'. One poem began by contrasting Spain, 'that forraine foe', to 'your sacred faith, and countries soile defend', where all English subjects became guardians of '[o]ur native countrie so long kept'. ${ }^{9}$ The appeal to Englishness was closely related to Protestantism - to the English as an 'elect' nation, favoured by God - but it was also an emotive one, urging English men and women to

4 Christopher Tomlins, Freedom Bound: Law, Labor, and Civic Identity in Colonizing English America, 1580-1865 (Berkeley: University of California Press, 2010), p. 90.

5 John Cowell, The interpreter (Cambridge, 1607 ; STC 5900), p. 59.

6 'Whereas by an order made the 26 th of October last (for reasons therein expressed, and according to auncient usage) the sonnes of strangers till the second discent are to pay strangership customes', 30 May 1628, Kew, The National Archives, PC 2/38.

7 Selwood, Diversity and Difference in Early Modern London, pp. 109-111.

8 An exhortacion to als [sic] English subjects to joine for the defence of Queen Elziabeth [sic], and their native country (London, 1588 ; STC 7582).

9 Ibid., no pagination. 
display a 'true English hart'. ${ }^{10}$ Executing one's duty to the soil became a useful means for those with a tenuous legal claim to Englishness to prove possession of a true English heart. Born in London to stranger parents, John Florio, a language tutor, lexicographer, translator, and preeminent advocate of the Italian language, repeatedly drew on horticultural imagery in his print Italian-English dual-language manuals to proclaim himself English. He was a gardener who, with great 'paines' and 'toyles', cultivated Italian/ English hybrid trees in English soil so that the lexical fruit may intellectually and culturally nourish his fellow Englishmen. ${ }^{11}$ Richard Collin's prefatory verse contribution to the first of these manuals, Florio his firste fruites (1578), stresses that this laboured execution of duty is the most significant determiner of nationhood: 'A Countrey man of ours, I warrant you, his deedes declare hym so: / True to his Prince, right gaineful to his friend, not hurtfull to his fo.' ${ }^{12}$ Thirty-five years later, the words Italus ore, Anglus pectore - 'Italian voice, English heart' - were engraved below a portrait of the author on the frontispiece of Florio's 1613 Italian-English dictionary, Queen Anna's new world of words. ${ }^{13}$ It reasserts this claim that, although, he proudly wears his Italian heritage, his career-long commitment to the betterment of his countrymen is what makes John - in his heart, where it matters - English.

The idea of 'native' as 'local' also pertained to English understandings of other people and the places they inhabited. The mistrust of travellers becoming corrupted by their journeys in Europe and further east suggested that Englishness might be tainted by an exposure to other customs and fashions. The soldier and author Barnabe Rich warned his readers that 'the sinnes of all those countries and of all the world besides are every day ingrossed and transported into England', in ways that domesticated the foreign and complicated English identity. ${ }^{14}$ By imitating the 'ambitious' Spanish, the 'false' French, the 'deceitful' Italian, the 'drunken' German, the 'idolatrous' Turk, and 'superstitious' Romans, Rich expounded, '[t]his

10 Ibid.

11 John Florio, Florio his firste fruites which yeelde familiar speech, merie proverbes, wittie sentences, and golden sayings (London, 1578; STC 4699); Florio, Florios second frutes to be gathered of twelve trees, of divers but delightsome tastes to the tongues of Italians and Englishmen (London, 1591; STC 11097), sig. B4r.

12 Ibid.

13 John Florio, Queen Anna's new world of words, or dictionarie of the Italian and English tongues, collected, and newly much augmented by John Florio, reader of the Italian unto the Soveraigne Majestie of Anna, crowned Queene of England, Scotland, France and Ireland, \&c. (London, 1611; STC 11099), frontispiece.

14 Barnabe Rich, My ladies looking glasse (London, 1616; STC 20991.7), sigs. A4v. 
propagation of sinne [...] [is] transported into England, [and] are now there resident and all entertained, not like strangers, but as natives that had been both borne and bred in the countrey'. ${ }^{15}$ Rich drew on the legal language of 'native' and 'stranger' to critique the English fascination with other places, and censured the English for adopting what was 'native' to other parts of the world in a process of cultural naturalisation.

The word 'native' is further complicated by the fact that it cannot be disentangled from settler colonialism. While 'native' peoples in colonial contexts continued to refer to local inhabitants, English assumptions about the inferiority of those Indigenous societies they sought to 'civilize' rooted 'native' to issues of subjugation and unequal balances of power. Early arguments in favour of colonisation in Virginia, for example, established that '[o]ur enemies must bee eyther the Natives, or Strangers [Spanish]; Against the first the war would be as easie as the argument'. ${ }^{16}$ Pro-imperial tracts repeatedly associated 'native', in an American context, with 'savage': in seeking to establish 'the West Empire', the English commonly iterated that ' $[t]$ he Savages' were 'the natives of the countrie.. ${ }^{17}$ In the case of Ireland, too, the lawyer and colonist John Davies argued in 1612 that the realm had not yet been 'subdued and reduced to Obedience to the Crowne of England' because the English had not maintained a sustained military effort to support their civilising initiatives. ${ }^{18}$ Those 'as are descended of our English race, would bee found more in number, then the ancient Natives', Davies insisted, but to truly secure the region, 'the Husbandman must first breake the Land, before it bee made capeable of good seede [...] So a barbarous Country must be first broken by a warre'. ${ }^{19}$ Since colonisation required the English to establish a permanent presence in Ireland and America through plantation, they often used the language of husbandry and cultivation of the soil to argue for regeneration. This would replace the 'ancient [n]atives' with 'our English race', relating plantation to acts of reform and supplanting. While 'native' potentially tied inhabitants to the soil, the English promoted a western empire by explicitly delegitimising Gaelic and Native American ties to their lands, articulating that these territories had been left to degenerate into wilderness.

15 Ibid., sigs. A4v-Bir.

16 Council for Virginia, A true and sincere declaration of the purpose and ends of the plantation begun in Virginia (London, 1610; STC 24832), sig. C4r.

17 Robert Johnson, Nova Britannia (London, 1609; STC 14699.5), sig. A4v.

18 John Davies, A discoverie of the true causes why Ireland was never entirely subdued (London, 1612; STC 6348), sig. A4r.

19 Ibid., sigs. A4r-B2r. 
The English use of 'native' has some connections to some similar terms applied in the Iberian colonial world, such as nativo (the Portuguese and Spanish equivalent for native) or its more recurrent synonymous 'natural' (Por. natural, naturais; Spa. natural, naturales). The Spanish and Portuguese classified the communities that lived outside the colonial apparatus as 'savage', 'barbarous', 'heathen', or 'infidel' according to the willingness of these groups to vow allegiance to Iberian monarchs and the Catholic Church. The often ambiguous positions and hybrid identities of these local populations, not to mention the myriad of juridical solutions developed to suit the specificities of different territories, granted native populations a rather liminal socio-political status that could lead to further exploitation, even when they conformed to the Iberian colonial and religious order. ${ }^{20} \mathrm{In}$ colonial Peru, the Jesuit Ludovico López wrote to Father Francisco Borgia on 29 December 1569 , that the Spanish settlers and the colonial officials were 'very cruel to the natives [naturales], treating them not as human beings, but as beasts [bestias], because this is the way they use them to get their goal which is silver'. ${ }^{21}$ A 1611 memorandum on the Portuguese occupation of Ceylon exposed the fragile status of the Singhalese naturaes ('natives' or 'naturals'), noting the 'little rewards we give to the natives who serve us in the war, being them Singhalese captains and soldiers, and they only have a handful of land, and many of them, to speak honestly, live in destitution after doing to His Majesty many services with great loyalty. ${ }^{22}$

Some naturais da terra ('naturals of the land') in Brazil, Angola, or India, however, due to their utility to the colonial apparatus, were eagerly co-opted by the Portuguese Crown. In 1644, João IV ennobled the Potiguara chief Poti, baptised António Filipe Camarão, as a recognition for his key role in the successful campaigns against the Dutch in Pernambuco. ${ }^{23}$ Besides being granted the title of Dom ('lord'), António Filipe Camarão received

20 For an overview of the Iberian models see, for example, Monarquias Ibéricas em Perspectiva Comparada (Sécs. XVI-XVIII):Dinâmicas Imperiais e Circulação de Modelos Administrativos, ed. by Ângela Barreto Xavier, Federico Palomo and Roberta Strumpf (Lisbon: Imprensa de Ciências Sociais, 2018); The Iberian World: 1450-1820, ed. by Fernando Bouza, Pedro Cardim, and Antonio Feros (London: Routledge, 2020).

21 'Pater Ludovicus Lopez to Patri Francisco Borgiae, Lima, 29 December 1569', in Monumenta Peruana: Vol. 1, ed. by Antonio de Egaña (Rome: Monumenta Historica Societatis Iesu, 1954), p. 327 .

22 'Apontamento sobre as cousa da ilha de Ceilão March 1611', in Documentos Remettidos da Índia ou Livro das Monções: Vol. 2, ed. by Raymundo António de Bulhão Pato (Lisbon: Academia Real das Sciencias, 1884), pp. 83, 86.

23 Ronald Raminelli, Nobrezas do Novo Mundo:Brasil e ultramar hispânico, séculos XVII e XVIII (Rio de Janeiro: Editora FGV, 2015), p. 51. 
other markers of aristocratic status such as a coat of arms and the habit of the Order of Christ. ${ }^{24}$ The concession of these privileges to Dom António's heirs contributed to the formation of an aristocratic and military lineage of Potiguara noblemen in Pernambuco. The Iberian context highlights crossovers, but also differences, between English and Portuguese or Spanish attitudes towards the 'native' in the context of empire. While Indigenous groups in Iberian colonial empires were confined to marginal status, viewed as conquered peoples of various and inferior origins, those who converted, collaborated, and whose services were useful to the colonial apparatus could be integrated in Iberian monarchies in ways the English rarely attempted with Native Americans.

The concept of 'native' further developed as English people migrated in larger numbers to America in the 1630 s and 1640s. In the Atlantic world, English women and men operated within a complex legal arrangement that saw them as natives of both the colonies and England. In 1648, the House of Lords introduced a bill 'for making the Planters that are born in New England free denizens of England'. ${ }^{25}$ This act did not pass, since many believed it unnecessary: the rights of English settlers were covered in many colonial charters that stipulated that settlers and their children would 'have and enjoy all liberties and Immunities of free and naturall Subjects within any of the Domynions of Us'. ${ }^{26}$ Although the 1648 act failed, the status of English settlers was gradually established through other means. The Navigation Acts from $165^{1}$ stipulated that ships in the colonies were considered the ships of 'native' subjects. As the legal historian Clive Parry suggested, 'between England and the plantations or colonies there seems to have been no distinction of nationality in general. ${ }^{27}$ However, settlers in the colonies were granted substantial levels of autonomy to naturalise and endenize individuals. The particular migration patterns to different colonies created substantial regional diversity in how English subjects identified with their rights and privileges in England. ${ }^{28}$

24 Ibid.

25 Letters of denization and acts of naturalization for aliens in England and Ireland, ed. by William Shaw (Lymington: Huguenot Society of London, 1911), p. xxvii.

26 Francis Newton Thorpe, Federal and State Constitution, Colonial Charters, and Other Organic Laws of the States, Territories and Colonies Now or Heretofore Forming the United States of America, Vol. III (Washington, D.C.: Government Printing Office, 1909), p. 1857.

27 Clive Parry, British Nationality Law and the History of Naturalization (Milano, Universita di Milano 1954), p. $5^{0 .}$

28 Ibid. 
As these questions over subjecthood were debated in multiple places, 'native' as a descriptor for Indigenous peoples remained largely pejorative, depicting part-victimised, part-idolatrous beings in conflict with conquistadors, or exoticised on London stages by those who endorsed empire. In the poet and playwright William Davenant's The Cruelty of the Spaniards in Peru (1658), the 'chief Priest of Peru enters with [...] a Garment of Feathers longer then any of those that are worne by other Natives.'. ${ }^{29}$ The rights of settlers invoking their 'native country' and the 'natives' encountered through conquest and colonisation could thus exist alongside each other with no seeming discrepancy, even as the former hinged on the dispossession of the latter. Meanwhile, colonial communities combined longstanding legal ideas with the experience of their new societies and environments to develop their own perceptions of what categorised a 'native'. The language of loyalty to one's 'native' country, from sixteenth-century feudal bonds of allegiance to fervent calls to escape the yoke of tyranny during the American Revolution, carried emotive resonances to those who lived in England and its colonies, but its true meaning was difficult to pin down.

Related keywords: alien/stranger, denizen, savage/barbarian, subject

29 William Davenant, The Cruelty of the Spaniards in Peru (London, 1658; Wing D321), p. 2; John Ogilby, America (London, 1670; Wing O164). 


\section{Pagan}

Like 'heathen', 'pagan' often appeared in discussions about idolatry, superstition, and polytheism. 'Pagans', like 'heathens', worshipped various deities, and unlike Christians, Muslims, and Jews, were not considered to be 'people of the book'. Protestants and Catholics equated superstitious beliefs to the 'unbelieving' other, but they also used 'pagan' to criticise perceived corruption in their own religious communities. In every age, Thomas Adams preached in 1615, churchmen have found cause to reprove their congregations: '[The Church Father] Chrysostome speaketh of his times: Christians now are become like Pagans or worse: Yet who will say that the Religion of Pagans was better th[a]n the Christians?' While 'heathen' appeared nearly 150 times in the King James Bible of 1611, however, 'pagan' did not appear at all. Although the terms overlapped and converged, this made 'heathen' more closely associated with scriptural culture, particularly the Old Testament. By contrast, 'pagan' often referred either to classical antiquity, or to the pre-Roman Anglo-Saxon English past. Paganus was a post-classical Latin term which carried resonance with pagus, denoting 'rustic' or 'the country', yoking its associations with landscapes and sites beyond the control of cities. ${ }^{2}$ Pagans were related to pantheistic, often nature-worshipping, expressions of faith. ${ }^{3}$

A mistrust of 'pagan' pasts was not merely an abstract or theoretical notion but entrenched in the mythology of ancient Britain itself. Late Elizabethan and Jacobean scholars became increasingly interested in recovering evidence of the classical past. Female and male figures infused the mythos of local cities and towns. Lady Godiva, or Godgifu, was celebrated for stripping herself of her attire and riding naked through the streets of Coventry in order to redeem 'the former freedoms' of less extractive tributes and taxation. ${ }^{4}$ Among news of contemporary events, the lawyer Simonds d'Ewes collected a manuscript account of the 'Conquest of Brittain by the Pagan Saxons' who had not yet been fully converted to Christianity. ${ }^{5}$ The works of William

\footnotetext{
1 Thomas Adams, Englands sickenes (London, 1615; STC 114), sig. H4v.

2 'Pagan, $n$. and adj.', Oxford English Dictionary.

3 Ibid.

4 John Speed, The theatre of the empire of Great Britaine (London, 1612; STC 23041), sig. O2r.

5 'A paper Book in to, before which, Sir Simonds D'Ewes prefixed the following title: Gildas Badonicus, soe named from the time of his birth', in A Catalogue of the Harleian Manuscripts, in the British Museum: With Indexes of Persons, Places, and Matters, ed. by Robert Nares, Stebbing Shaw, Joseph Planta, et al. (London: Record Commission, 1808), p. 334. See also Graham Parry,
} 
Camden and John Speed recounted ancient tales that imbued familiar localities with mythic battles and sacred sites. Staffordshire had been the 'habitation of Pagans, imbued with their bloud by King Edward the elder'. Recounting the first planting of Christianity in Britain, Speed described how the spread of Christianity became 'Englands great joy and fame, [being] still continued, though the spirituall sparkes thereof for a season have sometimes beene covered in the cinders of the Pagans desolations, or with the superstitious worships of man's inventions'. ${ }^{7}$

As Speed articulated, ancient stories about Christianity vanquishing 'superstition' served a contemporary purpose in the post-Reformation British Isles, as Catholics and Protestants continued to debate where religious legitimacy lay. In his travel compendium, Purchas his pilgrimage, the clergyman Samuel Purchas combined stories of global religions with a staunch defence of Protestantism, denouncing the 'Idolaters and Pagans' of China, India, and Africa alongside the 'Popish Christianitie' of Catholics. ${ }^{8}$ Confessional debates in the seventeenth century probed anxieties over whether the Eucharist could or should be called a 'sacrifice', due to its strong associations with pre-Christian ritual. ${ }^{9}$ Continuing interest in omens and portents in early modern England 'owed much to pagan mythology', and Protestant reformers struggled against popular pastimes like celebrating May Day, or lay people interpreting prodigies and freak incidents as messages from heaven. ${ }^{10}$ Protestants in early modern England were thus aware of the fragility and cultural porosity of the reformed faith in a realm where the vestiges of paganism and Catholicism threatened the established order. ${ }^{11}$

Beyond ancient Britain, pagans also existed in wider European cultural and intellectual discourse as a legacy of Greco-Roman antiquity. In reference to the classical world, 'pagan' and 'heathen' were at times interchangeable. In the translation of Henri Estienne's A world of wonders (1607), for example, the text refers to 'heathen poets' (Aristotle), 'pagan poets' (Ovid), and 'heathen

The Trophies of Time: English Antiquarians of the Seventeenth Century (Oxford: Oxford University Press, 1995).

6 John Speed, England, Wales, Scotland, and Ireland (London, 1627; STC 23035), sig. N2r.

7 Speed, The theatre of the empire of Great Britaine, sig. Xxir.

8 Samuel Purchas, Purchas his pilgrimage (London, 1613; STC 20505), pp. 387, 467.

9 Nicholas Moschovakis, "Irreligious Piety" and Christian History: Persecution as Pagan Anachronism in “Titus Andronicus”, Shakespeare Quarterly, 53 (2002), 46o-486 (p. 464).

10 Alexandra Walsham, Providence in Early Modern England (Oxford: Oxford University Press, 2001), p. 168.

11 Alexandra Walsham, The Reformation of the Landscape: Religion, Identity, and Memory in Early Modern Britain and Ireland (Oxford: Oxford University Press, 2011), p. 79. 
and profane pagans.' ${ }^{12}$ Poets and orators, wrote the Anglican churchman Thomas Tenison, were the means 'by which the Pagan Heroes were deified', their verses 'justly reputed one of the great store-houses of Idols.'. ${ }^{13}$ Paganism thus presented early modern Christian philosophers and poets with the challenge of acknowledging the political and cultural greatness of the Greek and Roman empires without condoning the fact that its thinkers had lived in religious error. The issue of salvation, and the essence of the divine, went to the heart of anxieties over Greco-Roman sophistication on one hand, and the ancients' lack of knowledge about the 'true' God on the other. The veneration of pagans as intellectual and even moral heroes meant that '[e]ither the doctrines must be altered [...] or it must be explained' how God could have endowed the unsaved with greatness while denying them everlasting life through Christ. ${ }^{14}$

Further, the Neoplatonism espoused by some thinkers acknowledged a debt to the philosophies of 'pagans' like Plato, who influenced the Christian theology of New Testament thinkers and influential medieval philosophers including Thomas Aquinas. ${ }^{15}$ As a result, pagan antiquity remained an accepted part of sixteenth- and seventeenth-century humanist culture, permeating everything from the depictions of gods and goddesses in tapestries, jewellery, and plays to inflecting the rhetoric of letters and diary entries. 'However fortune shall looke upon me, I will looke confidently on her', wrote the ambassador Thomas Roe to Elizabeth, Queen of Bohemia, in 1635. '[Fortune] is a Pagen Goddes, yet can only hurt those, who made her. ${ }^{16}$ At the theatre, staging pagan practices, from Ben Jonson's Sejanus (c. 1603) to John Dryden's The Indian emperour (c. 1665), served to visually impart the diversity of religious difference and ritual in the 'old' world and the 'new'. ${ }^{17}$

As with 'heathen', depictions of 'pagans' came from Christians more than from individuals who claimed the title for themselves. Since the Church

12 Henri Estienne, $A$ world of wonders, trans. by [Richard Carew?] (London, 1607; STC 10553), sigs. Gr, O6r, D2v.

13 Thomas Tenison, Of idolatry a discourse (London, 1678; Wing T704), p. 36.

14 John Marenbon, Pagans and Philosophers: The Problem of Paganism from Augustine to Leibniz

(Princeton, NJ: Princeton University Press, 2015), p. 13.

15 Ibid., p. 29.

16 [Sir Thomas Roe] to Elizabeth, Queen of Bohemia, 23 June 1635, Kew, The National Archives, SP $16 / 291$ f. $60 v$.

17 Ben Jonson, Sejanus his fall (London, 1605; STC 14782); John Dryden, The Indian Emperour, or the Conquest of Mexico by the Spaniards (London, 1667; Wing D2288); John Kuhn, 'Sejanus, the King's Men Altar Scenes, and the Theatrical Production of Paganism', Early Theatre: A Journal Associated with the Records of Early English Drama, 20 (2017), 77-98. 
recognised that not all people were saved, the question of how to assimilate non-Christian peoples into English society remained problematic. In 1610, the Member of Parliament, Edwin Sandys, lamented that Nanawack, a young Algonquian boy, had been living in London for several years, and yet theard not much of Religion, but saw and heard many times examples of drinking, swearing, and like evills, [and] remained as he was a meere Pagan.. ${ }^{18}$ Sandys desired Nanawack to be moved to a more godly home, where good example would compel him to embrace Christianity. The example also highlighted how the sinful behaviour of English men and women made them akin to pagans, rendering them incapable of successfully converting or 'civilising' non-Europeans.

Records suggest that conversion did not necessarily serve to fully integrate non-Christian peoples into English communities. The case of an unnamed 'negro'/'Moor' in the arraignment of Captain William Longcastle, brought to trial for piracy in 16og, presents one such example. An English factor brought the boy from North Africa to London to testify as a witness and to condemn Longcastle of piracy. Having been 'brought to be a Christian', the boy arrived in court to supply evidence. ${ }^{19}$ Longcastle seemed baffled at the appearance of his black servant, and 'denied him not to be his boy, but intreated of the Court, that the tongue of a Pagan, an Infidel, whose testimonies were no evidence to confirme the Jury [...] might not be the are [sic] to hew downe the tree of his life'. ${ }^{20}$ 'I beseech your Lordships', Longcastle pleaded, 'let the tongue of a Christian and not of a Pagan cut off my life. ${ }^{21}$ On one hand, the testimony of a North African boy in a London court speaks to the remarkable possibility that such a testimony might influence metropolitan judicial matters. On the other, while they may have taken the boy's testimony into account, those presiding over the court informed Longcastle before convicting him that 'it was not the aproovement of [the Moor's] tongue [...] which made them give credit, that now they stood guilty, but the resolved oath of Anthony Wye'. ${ }^{22}$ Longcastle's vehement repetition of 'pagan' - likely in an attempt to delegitimise the testimony of an individual who could not legitimately swear on the Bible in court - suggests that the word could be

18 Coll Thrush, Indigenous London: Native Travelers at the Heart of Empire (New Haven, CT: Yale University Press, 2016), pp. 57-58.

19 The lives, apprehensions, arraignments, and executions, of the 19 late pyrates (London, 1609;

STC 12805), sig. E2r.

20 Ibid.

21 Ibid., sig. E4r.

22 Ibid. 
invoked in attempts to strip non-European peoples from speaking with authority in the political realm.

Throughout the seventeenth century, 'pagan' remained a word that writers used to vilify or criticise those who rejected civil, Christian behaviour. 'Brutes that you are!' wrote the anonymous author of The reformed gentleman in 1693. 'How unreasonably do you style your selves Christians, when as you do that on the Lords-Day which a Modest Heathen would blush to do at any time? Are there any Pagans in Nature worse than your selves in Practice?'23 Such rhetoric pitched Christians against other societies and cultures, but it also reinforced the word's connection with the natural world and Indigenous belief systems, ones that the English sought to eradicate through violence and the enforcement of English civility in colonial spaces. In the political turmoil of the mid-seventeenth century and following Oliver Cromwell's schemes to target Spanish activity in the Caribbean (known as the 'Western Design'), concerted attempts to expand English sovereignty in America coincided with the language of paganism and heathenism often used by Puritans. The English were well placed, wrote Beauchamp Plantagenet in 1648, to 'conquer on Indians, and convert Pagans, and civilise them, and bring them to the obedience of our Soveraign [...] to make our Soveraign an Emperour of America'. ${ }^{24}$ In 1679, the long-time colonist in New England, Roger Williams, sent a deposition to London vouching for the reputation of the son of the recently-deceased planter Richard Smith. The younger Smith, Williams wrote, deserved to keep his lands in North America, for he had been well regarded among the 'English and pagans'. ${ }^{25}$ Smith had faithfully served under several generals in 'the late bloody pagan war', fighting to secure and maintain lands 'in the pagan wilderness and Nahigonsik country'. ${ }^{6}$ Such language placed the legitimacy of succession in English hands while seeking to dismiss Indigenous resistance.

'Pagan' thus contained meanings that remained in tension with each other. The veneration of classical antiquity, including Greco-Roman political

23 The reformed gentleman, or, The old English morals rescued from the immoralities of the present age (London, 1693; Wing M6), sig. I4v.

24 Beauchamp Plantagenet, A description of the province of New Albion (London, 1648; Wing P2378), sig. B3r.

25 'Deposition of Roger Williams touching the Narragansett countries, 21 July 1679', in Calendar of State Papers: Colonial, America and West Indies, Vol. 10: 1677-1680, ed. by W. Noel Sainsbury and J. W. Fortescue (London: Her Majesty's Stationery Office, 1896), pp. 395-403.

26 Ibid. On competing ideas of land and property, see Allan Greer, Property and Dispossession: Natives, Empires, and Land in Early Modern North America (Cambridge: Cambridge University Press, 2018). 
philosophy and poetry, retained a powerful hold over the English imaginary. Yet categorising non-European peoples as 'pagans', especially those who seemed to possess a powerful connection to the natural world or to what Europeans viewed as the wilderness, often justified dispossession and invasion, even as alternate ways of expressing spirituality and authority captivated those who encountered them.

Related keywords: convert, heathen, interpreter, savage/barbarian 


\section{Pirate}

In the late sixteenth century, the Italian civil lawyer Alberico Gentili, a Protestant who settled in England after fleeing the persecution of the Catholic Church, wrote from his post at Oxford that enemies 'are those who have officially declared war upon us, or upon whom we have officially declared; all others are brigands or pirates' ('hostes hi sunt, qui nobis, aut quibus nos publice bellum decreuimus caeteri latrones, aut praedones sunt'). ${ }^{1}$ Gentili used the Latin pirāata/piratae in his treatise, deriving from the word for 'attack' or 'assault', as well as the associations with sea theft that emerged from Old French in the thirteenth century. ${ }^{2}$ Early printed English dictionaries, such as The dictionary of syr Thomas Eliot (1538), defined 'pirate' as 'a rover or robber of the sea'. ${ }^{3}$ Gentili drew on this meaning and the works of the Roman legal theorists Sextus Pomponius and Ulpian when developing his concept of just war (justum bellum) as a conflict between two or more sovereign states that shared the same legal status and respected the law of nations. As Gentili reminded his readers, it was impossible to have a 'state of war' with pirates and brigands since lawful war 'is derived from the law of nations, and malefactors do not enjoy the privileges of a law to which they are foes'. ${ }^{4}$ The law of nations was 'an agreement and a compact' and those 'who have withdrawn from the agreement and broken the treaty of the human race' could never enjoy any legal right. 5

Until the Offences at Sea Act of 1536 , the English had punished piracy as a civil offence, not unlike the crimes of highwaymen. ${ }^{6}$ The Offences at Sea Act established that piracy should be treated according to common law processes, which allowed for accomplice testimony and trial by jury. ${ }^{7}$ Increasingly, however, defining piracy required attention to both domestic and international codes of law, for, in Gentili's words, 'pirates are the common enemy of all mankind' ('piratae omnium mortalium hostes sunt

1 Alberico Gentili, De Jure Belli Libris Tres, ed. by Thomas Erskine Holland (Oxford: Clarendon, 1857), p. 13.

2 'Pirate, $n$.', Oxford English Dictionary.

3 Thomas Elyot, The dictionary of syr Thomas Eliot knyght (London, 1538; STC 7659), sig. R6r.

4 Gentili, De Jure Belli, pp. 13-14.

5 Ibid., p. 14 .

6 Megan Wachspress, 'Pirates, Highwaymen, and the Origins of the Criminal in SeventeenthCentury English Thought', Yale Journal of Law \& Humanities, 26 (2015), 301-343.

7 Quoted in Peter T. Leeson, 'Rationality, Pirates, and The Law: A Retrospective', American University Law Review, 59 (2010), 1219-1230 (p. 2220). 
communes'), excluded from any kind of protection offered by the norms that regulated a just war. ${ }^{8}$ Pirates and other lawbreakers 'have utterly spurned all intercourse with their fellow men', living 'in the manner of wild beasts, and each one carried of what fortune offered to him as prey, trained to use his strength in accordance with his own impulses and to live for himself alone', rather than for the common good. ${ }^{9}$ Applying Aristotelian ideas of civil society to the particular problem of the rise of piracy and its shaky relationship to the English state, Gentili classified pirates as criminals whose decision to live without any regard for international or civil law made them a threat to the civilised world..$^{10}$ Influenced by Gentili and Roman piracy laws, the Jacobean jurist Edward Coke argued that as 'enemies of mankind' (hostis humanis generis), pirates should be trialled and punished as traitors. ${ }^{11}$

This perception of pirates as marginal figures or potential traitors became more complicated, however, when reasons of state were considered. Definitions of the 'pirate' were subject to flux, not least because the English, like other European maritime powers, relied on commissioned private agents to attack the merchant fleets and ports of enemy or rival states. English merchants and captains frequently accused other European powers of committing acts of piracy on their vessels, while they themselves did not shy away from committing similar acts in the Mediterranean, the Indian Ocean, and the Atlantic. ${ }^{12}$ The strained relationship between England and Spain throughout Elizabeth's reign had given pirates an ambiguous but at times privileged role in advancement the realm's political and economic interests.

English monarchs often used legal instruments such as letters of marque, a document that established the conditions in which a state employed naval private agents to attack ships of a rival nation. The considerable profits obtained from these commissions led many merchants to petition the Crown for such letters. In May 1627, a group of London merchants petitioned

8 Ibid.

9 Ibid.

10 Quotations taken from Peter Schröder, 'Vitoria, Gentili, Bodin: Sovereignty and the Law of Nations', in The Roman Foundations of the Law of Nations: Alberico Gentili and the Justice of Empire, ed. by Benedict Kingsbury and Benjamin Straumann (Oxford: Oxford University Press, 2010), pp. 174-176.

$11 \mathrm{R} v$ Marsh (1615), 3 Bulstrode 27, 81 ER 23; Hildebrand, Brimston, and Baker's case (1 rolle 285[1615], King's Bench, Hilary Term).

12 Christopher Harding, "Hostis Humani Generis" - The Pirate as Outlaw in the Early Modern Law of the Sea', in Pirates? The Politics of Plunder, 1550-1650, ed. by Claire Jowitt (London: Palgrave Macmillan, 2007), pp. 20-38. 
the Duke of Buckingham, as Lord High Admiral of England, to intervene on their behalf and obtain a letter of marque from the king 'for a voyage to Barbary in trade, and warfare.. ${ }^{13}$ The relationship between state and private agents stipulated by letters of marque led to the association of the word 'privateer' with these special assignments. George Carew, in his Lex talionis, or, The Law of marque or reprizals (1682), defined these instruments as 'ambulatory, and revokable at Pleasure, being usually granted to all persons in all Nations that will ask for the same, to weaken the Enemy; as they did at Oast-End, Dunkirk, Flushen and Diep, in the times of War between Spain and England, France and England, and Holland and England; and those are called Privatters, or Private men of War'.14

Other terms, such as 'buccaneer' or 'corsair', were also associated with state-sponsored maritime piracy across the Atlantic and the Mediterranean. 'Corsair' usually identified the French, Italian, Ottoman, and other Mediterranean equivalents of privateers. William Okeley complained that the southern Mediterranean coast from Algiers to Istanbul was plagued with 'Turkish Corsairs, which have long Tyrannized in, and been a Terror to the Neighbouring Seas'. 15 'Buccaneer' was a word used to refer to state-sponsored private pirates in North America and the Caribbean. The author of The English empire in America (1685) celebrated the actions of the English '[p]rivatiers, or Bucaniers Sloop, and Boatmen' based in Jamaica for 'their dayly attempts upon the Spaniards in Panama and other places, which for the hazard, conduct and daringness of their exploits have by some been compared to the Actions of Caesar and Alexander the Great'. ${ }^{16}$ Such grandiloquent and nationalist language aimed to attenuate the moral and legal ambiguity of predatory sea rovers in the Caribbean by highlighting their service to the English state.

The lives and careers of individual figures identified at various points as pirates expose the precariousness of their reputations and legal standing. Francis Drake remained widely celebrated by Protestant writers as the scourge of the Spanish empire in the Atlantic long after his death in 1596. The courtier Walter Ralegh, another of Elizabeth's favourites, lost his political

13 'Petition of John Webber, Thomas Lintall, and others [...] for a voyage to Barbary, 22 May 1627', in Calendar of State Papers: Domestic, Charles I, Vol. 64:1627-1628. ed. by John Bruce (London: Her Majesty's Public Record Office, 1858), p. 186.

14 George Carew, Lex talionis, or, The Law of marque or reprizals (London, 1682; Wing C549), pp. $24,26$.

15 William Okeley, Eben-ezer, or, A small monument of great mercy (London, 1684; Wing O193), sig. Cir.

16 R. B., The English Empire in America (London, 1685; Wing C7319), p. 209. 
power after James's accession to the throne and failed disastrously to find gold in his voyage to South America in 1617, yet gained a formidable reputation in popular lore. Elizabeth indulged Drake and Ralegh as heroes, while Drake's exploits also contributed to an enduring 'populist affective bond with the nation' that was not always directly related to the monarchical state, but rather with mercantile activity and the expansion of trading corporations. ${ }^{17}$ Elizabethan pirates were often 'cast as defensive measures used to protect English commerce', whereby a series of grants and concessions of privateering led to its legitimisation. ${ }^{18}$

The legal standing of pirates changed drastically in England with Elizabeth's death. Under James, a condemnation of piracy led to all pirates being declared illegitimate and outlawed. ${ }^{19}$ The Venetian ambassador in London in 1603 reported that when James heard of an English privateer attacking an Italian ship, the king 'twisting his body, striking his hands together [...] took the memorandum [...] and said in a loud voice, "By God I'll hang the pirates with my own hands". ${ }^{20}$ This evocative image of James writhing his body in frustration demonstrates his very real annoyance at subjects who interfered with the complex diplomatic interests of international law. 'Don't you know', Robert Cecil smoothly informed the Italian ambassador, 'that these are pirates, who took to buccaneering under the late Queen, and since God gave us his Majesty for our sovereign not one privateer has set sail'. ${ }^{21}$

Despite such active disapproval of acts of piracy, controlling pirates continued to elude the state, particularly along the expanding margins of English maritime activity. The absence of a coherent legislative apparatus in English colonies rendered laws against pirates in the Atlantic particularly difficult to regulate. The High Court of Admiralty could overturn the decisions made by colonial courts. ${ }^{22}$ Both colonial and metropolitan authorities often protected or stimulated acts of piracy that suited their strategic interests. This confusing situation was recognised in 1700 with the issuing of the Act

17 Mark Netzloff, 'Sir Francis Drake's Ghost: Piracy, Cultural Memory, and Spectral Nationhood', in Pirates? The Politics of Plunder, pp. 137-150 (p. 139).

18 Ibid., p. 140.

19 Claire Jowitt, The Culture of Piracy, 1580-1630: English Literature and Seaborne Crime (Burlington, VT: Ashgate, 2010), p. 137.

20 'Giovanni Carlo Scaramelli, Venetian secretary in England, to the Doge and Senate, 5 October 1603', in Calendar of State Papers Relating to English Affairs in the Archives of Venice, Vol. 10: 1603-1607, ed. by Horatio F. Brown (London: Her Majesty's Stationery Office, 1900), pp. 99-104. 21 Ibid.

22 Peter T. Leeson, The Invisible Hook: The Hidden Economics of Pirates (Princeton, NJ: Princeton University Press, 2009), p. 145; Ilias Bantekas and Susan Nash, International Criminal Law (Abingdon: Routledge, 2007), p. 176. 
for the More Effectual Suppression of Piracy, a legislative effort to end the complaints that 'Persons committing Piracies, Robberies and Felonies on the Seas, in or near the East and West Indies, and in Places very remote, cannot be brought to condign Punishment without great Trouble' by empowering English colonial authorities to arrest, try and punish pirates 'in any of his Majesty's Islands, Plantations, Colonies, Dominions, Forts, or Factories'. ${ }^{23}$

Individuals who engaged in the lucrative business of privateering were also understandably not always prepared to give it up. Peter Eston was one such pirate. Having fought against the Spanish in the Armada of 1588, Eston was undefeated in his sea battles, had pressed coastal fisherman into service, and amassed a formidable personal fleet of some twenty ships. Although James cancelled his letters of commission, Eston continued to attack ships in the Atlantic, particularly around Newfoundland. Whereas Elizabeth had channelled Eston's energies to the benefit of the Crown, James's hard anti-pirate stance only revealed the ruptures between monarchical power in theory and practice. When James offered Eston a pardon, the pirate refused. He was 'a famous pirate', an ambassador in London observed in 1612, 'who haughtily refused the pardon offered by his Majesty, declaring that he would not bow to the order of one king when he himself was in a way, a king as well. ${ }^{24}$ Eston retired in Savoy and lived as the Marquis of Duchy, living comfortably off a lifetime of spoils.

The other choice available to pirates was accepting the king's terms. Henry Mainwaring, who attacked Spanish ships on the Barbary Coast, accepted James's pardon in 1616. Assuming the role of the humble reformed pirate, Mainwaring presented the king with a 'Discourse on Piracy' and took up service in the royal navy, supporting the royalist cause in the English civil wars. Mainwaring admitted that 'experience proves it to be undoubtedly true, that English Pirates do first arm and horse themselves within your Highness' Dominions', reinforcing the idea, among authorities, that piracy was a form of rebellion or banditry that started with dissident behaviour on land. ${ }^{25}$ 'I fell not purposely but by mischance into those courses', Mainwaring insisted, and 'being in them, ever strove to do all the service I could to this State, and the merchants. ${ }^{26}$ Mainwaring played on the legal ambiguities

23 Quoted in Leeson, 'Rationality, Pirates, and The Law: A Retrospective', pp. 1221-1222.

24 'Antonio Foscarini, Venetian Ambassador in England, to the Doge and Senate, 15 October 1612', in Calendar of the State Papers Relating to English Affairs in the Archives of Venice, Vol. 12:1610-1613, ed. by Horatio F. Brown (London: His Majesty's Stationery Office, 1905), pp. 429-440.

25 Henry Mainwaring, 'Discourse of Pirates', in The Life and Works of Sir Henry Mainwaring, Vol. 2, ed. by G. E. Manwaring and W. Perrin (Toronto: Navy Records Society, 1922), p. 14.

26 Ibid., p. 8. 
of early modern English piracy, emphasising the patriotism of the pirate in serving the monarch and bolstering the realm's political economy.

Some literature in the late sixteenth and early seventeenth centuries celebrated commercial piracy as an alternative to, or an adaptation of, the knightly ethos of gentlemen, casting pirates as patriotic merchantadventurers or shrewd pragmatists who served English interests in the faraway. ${ }^{27}$ Claire Jowitt has pointed out that in the writing of a large range of English authors - from the prose fiction of Philip Sidney and Lady Mary Wroth, to the plays of Shakespeare, Thomas Heywood, Philip Massinger, and Robert Daborne, and in anonymous broadsheets and ballads in cheap print - the figure of the pirate played a vital conceptual role, 'simultaneously both central and marginal to orthodox conceptions of English identities'. ${ }^{28}$ This is particularly evident in the popular drama of the period, which includes plays such as The Famous Historye of the life and death of Captaine Thomas Stukeley (acted c. 1596-1597), Thomas Heywood's Fair Maid of the West, Part 1 (composed between 1596-1603), Thomas Heywood and William Rowley's Fortune by Land and Sea (1607-1609), Robert Daborne's A Christian Turned Turk (1612), and Philip Massinger's The Renegado (1623-1624). Pirates in such plays were presented as explorers and martial figures whose 'adventures' shift between the mercantile and the chivalric, even as they were denounced and punished as liminal, wandering figures of unregulated violence.

The ambiguous loyalties of pirates, as they travelled across national boundaries and navigated uncharted waters, also raised authorities' fears about breaking the social order. Their role in moving wealth in and out of state coffers and private stores suggested a pirate's ability to progress beyond established class hierarchies. Francis Drake began as a seaman on board William Hawkins's ships in the 1560 s, working his way to the position of admiral. In a portrait from 1581, Drake wore a large ruff and flamboyant court clothes, a clear statement of his own hand in securing the status of a gentleman. In pandering to court culture while living much of their life at sea, where alternative societies were formed on board ship, pirates often defied the carefully prescribed social orders of sixteenth- and seventeenth-century England, forming various alliances and enmities that did not map onto the idealised world picture expressed by English authorities.

Scholarship on piracy must also take into account the discrepancy between the status of 'pirate' and how such individuals actually saw, and termed, themselves. For all the English praise of the individual go-betweens 
who seemed to fight so intently for English interests abroad, the 'pirate' was not an enviable status for those who sought preferment and honour within the realm. Other words appeared in its stead in pro-English expansionist propaganda: 'captain', 'privateer', 'navigator', 'commander'. On the other side of this, certain words that might be associated with the actions of the pirate are tellingly absent, such as 'kidnapper' or 'slaver'. While Thomas Greepe celebrated Drake in The true and perfecte newes of the worrthy and valiaunt exploytes, performed and doone by that valiant knight Syr Frauncis Drake (1587), Drake's status as gentleman would have been tarnished by the label 'pirate', and the word does not appear once in Greepe's text. Similarly, George Peele's A farewell Entitled to the famous and fortunate generalls of our English forces (1589) and Philip Nichols's Sir Francis Drake revived (1626) referred to Drake as a 'general' or 'captain', never 'pirate'. Letters sent to Elizabeth's privy council concerning Drake similarly referred to him as 'knight' or 'lord admiral'. ${ }^{29}$ Conversely, the Spanish repeatedly called English merchants and colonists 'pirates'. One Spanish captive in the English colony in Virginia likened Jamestown to the most infamous den of piracy in the Mediterranean Sea: 'this new Algiers in America, which is being established' in Virginia, he wrote to a Spanish ambassador in London, has made the colonists nothing but corsairs, and the colony might easily become 'a gathering-place of all the pirates of Europe' $3^{\circ}$

As trading companies gained ascendancy in the later seventeenth century, they fiercely protected their trading monopolies from interlopers, and sought to punish those who operated outside of their regulations, often condemning them as pirates. This in fact exposed alternative ways of operating that challenged English religious, social, and moral codes, as when English privateers in West Africa and the Indian Ocean established new homes for themselves, married non-European or non-Christian women, and adopted alternate names and identities for themselves far from their country of origin..$^{11}$ Thus, the English merchant and East India Company (EIC) employee Edward Misselden asserted, pirates were one of the major

29 See, for example, 'Victualling of Ships', 13 July 1588, Hatfield House, CP 142/92; 'Mar[maduke] Darell to the privy council', July 1590, Hatfield House, CP 167/136. For the ambiguity of gentlemenprivateers into the 1620s, see Joe Moshenska, 'Sir Kenelm Digby's Interruptions: Piracy and Lived Romance in the 1620s', Studies in Philology, 113 (2016), 424-483.

30 'Don Diego de Molina to Don Alonso de Velasco [Spanish ambassador in London], 28 May 1613', in Jamestown Narratives: Eyewitness Accounts of the Virginia Colony: The First Decade: 1607-1617, ed. by Edward Wright Haile (Champlain, VA: Roundhouse, 1998), p. 746.

31 Jane Hooper, 'Pirates and Kings: Power on the Shores of Early Modern Madagascar and the Indian Ocean', Journal of World History, 22 (2011), 215-242 (p. 222). 
'forreine causes' for the nation's 'want of money'.32 Like pirates, Misselden maintained, interlopers into trade were 'evill Engines' who subverted the finance and power of the 'Companyes, yea, Kingdomes also'.33 Company officials believed interlopers were worse 'than Pirates \& deserve as much to be hanged', conveying the belief that pirates should be punished as low-born criminals. ${ }^{34}$

As in earlier periods, political imperatives and diplomatic relations helped dictate how and when pirates were celebrated or punished. In South Asia, for instance, seeking lucrative cargo from Indian ports, many English pirates targeted non-European ships, such as Mughal vessels near the Red Sea and Persian Gulf. ${ }^{35}$ The EIC came under fire in the early 1690 os after several incidents concerning so-called English pirates in the Indian Ocean, the most famous involving the seizure of two Mughal ships by the English captain Henry Avery. Angered by the incident, Mughal officials banned all European trade out of Surat and requested Avery be punished. Having long declared itself the only government over English people in the East, the EIC promised to pay full financial reparations. At Avery's trial one year later, the Advocate of the Admiralty Thomas Newton accused him of practicing 'many and great Pyracies'. ${ }^{6}$ According to Newton, the act of piracy exceeded '[t]heft or Robbery at Land'; to 'suffer pirates' would mean the 'Commerce of the World must cease', leading to the 'destruction of the Innocent English in to Countries' and to the 'total loss of the Indian trade'. 37 Newton thus concluded that piracy threatened English commercial and territorial aims, and would lead to the '[i]mpoverishment of this Kingdom', an example of the EIC using the language of piracy to place their own actions within the bounds of legality. ${ }^{3}$

The pirate both evaded authorities and acted on their behalf; represented dangerous self-seeking behaviour that harmed the state and placed individual glory at the expense of the common good; and could be admired and celebrated as a hero who advanced the well-being of the nation. Pirates pushed the boundaries of lawful violence and starkly exposed the governing

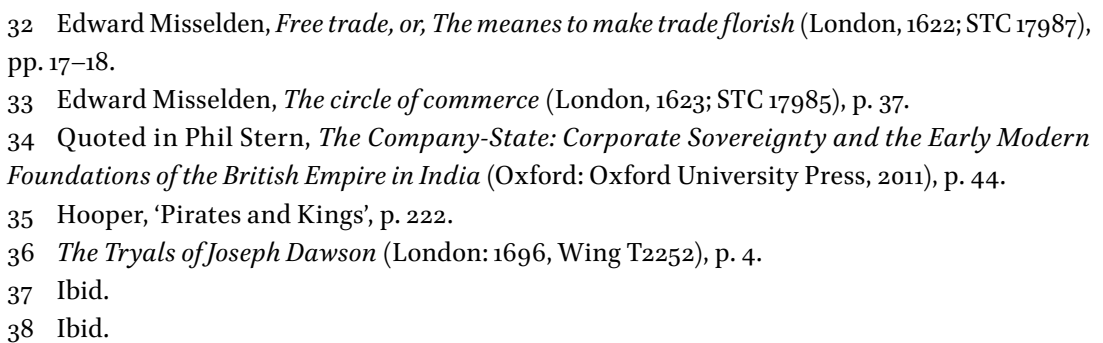


regime's ability or failure to execute justice, bringing questions of authority and jurisdiction to the oceanic worlds that Europeans navigated with increasing frequency. The pirate also operated in other roles: courtier or merchant, naval commander or traitor, renegade or vagrant. Such figures continually served as a prism through which the English interrogated nascent ideas of national identity, social order, and belonging, while their multicultural ships helped facilitate cultural transfer between areas across the globe, from Japan to Madagascar to Jamaica.

Related keywords: courtier, merchant, subject, traitor 


\section{Rogue}

A common figure in early modern life, the 'rogue' was part of a negatively perceived, transient group of people that also contained vagrants and vagabonds. The etymological origins of the word, perhaps appropriately, are unknown, but it developed during a period when the government was increasingly concerned with issues of population movement and ' $[\mathrm{m}]$ asterles Men', particularly after the Reformation, as Tudor monarchs from the midsixteenth century increasingly sought to consolidate their power within the realm. ${ }^{1}$ The term 'rogue' for the most part was reserved for the poorer classes, and in particular for homeless or economic migrants forced to move with seasonal work. Thomas Harman, who also wrote about Gypsies, was one of the first writers to use the word 'rogue'. ${ }^{2}$ According to Harman's definition, there were two types, one made and one born. A born rogue, according to Harman, was a '[w]ylde Roge' who had been 'begotten in barne or bushes' and was 'from his infancy traded up in treachery'. 3 This type of rogue had been referenced in John Awdelay's The fraternitye of vacabondes (1561), where he described them as having 'no abiding place but by his coulour of going abrode to beg' and stated that all who do this 'be properly called Roges'. ${ }^{4}$ Unlike a 'wylde Roge', the 'rogue made' was Harman's innovation. A rogue of this kind was 'neither so stoute or hardy as the uprightman' and despite possibly having to learn this trade there was 'nothing to them inferiour in all kynde of knavery'. ${ }^{5}$ In the seventeenth century, John Cowell built upon Harman's definition to include poor travellers as 'counterfeit rogues', describing the 'Roag' as an 'idle sturdie beggar [...] wandring from place to place without passport'. ${ }^{6}$ The rapid development of the word 'rogue' during the sixteenth and seventeenth centuries was therefore matched by legal and governmental attempts to define, legislate, and restrict the lives and mobility of those considered to be outside the reach of English authorities and policymakers.

1 Matthew Sutcliffe, The practice, proceedings and lawes of armes (London, 1593; STC 23468), p. 64; Nabil Matar, 'The Renegade in English Seventeenth-Century Imagination', Studies in English Literature, 1500-19oo, 33 (1993), 489-505.

2 Thomas Harman, A caveat for commen cursetors vulgarely called vagabones (London, 1567;

STC 12787), pp. 13-15.

3 Ibid., p. 15 .

4 John Awdelay, The fraternitye of vacabondes (London, 1561; STC 994), sig. Aiiiv.

5 Harman, A caveat for commen cursetors, p. 13.

6 John Cowell, The interpreter (London, 1607; STC 5900), sig. BbIr, Mmm2v. 
Elizabeth I's Parliaments attempted to restrict the movement of people and labour to prevent unregulated mobility. The Act for the Relief of the Poor (1563) and the Statute of Artificers (1563) were attempts to prevent the growth of transient people by regulating the movement of people and labour, and it is telling that these were created around the same time as 'rogue' appeared in popular print.7 The 1572 Act for Punishment of Vagabonds, known for reducing the severity of punishments for wandering players, introduced much harsher punishments for traditional 'rogues'. According to the Act, those 'Rogues [who] shall appeare to bee dangerous' and who refused to 'be reformed of their rogish kind of life' would not only risk a jail sentence but also, for the first time, could be punished with transportation or impressment 'perpetually to the Galleis of this Realme. ${ }^{8}$ The Act also accounted for foreign rogues, ordering that the 'Scottish, or Irish Rogue' be sent back to the parish or port that they entered from and 'be transported at the common charge of the Countrey where they were set on land'. ${ }^{9}$ It also became increasingly important to ensure that these laws were enforced, empowering 'Churchwardens and overseers' to punish rogues and answering public complaints that constables had 'in many places in suffering Rogues to wander \& beg in the streetes'. ${ }^{10}$ Furthermore, the Act also ordered that those constables who were found to be 'negligent, or remisse in the execution of the statute' were to be punished 'so farre as the law and authority of the chiefe Magistrate in that place will allow'.11 In London, the officers of the cities were given the authority to 'apprehend Rogues and to punish them' in twice-weekly patrols of the streets within their jurisdictions. ${ }^{12}$ The fixation on trying to resolve the issue of transient people continued into the eighteenth century, with proposals for finding employment for the poor that would keep 'all Rogues [...] kept and set to Work'. ${ }^{13}$ After the Restoration, Parliament passed an act in which local constables of towns and cities were

7 'Act for the Relief of the Poor', 1563, 5 Eliz. I c. 3; 'Statute of Artificers', 1562, 5 Eliz. I c. 4.

8 'Act for Punishment of Rogues, Vagabonds and sturdy Beggars', 1597, 39 Eliz. I c. 4; see also An acte for punishment of rogues, vagabonds and sturdie beggers (London, 1598; STC 8261.7), unpaginated.

9 Ibid.

10 Certaine articles concerning the statute lately made for the reliefe of the poor to be executed in London, by the churchwardens and overseers of every parish, according to the effect of the same statute (London, 1599; STC 9494.9), unpaginated.

11 Ibid.

12 Orders prescribed by her Majesties commandement by advise of her counsell (London, 1595; STC 8243).

13 Proposals for making provisions for setting the poor on work (London, 1700; Wing P3728), p. 2. 
to apprehend 'rogues' found begging or wandering and to punish them severely. ${ }^{14}$

The marginality and placelessness of figures that authorities identified as rogues, 'uprightmen', 'cony-catchers', or vagabonds, meant that the words were invariably inflected by social status. Patricia Fumerton has pointed out that the sense of estrangement that was associated with vagrants and rogues 'can be seen metonymically to embrace most of the lower orders, not just the indigent and homeless, of early modern England: itinerant laborers, including servants and apprentices, as well as those poor householders from the lowest depths of the amorphous "middling sort," who were at any time liable to such unsettling change. ${ }^{15}$ When Shakespeare's Hamlet calls himself a 'rogue and peasant slave' (II.ii), the association between poverty and being a rogue would have been commonplace. Despite the reality of isolation and insecurity, placelessness was frequently transformed into visions of rogues and vagrants as virtual 'strangers', representatives of an alternative social order operating simultaneously and beneath the state's government. As Nandini Das has shown, the fundamental premise underlying Robert Greene's hugely popular cony-catching pamphlets of the early 1590s, for instance, is the existence of a sprawling criminal underworld inhabited and governed by these marginal figures, with their own rules, laws, and vocabulary ('canting tongue'). Greene's A Notable Discovery of Cosenage (1591) 'presents the English reader with an unavoidable image of himself as a traveller and a stranger in his own land, and offers Greene's "R.G." as his only guide.. ${ }^{16}$ At the same time, that alterity is also exploited by Greene and contemporaries like Thomas Dekker, whose pamphlets The Bellman of London (1608) and plays like The Roaring Girl (1611) featured male and female cozenors with strong independent spirits. In such texts the 'rogue' becomes the stranger at home, whose perspective throws a raking light across familiar social practice and norms.

Throughout the seventeenth century, Parliament continued to punish and restrict those they called rogues. In 1603 , Parliament reintroduced the

\footnotetext{
14 'Burning of Houses Act', 1670, 22 and 23 Car. II c. 7.

15 Patricia Fumerton, “London's Vagrant Economy: Making Space for "Low" Subjectivity', in Material London, c. 1600 , ed. by Lena Cohen Orlin (Philadelphia: University of Pennsylvania Press, 2000), pp. 206-226 (p. 208).

16 Nandini Das, Renaissance Romance: The Transformation of English Prose Fiction, 1570-1620 (Farnham: Ashgate, 2011), p. 136. On the response to rogues in early modern English literature and a useful review of scholarship, see Rogues and Early Modern English Culture, ed. by Steve Mentz and Craig Dionne (Ann Arbor: University of Michigan Press, 2006).
} 
act of branding rogues with an ' $R$ ' the size of a shilling, with the punishment for repeat offences increased to death without benefit of clergy. ${ }^{17}$ Within six months of ascending to the English throne, James I issued a proclamation to combat the threat of 'Rogues' who had 'grow[en] againe and increase to bee incorrigible, and dangerous'. ${ }^{18}$ In 1621, a draft bill in Parliament, though never passed, explicitly sought to subject 'wandering rogues' to extremely harsh conditions that amounted almost to slavery. ${ }^{19}$ Increasingly too, English authorities used deportation as a solution. An Order of the Privy Council detailed specific nations and geographies where rogues could be deported to, which included 'the New-found Land, the East and West Indies, France, Germanie, Spaine, and the Low-countries, or any of them.' ${ }^{20}$ In 16o9, the Lord Mayor of London attempted to establish a fund to remove the city's idle poor to Virginia, acquiring financial help from the livery companies to do so. ${ }^{21}$ Although the scheme did not succeed, deportation to America and the Caribbean became increasingly popular in the seventeenth century, considered to be a solution to both a domestic problem, while addressing underpopulation in England's fledgling colonies, where death rates during particularly harsh winters could reach ninety per cent. By the later seventeenth century, indentured servants and transported felons make appearances in popular English literature. In Aphra Behn's play, The Widow Ranter, or, The History of Bacon in Virginia (169o), a newly arrived indentured servant in the colony humorously fails to understand colonial English, rich in underworld slang. 'You Rogue', Widow Ranter says, "tis what we transport from England first'. ${ }^{22}$ The mobility of 'rogues', and the difficulty of 'placing' them, made such individuals a focal point for intense debate about state regulation and visions of empire. While some MPs, like the Jacobean Edwin Sandys, saw the sending of 'rogues' to the colonies as a method that stabilised the colonies and solved domestic social ills, not all policymakers advocated

17 'Vagabonds Act', 1603, 1 Jac. I c. 7 .

18 By the King a proclamation for the due and speedy execution of the statute against rogues, vagabonds, idle, and dissolute persons (London, 1603; STC 8333), unpaginated.

19 'Proposed bill in Parliament, condemning to servile work persons convicted of petty larcenies, rogues, \&c', February 1621, Kew, The National Archives, SP 14/119, f. 132.

20 Ibid.

21 C. J. Ribton Turner, A History of Vagrants and Vagrancy and Beggars and Begging (London: Chapman and Hall, 1897), pp. 141-144; Misha Ewen, "Poore Soules": Migration, Labor, and Visions of Commonwealth in Virginia', in Virginia 1619: Slavery and Freedom in the Making of English America, ed. by Paul Musselwhite, Peter C. Mancall, and James Horn (Chapel Hill: University of North Carolina Press, 2019), pp. 133-149.

22 Aphra Behn, The Widow Ranter, or, the History of Bacon in Virginia (London, 169o; Wing B1774), sig. Civ. 
transportation. Francis Bacon believed it was a 'Shamefull and Unblessed Thing' to transport 'the Scumme of People, and Wicked Condemned Men' to found American settlements. ${ }^{23}$ Bacon warned that 'they will ever live like Rogues', and would 'not fall to worke, but be Lazie, and doe Mischiefe, and spend Victuals, and be quickly weary'. ${ }^{24}$

During the civil wars, both sides of the conflict used the word 'rogue' in their political pamphlets, but it appeared particularly in royalist literature to describe those who supported and fought for Parliament. The word became synonymous with 'rebel', regularly used by royalist forces to highlight what they believed to be the treacherous behaviour of their enemies, or as the commander the Earl of Northampton described them, 'base rogues \& Rebels'. ${ }^{25}$ Royalists often banded parliamentary forces - 'roundheads' with 'rogue': 'Rogues and Round heads', 'you Roundheaded Rogues', 'these Roundheadly Rogues'. ${ }^{26}$ As the staunch royalist Walter Balcanquhall wrote from Scotland, there was 'no better names then Rogues' for the 'offenders in the first uproare' against the Crown. ${ }^{27}$ In America, support for Parliament was lukewarm and came mostly from the settlers of Massachusetts Bay. After the restoration of the monarchy in 166o, many parliamentary supporters resettled in Massachusetts, prompting one Church of England minister to claim that the 'Governor of Boston' was a 'Rogue', leading a colony full of '[t]raitors \& Rebels against the King'. ${ }^{28}$

When used in the colonies, the word 'rogue' retained similar connotations to the word in England, signalling idle wanderers, prisoners, or journeymen, while interactions with foreign peoples, cultures, and faiths across the globe imbued it with a wider range of usages and meanings. Territorial and commercial expansion increased opportunities for English men and

23 'Of Plantations', in Francis Bacon, The essayes or counsels, civill and morall (London, 1625; STC 1148), p. 199.

24 Ibid.

25 James Compton, The battaile on Hopton-Heath in Staffordshire, betweene His Majesties forces under the Right Honourable the Earle of Northampton, and those of the rebels (London, 1643; Wing B1162), p. 4.

26 Captain Aiscogh, A relation of the actions of the Parliaments forces (London, 1642; Wing R811), p. 3 ; A narration of the expedition to Taunton (London, 1645; Wing N158), p. 4; Gods revenge upon his Parliaments and peoples enemies (London, 1643; Wing G961), p. 6.

27 Walter Balcanquhall, A large declaration concerning the late tumults in Scotland (London, 1643; STC 219o6), p. 3 o.

28 Maine Province and Court Records, Vol. II, ed. by Charles Thornton Libby and Robert E. Moody (Portland: Maine Historical Society, 1928), p. 141; Jenny Hale Pulsipher, Subjects unto the Same King: Indians, English, and the Contest for Authority in Colonial New England (Philadelphia: University of Pennsylvania Press, 2006), p. 54. 
women to encounter, and even transform into, another type of rogue: the apostate. Alongside commercial and diplomatic interactions with India, the Levant, North Africa, and Persia, religious exchanges with numerous faiths were an everyday part of life abroad. Rogue apostates not only highlighted the danger to the nation of cultural exposure abroad, but also presented a danger for the future reputation of the nation if they gave sway so easily. One example was in Constantinople in 1650, where the Levant Company reported that a man who had refused to convert to Islam whilst in captivity, did so upon his release at the persuasion of yet another unnamed English apostate, before he disappeared from the English records altogether. ${ }^{29}$ The consul at Tripoli, Thomas Baker, described one Englishman who converted to Islam and, having been 'admitted into that accursed Superstition', was 'secured' aboard a ship before the end of the day, 'like a Rogue'. ${ }^{30}$ It was not just conversion to Islam or Hinduism that the East India and Levant companies guarded against, but to Catholicism as well. In 1648, one of the factors at Fort St. George in Madras reported to the EIC that the grandson of the fort's founder had 'turn'd Papist rogue' and fled to São Tomé. ${ }^{1}$

The religious apostate, much like the anti-royalist rogue or the 'self-made rogue', was an individual whom others perceived as having deliberately abandoned part of his or her national allegiances. Rogues were consistently viewed as treacherous and operating in a state of 'doubleness', wilfully subverting English structures of governance and belief. ${ }^{32}$ On the stage, rogues were double-dealing characters, morally suspect and ferociously independent, often promoting their own interests at the expense of the common good. Meanwhile, the 'undeserving poor' were categorised as rogues and ruthlessly punished through English law. Whether travelling along the waterways of the Chesapeake or the fields of Shropshire, the 'rogue' was always believed to operate outside national interests.

Related keywords: alien/stranger, convert, Gypsy, traitor, vagrant

29 Levant Company Records, c. 1650, Kew, The National Archives, SP 105/74, f. 281.

30 Piracy and Diplomacy in Seventeenth-century North Africa: The Journal of Thomas Baker, English Consul in Tripoli, 1677-1685, ed. by C. R. Pennell (Madison, NJ: Fairleigh Dickinson University Press, 1989), p. 126.

$3^{1}$ 'Thomas Ivy at Fort St. George to the President and Council at Surat, 17 January 1648', in English Factories in India, 1618-1669, Vol. 8, ed. by William Foster (Oxford: Oxford University Press, 1914), p. 298.

32 Matar, 'The Renegade in English Seventeenth-Century Imagination', pp. 490-491. 


\section{Savage/Barbarian}

The 'savage' occupied a liminal space between the human and the animal. The Middle French sauvage pertained to the wilderness or to spaces beyond human control. The postclassical salvagiusi, like sauvage, looked back at the Latin silva (woods). It invoked the pastoral and natural, and did not always carry negative connotations. ${ }^{1}$ However, while 'savages' as 'naturals' or innocent beings appeared in the sixteenth-century writings of the French essayist Michel de Montaigne or the Huguenot colonist Jean de Léry in Brazil, the more neutral connotations of 'savage' or its variant 'salvage' appeared less frequently in English texts. ${ }^{2}$ The English acknowledged that they too had developed their societies from savage roots, but this did not incline them to envisage perceived savages as embodying a benign state of being. More often, 'savage' carried connotations of corruption, brutality, or barbarity. Since 'civil' rooted virtuous human behaviour in town-dwelling and political organisation, 'savage' was its antithesis, relating to remote or undomesticated places as well as peoples. 'Barbarian', on the other hand, was used to characterise polities that Europeans deemed tyrannical or corrupt. Both 'savage' and 'barbarian' were terms that heavily informed English articulations of their own sense of civility in the context of crosscultural encounters.

In the sixteenth century, 'savage' frequently related to animals and animal-like behaviour, particularly cruelty. In The historie offoure-footed beastes (1607), Edward Topsell described animals such as wolves, boars, and leopards as exhibiting 'savage' characteristics. These animals were often agents of divine retribution, signifying God's hand at work in nature through a providence 'executed by the raging ministery of wilde, savage, and ungentle beastes' on the lives of the sinful. ${ }^{4}$ At the same time, humans who acted cruelly were described as becoming feral. Anger caused people to regress, wrote George Turberville, '[f]or then he waxeth out a kinde of savage beast'. 5 The sense that one had been abandoned by God, the

\footnotetext{
$1 \quad$ 'Savage, $n$. and adj., Oxford English Dictionary.

2 The essayes or morall, politike and millitarie discourses of Lo: Michael de Montaigne, trans. by John Florio (1603; STC 18041); Jean de Léry, History of a Voyage to the Land of Brazil, trans. by Janet Whatley (Berkeley: University of California Press, 1992).

3 Ibid.; Jorge Cañizares-Esguerra, Puritan Conquistadors: Iberianizing the Atlantic, 1550-1700 (Stanford, CA: Stanford University Press, 2006).

4 Edward Topsell, The historie offoure-footes beastes (London, 1607; STC 24123), p. 583.

5 George Turberville, A plaine path to perfect vertue (London, 1568; STC 17244), sig. C4r.
} 
reformer John Calvin wrote, will cause 'griefe and anguishe of mynde, yea and even into some frenzie to play the savage beast, and to lift up him selfe agaynst God'. ${ }^{6}$ In Edmund Spenser's 'Sonnet XX', the speaker complains that his mistress is 'more cruell and more salvage wylde, / then either Lyon or Lionesse', taking 'glorie in her cruelnesse'.7 Similarly, in Shakespeare's Much ado about Nothing (c. 1599), Claudio rebukes his beloved by saying, 'you are more intemperate in your blood / Than Venus, or those pampred animalls / That rage in savage sensualitie'. ${ }^{8}$ In these cases, sixteenth-century masculine anxieties about women as sexual snares led them to equate female behaviour with the intemperance of animals.

While the meaning of 'savage' as bestial or cruel did not disappear, colonisation in Ireland and later America indelibly altered English associations. As the post-Reformation state began to extend its bounds and exercise more rigorous control of its internal territories, 'savage' entered political discourse to describe treason and criminality and to disparage less elite members of society. The humanist and Protestant education of English policymakers and colonial governors imbued them with the expectation that the Irish and Native Americans who resisted reform and conversion were dissidents who stood between the English and their aim of establishing civil society. ${ }^{9}$ Authorities frequently condemned the manners of those dwelling on perceived 'frontier' territories, such as the Scottish highlands and Gaelic Ireland. '[T] her ys no confidence to be had in the hearts of so varyable \& trayterous a nacion' as Ireland, Charles Cornwallis wrote to the Privy Council in 1608 , 'as also to have so just an occasion, to roote out that savage generac[i]on bredd in those partes, and to plant his own people where his Justice and moderac[i]on [...] wyll not onyle secure those partes, but allso envyte all others $\mathrm{w}[\mathrm{i}]$ thin that $\mathrm{k}[\mathrm{ing}] \mathrm{dom}[\ldots]$ to desire nothing more then to become wholly subject'. ${ }^{10}$ George Turberville, who travelled to the court of Ivan the Terrible in 1568 , wrote that savages and barbarians could be found closer to home: 'Wilde Irish are as civill as the Russies in their kinde / Hard choice which is the best of both, e[a]ch

6 Sermons of Master John Calvin, ed. by Arthur Golding (London, 1574; STC 4445), p. 28.

7 Edmund Spenser, Amoretti and Epithalamion (London, 1595; STC 23076), sig. B3v.

8 William Shakespeare, 'Much adoe about Nothing', in Mr William Shakespeares comedies, histories, \& tragedies (London, 1623; STC 22273), pp. 101-121 (p. 114).

9 Nicholas Canny, 'The Ideology of English Colonization: From Ireland to America', The William and Mary Quarterly, 30 (1973), 575-598.

10 'Sir Charles Cornwallis to the Privy Council', 9 June 1608, Hatfield House, CP 125/16ov. 
bloody, rude, and blinde. / If thou bee wise [...] covet not those barbarous coasts to see.".

Like 'savage', 'barbarian' often operated alongside discussions of foreignness and civility (or the lack of). A 'Barbarian' originally referred to an inhabitant of the North African Barbary coast, or to an 'uncivil' stranger. The Greek word barbaros and the Latin barbarus meant 'not Greek' or 'not Latin', juxtaposed against the classical or 'pure' and often used to discuss language, speech, and conversation. ${ }^{12}$ A cluster of related words appeared around 'barbarian' in some language manuals and dictionaries:

Barbarian, belonging to

Barbary, -ria, part of Africa.

Barbarism, rudeness of speech or behaviour.

Barbarous, cruel, inhumane. ${ }^{13}$

A barbarian was by definition a 'babbler' speaking in garbled or unfamiliar words, signalling moments of collapse in language or communication. 'Barbarian' appeared in dictionary entries alongside 'barbarisme', a 'rudeness or corrupt forme of writing or speaking'. ${ }^{14}$ Numerous Protestant devotional tracts cited 1 Corinthians 14:11: 'Therefore if I know not the meaning of the voyce, I shall bee unto him that speaketh, a Barbarian, and he that speaketh shall be a Barbarian unto me' (KJV). In his biblical annotations, the nonconformist minister Henry Ainsworth related '[b]arbarous speech' or 'speaking barbarously' to a 'strange, rude, uncouth language', one that served to refer to 'all speech that was not understood of God's people: which hee that speaketh is [...] a Barbarian, that is, a stranger'.5

While a 'barbarian' and 'barbarous' actions were not quite interchangeable, noun and adjective both involved a series of related concepts around perceived rudeness or deviation from orthodoxy. This association with rudeness and perceived underdevelopment is what often brought savage and barbarian together. 'Thou has here', presented the churchman and

11 George Turberville, 'To Parker', in Richard Hakluyt, The principal navigations (London, 1599-16oo; STC 12626a), sig. Kk3r.

12 'Barbarous, adj., Oxford English Dictionary; Ian Smith, Race and Rhetoric in the Renaissance: Barbarian Errors (Basingstoke: Palgrave, 2009).

13 Elisha Coles, An English dictionary explaining the difficult terms (London, 1677; Wing C5071), sig. D3v.

14 Robert Cawdry, A table alphabeticall (London, 1609; STC 4884.5), sig. B4v.

15 Henry Ainsworth, Annotations upon the five bookes of Moses (London, 1627; STC 219), sig. Oooooo5r. 
geographer Samuel Purchas in his expanded travel compendium of 1625, '[n]ations Christian, Jewish, Mahumetan, Ethnicke, Civill, Barbarian and Savage, innumerable wayes diversified. ${ }^{16}$ In the diversity of world peoples, 'Barbarian and Savage' were both distinct and grouped together in one category.

While 'barbarians' were often connected to 'savages' in terms of behaviour, there were political differences between the two. 'Barbarous' polities were those the English tended to regard as corrupt rather than apolitical, such as Spain, Russia, and the Ottoman and Persian empires. Defending the Church of England against charges of heresy, the Elizabethan John Jewel described Catholicism as inseparable from 'the tyranny of the Byshops of Rome and their barbarous Persian-like pride'. ${ }^{17}$ In his translation of a Swiss reformed text on tyranny, Thomas Twyne brought up the 'wantonesse, pride and disdayne [of] the barbarous Turkes', whose barbarism led to despotism. ${ }^{18}$ While 'savages' were believed to live outside the pale of human society, Spain's 'barbarous tyranny of wasting the West Indies' became a manifestation of the 'kingdome of the antichrist', ushering bondage rather than redemption. ${ }^{19}$

By contrast, colonial promoters related the behaviour of Indigenous peoples to the supposed savagery of its landscapes, where the perceived lack of land management ostensibly reflected a lack of culture. The English viewed uncultivated nature and woodlands as synonymous with an absence of domesticity, settlement, and civil structures. ${ }^{20}$ Desert spaces, like jungles, were 'baren and salvage, so that it is not able to nourishe any beastes for lacke of pasture'. ${ }^{21}$ In England, 'savage' spaces were subject to reform, engendering radical transformations to the domestic landscape through enclosure, surveying, tillage, husbandry, and industrial projects. ${ }^{22}$ In the colonies, legal discourse associated the right of possession of land with

16 Samuel Purchas, Purchas his pilgrimes (London, 1625; STC 20509), p. 1065.

17 John Jewel, An apologie or answere in defence of the Churche of England (London, 1564; STC 14591), sig. Iir.

18 Henrich Bullinger, The tragedies of tyrantes, trans. by Thomas Twyne (London, 1575; STC 4078), p. 87 .

19 Gabriel Powel, A consideration of the papists of state and religion (Oxford, 1604; STC 20144), sig. L2r.

20 Keith Thomas, Man and the Natural World:Changing Attitudes in England, 1500-1800 (London: Allen Lane, 1983), p. 25 .

21 Richard Eden, A treatyse of newe India (London, 1553; STC 18244), sig. Gir.

22 Thomas, Man and the Natural World, p. 254; Paul Slack, The Invention of Improvement: Information and Material Progress in Seventeenth-Century England (Oxford: Oxford University Press, 2014). 
either the absence of habitation and ownership altogether (terra nullius) or the absence of settlement and cultivation (vacuum domicilum). When Purchas wrote in 1613 that Native Americans 'seeme to have learned the savage nature of the wild Beasts, of whom and with whome they live', a case was being made to support the claim of English settlers. ${ }^{23}$ By 1629 , John Winthrop would utilise that argument in New England to assert that Native peoples had 'natural' but not 'civil' rights over the land because they had not 'subdued' it. ${ }^{24}$ These claims obscured the fact that the English often built their plantations on top of land that Indigenous groups had previously used for crops, gardens, and sacred burial sites.

Language played a prominent role in how the English positioned themselves in relation to 'savages' and 'barbarians'. Teaching invaded peoples English was a direct method of initiating the colonising and civilising projects of the Crown and corporations. Evangelism and education were closely related. The role of the dutiful Christian, the schoolmaster John Brinsley wrote in his educational tract of 1622 , was not only to advance 'your owne ends and projects' through colonisation, but to convert 'the verie savage [...] unto Jesus Christ, whether Irish or Indian'. ${ }^{25}$ Similarly, the origin of 'barbarian' as a 'babbler' loomed behind English expressions of linguistic superiority. The rising appreciation for the English language accompanied derisive attitudes towards Gaelic or Native American dialects. George Puttenham noted that the least developed language was 'spoken by the rude and barking language of the Affricans now called Barbarians'. ${ }^{26}$ '[T] he most laudable languages', Puttenham reminded his readers, 'are alwaies most plaine and distinct, and the barbarous most confuse and indistinct'. ${ }^{27}$ In 1602, the lord deputy of Ireland Charles Blount, Lord Mountjoy complained that the Gaelic Irish refused to abandon local styles of dress, including mantles. They did so not for lack of other options, but because 'the barbarous Customes in habits of apparell in their poets or herauldes' served to 'inchant' them 'in savage manners and sundry other such dregges of barbarism and Rebellion [...] already forbidden'. ${ }^{28}$ Heralds in Gaelic households, orally

24 Peter Hulme, Colonial Encounters: Europe and the Native Caribbean, 1492-1787 (London: Methuen, 1986), p. 159-6o.

25 John Brinsley, A consolation for our grammar schooles (London, 1622; STC 3767), sig. Av.

26 Quoted in Ian Smith, 'Barbarian Errors: Performing Race in Early Modern England', Shakespeare Quarterly, 49 (1998), 168-186 (p. 172).

27 George Puttenham, The arte of English poesie (London, 1589; STC 20519.5), sig. Lir.

28 Suggestions by Lord Mountjoy for the Government of Ireland, 1602, Hatfield House, CP $139 / 138$ r. 
sharing stories and news in the Gaelic tongue, were presented by colonists as perpetuating 'dregs of barbarism', manifested in turn through distinct clothing that opposed conformity to English Protestantism.

Even as the English targeted the 'savage' oral histories and language systems of those they sought to colonize, increased engagement with the classical translation and European languages brought an acute awareness of the questionable status of their own language and literature. The humanist reverence for the classical past in sixteenth-century England led to a sensitivity about the English language itself as 'barbarous' or inferior. 'The foulest vice in language is to speake barbarously', Puttenham wrote in The arte of English poesie (1589). ' [T] his terme grew by the great pride of the Greekes and Latines, when they were dominatours of the world reckoning no language so sweete and civill as their owne. ${ }^{29}$ '[B] arbarous conquerors invading [ancient Europe] with innumerable swarmes of strange nations, the Poesie metricall of the Grecians and Latines came to be much corrupted and altered' $3^{\circ}$ Aware of the quirks and eccentricities of the English vernacular, which at times stood at odds with classical theory, English translators and writers began to champion the literary value of their own language, especially from the 1570 s. $^{31}$ George Pettie, though demonstrating an awareness of its questionable status among other European languages, defended English in his translation of Stefano Guazzo's The civile conversation (1581). 'There are some others yet who wyll set lyght by my labours, because I wrote in Englysh', Pettie wrote. Some English travellers, hungry for French, Italian, or Spanish, will 'count it barren, they count it barbarous [...] they report abrode, that our Countrey is barbarous' $3^{2}$ Nonetheless, Pettie staunchly defended his decision to write in English, for the virtue of a language was always relative: 'the maners and fashions of eche Countrey, are thy only thyng that make it counted barbarous or civile'.33

As Pettie articulated, language was one part of a broader question among policymakers and educators about how to categorise different peoples on the

29 Puttenham, The arte of English poesie, sig. Ee3r; Cathy Shrank, Writing the Nation in Reformation England, 1530-1580 (Oxford: Oxford University Press, 2004); Writing the Other: Humanism versus Barbarism in Tudor England, ed. by Zsolt Almási and Mike Pincombe (Newcastle: Cambridge Scholars, 2008).

30 Puttenham, The arte of English poesie, sig. $\mathrm{C} 4 \mathrm{v}$.

31 Catherine Nicholson, Uncommon Tongues: Eloquence and Eccentricity in the English Renaissance (Philadelphia: University of Pennsylvania Press, 2014), p. 6. See also John Gallagher, Learning Languages in Early Modern England (Oxford: Oxford University Press, 2019).

32 George Pettie, The civile conversation of $M$. Steeven Guazzo written in Italian, and now translated (London, 1581; STC 12422), sigs. iir-v.

33 Ibid. 
spectrum of civility. 'Savage' and 'barbarian' were entrenched within these vital dialogues about the nature of society and who belonged. Technology played a further role in these categorisations. Humphrey Gilbert and other Elizabethan privateers and explorers were given permission to seek out those 'remote heathen and barbarous lands' that were not inhabited by 'any Christian prince or people' so that they might be 'planted' and fruitful industries might develop. ${ }^{34}$ By the 1650 s, Robert Wood, a mathematician affiliated with the Hartlib circle, wrote that the main difference between the 'Civility of the Europeans \& Barbarisme of the Americans' was that 'the former had the use of Iron', enabling Europeans to develop technologies, industries, and coinage. ${ }^{35}$

As the English presence in the Americas grew more secure, 'savage' became more aligned with 'barbarian', conveying perceived inferiority without denoting any real threat to English sovereignty abroad. By the Enlightenment, 'savages' and 'barbarians' were mostly foils for English articulations of their own manners, customs, and even humanity. 'Here was a Metamorphose wrought by the Force of Love and Beauty, a Barbarian civiliz'd to a milder Temper', a novel from 1687 marvelled..$^{6}$ This imparted the longstanding idea of civility as a marker of progress in which 'savages' and 'barbarians' might elevate their natures or soften their penchant for brutality through the pursuit of refined behaviour. Those who refused to conform to English ways of life, meanwhile, were continually accused of hindering, rather than advancing, progress.

Related keywords: alien/stranger, heathen, traitor, translator

34 Keith Thomas, In Pursuit of Civility: Manners and Civilization in Early Modern England (Waltham, MA: Brandeis University Press, 2018), p. 171.

35 'Copy of memorandum concerning coinage', 1 December 1658, The Hartlib Papers, 18/14/1A-2B. See also Joyce Chaplin, Subject Matter: Technology, the Body, and Science on the Anglo-American Frontier, 1500-1776 (Cambridge, MA: Harvard University Press, 2001).

36 Cynthia with the tragical account of the unfortunate lover of Almerin and Desdemona (London,

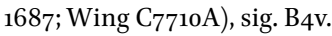




\section{Secretary}

In his 1592 'Discourse touching the Office of Principal Secretary of Estate', Nicholas Faunt drew on his seventeen years of experience as Sir Francis Walsingham's personal secretary to remark on the wide range of matters and tasks that secretaries dealt with. They were subjected to much 'cumber and variableness', he complained, that impeded an office that should be defined by a 'special method and order.' ${ }^{1}$ Like other bureaucratic figures with different titles but similar functions, secretaries acted as the overseers of early modern institutions and their complex administrative machineries, such as royal governments, merchant companies, universities, or religious bodies. The word originally derived from the Latin secretarius, a notary or scribe - individuals who served emperors and government officials and were often part of the apparatus of state expansion and imperial administration. ${ }^{2}$ Most early modern treatises on secretaryship described secretaries as facilitators of communication and as cultivated servants who used their humanist education and mastery of rhetoric to guide their masters in their correspondence with others. Their function, as the Italian secretary Vincenzo Gramigna observed in Il segretario dialogo (1620), was to be the 'pen-speaker' (dicitor dipenna) and an 'executor of the will of others'. ${ }^{3}$ Thomas Dekker expressed a similar sense of the word when he wrote that the 'Gunner of Gehanna' (Satan), by 'the Artillerie of his Secretaries penne, hath shaken the walls of his kingdome'. ${ }^{4}$

The production, analysis and management of information (letters, reports, and dispatches) was the secretary's main task, whether for resident embassies and special missions abroad, or for individual employers in England. ${ }^{5}$ The secretaries of the English mercantile companies, for example, played a pivotal role in controlling communication and registering all operations and decisions. They were responsible for a keeping a record of the activities of the

1 Nicholas Faunt, 'Discourse Touching the Office of Principal Secretary of Estate', ed. by Charles Hughes in The English Historical Review, 20:79 (1905), 499-508 (pp. 499-50o); Nicholas Popper, 'An Information State for Elizabethan England', The Journal of Modern History, 90 (2018), 503-535.

2 Livy, History of Rome 2, trans. by B. O. Foster (Harvard: Loeb, 1919), p. 257; Horace, Epistles, trans. by H. Rushton Fairclough (Harvard: Loeb, 1926), p. 307; 'Secretary, n.', Oxford English Dictionary.

3 Salvatore S. Nigro, 'The Secretary', in Baroque Personae, ed. by Rosario Villari (Chicago: Chicago University Press, 1995), pp. 82-99 (pp. 85-86).

4 Thomas Dekker, Newes from hell (London, 1606; STC 6514), sig. F2v.

5 Ibid., pp. 1-15 (p. 1). 
factories, draft minutes of meetings, besides managing the correspondence of the factory with the headquarters in England and a myriad of local actors from officials to merchants. ${ }^{6}$ Entrusted with the task of managing and producing information, the secretaries of the English factories in the Levant and Asia were often individuals with a good knowledge of local languages and trading practices. One good example is the case of Thomas Coke, the veteran secretary to the Levant Company and the English embassy in Istanbul, who cultivated an important network of privileged local informers who allowed the English to obtain intelligence from restricted Ottoman courtly circles. ${ }^{7}$

As in the case of the ambassador or the envoy, the secretary was an oratore or a messenger, someone who mediated the communication between his master or prince and other actors. Expanding state and diplomatic interests relied on secretaries and clerks who played a pivotal role in overseeing the flow of intelligence produced and managed by various organisations. In the 1640 s, the prophetic writer Lady Eleanor Davies appropriated this understanding of the function of the secretary as a trusted interpreter of sensitive information when she claimed a privileged access to divine wisdom, as 'a Writer or Secretary, concerning the unsealing or interpreting this obscure piece to open the Vision of Daniel'. ${ }^{8}$ That claim of proximity to the divine would allow Davies to overpass the restrictions imposed to the participation of women in the political and religious arenas, and to develop an active and interventive voice through her prophetic works. ${ }^{9}$

Although 'at the pleasure and appointment of another to be commanded', the secretary could enjoy a special status due to the sensitivity of the information to which he had access. The secretary was 'a keeper or conserver of the secret unto him committed'. ${ }^{10}$ Indeed, the word secretarius mentioned above related closely to secretum - the special chamber where confidential information could be written and stored, or a place of secrets. ${ }^{11}$ Faunt's work

6 See for example, Rupali Mishra, A Business of State: Commerce, Politics, and the Birth of the East India Company (Cambridge, MA: Harvard University Press, 2018), pp. 43-45.

7 See for example, John-Paul Ghobrial, The Whispers of Cities: Information Flows in Istanbul, London, and Paris in the Age of William Trumbull (Oxford: Oxford University Press, 2013), pp. 52-65.

8 Eleanor Davies, From the Lady Eleanor, her blessing, to her beloved daughter the Right Honorable Lucy, Countesses of Huntingdon (London, 1644; Wing D1991), p. 7 .

9 Diane Watt, Secretaries of God: Women Prophets in Late Medieval and Early Modern England (Woodbridge: Boydell \& Brewer, 2001), pp. 118-154.

10 Angel Day, The English secretary (London, 1599; STC 6404), pp. 102-103; See also Richard Rambuss, 'The Secretary's Study: The Secret Designs of the Shepheardes Calender', English Literary History, 59:2 (1992), 313-335 (p. 318).

11 Nigro, 'The Secretary', in Baroque Personae, p. 91. 
as a spy and intelligencer for Walsingham in Germany, France, and northern Italy during the 1580 s led him to emphasise the importance of 'secrecy and faithfulness' in managing business, but also in obtaining or discovering new secrets by conferring 'with secret intelligencers both strangers and others.' ${ }^{12}$ This link between secrecy and secretaryship allowed the secretary to enjoy a privileged, often intimate relationship with his master, one that the writer Angel Day believed was 'more special than that between the son and the father'. ${ }^{13}$

The writer Robert Greene referred to that unique bond between secretaries and their masters in his popular prose romance, Mamilia (1583). While describing his protagonist Pharicles' passion for Mamilia, Greene emphasised that as 'his fire was the more, his flame was the greater, and not being able so well to rule his lust', Pharicles had no option than to hide his feelings and 'used himself for a secretary, with whom to participate his passions, knowing that it were a point of mere folly to trust a friend in love'. ${ }^{14}$ While seemingly passive agents of their masters' will, therefore, secretaries often played key roles in moments of mediation and interpretation. On the day-to-day level of bureaucratic service, the bond between secretary and master was not one of friendship so much as one of necessity, calculation, and trust, as John Higgins would note:

It spites my heart to hear when noblemen

Cannot disclose their secrets to their friend,

In safeguard sure, with paper, ink, and pen,

But first they must a secretary find,

To whom they shew the bottom of their mind:

And be he false or true, a blab or close,

To him they must their counsel needs disclose. ${ }^{15}$

The access to sensitive documents on diplomatic, commercial, or political affairs allowed secretaries and other bureaucrats to use the information they produced and managed to their advantage. Many shared secrets with

12 Faunt, 'Discourse Touching the Office of Principal Secretary of Estate', p. 503; Angela Andreani, The Elizabethan Secretariat and the Signet Office: The Production of State Papers, 1590-1596 (London: Routledge, 2017), p. 167.

13 Paul E. J. Hammer, 'The Use of Scholarship: The Secretariat of Robert Devereux, Second Earl of Essex, c. 1585-1601', The English Historical Review, 109 (1994), 26-51 (p. 26).

14 Robert Green, Mamillia A mirrour or looking-glasse for the ladies of Englande (London, 1583; STC 12269), p. 6.

15 John Higgins, The falles of unfortunate princes (London, 1619; STC 13447), p. 468. 
relevant or influential political actors in exchange for friendship, further information, or political and social benefits. ${ }^{16}$ Through the intelligence networks they fostered, secretaries facilitated the growing market for news and information that connected men and women to the wider world. ${ }^{17}$

As mediators between their employers and other polities, secretaries were often confronted with a series of issues that required a detailed knowledge of legal, administrative, financial, ecclesiastical, and mercantile affairs. ${ }^{18}$ The multiple functions trusted to a secretary required an expertise and skills that were only possible through a privileged university education and humanist training. Treatises on secretaryship often depicted the secretary as a member of a restricted elite of scholars and bureaucrats recruited from universities and courtly milieus. For many graduates of Oxford, Cambridge, or the Inns of Court, secretaryship was often a stepping stone to prestigious posts in royal administration or diplomacy. In February 1609, the London gossip John Chamberlain wrote to Dudley Carleton that the poet John Donne, who sought professional advancement after the damage done by his secret marriage to Anne More in 1601, 'seeks to be preferred to be secretarie of Virginia'. ${ }^{19}$

Those who did succeed in becoming secretaries tended to progress in the royal administration or obtain ambassadorial posts. Robert Devereux, second Earl of Essex, employed a young well-educated and well-travelled Henry Wotton in 1594, partly in recognition of the correspondence network that Wotton had cultivated during his 'grand tour' of the Continent. ${ }^{20}$

Another example of the possibilities of social mobility offered by the office of the secretary is the case of Edward Barton, the secretary of William Harborne, the first English ambassador to the Ottoman court. Fynes Moryson, for example, praised the ascension of Barton, a man who, although 'was no more learned than the Grammar school', was able to become a

16 David Coast, Information, Politics and Diplomacy, 1618-1625 (Manchester: Manchester University Press, 2014), p. 53.

17 James Daybell, 'Gender, Politics, and Diplomacy: Women, News, and Intelligence Networks in Elizabethan England, in Diplomacy and Early Modern Culture, ed. by Robyn Adams and Rosanna Cox (Basingstoke: Palgrave, 2011), pp. 101-119; Popper, 'An Information State'; Noah Millstone, Manuscript Circulation and the Invention of Politics in Early Modern England (Cambridge: Cambridge University Press, 2016); Joad Raymond, The Invention of the Newspaper: English Newsbooks, 1641-1649 (Oxford: Clarendon Press, 1996).

18 Rayne Allinson, 'Parables and Dark Sentences: The Correspondence of Sir William Cecil and William Maitland (1559-1573)', in Secretaries and Statecraft, p. 96.

19 Quoted in Tom Cain, 'John Donne and the Ideology of Colonization', English Literary Renaissance, 31:3 (2001), 440-476 (p. 442).

20 Hammer, 'The Use of Scholarship', p. 30. 
pivotal element in Anglo-Ottoman relations thanks to his linguistic ability. ${ }^{21}$ As a young man he entered the service of William Harbourne, and when his patron was appointed as an ambassador to Istanbul, he became his secretary. In order to control the correspondence between the Sublime Porte and London, Barton decided to learn Turkish and rapidly became a crucial negotiator in Anglo-Ottoman relations. As he became aware of the subtleties of Ottoman bureaucracy and letter-writing, Barton was able to advise Elizabeth I and her state secretaries to change the style, format and rhetoric of their letters to guarantee a favourable reception from the sultan. His ability to speak Turkish made him a respected figure at the Ottoman court, granting him access to various courtly factions and sectors of the local administrative machinery. Responsible for securing a steady flow of communication between London and Istanbul, Barton developed a complex cipher system which caused William Cecil, Lord Burghley to complain that the letters sent by the English embassy at Istanbul took too long to decipher. Barton's linguistic skills and his ability to obtain and guard secrets were behind Elizabeth's decision to appoint Barton as Harborne's successor in $1583 .{ }^{22}$

Like Edward Barton, the MP John Pory is another case of the opportunities of social mobility available to secretaries. Although educated at Cambridge, he had no landed resources. His education, however, allowed him to serve in some financially rewarding posts which required a scholarly education. ${ }^{23}$ In 1619, Pory, who had worked as an assistant to the geographical compiler Richard Hakluyt, arrived in Virginia to serve as secretary in Jamestown. Pory felt disoriented in this new territory, remarking on the 'uncouthness of this place, compared with those partes of Christendome or Turkey where I had bene'. ${ }^{24}$ Though 'those of our nation and the Indians' were suffering from 'this Torride sommer', Pory looked forward to stepping into the duties of his role: 'I am, for faulte of a better, Secretary of Estate, the first that ever was chosen and appointed by Commission from the

21 Shakespeare's Europe: Unpublished Chapters of Fynes Moryson's Itinerary, Being a Survey of the Condition of Europe at the End of the 17th Century, ed. by Charles Hughes (London: Sherratt \& Hughes, 1903), p. 27.

22 Rayne Allinson, A Monarchy of Letters: Royal Correspondence and English Diplomacy in the Reign of Elizabeth I (London: Palgrave Macmillan, 2012), pp. 132-135; Gerald MacLean and Nabil Matar, Britain and the Islamic World, 1558-1713 (Oxford: Oxford University Press, 2011), pp. 47, 82. 23 See for example, William S. Powell, John Pory, 1572-1636: The Life and Letters of a Man of Many Parts (Chapel Hill: The University of North Carolina Press, 1977).

24 'Letter of John Pory to Sir Dudley Carleton, 30 September 1619', in Narratives of Early Virginia, 1606-1625, ed. by Lyon Gardiner Tyler (New York: Charles Scribner, 1907), p. 286. 
Counsell and Company in England'. ${ }^{25}$ As secretary, Pory served as speaker in the General Assembly of 1619, the first English elected representative assembly to be held in America.

Throughout the period, the diplomatic sense of the secretary as a go-between continued to be used less formally to denote communication of other forms, from godly interpreters of Scripture to the heralds of heart-matters: 'I must now impart', confides the fraudulent Sir Petronel Flash in Eastward hoe (1605), 'a loving secret [...] [and] you [shall] be the chosen Secretarie / Of my affections'. ${ }^{26}$ While secretaries had the power to operate as agents of deception, as when an enamoured lady in Mary Wroth's Urania (1621) treasured a sonnet that her paramour only pretended to write ("the truth is his friend made it for him, and so was his Secretary justly'), the troubles of miscommunication raises attention to the important, everyday role of the secretary in facilitating communication between individuals across towns, countries, and polities. ${ }^{27}$ Letters written by women to secretaries of state, and their personal employment of secretaries of their own, place women within networks of intelligence-gathering, petitioning, and the circulation of news. ${ }^{28}$ The English aristocrat and Spanish courtier Jane Dormer, Countess of Feria, for example, relied on her secretary Henry Clifford to maintain an active correspondence with other members of the Spanish nobility and English recusants and exiles scattered across Europe. Clifford's devotion to his employer manifested itself in an account of Dormer's life that survives to this day. ${ }^{29}$ Lady Anne Clifford's correspondence about her activities as a 'Maecenas' (a reference to Emperor Augustus' political advisor) and landowner often passed through her 'chief officers' and 'secretaries' George Sedgwick and Edward Hasell. ${ }^{30}$

25 Ibid., p. 283.

26 George Chapman, Ben Jonson, and John Marston, Eastward hoe (London, 1605; STC 4971), sig. E1v.

27 The Countesse of Mountgomeries Urania. Written by the right honnourable Lady Mary Wroath (London, 1621; STC 26051), p. 513.

28 The Cambridge Companion to Early Modern Women's Writing, ed. by Laura Lunger Knoppers (Cambridge: Cambridge University Press, 2009); John Davies, The writing schoolemaster (London, 1631; STC 6344.5).

29 Hannah Leah Crumé, 'Jane Dormer's Recipe for Politics: A Refuge Household in Spain for Mary Tudor's Ladies-in-Waiting', in The Politics of Female Households: Ladies-in-waiting across Early Modern Europe ed. Nadine Akkerman and Birgit Houben (Leiden: Brill, 2013), pp. 51-71 (p. 52); The Life ofJane Dormer Duchess of Feria by Henry Clifford, ed. by Joseph Stevenson (London: Burns and Oates, 1887).

30 George Charles Williamson, Lady Anne Clifford, Countess of Dorset, Pembroke \& Montgomery (1590-1676) (London: Kendal Titus Wilson \& Son, 1922), p. 470. 
Meanwhile, the cases of Barton in the Levant and Pory in North America demonstrate the importance of secretaries in developing early modern diplomatic and state administrative systems, and their role in producing and circulating knowledge and transmitting English systems and institutions in new territories. Their education, travels, and accumulated experience as intelligencers and often spies made them privileged go-betweens: experts with the capacity to shape the course of diplomatic exchanges.

Related keywords: alien/stranger, envoy, friend/ally, interpreter, spy 


\section{Settler}

English usages of the word 'settler' are now firmly entrenched within the language of eighteenth- and nineteenth-century imperialism, though the word contained other meanings in an era when English colonial endeavours were just emerging. While 'settler' had become an individual commonly associated with England's increasingly global territorial and commercial ambitions by the 1680 , the word previously more generally carried a sense of 'doing', of an identity rooted in profession or service. 'Settler' first appears in foreign language manuals published at the end of the sixteenth century. The second generation Italian migrant, John Florio, uses the word in 1598 to describe a hairdresser (acconciatore) as a 'mender, a setler, an ordrer'. ${ }^{2}$ Just over a decade later, in A dictionarie of the French and English tongues, Randle Cotgrave described 'a Ficheur' as a 'fixer, fastener, setler, or setter'.3 The most common domestic use of the word was within religious and political language, identifying an individual or group who had established, settled, or planted varying forms of religions and governments. This meant that early modern English people recognised different individuals and groups as settlers.

The most common domestic use of 'settler' in the early seventeenth century was what is often termed as the 'settling' or founding of Protestant religious authority. Protestants and Catholics identified Martin Luther, for instance, as a 'settler' in later discourses. Richard Smith, the Catholic chaplain to Viscountess Montague, described Luther as the 'setler of the Protestant Church'. ${ }^{4}$ Some years later, Smith again described Luther as a settler, calling him the 'renewer, the Founder, the Restorer, the setler and promulgator of [the Protestant] Church and Religion'. ${ }^{5}$ Smith had lived in Europe as a student and teacher at the English colleges in Rome and Seville during the height of the Counter-Reformation, and he hardly viewed

\footnotetext{
1 'Settler, n.', Oxford English Dictionary.

2 John Florio, A worlde of wordes (London, 1598; STC 11098), p. 5.

3 Randle Cotgrave, $A$ dictionarie of the French and English tongues (London, 1611; STC 5830), sig. Oo5r.

4 Richard Smith, The prudentiall ballance of religion wherin the Catholike and protestant religion are weighed together with the weights of prudence, and right reason (London 1609; STC 22813), p. 523 .

5 Richard Smith, Of the author and substance of the protestant church and religion two books (London, 1621; STC 22812), p. 293.
} 
Luther's role as a settler of religion as positive: Luther was a '[s]etler of a thing corrupted.' 6

In short, 'settler' developed out of increased mobility, becoming linked to individuals and religious communities who were forced to settle new communities as a result of confession, dispute, and the subsequent threats posed to their lives and livelihoods. Much like those who considered Luther the founding settler of the Protestant faith, many English migrants who established exile churches in Europe were considered settlers. The Catholic Smiths eventually settled in an English college in Paris and lived in the household of Cardinal Richelieu. Francisco de Peralta, the Spanish rector of the English Jesuit College of Seville where Smith had taught, described a group of English prisoners in Spain in the manner of settlers. These men had been converted to Catholicism by the English Jesuit Robert Persons: '[s]ome of the men settled here, while others took service on the King's service as sailors or soldiers' ('se quedaron a vivir por aca, otros sirviendo al Rey en las galeras por marineros y soldados'). ${ }^{7}$ Religious migrants who moved across the Channel to settle homes and churches in England were also identified as settlers. In 1636, the Archbishop of York wrote to William Laud, Archbishop of Canterbury, of the growing number of Dutch and French settlers in Lincoln, noting that amongst them was a minister called Cosellys who was the 'principal settler' of the church there. ${ }^{8}$

Alongside the practical acts of establishing or settling churches, English authors also discussed religion in terms of it being a settler of peace and stability across society, from the individual to the nation. The Calvinist cleric, Thomas Taylor, wrote of the role of religion and godly meditation in settling a peaceable domestic life, particularly for women, in his Commentarie upon the Epistle of S. Paulwritten to Titus (1612). Taylor was particularly concerned with the role of religious observation as a 'setler of the comfort of her life' as it 'suffereth not undutifulnes to the husband, unnaturalnes towards the children, unmercifulnes towards servants' and 'untowardnes in her owne duties'. ${ }^{9}$ On a national level, the dutiful observance of religion was also seen as a key means of ensuring peace, stability, and loyalty to the

6 Ibid., p. 294 .

7 'Some reasons why the English seminary at Seville is no burden to the Province, but rather to its advantage, honour and good repute, 1604', in Martin Murphy, St. Gregory's College, Seville 1592-1767 (London: Catholic Record Society, 1992), pp. 144-154.

8 Archbishop Neile, of York, to Archbishop York, 18 September 1636, Kew, The National Archives, SP 16/331, f. 108.

9 Thomas Taylor, A commentarie upon the Epistle of S. Paul written to Titus (London, 1612; STC 23825), p. 385 . 
government. As the poet Francis Quarles wrote, 'true Religion is a setler in a State', confirming 'an establisht Government'. ${ }^{10}$

Second to the religious identity of domestic settlers were those involved in the establishment of political and governmental authority in England. In the years surrounding the English civil wars, individuals and groups on both sides of the political divide were accused of encouraging instability by settling various forms of government. Linked to the religious use of the word, the 'settler' in the context of the political conflicts of the mid-seventeenth century was someone who could be perceived as either positively or negatively establishing a form of political order. In 1647 , one author pointed out the irony of claims that the army in its 'preparations for warre' was seen as being 'settlers of a happy Peace in England', since those who 'strive to settle Peace by the sword, distract it'. ${ }^{11}$ Following the return of Charles II from exile in Europe and the Restoration of the Crown in 1660, many who were wary of the turmoil and memory of the civil wars and Interregnum were keen to remind Charles of his responsibility as a settler of good government. The king was charged with establishing order as a 'settler of outward peace.' ${ }^{12}$ Like those who would venture abroad establishing English colonies in the Atlantic, Charles was seen as a '[s]etler and Establisher' whose movement and relocation would ensure that good English government was established and maintained, both in England and abroad. ${ }^{13}$

As English territorial and commercial endeavours expanded abroad, so too did attempts to establish and settle English authority upon peoples and geographies across the globe. Although the word is absent from colonial charters, those who ventured to America and the Caribbean were seen to be migrating to 'settle themselves, dwell and inhabit' specific places. ${ }^{14}$ This more established view of the 'settler' as colonist and migrant took shape in the years following the Restoration. Chief Justice John Vaughan advanced more nuanced legal definitions of settlers and their rights in the 1670 s. ${ }^{15}$

10 Francis Quarles, Enchiridion Containing institutions, divine contemplative (London, 1644; Wing Q87), sig. C2r.

11 Andrew All Truth, The Army brought to the barre (London, 1647; Wing A3709), p. 8.

12 John Hackett, A sermon preached before the Kings Majesty at Whitehall on Friday the 22 of March anno 1660 (London, 1660; Wing H172), p. 16.

13 John Nelme, England's royal stone at the head of the corner, through the wonderful working of almighty God (London, 166o; Wing N415), p. 11.

14 The Colonial Records of North Carolina, Vol. I: 1662-1712, ed. by William L. Saunders (Raleigh, NC: Hale, 1888), p. 22.

15 Crowv. Ramsey (1670) 1 English Reports [ER], 378; Craig Yirush, Settlers, Liberty, and Empire: The Roots of Early American Political Theory, 1675-1775 (Cambridge: Cambridge University Press, 2011), p. 42. 
In ensuing legal cases, common law for settlers 'twas their birthright' and upon all 'uninhabited country, newly found out by English subjects, all laws in force in England are in force'. ${ }^{16}$ The term 'uninhabited' referred to land not belonging to English or European powers, where the legal rights extended to settlers either ignored or did not take into account pre-existing Indigenous communities. Granting rights and privileges for English men and women to 'settle' therefore legitimised a process that allowed the English to subjugate or drive out Native Americans and other Indigenous groups - settler colonialism.

The role of 'settlers', therefore, became increasingly associated with the mechanisms of expansion and the establishment of various forms of trade and trading outposts. The member of Parliament, merchant, and Guinea Company investor Nicholas Crisp was one of the first men to use 'settler' in relation to trade, and he did so specifically in the context of the slave trade on the West Coast of Africa. In a petition to Parliament in 166o, Crisp pleaded he be granted $£_{20,000}$ in funds lost to trade, which would help to pay for his release from prison. ${ }^{17}$ Crisp believed that amount was long due in recognition of his 'merit from his Nation', since he had been the 'first Discover and Setler of that Trade' to Africa. ${ }^{18}$

In England, the landed elite had long built their authority around lineage and a sense of permanence, their power strengthened by their claims to settling land in a juxtaposition against tradesmen, journeymen, and agricultural workers who were often forced to move from county to county seeking work. ${ }^{19}$ The deportation of Africans to English plantations, and the dispossession of Indigenous groups of their lands, wove more racialised ideas of dominance within the word. A clear separation emerged between industrious 'settlers' and enslaved Africans. It pinpoints a moment of change, whereby the word 'settler', when applied in the context of plantation, merged domestic ideas of establishing peace and stability with colonial attempts to 'civilize' other territories and its peoples. Increasingly, the English believed that to 'settle' was not just to cultivate other geographies, but to dominate non-English peoples. In 1682, nearly twenty years after Charles II had reissued the Carolina Charter, one pamphlet celebrated the 'pleasant Pastures, and

\footnotetext{
16 Dutton v. Howell (1693), 1 ER, 17; Blankard v. Galdy (1693), 91 ER 356; Yirush, Settlers, Liberty, and Empire, p. 42.

17 Nicholas Crisp, To the Right Honourable the Commons of England assembled in Parliament (London, 166o; Wing C6915).

18 Ibid.

19 David Rollison, 'Exploding England: The Dialectics of Mobility and Settlement in Early Modern England', Social History, 24 (1999), 1-16 (pp. 8, 12-13).
} 
shady Savana's [sic]' that could 'most generously refresh the Setlers', with an abundance of natural resources 'to compensate the modest Care, and Industry of the Setler'. ${ }^{20}$ It was through the 'industrious Setlers, and Planters' that Carolina had been able to 'prosper very well'. ${ }^{21}$ Yet the success of these settlers hinged on the work of enslaved Africans, 'whose labour proclaims the Setlers plenty'. ${ }^{22}$

By the end of the seventeenth century, the identity of the 'settler' had been transformed. While men and women from across the globe settled in new spaces, 'settler' as a noun in English usage referred most frequently to white male heads of household. Women continued to be associated with earlier ideas of settling - Elizabeth 'settling' the Protestant religion - but taken abroad, the domestic concepts about orthodoxy and governance that surrounded 'settlers' were adapted and mutated into its more commonly-associated colonial meaning. ${ }^{23}$ By the end of the century, authors recalled how many '[p]roprietoryships' had been 'granted to the Settlers of Colonies in America', whilst others sought to 'incourage new Settlers' to travel abroad. ${ }^{24}$ Much like their domestic counterparts, the responsibility of these English settlers was to establish and ensure the stability and security of English governmental authority. However, unlike in England, colonial settlers also sought to extend this authority beyond the traditional boundaries of English control. In doing so, the colonial experience mutated the identity of the settlers from the protector of authority to the embodiment of authority.

Related keywords: exile, merchant, native, subject

20 R. F., The present state of Carolina with advice to the setlers (London, 1682 ; Wing F52A), pp. 16, 27.

21 Ibid., p. 9.

22 Ibid., p. 5 .

23 On female 'settlers' in the religious sense, see Oliver Almond, The casing of heresy (Douai, 1623; STC 12), sig. *5r; Nathaniel Bacon, The continuation of an historicall discourse (London, 1651; Wing B348), p. 272; Edmund Bohun, The character of Queen Elizabeth (London, 1693; Wing B3448), p. 42.

24 John Cary, An answer to Mr. Molyneux his Case of Ireland's being bound by acts of Parliament in England (London, 1698 ; Wing $\mathrm{C}_{724} \mathrm{~B}$ ), p. 43; Loyalty vindicated being an answer to a late false, seditious \& scandalous pamphlet entituled A letter from a gentleman of the City of New York to another (London, 1698; Wing L3384), p. 20. 


\section{Spy}

In 1598 , translating the Italian words for 'spy' (spia) and 'spying' (spirare) for his English dictionary, John Florio defined the words in relation to specific actions: 'to espy, to peer, to pry, to watch or scout with diligence, to ask or enquire for.'. As the closely related word 'intelligencer' suggests, the 'spy' was involved in the business of collecting valuable 'intelligence' or information, or of carefully observing the activities of others. ${ }^{2}$ Given the connection between 'spy' and espie, or to observe with the eyes, 'spy' was often associated with travellers or observers of foreign lands. In The preachers proclamacion discoursing the vanity of all earthly things (1591), Henry Smith compared the wise biblical king Solomon to a traveller or 'a spie sent into a strange Country, as if he were now come home from his pilgrimage; they gather about him to enquire, what he hath heard, and seene abroad, \& what he thinks of the world'. ${ }^{3}$ A spy could be a traveller or a merchant, therefore, as well as one who occupied a more official state position such as a diplomat, whose mobility and access to spheres of power made him a valued source of information. The 'spy' as observer is well illustrated by later English pamphlets and periodicals such as The London Spy (1698-1700).

In legal terms, the spy was someone who operated either to the benefit or detriment of the country. Those who worked on behalf of the state were often sanctioned to do so, whether they operated as professionals, as volunteers, or under duress to obtain information concerning the state's enemies. ${ }^{4}$ Those subjects who did so against the state were considered traitors. The Treason Act of 1351 stipulated that any individual who 'be adherent to the King's Enemies in his Realm, giving to them Aid and Comfort in the Realm, or elsewhere' was to be considered a traitor and so should be punished as one. ${ }^{5}$ This legal definition continued throughout the early modern period and those accused of spying for a foreign nation were considered to have committed treason and subsequently were traitors. During the Interregnum civilian spies in Ireland were tried under martial law for treason in what

1 John Florio, $A$ worlde of wordes (London, 1598; STC 11098), p. 389.

2 'Intelligencer, n.', Oxford English Dictionary.

3 Henry Smith, The preachers proclamacion (London 1591; STC 22684), sig. A5r.

4 Alan Marshall, Intelligence and Espionage in the Reign of Charles II, 1660-1685 (Cambridge: Cambridge University Press, 2013), p. 122.

5 25. Edw III Stat.5. 
were called High Courts of Justice. ${ }^{6}$ Doing so allowed the government to seize all property of those convicted by the court.

In the Tudor era, spies were primarily associated with individuals involved in secret activities related to political conspiracies and military operations. Thomas Styward, author of The pathwaie to martiall discipline (1582), recommended that 'for the greater safety of the army', a captain should send 'faithfull spies, which shall discover the coast, and make true report of all they see, in such sort as he doth, which is sette in some promontorie, to watch and give warning, of whatsoever enemies hee shall see to appear by sea' ${ }^{7}$ While these functions seem to be describing the scout or watchman, Styward clearly associated spies with the clandestine activities of gathering sensitive, strategic information. He advocated as a 'good policy to retain spies giving unto them great rewards that which by politique usage may be learned the state, the strength, the order, manners, \& determination of the enemies: by which means with secret usage, thou maist many ways have due revenge'. ${ }^{8}$ The 'secret usage' of spies was essential in enabling them, as Walter Haddon noted, to 'smell out either of our courtly affairs, what the Prince doth, what her counsellors and courtiers do, what is done in the common weale.' ${ }^{9}$

The ability of spies to conceal their identity or intentions, and their functions as informers for different political agents or foreign powers, contributed to a widespread perception of spies as treacherous and morally corrupt. In 1583, Nicholas Berden, who presented himself as a 'Spye', found it necessary to explain that he had embraced an 'odious though necessary' profession motivated 'nott for gayne, butt for the Saffetie of my Naty[ve] Countrie.. ${ }^{10}$ Berden's remark reveals a distinction between the patriotic individual who embraces espionage to protect his country and the mercenary or professional spy who serves different masters for his own benefit. The English Jesuit, Thomas Fitzherbert, accused of being involved in many secret Catholic conspiracies, condemned spies as 'wicked instruments' used by rulers 'for the discovery of every man's intention, nourishing division

6 John M. Collins, Martial Laws and English Laws c. 1500-1700 (Cambridge: Cambridge University Press, 2016), p. 277.

7 Thomas Styward, The pathwaie to martiall discipline (London, 1582; STC 23414), p. 125.

8 Ibid., p. 145 .

9 Walter Haddon, Against Jerome Osorius Byshopp of Silvane in Portingall and against his slaunderous invectives (London, 1581; STC 12594), p. 379.

10 Quoted in Stephen Alford, 'Some Elizabethan in the Office of Sir Francis Walsingham', in Diplomacy and Early Modern Culture, ed. by Robyn Adams and Rosanna Cox (London: Palgrave Macmillan, 2011), pp. 46-62 (p. 57). 
amongst the greatest the counterpoise one with another'. ${ }^{11}$ Referring to spies as 'Macchiavels [sic]', Fitzherbert saw such agents as destructive and untrustworthy, 'never be so much bound' to any one person but 'cutting off by one means or other, al those whose power, courage, or wit, he may think dangerous to his state'. ${ }^{12}$

After the Reformation, many English authorities perceived Catholic recusants as potential spies at the service of foreign masters such as the pope or Philip II of Spain. The mounting tension between England and Spain that culminated in Philip II's failed attempt to invade England with a fleet of 130 warships in 1588 generated a widespread suspicion of the allegiances and intentions of English Catholics. In 1583, William Cecil warned against recusants who contacted 'disguized persons (called scholars or Priests)' who followed the instructions 'of the Capital enemie the Pope or his Legates, to be secret espialles \& explorers in the Realme for the pope, to deliver by secret, Romish tokens [...] [and] poison the senses of the subjects, powring Into their hearts malicious and pestilent opinions against her Majesty'. ${ }^{13}$ Wherever the ' $\mathrm{R}$ [omish] religions is', wrote the theologian Walter Travers, 'every Priest is an intelligencer and a spy for the pope, who both by other means, \& especially by their auricular confession come to understand the deepest secrets of every state'. ${ }^{14}$ Fears of a second Spanish attempt to invade England in the aftermath of the Armada increased these suspicions. Flemish, Italian and Iberian subjects of the Spanish Habsburgs were often regarded by the English authorities as potential spies. On 24 September 1598, Thomas Middleton informed Robert Cecil of the presence of 'three Spaniards here bound for Spain' who included 'a very parlous fellow, and was sent over from the Groyn of purpose, as may be feared, for a spy'. ${ }^{15}$ The Elizabethan state generated its own spy network in response: Berden, mentioned above, was one of the many spies recruited by Elizabeth's 'spymaster', Sir Francis Walsingham, to monitor the activities of English intelligence-gathers in contact with the Holy See and Catholic powers.

11 Thomas Fitzherbert, The first part of a treatise concerning policy, and religion (London, 1606; STC 11017) pp. 384, 391.

12 Ibid., p. 392.

13 William Cecil, The execution of justice in England for maintenaunce of publique and Christian peace (London 1583; STC 4902), sig. C3v.

14 Walter Travers, An answere to a supplicatorie epistle, of G.T. for the pretended Catholiques written to the right Honorable Lords of her Majesties privy Councell (London, 1583; STC 24181), pp. 284-285.

15 'Thomas Myddelton to Sir Robert Cecil, 24 September 1598', in Calendar of the Manuscripts of the Most Hon. the Marquis of Salisbury, Preserved at Hatfield House, Hertfordshire, Vol. 8:1598, ed. by R. A. Roberts (London: Her Majesty's Stationery Office, 1899), p. 362. 
In the same way that Cecil and Travers feared the capacity of English Catholics to infiltrate Elizabethan society to work as spies, Catholic polities like Venice were aware that 'the Queen of England, and the Princes of Germany had des Agens Secrets [...] and for these secret Employments Merchants have been thought to be the fittest Instruments, because under the cloak of Trading they may also hide Affairs of State. ${ }^{16}$ Such suspicions on both sides reveal a perception of spies as extremely mobile individuals who, thanks to their capacity to cross frontiers, could change their identities and act covertly. Those who were denounced or identified as spies often faced violent punishments. Richard Burligh and Thomas Wade were two English merchants who were accused by one John Brooke, who also travelled with them, of espionage after returning from the Netherlands in 1592. The two men were arrested and tortured. Burligh was executed, while Wade 'was put in prison and died afterwards in the hospital. ${ }^{17}$ The fate of foreign spies often depended on their status and involvement in subversive activities. For example, Bernardino de Mendoza, Philip II's ambassador to England between 1576 and 1584, was expelled from England after the discovery of activities of espionage following the Throckmorton plot. ${ }^{18}$ Roderigo Lopez, the Portuguese physician of Elizabeth I, did not have the benefit of aristocratic status or diplomatic immunity. Accused of espionage and plotting against the queen, Lopez and his alleged co-conspirators, Estevão da Gama Ferreira and Manuel Luís Tinoco, were tortured and executed in $1594 .{ }^{19}$

The religious uncertainties of the Elizabethan and Jacobean eras, and the rise of political discourse and rumour disseminated in popular print, contributed to a perception that the English public space was heavily surveilled by spies and intelligencers. In the playwright Francis Beaumont's The Woman Hater (1607), Count Valore points out the ability of one of his spies to live 'in Alehouses, and Taverns' where he 'perceives some worthy men in this land, with much labour \& great expense, to have discovered things dangerously hanging over the State; hee thinks to discover as much out of the talk of drunkards in Taphouses: hee brings me informations,

16 James Howell, Proedria vasilike (London, 1664; Wing H3109), p. 180.

17 'Relation of William Pittes, 1592', in Calendar of the Manuscripts of the Most Hon. the Marquis of Salisbury, Preserved at Hatfield House, Hertfordshire, Vol. 4: 1590-1594, ed. by R. A. Roberts (London: Her Majesty's Stationery Office, 1892), p. 258.

18 Rayne Allinson, A Monarchy of Letters: Royal Correspondence and English Diplomacy in the Reign of Elizabeth I (London: Palgrave Macmillan, 2012), p. 70.

19 Edmund Valentine Campos, 'Jews, Spaniards, and Portingales: Ambiguous Identities of Portuguese Marranos in Elizabethan England', English Literary History, 69:3 (2002), 599-616 (p. 605). 
picked out of broken words, in men's common talk, which with his malicious misapplication, hee hopes will seeme dangerous, he doeth besides bring me the names of all the young Gentlemen in the Citie, that use Ordinaries, or Taverns' ${ }^{20}$ Valore's description of the modus operandi of his spy also explores a perception that spies were a part of an underworld formed by those who frequented places like the chambers and shady back rooms of taverns and alehouses. ${ }^{21}$ The traveller Fynes Moryson advised his readers to be aware of such places 'since Thieves have their spies commonly in all Innes, to inquire after the condition of passengers. ${ }^{22}$ Throughout the seventeenth century, espionage was cynically portrayed as a role that could only be occupied by morally dubious individuals who were ever ready to change sides or betray their masters.

Ambassadors were also associated with the moral corruption of espionage. States often presented their diplomats as honest spies, as foreign agents sent by a prince to facilitate communication and obtain relevant information about their host society. The host countries, however, often thought differently about the foreign visitors accessing the heart of the political realm. During negotiations for the Spanish Match, in which the Crown considered James's son Charles as a potential suitor for the Spanish Infanta, the Puritan satirist Thomas Scot published an anonymous pamphlet that scathingly criticised the Spanish ambassador, the Count of Gondomar. Scot's document pretended to be a secret report written by Gondomar himself, in which he enthusiastically described his spying activities: 'I made that a cover for much intelligence, and a means to obtain whatsoever I desired, whilst the state of England longed after that marriage, hoping thereby, (though vainly) to settle peace, and fill the exchequer. ${ }^{23}$ As one witness testified in a report about a meeting between the Gunpowder Treason conspirators: 'this Taylor said that all Princes Ambassadors were but Honorable Spies', a statement that must have seemed an impossible juxtaposition in the wake of political intrigue and subversion. ${ }^{24}$

Women, too, were associated both with espionage and the revelation of private information. On the one hand, books such as Joseph Swetnam's The araignment of lewde, idle, forward, and unconstant women (1615) warned

20 Francis Beaumont, The Woman hater (London 1607; STC 1693), sig. Cir.

21 Lawrence Manley, 'London and Urban Popular Culture', in The Ashgate Research Companion to Popular Culture in Early Modern England, ed. by Abigail Shinn, Matthew Dimmock and Andrew Hadfield (Farnham: Ashgate, 2014), p. 367.

22 Fynes Moryson, An itinerary (London, 1617; STC 18205), sig. Eeee6r.

23 Thomas Scot, Vox populi, or Newes from Spayne (London, 1620; STC 22100.2), sig. Biv.

24 'Gunpowder Plot', November 1605, Hatfield House, CP 112/16or. 
readers that women were unable to keep secrets: 'if thou unfoldest any thing of secret to a woman, the more thou chargest her to keep it close, the more she will seem as it were to bee with child till she have revealed it amongst her gossips [...] for every woman hath one special gossip at the least, which she doth love \& affect above all the rest, and unto her shee runneth with all the secrets she knoweth'. ${ }^{25}$ Such words perpetuated a widespread perception that women were gossip-mongers and therefore ill-equipped to spy. On the other hand, the perception that they were frivolous allowed some women to move effectively within spaces barred to male intelligencers, obtaining confidential information that placed them within networks of state secrets and information-exchange. ${ }^{26}$ In 1642 , a parliamentarian pamphlet revealed the discovery of a conspiracy led by a female spy on the royalist payroll. ${ }^{27}$ Her confession reveals how women could exploit prevalent views of women as chattering voices that delight in rumours, using that apparent inability to keep secrets to obtain and reveal confidential information. After being captured, this alleged royalist spy confessed that her function was to 'bring them news from his Excellencies Army what everyday she heard, which she had to them faithfully performed to the disadvantage of the Parliaments force, and that she had be often of late in the City of London to hear now and which way the People stood affected both to the King and Parliament'. ${ }^{28}$

On the other end of the spectrum from Swetnam's denunciation, though equally misogynistic, were contemporary male views of women as seductive, manipulative and fond of rumours and 'any thing secret', which made them easy targets for accusations of espionage and treason. In Ben Jonson's Epicoene, or the Silent Woman (performed 1609), Truewit tells Morose that Lady Haughty was able to teach 'all the Misteries, of writing Letters, corrupting Servants, taming Spies'. ${ }^{29}$ As these examples suggest, spying might involve state-level intelligence but also the everyday life of the household, bringing issues of gender, power, and the gaze to 'espying', to acts of surveillance and control..$^{30}$ In Jonson's The devil is an asse (first

25 Joseph Swetnam, The araignment of lewde, idle, forward, and unconstant women (London, 1615; STC 23534), p. 41.

26 See, for example, the Royalist 'she-intelligencers' Susan Hyde and Elizabeth Murray, discussed in Nadine Akkerman, Invisible Agents, Women and Espionage in Seventeenth-Century Britain (Oxford: Oxford University Press, 2018), pp. 118-157.

27 A true discovery of a womans wickednesse, in endeavouring to betray the city of London to the Caveliers (London, 1642; Wing T268oA), p. 4.

28 Ibid.

29 Ben Jonson, Epicoene, or the silent woman (London, 1620; STC 14763), sig. D1v-D2r.

30 Daniel Fischlin, 'Political Allegory, Absolutist Ideology, and the "Rainbow Portrait" of Queen Elizabeth I', Renaissance Quarterly, 50 (1997), 175-206; Early Modern Visual Culture: 
performed 1616), the foolish gentleman Fabian Fitzdottrel's cloistered and heavily-monitored wife laments: 'My husbands new groome, is a spie upon me, / I find already' ${ }^{11}$ The lively prologue of Aphra Behn's The forc'd marriage (1671) sets the scene with women speaking back: they venture out 'Not with design to Conquer, but to Scout [...] / The Poetess too, they say, has spyes abroad' $3^{2}$ Another example of the perception of the dangers posed by women spies due to their ability to enter into intimate space is the case of the French aristocrat Louise de Kéroualle, Duchess of Portsmouth and mistress of Charles II. Her nationality, Catholicism and influence at the English court contributed to persistent rumours that Kéroualle was a French spy sent by Louis XIV to seduce and manipulate the English king. Most of these rumours derived from Kéroualle's rather indiscreet involvement in French diplomatic manoeuvres, as well as from her correspondence with Louis XIV, who sent her gifts. One anonymous pamphlet entitled Articles of treason and other high-crimes and misdemeanors against the Dutches of Portsmouth (1680) accused her of working 'to alter and subvert the Government in Church and State' and 'foment and maintain that fatal and destructive Correspondency and Alliance between England and France being sent over and pensioned by the French King'.33

Throughout the English civil wars, spies were regarded both as strategically useful and morally destructive. Marchamont Nedham, who worked as a propagandist and spy for both royalists and parliamentarians, complained to Oliver Cromwell that '[i]f you set Spies upon the people, and deprive them of the liberty of hearing, speaking, easing and uttering their minds to each other, then they reckon they have lost all and so grow desperate. ${ }^{34}$ This capacity of spies, especially those embedded in a community, to circulate invisibly and sow dissent led Nedham to present spies as 'pestiferous creatures' and 'mercenary varlets' who 'feed their Patrons with more frivolous

Representation, Race, and Empire in Renaissance England, ed. by Peter Erickson and Clark Hulse (Philadelphia: University of Pennsylvania Press, 200o); Fischlin, 'Political Allegory, Absolutist Ideology, and the "Rainbow Portrait" of Queen Elizabeth I'; Matthew Dimmock has contested this interpretation in Elizabethan Globalism: England, China, and the Rainbow Portrait (New Haven, CT: Yale University Press, 2019).

31 Ben Jonson, Bartholmew fayre [...] The divell is an asse [...] The staple of newes (London, 1631; STC 14753.5), p. 116.

32 Aphra Behn, The forc'd marriage (London, 1671; Wing B1734), sig. A2r.

33 Articles of treason and other high-crimes and misdemeanors against the Dutches of Portsmouth (London, 1680; Wing A3846), p. 1.

34 Marchamont Nedham, Certain considerations tendered in all humility to an honorable member of the councell of state (London, 1649; Wing N381), pp. 8-9. 
matters and fopperies, than realities' ${ }^{35}$ George Monck, duke of Albemarle, shared Nedham's negative views of spies. 'Concerning Spies', he wrote in Observations upon military \& political affairs (1671), one should 'be always suspicious of them; because as it is a dangerous task for him that undertaketh, so it is also for him that imployeth them [...] they should be examined severally, that by the agreement or disagreement of their advices, you may judge whether they be good'. ${ }^{6}$ Due to the uncertain loyalty of spies, those who employed them should be 'very liberal to them; for they are faithful to those who give them most'. ${ }^{37}$ As Monck noted, the risks faced by spies and the value of the information they could obtain forced their masters to constantly negotiate or buy their loyalty to avoid the perils of losing access to relevant intelligence or being exposed.

Despite their involvement in espionage during the civil wars and the Restoration, Nedham and Monck's comments shared a mistrust of spies that had deep roots in Elizabethan and Jacobean anxieties around the disturbing presence of Catholic spies and domestic agents. Through the tumults of war and dynastic upheaval, these anxieties and hatred of spies increased, especially during the brief and troubled reign of James II. The Catholic Stuart monarch relied on a vast spy network that forced his subjects to be 'vigilant and careful', for 'Hell scarce has more Intelligence and Spies / Than this suspicious Court in every Corner' $3^{8}$ Spies were projected as both a cause and a consequence of the instability of early modern England in an age of religious and political turmoil. These anxieties are well patent in the Turkish Spy phenomenon, the fictional letters of an Ottoman spy operating in Paris. The 30 letters originally written by Giovanni Paolo Marana grew to 102 in the first French translation and to 632 letters in an eight-volume English translation. These letters addressed European debates on politics and religion through the eyes of Mahmut, a Turkish spy who epitomised the dangerous ability of intelligencers to cross political, religious, geographical, and linguistic boundaries, but also to gather and analyse information. Indeed, Mahmut was not only a shadowy figure who navigated the inbetween, but someone who studied his target society. 39

36 George Monck, Observations upon military \& political affairs (London, 1671; Wing A864), p. 39 .

37 Ibid.

38 The Late Revolution, or the Happy Change (London, 169o; Wing L558), p. 12.

39 For a brief overview of the 'Turkish spy' phenomenon see Jacob Crane, 'The Long Transatlantic Career of the Turkish Spy', Atlantic Studies, 10:2 (2013), 228-246. 
As forms of government changed or broke down, Protestant and Catholic monarchs took their thrones, and the rise of print and newspapers encouraged a wide network of intelligence-gathering, the 'spy' was a shadowy figure who navigated the in-between. 'A Spy', wrote Thomas Gipps in 1698, 'when he is taken, [he] is always put to death, but an open Enemy is only made a Prisoner of War..$^{40}$ Whether he or she acted for the perceived good of the realm, or their own private benefit, was difficult to verify or even always prise apart. By breaching their political or personal allegiances and disregarding moral norms of conduct, those who spied were consistently defined as a subversive presence that threatened order and flirted with treason.

Related keywords: ambassador, courtier, envoy, mercenary, traitor 


\section{Subject}

'Subject' entered the English language from multiple sources, including the classical Latin subiectus, which indicated a subordinate or dependent individual ruled by a monarch or sovereign state, and from the AngloNorman suget, suject, and its variants. The subject's political, legal, and social identities thus had a long tradition in England, whose foundations were firmly rooted in common and civil law. Dating as far back as the thirteenth century, the 'subject', as position and identity, was legally defined through a complicated mixture of both 'soil and blood'. ${ }^{1}$ Early modern subjecthood had its foundations in medieval ideas of territorial allegiance, established at birth. The thirteenth-century English jurist and cleric Henry de Bracton acknowledged this when he suggested that foreign-born subjects of another king could not be heard at an English court 'as an Englishman is not heard, if he implead any one concerning lands and tenements in France.'. ${ }^{2}$ This meant that allegiance, and subsequently subjecthood, was 'based on territory - not by virtue of land one owned, but because of the monarch in whose land one was born'. ${ }^{3}$ Bracton's definition of subjecthood highlighted the common law tradition in England from which jus soli ('right of the soil') stemmed from. On the other hand, the idea of jus sanguinis ('right of blood'), which had its roots in civil law, also fashioned English legal perceptions of subjecthood.

Passed during the reign of Edward III, the statute of De natis ultra mare highlights how these two legal traditions operated in conjunction in English law. ${ }^{4}$ The law, which according to Kim Keechang was passed to guarantee the status of the children of the king's soldiers born abroad, stated that those children who were born outside England but whose 'fathers and mothers, at the time of their birth' were English would have and 'enjoy, the

1 Jacob Selwood, Diversity and Difference in Early Modern London (Farnham: Ashgate, 2010), p. 9o; Polly. J. Price, 'Natural Law and Birthright Citizenship in Calvin's Case (1608)', Yale Journal of Law and Humanities, 9:1 (1997), 92-97; 'Subject, n.', Oxford English Dictionary.

2 Selwood, Diversity and Difference, p. 90; Henry De Bracton, Legibus et Constuetudinbus Angliae, cited in Calvin's Case or The Case of the Postnati (1608), 7 Coke Report 1a, 77 ER, p. 397.

3 Selwood, Diversity and Difference, p. 90.

4 'Status of Children Born Abroad', 1350, 25 Edw. III Stat.1; Kim Keechang, Aliens in Medieval Law: The Origins of Modern Citizenship (Cambridge: Cambridge University Press, 2000), pp. 116-125; Selwood, Diversity and Difference, p. 9o; J. Mervyn Jones, British Nationality Law and Practice (Oxford: Oxford University Press, 1947), p. 66. 
same benefits and advantages' as their parents. ${ }^{5}$ As Polly J. Price has shown, the act 'permitted children to acquire subject status by birth according to descent', fusing together the two legal forms. ${ }^{6}$ The statute did ultimately weigh in favour of jus soli, however, as a child could only obtain subjecthood through the blood of English-born parents. This was further entrenched in 1368, when Parliament responded to a petition that requested that children born in the king's overseas territories should be able to inherit as those born in England. 7 The act ensured that anyone born in the sovereign's territories outside England were entitled to the same rights and status of those born in England. ${ }^{8}$

During the sixteenth and seventeenth centuries, with the spread of print, authorities encouraged godly meditation in ways that reinforced the connection between dutiful subjects and allegiance to the Crown. Printed sermons propagated obedience to the monarch, extending God's sovereignty to that of his appointed monarchs on earth. The Book of Common Prayer cemented this allegiance into the practice of the state Church, declaring that 'Almighty God, whose kingdom is everlasting [...] rule the heart of thy chosen servant Edward the sixt, our kyng and governour [...] that we his subjects (duly considering whose authority he hath) he faithfully serve, honour, \& humbly obey him, in thee, and for thee'. ${ }^{9}$ The image at the start of $A$ booke of Christian prayers (1578) placed a pious Elizabeth within the history of salvation and Protestant providentialism, her own loyalty to God serving as an inducement for her subjects to do the same by obeying her. ${ }^{10}$

From a legal perspective, however, the implications of the 1368 act 'remained in doubt' and consequently the definition of the 'subject' remained legally blurred until debates resurfaced in 1608 with the legal battle popularly known as 'Calvin's case'." The debates at this point were crucially important in not only defining the legal parameters for subjecthood, but also in defining the key differences between it and terms such as 'alien', 'stranger', and 'denizen'. In the case of 'subject', it reinterpreted the term's definition to

5 Keechang, Aliens in Medieval Law, p. 123; 'Status of Children Born Abroad', 1350, 25 Edw. III Stat.1.

6 Price, 'Natural Law', p. 77.

7 'A statute made at Westminster on the first day of May in the forty-second year of King Edward III', 1368, 42 Edw. III c. 10.

8 Keechang, Aliens in Medieval Law, p. 142; Selwood, Diversity and Difference, p. 91; Jones, British Nationality Law, pp. 66-67.

9 Church of England, The booke of common prayer (London, 1549; STC 16270a), sig. O7r.

10 Richard Day, A booke of Christian prayers (London, 1578; STC 6429).

11 Selwood, Diversity and Difference, p. 91. For references in Coke's report see Calvin's Case or

The Case of the Postnati (1608) 7 Coke Report 1a, 77 ER, pp. 403-404. 
encompass a wider jurisdiction, while at the same time decisively defining the legal rights of other groups such as aliens and denizens, and how they could obtain naturalisation. The case decided that Scottish children, known as the postnati (born after the Scottish King James VI inherited the throne of England in 1603), had the legal right under English law to be considered English subjects. In doing so Calvin's case 'mapped out the precise borders of English refusal' to extend subjecthood to all the king's Scottish subjects by considering the 'status of a particular subset of Scottish subjects' - the postnati. $^{12}$

This was hugely significant. The ruling affirmed ideas of jus soli, based around an enduring bond between subjects and the monarch, in which children of immigrants were granted subjecthood as a natural birthright through their connection to the monarch. If a child born in Scotland after the union pledged allegiance to the Scottish Crown, then they also pledged allegiance to the English Crown by proxy. Coke's decision to blur the boundary between 'status and place of origin' meant that subjecthood became fully portable. ${ }^{13}$ This allowed the English state to hold subjects accountable to the English monarch no matter where in the Crown's individual dominions they went. As the Lord Chancellor Thomas Egerton noted during the case, 'diversities of Lawes and Customs makes no breach of the unities of obedience, faith and allegiance, which all liege subjects owe to their liege King and Sovereign Lord'. ${ }^{4}$

Calvin's case and the debates surrounding questions of the Scottish union firmly defined the subject's identity around his or her relationship, or allegiance, to the Crown. Ligence or allegiance was the 'personal bond prevailing between the natural person of the King and the natural subject wherever he or she might reside in the kings domains'. ${ }^{15}$ This relationship between sovereign and subject was a bond that transcended the political, legal, and geographic obstacles and destinations that existed between those domains and tied both parties together. Coke clearly defined the bond as one where the subjects 'are bound to obey and serve' their sovereign, whilst monarchs 'should maintain and defend' their subjects. ${ }^{16}$ This raised significant questions about whether the individual subject's allegiance was rightfully and naturally aligned with the sovereign of their place of birth.

Christopher Tomlins, Freedom Bound: Law, Labor, and Civic Identity in Colonizing English America, 1580-1865 (Berkley: University of California Press, 2010), p. 83.

13 Ibid., p. 90.

14 Calvin's Case or The Case of the Postnati (16o8), 2 St. Tr. 559, p. 684.

15 Tomlins, Freedom Bound, pp. 84-85.

167 Coke Report 1a, 77 ER, 377. 
Furthermore, the ruling addressed whether, and how, non-subjects (like those born before James VI ascended the throne of England, the antenati) could become English subjects. Commentators such as Bacon and Coke dealt with the former by defining the issue of the king's two bodies (the king's 'natural' or physical self, and his political body, or the state) ${ }^{17}$ Bacon suggested that the monarch's natural and political bodies were inseparable: the king's 'two capacities are in no sort confounded [...] [A]s his capacity politic worketh so upon his natural person [...] so e converso'. ${ }^{18}$ As such, a subject who pledged allegiance to James of Scotland also did so to James of England, allegiance given to both at the same time.

Although Calvin's case was influential in structuring early modern ideas perceptions and the rights of subjecthood, it did not fully settle these rights about who could be and could become a subject. On several occasions throughout the seventeenth century, court cases expanded and contracted the definition of subjecthood. In Rex $v$. Eaton (1627), a child born outside of England to an English merchant and Polish mother had the rights of a subject extended to him. Crucially, the case makes a point about rights pertaining to both genders, in the sense that the judges argued that de natis required only one parent, who could be either the mother or the father, to be English. ${ }^{19}$ Legal cases in 1641 and 1664 reinforced this. ${ }^{20}$ In Bacon v. Bacon (1664), the daughter of an English merchant born after his death also to a Polish mother was considered an English subject. ${ }^{21}$ In 1666, the House of Lords considered a bill that concerned the rights of Richard, son of Richard Fanshawe, the king's ambassador to Spain, who had died in Madrid. On his deathbed, Fanshawe, concerned about the status of his Spanish-born son, ordered that he be naturalised upon his return to England. ${ }^{22}$ The request was referred to the Lords, who declared that 'the children of Ambassadors (employed by the King), born in foreign countries, are no aliens' but subjects of the king of England. ${ }^{23}$ In 1677 , Charles II also sought to extend the status of 'subject' to children born abroad to parents who had fled England during the Interregnum. The Naturalisation (Children Born Abroad during the

17 Selwood, Diversity and Difference, pp. 96-98; Price, 'Natural Law', p. 108.

18 State Trials, vol. 2, col. 597 .

19 Rex v. Eaton, Lit. Rep. 23 (1627).

20 Bacon v. Bacon, Cro. Car. 601, 602 (1641); Collingwood v. Pace, 1 Vent. 413 (1664).

21 Bacon v. Bacon, Cro. Car. 601, 602 (1641); J. M. Ross, 'English Nationality Law: Soli or Sanguinis', in Groatian Society Papers 1972: Studies in the History of the Law of Nations, ed. by C. H. Alexandrowicz (The Hague: Martinus Nihoff, 1972), p. 13.

22 Ibid., p. 14.

23 Quoted ibid., p. 14. 
Troubles) Act ensured that any persons born outside of England between 14 June 1641 and 24 May 1660 'whose fathers or mothers were natural born subjects of this realm, are hereby declared [...] to be and to have been the King's natural born subjects of this Kingdom [...] as if they had been born in England'. ${ }^{24}$ Similar action was again taken in 1698 to ensure that children born to English soldiers fighting William III's wars in France were guaranteed the rights of a subject. ${ }^{25}$

In the years after the 'Glorious Revolution' of 1688 , the 'subject' developed a slightly different identity. The relationship between the individual, the state, and the Crown had shifted as Parliament and its rights, privileges, and position became more secure. The rights of subjects were increasingly formalised, and allegiance considered contractual. Following the flight of James II, Parliament resolved that James had broken the 'original contract' with his subjects 'abdicating the government' and leaving the throne 'vacant'. ${ }^{26}$ The language used by Parliament marked a shift to a new constitutional order epitomised by the political philosopher John Locke's 'social contract' theory, which holds that legitimate government only exists by the consent of those governed. ${ }^{27}$ Opposed to the idea of the king's two bodies, Locke argued that every man was born free according to natural law, and as such they were free to choose to whom they were subject rather than being allocated subjecthood upon birth. Locke suggested that rather than owing allegiance to a father from birth as the head of the household, 'the subjection due from a child to a father took not away his freedom from uniting into what political society he thought fit'. ${ }^{28}$

In doing so, Locke transferred the agency in the contractual act of subjugation from the ruler to the subject. The 1689 Bill of Rights established a contract between subject and Crown that declared 'the rights and liberties of the Subject' and reinforced the authority of Parliament as the body that represented the Crown's subjects. ${ }^{29}$ By listing Parliament's grievances towards James II, the Bill of Rights set out to define the rights of English subjects and secure Parliament's prerogative to protect those rights and

\footnotetext{
24 'Naturalization (Children Born Abroad During the Troubles) Act', 1677, 29 Car. II c. 6 (1677).

25 'Naturalization (Persons Born Abroad During the War) Act', 1698, 9 Will. III c. 20 (1698).

26 Quoted in Henry Horwitz, Parliament, Policy, and Politics in the Reign of William III (Manchester: Manchester University Press, 1977), pp. 9-10.

27 Jeremy B. Bierbach, Frontiers of Equality in the Development of EU and US Citizenship (The Hague: T. M. C. Asser Press, 2017), p. 35.

28 John Locke, Second Treatise of Government, ed. B. McPherson (Cambridge: Hackett, 1980), p. 131.

29 'Bill of Rights', 1668, 1 Will. \& Mar. sess. 2, c. 2 (1688).
} 
ensure they were not violated. The Bill of Rights marked a shift from early modern to modern perceptions of the subject. No longer was the subject defined by their allegiance to the Crown, but by a contractual agreement set out in distinct rights that were enshrined in legislation and protected by those bodies elected by them. In this sense, the subject remained subjected to two bodies, but no longer were they both the Crown's. One remained the Crown's whilst the other was Parliament's, all three subjugated to each other in a contractual bond.

Related keywords: alien/stranger, citizen, denizen, foreigner, native 


\section{Traitor}

Derived from Old French traitre and Latin traditor (one who delivers or hands over), 'traitor' was a well-established word in Middle English. ${ }^{1}$ Early modern English perceptions of traitors were largely influenced by the biblical descriptions of Judas, who was presented as being synonymous with moral corruption and betrayal. Luke 6:16 mentions 'Judas Iscariot, which also was the traitor.'. This passage influenced numerous theologians and moralists. In 1558, Thomas Watson warned that those who live after the flesh, and be fettered in the chains of sin and vice, they receive with Judas the traitor poison, and run to the halter of spiritual hanging in hell, being condemned both for their other manifold sins'. ${ }^{3}$ In 1598, the surveyor and author of popular devotional works, John Norden, castigated 'that notorious Arch-traitor Judas, who for monie betrayed his Master, and Lord, the Saviour of the world Jesus Christ'. ${ }^{4}$

While the figure of Judas Iscariot provided the ethical parameters that defined treason and traitors in popular culture, a 'traitor' was any individual who acted against the Crown. Such were the parameters issued in the first statute of treason under Edward III in 1352. During Henry VIII's reign, legislation against treason was expanded to enforce the Reformation, with established treason becoming an offence against both the monarch and the reformed Church. The emergence of the Counter-Reformation, and attempts made by Catholic powers to destabilise Elizabeth I's regime, instigated the establishment of new treason statutes throughout the $1570 \mathrm{~s}$ and 1580 s. The papal bull Regnans in Excelsis (1570) excommunicated Elizabeth and denied her royal status. In response, the new English legislation on treason established by the 'Acte whereby certayne Offences bee made Treason' (1570) declared the pope and the 'Romish Religion' as enemies of the queen and the English state and Church. As a result, all subjects who followed the Catholic Church became potential traitors. The new legislation defined treason as any attack or conspiracy against the life and royal dignity of the monarch, including attempts to 'maliciously,

\footnotetext{
1 'Traitor, n.', Oxford English Dictionary.

2 The holie Bible conteynyng the olde Testament and the newe, ed. by Matthew Parker (London, 1568; STC 2099), p. xxxviii.

3 Thomas Watson, Holsome and catholyke doctryne concerninge the seven Sacramentes of Chrystes Church (London, 1558; STC 25112.5), p. lvi.

4 John Norden, A sinfull mans solace most sweete and comfortable, for the sicke and sorowful soule (London 1585; STC 18634), p. 18.
} 
advisedly and directly publish, declare, hold opinion, affirm or say by any speech express words or sayings, that our said sovereign lady Queen Elizabeth during her life is not or ought not to be Queen of this realm of England and also of the realms of France and Ireland'. 5 The act also made it treasonable to circulate and promulgate papal bulls in dominions ruled by the queen. Subsequently, the 'Acte to Retain the Queen's Majesty's Subjects in the Due Obedience' (1581) established as traitors any who promised '[o]bedience to any pretended Authority of the See of Rome, or to any other Prince, State or Potentate, to be had or used within her Dominions [...] or shall do any overt Act to that Intent or Purpose; and every of them shall be to all Intents adjudged to be Traytors, and being thereof lawfully convicted shall have Judgement, suffer and forfeit, as in Case of High Treason'. ${ }^{6}$

One of the main elements associated with traitors was their mobility between England and enemy countries. Leading figures of the English Catholic community in continental Europe, such as the Jesuit Robert Parsons, were often labelled as traitors for living in hostile countries and rejecting Elizabeth's authority. The option to live in exile, though not necessarily an act of treason, was a consequence of a rejection of the political and religious regime and symbolically indicated that an English subject accepted a 'strange and forein law, [which] is both a strange power, and a forein traitor to the Kings crowne.? This observation made by Gervase Babington on the legitimacy of the appeals made by Englishmen based on canon law suggested that those who lived outside England and opted to live according to foreign laws could be considered traitors, since they rejected or lived outside the legal apparatus that legitimated and supported the English Crown. Babington used the expression 'forein traitor', and suggested that any act against the Crown, even when performed by a foreigner, could be regarded as treason. This happened in the case of Roderigo Lopez, the Portuguese physician and converso who was executed for high treason in 1594 for his alleged attempts to poison the queen.

Traitors were therefore associated with specific political figures or as outcasts who decided to embrace a life of exile, dependent on the goodwill of more or less sympathetic foreign powers while often moving between

5 'An Acte whereby certayne Offences bee made Treason (1570)', in The Statutes at Large, of England and of Great-Britain: From Magna Carta to the Union of the Kingdoms of Great Britain and Ireland, Vol. IV: 1553-1640, ed. by John Raithby (London: Eyre and Strahan, 1811), p. 275.

6 'An Acte to Retain the Queen's Majesty's Subjects in the Due Obedience (1581)', ibid., p. 374.

7 George Babington, Certaine considerations drawne from the canons of the last Sinod (London, 1605; STC 4585), sig. G3r. 
home and abroad. According to Elizabeth's secretary of state, William Cecil, the new statutes on treasonable acts aimed to target these individuals who had 'escaped into forreine countries, \& there because in none or few places rebels and traitors to their natural Princes and countries', particularly those intelligencers who had 'falsely informed many Kings, Princes and States, and specially the Bishop of Rome, commonly called the Pope, (from whom they all had secretly their first comfort to rebell) that the cause of their fleeing from their countries was for the religion of Rome, and for maintenance of the said Pope's authority.' ${ }^{8}$ Some of these exiles and fugitives, according to Cecil, led 'notorious evil and wicked lives'. He evoked the Catholic earl Charles Neville as a 'person utterly wasted by looseness of life, \& by Gods punishment [...] his body is nowe eaten with ulcers of lewd causes, all his companions do see, that no enemy he had can wish him a viler punishment'. ${ }^{9}$ Another rebel, Thomas Stukeley, was 'a defamed person almost through all Christendome, \& a faithless beast rather than a man, fleeing first out of England for notable piracies, and out of Ireland for treacheries not pardonable'. ${ }^{10}$ The fact that the Catholic Church used these men who were 'void of all Christian religion' demonstrated the amorality of traitors who, motivated by 'wicked purposes', accepted 'to take arms against their lawful Queen, to invade her realme with forreine forces, to pursue al her good subjects and their native countries with fire \& sword." ${ }^{11}$ According to Cecil, the Catholic exiles who conspired against Elizabeth, by serving a foreign prince and rejecting the Reformation, acted not only against the queen but were 'contrary to all the Laws of God and man'..12

The traitor was not only a political agent. The increasing legislative effort to control and normalise the population favoured the establishment of different analogies between the commonwealth and the household. In the same way that high treason was conceptualised as a crime against the state and social order, petty treason encompassed a series of offences related both to the morality and organisation of the public and domestic order. Among the crimes of petty treason were, for example, the murder of a master by a servant and the adultery committed by married women $(25$ Ed. II. St. 5 , cap. 2) - two crimes which attacked and questioned the socioeconomic and gender hierarchy. Although these treasonable transgressions were rare

8 William Cecil, The execution of justice in England for maintenaunce of publique and Christian peace (London, 1583; STC 4902), sig. A2v.

9 Ibid., sig. A2v.

10 Ibid.

11 Ibid.

12 Ibid., sig. A3r. 
crimes, they were frequently the subject of literary and dramatic pieces. ${ }^{13}$ In John Donne's poem, 'The Anniversary' (c. 1598), the threat of treason or duplicity infiltrates the secret bonds between lovers: 'Who is so safe as we? Where none can do / Treason to us, except one of us two'.14 'She-traytors', such as the two women executed in Gloucester, one for stabbing her husband with a penknife and the other for being a 'wanderer' and pickpocket, were invoked to detract women from transgressing social and political norms. ${ }^{15}$ Women could be condemned by law for high treason, as in the execution of Mary Queen of Scots in 1587 and Elizabeth Gaunt in 1685, though such cases were rare. ${ }^{16}$ However, such cases were inevitable at a time that saw the unprecedented rise of women in positions of power in England and beyond ${ }^{17}$ In 1644, the royalist commander Richard Grenville published a tract denouncing the 'shee Traytor together with the Articles prooved on oath against Her at a Councell or Warre'. ${ }^{18}$ After the Restoration, those who had supported the royalist cause lamented that Henrietta Maria, the French wife of Charles I, had been 'Proclaim'd [...] Traytor' by the Parliamentary side. ${ }^{19}$ Such discourses around traitors and allegiance cut across the more metaphorical or moral accusations of female treachery or falseness in much love poetry of the time, and reveal the slipperiness of subjecthood and loyalty at a time of shifting political regimes.

One of the difficulties in pinning down the precise meaning of 'traitor' was that acts of treason could be performed by anyone, in a variety of ways. Cecil believed that traitors had 'divers conditions and qualities' and included not only those who were exiled abroad, but those who lived 'in beggerie', those who were 'discontented for lacke of preferments, which they gaped for unworthily in Universities \& other places' or 'banckerupt Marchants'. ${ }^{20}$

13 Frances E. Dolan, 'Home-Rebels and House-Traitors: Murderous Wives in Early Modern England', Yale Journal of Law \& the Humanities, 4 (1992), 1-32.

14 John Donne, 'The Anniversary', in The Complete Poems ofJohn Donne, ed. by Robin Robbins (Harlow: Longman, 2010), p. 129.

15 Itur Mediteranium (London, 1658; Wing L2331), p. 6.

16 A defence of the honourable sentence and execution of the Queene of Scots (London, 1587; STC 17566.3); A True account of the behaviour and manner of the execution of six persons viz. Henry Cornish and Elizabeth Gaunt condemned for high-treason (London, 1685; Wing T2345).

17 Nadine Akkerman, Invisible Agents: Women and Espionage in Seventeenth-Century Britain (Oxford: Oxford University Press, 2018); James Daybell, Women and Politics in Early Modern England, 1450-1700 (London: Routledge, 2004).

18 Richard Grenville, A continuation of the true narration of the most observable passages in and about Plymouth, from January 26. 1643. till this present (London, 1644; Wing C5973), title page.

19 An Elegie on the death of the Most Serene Majesty of Henrietta-Maria, Queen-Mother of Great Britain (London, 1669; Wing E39A), [single sheet].

20 Cecil, The execution of justice, sig. A3r. 
Mobility and contacts with rival or hostile countries could instigate treasonable acts, since many traitors spent most of their lives 'running up and downe, from Countrey to country', evading the laws of society that kept subjects in check. Further, to write and share 'public infamous libels, ful of despitefull vile termes and poysoned lyes, altogether to uphold the foresaide antichristian and tyrannous warrant of the Popes Bull' were treacherous acts. ${ }^{21}$ Such remarks on 'traitors' as those who used 'vile terms and poisoned lyes' as their arsenal reveal a perception that traitors were not only those who threatened the life of the monarch, but, increasingly, their reputation. The rise of print and literacy made it easier to disseminate dangerous ideas, on a scale that was difficult to control. Anyone who spread ideas or used injurious words had the potential to damage the dignity and legitimacy of the monarch. Tudor state authorities went to great lengths, often unsuccessfully, to curb the spread of news and rumour in moments of social or political unrest. Those who spread destructive words were 'wicked and traitorous persons, monsters of men', individuals that 'without regard of duty or conscience, and without fear of God or man' used their 'malice' to attack the queen and her government 'not only by railing open speeches but also by false, lying and traitorous libels.' ${ }^{22}$

The concern with treason by words exposes the state's attempts to respond to, and control, the growing print market that different political and religious groups used to transmit their ideas. As Edward Nisbet noted in 1601, 'seditious thoughts like an inwarde maladie, bee hurtful to the heart, wherein they rest, therefore are they to be avoided: but seditious words like a contagious disease do infect others, therefore are they more to be abhorred'. ${ }^{23}$ Apart from an attempt to censor the contents and impact of the polemical works published in early modern England, the Elizabethan and Stuart concerns with words reveal a perception that speech could reveal the mind and intentions of a traitor, with speech in some ways actualising their thoughts. In the case of Arthur Crohagan, an Irish Dominican friar who in a heated discussion with English merchants and sailors in Lisbon stated that he would kill James I, Crohagan's words revealed 'his traitorous intent, and the imagination of his heart'. ${ }^{24}$ Nonetheless, as David Cressy has observed, few Elizabethan and Stuart subjects were executed as traitors for using words against the sovereign. One of the leading Elizabethan and Jacobean jurists,

Ibid. 
Edward Coke, emphasised 'that bare words may make an heretic, but not a traitor without an overt act' and that 'merely speaking scandalous words of the king was not treason', although the use of 'words which incited to his murder were an overt act' could deserve the capital punishment. ${ }^{25}$

Coke was an expert in cases of treason. He was the attorney-general in the trials that condemned Walter Ralegh for his involvement in the Main Plot of 1603, a conspiracy to overthrow James I and invite foreign troops to invade England, and those involved in the Gunpowder Plot of 1605, a failed regicide attempt by a group of Catholics including Robert Catesby and Guy Fawkes. These two conspiracies revealed the initial fragilities and anxieties of the king regarding the loyalty of his subjects, where confessional dispute bred traitors at home at a time when subjects were no longer united politically through their religion. While the thwarting of the Gunpowder Plot seemed to confirm perceptions of the 'traitor' as an English Catholic who followed foreign interests, Ralegh's trials and eventual execution for high treason in 1618 revealed a perception of the figure of the traitor as a deviant character who rejected the social and political order. Commenting on the trials of the Main Plot, John Cowell defined treason in 1607 as 'an offence committed against the amplitude and majesty of the commonwealth' and high treason as 'an offence done against the security of the commonwealth, or of the King's most excellent Majesty'. ${ }^{26}$ Ralegh's trial, condemnation, pardon, and execution reveal the different levels of treason at play in how individuals were identified according to various interests of state. Although James initially pardoned Ralegh, the English aristocrat and Elizabeth's old favourite was executed in 1618 following Spanish diplomatic pressures to annul the king's pardon following the explorer's botched expedition to Guiana (modern-day Venezuela) in 1617. In other words, Ralegh's trial confirmed the traitor as a pariah who acted against the interest of the community or attacked the royal dignity and authority of the monarch, who embodied the commonwealth.

The necessities of state and laws on treason led Parliament to condemn their own king, Charles I, as a 'traitor' in 1649. Although the king was head of state, members of Parliament considered his authority to be limited. Parliament framed Charles's decision to 'levy War against the parliament and Kingdom of England' as an act against the true sovereign power in the realm, Parliament and English laws. Although the execution of Charles was

25 Quoted in David Cressy, Dangerous Talk: Scandalous, Seditious, and Treasonable Speech in Pre-Modern England (Oxford: Oxford University Press, 2010), pp. 9o-91.

26 John Cowell, The Interpreter (London, 1607; STC 5900), sig. vvviv. 
the ultimate consequence of the royalist defeat in the English civil wars, the fact that the king was put to trial as a traitor was both an innovation and a confirmation of English legal and moralist perceptions of treason. The king's execution was justified by citing his actions against the commonwealth and the sovereign institutions of the state, but also from a moral perspective which associated treason with wickedness, cruelty, and unlawful behaviour, rendering Charles 'a Tyrant, Traitor and Murtherer [...] a Publique Enemy to the Comonwealth of England'. ${ }^{27}$

After the Restoration, supporters of the House of Stuart used the same image of the traitor as a morally corrupt enemy of the commonwealth, this time to support the royalist cause. In a post-Restoration account of Charles's trial, John Nalson presented the execution of the king as the unprecedented act of treason perpetrated by 'Enemies of Mankind', '[t]raitors' who 'with the most plausible Pretences of the Public Good' had reached 'unheard of flights of insolent Wickedness, so as not only to subvert the Government, and dethrone their Sovereign, but to Arraign and Judge, Condemn and Execute their King. ${ }^{28}$ Regicide was an act that 'with all the solemn and impudent Formalities' only brought 'pretended Justice, even in the Face of the Sun, and view of the whole World, as if they would at the same instant defy both the Vengeance of Heaven and Earth'. ${ }^{29}$ 'Traitor' was thus described in a way that seemed unnatural; a figure that operated against the laws of man and God and even the '[f]ace of the Sun'. Although the growth of the early modern state made 'traitor' a heavily political word, it remained grounded in ideas of liegance articulated in terms of personal betrayal and broken trust. ' $[\mathrm{T}]$ he blackest' monster was 'the Traytor-Friend', one who chose to break the bonds of amity and loyalty..$^{30}$ It was the traitor's slipperiness, his or her willingness to abandon 'Englishness' for cross-confessional or cross-national loyalties, that made such individuals the subject of mistrust and double-dealing.

Related keywords: convert, exile, foreigner, subject, traveller

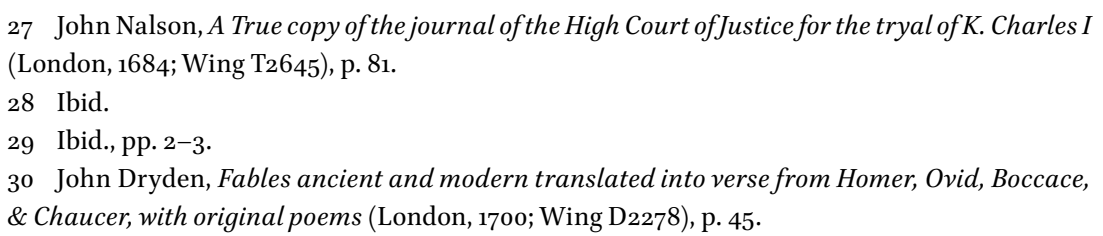




\section{Translator}

In early modern usage, to 'translate' - from the Latin translatus (the past participle of transferre, literally 'to transfer') - was an act of cultural mediation, facilitating the movement of an integral meaning or spirit from one context to another. ${ }^{1}$ Such a process was not necessarily textual. In an age preoccupied with clothing's ability to shape, mould, and fashion subjecthood and virtue, translation often referred to or was conceptualised as a process of undressing and redressing. When an apprentice became incorporated into a guild as a full member, for example, they were invested with the company livery in a ceremony referred to as 'translation.' 2 In a tailor's shop, the offcuts of a sheet of cloth used to create a new suit were then 'translated' into a different garment. ' 'Englishing' a text was much the same process, in which the original was stripped and redressed into English language and cultural resonances. Underscoring this process was a series of complex negotiations between the primary text, the limitations, specifications, and nuances of the secondary language, and the cultural frame of reference of the intended readership. The result was not a wholly original composition, but rather an old idea dressed in new clothes.

Though the roles of the translator and the interpreter frequently overlapped earlier in the sixteenth century, translators were generally distinguished from the latter by the mode and form in which they conveyed information. By the beginning of the seventeenth century, the state official Lodowick Bryskett recognised this literary element as a definitive feature of translation in the epistle to his 1606 English edition of Giovanni Battista Giraldi's Tre dialoghi della vita civil (1565): it is to be 'set downe in writing, as a translation must be'. ${ }^{4}$ As well as the mode of delivery, the translator also required a superior knowledge of the original cultural and linguistic contexts in order to correctly convey the meaning of a text and 'rewrite' the spirit of the work in new terms. 'You grow Familiar, Intimated and Fond', wrote Wentworth Dillon, fourth Earl of Roscommon, 'Your Thoughts, your words, your Stiles, your Souls agree, / No Longer his Interpreter, but He'. 5

$1 \quad$ 'Translate, $n$. and adj., Oxford English Dictionary.

2 Anne Rosalind Jones and Peter Stallybrass, Renaissance Clothing and the Materials of Memory

(Cambridge: Cambridge University Press, 200o), p. 220.

3 Ibid.

4 Lodowick Bryskett, A discourse of civill life (London, 16o6; STC 3958), p. 29.

5 Quoted in Lawrence Venuti, The Translator's Invisibility: A History of Translation (Abingdon: Routledge, 1995), p. 238. 
This notion of a union of souls between original author and translator resonates with Michel de Montaigne's celebration of Jacques Amyot's 1572 Vies des hommes illustres, a translation of Plutarch's Moralia, in the 1580 edition of his Essaies:

everywhere in his translation I see a meaning so beautiful, so coherent and so consistent with itself that either he has definitely understood the true meaning of his author or else, from a long frequentation with him, he has planted in his own soul a vigorous generic Idea of Plutarch's, and has at least lent to him nothing which belies him or contradicts him. ${ }^{6}$

It was commonly held that translating a text into another language always resulted in some degree of intellectual and cultural forfeiture. 'It is true that wit distilled in one language', wrote Robert Stapylton in his Dido and Aeneas (1634), 'cannot be transfused into another without losse of spirits'? As with Amyot's Vies des hommes illustres, however, this discordance was not inevitable. Montaigne argues in platonic terms that the 'generic Idea' or spirit of the 'moralia' has imprinted itself on the translator's soul either through a kind of transliterary, transhistorical medullary connection, or through long and frequent exposure to both the original text and the author's wider literary corpus.

Within the translated text, this union was often conceptualised in terms of hosting or hospitality. Drawing on earlier Italian humanist tropes of love and familiaritas, the fifteenth-century printer and pedagogue Jodocus Badius Ascensius cultivated a paratextual presence in his translations through the use of commentaries, justifying their inclusion on the grounds that he did not wish to be 'hospes asymbolus', a guest who brings nothing to the entertainment. ${ }^{8}$ In a closing note to his translation of Giraldi, Bryskett, the son of a settled Genoese merchant, pre-emptively chastised potential critics for their 'breach of the law of hospitalitie' as they try 'overruling me in mine owne house'. ${ }^{9}$ This guest/host dynamic could be weighted to either celebrate

6 Quoted in Warren Boutcher, 'From Cultural Translation to Cultures of Translation? Early Modern Readers, Sellers, and Patrons', in The Culture of Translation in Early Modern England and France, 1500-1660, ed. by Tania Demetriou and Rowan Tomlinson (Basingstoke: Palgrave Macmillan, 2015), pp. 22-44 (p. 28).

7 Virgil, Dido and Aeneas the fourth booke of Virgils Aeneis now Englished by Robert Stapylton (London, 1634; STC 24812), sig. A4v.

8 Quoted in Paul White, 'From Commentary to Translation: Figurative Representations of the Text in the French Renaissance', in The Culture of Translation in Early Modern England and France, pp. $71-85$ (p. 77).

9 Bryskett, $A$ discourse of civill life, p. 30. 
or minimise the translator's involvement. For Margaret Tyler and other women writers, framing themselves as simple 'hosts' gave them license to bring their works into print. In the epistle to The mirrour of princely deedes and knighthood (1578), Tyler assures the reader that her 'part therein none but the translation, as it were onely in giving enterteinment to a straunger, before this time unacquainted with our country guise..10

Translation, then, was a delicate balancing act of passivity and revelation, the skilful enacting of simultaneous 'self-erasure and self-assertion'.11 Those who took up the task often justified their presumptuousness by stressing the transcultural nature of their international careers, heritage, education, or travels. In late sixteenth-century London, individuals from the City's diverse communities of strangers often catered to the demand for foreign language tutors and translators brought about by increased cultural and commercial exchange with the Continent. ${ }^{12}$ The most well-known of these, the linguist, translator, and lexicographer John Florio, born in London to an Italian father and (possibly) French mother, spent a career creating a composite identity that carefully asserted an authoritative Anglo-Italian national and cultural identity. A self-described 'Englishman in Italiane', Florio did not fully anglicise his name like his contemporary Bryskett (born Lodovico Bruschetto) $\cdot{ }^{13}$ Rather, as Manfred Pfister notes, he would present as 'Giovanni', a cultural Italian, in his Italian language epistles, and 'John', the naturalised Englishman, in the English language equivalent. ${ }^{14}$

10 Quoted in Edward Wilson-Lee, 'Women's Weapons: Country House Diplomacy in the Countess of Pembroke's French Translations', in The Culture of Translation in Early Modern England and France, pp. 128-144 (p. 132).

11 Ibid., p. 140.

12 See Karen Newman and Jane Tylus, 'Introduction', in Early Modern Cultures of Translation, ed. by Karen Newman and Jane Tylus (Philadelphia: University of Pennsylvania Press, 2005), pp. 1-24 (p. 14); Sergio Portelli, 'Translation and Adaptation in Original Composition: Lodowick Bryskett's Use of His Sources in A Discourse of Civill Life (16o6)', in Translators, Interpreters and Cultural Negotiators: Mediating and Communicating Power from the Middle Ages to the Modern Era, ed. by Federico M. Federici and Dario Tessicini (London: Palgrave Macmillan, 2014), pp. 105-120; Manfred Pfister, 'John/Giovanni Florio: The Translator as Go-Between', in Translation Practices: Through Language to Culture, ed. by Ashley Chantler, Carla Dente, and Manfred Pfister (Amsterdam: Rodopi, 2009), pp. 184-202; John Gallagher, Learning Languages in Early Modern England (Cambridge: Cambridge University Press, 2019).

13 John Florio, Florios second frutes to be gathered of twelve trees, of divers but delightsome tastes to the tongues of Italians and Englishmen (London, 1591; STC 11097), sig. B1r.

14 Manfred Pfister, 'Inglese Italiano - Italiano Anglizzato: John Florio', in Renaissance GoBetweens: Cultural Exchange in Early Modern Europe, ed. by Andreas Höfele (New York: Walter de Gruyter, 2005), pp. 32-34 (p. 39). 
Florio's career offers a window into the networks of patronage that nurtured England's nascent translation culture. After his family was expelled during the Marian persecutions, the young Florio spent his adolescence moving between Europe's Protestant enclaves. He eventually returned to London in the early 1570s, where he set his sights on Robert Dudley, Earl of Leicester. As a man of letters, Leicester was an ideal prospective patron for Florio's desired career as a linguist. A 'noble Mecenas' and protector of strangers, Leicester was surrounded by knowledge-gatherers who benefitted from his 'continuall delight in setting foorth of good letters'. ${ }^{15}$ Like his rival at court, William Cecil, Lord Burghley, another prolific patron of translators, Leicester's support of the arts was underpinned by a fervent reformist agenda. ${ }^{16}$ He sponsored English editions of sermons and works of theology by Peter Martyr, Theodore Beza, and John Calvin, and was the dedicatee of John Field's 1579 translation of Philippe de Mornay's renowned defence of church reform, Traicté de l'église (1578). ${ }^{17}$ On Leicester's death in 1588, his extended family took up the mantle. Members of the Sidney-Herbert faction were prolific patrons of plays, poetry, and translations of Italian and French prose works, as well as more sober works of Protestant exegesis. Many were translators themselves. Mary Sidney Herbert, Countess of Pembroke, remained a committed patron of the arts throughout her life, producing celebrated translations of Petrarch, Mornay, and the Book of Psalms.

Not all aspired to such intellectual heights, however, and in the final decades of the sixteenth century, cheap translated foreign news flooded the English book market in unprecedented numbers. ${ }^{18}$ Translators-for-hire, often unacknowledged or listed by their initials, were employed by commercially minded printers and booksellers to 'copy' a text from one language into another through what we might now refer to as 'transliteration'. Yet despite both the insatiable appetite for print and the growing appreciation for translation as an intellectual pursuit in itself, few can be considered professional in the sense that their output contributed significantly to their income or

15 Florio, Florios second frutes, sig. A3r. See Eleanor Rosenberg, Leicester: Patron of Letters (New York: Columbia University Press, pp. 152-153.

16 Graham Parry, 'Patronage and the Printing of Learned Works for the Author', in The Cambridge History of the Book in Britain, Vol. IV, 1557-1695, ed. by John Barnard, D. F. McKenzie, and Maureen Bell (Cambridge: Cambridge University Press, 2002), pp. 174-188 (pp. 175-178).

17 Ibid., p. 176.

18 See Sara Barker, “Newes Lately Come”: European News Books in English Translation', in Renaissance Cultural Crossroads: Translation, Print and Culture in Britain, 1473-1640, ed. by S. K. Barker and Brenda M. Hosington (Leiden, Brill, 2015), pp. 227-244. 
was the basis of their renown. ${ }^{19}$ Rather, paid acts of cultural mediation were often undertaken secondarily to (and in conjunction with) the individual's official role as merchant, diplomat, teacher, scholar, churchmen, or stationer. Edward Aggas, one of the most prolific translators of the late 1580s, was first and foremost a bookseller with a shop at the sign of the Dragon in St. Paul's Churchyard..$^{20}$ Like his fellow prodigious booksellers/printers/translators Richard Field and John Charlewood, much of his output in this period was sponsored by Cecil as part of an orchestrated propaganda effort to shore up support for Protestant regimes abroad. ${ }^{21}$

This is not to say that the translator was driven exclusively by profit or political expediency. At the heart of England's developing translation culture was the desire to adopt and adapt continental forms of civility and humanist systems of knowledge production. Translations from classical and vernacular languages provided the means through which to engage with the scientific, philosophical, and theological debates taking place on the Continent, whilst simultaneously affirming the cultural and intellectual worthiness of the English language, feeding into emerging ideologies of nationhood. The pursuit of an exclusively English culture was entwined with the tradition of vernacular bible translation promoted by reformers. The 'boy that driveth the plough', William Tyndale reportedly pronounced, 'shall know more of the Scriptures' than the ecclesiastics who obtained their understanding of the Christian faith through the Latin apocrypha. ${ }^{22}$ This sentiment would come to underpin the English Protestant project, with successive monarchs authorising new translations. The 1611 King James Bible was celebrated as a triumph of both English language prose and Protestantism that 'openeth the window, to let in the light; that breaketh the shell, that we may eat the kernel'. ${ }^{23}$

As the English turned an evangelical eye beyond Christendom in the latter half of the seventeenth century, translations of the Scripture out of English into non-European vernaculars were required. Catholic missionaries had long

19 Peter Burke, 'The Renaissance Traveller as Go-Between', in Renaissance Go-Betweens: Cultural Exchange in Early Modern Europe, ed. by Andreas Höfele (New York: Walter de Gruyter, 2005), pp. 17-31 (p. 19).

20 See H. R. Tedder and I. Gadd, 'Aggas, Edward (b. in or before 1549, d. 1625?), bookseller and publisher', Oxford Dictionary of National Biography, <https://doi.org/10.1093/ref:odnb/209> [Accessed 14 March 2020].

21 Lisa Ferraro Parmelee, 'Printers, Patrons, Readers, and Spies: Importation of French Propaganda in Late Elizabethan England', The Sixteenth Century Journal, 25:4 (1994), 853-872 (p. 861). 22 William Tyndale, The whole workes of W. Tyndall,John Frith, and Doct. Barnes, three worthy martyrs (London, 1574; STC 24436), sig. Bir.

23 Cornelius Bol, The Holy Bible conteyning the Old Testament, and the New: newly translated out of the originall tongues (London, 1611; STC 2216), sig. A4v. 
recognised the effectiveness of inculturation as a means of evangelising local populations. In 1616, the Jesuit Thomas Stephens printed his Kristapurana, a biblical epic based on the Old and New Testaments in the Indian regional languages of Konkani and Marathi, in Goa. A resident in India for 40 years, Stephens was able to mediate between western Roman Christianity and local Indian cultures by incorporating elements of Marathi and Konkani literary culture into the work. The evangelical policies of the English colonial enterprises in North America encouraged the translation of religious pamphlets and the Bible into local languages, which involved transcribing the orality of Algonquian dialects into text. John Eliot, a missionary in Massachusetts, translated and printed the English Bible into Algonquian in 1663. The introduction to this Mamusse wunneetupanatamwe Up-Biblum God reveals the connection between translators, readers, and patrons, and how translations of the Bible in colonies bound Algonquians, missionaries, and English subjects together within a godly community. ${ }^{24}$ Also in the 1660 , the orientalist scholar William Seaman translated the New Testament and a catechism into Turkish with the support of the Levant Company.

An interest in translating non-Christian religious texts into English at home followed an increase in cross-cultural encounters with non-European populations overseas. The first English edition of the Quran, The Alcoran of Mahomet (1649), was a translation from André du Ryer's French edition (1647). ${ }^{25}$ Its publication was the subject of a petition to Parliament in March 1649 by Colonel Anthony Welden, who urged the House to seize the 'Turkish Alcoran' and have it burnt. ${ }^{26}$ Parliament gave the translator, the Scottish clergyman and controversialist Thomas Ross, 'a monition to meddle noe more wth any thing of yt nature.. ${ }^{27}$ This relatively light stricture was probably due to the above-board licensing of the text and the careful way

24 John Eliot, The Holy Bible containing the Old Testament and the New, translated into the Indian language (Cambridge, 1663; Wing B2748). On Eliot's Algonquian translators and interpreters, see Cathy Rex, 'Indians and Images: The Massachusetts Bay Colony Seal, James Printer, and the Anxiety of Colonial Identity', American Quarterly, 63:1 (2011), 61-93.

25 See Matthew Dimmock, Mythologies of the Prophet Muhammad in Early Modern English Culture (Cambridge: Cambridge University Press, 2013); Dimmock, 'Tolerating Mahomet: or, Thinking About Then, Now', in Religious Tolerance in the Atlantic World: Early Modern and Contemporary Perspectives, ed. by Eliane Glasser (Basingstoke: Palgrave, 2013), pp. 214-234; and Dimmock, "Machomet dyd before as Luther doth nowe': Islam, the Ottomans and the English Reformation', Reformation, 9:1 (2004), 99-130.

26 Mordechai Feingold, “The Turkish Alcoran”: New Light of the 1649 Translation of the Koran', The Huntington Library Quarterly, 75:4 (2012), 475-501 (p. 481). See also Noel Malcolm, 'The 1649 Translation of the Koran: Its Origins and Significance', Journal of the Warburg and Courtald Institutes, 75 (2012), 261-295 (pp. 261-262).

27 Ibid., p. 262. 
in which Ross addressed contemporary anxieties. He included a '[n]eedful Caveat' in the prefatory material which posited a series of propositions on the necessity of the translation as a means of highlighting the truth of the gospel. His role as a go-between was thus framed in evangelical terms, where the translator's purpose is to present to 'the publick view [...] the sight of a Monstrous mishapen creature' to 'induce the beholder to praise God'. ${ }^{28}$

Earlier printed works of translation from Arabic, such as William Bedwell's Mohammedis imposturae (1615), were similarly justified in the epistolary material as revelations of the illogical and heretical nature of Islam. Though Bedwell's text was translated from a 1570 s work of Catholic anti-Islam propaganda entitled the Musahaba ruhaniya baina-l'alimain, Bedwell also notes the value of the text for those 'which are desirous to understand that language.'. ${ }^{29}$ There was a growing interest in learning Arabic and acquiring manuscripts and printed scientific, theological, and philosophical works from the Ottoman Empire in the early decades of the seventeenth century. Several scholars and churchmen in the orbit of William Laud, Archbishop of Canterbury, were among the first accomplished orientalists. The formidable polyglot and legal scholar, John Selden, translated numerous works from Arabic into both English and Latin, including Eutychius's history of the early Church, Eutychii Aegyptii, patriarchae orthodoxorum Alexandrini (1642). Edward Pococke's passion for languages brought him to Laud's attention. He was studying Arabic in Aleppo (1629) and Istanbul (1636-1639) as chaplain to the Levant Company when Laud implemented a quota on company ships in 1634 to 'bring home one Arab: or Persian MS. Booke'. $3^{0}$ Though poorly enforced, Pococke amassed a number of texts for the Archbishop, who then created a Chair of Arabic for the Chaplain to fill upon his return to England in 1636 . Throughout a long career, Pococke used his multilingualism to translate several manuscripts on a range of subjects, including a collection of 6000 proverbs, a dual language manual on coffee consumption entitled Nature of the Drink Kauhi, or Coffee (1659), and the Carmen Tograi, a Latin rendering of the twelfth-century poem Lämiyyat al-Ajam (1661) by Hassan ibn 'Ali al-Tughra'i. ${ }^{31}$

28 The Alcoran of Mahomet, trans. by Thomas Ross (London, 1649; Wing K747A), p. xix.

29 Gerald MacLean and Nabil Matar, Britain and the Islamic World, 1558-1713 (Oxford: Oxford University Press, 2011), p. 31; William Bedwell, Mohammedis imposturce: that is, A discovery of the manifold forgeries, falshoods, and horrible impieties of the blasphemous seducer Mohammed with a demonstration of the insufficiencie of his law (London, 1615; STC 17995), sig. B1r.

30 G. J. Toomer, Eastern Wisdom and Learning: The Study of Arabic in Seventeenth-Century England (Oxford: Clarendon Press, 1996), p. 108.

$3^{1}$ Alastair Hamilton, 'The Learned Press: Oriental Languages', in The History of the Oxford University Press, Vol. I: Beginnings to 1780, ed. by Ian Gadd (Oxford: Oxford University Press, 
While translating such texts was often motivated by a combination of scholarly interests or religious purposes, as well as the career strategies of some translators, the interest in translating colonial knowledge nurtured by patrons like Laud gave rise to a new generation of scholar-translators whose work was often embedded deeply in the developing imperial ambitions of the English. As the chaplain for the English ambassador at the Sublime Porte between 1628 and 1639, Seaman translated the Tac üt-tevarih, a history of the Ottomans commissioned by Sultan Murad III, into English. ${ }^{32}$ Several other former chaplains of the Levant Company became scholars at Cambridge and Oxford thanks to their proficiency in Arabic, Greek, Syriac, or Hebrew. These intellectual projects, although influenced by antiquarian perspectives, paved the way for the emergence of Orientalist disciplines that supported the development of English colonial activities later in the eighteenth and nineteenth centuries. Earlier attempts by proto-colonialists to attract potential investors reveal the role of the translator as a cultural mediator who offers access to useful industry knowledge for further expansion and investment. In 1585, the clergyman and colonial promoter Richard Hakluyt commissioned Florio to translate Jacques Cartier's treatise on the discovery of New France, intending to promote the English discovery of the North-West Passage. In the customary translator's epistle, Florio argues that translations of foreign works were necessary 'to animate and encourage the Englishe Marchants' and 'propose unto them the infinite treasures (not hidden to themselves) whiche both the Spaniardes, the Portugales, and the Venetians have severally gained by their suche navigations and travailes'. ${ }^{3}$ While Hakluyt's own monumental Principal Navigations, Voyages, and Discoveries of the English Nation (1589; expanded 1598-1600) emphasised the centrality of English 'witnesses' and travel accounts, it nevertheless contains a substantial body of texts in translation. The development of English trade in the Levant and South Asia and colonisation in North America advocated by individuals like Hakluyt stimulated the development of new bodies of texts and knowledge. Activity in these regions was dependent on the work of translators and interpreters, and some of this new information has left its mark on language. Turkish words such as 'aga' or 'vizier' were introduced by John Shute's translation of Andrea Gambino's Commentari delle cose de

2013), pp. 399-417 (pp. 404-405); Alison Games, Web of Empire: English Cosmopolitans in an Age of Expansion, 1560-166o (Oxford: Oxford University Press, 2008), p. 232.

32 Toomer, p. 175; Charles G. D. Littleton, 'Ancient Languages and New Science. The Levant in the intellectual life of Robert Boyle', in The Republic of Letters and the Levant, ed. by Alastair Hamilton, Maurits H. Van Den Boogert, and Bart Westerweel (Leiden: Brill, 2005), pp. 151-172 (p. 158).

33 Jacques Cartier, A shorte and briefe narration (London, 1580; STC 4699), sig. A2r. 
Turchi, for instance, and words such as 'mosquito' or 'tobacco' were derived from translations of Iberian colonial writing about the Americas. ${ }^{34}$

When considering both the translator's role as a key asset to the English expansionist project and the debates over the place of translation in articulating a clear cultural or religious English identity, it comes as no surprise that the language around translation swelled with issues of migration, belonging, and difference. The translated work was itself a migrant, and its translator the one who helped them assimilate to English life. Florio compared his role in translating Montaigne's Essaies to that of a 'fondling foster-parent' who transports a child from France to England, clothes it in English dress and teaches it to 'talke our tongue'. ${ }^{55}$ Stapylton was more explicit in Dido and Aeneas. The function of the translator, he wrote, is to transform a 'Forraigner' into a 'Native': 'The Queene of Carthage hath learned English to converse with you: be pleased now to esteeme her as a Native, but in the errours of her language, still remember she was borne a Forraigner' ${ }^{36}$ In this scenario, Stapylton is the tutor ('In Englishing Virgil', he wrote, 'I have given him a Language'), and any 'errours of her language' are to be forgiven as an inevitable consequence of the translation process in the same way as one would forgive a non-native speaker. ${ }^{37}$ In an earlier translation of Lancelot-Voisin de La Popelinière's Dessein de l'histoire nouvelle des François (1571), Thomas Barrett bids his patron to give safe conduct to 'my newe English Denizen' and 'entertain his broken englishe' $3^{8}$ With patience, he assures them, 'you shall finde him very delightfull'.39

Related keywords: foreigner, host, interpreter, native

34 Andrea Cambarini, Two very notable commentaries the one of the originall of the Turcks and Empire of the house of Ottomanno, trans. by John Shute (London, 1562; STC 4470), p. 53. For examples of words introduced from the Iberian colonial world, see Richard Perceval, $A$ dictionarie in Spanish and English (London, 1599; STC 19620), pp. 173, 225; Edward Topsell, The history of four-footed beasts and serpents (London, 1658; Wing G624), p. $95^{2}$.

35 The essayes or morall, politike and millitarie discourses of Lo: Michaell de Montaigne, trans. by John Florio (London, 1603; STC 18042), sig. A2r.

36 Dido and Aeneas the fourth booke of Virgil, sig. A2r.

37 Ibid.

$3^{8}$ Thomas Barrett, The historie of France the foure first bookes (London, 1595; STC 11276) sigs. A2v-A3r.

39 Ibid. 


\section{Traveller}

The etymology of 'traveller' is closely linked to the hardship of travelling, originating from the old French travail and its associated verb, travailer. Both travail and travailer meant bodily or mental toil and exertion, and usage in the Middle Ages often linked them closely to childbirth, as well as to agricultural labour. ${ }^{1}$ As one medieval author wrote, 'Call the workmen and yield him here travail', whilst the fourteenth-century poet William Langland spoke of 'trewe travaillours and tilieres of pe erthe'. ${ }^{2}$ By the fifteenth century, travail and the travailer were associated with journeying. While in France travailleur continued to be associated with toil and arduous journeys, in England the word became interchangeable with the identity of the traveller. Mandeville's Travels refers to a 'way es comoun and wele ynogh knawen with all men pat usez trauvaile' whilst Thomas Hoby, in his translation of The courtyer of Count Baldessar Castilio, would later write of Castiglione's 'yeeres travaile abrode' as part of his civil education. ${ }^{3}$ By the sixteenth century, the 'traveller' could be both a labourer and a journeyer. Thus on the one hand, a late sixteenth-century sermon could describe 'the traveller' as an individual who 'passeth from towne unto towne, until he comes to his Inne'. ${ }^{4}$ On the other, the geographer Richard Hakluyt described his labour of compiling the travel accounts in The Principal Navigations (1589) as an act of travel and travail, lamenting 'what restlesse nights, what painefull dayes, what heat, what cold I have indured; how many long \& chargeable journeys I have traveiled' in the making of his compendium. ${ }^{5}$

1 'Travail $n$. and v.', Oxford English Dictionary; Travel and Travail: Early Modern Women, English Drama, and the Wider World, ed. by Patricia Akhimie and Bernadette Andrea (Lincoln: University of Nebraska Press, 2019); Amazons, Savages, and Machiavels: Travel and Colonial Writing in English, 1550-1630: An Anthology, ed. by Andrew Hadfield (Oxford: Oxford University Press, 2001).

2 'Dominica in Sexagesima', in An Old English Miscellany containing a Bestiary, Kentis Sermons, Proverbs of Alfred, Religious Poems of the thirteenth century, ed. by Richard Morris (London: Early English Text Society, 1872), p. 33; William Langland, The Vision of William concerning Piers Plowman (1377), ed. Walter W. Skeat (London: Early English Text Society, 1867), p. 223.

3 John Mandeville, The Egerton Version of Mandeville's Travels (London: Early English Text Society, 2010), p. 30; Baldassare Castiglione, The courtier of Count Baldessaer Castilio, trans. by Thomas Hoby, (London, 1561; STC 4778), sig. Eiii.

4 Henry Smith, The sermons of Maister Henrie Smith gathered into one volume (London, 1593; STC 22719), p. 677 .

5 Richard Hakluyt, The principal navigations, (London, 1589; STC 12625), sig. *4V. 
Hakluyt's description of a traveller's endurance in the quest for knowledge is an important element of how writers understood and presented the idea of the 'traveller' in the sixteenth and seventeenth centuries. In reality, men and women of varying social status travelled for a range of reasons, from marriage to the search for work. Enforced mobility due to religious, economic, and political reasons imposed travel as a condition of survival on large numbers of the population. Many women were travellers on some scale, moving by coach, ship, or horseback to new households as a result of marriage, or to accompany husbands on diplomatic posts abroad. ${ }^{6}$ Yet the word 'traveller' in humanist discourse typically drew from biblical and classical tropes and exemplars to engage with ideas of belonging and allegiance in specific ways. The traveller who went 'farre from his countrey and family, yet is desirous to returne thither againe', explained the author of a 1597 devotion text, was akin to humans 'banished from this worlde' and longing to 'returne to heaven, our true borne country'. ${ }^{7}$ Classical tropes of exile and homecoming in figures such as Ulysses and Aeneas took centre stage. In Thomas More's Utopia (1516), Raphael Hythloday embodied the prototypical humanist traveller. Initially appearing to be a ship's captain, this man was, one character insisted, 'as the experte and prudent prince' Ulysses. ${ }^{8}$ Eager to see the world, Hythloday had left his estates to his brothers to join Vespucci's voyages to the Indies, and 'there is no man this daye lyvynge that can tell you of so manye strange and unknown peoples and contreis as this man can'. ${ }^{9}$ A hundred years later, the eccentric traveller Thomas Coryate warned his mother that his travels in India would not be complete until he had travelled seven years, like Ulysses. ${ }^{10}$

The 'traveller' therefore emerged as a specific type in the sixteenth century, one who undertook travel in the hope of individual or collective profit or pleasure. Such individuals sought to experience foreign cultures and lands, often through employment as scholars, merchants, consuls, soldiers, sailors, chaplains and governors. Commercial and territorial expansion involved the enlargement of a body of 'professional expatriates' who moved between cultures and nations, working as an arm of the English state, though

6 Eva Johanna Holmberg, 'Introduction: Renaissance and Early Modern Travel: Practice and Experience, 1500-1700', Renaissance Studies, 33 (2019), 515-523 (pp. 517-519).

7 Edmund Mats, A devoute mans purposes (London, 1597; STC 17231), p. 1.

8 Thomas More, A fruteful, and pleasaunt worke of the beste state of a publyqye weale, and of the newe yle called Utopia (London, 1551; STC 18094), sig. B3r.

9 Ibid., sigs B $3 \mathrm{r}-\mathrm{v}$.

10 Thomas Coryate, Thomas Coriate traveller for the English wits (London, 1616; STC 5811), p. 6. 
often accompanied by personal interests. ${ }^{11}$ The Welsh courtier and poet Ludovic Lloyd commended Spanish expansion in this period, recognising and envying the Spanish use of travel for commercial and territorial gain. ${ }^{12}$ For Lloyd and many like him, the Spanish were successful conquerors because they were 'greatest travellers'. ${ }^{13}$ Over 30 years later, Thomas Palmer described the people of Britain, rather than the Spanish, as great travellers in their attempts to overcome geographic isolation. 'The people of great Britaine', being separated from the 'maine Continent of the world', Palmer asserted, were 'so much the more interessed to become Travaillers, by how much the necessitie of everie severall estate of men doth require that for their better advancement'. ${ }^{14}$

The insights gained by such a 'traveller' made them a socio-political and economic agent of significance. Policymakers viewed travel as beneficial to gathering information and knowledge that served the interests of the commonwealth. The traveller informed and encouraged others to widen the nation's perspectives and interests. Whether observing culture, language, history, flora, fauna, politics, or law, 'nothing should escape the careful attention and later recall of the thoughtful traveller. ${ }^{15}$ In 1576 , explaining the reason for his journey to Geneva, Thomas Bodley admitted to being driven by the desire to gain 'the knowledge of some speciall moderne tongues, and for the encrease of my experience [...] being wholly then addicted to employ my selfe [...] in the publique service of the State'. ${ }^{16}$ Anthony Munday was a young apprentice to the printer John Allde in 1578, when 'being very desirous to attaine to some understanding in the languages' so that 'in time to come: [he] might reap therby some commoditie', he cancelled his indentures and embarked on a journey through France and Italy, subsequently using that experience as the basis of his work as an

11 Gerald M. MacLean, The Rise of Oriental Travel: English Visitors to the Ottoman Empire, 1580-1720 (Basingstoke: Palgrave, 2004), p. 30; John Stoye, English Travellers Abroad, 1604-1667: Their Influence in English Society and Politics (revised edition) (New Haven, CT: Yale University Press, 1989).

12 Lloyd Lodowick, The pilgrimage of princes, penned out of sundry Greeke and Latine aucthours (London, 1573; STC 16624).

13 Ibid., sig. W2v.

14 Thomas Palmer, An essay of meanes how to make our Travailes, into forraine Countries, the more profitable and honorable (London, 1606; STC 19156), sig. A2v.

15 Catherine Levesque, Journey Through Landscape in Seventeenth-Century Holland: The Haarlem Print Series and Dutch Identity (Philadelphia: Penn State Press, 1994), p. 20.

16 Thomas Bodley, The Life of Sir Thomas Bodley, the honourable founder of the publique library in the University of Oxford, written by himselfe (Oxford: Bodleian Library, 1983), p. 4. 
informer and a writer. ${ }^{17}$ As these two examples show, early modern travellers were often torn between the expectations of their role for the state and their own private interests. Munday's career demonstrates how travellers were often in constant negotiation with their surroundings, and, by extension, with larger issues of political loyalties, confessional alliances and cultural difference. ${ }^{18}$ They were driven by the possibilities of professional and social advancement as well as constant fear of religious, cultural, and political corruption.

Different motivations for travel for were reflected in the variety of travel literature available, which grew exponentially with the rise of print. Pamphlets, ballads, costume books, plays, and travel reports made it possible for readers to travel from the safety of their own chambers. Reading about other places and peoples became a means of experiencing the world's diversity, often refracted through the prism of Protestant devotion. Works intended for use by pilgrims on spiritual journeys had different generic conventions to those intended for merchants or diplomats. While the former would typically focus on framing spatial connections between pilgrimage routes and biblical history, the latter intended to include a greater level of detail regarding the granular economic processes at work within different countries. Hakluyt's The Principal Navigations, with its wide selection of reports, treatises, Continental translations, and private letters, indicates the range of advice available to travellers by the late sixteenth century.

Much travel advice placed a considerable emphasis on specifying the desirable qualities of a good traveller. This figure, however, was often predicated on a model of an assumed 'typical' traveller, which did not necessarily reflect reality, or the increasing volume and variety of generic models which dispensed travel advice. Jerome Turler's De peregrinatione (1574), translated a year later into English, listed the people and groups that he considered unfit to be travellers. These included 'Infants, Aged persons, \& such as have weake bodies', including women and 'frantique and furious Persons', all of whom were 'unméet for [travel], not being able to abide those paynes that accustomablye befal the traveiller.' ${ }^{19}$ Thomas Palmer's meticulous strictures

17 Anthony Munday, The mirrour of mutabilitie, or Principall part of the Mirrour for magistrates (London, 1579; STC 18276), sig. Ciir.

18 See Melanie Ord, 'Representing Rome and the Self in Anthony Munday's The English Roman Life', in Travels and Translations in the Sixteenth Century: Selected Papers from the Second International Conference of the Tudor Symposium, ed. by Mike Pincombe (Abingdon: Routledge, 2017), pp. 45-61 (p. 49).

19 Jerome Turler, The traveiler ofJerome Turler devided into two books (London, 1575; STC 24336), pp. $7-10$. 
on the appropriate age, profession, and social background for the traveller were linked intrinsically to the expectations of travel and the traveller's growing importance as a source of knowledge and information. His emphasis on the traveller's duty to 'make prudent observation of things beneficiall to the State' is representative of a whole body of humanist literature, the ars apodemica or methodus apodemica, that encouraged gentlemen to observe and record their travel experiences according to specific conventions. ${ }^{20} \mathrm{~A}$ traveller himself, the lawyer Francis Bacon noted the potential uses of travel in his essay on the subject, advising his readers to 'prick in some Flowers, of that he hath Learned abroad, into the Customes of his owne Country.' ${ }^{21}$ In his account of his time in India, the chaplain Edward Terry wrote that 'he is the best observer, who strictly and impartially so looks about him, that he may see through himself. That as the Beams of the Sun put forth their vertue, and do good by their reflection: so, in this case the onely way for a man to receive good, is by reflecting things upon himself.'. ${ }^{22}$ In most of these works, ideal travellers showed graceful discernment, adorning themselves with select 'flowers' of foreign experience without losing their sense of self.

Such 'reflection' of foreign experience could also be treated with suspicion and unease. It was precisely because English authorities and humanist thought pitched travellers as politically useful that they became so contentious. Anxieties over cross-cultural encounters were frequently expressed, where fears of an individual's mutability contained the possibilities of undermining the strength and cohesion of the Protestant state and Church. A traveller's exposure to other religions and societies, for example Catholic Italy or the Islamic Ottoman Empire, were perceived as a threat to the national, spiritual, and physical identity of the traveller, even as knowledge-gathering could advance English interests. As Andrew Hadfield points out, the traveller who expressed overt enthusiasm about another nation, government, faith or culture 'ran the risk of treasonably denigrating their own country'. ${ }^{23}$ Like rogues and vagrants, English authorities were wary of the traveller's

20 Ibid., p. 21. On early modern English travel advice literature and the tradition of the ars apodemica, see Artes Apodemicae and Early Modern Travel, ed. by Karl A. E. Enenkel \& Jan de Jong (Leiden; Brill, 2019); Joan-Paul Rubiés, 'From the History of Travayle to the History of Travel Collections: The Rise of an Early Modern Genre', in Richard Hakluyt and Travel Writing in Early Modern Europe, ed. by Daniel Carey and Claire Jowitt (Farnham: Ashgate, 2012), pp. 24-44; and The Art of Travel, 1500-1850 database <https://artoftravel.nuigalway.ie/> [Accessed 20 January 2021]. 21 Francis Bacon, The Essayes or Counsels, Civill and Morall, ed. by Michael Kiernan (Oxford: Clarendon Press, 1985), p. 58.

22 Edward Terry, A voyage to East-India (London, 1655: Wing T782), p. 453.

23

Hadfield, Amazons, Savages, and Machiavels, p. 13. 
loyalties, questioning their ability to 'transform themselves into strangers' when they returned. ${ }^{24}$

The substantial body of anti-travel literature produced in the period includes Roger Ascham's Scholemaster (1570), which described the 'English man Italianated' as one who, 'by living, and travelling in Italie, bringeth home into England out of Italie, the Religion, the learning, the policie, the experience, the maners of Italie'. ${ }^{25}$ Having travelled to Germany and Italy, Ascham admitted, his attempts to learn the language had led him dangerously close to becoming 'almost an Italian myself' ${ }^{26}$ The Calvinist theologian Thomas Holland, who had spent time in the Netherlands, wrote of the pernicious effects of travelling into Catholic nations in particular. While Holland notes that 'the wise and godly may suck sweetnes out of travail', he also describes the 'great abuses by travaile, and by it many corruptions have crept into florishing nations'. ${ }^{27}$ Holland blamed 'unprofitable, daungerous, and foolish travellers' who 'come to gaze, \& to bee gazed on' rather than to learn. ${ }^{28}$ Another vehement critic of travel was the Norfolk bishop Joseph Hall, who lamented 'how few young travellers have brought home, sound and strong, and (in a word) English bodies'. ${ }^{29}$ Popular culture replicated such critiques. In The English ape, the Italian imitation, the foote-steppes of Fraunce (1588), William Rankins described the destructive potential of the 'merchandize' gathered by the English traveller: 'Thus (imitating the Ape) the Englishman killeth his owne with culling [...] He lovingly bringeth his merchandize into his native Country, and there storeth with instruction the false affectors of this tedious trash' $3^{3}$ In Thomas Nashe's prose fiction, The unfortunate traveller (1594), the apish English traveller becomes a figure of

24 Alison Games, Web of Empire: English Cosmopolitans in an Age of Expansion, 1560-1660 (Oxford: Oxford University Press, 2008), p. 25.

25 Roger Ascham, The scholemaster (London, 1570; STC 832), p. 26. On the critique of travel, see also Andrew Hadfield, 'The Benefits of a Warm Study: The Resistance to Travel before Empire', in A Companion to the Global Renaissance: English Literature and Culture in the Era of Expansion, ed. by Jyotsna Singh (Chichester: Blackwell, 2009), pp. 101-113; Sara Warneke, Images of the Educational Traveller in Early Modern England (Leiden: Brill, 1994); Nandini Das, Renaissance Romance: The Transformation of English Prose Fiction, 1570-1620 (Farnham: Ashgate, 2011), p. 99. 26 The Whole Works of Roger Ascham, Vol. 1, Part II, ed. by J. A. Giles (London: John Russell Smith, 1865), p. 266.

27 Thomas Holland, Paneguris D. Elizabethae, Deigratiâ Angliae, Franciae, \& Hiberniae Reginae (London, 1601; STC 13597), sig. D4r.

28 Ibid.

29 Joseph Hall, Quo vadis? A just censure of travell as it is commonly undertaken by the gentlemen of our nation (London, 1617; STC 12705), p. 18.

30 William Rankins, The English ape, the Italian imitation, the footesteppes of Fraunce (London, 1588; STC 20698), pp. 2-3. 
ridicule, observed curiously by locals. 'At my first coming to Rome', Nashe's page-boy hero, Jack Wilton reports, 'I, being a youth of the English cut [...] imitated four or five sundry nations in my attire at once, which no sooner was noted, but I had all the boys of the city in a swarm wondering about me'. ${ }^{1}$ For many commentators, foreign travel and the adoption of certain positive customs at home was no bad thing, while most believed that unfettered interaction and 'aping' of foreign examples could lead to the loss of an individual's national and cultural identity.

English officials sought to regulate movement abroad through stricter monitoring processes, such as the granting of passports and licences. These were granted by the Crown to signify that an individual had permission to travel abroad. In 1599, Lord Willoughby reported that another noble, Lord Hume, was 'disposing of himself to travell' and had requested that Queen Elizabeth grant him a 'passport, and transportance as are needfull to a traveller' ${ }^{2}$ With the exception of established merchants, individuals were required by law to request permission to leave the country, under the condition that they 'do not haunte or resorte unto the territories or dominions of any foreign prince or potentate not being with us in league or amitie'. ${ }^{33}$ This included passports for female travellers, as when Mary I's lady-in-waiting, Jane Dormer, Duchess of Feria, travelled with her Spanish husband the Duke of Feria to Madrid via the Low Countries. ${ }^{34}$ These passports not only shed light on individual travellers but on their retinues and wealth: Dormer travelled with six gentlewomen, a laundress, a yeoman of the wardrobe, five gentlemen, two pages, two chaplains, seven 'gentlemen's men', a large number of horses and mules, silver, jewels, and dogs. ${ }^{35}$ In addition, Dormer acquired a passport for her mother, her mother's servants and chaplains, and other attendants. ${ }^{36}$ As such licences show, passports were designed to protect the individual and the state, seeking to monitor the circulation of people and goods into foreign spaces and to curb a traveller's spontaneous decision to visit places not designated in their passport.

31 Thomas Nashe, The unfortunate travaller. Or, The life ofJacke Wilton (London, 1594; STC 18380) p. 326.

32 Lord Willoughby to Sir William Knollys, Comptroller of the Household, 21 April 1599, Hatfield House, CP 31/101.

33 Quoted in Clare Howard, English Travellers of the Renaissance (New York: John Lane, 1913), p. 86.

34 Note of a passport required for the Countess of Feria, 1559, Kew, The National Archives, SP 15/9/1, f. 87 .

35 Ibid.

36 Ibid. 
Although the Tudor administration sought to exert greater control over those who crossed its boundaries, the attempts to regulate the movement of travellers was only so effective. Once abroad, travellers could ignore the parameters of the licence, choosing to travel where they wished, and for longer amounts of time than such licenses allowed. Edward, Lord Zouch described his passport as nothing less than 'an imprisonment', complaining that he could not 'tell whether I shall do well or not to touch the part of the licence which prohibited me in general to travel to some countries' ${ }^{37}$ In the 1570s, Edward de Vere, seventeenth Earl of Oxford, went to the Low Countries without a licence, then on to Italy. Despite attempts by William Cecil, the earl's father-in-law and secretary of state, to call him back, de Vere refused to return.$^{8}$ Some years later, James I himself acknowledged the difficulty of enforcing the licenses abroad, noting how travellers 'under pretence of travel for their experience, do pass the Alps [...] [and] daily flock to Rome, out of vanity and curiosity to see the Antiquities of that City; where falling into the company of Priests and Jesuits'. ${ }^{39}$ As James suggested, the root cause behind spiritual warfare and fears of political degeneration was often the potency of wonder and the issue of return. The beguiling alternatives to English life that travellers encountered abroad always carried the possibility of rendering the traveller 'averse to Religion and ill-affected to Our State and Government'. ${ }^{\circ}$ Cross-cultural encounters thus risked splitting the loyalties of an individual. This concern became increasingly problematic as travellers became colonists and settlers, the chief instruments in English expansion. This sense of separation or distance is evident in letters and poems between friends: 'Went you to conquer? And have you so much lost / Yourself?' John Donne writes in a poem to his friend Henry Wotton, then in Ireland. ${ }^{41}$

Whether on royal progress from Edinburgh to London or on board a ship crossing the Indian Ocean, the traveller fought the perils of disease and violence and risked death to experience the unfamiliar, satisfy curiosity, or out of political or spiritual devotion. While the experience of travel in the sixteenth and seventeenth centuries varied widely depending on the individual and his or her purpose, the 'traveller' in much English writing

37 Edward Lord Zouch to Lord Burghley, 20 August 1591, Kew, The National Archives, SP 12/239, f. 238 .

38 Howard, English Travellers, p. 65.

39 Quoted in Howard, English Travellers in the Renaissance, pp. 87-88.

40 Logan Pearsall Smith, The Life and Letters of Sir Henry Wotton, Vol. 1 (Oxford: Oxford University Press, 1907), p. 70 .

41 John Donne, 'Henrico Wotton in Hibernia Belligeranti', in The Complete Poems ofJohn Donne, ed. by Robin Robbins (Harlow: Longman, 2010), p. 89 . 
evoked a specific type, one who returned home after their journey, and who asserted their authority as an eyewitness. The traveller-turned-author, one who self-consciously used their narrative to explore the bounds of truth and fantasy, was a well-entrenched persona by the later seventeenth century. 'I was my self an Eye-Witness, to a great part, of what you will find here set down', Aphra Behn wrote at the start of Oroonoko (1688), 'in a Colony in America, called Suriname, in the West-Indies..$^{22}$ Oroonoko was not a straightforward travel book, but a romance woven with observations about life on a South American plantation. Behn's exploration of cultural interactions between Africans, Native Americans, and Europeans, played out on a heroic scale, reinforced what the scholar John Stoye wrote of Elizabethan travellers, that there existed 'a distinct idea of travel as an "art". 43 Urbane, self-sufficient, and wilfully-mobile, the 'traveller' was open to the wonders and variety of the world but guarded against over-indulging in the temptations of the foreign. Ultimately, travel tended to be viewed as a temporary activity. Like Odysseus' trajectory, the ultimate aim was to return, even if home did not always look the same after being elsewhere.

Related keywords: ambassador, exile, merchant, rogue, subject

42 Aphra Behn, Oroonoko, or, The royal slave (London, 1688; Wing B1749), pp. 2-3. On travellers as witnesses, see Nandini Das, 'Hakluyt', in The Oxford Handbook of English Prose, 1500-1640, ed. by Andrew Hadfield (Oxford: Oxford University Press, 2013), pp. 292-309.

43 Stoye, English Travellers, p. x. 


\section{Turk}

'Turk' was a mutable word in early modern England, difficult to untangle from a range of associations with Muslims, the Ottoman imperial state, and English converts to Islam. ' 'Turks' were often synonymous with Ottomans and the power of Ottoman sultans, while Muslims originating from central Asia or Africa could also be described as such. ${ }^{2}$ Elizabethan and Stuart encounters with Ottomans through popular print, sermons, travel literature and plays revealed a rich, if at times contradictory, interaction with ideas of the Turk. ${ }^{3}$ Alongside a sense of awe at Ottoman imperial power, there were accounts of pirates who converted to Islam, Englishmen enslaved on Ottoman galleys, and travellers such as George Sandys who, behind assumptions of Christian superiority, admired aspects of Muslim hospitality or charity. This was not a world in which Europe necessarily emerged superior. ${ }^{4}$ The 'mightie Empire of the Turks', acknowledged the historian and translator Richard Knolles in 1603, was 'the greatest terror of the world, and holding in subjection many great and mightie kingdomes'. ${ }^{5}$

English imperial rivalry with Spain in the Atlantic also implicated the Islamic world. Not only did the Ottomans serve as an exemplum for empire, but the English frequently relied on Spanish writings that positioned the Atlantic within a long history of Christian conquest and conversion against 'Moors', 'Turks', and 'infidels' in the East. ${ }^{6}$ To many sixteenth-century Spanish authorities, colonisation in Central and South America was an extension

1 Gerald MacLean, Looking East: English Writing and the Ottoman Empire Before 1800 (Basingstoke: Palgrave, 2007), p. 8; 'Turk, n.', Oxford English Dictionary.

2 MacLean, Looking East, p. 1.

3 Ibid., p. 5. See also Jerry Brotton, The Sultan and the Queen: The Untold Story of Elizabeth and Islam (New York: Viking, 2016); Matthew Dimmock, Mythologies of the Prophet Muhammad in Early Modern English Culture (Cambridge: Cambridge University Press, 2012); Gerald MacLean and Nabil Matar, Britain and the Islamic World, 1558-1713 (Oxford: Oxford University Press, 2011); The Dialectics of Orientalism in Early Modern Europe, ed. by Marcus Keller and Javier Irigoyen-García (London: Palgrave, 2018). Many of these texts challenge or modify Edward Said's influential Orientalism (1978), which argued that 'the Orient' is, and always has been, a construction or 'cultural enterprise' created largely by imperial-minded Western travellers. Edward Said, Orientalism: Western Conceptions of the Orient (New York: Penguin, 1978), pp. 4-5. 4 Ian Smith, 'The Queer Moor: Bodies, Borders, and Barbary Inns', in A Companion to the Global Renaissance: English Literature and Culture in the Era of Expansion, ed. by Jyotsna G. Singh (Chichester: Blackwell, 2009), pp. 190-204 (p. 198).

5 Richard Knolles, The generall historie of the Turkes (London, 1603; STC 15051), sig. A4v.

6 Barbara Fuchs, Mimesis and Empire: The New World, Islam, and European Identities (Cambridge: Cambridge University Press, 2001). 
of centuries-old conflicts against Islamic peoples, as when the chronicler Francisco López de Gómara wrote in the mid-1550s that the 'conquest of the Indians began after that of the Moors was completed, so that the Spaniards would ever fight the infidels'? The naval officer Richard Hawkins, complaining of his imprisonment in Seville in a letter to Queen Elizabeth, criticised the prevalence of 'turkes' in the Mediterranean and accused Spain of being 'peopled of a myngled nacion of moores, turkes, jues \& negroes', believing this caused civil unrest more than 'domestic enemyes'. ${ }^{8}$ Hawkins's letter evoked the transcultural Mediterranean world with its mixed ethnicities, where the range of Islamic, Christian, Jewish, and African beliefs and peoples were collapsed into uncertain categories whose identifications could hardly be encapsulated in broad terms like 'Moor' and 'Turk'.

While the English had encountered 'Turks' in the Mediterranean and at sea, Queen Elizabeth was the first English monarch to allow her subjects to trade and interact with Muslims without being liable for prosecution for dealing with 'infidels'. ${ }^{10}$ The creation of the Levant Company in 1592, a merger between the Turkey Company and Venice Company, led to a series of trade and diplomatic negotiations in transcultural contact zones. ${ }^{11}$ This included Muslim powers such as the Safavids of Persia or Mughals of India, but also significant contact with Ottomans and North Africans. ${ }^{12}$ George Manwaring, who travelled to the Ottoman Empire and Persia in the retinue of the adventurer Anthony Sherley in the late 1590s, recorded an incident in which he used 'Turk' as a more disparaging term that contrasted with the identity of the janissaries, or elite soldiers, in Sherley's company. 'I met with a Turk', Manwaring wrote, who insulted and struck him, after which a janissary rose to the Englishman's defence and severely beat the offender's feet until he could no longer walk. ${ }^{13}$ Manwaring's account evoked a system

$7 \quad$ Quoted in ibid., p. 7.

8 'Richard Hawkins to Queen Elizabeth, 12 June 1598', Hatfield House, CP 177/36[61?].

9 On the overlap between 'racial etymologies', see Imtiaz Habib, Black Lives in the English Archives, 1500-1677: Imprints of the Invisible, 2nd edn (Abingdon: Routledge, 2016), pp. 13, 21.

10 Nabil Matar, Turks, Moors, and Englishmen in the Age of Discovery (New York: Columbia University Press, 1999), p. 19.

11 Nandini Das, “Apes of Imitation”: Imitation and Identity in Sir Thomas Roe's Embassy to India', in A Companion to the Global Renaissance, pp. 114-128.

12 A Companion to the Global Renaissance, pp. 6-7. See also Brotton, The Sultan and the Queen; Dimmock, Mythologies of the Prophet Muhammad; MacLean and Matar, Britain and the Islamic World.

13 Manwaring's account is cited in Imtiaz Habib, 'Othello's "Malignant Turk" and George Manwaring's “A True Discourse”: The Cultural Politics of a Textual Derivation', Medieval and Renaissance Drama in England, 26 (2013), 207-239. 
of honour and disgrace that undercut religious and political difference, in which the base or uncivil behaviour of the 'Turk', however gallant he had initially appeared, contrasted to that of the officers of the law. ${ }^{14}$

Portraying them as luxurious and ruthless in battle, the English admired 'Turks' for their military might and commercial potential. 15 'Who can deny that the Emperor of Christendome hath had league with the Turke', Richard Hakluyt wrote in 1599; " $[w]$ hy then should that be blamed in us, which is usuall, and common?"16 At the same time, English churchmen, travellers, and policymakers often condemned Ottomans for their Islamic faith. Memories of the 1571 Battle of Lepanto, in which Catholic forces defeated the Ottoman fleet in the Mediterranean, still lingered powerfully over the European imaginary into the seventeenth century. In 1603, London printers reissued King James's poem on Lepanto in the aftermath of his ascension to the English throne. Framed in highly biblical language, the heroic verse celebrated the 'bloudly battell' between 'the baptiz'd race, / And circumcized Turband Turkes'. ${ }^{17}$ James conformed to commonplace assumptions that the ethnographic identity of the 'Turk' was inseparable from religion: 'Are we not day by day / By cruell Turkes and Infidels / Most spitefully opprest?'18

Beyond military strength and religion, visual differences set Ottomans apart. James I's reference to the 'circumcized Turband Turkes' captures some of the primary markers of the 'Turk' in early modern England: bodily modification and the turban. Costume books and cosmographies often visually depicted turbans as key markers of Turkishness. ${ }^{19}$ The English considered the practice and ritual of circumcision to be a fundamental part of Turkish identity, a rite shared with Jewish practices that raised profound anxieties about the irreversibility of conversion away from Christianity. The pirate John Ward, for example, died in Tunis in 1623, having converted to Islam by 1610 and adopted the name of Issouf Reis (Yusuf Raïs). ' [O]nce a great Pyrat', the Scottish traveller William Lithgow wrote, recalling his meeting with Ward in Tunis, 'in despight of his denied acceptance in England had turned Turke, and built there a faire Palace, beautifyed with rich Marble and

\footnotetext{
14 Ibid., p. 210.

15 Matar, Turks, Moors, and Englishmen, p. 19.

16 Quoted in Anders Ingram, Writing the Ottomans: Turkish History in Early Modern England

(Basingstoke: Palgrave, 2015), p. 92.

17 James I, His Majesties Lepanto (London, 1603; STC 14379.3), sig. A4r.

18 Ibid., sig. Biv.

19 The Turk and Islam in the Western Eye, 1450-1750: Visual Imagery before Orientalism, ed. by James G. Harper (Farnham: Ashgate, 2011).
} 
Alabastor [...] With whom I found Domestick some fifteene circumcised English Runnagats'. ${ }^{20}$ Lithgow's report acknowledged an uncomfortable truth: that a rejection of Christianity could lead to a prosperous life.

Ward gave Lithgow a magnanimous welcome, but English authorities in London viewed Ward's willingness to 'turn Turk' as an act of damnation and disloyalty. Circumcision was an irrevocable physical act, and plays like Robert Daborne's A Christian turn'd Turke (1612) recast Ward's trajectory as one that inevitably led to divine punishment. The malleability of the human body and soul to the customs of the Turk presented a problem in cases of English prisoners subjected to forced circumcision. When Richard Burges and James Smith, two young men captured in Tripoli in 1583, refused to convert to Islam, they were told 'thou shalt presently be made a Turke', implying that 'turning Turk' could be a forcible act wrought by physical change. ${ }^{21}$ Afterwards, Burges strongly resisted this notion by proclaiming that although 'they had put on him the habite of a Turke', nonetheless a 'Christian I was borne, and so I will remaine, though you force me to doe otherwise.'.22

Direct contact between Englishmen and Ottomans often happened at sea. Captivity accounts related the stories of fearful encounters between sailors and merchants that could lead to death or capture. Edward Webbe recounted his 'time in the wars and affayres of the great Turke' during and following his capture, narrating his travels through Damascus and Constantinople, Persia and the Mughal Empire, in service of the Ottoman army in the $1570 \mathrm{os}^{23}$ The English state maintained that captives who forcibly turned Turk had not lost their status as subjects; they continued to be subjects of the English Crown. ${ }^{24}$ On several occasions the Crown sent officials to ransom English captives and converts in the hope that they would return to England and reconvert. ${ }^{25}$ Stories like Webbe's were disseminated in London by cheap print, which often carried a strong didactic edge, ending with subjects re-entering the fold of the English community. The popularity of printed

20 William Lithgow, The totall discourse, of the rare adventures (London, 1640; STC 15714), sig. Aa3v.

21 Thomas Sanders' account of 'The voyage made to Tripolis in Barbarie, in the yeere $1583^{3}$, in Richard Hakluyt, The principal navigations (London, 1599-1600; STC 12626a), sig. Q5r.

22 Ibid.

23 Edward Webbe, The rare and most wonderfull things which Edw. Webbe an Englishman borne, hath seene and passed in his troublesome travailes (London, 1590; STC 25152), title page.

24 Edmund Cason, A relation of the whole proceedings concerning the redemption of the captives in Argier and Tunis (1647; Wing R89o), p. 9.

25 John B. Wolf, The Barbary Coast: Algiers Under the Turks, 1500 to 1830 (New York: W. W. Norton, 1979), p. 237. 
captivity narratives and broadsides heavily shaped popular understandings of Islam in early modern England, portraying cross-cultural interactions in the religious, redemptive language of Protestant reform. ${ }^{26}$ The ethno-biblical perspective that dominated much writing about the Ottomans in the Tudor period shifted under the Stuarts. By the 1640s, accounts often framed captives as explorers and adventurers who provided valuable intelligence about Ottoman affairs, particularly in matters of business and trade, the result of increased engagement with the Ottomans in the seventeenth century. ${ }^{27}$

Travellers were not the only ones to encounter Ottomans. In 1625, a report to the privy council noted that there were ' 3 or 4 Turkes or Moores' in Exeter, the same in Bristol, and some 30 in Plymouth. ${ }^{28}$ While Muslims who came to England were often captured pirates or merchant seamen, there were others too. ${ }^{29}$ High-ranking officials, such as the Moroccan ambassador Abd el-Ouahed ben Messaoud, visited the Elizabethan court in 1600, where they would enjoy the protection of the monarch and freely wear North African clothes. A surviving portrait of the ambassador in a white turban and richly embellished sword depicts a man of elite status permitted to proclaim his distinct heritage. This suggests that the treatment of Muslims in early modern England was, as with many other groups, often largely dependent on social rank.

Though the English encountered 'Turks' and 'Mahometans' in religious polemic, popular print, and travel and diplomatic exchange, large audiences also saw Ottomans represented on the stage. In plays, Islam became 'a discursive site upon which contesting versions of Englishness, Christianity, masculinity, femininity, and nobility are elaborated and profferred'. ${ }^{30}$ More than sixty plays featured 'Turks', Moors, and Persians in the 1570 s to $1603 .{ }^{31}$ Marlowe's thunderous Tamburlaine (c. 1587) in many ways embodies the 'imperial envy' that the English exhibited towards the might of central Asia in this period.$^{32}$ Tamburlaine's conquering energies and thirst for slaughter are fuelled by his defeat of the Turkish emperor, who goads him to escalating

Ibid., sigs. $\mathrm{C}_{3} \mathrm{v}-\mathrm{C} 4 \mathrm{r}$.

7 MacLean and Matar, Britain and the Islamic World, pp. 131-132.

28 Matar, Turks, Moors, and Englishmen, p. 25.

29 Ibid., p. 32.

30 Jonathan Burton, Traffic and Turning: Islam and English Drama, 1579-1624 (Newark: University of Delaware Press, 2005), p. 28.

31 Brotton, The Sultan and the Queen, p. 172.

32 Christopher Marlowe, Tamburlaine the Great (London, 1590; STC 17425), sig. K6r; MacLean, Looking East, p. 20; Emily C. Bartels, Spectacles of Strangeness: Imperialism, Alienation, and Marlowe (Philadelphia: University of Pennsylvania Press, 1993). 
violence. Plays that staged or referenced Ottomans often related turbans to the unseen but physical presence of circumcision. ${ }^{33}$ When the pirate John Ward 'takes the turban' in A Christian turn'd Turke, he is required to undergo circumcision, though Ward evades this rite through deception. ${ }^{34}$

As the English sought to consolidate their position in the Mediterranean, they came under pressure to engage with Ottomans as commercial and even legal equals. The 1686 articles of peace between England and Algeria declared that if an Englishman ever struck, wounded, or murdered a 'Turke or Moor' in the 'Kingdom of Algiers' they were to 'be punished in the same manner, and with no greater severity th[a]n a Turk ought to be'. ${ }^{35}$ However, not everyone supported growing trade relations with the Ottoman empire. Just as the importation of luxury products from South Asia or the Americas came under attack, so too did coffee, that 'exotic' commodity that became popular from the mid-seventeenth century. Broadsides rebuked the growing trend for drinking coffee in English towns and cities such as London or Oxford. A Broad-side against COFFEE; Or, the Marriage of the Turk (1672) sexualised the consumption of coffee as an act of cultural commingling. The verses describe a marriage between Coffee, a 'Turkish renegade', and Christian England, a 'melting Nymph', through a series of sexual innuendos and racialised associations that pitch coffee as an assault on English purity: 'Coffee so brown as berry does appear, / Too swarthy for a Nymph so fair' ${ }^{36}$

An element of Ottoman life that the English remained largely approving of was that of female submission. The 'wife of a Turke dare never come where a company of men be gathered together: neither is it lawfull for them to go to markets to buy and sell [...] [in public] There is seldome any speech or conference betwixt men and women'. ${ }^{37}$ English writers at times evoked Turkish women to critique the outspokenness and brazenness of women in England. ${ }^{38}$ In Philip Massinger's The Renegado (c. 1630), a North African

33 Robert Lublin, Costuming the Shakespearean Stage: Visual Codes of Representation in Early Modern Theatre and Culture (Farnham: Ashgate, 2011), p. 146.

34 Ibid., p. 147; Robert Daborne, A Christian turn'd Turke (London, 1612; STC 6184), sig. F3r.

35 Articles of peace and commerce between the most serene and mighty prince James II [...] and the most illustrious lords, the Douletli Basha, Aga \& Governours of the famous city and kingdom of Algiers in Barbary ratified and confirmed by Sir William Soame (London, 1687; Wing J153), p. 14. ${ }_{3} 6$ A broad-side against coffee; or, the marriage of the Turk (London, 1672; Wing B4830) [single sheet].

37 Johannes Boemus, The manners, lawes, and customs of all nations, trans. by Edward Aston (London, 1611; STC 3198.5), pp. 148-149.

38 Nabil Matar, 'The Representation of Muslim Women in Renaissance England', The Muslim World, 86 (1996), 50-61 (p. 58); Bernadette Andrea, Women and Islam in Early Modern English Literature (Cambridge: Cambridge University Press, 2007); Walter G. Andrews and Mehmet 
queen notes that 'Christian ladies live with much more freedome [...] our jealous Turkes, / Never let their poor wives to be seene', but prefer them 'vayled, and guarded'. ${ }^{39}$ Modestly-clad Turkish women in veils appeared in drawings and costume books, and veils became popular costumes for elite women in English court masques. When George Sandys observed during his travels that Ottoman women revealed their beauty only in private, to their families or husbands, he did not cast this in a negative light. ${ }^{40}$ Rather, English writers seemed both fascinated by the sexual license of Ottoman men, and largely approving of the submission of Ottoman women. ${ }^{41}$ The seraglio of the sultan became, to the English, 'a proverbial site for sexual excess, sadistic entertainments, and private, pornographic spectacle', impelling Edgar in King Lear to boast that in women, he had 'out-paramoured the Turk'. ${ }^{2}$

The figure of the Turk (and the related 'Mahometan') in Tudor and Stuart England raised a series of interrelated questions about identity and empire, luxury and political economy. At a time when the English sought to convey their own authority and legitimacy as a Protestant nation in a global context fraught with confessional strife, English writers struggled with the allure and seeming transgressiveness of the Islamic Ottoman world. What Erasmus had deemed the 'power-lust' of the Turk was both a cautionary tale and a thing of wonder. ${ }^{43}$ Yet much changed between perception of the Ottomans in the 1520 and a hundred years later, where confessional conflict began to unfold into one of the bloodiest in European history with the Thirty Years' War (1618-1648), and again in the later seventeenth century as the English expanded their commercial empire. Moreover, more moderate perceptions of Ottoman life circulated alongside the discourses about Turkish might penned by soldiers, prisoners, and playwrights. An album of watercolours from the 158 os, for example, possibly produced in Constantinople by European artists, engaged with the diversity of Ottoman life. The bright illustrations include a view of the Topkapı Palace and 'A Coffee drinker' (likely a dervish,

Kalpakh, The Age of Beloveds: Love and the Beloved in Early Modern Ottoman and European Culture and Society (Durham, NC: Duke University Press, 2005).

39 Matar, 'The Representation of Muslim Women in Renaissance England', p. 51.

40 Ibid., p. $5^{2}$.

41 Ibid.

42 Daniel J. Viktus, 'Early Modern Orientalism: Representations of Islam in Sixteenth and Seventeenth-Century Europe', in Western Views of Islam in Medieval and Early Modern Europe: Perception of Other, ed. David R. Blanks and Michael Frassetto (New York: St. Martin's Press, 1999), pp. 207-230 (p. 223).

43 Matthew Dimmock, New Turkes: Dramatizing Islam and the Ottomans in Early Modern England (Aldershot: Ashgate, 2005), p. 20. 
or religious man) in a sheepskin cloak, multicoloured cap, and large gold earring. ${ }^{44}$ The album labels, in English, offer a sliver of insight into English curiosity about Ottoman life, including coffee-drinking, from an earlier period than might be expected. Commenting on his travels through the Levant in the 1610s, George Sandys recounted how the 'Saracens and Turks' who 'enlarged their Empires, doth at this day wel-nigh over-run three parts of the earth; of that I mean that hath civill Inhabitants'. ${ }^{45}$ The 'Turk' did not just exist in the English imaginary, then, but represented a global reality that the English were increasingly forced to confront, one that was more 'civill' than they were at times willing to admit.

Related keywords: convert, heathen, Mahometan, pirate

44 'Dryden Album', c. 1580-1590, Cambridge, Trinity College Library, MS R.14.23, f. 28r; William Kynan-Wilson, 'Souvenirs and Stereotypes: An Introduction to Ottoman Costume Albums', Heritage Turkey, 3 (2013), 35-36.

45 George Sandys, Sandys travailes containing a history of the originall and present state of the Turkish empire (London, 1652; Wing S677), p. 42. 


\section{Vagrant/Vagabond}

The Anglo-Norman wakerant and its variants were associated with Latin vagari (to wander), and through that to 'vagabond', a word whose variants appear in French, Italian, Portuguese, and multiple other European languages. ${ }^{1}$ In England, they represented a threat to law and order in the earliest recorded uses in legal enactments from the fourteenth century, and continued to attract similar attention in centuries to follow. In a speech to the Lord Mayor and the governors of Christ's Hospital in 1676, Benjamin Long demanded that all vagrants leave London so they would no longer 'infest the Air' of the city with their 'noysom breath'. ${ }^{2}$ Long's speech was partly a reaction to the rapid population growth of the sixteenth and seventeenth centuries, which had resulted in a large underemployed migratory labour force. As early as 1583, the English pamphleteer Philip Stubbes maintained that various travelling groups, such as tramps and itinerant beggars, 'runne roging like vagarents up \& downe the countries like maisterlesse men'. ${ }^{3}$ The glut in the rural labour market meant that England's towns and cities underwent a period of substantial urban growth, as people migrated from rural to urban areas in search of work. From 1520 to 1700 , London's population increased nearly tenfold, from 60,000 to an estimated 575,000 , bringing increased numbers of unemployed or seasonally employed 'maisterlesse men' who migrated to the city. ${ }^{4}$ Local and national authorities perceived 'masterless men' as a threat to hierarchical, patriarchal society, and sought to restrict and prevent the influx of the unemployed poor. ${ }^{5}$ One method of doing so was to differentiate between the 'deserving' and 'undeserving, or the impotent poore' and 'impudent poore. ${ }^{6}$ 'Vagrants' were placed in the latter category. Scorned for their landlessness, mobility, and suspect occupations, vagrants, alongside rogues,

1 'Vagrant, $n$. and adj., Oxford English Dictionary.

2 Benjamin Long, An oration spoken in the grammar-school of Christ's-Hospital before the right honourable the Lord Mayor (London, 1675; Wing O366), p. 8.

3 Keith Wrightson and David Levine, Poverty and Piety in an English Village: Terling, 1525-1700 (Oxford: Oxford University Press, 1995), p. 4; Philip Stubbes, The second part of the anatomie of abuses (London, 1583; STC 23380), p. 367.

4 Peter Clark and Paul Slack, English Towns in Transitions, 1500-1700 (Oxford: Oxford University Press, 1976), p. 83; Wrightson and Levine, Poverty and Piety, p. 4.

5 A. L. Beier, Masterless Men: The Vagrancy Problem in England, 1560-1640 (New York: Methuen, 1986).

6 Nehemiah Rogers, The good Samaritan; or an exposition on that parable (London, 1658; Wing R1823A), p. 91. 
vagabonds, enslaved peoples, apostates, itinerant ministers, and others, were considered a 'blemish of our government, and a burthen to the commonwealth' and like rogue were for the most part members of the lower classes. ${ }^{7}$ Authorities placed vagrants under severe legal restrictions that were both popular and onerous, introducing 'extreme punishement of all vagarantes'. ${ }^{8}$ By the end of the seventeenth century, Long's perception of vagrants as a 'verminous brood' who 'swarm and poison our streets' was commonplace, as was his hope that they 'meet with the lash, and be taught the Lesson of Industry'. ${ }^{9}$

As noted in the discussion of the related keyword, 'rogue', literature and plays provided a means of both expressing and exploiting anxieties about social order and unrest. The subject of paranoid fixation, vagrants became scapegoats for tribulations that individual towns and the nation faced. Those who were most vulnerable to the large-scale socio-economic changes of the period often became those most harshly punished for their existence. In texts such as John Awdelay's The fraternitye of vacabondes (1561), Thomas Harman's A caveat for commen cursetors vulgarely called vagabones (London, 1567), and Robert Greene's popular cony-catching pamphlets of the 159os, they came to represent a form of alterity to social order, which was as fascinating as it was threatening.

Throughout such debates, authorities used the word 'vagrant' to refer to specific individuals, and as a blanket word for the undeserving poor, defined by unemployed migratory status. Occupying the other side of the spectrum were the 'deserving poor', who were provisioned for on a local level through national and parish legislation. The deserving poor included those who were precluded from working due to age, health, or familial situations, in need of charity 'through necessitie and not of choise. ${ }^{10}$ Often, the deserving poor were linked to specific parishes, whereas the vagrant was defined by their mobility and a lack of belonging, with early modern descriptions emphasising their placelessness. As early as 1496, statutes were passed ordering parishes to provide provisions for these individuals. ${ }^{11}$ At the same time, those who were considered to fall within the brackets of these 'uncomely companies' of 'idle vagrants' were immediately placed beyond the boundaries of poor relief and considered 'altogether unworthy of any

7 John Downame, The plea of the poore (London, 1616; STC 7146), p. 38.

8 Thomas Harman, A caveat for commen cursetors vulgarely called vagabones (London, 1567;

STC 12787), p. 3 .

9 Long, An oration spoken, p. 8.

10 Downame, The plea of the poore, p. 38; Rogers, The good Samaritan, p. 91.

11 'Act against Vagabonds and Beggars', 1494, 11 Hen. VI c. 2. 
almes. ${ }^{12}$ The mass migration of the poor into town, cities, and colonies meant that those categorised as 'vagrants' played a key, although negatively viewed, part in the growth of urban spaces. 'Swarming like caterpillars', vagrants were accused of 'walking without shame, in theft, drunkennesse, and whoredome, in prophanenesse of life, and all ungodlinesse, swearing and cursing, lying and murthering, begetting a monstrous ofspring'.13 In creating strict legislation against them, authorities hoped to prevent 'indiscreete and wastfull giving' to 'counterfeit poore, or to vagrant and inordinate persons. ${ }^{14}$ Between $155^{\circ}$ and 1700 , vagrants expanded to include a variety of professions that were believed to be socially and legally unacceptable: seamen, who lived 'alwaies as vagarants', to 'tinkers', 'pedlers', 'English fugitives, vagrant in forraine Regions', 'Mercenarie preachers' and 'Usurers, Brokers [...] Ruffians, Blasphemers, Tiplers, Churles, Wantons, Pedlers of pernicious wares; Seminaries, Incendiaries, Apostates, Humorists'. ${ }^{15}$ Whether considered an individual vagrant or a member of a vagrant group, like Gypsies, those who so identified were seen to be 'seditious troublers of our peace' by the legal, political, and religious leaders of Tudor and Stuart England. ${ }^{16}$ One particular profession famously implicated as such were actors, for whom touring left them vulnerable to charges of vagrancy. ${ }^{17}$ However, as Jeffrey Knapp has pointed out there were legal distinctions 'between licensed and unlicensed players' which centred on the 1572 Act for the Punishment of Vagabonds..$^{18}$ Nonetheless, professional actors who were licensed and had fixed abodes still struggled to shake the longstanding perception that they were 'masterless men' and vagrants as detractors of the theatre continued to discredit them. ${ }^{19}$

\footnotetext{
12 Robert Allen, A treatise of christian beneficence (London, 1600 ; STC 367 ), A2r.

13 William Westerman, Two sermons of assise (London, 160o; STC 25282), p. 23.

14 Allen, A treatise of christian beneficence, p. 67 .

15 Richard Barckley, A Discourse of the felicitie of man (London, 1598; STC 1381), p. 367 ; Anno quinto et sexto Eduardi Sexti Actes made in the session of this present parlament, holden upo[n] prorogacion at Westminster (London, 1552; STC 9433), p. xxx; George Whetstone, The English myrror (London, 1586; STC 25336), p. 173; Francis Johnson, An answer to Maister H.Jacob (London, 1600; STC 14658), p. 164; Thomas Adams, The devills banket described in foure sermons (London, 1614; STC 110.5), p. 13 .

16 Adams, The devills banket, p.13.

17 Jeffrey Knapp, Shakespeare's Tribe: Church, Nation and Theater in Renaissance England (Chicago, IL; University of Chicago Press, 2004), pp. 66-67.

18 Ibid., p. 67; 'Act for the Punishment of Vagabonds, and for Relief of the Poor and Impotent', 1572, 14 Eliz. I c. 5 .

19 Knapp, Shakespeare's Tribe, p. 68.
} 
Local and national authorities regularly legislated against vagrancy. This served to remind vagrants of the legal and governmental forces that were vigilant to their presence and encouraged officials to enforce the law and punish those judged to be vagrants. Although Parliament had passed statutes against vagrants from the first half of the fifteenth century, a stream of legislation emerged under the Tudors and Stuarts. Punishment varied and became increasingly harsh. Initially, arrested vagrants were given 'three days and three nights and have none other sustenance but bread and water', a punishment that changed to a whipping in 1530. Six years later, the punishment for repeat offenders was at first cropping (mutilation), then execution. ${ }^{20}$ The Duke of Somerset's 1547 Vagabonds Act provided for certain kinds of vagrants to be enslaved for a period of two years, and if caught trying to escape, the slavery extended for life. ${ }^{21}$ Although quickly repealed in favour of a previous statute, the act, as Ben Lowe has described it, was 'symptomatic of the desperation' felt by successive governments at the 'social dislocations that were occurring throughout the realm. ${ }^{22}$

This dislocation contributed to the development of the Elizabethan poor laws, including the Vagabond Act (1572). This required local 'Overseers of the Poor' to survey and register 'all aged poor impotent and decayed persons' and to punish the individuals harshly. ${ }^{23}$ As with the repeal of the 1547 act mentioned above, the more draconian elements were revised in 1597. This suggests that few local authorities were willing to enact punishments, instead favouring those 'vagrants wandrying and misordering themselves' to be punished by imprisonment 'there to remayne without bayle or maynprise.. ${ }^{24}$ Although the Vagabonds Act of 1597 did act as a reprieve to the more gruesome punishments, it also introduced penal transportation as a form of

20 'Act against Vagabonds and Beggars', 1494, 11 Hen. VI c. 2; 'Act directing how aged, poor, and impotent Persons, compelled to live by Alms, shall be ordered; and how Vagabonds and Beggars shall be punished', 1530, 22 Hen. VIII c. 12; 'Act for Punishment of sturdy Vagabonds and Beggars', 1535, 27 Hen. VIII c. 25.

21 'Act for the Punishment of Vagabonds, and for the Reliefe of the poore and impotent Persons', 1547, 1 Edw. VI c. 3; C. S. L Davies, 'Slavery and Protector Somerset; The Vagrancy Act of 1547', The Economic History Review, 19 (1966), 533-549.

22 Ben Lowe, Commonwealth and the English Reformation: Protestantism and the Politics of Religious Change in the Gloucester Vale, 1383-156o (Farnham: Ashgate, 2010), p. 135.

23 'Act for the Punishment of Vagabonds, and for Relief of the Poor and Impotent', 1572, 14 Eliz. I c. 5 .

24 Annoxiiij. reginae Elizabethe at the Parliament begunne and holden at Westminster the eyght of Maye, in the xiiij. yere of the raigne of our most gratious soveraigne lady Elizabeth (London, 1572; STC 9477a.5). 
punishment for the first time, and impressment into the navy. ${ }^{25}$ The act also directed local authorities as to how they were to deal with vagrant women and children, ordering them to 'be placed with the husband', and, if the husband was deceased, for wife and children to be sent to 'where she was borne or dwelt'. ${ }^{26}$ Furthermore, if 'the vagrant Parents' of children died, local authorities were ordered that they 'once setled must remaine there still' and rely on charity until the age of seven. ${ }^{27}$ This series of acts and statutes passed over the sixteenth century by successive Tudor governments highlighted the concerns of English officials to combat growing levels of internal migration. Through a combination of incentives and punitive measures, they emphasise the identification and legal 'placing' of a person within a specific locality.

In the final years of Elizabeth's reign, the Act for the Relief of the Poor (1601) refined all previous acts. This legislation established a national system of poor relief, punishment, and correction that fundamentally distinguished between vagrants and the settled poor. The act set out the Church as the sole enforcer, ordering parishes to provide poor relief and to set to work the able-bodied poor, including vagrants, while sending away those who refused to the 'house of correction or common Gaol'. ${ }^{28}$ Following the coronation of James I, the act continued to be enforced, and attempts to bolster its effectiveness included new compendia outlining how to apply the law more forcefully. ${ }^{29}$

In 1656, William Foster produced an account of the law in practice, detailing how various counties across England had enforced the 1601 poor laws. This included a case involving a '[v] agrant going under the name of a Souldier' in Kent, who was charged with 'being an idle person, and intending craftily, falsely, and feloniously to deceive and defraud the Keepers of the Libertie of England'. $3^{30}$ The act required that each parish be responsible for poor relief and the punishment of vagrants, and this led to some concern over the status of migrant people in more generous parishes by the second half of the seventeenth century. The Act for the Better Relief of the Poor of this Kingdom (1662), also known as the Settlement Act, attempted to deal with

25 'Act for Punishment of Rogues, Vagabonds and sturdy Beggars', 1597, 39 Eliz. I c. 4.

26 Ibid.

27 Ibid.; see also By the Queene. A proclamation for the due observation of fish dayes, suppressing of unneccessary number of alehouses, and for the better execution of the late acte for punishment of rogues, vagabonds and beggers (London, 1600; STC 8271).

28 'An Acte for the Reliefe of the Poor', 1601, 40 Eliz. I c. 2.

29 The complete justice (London, 1637; STC 14887.5), pp. 132, 177, 223-226.

30 William Foster, The lay-mans lawyers revieved \& enlarged (London, 1656; Wing F1611), p. 67. 
these concerns by establishing which parish a person belonged to, and so who was responsible for their regulation. ${ }^{11}$ The Settlement Act reintroduced transportation as a punishment to individual vagrants whom justices of the peace 'shall think fit to be transported' to English colonies..$^{22}$ Although Parliament continued to legislate against vagrants, the enforcement of the law varied from county to county. Local authorities, such as those in London, interpreted the law in different ways to deal with the pressures created by the poor and vagrants in their constituencies.

The early modern vagrant was part of a social category that left the individual on the fringes or margins of society, in circumstances that involved voluntary migration, perhaps, but also circumstances that forced movement and travel onto people. The effects of the series of acts that sanctioned the transportation of vagrants to England's Atlantic colonies were discussed and contested throughout the seventeenth century. Although the policy of penal transportation had its detractors, some viewed the forced transportation of 'vagrants' to English colonies as a twin solution: it rid the nation of its perceived undesirables while helping address the low population numbers in developing colonies where the death rates remained high. ${ }^{33}$ Richard Boothby, in his description of Madagascar, suggested that the transportation of vagrants would 'disburden' the nation 'of many unnecessary idle vagrant people', benefiting 'English Planters' and the nation. ${ }^{34}$ Likewise, the MP and governor of the East India Company, Josiah Child, noted that the success of England's colonies had in fact been ensured by a 'sort of loose vagrant People'.35

In reference to non-English peoples, the word 'vagrant' also came to be associated with wandering pastoral life, rather than subversiveness. The English view of vagrants as individuals who were both recalcitrant and at times sympathetic figures often featured in accounts of foreign lands, particularly those where the English considered the governing regimes to be particularly corrupt. In his travel compendium, Richard Hakluyt noted

33 Francis Bacon, 'Of Plantation', in The essayes or counsels, civill and morall (London, 1625; STC 1148), p. 199; Misha Ewen, "Poor Soules”: Migration, Labour, and Visions for Commonwealth in Virginia', in Virginia 1619: Slavery and Freedom in the Making of English America, ed. by Paul Musselwhite, Peter C. Mancall, and James Horn (Chapel Hill: University of North Carolina Press, 2019), pp. 133-149.

34 Richard Boothby, A briefe discovery or description of the most famous island of Madagascar (London, 1647; Wing B3744), p. 29.

35 Josiah Child, A discourse about trade (London, 169o; Wing C3853), pp. 170-172. 
the existence of vagrant peoples in Russia. Since in England, 'Tartars' were described as 'living a wild and vagrant life' by refusing to submit to Russian authorities, Giles Fletcher conjectured that the origin of the word 'Tartar' must 'signifieth a Shepheard or one that followeth a vagarant and wilde kinde of life'.$^{6}$ In his account of the Ottoman Empire, Richard Knolles associated vagrants with political exiles who lead a poore exiled and vagrant life', 'banished' and destined to 'lead a miserable and vagrant life', viewing vagrancy as a condition of forced or desperate migration. ${ }^{37}$ Overall, however, the English attitudes towards their own 'vagrants' remained severe, pitting them as a challenge to established law.

Related keywords: exile, Gypsy, rogue, traveller 


\section{Bibliography}

\section{Legal Cases}

Baconv. Bacon (1641) Croke Car. 601, 60279 ER 1117

Blankard v. Galdy (1693) 91 ER 356

Case of the Postnati (16o8) 2 St. Tr. 559

Coke, Edward, Calvin's Case or The Case of the Postnati (1608) 7 Coke Report 1a, 77 ER 377

Collingwood v. Pace (1664) 1 Vent. 413

Crowv. Ramsey (1670) 1 ER 378

Dutton v. Howell (1693) 1 ER 17

Elizabeth Johnson brought for grand larceny, 3 July 1695, Proceedings of the Old Bailey, t16950703-8

Hildebrand, Brimston, and Baker's case (1615) 1 Rolle 285, King's Bench, Hilary Term

Ordinary's Account, 18 September 1695, Proceedings of the Old Bailey, OA16950918 Rv. Marsh (1615) 3 Bulstrode 27, 81 ER 23

Rex v. Eaton (1627) Lit. Rep. 23

\section{Manuscript Sources}

British Library, London, UK

Cotton MS Caligula C III

Egerton MS 2385

Egerton MS 2533

Harley MS 7368

IOR B/5

\section{Cambridge University Library, Cambridge, UK}

FP 151

MS R.14.23

Folger Shakespeare Library, Washington D.C., USA

MS X.d.564 
Hatfield House, Hatfield, UK
$\mathrm{CP}_{23} / 2$
CP 24/93
$\mathrm{CP}_{31 / 101}$
CP $39 / 108$
$\mathrm{CP} 46 / 62$
CP $58 / 20$
CP 6o/98
CP $98 / 137$
CP 102/12
CP 103/14
CP $112 / 160$
CP $119 / 149$
CP $122 / 129$
$\mathrm{CP} 124 / 15^{2}$
CP $125 / 160$
CP $139 / 138$
CP $142 / 92$
$\mathrm{CP} 167 / 136$
CP $177 / 36$

University of Liverpool Special Collections, Liverpool, UK

SPEC Fraser 1566

SPEC Fraser 1567

The National Archives, Kew, UK

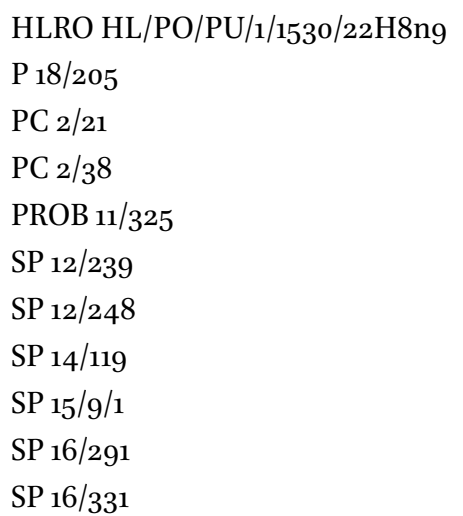


SP $18 / 126$

SP $63 / 85$

$\mathrm{SP} 81 / 4 / 1$

SP $89 / 1$

SP $97 / 1$

SP $105 / 74$

\section{University of Sheffield Library, Sheffield, UK}

Hartlib Papers, 18/14/1A-2B

\section{Parliamentary Papers}

3 Edw. I c. 31 1275: Statute for Tolls in Markets and Murage

25 Edw. III Stat. 1 1350: Status of Children Born Abroad

25 Edw. III Stat. 5 1351: Treason Act

42 Edw. III c. 10 1368: A statute made at Westminster on the first day of May in the forty-second year of King Edward III

11 Hen. VII c. 2 1494: Act against Vagabonds and Beggars

5 Hen. VIII c. 1 1513: Act concerning Ministration of Justice in the City of Turneye 21 Hen. VIII c. 16 1529: Act ratifying a Decree made in the Star Chamber, concerning Strangers and Handycraftsmen inhabiting the Realm of England 22 Hen. VIII c. 8 1530: Acte for Denyzens to paye Straungers

22 Hen. VIII c. 12 1530: Act directing how aged, poor, and impotent Persons, compelled to live by Alms, shall be ordered; and how Vagabonds and Beggars shall be punished

27 Hen. VIII c. 25 1535: Act for Punishment of sturdy Vagabonds and Beggars

37 Hen. VIII c. 25 1545: Taxation Act

1 Edw. VI c. 3 1547: Act for the Punishment of Vagabonds, and for the Reliefe of the poore and impotent Persons

5 Eliz. I c. 4 1562: Statute of Artificers

5 Eliz. I c. 2 1562: Tillage Act

5 Eliz. I c. 3 1563: Act for the Relief of the Poor

14 Eliz. I c. 5 1572: Act for the Punishment of Vagabonds, and for Relief of the Poor and Impotent

39 Eliz. I c. 4 1597: Act for Punishment of Rogues, Vagabonds and sturdy Beggars 43 Eliz. I c. 2 16o1: An Acte for the Releife [sic] of the Poore

1 Jac. I c. 7 1603: Vagabonds Act

3 \& 4 Jac. I c. 4 16o6: Act for the better discovering and repressing of Popish recusants 
12 Car. II c. 18 166o: An Act for the Encouraging and increasing of Shipping and Navigation

13 Car. II st. 2 c. 1 1661: Corporation Act

14 Car. II c. 12 1662: Act for the better Releife of the Poore of this Kingdom

22 and 23 Car. II c. 7 1670: Burning of Houses Act

21 Car. II c. 2 1672: Act for preventing Dangers which may happen from Popish Recusants

29 Car. II c. 6 1677: Naturalization (Children Born Abroad During the Troubles) Act 1 Will. \& Mar. sess. 2, c. 2 1668: Bill of Rights

9 Will. III c. 20 1698: Naturalization (Persons Born Abroad During the War) Act

\section{Printed Primary Sources}

A. B., A letter to a friend being an historical account of the affairs of Hungary (London, 1684; Wing $\mathrm{B} 17$ )

Abbot, George, The supplication of all the papists of England to King James (London, 1642; STC 6189)

Abbot, Robert, The second part of the Defence of the Reformed Catholicke (London, 1607; STC 49)

Abernethy, John, The dignity and duty of a Christian (London, 1620; STC 76)

An Account of the present condition of the Protestants in the Palatinate in two letters to an English gentleman (London, 1699; Wing A336)

Acosta, José de, The naturall and morall historie of the East and West Indies (London, 1604; STC 94)

Acte for punishment of rogues, vagabonds and sturdie beggers (London, 1598; STC 8261.7)

Adams, Thomas, The devills banket described in foure sermons (London, 1614; STC 110.5)

Adams, Thomas, Englands sickenes (London, 1615; STC 114)

Adis, Henry, A fannaticks mite cast into the Kings treasury being a sermon printed to the King because not preach'd before the King (London, 1660; Wing A581)

Ainsworth, Henry, The confession offaith of certayn English people living in exile, in the Low countreyes (London, 1607 ; STC 18435)

Ainsworth, Henry, A defence of the Holy Scriptures, worship, and ministerie (London, 1609; STC 235)

Ainsworth, Henry, Annotations upon the five bookes of Moses (London, 1627; STC 219)

The Alcoran of Mahomet, trans. by Thomas Ross (London, 1649; Wing K747A)

Alemán, Mateo, The Rogue or The Life of Guzmán de Alfarache (London, 1623; STC 289)

Allen, Robert, A treatise of christian beneficence (London, 16oo; STC 367 ) 
Allen, William, A true, sincere and modest defence, of English Catholiques that suffer for their faith both at home and abrode (Rouen, 1584; STC 373)

Allen, William, The copie of a letter written by M. Doctor Allen (London, 1587; STC 370)

Allen, William, An admonition to the nobility and people of England and Ireland concerninge the present warres (London, 1588 ; STC 368 )

Allen, William, and Robert Persons, A conference about the next succession to the crowne of Ingland divided into two partes (Antwerp, 1595; STC 19398)

Almond, Oliver, The casing of heresy (Douai, 1623; STC 12)

Alsop, Vincent, Melius inquirendum (London, 1678; Wing A2914)

Ambrose, Isaac, Media: the middle things, in reference to the first and last things (London, 1649; Wing A2958)

An answer to a late tract, entituled, An essay on the East-India trade (London, 1697; Wing A3311)

'An open warrant to the Lord Mayor of London (1596)', in Acts of the Privy Council, Vol. 26, 1595-1596 (London: Mackie and Co, 1902)

Anno quinto et sexto Eduardi Sexti Actes made in the session of this present parlament, holden upo [n] prorogacion at Westminster (London, 1552; STC 9433)

Anno xiiij. reginae Elizabethe at the Parliament begunne and holden at Westminster the eyght of Maye (London, 1572; STC 9477a.5)

Aristotle, The Politics, trans. by T. A. Sinclair, revised by Trevor J. Saunders (London: Penguin, 1981)

The Army brought to the barre (London, 1647; Wing A3709)

Articles of peace and commerce, between the high and mighty kings, Charles (London, 1642; Wing C2147)

Articles of peace and commerce between the most serene and mighty prince James II [...] and the most illustrious lords, the Douletli Basha, Aga \& Governours of the famous city and kingdom of Algiers in Barbary ratified and confirmed by Sir William Soame (London, 1687; Wing J153)

Articles of peace, union and confederation, concluded and agreed between his Highness Oliver Lord Protector of the common-wealth of England, Scotland \& Ireland, and the dominions thereto belonging (London, 1654; Thomason, E1603[35])

Articles of treason and other high-crimes and misdemeanors against the Dutches of Portsmouth (London, 1680; Wing A3846)

Ascham, Roger, The scholemaster (London, 1570; STC 832)

Atkinson, Ernest George (ed.), Calendar of State Papers Ireland, Vol. 8:1599-16oo (London: Her Majesty's Stationery Office, 1899)

Aubrey, John, Aubrey's Brief Lives ed. by Oliver Lawson Dick (London: Secker and Warburg, 1950)

Austin, Benjamin, Scripture manifestation of the equality of the Father, Sonne, and Holy-Ghost (London, 1650; Wing A4242) 
Awdelay, John, The fraternitye of vacabondes (London, 1561; STC 994)

Babington, George, Certaine considerations drawne from the canons of the last Sinod (London, 1605; STC 4585)

Bacon, Francis, The essayes or counsels, civill and morall (London, 1625; STC 1148)

Bacon, Francis, Sylva sylvarum (London, 1627; STC 1168)

Bacon, Francis, Certain miscellany works of the Right Honorable Francis Lo. Verulam,

Viscount S. Alban (London, 1629: STC 1124)

Bacon, Francis, A speech delivered by Sir Francis Bacon, in the lower House of Parliament quinto Jacobi, concerning the article of naturalization of the Scottish nation (London, 1641; STC 20706.5 and Wing B326)

Bacon, Francis, The Essayes or Counsels, Civill and Morall, ed. by Michael Kiernan (Oxford: Clarendon Press, 1985)

Bacon, Nathaniel, The continuation of an historicall discourse (London, 1651; Wing B348)

Balcanquall, Walter, A large declaration concerning the late tumults in Scotland (London, 1643; STC 21906)

Bale, John, An excellent and a right learned meditacion, compiled in two prayers most frutefull and necessary to be used and said of al ttue [sic] English men, in these daungerous daies of affliction (London, 1554; STC 17773)

Ball, Robert, The mirror of pure devotion (London, 1635; STC 1323)

Barbon, Nicholas, An apology for the builder, or, A discourse shewing the cause and effects of the increase of building (London, 1685; Wing B704)

Barckley, Richard, A Discourse of the felicitie of man (London, 1598; STC 1381)

Barnes, Thomas, Vox Belli: or, an Alarum to Warre (London, 1626; STC 1478)

Barrett, Thomas, The historie of France the foure first bookes (London, 1595; STC 11276)

Barrow, Harry, A brief discoverie of the false church (London [?], 1591; STC 1517)

Bartholomew, Robert, A blow for the pope (London, 1615; STC 21096.5)

Beaumont, Francis, The Woman hater (London 1607; STC 1693)

Bedwell, William, Mohammedis imposturae: that is, A discovery of the manifold forgeries, falshoods, and horrible impieties of the blasphemous seducer Mohammed with a demonstration of the insufficiencie of his law (London, 1615; STC 17995)

Bedwell, William, Mahomet unmasked (London, 1624; STC 17995.5)

Behn, Aphra, The forc'd marriage (London, 1671; Wing B1734)

Behn, Aphra, Oroonoko, or, The royal slave (London, 1688; Wing B1749)

Behn, Aphra, The Widow Ranter, or, the History of Bacon in Virginia (London, 169o; Wing B1774)

Bent, James Theodore (ed.), Early Voyages and Travels in the Levant (London: Hakluyt Society, 1893)

Bentham, Joseph, The Christian conflict a treatise (London, 1635; STC 1887) 
Beza, Théodore de, The treasure of trueth [with additions by John Foxe] (London, 1576; STC 2049)

Bible and Holy Scriptures (Geneva, 1560)

Biddulph, William, The travels of certaine Englishmen into Africa, Asia, Troy, Bythinia, Thracia, and to the Blacke Sea and into Syria, Cilicia, Pisidia, Mesopotamia, Damascus, Canaan, Galile, Samaria, Iudea, Palestina, Ierusalem, Iericho, and to the Red Sea (London, 1609; STC 3051)

Blackstone, William, An analysis of the laws of England (London, 1771; ESTC T56692) Bland, John, To the Kings Most Excellent Majesty the humble remonstrance of John Blande of London, merchant, on the behalf of the inhabitants and planters in Virginia and Mariland (London, 1661; Wing B3157)

Blount, Henry, A Voyage into the Levant (London,1636; STC 3136 )

Bohun, Edmund, The character of Queen Elizabeth (London, 1693; Wing B3448)

Bodley, Thomas, The Life of Sir Thomas Bodley, the honourable founder of the publique library in the University of Oxford, written by himselfe (Oxford: Bodleian Library, 1983)

Boemus, Johannes, The manners, lawes, and customs of all nation, trans. by Edward Aston (London, 1611; STC 3198.5)

The booke of common prayer (London, 1549; STC 16270a)

Bol, Cornelius, The Holy Bible conteyning the Old Testament, and the New: newly translated out of the originall tongues (London, 1611; STC 2216)

Boethius, Boecius de consolacione philosophie (London, 1478; STC 3199)

Bonoeil, John, His Majesties gracious letter to the Earle of South-Hampton (London, 1622; STC 14378)

Boothby, Richard, A briefe discovery or description of the most famous island of Madagascar (London, 1647; Wing B3744)

Bradford, John, A godlye medytacyon composed by the faithfull [...] I. B. latlye burnte in Smytfelde (London, 1559; STC 3483)

Bradstreet, Anne, 'A Dialogue Between Old England and New', in Several poems (Boston, 1678; Wing B4166)

Brathwaite, Richard, An excellent piece of conceipted poesy (London, 1658; Wing B4263) Brereton, John, A briefe and true relation of the discoverie of the north part of Virginia (London, 1602; STC 3611)

Breton, Nicholas, The court and country (London, 1618; STC 3641)

Brinsley, John, A consolation for our grammar schooles (London, 1622; STC 3767)

A broad-side against coffee; or, the marriage of the Turk (London, 1672; Wing B4830)

Brooks, Francis, Barbarian cruelty, being a true history of the distressed condition of the Christian captives under the tyranny of Mully Ishmael, Emperor of Morocco (London, 1693; Wing B4973) 
Brown, Horatio F. (ed.), Calendar of State Papers Relating to English Affairs in the Archives of Venice, Vol. 10: 1603-1607 (London: Her Majesty's Stationery Office, 1900)

Brown, Horatio F. (ed.), Calendar of the State Papers Relating to English Affairs in the Archives of Venice, Vol. 12:1610-1613 (London: His Majesty's Stationery Office, 1905) Brown, Robert (ed.), The History and Description of Africa by Leo Africanus (Cambridge: Cambridge University Press, 1896)

Browne, Robert, $A$ Booke which showeth the life and manners of all true Christians, and howe unlike they are unto Turkes and Papistes, and Heathen folke (Middelburg, 1582; STC 39103)

Bruce, John (ed.), Calendar of State Papers Domestic: Charles I, Vol. 64: 1627-1628 (London: Her Majesty's Public Record Office, 1858)

Bryskett, Lodowick, A discourse of civill life (London, 16o6; STC 3958)

Bulhão Pato, Raymundo António de (ed.), Documentos Remettidos da Índia ou Livro das Monções: Vol. 2 (Lisbon: Academia Real das Sciencias, 1884)

Bullinger, Henrich, The tragedies of tyrants, trans. by Thomas Twyne (London, 1575; STC 4078)

Bunny, Edmund, The whole summe of Christian religion (London, 1576; STC 4096)

Burges, Cornelius, The first sermon, preached to the Honourable House of Commons (London, 1641; Wing B5671)

By the King a proclamation for the due and speedy execution of the statute against rogues, vagabonds, idle, and dissolute persons (London, 1603; STC 8333)

By the King. A proclamation for the search and apprehension of certaine pirates (London, 1604; STC 8363)

By the Mayor An act of Common Councell, prohibiting all strangers borne, and forrainers, to use any trades, or keepe any maner of shops in any sort within this citty, liberties and freedome thereof (London, 1606; STC 16722)

By the Mayor Orders set downe for Blackewelhall (London, 1604; STC 16719)

By the Mayor Whereas divers good acts and ordinances have heeretofore bene made, aswell by publique proclamations, as other waies: for the restraning the great abuses daily committed and used in brewing and uttering of extraordinary strong ale and beere (London, 1615 ; STC 16725.7)

By the Queene. A proclamation for the due observation offish dayes, suppressing of unneccessary number of alehouses, and for the better execution of the late acte for punishment of rogues, vagabonds and beggers (London, 1600; STC 8271)

Calvin, John, The Institution of Christian Religion, trans. by Thomas Norton (London, 1561; STC 4415)

Cambarini, Andrea, Two very notable commentaries the one of the originall of the Turcks and Empire of the house of Ottomanno, trans. by John Shute (London, 1562; STC 4470) 
Camden, William, Annales the true and royall history of the famous empresse Elizabeth Queene of England (London, 1625; STC 4497)

Captain Aiscogh, A relation of the actions of the Parliaments forces (London, 1642; Wing R811)

Carew, George, Lex talionis, or, The Law of marque or reprizals (London, 1682; Wing C549)

Carew, Thomas, Poems By Thomas Carew Esquire (London, 1640; STC 4620)

Cartier, Jacques, $A$ shorte and briefe narration (London, 1580; STC 4699)

Cary, Elizabeth, The tragedie of Mariam, the faire queene of Jewry (London, 1613; STC 4613)

Cary, John, An answer to Mr. Molyneux his Case of Ireland's being bound by acts of Parliament in England (London, 1698; Wing $\mathrm{C}_{724} \mathrm{~B}$ )

Carpenter, Nathanael, Geographie delineated forth in two bookes (London, 1635; STC 4677)

Cason, Edmund, A relation of the whole proceedings concerning the redemption of the captives in Argier and Tunis (1647; Wing R89o)

Castiglione, Baldassare, The courtier of Count Baldessaer Castilio, trans. by Thomas Hoby (London, 1561; STC 4778)

Cavendish, Margaret, CCXI sociable letters written by the thrice noble, illustrious, and excellent princess, the Lady Marchioness of Newcastle (London, 1664; Wing N872)

Cawdry, Robert, A table alphabeticall (London, 16o9; STC 4884.5)

Caxton, William, The Chronycles of England (London, 1492; STC 9992)

Cecil, William, The execution of justice in England for maintenaunce of publique and Christian peace (London 1583; STC 4902)

Certaine articles concerning the statute lately made for the reliefe of the poor to be executed in London, by the churchwardens and overseers of every parish, according to the effect of the same statute (London, 1599; STC 9494.9)

Cervantes, Miguel de, The history of the valorous and witty knight-errant, DonQuixote of the Mancha, trans. by Thomas Shelton (London, 1612; STC 4195)

Chaplin, Joyce, Subject Matter: Technology, the Body, and Science on the AngloAmerican Frontier, 1500-1776 (Cambridge, MA: Harvard University Press, 2001)

Chapman, George, Ben Jonson, and John Marston, Eastward hoe (London, 1605; STC 4971)

Chapman, Richard, Hallelu-jah (London, 1635; STC 4998)

Chardin, John, The travels of Sir John Chardin into Persia and the East-Indies (London, 1681; Wing C2043)

'Charter of New England' (1620), American History: Documents (2012) www.let.rug. $\mathrm{nl} /$ usa/documents (accessed October 2020)

Chaucer, Geoffrey, Troilus and Criseyde (Westminster, 1483; STC 5094)

Child, Josiah, A discourse concerning trade (London, 1689; Wing D159o) 
Child, Josiah, A discourse about trade (London, 1690; Wing C3853)

Churchyard, Thomas, A generall rehearsall of warres (London, 1579; STC 5235.2)

Churchyard, Thomas, A sparke offrendship and warme goodwill (London, 1588; STC 5257)

Churchyard, Thomas, Chuchyards challenge (London, 1593; STC 5220)

Churchyard, Thomas, A pleasant discourse of court and wars (London, 1596; STC 5249)

Cicero, Marcus Tullius, The booke offreendeship of Marcus Tullie Cicero, trans. by John Harrington (London, 1550; STC 5276)

Clamor sanguinis martyrum, or The bloody inquisition of Spain (London, 1656; Wing C4403)

Clark, Andrew (ed.), The English register of Godstow Nunnery, near Oxford, written about 1450 (London: Early English Text Society, 1906)

Cockayne, Aston, The tragedy of Ovid (London, 1669: Wing C490o)

Cockerham, Henry, The English dictionarie, or, An interpreter of hard English words (London, 1623; STC 5461)

Cocks, Richard. Diary of Richard Cocks, Cape-merchant in the English Factory in Japan, 1615-1622: Vol. 1, ed. by Edward Maude Thompson (London: Hakluyt Society, 1883)

Cohen, J. M. (ed.), The Four Voyages of Christopher Columbus, (London: Penguin, 1969)

Coke, Roger, Reflections upon the East-Indy and Royal African Companies with animadversions, concerning the naturalizing offoreigners (London, 1695; Wing C4980)

Coles, Elisha, An English dictionary explaining the difficult terms (London, 1677; Wing $\mathrm{C}_{5071}$ )

Collection of paintings, and several other curiosities (London, 1690; Wing C5163)

Collection of the statutes made in the reigns of King Charles the I and King Charles the II (London, 1667; Wing E898)

The Complete Justice (London, 1637; STC 14887.5)

Compton, James, The battaile on Hopton-Heath in Staffordshire, betweene His Majesties forces under the Right Honourable the Earle of Northampton, and those of the rebels (London, 1643; Wing B1162)

Congreave, William, The way of the world a comedy (London, 1700; Wing C5878)

Cooke, Robert, Visitation of London, 1568, ed. by Joseph Jackson Howard and George J. Armytage (London: Harleian Society, 1869)

Copley, Anthony, Another letter of Mr. A. C. to his dis-Jesuited kinseman (London, 1602; STC 5736)

Copland, Patrick, Virginia's God be thanked (London, 1622; STC 5727)

Coryate, Thomas, Coryats crudities (London, 1611; STC 5808)

Coryate, Thomas, Thomas Coriate traveller for the English wits (London, 1616; STC $5811)$ 
Cotgrave, John, Wits interpreter, the English Parnassus (London, 1655; Wing C6370)

Cotgrave, Randle, A dictionarie of the French and English tongues (London, 1611; STC 5830)

Cotton, John, The way of Congregational churches cleared in two treatises (London, 1648; Wing C6469)

Council for Virginia, A true and sincere declaration of the purpose and ends of the plantation begun in Virginia (London, 1610; STC 24832)

The Courtyer of Count Baldessar Castilio, trans. by Thomas Hoby (London, 1561; STC 4778)

Coverdale, Miles, Biblia the Bible (Cologne, 1535; STC 2063.3)

Cowell, John, The interpreter (Cambridge, 1607 , STC 5900)

Crell, Johann, The justification of a sinner being the maine argument of the Epistle to the Galatians (London, 1650; Wing C6878)

Crisp, Nicholas, To the Right Honourable the Commons of England assembled in Parliament (London, 166o; Wing C6915)

Cust, Katherine Isabella (ed.), The Pylgremage of the Sowle, translated oute of Frensshe into Englysshe (London: P. M. Pickering, 1859)

Cynthia with the tragical account of the unfortunate lover of Almerin and Desdemona (London, 1687; Wing $\mathrm{C}_{7710 \mathrm{~A})}$

Cyvile and uncyvile life (London 1579; STC 15589.5)

Daborne, Robert, A Christian turn'd Turke (London, 1612; STC 6184)

A defence of the honourable sentence and execution of the Queene of Scots (London, 1587; STC 17566.3)

Dalechamp, Caleb, Christian hospitalitie handled common-place-wise in the chappel of Trinity Colledge in Cambridge (London, 1632; STC 6192)

Dampier, William, A new voyage round the world (London, 1697; Wing D161)

Danvers, Frederick Charles (ed.), Letters Received by the East India Company, 1602-1613: Vol. 1 (London: Sampson Low, Marston \& Company, 1896)

Davenant, William, The Cruelty of the Spaniards in Peru (London, 1658; Wing D 321 )

Davies, Eleanor, From the Lady Eleanor, her blessing, to her beloved daughter the Right Honorable Lucy, Countesses of Huntingdon (London, 1644; Wing D1991)

Davies, John, A discoverie of the true causes why Ireland was never entirely subdued (London, 1612; STC 6348)

Davies, John, The writing schoolemaster (London, 1631; STC 6344.5)

Day, Angel, The English secretary (London, 1599; STC 6404)

Day, Richard, A booke of Christian prayers (London, 1578; STC 6429)

Dekker, Thomas, The pleasant comedie of old Fortunatus (London, 1600; STC 6517)

Dekker, Thomas, Newes from hell (London, 1606; STC 6514)

Dekker, Thomas, The belman of London (London, 1608; STC 6480.5)

Dekker, Thomas, Lanthorne and candle-light (London, 16o9; STC 6486) 
Denison Ross, E. (ed.), 'Discours of the Turkes by Sir Thomas Sherley', in Camden Miscellany, Vol. XVI (London: Offices of the Society, 1936)

Digges, Thomas, Foure paradoxes, or politique discourses, ed. by Dudley Digges (London, 1604; STC 6872)

Dod, John, A plaine and familiar exposition of the thirteenth and fourteenth chapters of the Proverbs of Salomon (London, 1608; STC 6959.5)

Donne, John, Poems (London, 1633; STC 7045)

Donne, John, Fiftie sermons (London, 1649; Wing D1862)

Dorke, Walter, A tipe or figure offriendship Wherein is livelie, and compendiouslie expressed, the right nature and propertie of a perfect and true friend (London, 1598; STC 7060.5)

Downame, John, The plea of the poore (London, 1616; STC 7146)

Downame, John, The summe of sacred divinitie briefly \& methodically propounded (London, 1625; STC 7148.3)

Downes, Theophilius, $A$ discourse concerning the signification of allegiance, as it is to be understood in the new oath of allegiance (London, 1689; Wing D2082)

Dryden, John, The Indian Emperour, or the Conquest of Mexico by the Spaniards (London, 1667; Wing D2288)

Dryden, John, The state of innocence and fall of man (London, 1677; Wing D2372)

Dryden, John, Fables ancient and modern translated into verse from Homer, Ovid, Boccace, \& Chaucer, with original poems (London, 1700; Wing D2278)

Dudley Lord North, A forest of varieties (London, 1648; Wing N1283)

East India Company, An impartial vindication of the English East-India-Company (London, 1688; Wing I9o)

East India Company, Reasons humbly offered by the Governour, Assistants fellowship of Eastland-Merchants against the giving of a general liberty to all persons whatsoever to export the English woollen-manufacture whither they please (London, 1689; Wing R532)

Eden, Richard, A treatyse of newe India (London, 1553; STC 18244)

Eden, Richard, The history of travayle in the West and East Indies (London, 1577; STC 649)

Edward VI, A proclamacion set furth by thee Kynges Maiesty (London, 1550; STC 7831) Egaña, Antonio de (ed.), Monumenta Peruana: Vol. 1 (Rome: Monumenta Historica Societatis Iesu, 1954)

Eglesfield, Francis, The life and reigne of our sovereign lord, King Charles the II in a compendious chronicle relating both to His Majesties person and affairs (London, 1660; Wing E237A)

An Elegie on the death of the Most Serene Majesty of Henrietta-Maria, Queen-Mother of Great Britain (London, 1669; Wing E39A) 
Eliot, John, Ortho-epia Gallica, Eliots fruits for the French: enterlaced with a double new invention, which teacheth to speake truely, speedily and volubly the Frenchtongue (London, 1593; STC 7574)

Eliot, John, The Holy Bible containing the Old Testament and the New, translated into the Indian language (Cambridge, 1663; Wing B2748)

Elyot, Thomas, The dictionary of syr Thomas Eliot knyght (London, 1538; STC 7659) England and Wales, Articles of peace, entercourse, and commerce concluded in the names of the most high and mighty kings, Charles by the grace of God King of Great Britaine, France and Ireland, defender of the faith (London, 1630; STC 9251.3)

England's advocate, Europe's monitor being an intreaty for help in behalf of the English silk-weavers and silk-throsters [...] in a letter to a member of the Honourable House of Commons (London, 1699; Wing N2)

Ephemeris parliamentaria (London, 1654; Wing F2422)

Episcopius, Simon, The Popish labyrinth (London, 1673; Wing E3163)

Estienne, Henry, A world of wonders, trans. by [Richard Carew?] (London, 1607; STC 10553)

Everett Green, Mary Anne (ed.), Calendar of State Papers, Domestic, of the reign of James I, Vol. 6: 1611-1618 (London: Her Majesty's Record Office, 1858)

Everett Green, Mary Anne (ed.), Calendar of State Papers, Domestic, 1601-1603 with Addenda, Vol. 6: 1547-1565 (London: Her Majesty's Stationery Office, 186o)

Exhortacion to als [sic] English subjects to joine for the defence of Queen Elziabeth [sic], and their native country (London, 1588; STC 7582)

The famous historye of the life and death of Captaine Thomas Stukeley (London, 1605; STC 23405)

Faria e Sousa, Manuel de, The Portugues Asia (London, 1695; Wing F428)

Ferguson, Robert, A briefjustification of the Prince of Orange's descent into England (London, 1689; Wing F733)

Ferguson, Robert, A brief account of some of the late incroachments and depredations of the Dutch upon the English (London 1695; Wing F731)

The fifteen comforts of rash and inconsiderate marriage (London, 1694; Wing F886)

The first examinacio[n] of Anne Askewe latelye martired in Smythfelde (London, 1547; STC 851)

Fitzherbert, Thomas, The first part of a treatise concerning policy, and religion (London, 16o6; STC 11017)

Flecknoe, Richard, A relation of ten years in Europe, Asia, Affrique, and America (London, 1656; Wing F1232)

Fletcher, Giles, The policy of the Turkish empire (London, 1597; STC 24335)

Florio, John, Florio his firste fruites which yeelde familiar speech, merie proverbes, wittie sentences, and golden sayings (London, 1578; STC 11096) 
Florio, John, Florios second frutes to be gathered of twelue trees, of divers but delightsome tastes to the tongues of Italians and Englishmen (London, 1591; STC 11097) Florio, John, A worlde of wordes (London, 1598; STC 11098)

Florio, John, Queen Anna's new world of words, or dictionarie of the Italian and English tongues, collected, and newly much augmented by John Florio, reader of the Italian unto the Soveraigne Majestie of Anna, crowned Queene of England, Scotland, France and Ireland, \&c. (London, 1611; STC 11099)

Ford, William, A sermon preached at Constantinople in the Vines of Perah, at the funerall of the vertuous and admired Lady Anne Glover, sometime wife to the honourable Knight Sir Thomas Glover (London, 1616; STC 11176)

Forshall, Josiah, and Frederic Madden (eds.), The Holy Bible, containing the Old and New testaments with the Apocryphal Books in the earliest English versions made from the Latin Vulgate by John Wycliffe and his followers, Vol. 2 (Oxford: Oxford University Press, 1850)

Foster, William, The lay-mans lawyers revieved \& enlarged (London, 1656; Wing F1611)

Foster, William (ed.), Letters Received by the East India Company, Vol. 2: 1613-1615 (London: Sampson, Low, and Marston, 1897)

Foster, William (ed.), The Embassy of Sir Thomas Roe to the Court of the Great Mogul, 1615-1619: As Narrated in his Journal and Correspondence (London: Hakluyt Society, 1899)

Foster, William (ed.), English Factories in India, 1618-1669, 8 vols (Oxford: Clarendon, 1906-1914)

Foster, William (ed.), The Travels ofJohn Sanderson in the Levant, 1584-1602 (London: Hakluyt Society, 1931)

Foxe, John, Actes and monuments (London, 1563; STC 11222)

Gage, Thomas, The English-American, his travail by sea and land (London, 1648; Wing G109)

G[ainsford], T[homas], The rich cabinet (London, 1616; STC 11522)

Galfridus, Anglicus, Promptuarium paruulorum clericorum quod apud nos Medulla grammatice appellatur scolasticis (London, 1512; STC 20437)

Galvão, António, The discoveries of the world (London, 1601; STC 11543)

Gardiner, J. (ed.), Letters and Papers, Foreign and Domestic, of the Reign of Henry VIII, Vol. 5: 1531-1532 (London: Longman, 1880)

Gates, Geffrey, The defense of the militarie profession (London, 1579; STC 11683)

Gentili, Alberico, De legationibus libre tres (London, 1585; STC 11737)

Gentili, Alberico, De Jure Belli Libris Tres, ed. by Thomas Erskine Holland (Oxford: Clarendon, 1857)

Giles, J. A. (ed.), The Whole Works of Roger Ascham, Vol. 1, Part II (London: John Russell Smith, 1865)

Gipps, Thomas, Remarks on remarks (London, 1698; Wing G78o) 
Given-Wilson, Chris, Paul Brand, Seymour Phillips, Mark Ormrod, Geoffrey Martin, Anne Curry, and Rosemary Horrox (eds.), Parliament Rolls of Medieval England (Woodbridge: Boydell, 2005)

Golding, Arthur (ed.), Sermons of Master John Calvin (London, 1574; STC 4445)

Gods revenge upon his Parliaments and peoples enemies (London, 1643; Wing G961) Goodwin, George, Babels balm (London, 1624; STC 12030)

Green, Robert, Mamillia A mirrour or looking-glasse for the ladies of Englande (London, 1583; STC 12269)

Grenville, Richard, A continuation of the true narration of the most observable passages in and about Plymouth, from January 26. 1643. till this present (London, 1644; Wing C5973)

Greville, Fulke, Certaine learned and elegant works [...] written in his youth, and familiar exercise with Sir Philip Sidney (London, 1633; STC 12361)

Hackett, John, A sermon preached before the Kings Majesty at Whitehall on Friday the 22 of March anno 1660 (London, 166o; Wing H172)

Haddon, Walter, Against Jerome Osorius Byshopp of Silvane in Portingall and against his slaunderous invectives (London, 1581; STC 12594)

Haile, Edward Wright (ed.), Jamestown Narratives: Eyewitness Accounts of the Virginia Colony: The First Decade: 1607-1617 (Champlain, VA: Roundhouse, 1998)

Hakewill, William, The libertie of the subject: against the pretended power of impositions (London, 1641; H210)

Hakluyt, Richard, A Discourse Concerning Western Planting (1584), ed. by Charles Deane (Cambridge: Wilson \& Son, 1887)

Hakluyt, Richard, The principal navigations, voyages, and discoveries of the English nation (London, 1589; STC 12625)

Hakluyt, Richard, The principal navigations, voyages, traffiques and discoveries of the English nation (London, 1598-1600; STC 12626a)

Hall, Joseph, Quo vadis? A just censure of travell as it is commonly undertaken by the gentlemen of our nation (London, 1617; STC 12705)

Hall, Joseph, The works ofJoseph Hall Doctor in Divinitie (London, 1625; STC 12635b)

Hanmer, Meredith, The baptizing of a Turke (London, 1586; STC 12744)

Hansard, George, A Treatise on the Law Relating to Alien, and Denization and Naturalization (London: V\&R Stevens, 1844)

Hariot, Thomas, A briefe and true report of the new found land of Virginia (London, 1588; STC 12785)

Harman, Thomas, A caveat for commen cursetors vulgarely called vagabones (London, 1567; STC 12787)

Haylin, Peter, A short view of the life and reign of King Charles (the second monarch of Great Britain) from his birth to his burial (London, 1658; Wing $\mathrm{H}_{1735} \mathrm{~B}$ )

Heylyn, Peter, Cosmographie (London, 1652; Wing H1689) 
Heywood, Thomas, The second part of, Ifyou know not me, you know no bodie (London, 1605; STC 13336)

Higden, Ranulf, Polychronicon Ranulphi Higden monachi Cestrensis: Together with the English Translation ofJohn Trevisa and of an Unknown Writer of the Fifteenth Century, Vol. III, ed. by Churchill Babington and J. R. Lumby (London: Longman \& Company, 1871)

Higgins, John, The falles of unfortunate princes (London, 1619; STC 13447)

Hobbes, Thomas, Leviathan; or, the matter, form, and power of a common-wealth ecclesiastical and civil (London: Wing H2246, 1651)

Hobbes, Thomas, De Cive: The English Version, ed. by Howard Warrender (Oxford: Clarendon, 1983)

Holland, Thomas, Paneguris D. Elizabethae, Dei gratiâ Angliae, Franciae, \& Hiberniae Reginae (London, 1601; STC 13597)

The Holie Bible conteynyng the olde Testament and the newe (London, 1568; STC 2099) Holinshed, Raphael (ed.), The first and second volumes of Chronicles comprising the description and historie of England (London, 1587; STC 13569)

Holy Bible, conteyning the old testament and the new (London, 1611; STC 2216)

Homer alamode, the second part, in English burlesque (London, 1681; Wing S2133)

The Honour of London apprentices (London, 1647; Wing H2596)

Hoper, Richard, The instruction of a Christian man, in vertue and honestie (London, 1580; STC 13766.5)

Horace, Epistles, trans by. H. Rushton Fairclough (Cambridge, MA: Loeb, 1926)

Hotman, Jean, The ambassador (London, 1603; STC 13848)

Howell, James, Instructions for forreigne travell (London, 1642; Wing H3082)

Howell, James, Proedria vasilike (London, 1664; Wing H3109)

Hughes, Charles (ed.), 'Nicholas Faunt's Discourse Touching the Office of Principal

Secretary of Estate, \&cc, 1592', The English Historical Review, 20 (1905), 499-508

Hughes, Charles (ed.), Shakespeare's Europe: Unpublished Chapters of Fynes Moryson's Itinerary, Being a Survey of the Condition of Europe at the End of the 17th Century (London: Sherratt \& Hughes, 1903)

The humble petition of the Protestant inhabitants of the counties of Antrium, Downe,

Tyrone, \&c, part of the province of Ulster, in the kingdome of Ireland (London, 1641; Wing H3573)

Humphrey, Laurence, $A$ view of the Romish hydra and monster, traison, against the Lords anointed (London, 1588; STC 13966)

Itur Mediteranium (London, 1658; Wing L2331)

J. R., Proposals in behalfe of the poore of this nation (London,1653; Wing R29) James I, His Majesties Lepanto (London, 1603; STC 14379.3)

A Jerk for the Jacks, or, All their hopes are lost being an account of the vast and prodigious expectations (London, 1696; Wing J680) 
Jewel, John, An apologie or answere in defence of the Churche of England (London, 1564; STC 14591)

Johnson, Francis, An answer to Maister H.Jacob (London, 160o; STC 14658)

Johnson, Francis, A seasonable treatise for this age occasioned by a letter (London, 1657; Wing S2245)

Johnson, Robert, Nova Britannia (London, 1609; STC 14699.5)

Johnson, Thomas, A plea for free-mens liberties (London, 1646; Wing J850)

Jonson, Ben, Sejanus his fall (London, 1605; STC 14782)

Jonson, Ben, His Case is alterd (London, 1609; STC 14757)

Jonson, Ben, The works of Benjamin Jonson (London, 1616; STC 14752)

Jonson, Ben, Epicoene, or the silent woman (London, 1620; STC 14763)

Jonson, Ben, The staple of newes (London, 1631; STC 14753.5)

Jonson, Ben, Bartholmew fayre [...] The divell is an asse [...] The staple of newes (London, 1631; STC 14753.5)

Kellet, Edward, Miscellanies of divinitie (London, 1635; STC 14904)

Knolles, Richard, The generall historie of the Turkes (London, 1603; STC 15051)

The Kings cabinet opened (London, 1645; Wing C2358)

Langland, William, The Vision of William concerning Piers Plowman (1377), ed. by Walter W. Skeat (London: Early English Text Society, 1867)

Langland, William, William Langland's 'Piers Plowman': The C Version, trans. by

George Economou (Philadelphia: University of Pennsylvania Press, 1996)

The Late Revolution, or the Happy Change (London, 1690; Wing L558)

Lee, Maurice (ed.), Dudley Carleton toJohn Chamberlain, 1603-1624 (New Brunswick, NJ: Rutgers, 1972)

Lefroy, J. Henry (ed.), Historye of the Bermudaes or Summer Islands. Edited, from a MS in the Sloane Collection, British Museum (London: Hakluyt Society, 1882)

Léry, Jean de, History of a Voyage to the Land of Brazil, trans. by Janet Whatley (Berkeley: University of California Press, 1992)

Levens, Peter, Manipulus Vocabulorum (London, 1570; STC 15532)

Lindberg, Conrad (ed.), The Earlier Version of the Wycliffite Bible: Vol. 1 (Stockholm: Stockholm Studies in English, 1959)

Linschoten, Jan Huyghen van, John Huighen van Linschoten. His discours of voyages into the Easte \& West Indies (London, 1598; STC 15691)

Lithgow, William, The totall discourse, of the rare adventures (London, 1640; STC 15714) Littleton, Edward, The groans of the plantations (London, 1689; Wing L2577)

The Lives, apprehensions, arraignments, and executions, of the 19 late pyrates (London, 1609; STC 12805)

Livy, History of Rome 2, trans. by B. O. Foster (Cambridge, MA: Loeb, 1919)

Lodowick, Lloyd, The pilgrimage of princes, penned out of sundry Greeke and Latine aucthours (London, 1573; STC 16624) 
Long, Benjamin, An oration spoken in the grammar-school of Christ's-Hospital before the right honourable the Lord Mayor (London, 1675; Wing $\mathrm{O}_{3} 66$ )

Lord, Henry, A display of two forraigne sects in the East Indies (London, 1630; STC 16825)

Love, Christopher, The whole triall of Mr. Christopher Love (London, 1660; Wing W2065)

Love in a barn. Or, Right country courtship (London, 1670; Wing L3206)

Loyalty vindicated being an answer to a late false, seditious \& scandalous pamphlet entituled A letter from a gentleman of the City of New York to another (London, 1698; Wing L3384)

Lupton, Thomas, A persuasion from papistrie (London, 1581; STC 16950)

Magurn, Ruth (ed.), The Letters of Peter Paul Rubens, (Cambridge, MA: Harvard University Press, 1955)

Mandeville, John, The Egerton Version of Mandeville's Travels (London: Early English Text Society, 2010)

Manwaring, G. E., and W. Perrin (eds.), The Life and Works of Sir Henry Mainwaring, Vol. 2 (Toronto: Navy Records Society, 1922)

Marguerite, Queen consort of Henry II, A godly medytacyon of the christen sowle (London, 1548; STC 17320)

Markham, Gervase, $A$ health to the gentlemanly profession of servingmen (London, 1598; STC 17140)

Marlowe, Christopher, Tamburlaine the Great (London, 1590; STC 17425)

Marvell, Andrew, Miscellaneous poems by Andrew Marvell (London, 1681; Wing M872)

Mather, Increase, The first principles of New-England concerning the subject of baptisme \& communion of churches (London, 1675; Wing M1211)

Mather, Increase, David serving his generation, or, A sermon (Boston: 1698, Wing M1195)

Mather, Samuel, A testimony from the Scripture against idolatry \& superstition in two sermons (London, 1670; Wing M1283)

Mats, Edmund, A devoute mans purposes (London, 1597; STC 17231)

Metcalfe, W. M. (ed.), Legends of the Saints in the Scottish Dialect of the Fourteenth Century: Vol. II (Edinburgh: William Blackwood and Sons, 1896)

Methinks the poor town has been troubles too long, or, A Collection of the several songs now in mode either at the court or theatres (London, 1673; Wing M1940)

Morleand, W. H. (ed.), Relations of Golconda in the Early Seventeenth Century (London: Hakluyt Society, 1931)

Middleton, Thomas, Sir Robert Sherley, sent ambassadour in the name of the King of Persia (London, 16o9; STC 17894.5)

Middleton, Thomas, and William Rowley, The Spanish gipsie (London, 1653; Wing Mig86) 
Mignard, Pierre, 'Louise de Kéroualle, Duchess of Portsmouth', 1682, National Portrait Gallery, NPG 497

Misselden, Edward, Free trade, or, The meanes to make trade florish (London, 1622; STC 17987)

Misselden, Edward, The circle of commerce (London, 1623; STC 17985)

Monck, George, Observations upon military \& political affairs (London, 1671; Wing A864)

Montaigne, Michael de, Essayes or morall, politike and millitarie discourses of Lo: Michaell de Montaigne, trans. by John Florio (London, 1603; STC 18041)

Montaigne, Michel de, Essays, trans. by John Florio (London, 1613; STC 18042)

More, Thomas, A fruteful, and pleasaunt worke of the beste state of a publyqye weale, and of the newe yle called Utopia (London, 1551; STC 18094)

More, Thomas, A dialogue of comfort against tribulacion (London, 1553; STC 18082)

Morris, Richard (ed.), An Old English Miscellany containing a Bestiary (London: Early English Text Society, 1872)

Moryson, Fynes, An itinerary (London 1617; STC 18205)

Mountague, William, The delights of Holland (London, 1696; Wing M2477)

Mulcaster, Richard, Positions wherein those primitive circumstances be examined, which are necessary for the training up of children (London, 1581; STC 18253)

Multibibus, Blasius, A solemne joviall disputation (London, 1617; STC 3585)

Munday, Anthony, The mirrour of mutabilitie, or Principall part of the Mirrour for magistrates (London, 1579; STC 18276)

Nalson, J., A True copy of the journal of the High Court ofJustice for the tryal of K. Charles I (London, 1684; Wing T2645)

Nares, Robert, Stebbing Shaw, Joseph Planta, et al (eds.), A Catalogue of the Harleian Manuscripts, in the British Museum: With Indexes of Persons, Places, and Matters, 4 vols (London: Record Commission, 1808)

A narration of the expedition to Taunton (London, 1645; Wing N158)

Nashe, Thomas, The unfortunate travaller. Or, The life of Jacke Wilton (London, 1594; STC 18380)

Nashe, Thomas, Christs teares over Jerusalem (London, 1613; STC 18368)

Nedham, Marchamont, Certain considerations tendered in all humility to an honorable member of the councell of state (London, 1649; Wing N381)

Neill, Edward Duffield (ed.), Memoir of Rev. Patrick Copland: Rector elect of the first projected college in the United States: A chapter of the English colonization of America (New York: Scribner, 1871)

Nelme, John, England's royal stone at the head of the corner, through the wonderful working of almighty God (London, 166o; Wing N415)

Nicholl, John, An houre glasse of Indian newes (London, 1607; STC 18532)

Nichols, John (ed.), The Progresses and Public Progressions of Queen Elizabeth: Vol. III (London: J. Nichols and Sons, 1823) 
Nisbet, Edward, Caesars dialogue (London, 1601; STC 18432.5)

Norden, John, A sinfull mans solace most sweete and comfortable, for the sicke and sorowful soule (London, 1585; STC 18634)

Norden, John, A pathway to patience (London, 1626; STC 18615)

Northleigh, John, Natural allegiance, and a national protection (London, 1688; Wing N1300)

Oakley, William, Eben-ezer, or, A small monument of great mercy (London, 1684; Wing O193)

The oath of every free-man of the citie of London (London, 1628; STC 16764.5)

Observations on the last Dutch wars, in the years 1672 and 1673 (London, 1679; Wing O104)

Ogilby, John, America (London, 1670; Wing O164)

Oppenheim, Samuel, 'An Early Jewish Colony in Western Guiana, 1658-1666: And its relation to the Jews in Surinam, Cayenne and Tobago', Publications of the American Jewish Historical Society, 16 (1907)

Orders prescribed by her Majesties commandement by advise of her counsell (London, 1595; STC 8243)

An Ordinance of the Lords and Commons assembled in Parliament declaring that it shall and may be lawfull for all foreigners and strangers in amity with this kingdome to have free trade and commerce to and from the city of London (London, 1644; E1833)

Ovid's metamorphosis englished by G[eorge] S[andys] (London, 1628; STC 18965)

Ovid. De tristibus: or Mournefull elegies in five bookes: composed in his banishment, trans. by Zachary Catlin (London, 1639; STC 18981)

Ovington, John, A voyage to Suratt in the year 1689 (London, 1696; Wing O701)

Page, William (ed.), Letters of Denization for Aliens in England, Vol. 8:1509-16o3 (Lymington: Huguenot Society of London, 1893)

Painter, William, The second tome of the Palace of pleasure (London, 1567 ; STC 19124) Palmer, Thomas, An essay of meanes how to make our Travailes, into forraine Countries, the more profitable and honorable (London, 1606; STC 19156)

Paynall, Thomas, The piththy [sic] and moost notable sayinges of al scripture, gathered by Thomas Paynel (London, 1550; STC 19494.3)

Peckham, George, A true report, of the late discoveries (London, 1583; STC 19523)

Peel, George, The battell of Alcazar (London, 1594; STC 19531)

Penry, John, An exhortation unto the governours, and people of Hir Majesties countrie of Wales (Aldermanbury [?], 1588; STC 19605.5)

Perceval, Richard, A dictionarie in Spanish and English (London, 1599; STC 19620)

Pettie, George, The civile conversation of $M$. Steeven Guazzo written in Italian, and now translated (London, 1581; STC 12422)

Petyt, William, Britannia languens: or, A discourse of trade (London, 1689; Wing P1947) 
Plantagenet, Beauchamp, A description of the province of New Albion (London, 1648; Wing P2378)

Pory, John, A geographical historie of Africa (London, 1600; STC 15481)

Powel, Gabriel, A consideration of the papists of state and religion (Oxford, 1604; STC 20144)

Praed, John, An essay on the coin and commerce of the kingdom trade and treasure (which are twins) being the only supporters thereofnext to religion and justice (London, 1695; Wing $\mathrm{P}_{3163} \mathrm{~A}$ )

A prefatory discourse (London, 1681; Wing A3032)

Proposals for making provisions for setting the poor on work (London, 1700; Wing $\mathrm{P}_{3728)}$

Proposals in behalfe of the poore of this nation (London, 1653; Wing R29)

Prynne, William, The unloveliness of love lockes (London, 1628; STC 20477)

Ptolemy, Tertrabiblos, trans. by F. E. Robbins (Cambridge, MA: Loeb, 1940)

Purchas, Samuel, Purchas his pilgrimage (London, 1613; STC 20505)

Purchas, Samuel, Purchas his pilgrimes (London, 1625; STC 20509)

Purchas, Samuel, Purchas his pilgrimage (London, 1626; STC 20508.5)

Purnell, F. K., and A. B. Hinds (eds.), Report on the Manuscripts of the Marquess of Downshire, Paper of William Trumbull the Elder, Vol. 2: 1605-161o (London: His Majesty's Stationery Office, 1936)

Puttenham, George, The arte of English poesie (London, 1589; STC 20519.5)

Quarles, Francis, Enchiridion Containing institutions, divine contemplative (London, 1644; Wing Q87)

R. B., The English Empire in America (London, 1685; Wing C7319)

Raithby, John (ed.), The Statutes at Large, of England and of Great-Britain: From Magna Carta to the Union of the Kingdoms of Great Britain and Ireland, Vol. IV: 1553-1640 (London: Eyre and Strahan, 1811)

Ralegh, Walter, The discoverie of the large, rich, and bewtiful empire of Guiana (London, 1596; STC 20634)

Ralegh, Walter, The history of the world (London, 1614; STC 20638)

Rankins, William, The English ape, the Italian imitation, the footesteppes of Fraunce (London, 1588; STC 20698)

Rastell, John, An exposition of certaine difficult and obscure words, trans. by William Rastell (London, 1579; STC 20706.5)

Rastell, John, Les termes de la ley (London, 1683; Wing R292)

Reasons humbly offered against the clause intended in the act for the establishing the land-bankfor denizing or naturalizing of all aliens that shall subscribe $500 l$. to the said bank (London, 1695; Wing $\mathrm{R}_{527}$ )

The Reformed gentleman, or, The old English morals rescued from the immoralities of the present age (London, 1693; Wing M6) 
R. F., The present state of Carolina with advice to the setlers (London, 1682; Wing $\mathrm{F}_{52} \mathrm{~A}$ )

Rich, Barnabe, A souldiers wishe to Britons welfare: or a discourse, fit to be read of all gentlemen and souldiers (London, 1603; STC 21000)

Rich, Barnabe, My ladies looking glasse (London, 1616; STC 20991.7)

Rid, Samuel, The art of jugling or legerdemaine (London, 1614; STC 21028)

Robbins, Robin (ed.), The Complete Poems ofJohn Donne (Harlow: Longman, 2010)

Roberts, Lewes, The merchants map of commerce (London, 1638; STC 21094)

Roberts, R. A. (ed.), Calendar of the Manuscripts of the Most Hon. the Marquis of Salisbury, Preserved at Hatfield House, Hertfordshire, Vol. 4:1590-1594 (London: Her Majesty's Stationery Office, 1892)

Roberts, R. A. (ed.), Calendar of the Manuscripts of the Most Hon. the Marquis of Salisbury, Preserved at Hatfield House, Hertfordshire, Vol. 8: 1598 (London: Her Majesty's Stationery Office, 1899)

Rogers, Nehemiah, The good Samaritan; or an exposition on that parable (London, 1658; Wing R1823A)

Sainsbury, W. Noël (ed.), Calendar of State Papers, Colonial Series: East Indies, China and Japan, Vol. II: 1513-1616 (London: Longman, 1862)

Sainsbury, W. Noël (ed.), Calendar of State Papers Colonial: East Indies, China, Japan, Vol. III: 1617-1621 (London: Longman, 1870)

Sainsbury, W. Noël, and J. W. Fortescue (eds.), Calendar of State Papers: Colonial, America and West Indies, Vol. 10: 1677-1680 (London: Her Majesty's Stationery Office, 1896)

Saltmarsh, John, The practice of policie in a Christian life taught from the Scriptures (London, 1639; STC 21639)

Sanderson, Thomas, Ofromanizing recusants, and dissembling Catholicks (London, 1611; STC 21711)

Sandys, George, Sandys travailes containing a history of the originall and present state of the Turkish empire (London, 1652; Wing S677)

Satow, Ernest M. (ed.), The Voyage of Captain John Saris to Japan (London: Hakluyt Society, 1908)

Saunders, William L. (ed.), The Colonial Records of North Carolina, Vol. I: 1662-1712 (Raleigh: Hale, 1888)

Scargill-Bird, S. R. (ed.), Calendar of the Manuscripts of the Most Hon. the Marquis of Salisbury, Preserved at Hatfield House, Hertfordshire, Vol. 1: 1306-1571 (London: Her Majesty's Stationery Office, 1883)

Scot, Thomas, Vox populi, or Newes from Spayne (London, 1620; STC 22100.2)

Shakespeare, William, Mr. William Shakespeare's comedies, histories, \& tragedies published according to the true originall copies (London, 1623; STC 22273)

Shirley, James, Changes: or, Love in a maze (London, 1632; STC 22437) 
A short and true relation of intrigues transacted both at home and abroad to restore the late King James (London, 1694; Wing S3557)

Short notes and observations drawn from the present decaying condition of this kingdom in point of trade, laid down in twelve particulars (London, 1662; Wing $\left.\mathrm{S}_{3} 608 \mathrm{~A}\right)$

Sidney, Philip, An apologie for poetrie (London, 1595; STC 22534)

Smith, Henry, The preachers proclamacion (London 1591; STC 22684)

Smith, Henry, The sermons of Maister Henrie Smith gathered into one volume (London, 1593; STC 22719)

Smith, John, A generall historie of Virginia, New-England, and the Summer Isles (London, 1624; STC 22790)

Smith, Richard, The prudentiall ballance of religion wherin the Catholike and protestant religion are weighed together with the weights of prudence, and right reason (London 1609; STC 22813)

Smith, Richard, Of the author and substance of the protestant church and religion two books (London, 1621; STC 22812)

Weatherly, Edward (ed.), Speculum sacerdotale (Oxford: Oxford University Press, 1936)

Speed, John, The theatre of the empire of Great Britaine (London, 1612; STC 23041)

Speed, John, England, Wales, Scotland, and Ireland (London, 1627; STC 23035)

Spenser, Edmund, The shepheardes calender (London, 1579; STC 23089)

Spenser, Edmund, Amoretti and Epithalamion (London, 1595; STC 23076)

Stoneham, Matthew, Two sermons of direction for judges and magistrates (London, 1608; STC 23290)

Stow, John, A survay of London (London, 1598; STC 23342)

Stubbes, Philip, The second part of the anatomie of abuses (London, 1583; STC 23380)

Subtilty and cruelty: or A true relation of the horrible and unparalleld abuses and intolerable oppressions, exercised by Sir Sackvile Crow His Majesties ambassador at Constantinople (London, 1657; Wing S6112)

Sundry considerations touching naturalization of aliens (London, 1695; Wing S6178)

Sutcliffe, Matthew, The practice, proceedings and lawes of armes (London, 1593; STC 23468)

Sutcliffe, Matthew, A briefe replie to a certaine odious and slanderous libel (London, 1600; STC 23453)

Swetnam, Joseph, The araignment of lewde, idle, forward, and unconstant women (London, 1615; STC 23534)

Sylvester, Josuah, Lachrimae lachrimarum (London, 1612; STC 23576)

Sylvester, Josuah, The parliament of vertues royal (London, 1614; STC 23581)

Sylvester, Josuah, Tobacco battered, \& the pipes shattered (London, 1616; STC 23582a) Taylor, Jeremy, The measures and offices offriendship (London, 1657; Wing T350) 
Taylor, John, Three weekes, three daies, and three houres observations and travel, from London to Hamburgh in Germanie (London, 1617; STC 23807)

Taylor, Thomas, A commentarie upon the Epistle of S. Paul written to Titus (London, 1612; STC 23825)

T. C., The New Atlas (London, 1698; Wing C139)

T. F., Newes from the north (London, 1579; STC 24062)

Tenison, Thomas, Of idolatry a discourse (London, 1678; Wing T704)

Terry, Edward, The merchants and mariners preservation and thanksgiving (London, 1649; Wing $\mathrm{T}_{7} 80$ )

Terry, Edward, A Voyage to East-India (London, 1655, Wing T782)

Thomas, Styward, The pathwaie to martiall discipline (London, 1582; STC 23414)

Thorpe, Francis Newton (ed.), Federal and State Constitutions, Colonial Charters, and Other Organic Laws of the States, Territories and Colonies Now or Heretofore Forming the United States of America, Vols. I-VII (Washington, D.C.: Government Printing Office, 1909)

To His Excellency General Monck (London, 166o; Wing T1345A)

Topsell, Edward, The historie offoure-footes beastes (London, 1607; STC 24123)

Topsell, Edward, The history offour-footed beasts and serpents (London, 1658; Wing G624)

Travers, Walter, An answere to a supplicatorie epistle, of G. T. for the pretended Catholiques written to the right Honorable Lords of her Majesties privy Councell (London, 1583; STC 24181)

A true account of the behaviour and manner of the execution of six persons viz. Henry Cornish and Elizabeth Gaunt condemned for high-treason (London, 1685; Wing T2345)

A true discovery of a womans wickednesse, in endeavouring to betray the city of London to the Caveliers (London, 1642; Wing T2680A)

The Tryals ofJoseph Dawson (London: 1696, Wing T2252)

Turberville, George, A plaine path to perfect vertue (London, 1568; STC 17244)

Turler, Jerome, The traveiler of Jerome Turler (London, 1575; STC 24336)

Tusser, Thomas, Five hundreth points of good husbandry united to as many of good huswiferie first devised (London, 1573; STC 24375)

T. W., Certaine wholesome observations and rules fo [sic] inne-keepers, and also for their guests (London, 1615; STC 24916.7)

Tyndale, William, The whole workes of W. Tyndall, John Frith, and Doct. Barnes, three worthy martyrs (London, 1574; STC 24436)

Tyrell, Anthony, A fruitfull sermon preached in Christs-Church (London, 1589; STC 24474)

Upham, Edward, John Pridden and John Strachey (eds.), Rotuli Parliamentorum, Vol. I (London: House of Lords, 1832) 
Vaz de Camões, Luís, The Lusiad, or, Portugals historicall poem, trans. by Richard Fanshawe (London, 1655; Wing C397)

Virgil, Dido and Aeneas the fourth booke of Virgils Aeneis now Englished by Robert Stapylton (London, 1634; STC 24812)

Virgil, The works of Virgil containing his Pastorals, Georgics and Aeneis, trans. by John Dryden (London: 1697, Wing V616)

Waller Hening, William (ed.), The Statutes at Large: Being a Collection of all the Laws of Virginia, from the First Session of the Legislature in the Year 1619, Vol. 2 (New York: R. \& W. Bartow, 1823)

Ward, Edward [Ned], Female policy detected (London, 1695; Wing W734)

Watson, Thomas, Holsome and catholyke doctryne concerninge the seven Sacramentes of Chrystes Church (London, 1558; STC 25112.5)

Webbe, Edward, The rare and most wonderfull things which Edw. Webbe an Englishman borne, hath seene and passed in his troublesome travailes (London, 1590; STC 25152)

Webster, John, The Works ofJohn Webster, ed. by Alexander Dyce (London: George Routledge, 1877)

Westerman, William, Two sermons of assise (London, 1600; STC 25282)

Wheatley, Henry B. (ed.), The Diary of Samuel Pepys, Vol. 16: May/June 1662 (Project Gutenberg ePublication, 2004), http://www.gutenberg.org/cache/epub/4134/ pg4134-images.html (accessed October 2020)

Whetstone, George, The English myrror (London, 1586; STC 25336)

Whitney, Geoffrey, Choice of Emblemes (Leiden, 1586; STC 25438)

W. I., Newes from Spaine The king of Spaines edict, for the expulsion \& banishment of more then nine hundred thousand Moores out of his kingdome (London, 1611; STC 22992.7)

Willet, Andrew, Ecclesia triumphans (London, 1603; STC 25676)

Williams, Roger, The hirelings ministry none of Christs (London, 1652; Wing W2765)

Williamson, George Charles (ed.), Lady Anne Clifford, Countess of Dorset, Pembroke \& Montgomery: 1590-1676. Her Life, Letters, and Works (Kendal: Titus Wilson \& Son, 1922)

Wilson, Robert, The pleasant and stately morall, of the three lordes and three ladies of London (London, 1590: STC 25783)

Wilson, Thomas, The Arte of Rhetorique (London, 1553; STC 25799)

Wither, George, The great assises holded in Parnassus (London, 1645; Wing W3160)

Wither, George, Juvenilia: Poems by George Wither (Manchester: Spenser Society, 1871)

Wotton, Henry, The elements of architecture, collected by Henry Wotton Knight, from the best authors and examples (London, 1624; STC 26011) 
Wotton, Henry, Reliquiae Wottoniae or a Collection of Lives, Letters, Poems, with Characters of Sundry Personages, and Other Incomparable Pieces of Language and Art (London, 1651; Wing 3648)

Wright, William, A briefe treatise in which, is made playne, that Catholikes living and dying in their profession, may be saved (London, 1623; STC 26044)

Wroth, Mary, The Countesse of Mountgomeries Urania. Written by the right honnourable Lady Mary Wroath (London, 1621; STC 26051)

\section{Secondary Sources}

Acton, Thomas, and Gary Mundy (eds.), Romani Culture and Gypsy Identity (Hatfield: University of Hertfordshire Press, 1999)

Adams, Robyn, and Rosanna Cox, Diplomacy and Early Modern Culture (London: Palgrave Macmillan, 2011)

Adelman, Janet, Blood Relations: Christian and Jew in the Merchant of Venice (Chicago: University of Chicago Press, 2008)

Akhimie, Patricia, and Bernadette Andrea (eds.), Travel and Travail: Early Modern Women, English Drama, and the Wider World (Lincoln: University of Nebraska Press, 2019)

Akkerman, Nadine, Invisible Agents, Women and Espionage in Seventeenth Century Britain (Oxford: Oxford University Press, 2018)

Akkerman, Nadine, and Birgit Houben (eds.), The Politics of Female Households: Ladies-in-waiting across Early Modern Europe (Leiden: Brill, 2014)

Aksan, Virginia, and Daniel Goffman (eds.), The Early Modern Ottomans: Remapping the Empire (Cambridge: Cambridge University Press, 2007)

Alexander, Catherine M. S., and Stanley Wells (eds.), Shakespeare and Race (New York: Cambridge University Press, 200o)

Alexandrowicz, C. H. (ed.), Groatian Society Papers 1972: Studies in the History of the Law of Nations (The Hague: Martinus Nihoff, 1972)

Allen, Gemma, 'The Rise of the Ambassadress: English Ambassadorial Wives and Early Modern Diplomatic Culture', The Historical Journal, 62:3 (2019), 617-638

Allinson, Rayne, A Monarchy of Letters: Royal Correspondence and English Diplomacy in the Reign of Elizabeth I (Basingstoke: Palgrave Macmillan, 2012)

Almási, Zsolt, and Mike Pincombe (eds.), Writing the Other: Humanism versus Barbarism in Tudor England (Newcastle: Cambridge Scholars, 2008)

Anderson, Roberta, and Charlotte Backerra (eds.), Confessional diplomacy in Early Modern Europe (London: Routledge, 2020)

Andrea, Bernadette, 'Lady Sherley: The First Persian in England?', The Muslim World, 95 (2005), 279-295 
Andrea, Bernadette, Women and Islam in Early Modern English Literature (Cambridge: Cambridge University Press, 2007)

Andreani, Angela, The Elizabethan Secretariat and the Signet Office: The Production of State Papers, 1590-1596 (London: Routledge, 2017)

Andrews, Walter G., and Mehmet Kalpakh, The Age of Beloveds: Love and the Beloved in Early Modern Ottoman and European Culture and Society (Durham, NC: Duke University Press, 2005)

Archer, Ian W., The Pursuit of Stability: Social Relations in Elizabethan London (Cambridge: Cambridge University Press, 2002)

Archer, Ian W., 'Palavicino, Sir Horatio (c. 1540-16oo), merchant and diplomat', Oxford Dictionary of National Biography (January 2008), https://doi.org/10.1093/ ref:odnb/21153 (accessed October 2020)

Arens, William, The Man-Eating Myth: Anthropology and Anthropophagy (New York: Oxford University Press, 1979)

Arlidge, Anthony, Shakespeare and the Prince d'Amour: The Feast of Misrule in the Middle Temple (London: Giles de la Mar, 2000)

Armitage, David, and Jennifer Pitts (eds.), The Law of Nations in Global History (Oxford: Oxford University Press, 2017)

Aubert, Guillaume, "The Blood of France": Race and Purity of Blood in the French Atlantic World', The William and Mary Quarterly, 61:3 (2004), 439-478

Avramescu, Cătălin, An Intellectual History of Cannibalism, trans. by Alistair Ian Blyth (Princeton, NJ: Princeton University Press, 2009)

Bantekas Ilias, and Susan Nash, International Criminal Law (Abingdon: Routledge, 2007) Barker, Francis, Peter Hulme and Margaret Iversen (eds.), Cannibalism and the Colonial World (Cambridge: Cambridge University Press, 1998)

Barnard, John, D. F. McKenzie, and Maureen Bell (eds.), The Cambridge History of the Book in Britain, Vol. IV: 1557-1695 (Cambridge: Cambridge University Press, 2002) Baroja, Julio Caro, Los Judios en la España Moderna y Contemporánea, Vol. 1 (Madrid: Istmo, 200o)

Barreto Xavier, Ângela, Federico Palomo and Roberta Strumpf (eds.), Monarquias Ibéricas em Perspectiva Comparada (Sécs. XVI-XVIII): Dinâmicas Imperiais e Circulação de Modelos Administrativos (Lisbon: Imprensa de Ciências Sociais, 2018)

Barroll, Leeds, Anna of Denmark, Queen of England: A Cultural Biography (Philadelphia: University of Pennsylvania Press, 2001)

Bartels, Emily C., 'Imperial Beginnings: Richard Hakluyt and the Construction of Africa', Criticism, 34 (1993), 517-538

Bartels, Emily C., Spectacles of Strangeness: Imperialism, Alienation, and Marlowe (Philadelphia: University of Pennsylvania Press, 1993)

Bartels, Emily C., 'Too Many Blackamoors: Deportation, Discrimination, and Elizabeth I', Studies in English Literature, 1500-1900, 46 (2006), 305-322 
Beem, Charles (ed.), The Foreign Relations of Elizabeth I (Basingstoke: Palgrave, 2011)

Beier, A. L., Masterless Men: The Vagrancy Problem in England, 1560-1640 (New York: Methuen, 1986)

Beller, E. A., 'The Negotiations of Sir Stephen Le Sieur, 1584-1613', The English Historical Review, 40 (1925), 22-33

Bennett, Tony, Lawrence Grossberg and Meaghan Morris (eds.), New Keywords: A Revised Vocabulary of Culture and Society (Oxford: Blackwell, 2005)

Berek, Peter, 'The Jew as Renaissance Man', Renaissance Quarterly, 51 (1998), 128-162 Bethencourt, Francisco, The Inquisition: A Global History, 1478-1834 (Cambridge: Cambridge University Press, 2009)

Bethencourt, Francisco, Racisms: From the Crusades to the Twentieth Century (Princeton, NJ: Princeton University Press, 2014)

Bierbach, Jeremy B., Frontiers of Equality in the Development of EU and US Citizenship (The Hague: T. M. C Asser Press, 2017)

Biow, Douglas, 'Castiglione and the Art of Being Inconspicuously Conspicuous', Journal of Medieval and Early Modern Studies, 38 (2008), 35-55

Blanks, David R., and Michael Frassetto (eds.), Western Views of Islam in Medieval and Early Modern Europe: Perception of Other (New York: St. Martin's Press, 1999) Bodian, Miriam, Hebrews of the Portuguese Nation: Conversos and Community in Early Modern Amsterdam (Bloomington: Indiana University Press, 1999)

Booth, Roy (ed.), The Collected Poems ofJohn Donne (Hertfordshire: Wordsworth Editions, 1994)

Bouza, Fernando, Pedro Cardim, and Antonio Feros, The Iberian World: 1450-1820 (London: Routledge, 2020)

Bowen, H. V., Margarette Lincoln, and Nigel Rigby (eds.), The Worlds of the East India Company (Woodbridge: Boydell Press, 2002)

Bradford, William, Of Plymouth Plantation, 1620-1647: The Complete Text (New York: Alfred Knopf, 1952)

Bray, William (ed.), The Diary ofJohn Evelyn (London: M. W. Dunne, 1901)

Brenner, Richard, 'The Social Basis of English Commercial Expansion, 1550-1650', The Journal of Economic History, 32:1 (1972), 361-384

Brett, Annabel S., Changes of State: Nature and the Limits of the City in Early Modern Natural Law (Princeton: Princeton University Press, 2011)

Britland, Karen, Drama in the Courts of Queen Henrietta Maria (Cambridge: Cambridge University Press, 2006)

Brotton, Jerry, The Sultan and the Queen: The Untold Story of Elizabeth and Islam (New York: Viking, 2016)

Bryson, Anna, From Courtesy to Civility: Changing Codes of Conduct in Early Modern England (Cambridge: Cambridge University Press, 1998) 
Burke, Peter, The Fortunes of the Courtier: The European Reception of Castiglione's Cortegiano (Cambridge: Polity Press, 1995)

Burke, Peter, Exiles and Expatriates in the History of Knowledge, 1500-1700 (Waltham: Brandeis University Press, 2017)

Burton, Jonathan, Traffic and Turning: Islam and English Drama, 1579-1624 (Newark: University of Delaware Press, 2005)

Cain, Tom, 'John Donne and the Ideology of Colonization', English Literary Renaissance, 31:3 (2001), 440-476

Calvet de Magalhães, José, The Pure Concept of Diplomacy, trans. by Bernardo Futscher Pereira (London: Greenwood, 1988)

Campos, Edmund Valentine, 'Jews, Spaniards, and Portingales: Ambiguous Identities of Portuguese Marranos in Elizabethan England', English Literary History, 69:3 (2002), 599-616

Cañizares-Esguerra, Jorge, Puritan Conquistadors: Iberianizing the Atlantic, 1550-1700 (Stanford, CA: Stanford University Press, 2006)

Cañizares-Esguerra, Jorge, and Erik R. Seeman (eds.), The Atlantic in Global History: 1500-200o (London: Routledge, 2016)

Canny, Nicholas, 'The Ideology of English Colonization: From Ireland to America', The William and Mary Quarterly, 30 (1973), 575-598

Canny, Nicholas, The Elizabethan Conquest of Ireland (Sussex: Harvester Press, 1976)

Canny, Nicholas, (ed.) The Oxford History of the British Empire, Vol. I (Oxford: Oxford University Press, 1998)

Carey, Daniel, Gábor Gelléri, and Anders Ingram, The Art of Travel (2020) https:// artoftravel.nuigalway.ie/ (accessed October 2020)

Carroci, Max, and Stephanie Pratt (eds.), Native American Adoption, Captivity, and Slavery in Changing Contexts (Basingstoke: Palgrave, 2012)

Catterall, Douglas, Community without Borders: Scots Migrants and the Changing Face of Power in the Dutch Republic, c. 160o-170o (Leiden: Brill, 2002)

Chacon, Richard J., and David H. Dye (eds.), The Taking and Displaying of Human Body Parts as Trophies by Amerindians (New York: Springer, 2007)

Chakravarty, Urvashi, 'The Renaissance of Race and the Future of Early Modern Race Studies,' English Literary Renaissance, 50:1 (2020), 17-24

Charry, Brinda, and Gitanjali Shahani (eds.), Emissaries in Early Modern Literature and Culture: Mediation, Transmission, Traffic, 1550-1700 (London: Routledge, 2009)

Chaudhuri, K. N., The English East India Company: The Study of an Early Joint-stock Company, 1600-1640 (London: Routledge, 1965)

Chew, Samuel C., The Crescent and the Rose: Islam and England during the Renaissance (Oxford: Oxford University Press, 1937)

Chitty, C. W., 'Aliens in England in the Sixteenth Century', Race, 8:2 (1966/67), 129-145. 
Clark, Peter, and Paul Slack, English Towns in Transitions, 1500-170o (Oxford: Oxford University Press, 1976)

Coast, David, Information, Politics and Diplomacy, 1618-1625 (Manchester: Manchester University Press, 2014)

Cohen, Richard I., Jewish Icons: Art and Society in Modern Europe (Berkeley: University of California Press, 1998)

Collins, John M., Martial Laws and English Laws, c. 1500-1700 (Cambridge: Cambridge University Press, 2016)

Conklin, Beth A., Consuming Grief: Compassionate Cannibalism in an Amazonian Society (Austin: University of Texas Press, 2001)

Corens, Liesbeth, Confessional Mobility and English Catholics in Counter-Reformation Europe (Oxford: Oxford University Press, 2018)

Cottret, Bernard, The Huguenots in England: Immigration and Settlement c.1550-1700, trans. by Peregrine and Adriana Stevenson (Cambridge: Cambridge University Press, 1991)

Crane, Jacob, 'The Long Transatlantic Career of the Turkish spy', Atlantic Studies, 10:2 (2013), 228-246

Crawford, Patricia, and Laura Gowing (eds.), Women's Worlds in Seventeenth-Century England: A Sourcebook (London: Routledge, 2000)

Cressy, David, Dangerous Talk: Scandalous, Seditious, and Treasonable Speech in Pre-Modern England (Oxford: Oxford University Press, 2010)

Cressy, David, 'Trouble with Gypsies in Early Modern England', The Historical Journal, 59 (2016), 45-70

Cressy, David, Gypsies: An English History (Oxford: Oxford University Press, 2018)

Croft, Pauline (ed.), The Spanish Company (London: London Record Society, 1973)

Crome, Andrew (ed.), Prophecy and Eschatology in the Transatlantic World, 1550-1800 (Basingstoke: Palgrave, 2016)

Cruz, Anne J. (ed.), The Life and Writings of Luisa de Carvajaly Mendoza (Toronto: Centre for Reformation and Renaissance Studies, 2014)

D'Addario, Christopher, Exile and Journey in Seventeenth-Century Literature (Cambridge: Cambridge University Press, 2007)

Das, Nandini, Renaissance Romance: The Transformation of English Prose Fiction, 1570-1620 (Farnham: Ashgate, 2011)

Das, Nandini, 'The Stranger at the Door: Belonging in Shakespeare's Ephesus', Shakespeare Survey, 73 (2020), 10-20

Das, Nandini, and Tim Youngs (eds.), The Cambridge History of Travel Writing (Cambridge: Cambridge University Press, 2019)

Davies, C. S. L., 'Slavery and Protector Somerset; The Vagrancy Act of 1547', The Economic History Review, 19 (1966), 533-549. 
Davies, Surehka, Renaissance Ethnography and the Invention of the Human: New Worlds, Maps, and Monsters (Cambridge: Cambridge University Press, 2016)

Daybell, James, Women and Politics in Early Modern England, 1450-1700 (London: Routledge, 2004)

Demetriou, Tania, and Rowan Tomlinson (eds.), The Culture of Translation in Early Modern England and France, 1500-166o (Basingstoke: Palgrave Macmillan, 2015) Derrida, Jacques, Of Hospitality (Stanford, CA: Stanford University Press, 200o) Dijk, Arjan van, 'Early Printed Qur'ans: The Dissemination of the Qur'an in the West', Journal of Qur'anic Studies, 7:2 (2005), 136-143

Dimmock, Matthew, “Machomet dyd before as Luther doth nowe": Islam, the Ottomans and the English Reformation', Reformation, 9:1 (2004), 99-130

Dimmock, Matthew, New Turke: Dramatizing Islam and the Ottomans in Early Modern England (Aldershot: Ashgate, 2005)

Dimmock, Matthew, Mythologies of the Prophet Muhammad in early modern English culture (Cambridge: Cambridge University Press, 2013)

Dimmock, Matthew, 'Converting and Not Converting “Strangers” in Early Modern London', Journal of Early Modern History, 17 (2013), 457-478

Dimmock, Matthew, Elizabethan Globalism: England, China, and the Rainbow Portrait (New Haven, CT: Yale University Press, 2019)

Dolan, Frances E., 'Home-Rebels and House-Traitors: Murderous Wives in Early Modern England', Yale Journal of Law \& the Humanities, 4 (1992), 1-32

Dover, Paul M. (ed.), Secretaries and Statecraft in the Early Modern World (Edinburgh: Edinburgh University Press, 2016)

Dunn-Hensley, Susan, Anna of Denmark and Henrietta Maria: Virgins, Witches, and Catholic Queens (Basingstoke: Palgrave, 2017)

Eacott, Jonathan, Selling Empire: India in the Making of Britain and America, 16oo-1830 (Chapel Hill: University of North Carolina Press, 2016)

Earle, Thomas Foster, and Kate J. P. Lowe (eds.), Black Africans in Renaissance Europe (Cambridge: Cambridge University Press, 2005)

'Early Black British History', Oxford Dictionary of National Biography, https:// www.oxforddnb.com/applib/newsitem/295/early-black-british-history-andthe-oxford-dnb (accessed October 2020)

Ebert, Christopher, 'Early Modern Atlantic Trade and the Development of Maritime Insurance to 1630', Past \& Present, 213:1 (2011), 87-114.

Edwards, Philip, Sea-Mark: The Metaphorical Voyage, Spenser to Milton (Liverpool: Liverpool University Press, 1997)

Elias, Norbert, The Civilizing Process, trans. by Edmund Jephcott (Oxford: Blackwell, 1978) Enenkel, Karl A. E. and Jan de Jong (eds.), Artes Apodemicae and Early Modern Travel (Leiden; Brill, 2019) 
Engler, Bernd, 'Literary Form as Aesthetic Program: The Envoy in English and American Literature,' REAL: The Yearbook of Research in English and American Literature, 7 (1990), 61-97.

Erikson, Emily, Between Monopoly and Free Trade: The English East India Company, 1600-1757 (Princeton, NJ: Princeton University Press, 2014)

Erickson, Peter, and Clark Hulse (eds.), Early Modern Visual Culture: Representation, Race, and Empire in Renaissance England (Philadelphia: University of Pennsylvania Press, 2000)

Erickson, Peter, and Kim F. Hall, “A New Scholarly Song”: Rereading Early Modern Race', Shakespeare Quarterly, 67 (2016), 1-13

Ellis, Steven G., Guðmundur Hálfdanarson and Ann Katherine Isaacs (eds.), Citizenship in Historical Perspective (Pisa: Pisa University Press, 2006)

Espinosa, Ruben, and David Ruiter (eds.), Shakespeare and Immigration (London: Routledge, 2014)

Ewen, Misha, 'Women Investors and the Virginia Company in the Early Seventeenth Century', Historical Journal, 62:4 (2019), 853-874

Fanshawe, Herbert Charles (ed.), The Memoirs of Ann, Lady Fanshawe (London: John Lane, 1907)

Fassbender, Bardo, and Anne Peters (eds.), The Oxford Handbook of the History of International Law (Oxford: Oxford University Press, 2012)

Fausto, Carlos, Warfare and Shamanism in Amazonia (Cambridge: Cambridge University Press, 2012)

Fausz, J. Frederick, 'Middlemen in Peace and War: Virginia's Earliest Indian Interpreters, 1608-1632', The Virginia Magazine of History and Biography, 95:1 (1987), 41-64

Fedele, Dante, 'The Renewal of Early-Modern Scholarship on the Ambassador: Pierre Ayrault on Diplomatic Immunity',Journal of the History of International Law, 18 (2006), 449-468

Fedele, Dante, Naissance de la diplomatie moderne (XIIIe-XVIIe siècles): L'ambassadeur au croisement du droit, de l'éthique et de la politique (Baden-Baden: Nomos Verlag, 2017)

Federici, Federico M., and Dario Tessicini (eds.), Translators, Interpreters and Cultural Negotiators: Mediating and Communicating Power from the Middle Ages to the Modern Era (London: Palgrave Macmillan, 2014)

Feerick, Jean E., Strangers in Blood: Relocating Race in the Renaissance (Toronto: University of Toronto Press, 2010)

Feingold, Mordechai, “"The Turkish Alcoran”: New Light of the 1649 Translation of the Koran', The Huntington Library Quarterly, 75:4 (2012), 475-501

Ferrier, R. W. 'An English View of Persian Trade in 1618: Reports from the Merchants Edward Pettus and Thomas Barker', Journal of the Economic and Social History of the Orient, 19:2 (1976), 182-214 
Fischel, Walter J., 'Abraham Navarro: Jewish Interpreter and Diplomat in the Service of the English East India Company (1682-1692)', Proceedings of the American Academy for Jewish Research, 25 (1956), 39-62

Fischel, Walter J., 'Abraham Navarro:Jewish Interpreter and Diplomat in the Service of the English East India Company (1682-1692)', Proceedings of the American Academy for Jewish Research, 26 (1957), 25-39

Fischlin, Daniel, 'Political Allegory, Absolutist Ideology, and the "Rainbow Portrait" of Queen Elizabeth I', Renaissance Quarterly, 50 (1997), 175-206

Fleck, Andrew, 'Here, There, and In Between: Representing Difference in the “Travels” of Sir John Mandeville', Studies in Philology, 97:4 (2000), 379-400

Floyd-Wilson, Mary, and Garrett A. Sullivan, Jr (eds.), Renaissance Drama Series, 35: Embodiment and Environment in Early Modern Drama and Performance (Evanston, IL: Northwestern University Press, 2006)

Fraser, William (ed.), Douglas Book, Vol. 3 (Edinburgh: Edinburgh University Press, 1885)

Frias, Pedro de, Crónica del-rei D. António, ed. by Mário Alberto Nunes da Costa (Coimbra: Universidade de Coimbra, 1955)

Frigo, Daniela, 'Prudence and Experience: Ambassadors and Political Culture in Early Modern Italy',Journal of Medieval and Early Modern Studies, 38 (2008), 15-34 Froide, Amy, Silent Partners: Women as Public Investors during Britain's Financial Revolution, 169o-1750 (Oxford: Oxford University Press, 2016)

Frye, Susan, and Karen Robertson (eds.), Maids and Mistresses, Cousins and Queens: Women's Alliances in Early Modern England (Oxford: Oxford University Press, 1999)

Fuchs, Barbara, Mimesis and Empire: The New World, Islam, and European Identities (Cambridge: Cambridge University Press, 2001)

Gabrieli, Vittorio, Sir Kenelm Digby: Un inglese italianato nell'età della controriforma (Rome: Edizione di Storia e Letteratura, 1957)

Gadd, Ian (ed.), The History of the Oxford University Press, Vol. I: Beginnings to 1780 (Oxford: Oxford University Press, 2013)

Gallagher, John, Learning Languages in Early Modern England (Cambridge: Cambridge University Press, 2019)

Games, Alison, The Web of Empire: English Cosmopolitans in an Age of Expansion, 1560-166o (Oxford: Oxford University Press, 2008)

Gelder, Martje van, and Tijana Krstić, 'Introduction: Cross-confessional Diplomacy and Diplomatic Intermediaries in the Early Modern Mediterranean', Journal of Early Modern History, 19:2-3 (2015), 93-105

Gelders, Ralf, 'Genealogy of Colonial Discourse: Hindu Traditions and the Limits of European Representation', Comparative Studies in Society and History, 51:3 (2009), 563-589 
Ghobrial, John-Paul, The Whispers of Cities: Information Flows in Istanbul, London, and Paris in the Age of William Trumbull (Oxford: Oxford University Press, 2013)

Gikandi, Simon, Slavery and the Culture of Taste (Princeton, NJ: Princeton University Press, 2011)

Glaser, Eliane, Judaism without Jews: Philosemitism and Christian Polemic in Early Modern England (Basingstoke: Palgrave, 2007)

Glaser, Eliane (ed.), Religious Tolerance in the Atlantic World: Early Modern and Contemporary Perspectives (Basingstoke: Palgrave, 2013)

Goffman, Daniel, Britons in the Ottoman Empire 1642-166o (Seattle: University of Washington Press, 1998)

Goose, Nigel, and Lien Luu (eds.), Immigrants in Tudor and Early Stuart England, (Eastbourne: Sussex Academic Press, 2003)

Grafton, Anthony, and Ann Blair (eds.), The Transmission of Culture in Early Modern Europe (Philadelphia: Pennsylvania University Press, 199o)

Greenblatt, Stephen, Renaissance Self-Fashioning: From More to Greenblatt (Berkeley, CA: Stanford University Press, 1980)

Greenblatt, Stephen, Marvellous Possessions: The Wonder of the New World (Oxford: Clarendon, 1991)

Greer, Allan, Property and Dispossession: Natives, Empires, and Land in Early Modern North America (Cambridge: Cambridge University Press, 2018)

Grogan, Jane, The Persian Empire in English Renaissance Writing, 1549-1622 (Basingstoke: Palgrave, 2014)

Guasco, Michael, Slaves and Englishmen: Human Bondage in the Early Modern Atlantic World (Philadelphia: University of Pennsylvania Press, 2011)

Guibbory, Achsah, Christian Identity, Jews, and Israel in Seventeenth Century England (Oxford: Oxford University Press, 2010)

Habib, Imtiaz, 'Othello's "Malignant Turk” and George Manwaring's "A True Discourse": The Cultural Politics of a Textual Derivation', Medieval and Renaissance Drama in England, 26 (2013), 207-239

Habib, Imtiaz, Black Lives in the English Archives, 1500-1677: Imprints of the Invisible, 2nd edition (Abingdon: Routledge, 2016)

Hadfield, Andrew, Literature, Travel, and Colonial Writing in the English Renaissance, 1545-1625 (Oxford: Clarendon Press, 1998)

Hadfield, Andrew (ed.), Amazons, Savages, and Machiavels: Travel and Colonial Writing in English, 1550-1630: An Anthology (Oxford: Oxford University Press, 2001)

Hadfield, Andrew (ed.), The Oxford Handbook of English Prose, 1500-1640 (Oxford: Oxford University Press, 2013)

Hailwood, Mark, and Jane Whittle, 'Women's Work in Rural England, 1500-1700: A New Methodological Approach', Local Population Studies, 96 (2016), 66-71 
Hakim, Adi (ed.), Black British History: New Perspectives from the Roman Times to the Present Day (London: ZED Books, 2019)

Hall, Kim F., Things of Darkness: Economies of Race and Gender in Early Modern England (Ithaca, NY: Cornell University Press, 1995)

Hamilton, Alastair, Maurits H. Van Den Boogert and Bart Westerweel (eds.), The Republic of Letters and the Levant (Leiden: Brill, 2005)

Hamilton, Keith, and Richard Langhorne, The Practice of Diplomacy: Its Evolution, Theory, and Administration (London: Routledge, 2011)

Hamling, Tara, and Catherine Richardson (eds.), Everyday Objects: Medieval and Early Modern Material Culture and its Meanings (Farnham: Ashgate, 2010)

Hammer, Paul E. J., 'The Use of Scholarship: The Secretariat of Robert Devereux, Second Earl of Essex, c. 1585-1601', The English Historical Review, 109 (1994), 26-51 Hampton, Timothy, Fictions of Embassy: Literature and Diplomacy in Early Modern Europe (Ithaca, NY: Cornell University Press, 2009)

Harper, James G. (ed.), The Turk and Islam in the Western Eye, 1450-1750: Visual Imagery before Orientalism (Farnham: Ashgate, 2011)

Harris, Jonathan Gil (ed.), Indography: Writing the 'Indian' in Early Modern England (Basingstoke: Palgrave, 2012)

Heal, Felicity, 'The Idea of Hospitality in Early Modern England', Past \& Present, 102 (1984), 66-93

Hendricks, Margo, and Patricia Parker (eds.), Women, 'Race', and Writing in the Early Modern Period (Abingdon: Routledge, 1994)

Herbert, Amanda, Female Alliances: Gender, Identity, and Friendship in Early Modern Britain (New Haven, CT: Yale University Press, 2014)

Herrmann, Rachel B., 'The "tragicall historie": Cannibalism and Abundance in Colonial Jamestown', The William and Mary Quarterly, 68 (2011), 47-74

Hervey, Mary F. S., The Life, Correspondence \& Collections of Thomas Howard, Earl of Arundel (Cambridge: Cambridge University Press, 1921)

Hessayon, Ariel, and Nicholas Keene (eds.), Scripture and Scholarship in Early Modern England (Farham: Ashgate, 2006)

Hillgarth, J. N., The Mirror of Spain, 1500-1700: The Formation of a Myth (Ann Arbor: University of Michigan Press, 2000)

Hodgen, Margaret, Anthropology in the Sixteenth and Seventeenth Centuries (Philadelphia: University of Pennsylvania Press, 1964)

Höfele, Andreas, and Werner von Koppenfels (eds.), Renaissance Go-betweens: Cultural Exchange in Early Modern Europe (Berlin: Walter de Gruyter, 2005)

Hoffman, George, Reforming French Culture: Satire, Spiritual Alienation, and Connection to Strangers (Oxford: Oxford University Press, 2017)

Holmberg, Eva Johanna, Jews in the Early Modern Imagination: A Scattered Nation (Farnham: Ashgate, 2011) 
Holmberg, Eva Johanna, 'Introduction: Renaissance and Early Modern Travel: Practice and Experience, 1500-1700', Renaissance Studies, 33 (2019), 515-523

Hooper, Jane, 'Pirates and Kings: Power on the Shores of Early Modern Madagascar and the Indian Ocean', Journal of World History, 22 (2011), 215-242

Hoppe, Matthew, Turncoats and Renegadoes: Changing Sides during the English Civil Wars (Oxford: Oxford University Press, 2012)

Horwitz, Henry, Parliament, Policy, and Politics in the Reign of William III (Manchester: Manchester University Press, 1977)

Howard, Clare, English Travellers of the Renaissance (New York: John Lane, 1913)

Howarth, David, Lord Arundel and his Circle (New Haven, CT: Yale University Press, 1985)

Howarth, David. 'The Patronage and Collecting of Aletheia, Countess of Arundel, 1606-54', Journal of the History of Collections, 10:2 (1998), 125-137

Hulme, Peter, Colonial Encounters: Europe and the Native Caribbean, 1492-1797 (London: Methuen, 1986)

Hulme, Peter, and Tim Youngs (eds.), The Cambridge Companion to Travel Writing (Cambridge: Cambridge University Press, 2002)

Hunt, Alice, and Anna Whitelock (eds.), Tudor Queenship (New York: Palgrave Macmillan, 2010)

Hutson, Lorna, 'On the Knees of the Body Politic', Representations, 152 (2020), 25-54

Hutson, Lorna (ed.), The Oxford Handbook of Law and Literature, 1500-170o (Oxford: Oxford University Press, 2020)

Huxley, Gervas, Endymion Porter: The Life of a Courtier 1587-1649 (London: Chatto and Windus, 1959)

Huyle, Henry and A. C. Burnell, Hobson-Jobson: A Glossary of Colloquial Anglo-Indian Words and Phrases, and of Kindred Terms, Etymological, Historical, Geographical and Discursive (London: Kegan Paul, 1903)

Ingram, Anders, Writing the Ottomans: Turkish History in Early Modern England (Basingstoke: Palgrave, 2015)

Ingram, Kevin, and Juan Ignacio Pulido Serrano (eds.), The Conversos and Moriscos in Late Medieval Spain and Beyond, Vol. 3: Displaced Persons (Leiden: Brill, 2016) Isaacs, Ann Katherine (ed.), Immigration and Emigration in Historical Perspective (Pisa: Pisa University Press, 2007)

Iyengar, Sujata, Shades of Difference: Mythologies of Skin Color in Early Modern England (Philadelphia: University of Pennsylvania Press, 2005)

Jager, Rebecca Kay, Malinche, Pocahontas, and Sacagawea: Indian Women as Cultural Intermediaries and National Symbols (Norman: University of Oklahoma Press, 2015) Jansson, Maija, 'Measured Reciprocity: English Ambassadorial Gift Exchange in the 17 th and 18th Centuries', Journal of Early Modern History, 9:3 (2005), 348-370 
Jeffrey, David Lyle, The King James Bible and the World that Made It (Waco, TX: Baylor University Press, 2011)

Johnson, Carina L., 'Idolatrous Cultures and the Practice of Religion', Journal of the History of Ideas, 67 (2006), 597-622

Johnson, Lauren, 'Catalina of Motril (fl. 1501-31)', Oxford Dictionary of National Biography, https://doi.org/10.1093/odnb/9780198614128.013.369157 (accessed October 2020)

Jones, Anne Rosalind, and Peter Stallybrass, Renaissance Clothing and the Materials of Memory (Cambridge: Cambridge University Press, 200o)

Jones, J. Mervyn, British Nationality Law and Practice (Oxford: Oxford University Press, 1947)

Jowitt, Claire (ed.), Pirates? The Politics of Plunder, 1550-1650 (London: Palgrave Macmillan, 2007)

Jowitt, Claire, The Culture of Piracy, 1580-1630: English Literature and Seaborne Crime (Burlington, VT: Ashgate, 2010)

Jowitt, Claire, and David McInnes (eds.), Travel and Drama in Early Modern England:

The Journeying Play (Cambridge: Cambridge University Press, 2018)

Kagan, Richard, and Philip Morgan (eds.), Atlantic Diasporas:Jews, Conversos, and Crypto-Jews in the Age of Mercantilism, 1500-1800 (Baltimore, MD: Johns Hopkins University Press, 2009)

Kamen, Henry, The Spanish Inquisition: A Historical Revision (New Haven, CT: Yale University Press, 2008)

Kaplan, M. Lindsay, 'Jessica's Mother: Medieval Constructions of Jewish Race and Gender in “The Merchant of Venice"', Shakespeare Quarterly, $5^{8}$ (2007), 1-30

Kaplan, Yosef (ed.), Early Modern Ethnic and Religious Communities in Exile (Cambridge: Cambridge Scholar Publishing, 2017)

Katz, David S., The Jews in the History of England, 1485-1850 (London: Clarendon Press, 1994)

Katz, David S., 'Menasseh Ben Israel (1604-1657)', in Oxford Dictionary of National Biography, https://doi.org/10.1093/ref:odnb/17916 (accessed October 2020)

Kaufmann, Miranda, 'Caspar van Senden, Sir Thomas Sherley and the "Blackamoor" Project', Historical Research, 81 (2008), 366-371

Kaufmann, Miranda, Black Tudors: The Untold Story (London: Oneworld, 2017)

Keblusek, Marika, and Badeloch Vera Noldus (eds.), Double Agents: Cultural and Political Brokerage in Early Modern Europe (Leiden: Brill, 2011)

Keechang, Kim, Aliens in Medieval Law: The Origins of Modern Citizenship (Cambridge: Cambridge University Press, 2000)

Keller, Marcus Javier Irigoyen-García (eds.), The Dialectics of Orientalism in Early Modern Europe (London: Palgrave, 2018) 
Kershen, Anne, Strangers, Aliens and Asians: Huguenots, Jews, and Bangladeshis in Spitalfields 1666-200o (Abingdon: Routledge, 2004)

King, John, 'The Godly Woman in Elizabethan Iconography', Renaissance Quarterly, 38 (1985), 41-84

Kingsbury, Benedict, and Benjamin Straumann (eds.), The Roman Foundations of the Law of Nations: Alberico Gentili and the Justice of Empire (Oxford: Oxford University Press, 2010)

Kirby, Torrance, Persuasion and Conversion: Essays on Religion, Politics, and the Public Sphere in Early Modern England (Leiden: Brill, 2013)

Kirk, R. E. G., and Ernest F. Kirk (eds.), Returns of Aliens Dwelling in the City and Suburbs of London from the Reign of Henry VIII to that ofJames I, Vol. 2 (Aberdeen: Aberdeen University Press, 1900-1908)

Kitch, Aaron, 'Shylock's Sacred Nation', Shakespeare Quarterly, 59 (2008), 131-155.

Knapp, Jeffrey, Shakespeare's Tribe: Church, Nation and Theater in Renaissance England (Chicago, IL; University of Chicago Press, 2004)

Knoppers, Laura Lunger (ed.), The Cambridge Companion to Early Modern Women's Writing (Cambridge: Cambridge University Press, 2009)

Koenigsberger, Helmut, 'English Merchants in Naples and Sicily in the Seventeenth Century', The English Historical Review, 62 (1947), 304-326

Kogut Lessa de Sá, Vivien (ed.), The Admirable Adventures and Strange Fortunes of Master Anthony Knivet: An English Pirate in Sixteenth-Century Brazil (Cambridge: Cambridge University Press, 2015)

Kuhn, John, 'Sejanus, the King's Men Altar Scenes, and the Theatrical Production of Paganism', Early Theatre: AJournal Associated with the Records of Early English Drama, 20 (2017), 77-98

Kupperman, Karen Ordahl (ed.), Captain John Smith: A Select Edition of His Writings (Chapel Hill: University of North Carolina Press, 1988)

Kupperman, Karen Ordahl, Indians and English: Facing Off in Early America (Ithaca, NY: Cornell University Press, 200o)

Kupperman, Karen Ordahl, Pocahontas and the English Boys: Caught Between Cultures in Early Virginia (New York: New York University Press, 2019)

Kynan-Wilson, William, 'Souvenirs and Stereotypes: An Introduction to Ottoman Costume Albums', Heritage Turkey, 3 (2013), 35-36

Lambert, Bart, and W. Mark Ormrod, 'Friendly Foreigners: International Warfare, Resident Aliens and the Early history of Denization in England, 1250-1400', English Historical Review, 130 (2015), 1-24

Landes, Jordan, London Quakers in the Transatlantic World: The Creation of an Early Modern Community (London: Palgrave Macmillan, 2015)

Langhorne, Richard, 'Alberico Gentili on Diplomacy', The Hague Journal of Diplomacy, 4 (2009), 307-318 
Lebedinski, Ester, “'Obtained by peculiar favour, \& much difficulty of the Singer”: Vincenzo Albrici and the Function of Charles II's Italian Ensemble at the English Restoration Court', Journal of the Royal Musical Association, 143:2 (2018), 325-359 Leech, Peter, 'Musicians in the Catholic chapel of Catherine of Braganza, 1662-92', Early Music, 29:4 (2001), 571-587

Leeson, Peter T., The Invisible Hook: The Hidden Economics of Pirates (Princeton, NJ: Princeton University Press, 2009)

Leeson, Peter T., 'Rationality, Pirates, and the Law: A Retrospective', American University Law Review, 59 (2010), 1219-1230

Leoni, Aron Di Leone, The Hebrew Portuguese Nations in Antwerp and London at the Time of Charles V and Henry VIII (Jersey City: KTAV, 2005)

Leoni, Aron Di Leone, La Nazione Ebraica Spagnola e Portoghese di Ferrara (1492-1559): I suoi rapporti col governo ducale e la popolazione locale e i suoi legami con le Nazioni Portoghesi di Ancona, Pesaro e Venezia (Florence: Leo S. Olschki, 2011)

Levesque, Catherine, Journey Through Landscape in Seventeenth-Century Holland: The Haarlem Print Series and Dutch Identity (Philadelphia: Penn State Press, 1994) Lewis, James, 'Nifon catange or Japon fation': A Study of Cultural Interaction in the English Factory in Japan, 1613-1623 (unpublished PhD dissertation, University of Sheffield, 2004)

Liberman, Anatoly, Word Origins ... and How We Know Them: Etymology for Everyone (Oxford: Oxford University Press, 2005)

Lockwood, Matthew, "Love ye therefore the strangers": Immigration and the Criminal Law in Early Modern England', Continuity and Change, 29 (2014), 349-371

Lodge, Richard, 'The English Factory at Lisbon: Some Chapters in Its History', Transactions of the Royal Historical Society, 16 (1933), 211-247

'London Aliens', Map of Early Modern London (2020), https://mapoflondon.uvic. ca/ALIE1.htm (accessed October 2020)

Loomba, Ania, Shakespeare, Race, and Colonialism (Oxford: Oxford University Press, 2002)

Loomba, Ania, and Jonathan Burton (eds.), Race in Early Modern England: A Documentary Companion (London: Palgrave Macmillan, 2007)

Loop, Jan, Alastair Hamilton, and Charles Burnett (eds.), The Teaching and Learning of Arabic in Early Modern Europe (Leiden: Brill, 2017)

López-Peláez Casellas, Jesús, “Paradoxing” the Alien: The Morisco in Early Modern English Texts', Miscelánea: A Journal of English and America Studies, 46 (2012), $34-36$

Loveman, Kate, 'The Introduction of Chocolate into England: Retailers, Researchers, and Consumers, 1640-1730', Journal of Social History, 47 (2013), 27-46 
Lowe, Ben, Commonwealth and the English Reformation: Protestantism and the Politics of Religious Change in the Gloucester Vale, 1383-156o (Farnham: Ashgate, 2010)

Lozano, Cristina Bravo, 'Popular Protests, the Public Sphere and Court Catholicism. The Insults to the Chapel of the Spanish Embassy in London, 1685-1688', Culture \& History Digital Journal, 6:1 (2017), https://doi.org/10.3989/chdj.2017.007

Lublin, Robert, Costuming the Shakespearean Stage: Visual Codes of Representation in Early Modern Theatre and Culture (Farnham: Ashgate, 2011)

Luu, Lien Bich, Immigrants and the Industries of London 1500-1700 (London: Routledge, 2005)

Mabbett, Margaret, 'Italian Musicians in Restoration England (166o-9o)', Music \& Letters, 67:3 (1986), 237-247

MacDonald, Joyce Green, Women and Race in Early Modern Texts (Cambridge: Cambridge University Press, 2002)

MacLean, Gerald M., The Rise of Oriental Travel: English Visitors to the Ottoman Empire, 1580-1720 (Basingstoke: Palgrave, 2004)

MacLean, Gerald M., Looking East: English Writing and the Ottoman Empire Before 1800 (Basingstoke: Palgrave, 2007)

MacLean, Gerald, and Nabil Matar, Britain and the Islamic World, 1558-1713 (Oxford: Oxford University Press, 2011)

Macrae-Gibson, Osgar Duncan (ed.), Of Arthour and Merlin (Oxford: Oxford University Press, 1973)

Magee, Glenn Alexander (ed.), The Cambridge Companion to Western Mysticism and Esotericism (Cambridge: Cambridge University Press, 2016)

Magurn, Ruth (ed.), The Letters of Peter Paul Rubens (Cambridge, MA: Harvard University Press, 1955)

Major, Philip (ed.), Literatures of Exile in the English Revolution and its Aftermath, 1640-169o (Burlington: Ashgate, 2010)

Malcolm, Noel, 'The 1649 Translation of the Koran: Its Origins and Significance', Journal of the Warburg and Courtauld Institutes, 75 (2012), 261-295

Mancall, Peter, Hakluyt's Promise: An Elizabethan's Obsession for an English America (New Haven, CT: Yale University Press, 2007)

Marcocci, Giuseppe, and José Pedro Paiva, História da Inquisição portuguesa (1536-1821) (Lisbon: Esfera dos Livros, 2013)

Marenbon, John, Pagans and Philosophers: The Problem of Paganism from Augustine to Leibniz (Princeton, NJ: Princeton University Press, 2015)

Marotti, Arthur, F. (ed.), Catholicism and Anti-Catholicism in Early Modern English Texts (Basingstoke: Palgrave, 1999)

Marshall, Alan, Intelligence and Espionage in the Reign of Charles II, 1660-1685 (Cambridge: Cambridge University Press, 2013) 
Matar, Nabil, 'The Renegade in English Seventeenth-Century Imagination', Studies in English Literature, 1500-1900, 33 (1993), 489-505

Matar, Nabil, 'The Representation of Muslim Women in Renaissance England', The Muslim World, 86 (1996), 50-61

Matar, Nabil, Islam in Britain, 1558-1685 (Cambridge: Cambridge University Press, 1998)

Matar, Nabil, Turks, Moors, and Englishmen in the Age of Discovery (New York: Columbia University Press, 1999)

Mather, James, Pashas: Traders and Travellers in the Islamic World (New Haven, CT: Yale University Press, 2009)

Mattingly, Garett, Renaissance Diplomacy (London: Jonathan Cape, 1963)

Maurer, Margaret, 'The Real Presence of Lucy Russell, Countess of Bedford, and the Terms of John Donne's "Honour is So Sublime Perfection"', ELH: A Journal of English Literary History, 47:2 (1980), 205-234

Mayall, David, Gypsy Identities, 1500-200o: From Egipcyans and Moon-men to the Ethnic Romany (New York: Routledge, 2004)

McBride, Gordon K., 'Elizabethan Foreign Policy in Microcosm: The Portuguese Pretender, 1580-89', Albion: A Quarterly Journal Concerned with British Studies, 5:3 (1973), 193-210

McConchie, R. W., Alpo Honkapohja, and Jukka Tyrkkö (eds.), Selected Proceedings of the 2008 Symposium on New Approaches in English Historical Lexis (Sommerville, MA: Cascadilla Proceedings Project, 2009)

McGowan, Andrew, 'Eating People: Accusations of Cannibalism Against Christians in the Second Century', Second-Century Journal of Early Christian Studies, 2:4 (1994), 413-442

McKeown, Adam N., English Mercuries: Soldier Poets in the Age of Shakespeare (Nashville, TN: Vanderbilt University Press, 2009)

McPherson, B. (ed.), Second Treatise of Government (Cambridge: Hackett, 1980)

Melammed, Renee Levine, A Question of Identity: Iberian Conversos in Historical Perspective (Oxford: Oxford University Press, 2004)

Mentz, Steve, and Craig Dionne (eds.), Rogues and Early Modern English Culture (Ann Arbor: University of Michigan Press, 2006)

Metcalf, Alida C., Go-Betweens and the Colonization of Brazil, 1500-16oo (Austin: University of Texas Press, 2005)

Meyers, Debra, and Melanie Perreault (eds.), Order and Civility in the Early Modern Chesapeake (Lanham: Lexington, 2014)

Michaelis, Adolf, Ancient Marbles in Great Britain, trans. by C. A. M. Fennell (Cambridge: Cambridge University Press, 1889)

Mills, Simon, 'The English Chaplains at Aleppo: Exploration and Scholarship between England and the Ottoman Empire, 1620-1760', Bulletin for the Council for British Research in the Levant, 6:1 (2011), 13-20 
Millstone, Noah, 'Seeing Like a Statesman in Early Stuart England', Past \& Present, 223 (2014), 77-127

Millstone, Noah, Manuscript Circulation and the Invention of Politics in Early Modern England (Cambridge: Cambridge University Press, 2016)

Mishra, Rupali, 'Diplomacy at the Edge: Split interests in the Roe Embassy to the Mughal court', Journal of British Studies, 53:1 (2014), 5-28

Mishra, Rupali, A Business of State: Commerce, Politics, and the Birth of the East India Company (Cambridge, MA: Harvard University Press, 2018)

Mitsis, Phillip, and Christos Tsagalis (eds.), Allusion, Authority, and Truth:Critical Perspectives on Greek Poetic and Rhetorical Praxis (Berlin: De Gruyter, 2010)

Molyneux, Catherine, 'Pleasures of the Smoke: "Black Virginians” in Georgian London's Tobacco Shops', The William and Mary Quarterly, 64 (2007), 327-376

Moore, Susan Harman, Abandoning America: Life-Stories from Early New England (Woodbridge: Boydell, 2015)

Moschovakis, Nicholas, "Irreligious Piety" and Christian History: Persecution as Pagan Anachronism in “Titus Andronicus”', Shakespeare Quarterly, 53 (2002), $460-486$

Moshenska, Joe, 'Sir Kenelm Digby's Interruptions: Piracy and Lived Romance in the 1620s', Studies in Philology, 113 (2016), 424-483

Mundill, Robin R., England's Jewish Solution: Experiment and Expulsion, 1262-129o (Cambridge: Cambridge University Press, 1998)

Murphy, Kathryn, 'Robert Burton and the Problems of Polymathy', Renaissance Studies, 28 (2014), 279-297

Murphy, Martin, St. Gregory's College, Seville 1592-1767 (London: Catholic Record Society, 1992)

Musselwhite, Paul, Peter C. Mancall, and James Horn (eds.), Virginia 16rg: Slavery and Freedom in the Making of English America (Chapel Hill: University of North Carolina Press, 2019)

Nahón, Gerard, 'Les sefarades dans la France modern (XVIe-XVIIIe siècles)', Les Nouveaux Cahiers, 62 (1980), 16-25

Netzloff, Mark, “'Counterfeit Egyptians” and Imagined Borders: Jonson's “The Gypsies Metamorphosed"', ELH: A Journal of English Literary History, 68:4 (2001), 763-93

Netzloff, Mark, England's Internal Colonies: Class, Capital, and the Literature of Early Modern English Colonialism (Basingstoke: Palgrave, 2003)

Newman, Karen, and Jane Tylus (eds.), Early Modern Cultures of Translation (Philadelphia: University of Pennsylvania Press, 2005)

Newson, Linda A., Conquest and Pestilence in the Early Spanish Philippines (Honolulu: University of Hawaii Press, 2009)

Niayesh, Ladan, 'Shakespeare's Persians', Shakespeare, 4:2 (2008), 127-136 
Nicholson, Catherine, Uncommon Tongues: Eloquence and Eccentricity in the English Renaissance (Philadelphia: University of Pennsylvania Press, 2014)

Nubia, Onyeka, 'Africans in England and Scotland, 1485-1625', Oxford Dictionary of National Biography (October 2019), https:/doi.org/10.1093/ odnb/9780198614128.013.112804 (accessed October 2020)

NYUP 'Keywords' series (New York: New York University Press, 2011-present), https://keywords.nyupress.org/ (accessed October 2020)

O'Callaghan, Michelle, The 'Shepheards Nation': Jacobean Spensarians and Early Stuart Political Culture, 1612-1625 (Oxford: Clarendon, 2000)

O'Callaghan, Michelle, The English Wits: Literature and Sociability in Early Modern England (Cambridge: Cambridge University Press, 2007)

O'Connor, Daniel, The Chaplains of the East India Company 1601-1858 (London: Bloomsbury Academic, 2012)

Ogborn, Miles, Global Lives: Britain and the World, 1550-1800 (Cambridge: Cambridge University Press, 2008)

Oldenberg, Scott, Alien Albion: Literature and Immigration in Early Modern England (Toronto: University of Toronto Press, 2014)

Onuf, Nicholas, Making Sense, Making Worlds: Constructivism in Social Theory and International Relations (London: Routledge, 2013)

Onyeka, Blackamoores: Africans in Tudor England, Their Presence, Status and Origins (London: Narrative Eye, 2013)

Orlin, Lena (ed.), Material London, c. 1600 (Philadelphia: University of Pennsylvania Press, 2000)

Ouditt, Sharon (ed.), Displaced Persons: Conditions of Exile in European Culture (Aldershot: Ashgate, 2002)

Oxford Dictionary of National Biography, https://www.oxforddnb.com

Oxford English Dictionary, https://www.oed.com

Pagden, Anthony, The Fall of Natural Man: The American Indian and the Origins of Comparative Ethnology (Cambridge: Cambridge University Press, 1982)

Parmelee, Lisa Ferraro, 'Printers, Patrons, Readers, and Spies: Importation of French Propaganda in Late Elizabethan England', The Sixteenth Century Journal, 25:4 (1994), 853-872

Parry, Clive, British Nationality Law and the History of Naturalization (Milano: Universita di Milano, 1954)

Parry, Graham, The Trophies of Time: English Antiquarians of the Seventeenth Century (Oxford: Oxford University Press, 1995)

Partridge, Mary, 'Lord Burghley and Il Cortegiano: Civil and Martial Models of Courtliness in Elizabethan England', Transactions of the Royal Historical Society, 19 (2009), 95-116 
Peltonen, Markku, The Duel in Early Modern England: Civility, Politeness, and Honour (Cambridge: Cambridge University Press, 2003)

Pennell, C. R. (ed.), Piracy and Diplomacy in Seventeenth-century North Africa: The Journal of Thomas Baker, English Consul in Tripoli, 1677-1685 (Madison, NJ: Fairleigh Dickinson University Press, 1989)

Percy, Sarah, Mercenaries: The History of a Norm in International Relations (Oxford: Oxford University Press, 2007)

Pestana, Carla Gardina, Protestant Empire: Religion and the Making of the Atlantic World (Philadelphia: University of Pennsylvania Press, 2009)

Pettegree, Andrew, Foreign Protestant Communities in Sixteenth-Century London (Oxford: Clarendon Press, 1986)

Pettigrew, William A., 'Corporate Constitutionalism and the Dialogue between the Global and the Local in Seventeenth-Century English History', Itinerario, 39:3 (2015), 487-501

Pettigrew, William A., and David Veevers (eds.), The Corporation as a Protagonist in Global History, 1550-1750 (Leiden: Brill, 2018)

Pfister, Manfred, Ashley Chantler, and Carla Dente (eds.), Translation Practices: Through Language to Culture (Amsterdam: Rodopi, 2009)

Picton, James A. (ed.), City of Liverpool: Selections from the Municipal Archives and Records, From the 13th to the 17th Century Inclusive, Vol. 1 (Liverpool: Gilbert G. Walmsley, 1870)

Pincombe, Mike (ed.), Travels and Translations in the Sixteenth Century: Selected Papers from the Second International Conference of the Tudor Symposium (Abingdon: Routledge, 2017)

Platt, F. Jeffrey, 'The Elizabethan Foreign Office', The Historian, 56 (1994), 725-740. Popper, Nicholas, 'An Information State for Elizabethan England', The Journal of Modern History, 90 (2018), 503-535

Price, Polly J., 'Natural Law and Birthright Citizenship in Calvin's Case (1608)', Yale Journal of Law and Humanities, 9 (1997), 73-145

Pullin, Naomi, Female Friends and the Making of Transatlantic Quakerism, 1650-1750 (Cambridge: Cambridge University Press, 2018)

Pulsipher, Jenny Hale, Subjects unto the Same King: Indians, English, and the Contest for Authority in Colonial New England (Philadelphia: University of Pennsylvania Press, 2006)

Queller, Donald E., Office of the Ambassador (Princeton, NJ: Princeton University Press, 1967)

Questier, Michael, Conversion, Politics, and Religion in England, 1580-1625 (Cambridge: Cambridge University Press, 1996)

Raman, Shankar, Framing 'India': The Colonial Imaginary in Early Modern Culture (Stanford, CA: Stanford University Press, 2001) 
Rambuss, Richard, 'The Secretary's Study: The Secret Designs of the Shepheardes Calender', English Literary History, 59:2 (1992), 313-335

Raminelli, Ronald, Nobrezas do Novo Mundo: Brasil e ultramar hispânico, séculos XVII e XVIII (Rio de Janeiro: Editora FGV, 2015)

Ravelhofer, Barbara, The Early Stuart Masque:Dance, Costume, and Music (Oxford: Oxford University Press, 2006)

Raymond, Joad, The Invention of the Newspaper: English Newsbooks, 1641-1649 (Oxford: Clarendon, 1996)

Rex, Cathy, 'Indians and Images: The Massachusetts Bay Colony Seal, James Printer, and the Anxiety of Colonial Identity', American Quarterly, 63:1 (2011), 61-93

Rhodes, Neil, Gordon Kendal, and Louise Wilson (eds.), English Renaissance Translation Theory, Tudor and Stuart Translations, 9 (Cambridge: MHRA, 2013)

Ribton Turner, C. J., A History of Vagrants and Vagrancy and Beggars and Begging (London: Chapman and Hall, 1897)

Richards, Jennifer, Rhetoric and Courtliness in Early Modern Literature (Cambridge: Cambridge University Press, 2003)

Rivère de Carles, Nathalie (ed.), Early Modern Diplomacy, Theatre and Soft Power: The Making of Peace (London: Palgrave Macmillan, 2016)

Robbins, Robin (ed.), The Complete Poems ofJohn Donne (Harlow: Longman, 2010)

Rollison, David, 'Exploding England: The Dialectics of Mobility and Settlement in Early Modern England', Social History, 24 (1999), 1-16

Roshchin, Evgeny, Friendship Among Nations (Oxford: Oxford University Press, 2017)

Rothman, Natalie, Brokering Empire: Trans-Imperial Subjects between Venice and Istanbul (Ithaca, NY: Cornell University Press, 2011)

Rothman, Natalie, 'Afterword: Intermediaries, Mediation and Cross-Cultural Diplomacy in the Early Modern Mediterranean',Journal of Early Modern History, 19 (2015), 245-259

Rubiés, Joan-Pau, 'Political Rationality and Cultural Distance in the European Embassies to Shah Abbas', Journal of Early Modern History, 20:4 (2016), 351-389

Russell-Wood, A. J. R., 'Settlement, Colonization and Integration in the Portuguese Influenced World, 1415-1570', Portuguese Studies Review, 15 (2007), 1-35

Said, Edward, Orientalism: Western Conceptions of the Orient (New York: Penguin, 1978)

Salomon, Frank, and Stuart B. Schwartz (eds.), The Cambridge History of the Native Peoples of the Americas: Vol. 3 , South America (Cambridge: Cambridge University Press, 1999)

Samuel, Edgar, 'Dunstan Anes', Oxford Dictionary of National Biography (September 2004), https://doi.org/10.1093/ref:odnb/40770 (accessed October 2020)

Sanday, Peggy Reeves, Divine Hunger: Cannibalism as a Cultural System (Cambridge: Cambridge University Press, 1986) 
Santos, Kathryn Vomero, “Let me be th'interpreter": Shakespeare and the Tongues of War', Shakespeare Studies, 48 (2020), 66-72

Saraiva, António José, Marrano Factory: The Portuguese Inquisition and its New Christians 1536-1765 (Leiden: Brill, 2001)

Scannel, Paul, Conflicts and Soldiers' Literature in Early Modern Literature: The Reality of War (London: Bloomsbury, 2014)

Schalk, Ellery, From Valor to Pedigree: Ideas of Nobility in France in the Sixteenth and Seventeenth Centuries (Princeton, NJ: Princeton University Press, 1986)

Schmidt, Adriane, 'Women \& Guilds: Corporations and Female Labour Market Participation in Early Modern Holland', Gender \& History, 21 (2009), 170-189

Sebek, Barbara, and Stephen Deng (eds.), Global Traffic: Discourses and Practices of Trade in English Literature and Culture from 1550 to 1700 (New York: Palgrave, 2008) Selwood, Jacob, “English-Born Reputed Strangers": Birth and Descent in Seventeenth Century London', Journal of British Studies, 44 (2005), 728-753

Selwood, Jacob, Diversity and Difference in Early Modern London (Farnham: Ashgate, 2010; 2014)

Shagan, Ethan, The Birth of Modern Belief: Faith and Judgement from the Middle Ages to the Enlightenment (Princeton, NJ: Princeton University Press, 2020)

Shapiro, James, Shakespeare and the Jews (New York: Columbia University Press, 1996; 2016)

Sharp, Buchanan, and Mark Charles Fissel (eds.), Law and Authority in Early Modern England: Essays Presented to Thomas Barnes (Newark: University of Delaware Press, 2007)

Shaw, William (ed.), Letters of Denization and Acts of Naturalization for Aliens in England and Ireland (Lymington: Huguenot Society of London, 1911)

Shawcross, John T., 'John Milton and His Spanish and Portuguese Presence', Milton Quarterly, 322 (1998), 41-52

Shepard, Alexandra, Meanings of Manhood in Early Modern England (Oxford: Oxford University Press, 2003)

Shinn, Abigail, Matthew Dimmock, and Andrew Hadfield (eds.), The Ashgate Research Companion to Popular Culture in Early Modern England (Farnham: Ashgate, 2014)

Shrank, Cathy, Writing the Nation in Reformation England, 1530-1580 (Oxford: Oxford University Press, 2004)

Singh, Jyotsna G. (ed.), A Companion to the Global Renaissance: English Literature and Culture in the Era of Expansion (Oxford: Blackwell, 2009)

Slack, Paul, The Invention of Improvement: Information and Material Progress in Seventeenth-Century England (Oxford: Oxford University Press, 2014)

Smith, David M., The Company of Merchant Adventurers in the City of York: Register of Admissions 1581-1835 (York: Borthwick Publications, 1996) 
Smith, Edmond, 'The global interests of London's commercial community, 1599-1625: Investment in the East India Company', Economic History Review, 71:4 (2018), 1118-1146

Smith, Ian, 'Barbarian Errors: Performing Race in Early Modern England', Shakespeare Quarterly, 49 (1998), 168-186

Smith, Ian, Race and Rhetoric in the Renaissance: Barbarian Errors (Basingstoke: Palgrave, 2009)

Smith, Logan Pearsall, The Life and Letters of Sir Henry Wotton, 2 vols (Oxford: Oxford University Press, 1907)

Smith, Pamela H., and Benjamin Schmidt (eds.), Making Knowledge in Early Modern Europe: Practices, Objects, and Texts, 1400-180o (Chicago: University of Chicago Press, 2007)

Smuts, Malcolm, Court Culture and the Origins of a Royalist Tradition in Early Stuart England (Philadelphia: University of Pennsylvania Press)

Snyder, Jon, Dissimulation and the Culture of Secrecy in Early Modern Europe (Los Angeles: University of California Press, 2009)

Sowerby, Tracey A., and Jan Hennings (eds.), Practices of Diplomacy in the Early Modern World c. 1410-180o (London: Routledge, 2017)

Sowerby, Tracey A., and Joanna Craigwood (eds.), Cultures of Diplomacy and Literary Writing in the Early Modern World (Oxford: Oxford University Press, 2019)

Spink, Ian, 'The Musicians of Queen Henrietta-Maria: Some Notes and References in the English State Papers', Acta Musicologica, 36:2/3 (1964), 177-182

Statt, Daniel, Foreigners and Englishmen: The Controversy Over Immigration and Population, 1660-176o (Cranbury: University of Delaware Press, 1995)

Stern, Philip J., The Company-State: Corporate Sovereignty and the Early Modern Foundations of the British Empire in India (Oxford: Oxford University Press, 2011) Stern, Philip J., and Carl Wennerlind (eds.), Mercantilism Reimagined: Political Economy in Early Modern Britain and its Empire (Oxford: Oxford University Press, 2013)

Stevenson, Joseph (ed.), The Life ofJane Dormer Duchess of Feria by Henry Clifford (London: Burns and Oates, 1887)

Stewart, Alan, “Euery Soyle to Mee is Naturall”: Figuring Denization in William Haughton's Englishman for my Money', Renaissance Drama, 35 (2006), 55-81

Stone, Lawrence, The Crisis of the Aristocracy, 1558-1641 (Oxford: Clarendon Press, 1965) Stoye, John, English Travellers Abroad, 1604-1667: Their Influence in English Society and Politics (revised edition) (New Haven, CT: Yale University Press, 1989)

Stoyle, Mark, Soldiers and Strangers: An Ethnic History of the English Civil War (New Haven, CT: Yale University Press, 2005)

Stretton, Tim, and Krista J. Kesselring (eds.), Married Women and the Law: Coverture in England and the Common Law World (Montreal: McGill-Queen's University Press, 2013) 
Suárez, José Ramón Fernández, 'Francis Cottington: su correspondencia inédita con el Conde de Gondomar (1616-1619)', ES: Revista de filología inglesa, 7 (1977), 69-116 Subrahmanyam, Sanjay, Three Ways to be Alien: Travails and Encounters in the Early Modern World (Brandeis, MA: Brandeis University Press, 2011)

Subrahmanyam, Sanjay, Courtly Encounters: Translating Courtliness and Violence in Early Modern Eurasia (Cambridge, MA: Harvard University Press, 2012)

Subrahmanyam, Sanjay, Empires between Islam and Christianity, 1500-180o (Albany: SUNY Press, 2019)

Sugg, Richard, “Good Physic but Bad Food”: Early Modern Attitudes to Medicinal Cannibalism and its Suppliers', Social History of Medicine, 19:2 (2006), 225-240 Sullivan, Robert, A Dictionary of Derivations, Or, An Introduction to Etymology (London, 1838)

Taverner, Charlie, 'Consider the Oyster Seller: Street Hawkers and Gendered Stereotypes in Early Modern London', History Workshop Journal, 88 (2019), 1-23 Tavim, J. A., 'Portuguese New Christians in the Turkish "Carrefour" Between the Mediterranean and the Indian Ocean in the Sixteenth Century: Decentralization and Conversion' Journal of Early Modern History, 17:5/6 (2013), 561-584

Tavim, J. A., 'Sephardic Intermediaries in the Ottoman Empire', Oriente Moderno, 93 (2013), 454-476

Taylor, Becky, Another Darkness, Another Dawn: A History of Gypsies, Roma and Travellers (London: Reaktion, 2014)

Tedder, H. R., and I. Gadd, 'Aggas, Edward (b. in or before 1549, d. 1625?), bookseller and publisher', Oxford Dictionary of National Biography (January 2008), https:// doi.org/10.1093/ref:odnb/209 (accessed October 2020)

Thomas, Keith, Man and the Natural World: Changing Attitudes in England, 1500-1800 (London: Allen Lane, 1983)

Thomas, Keith, In Pursuit of Civility: Manners and Civilization in Early Modern England (Brandeis, MA: Brandeis University Press, 2018)

Thomson, Ayanna (ed.), The Cambridge Companion to Shakespeare and Race (Cambridge: Cambridge University Press, 2021)

Thornton Libby, Charles, and Robert E. Moody (eds.), Maine Province and Court Records: Vol. II (Portland: Maine Historical Society, 1928)

Thorpe, Francis Newton, Federal and State Constitution, Colonial Charters, and Other Organic Laws of the States, Territories and Colonies Now or Heretofore Forming the United States of America, 7 vols (Washington, D.C.: Government Printing Office, 1909)

Thrush, Coll, Indigenous London: Native Travelers at the Heart of Empire (New Haven, CT: Yale University Press, 2016)

Todd, Margo, Christian Humanism and the Puritan Social Order (Cambridge: Cambridge University Press, 1987) 
Tomlins, Christopher, Freedom Bound: Law, Labor, and Civic Identity in Colonizing English America, 1580-1865 (Berkley: University of California Press, 2010)

Toomer, G. J., Eastern Wisdom and Learning: The Study of Arabic in SeventeenthCentury England (Oxford: Clarendon Press, 1996)

Torres, Max S. Hering, María Elena Martínez, and David Nirenberg (eds.), Race and Blood in the Iberian World (Münster: Lit Verlag, 2012)

Trivellato, Francesca, The Familiarity of Strangers: The Sephardic Diaspora, Livorno, and Cross-Cultural Trade in the Early Modern Period (New Haven, CT: Yale University Press, 2012)

Turner, Henry, The Corporate Commonwealth: Pluralism and Political Fictions in England, 1516-1651 (Chicago: University of Chicago Press, 2016)

Tyler, Lyon Gardiner (ed.), Narratives of Early Virginia, 1606-1625 (New York: Charles Scribner, 1907)

Van Berkel, Maaike, and Jeroen Duindam (eds.), Prince, Pen, and Sword: Eurasian Perspectives (Leiden: Brill, 2018)

Vaughan, Alden T., and Virginia Mason Vaughan, Shakespeare's Caliban: A Cultural History (Cambridge: Cambridge University Press, 1991)

Vaughan, Alden T., Transatlantic Encounters: American Indians in Britain, 1550-1776 (Cambridge: Cambridge University Press, 2006)

Venuti, Lawrence, The Translator's Invisibility: A History of Translation (Abingdon: Routledge, 1995)

Vigne, Randolph, and Charles Littleton (eds.), From Strangers to Citizens: the Integration of Immigrant Communities in Britain, Ireland and Colonial America, 1550-1750 (Brighton: Sussex Academic Press, 2001)

Viktus, Daniel J. (ed.), Piracy, Slavery and Redemption: Barbary Captivity Narratives from Early Modern England (New York: Columbia University Press, 2001)

Villari, Rosario (ed.), Baroque Personae (Chicago: Chicago University Press, 1995) Wachspress, Megan, 'Pirates, Highwaymen, and the Origins of the Criminal in Seventeenth-Century English Thought', Yale Journal of Law \& Humanities, 26 (2015), 301-343

Waite, Gary K., 'Empathy for the Persecuted or Polemical Posturing? The 1609 Spanish Expulsion of the Moriscos as Seen in English and Netherlandic Pamphlets', Journal of Early Modern History, 17:2 (2013), 95-123

Walsham, Alexandra, Providence in Early Modern England (Oxford: Oxford University Press, 2001)

Walsham, Alexandra, Charitable Hatred: Tolerance and Intolerance in England, 1500-1700 (Manchester: Manchester University Press, 2006)

Walsham, Alexandra, The Reformation of the Landscape: Religion, Identity, and Memory in Early Modern Britain and Ireland (Oxford: Oxford University Press, 2011) 
Ward, Joseph, Metropolitan Communities: Trade Guilds, Identity, and Change in Early Modern London (Stanford, CA: Stanford University Press, 1997)

Warneke, Sara, Images of the Educational Traveller in Early Modern England (Leiden: Brill, 1994)

Watanabe-O'Kelly, Helen, and Adam Morton (eds.), Queens Consort, Cultural Transfer and European Politics, c. 1500-180o (London: Routledge, 2017)

Watkins, John, 'Toward a New Diplomatic History of Medieval and Early Modern Europe', Journal of Medieval and Early Modern Studies, 38:1 (2008), 1-13

Watson, Kelly L., Insatiable Appetites: Imperial Encounters with Cannibals in the North Atlantic World (New York: New York University Press, 2015)

Watt, Diane, Secretaries of God: Women Prophets in Late Medieval and Early Modern England (Woodbridge: Boydell \& Brewer, 2001)

White, Jason Cameron, 'Royal Authority Versus Corporate Sovereignty: The Levant Company and the Ambiguities of Early Stuart Statecraft', The Seventeenth Century, 32:3 (2017), 231-255

White, Richard, The Middle Ground: Indians, Empires, and Republics in the Great Lakes Region, 1650-1815 (Cambridge: Cambridge University Press, 2010)

Whitehead, Neil, 'Hans Staden and the Cultural Politics of Cannibalism', The Hispanic American Historical Review, 80:4 (2000), 721-751

Williams, Raymond, Keywords: A Vocabulary of Culture and Society (Glasgow: Fontana, 1976)

Williamson, H. G. M., Isaiah 6-12: A Critical and Exegetical Commentary (London: Bloomsbury, 2018)

Winship, Michael P., Godly Republicanism: Puritans, Pilgrims, and a City on a Hill (Cambridge: Harvard University Press, 2012)

Winterbottom, Anne, Hybrid Knowledge in the Early East India Company World (Basingstoke: Palgrave, 2016)

Withington, Phil, The Politics of Commonwealth: Citizens and Freemen in Early Modern England (Cambridge: Cambridge University Press, 2005)

Withington, Phil, 'Public Discourse, Corporate Citizenship, and State Formation in Early Modern England', The American Historical Review, 112 (2007), 1016-1038 Withington, Phil, Society in Early Modern England: The Vernacular Origins of Some Powerful Ideas (Cambridge: Polity Press, 2010)

Wolf, John B., The Barbary Coast: Algiers Under the Turks, 1500 to 1830 (New York: W. W. Norton, 1979)

Wolf, Lucien (ed.), Menasseh Ben Israel's Mission to Oliver Cromwell (London: Jewish Historical Society of England, 1901)

Wood, Alfred C, 'The English Embassy at Constantinople, 1660-1762', The English Historical Review, 40 (1925), 533-561 
Working, Lauren, The Making of an Imperial Polity: Civility and America in the Jacobean Metropolis (Cambridge: Cambridge University Press, 2020)

Wrightson, Keith, and David Levine, Poverty and Piety in an English Village: Terling, 1525-1700 (Oxford: Oxford University Press, 1995)

Wyatt, Michael, The Italian Encounter with Tudor England: A Cultural Politics of Translation (Cambridge: Cambridge University Press, 2005)

Yates, Frances A., Giordano Bruno and the Hermetic Tradition (New York: Routledge, 1964)

Yirush, Craig, Settlers, Liberty, and Empire: The Roots of Early American Political Theory, 1675-1775 (Cambridge: Cambridge University Press, 2011)

Yungblut, Laura Hunt, 'Strangers Settled Here Amongst Us': Policies, Perceptions, and the Presence of Aliens in Elizabethan England (London: Routledge, 1996)

Zurcher, Erik-Jan (ed.), Fighting for a Living: A Comparative History of Military Labour, 1500-200o (Amsterdam: Amsterdam University Press, 2013) 



\section{Index}

Abbot, George, Archbishop of Canterbury 102 Abbot, Robert 64-65

Aceh, Sultan of 118

de Acosta, José 72

Acts of Parliament

'Acte for Denyzens to paye Straungers' (1530) 11

'Act for the Encouraging of the Importation of Negroes and Slaves' (1671) 79

Act for the More Effectual Suppression of Piracy (1700) 206

Act for the Punishment of Vagabonds (1572) 212, 286

The Act for the Better Relief of the Poor of this Kingdom (1662) 288-89

Act for the Relief of the Poor (1563) 212

Act for the Relief of the Poor (1601) 288

'Acte to Retain the Queen's Majesty's Subjects in the Due Obedience' (1581) 252

Act of Uniformity (1588) 102

'Acte whereby certayne Offences bee made Treason' (1570) 251

Corporation Act (1661) $\quad 78$

Egyptian Act (1562) 128

Naturalisation (Children Born Abroad during the Troubles) Act (1677) 248

Navigation Acts (1651-1696) 28, 114-5, 194

Offences at Sea Act (1536) 202

Test Act (1672) $\quad 78$

Treason Act (1351) $\quad 236$

Vagabonds Act (1547) $\quad 287$

Vagabonds Act (1597) $\quad 287$

Adams, Thomas 196,286

Adams, William $151,155,184$

D'Addario, Christopher 107

Africa $66,100,122,135,168,185,277$

'Africana' in literature and performance $47-48,281-82$

commodities 182

North Africa $\quad 40,167,216,219,277,280$

South Africa 153

West Africa $44,106,208,234$

see also Royal African Company

Africans 42, 275

description 49, 219

in England $\quad 43-45,46-47,48-49,199$

enslavement of $45-46,78,234-35$

ideas of blackness and colourism $\quad 42$

in portraiture $47,49,56$

traders 153

women 135

see also Muslim

Africanus, Leo

Description of Africa $\quad 41,46$
Aggas, Edward $\quad 262$

Agglinton, John $\quad$ 127-28

Agra $54,76,172$

Aḥmad al-Gulshan̄̄ $\quad 155$

Aimoré 55

Ainsworth, Henry 104, 219

Al-Andalus 40, 41

al-Mansur, Moroccan emperor/sultan $\quad 97,106$

Alba, Duke of 105

Alcazar, Battle of $\quad 177$

alchemy 79

Alemán, Matias 160

Algiers 61, 204, 208, 281

Algonquian 14, 55, 74-75, 97, 152-54, 199, 263

Aleppo $155,157,161,264$

Allde, John $\quad 269$

Allen, Robert 138

Allen, William $\quad 102,112,176$

Amazonia, Greater $\quad 145,153$

Ambrose, Isaac 102

America 9, 78, 102, 131, 145, 185

America, Central $\quad 45,276$ see also Mexico

America, North $49,58,102,134,144-45,230$ see also tobacco

America, South $\quad 60,144,165,205,275,276$

America, Spanish 74, 145

American Revolution 195

commodities of 182

English colonies $10,92,123,146,192,200$, 204, 265

English colonists $14,93-94,107-08,134$, 194, 214, 233-35

English slavers, human trafficking 44,78

English sovereignty in $\quad 200,215,229$

piracy in 204,208

Americas $44-45,266,281$

deportation to $214-5$

English sovereignty in 49

Native Americans $14,45,57,60,74,75,123$,

132, 192, 194, 234, 275

of Brazil 55

conversion, evangelising of $72,74,263$

in England 153 see also Pocahontas

as idolaters 132

as 'Indians' 143, 145

as savages $\quad 59,145,192,218,221,223$

see also Algonquian, Iroquois, and Pequot

Amsterdam 103-4, 16o, 165, 183

Amyot, Jacques

Vies des hommes illustres (1572) 259

Anabaptists 70

androphagi 57 
Anes, Dunstan 159

Anglican $133,159,169,198$ see also Church of England

Anglo-Norman 80, 88, 143, 245, 284

Anglo-Saxon 116, 196

Angola 46, 193

Anne of Denmark $\quad 47,80,84$

antinati 25,26

see also migrants in England, legal status of antiquarians, antiquarianism $65,82,178,265$

Dom António of Crato 105-06

apostasy $\quad 76-77$

apprentices, apprenticeships $\quad 66,69,91,113$ $127-8,181,184,213,258,269$

Aquinas, Thomas 198

Arab 40

Mahomet, Mohammed as Arabian $\quad$ 167-68 traders 128

Arabic

culture, literature, scholarship $\quad$ 167, 171-72 language $97,147150,155,171,264-65$

Archer, Ian 17, 21, 110,

Archibald, Douglas, Earl of Angus 105

Arens, William 58

Ariosto, Ludovico

Orlando furioso (1516) 171

aristocracy $32,56,68,80,82-83,86,96,129,145$, $178,180,183,194,229,239,242,256$

Aristotle 57, 138, 197, 203

Nicomachean Ethics $\quad 116$

Politics 63

Arnold of Spain $\quad 51$

arsapodemica 271

art collecting 35,56

artisans $21,66,69,110,113,120$

Arundel, Countess of see Howard, Aletheia

Ascensius, Jodocus Badius 259

Ascham, Roger

Scholemaster (1570) 272

Asia $37,53-5,66,100,144,145,266,276,280-81$

Central 276, 280

commodities $182,185^{-7}, 281$

East India Company (EIC) factories in 10 , 225

English piracy in 209

Minor 169

South $36-37,55,134,150,155,177,209,266$

South East $\quad 53,150$

languages $150,155,186$

Athens 56

the Atlantic $49,57,123,135,144,194$

Catholic Spain in 72

English colonies in $\quad 92-94,233,289$

English imperialism in $\mathbf{1 3 5}$

English imperial rivalry with Spain in $\quad 276$

English migration across $\quad 107$

the Indies 144

Jewish migration across $\quad 165$

Native Americans in 75

$$
\begin{aligned}
& \text { piracy } \quad 144,203-066 \\
& \text { slavery } 42,44-45
\end{aligned}
$$

Atlantic world 78,194

Aubrey, John 178

Avery, Henry 209

Awdelay, John

The fraternitye of vacabondes (1561) 211 , 285

Azores 106

Babington, Gervase $\quad 252$

Babylon 101-02, 108, 161, 170

Bach, Rebecca Ann 145

Bacon, Francis $\quad 25,64,73,88,111,113,120,124$, $185,215,248,271$

Bacon, Gertrude $\quad 185$

Bahia 55

Baker, Thomas 216

Balcanquall, Walter 215

ballads $96,130,177,207,270$

Bale, Thomas 112

Balkan provinces 125

Bantam 118, 151

baptism $44,75,78-79$

Baptists 78

Barbados 115, 166

Barbary Coast $\quad 36,150,204,206,219$

Barbary Company $\quad 151,182$

Barbon, Nicholas 67

Barnes, Thomas 176

Baron, Samuel 54

Barrett, Thomas 266

Barrow, Henry

A brief discoverie of the false church (1591) 174

Bartels, Emily $\quad 42,45$

Barton, Edward 227-28, 230

Batten, Sir William 49

Beaumont, Francis 68

The Woman Hater (1607) 239

Becudo, Matias 97

Bencoolen factory 155

Bedwell, William

Mohammedis Imposturae (1615) 171, 264

Behn, Aphra

The forc'd marriage (1671) 242

Oroonoko (1688) 275

The Widow Ranter, or, The History of Bacon in Virginia (169o) 214

Bennett, Tony

New Keywords A Revised Vocabulary of Culture and Society (2005) 15

Berber 40

Berden, Nicholas $\quad 237,238$

Bermuda 46, 61

Bertie, Peregrine, Lord Willoughby

d'Eresby 47

Berwick-upon-Tweed 28

Beza, Theodore 72,261 
the Bible $138,199,262-63$

Coverdale Bible 148

Geneva Bible 70

Genesis 20, 148

Gospel of Matthew $\quad 138$

King James Bible $\quad 21,196,262$

Vulgate Bible 20

Biddulph, William 132,157

Bill of Rights (1689) 249-50

Black Knight 34

Blackburn 109-10

Blackstone, William 20

Blackwell Hall 113

Blackwell, Joshua $\quad 76-77,172-73$

Bland, John 115

Blount, Charles, Lord Mountjoy 221

Blount, Edward

translation of Matias Alemán's Guzmán de Alfarache (1623) $\quad 160$

Bodley, Thomas $\quad 269$

Boiardo, Matteo

Inamoramento de Orlando (1483) 171

Bolton 109-10

Bombay 76,155

Book of Common Prayer 246

Book of Psalms 261

Boorde, Andrew 126

Boothby, Richard $\quad 289$

Bordeaux 158

Borgia, Father Francisco 193

Bradford, John 11

Bradford, William 134

de Bracton, Henry 245

Bradstreet, Anne 108

Braganza, Dukes of 96

Brandenburg, Elector of 98

Brazil 55, 6o, 151, 164, 166, 193, 217

Brenner, Richard $\quad 182$

Brerewood, Robert $\quad 132$

Breton, Thomas $\quad 76-77,172-73$

Bridgeman, Orlando 27

Brinsley, John 221

Bristol 158, 280

British Isles $\quad 25,78,110,114,126,189-90,197$

broadsheets, broadsides $138,207,280-81$

Brook, Francis 100

Brooke, John 239

Browne, Robert 133

Bryskett, Lodowick 259, 260

A discourse of civil life (16o6) $\quad 81,25^{8}$

Buda 77

Burges, Cornelius 103

Burges, Richard 279

Burligh, Richard 239

Burton, Jonathan $10,100,171$

Byzantine Empire $\quad 125,167$

cabinets of curiosities $\quad 185$

Cádiz 121
Calais $\quad 189$

Caliban 61, 145

calico 53

see also materials

de Callières, François

De la manière de négocier avec les Souverains (1716) 95

Calvin, John $\quad 70,109,218,261$

Calvin's Case $\quad 25,189-90,246-48$

Calvinism $\quad 23,102,111,164,232,272$

Camarão, António Filipe 193 see also Poti

Cambay see Khambhat

Cambridge University $\quad 31,228$

Camden, William $\quad 82,138,197$

Canada 143

Canterbury 12,65

Carew, George

Lex talionis, or, The Law of marque or reprizals (1682) 204

Carib 57, 153

Carib 'Indians' 59, 144

Caribbean 45, 144-45, 200, 204, 214, 233 colonies $27,49,166$

Carleton, Dudley $\quad 35,48,227$

Carpenter, Nathaniel 25

Carolina 93-94

Carolina Charters $\quad$ 93, 234-35

Cartier, Jacques $\quad 265$

de Carvajal y Mendoza, Luisa 71

Cary, Elizabeth

The tragedie of Mariam (1613) $\quad 163$

della Casa, Giovanni Galateo (1558) 80

Castiglione, Baldassare $\quad 267$ Il Cortegiano (1528) 80-81, 267

Castile 160

Catesby, Robert $\quad 256$

Catlin, Zachary $\quad 108$

Catalina of Motril 44

Cathay 144

Catherine of Aragon $\quad 44$

Catherine of Braganza 80

Catherine de Médicis 106

Catholicism $58,76,77-78,84,86,109,131,216$, 220,242

association with Islam $\quad 167,264$

association with Judaism $\quad 157-59$

Catholic, anti $\quad 84,131-32$

Catholic armies 177,278

Catholic Church 131, 193, 202, 251, 253

Catholic conspiracies $235,239,243,253$, 256

Catholic conversion, evangelism $\quad 71-79$, $158,170,263$

Catholic Europe $84,121,128,182,272$

Catholic Italy 121, 271

Catholic League $\quad 176$

Catholic monarchy $\quad 243-44$ 
Catholic Spain $\quad 72,176$

popery 132

popish $77,112,159,174,197$

recusancy $73,78,229,238$

superstition $133,157,167$

Catholics $23,56,71^{-73}, 91,102,104,128,178$, $196,197,231$

English $111-12,150,170,176,184,232$, $238-39,25^{2-53}$

Japanese $15^{1-52}$

Cavendish, Margaret, Duchess of

Newcastle 87

Caxton, William $\quad 30,51$

Cecil, Robert, Earl of Salisbury $\quad 33,45,56,84$, $85,144,205$

Cecil, William, Lord Burghley $\quad 82,96,228$, $238-39,253,254,261,262,274$

ceramics $\quad 187-88$

see also materials

Cervantes, Miguel Don Quixote (1612) 41

Ceylon 193

Chamberlain, John $\quad 227$

Chapman, George The Odyssey (1615) 137

Chapman, Richard 68

Chardin, John 99, 100

Charles I, king of England $36,47,84,91,114$, $121,178,204,254,256-57$

Charles II, king of England $\quad 54,78,84,93,103$, $106,108,233-34,242,248$

Chaucer, Geoffrey

'Lenvoy to King Richard' 96

Troilus and Criseyde (c. 1374) 30

Chauduri, Kirti $\quad 187$

Chesapeake 97, 216

Child, Josiah $\quad$ 10, 27, 187-78, 289

China 119, 146, 155, 197 see also Cathay

chivalry $171,177,207$

chocolate 36,188

Christendom 134, 140, 177, 228, 253, 262, 278

Christian humanism 64

Church of England $\quad 78,167,174,215,220$ see also Anglican

Churchyard, Thomas $\quad 116,175,177-78$

Cicero

De amicitia 116, 117

citizenship $\quad 15,29,58,63-69$

civic humanism 65

civil society $\quad 58,61-62,123,203,218$

civil war, English $\quad 38,86,103,108,110,134,174$, $178,206,215,233,242,243,257$

civility $10,13,32,42,122-23,188,219,222-23$ continental, European $\quad 60,223,262$

English 200, 217

foreign 140

friendship as $\quad 122-23$

civitas 63
Clarendon codes $\quad 78$

Clifford, Lady Anne $\quad$ 84, 229

Clifford, Henry 229

Cockayne, Sir Aston 108

Cockerham, Henry

The English dictionarie, or, An interpreter of hard English words (1623) 148

Cocks, Richard $118,141,151$

Codex Alexandrinus 36

coffee $173,186,188,264-65,281,283,297$

Coke, Edward 16o, 203, 247-48, 256 see also Calvin's Case

Coke, Roger $\quad 27,181-82$

Coke, Thomas 225

Colchester 17,65

de Coligny, Gaspar 175

College of Arms 159

Collin, Richard 191

colonialism 147

English 123

settler $9,192,234$

colonisation $10,195,221$

in Central and South America $45,60,74$, $144-45,165,205,275^{-7} 6$

in Ireland 192,218

in North America $\quad 265$

via plantation 192

in Virginia 192

Columbus, Christopher $\quad 57,143,144,146$

Colville, James see also Calvin's Case

Committee of Trade and Plantations $\quad 165$

Compton, James, Earl of Northampton $\quad 215$

Congregationalists 104

Constantinople $36,161,164,167,168,188,216$, 279,282

consumption $36,57,62,69,188$

conspicuous $\quad 51-2,80$

foreign 186

global 36,187

habits $35,82,188$

mass 186

practices of 9

sugar 45,49

tea $36,173,186,188$

see also coffee; tobacco

contact zone 80

converso $72,73,106,158,159,160,165,166,25^{2}$

Conway, Sir Edward 183

Copland, Patrick $\quad 75,146$

Coree the Saldanian 153

Cornwallis, Charles 218

Cortés, Hernán $\quad 55,154$

Coryate, Thomas $140,162,268$

Coryats crudities (1611) 161

cosmography $57,131,144,278$

costume books $110,270,278,282$

Cotgrave, John

Wits Interpreter (1655) 155-6 
Cotgrave, Randle $\quad 231$ courtier

ideal courtier $\quad 32,81$

Cottington, Francis 86

Cotton, John 104

Cottret, Bernard 17

Counter-Reformation $\quad 71,174,231,251,253$

Court of Common Council 90

Courten, William 92, 190

Coverdale, Miles 148

Cowell, John 211, $25^{6}$

Crell, Johann 122

Cressy, David 128, 255

Crisp, Nicholas 234

Crohagan, Arthur 255

Cromwell, Oliver $\quad 165,200,242$

Cromwellian state 23

Cromwell's protectorate $\quad 26,86$

Crowe, Sir Sackville $\quad 38$

Crusades 165

Cushman, Robert 123

customs duty $28,90,92,184,190$

Cyrus $\quad 169-70$

Daborne, Robert

A Christian Turn'd Turk (1612) 162, 207, 279

Dalechamp, Caleb 142

Dallam, Thomas $\quad 161$

Dampier, William 135

Danube 125

Das, Nandini $\quad 22,213,272,275,277$

Daubeny, Elyas 89

Davenant, William

The Cruelty of the Spaniards in Peru (1658) 195

Davies, Lady Eleanor $\quad 225$

Davies, John 192

Day, Angel $\quad 226$

Day, John

The Travels of the Three English Brothers (1607) 170

De Natis statute (1351) 184-5, 245, 248

Dekker, Thomas $125,127,128,129,224$

The Bellman of London (1608) 51-2, 213

The pleasant comedie of old Fortunatus (1600) 81-2

The Roaring Girl (1611) 213

Westward Ho (performed 1604) 68

Denmark 84

Derrida, Jacques $\quad 137$

Devereaux, Robert, second Earl of Essex $\quad 82$, $151,174,178,227$

diet 22,33

difference 11-12, 266

cultural 11, 17, 57, 79, 110, 125, 147, 171, 270

ethnic $17,126,130,132,146$

geopolitical 17

identity 60

national 23 racial $10-11,17,42$

religious, confessional $\quad 23,65,105,159,171$, 198,278

social $87,142,173$

visual 129,278

Digby, Kenelm 86, 208

Digges, Thomas $\quad 175^{-7} 6$

Dillon, Wentworth, fourth Earl of

Roscommon 258

Dimmock, Matthew 17

Dittis, Andre 118

Dod, John

A plaine and familiar exposition (1608) 139

Donne, John 51, 79, 83, 227, 274

'The Anniversary' (c. 1598) 254

'The Sunne Rising' (printed 1633) 144

Dono, Yasimon 141

Dorke, Walter

A tipe or figure offriendship (1598) 116-7

Dormer, Jane, Countess of Feria $\quad 229,273$

Down, County 104

dragomen $15^{\circ}$

Drake, Francis $\quad 46,204-05$, 207-08

dress $22,32,52,57,129,161,221,258,266,280$

Dryden, John 35

Amboyna (1673) 143

The Indian emperour (c. 1665) 198

Dudley, Robert, Earl of Leicester $\quad$ 104, 159, 26

the Dutch 10, 166, 186, 193

in Colchester 17

in England 98, 190

English competition with $54,120,141,15^{1}$

English troops in Dutch armies, enterprises $\quad 176-77$

in Lincoln $\quad 232$

migration $\quad 66,92,183$

refugees 138

trading practices $\quad 27$

Dutch East India Company $\quad 120,151,177$

van Dyck, Anthony

'George Gage and Two Attendants' (c. 1620s) $5^{6}$

East India Company (EIC) 9, 10, 27, 38, 134,

$182,188,289$

in Bantam 118,151

in Baroda 54

in China 118

conflict with the Dutch East India

Company $54,120,177$

diplomacy $\quad 38-39,99$

evangelism $75^{-6}, 135,146,155,172,216$

Factors $37-38,53,216$

in India 37,55

in Japan $\quad 141-42,151,184$

language skills $\quad 150-51,153,155$

monopoly on trade 146

piracy 208-09

profits $\quad 187-88$ 
religious difference $\quad 145-46$ in South East Asia $\quad 150,182-83$

in Surat 53

women investors 183

Eastland Company $\quad 185$

Eden, Richard 144

The history of travayle in the West and East Indies (1577):131-32

Edict of Expulsion (1290) 159

Edmondes, Thomas 33

Edward I, king of England $\quad 89,158,189$

Edward III, king of England $\quad 89,245,251$

Edward VI, king of England 12

Eliot, John

Mamusse wunneetupanatamwe Up-Biblum God (1663) 263

Ortho-epia Gallica (1593) 9

Elizabeth I, queen of England 24, 174, 181, 277

Armada and Spain 190, 203

authorisation to deport 'blackamoors' 45

defections, uprisings, plots against 104,

$159,176,239,251,25^{2-53}$

and denization 91

and diplomacy $\quad 31,37,96-8,161,228$

and Dutch refugees 138

and friendship $\quad 117-18$

and Judaism 163

and marriage 122

and mobility $\quad 182,212,273$

and piracy $\quad 203,204-05,206$

and Protestantism 235, 246

excommunication $\quad 251$

support for Dom António 106

Elizabeth, queen of Bohemia 198

Englishness $23,83,94,128,158,163,171,190-91$, 257,280

Ephesians 23, 64, 111

Erasmus, Desiderius $\quad 65,282$

Esdras 20

Estado da Índia 177

Estienne, Henri

A world of wonders (1607) $\quad 197-98$

Eston, Peter 206

Eucharist $\quad 58,197$

Evelyn, John $\quad 162$

d'Ewes, Simonds 196

Eutychius

Eutychii Aegyptii, patriarchae orthodoxorum Alexandrini (1642) 264

factories $10,37,54,154,206,225$

East India Company (EIC) 10,54

Levant Company (LC) 37, 154, 225

Fanshawe, Ann 34-35

Fanshawe, Richard $\quad 248$ as translator of Luís Vaz de Camões 35

Fantom, Carlo 178

de Faria e Sousa, Miguel Asia Portuguesa (1695) 41

Fawkes, Guy $\quad 256$
Faunt, Nicholas $\quad 225^{-2} 6$

'Discourse touching the Office of Principal Secretary of Estate' (1592) 224

Feerick, Jean 82-83

Ferguson, Robert $\quad 105$

Ferneley, Anne $\quad 187$

Ferrers $\quad 5^{2-53}$

Field, John 261-62

Finch, Henry 22-23

Fitch, Ralph $\quad 5^{2}$

Fitzherbert, Thomas $\quad 237-38$

Flecknoe, Richard $\quad 187$

Fletcher, Giles

The policy of the Turkish empire (1597) 167-68

Fletcher, John The Island Princess (1621) 143

Florio, John $\quad 60,191,231,236,260-61,265$

Florio his firste fruites (1578) 191

translation of Montaigne's Essaies (1603) 266

Queen Anna's new vvorld of words (1613) 191

Foster, William $\quad 288$

France $20,21,30,33,51-2,84,90,97,106,113$, $117,119,125,175,204,214,226,242,245,249$, $252,266,267,269$

Frampton, John $\quad 185$

Frattarelli Fischer, Lucia 121

Fumerton, Patricia 213

Fust, Richard 183

Gaelic 128, 192, 218, 221-2

Gage, George $\quad 5^{6}$

Gage, Thomas 45,74

Gainsford, Thomas $\quad 174-75$

Galvão, António Tratado dos Descobrimentos (1601) 41

da Gama Ferreira, Estevão $\quad 239$

Gambino, Andrea

Commentari delle cose de Turchi (1562) 266

Gates, Geffrey

The defense of the militaire profession (1579) 176

Gaunt, Elizabeth $\quad 254$

genealogy $82-83,159$

General Assembly (1619) $\quad 229$

Geneva 164,269

Gentiles 9, 76, 134, 136

Gentili, Alberico 202-03

De legationibus libri tres (1590) 31

Germany 20, 52, 90, 97, 125, 140, 226, 239, 272

Ghobrial, John-Paul 99

gifting $35,36,120,141,242$

Gikandi, Simon 49

Gil Harris, Jonathan 143

Gilbert, Humphrey $\quad 93,223$

Gipps, Thomas 244

Giraldi, Giovanni Battista

Tre dialoghi della vita civil (1565) 258-59

Glorious Revolution 105, 249 
Gloucestershire $\quad 26,254,287$

Goa 73,263

Godiva, Lady, or Godgifu 196

Golconda 134

gold $10,51,59,79,130,146,162,205,283$ see also materials

gold mines 145

goldsmiths 44, 113

Goldsmiths Company 66

de Gómara, Francisco Lopez 277

Goodwin, George 62

Goose, Nigel 17

Gramigna, Vincenzo

Il segretario dialogo (1620) $\quad 224$

'grand tour' 86,227

Gravesend 75

Greco-Roman

art 35,56

antiquity 197,200

thought $82,133,198$

Greenblatt, Stephen $5^{8}$

Greene, Robert $\quad 68,285$

Mamilia (1583) 226

A Notable Discovery of Cosenage (1591) 213

Greenwich 84

Greepe, Thomas

The true and perfecte newes of the worrthy and valiaunt exploytes, performed and doone by that valiant knight Syr Frauncis Drake (1587) 208

Grenville, Richard $\quad 254$

Gresham, Thomas $\quad 187$

Greville, Fulke 186

Grocers' Company 183

Guiana 153,256

Guibbory, Achsah 163

guilds $63,65,66,68,110,258$

Guinea 44, 135

Guinea Company 234

Gunpowder Treason 112, 240, 256

de Guzmán, Gaspar, Duke of Olivares 86

Gypsy $125-30,132,168$

Haberdashers' Company 183

Habib, Imtiaz $\quad 43,48,49,143$

Habsburgs 238

Haddon, Walter $\quad 174,237$

Hadfield, Andrew 17

the Hague 31

Hakewell, William 70

Hakluyt, Richard $\quad 9-10,131,228,266,278$, 289-9o

'A Discourse Concerning Western Planting' (1584) 72

The Principal Navigations, Voyages, Traffiques and Discoveries of the English Nation (1589; expanded 1598-16oo):

$36,183-84,265,267-68,270$

Hall, Joseph $\quad 167-68,272$

Hall, Kim F. 5
Hamburg 140, 161, 313

Hanmer, Meredith $\quad 169$

Harborne, William 37, 128, 227-28

Hardman Moore, Susan 107

Harington, Lucy, Countess of Bedford 55

Hariot, Thomas 14, 153

Harman, Thomas 129, 211

A caveat for commen cursetors vulgarely called vagabones $(1567) \quad 285$

Harrington, John

De amicitia (1550) $\quad 116$

Harrison, William Description of England (1577) $\quad 180-81$

Hartlib circle 223

Hartwell, Abraham

A reporte of the kingdome of Congo (1597) 42

Hasell, Edward 229

Hassan ibn 'Ali al-Tughra'i

Lāmiyyat al-'Ajam (1661) 265

Haughton, William

Englishmen for my Money (1598) 67

Hawkins, John 46

Hawkins, Richard 277

Hawkins, William 207

heathens $9,132-35,145,164,173,177,196-98$

Henrietta Maria of France $\quad 47,80,84,254$

Henry II, king of France $\quad 151$

Henry VII, king of England 30

Henry VIII, king of England $30,44,63,71,85$, 105,251

Herodotus 57

Heylyn, Peter 119-20

Heywood, Thomas

Fair Maid of the West, Part 1 (composed between 1596-1603) 207

Fortune by Land and Sea (1607-1609) 207

Ifyou know not me, you know nobody, Part 2 (printed 1606) 113

Higden, Ranulf 20

Higgins, John $\quad 226$

High Court of Admiralty 205

High Courts of Justice $\quad 237$

Hindu

faith 75,216

peoples 75,135

polities 134

sophistication 132

Hobbes, Thomas 21, 63-64

Hoby, Thomas $\quad 80-81,82,267$

Holbein, Hans 85

Holland 27, 98, 164, 204

Holland, Thomas 272

Holy Roman Empire 97

Homer

Iliad 138

Honduras 144

Hoper, Richard

The instruction of a Christian man, in vertue and honestie (1580) 116 
Hotman, Jean $\quad 31,34,149$

Howard, Aletheia, Countess of Arundel $\quad 56,86$

Howard, Thomas, Earl of Arundel $35,56,86$

Hueriblock, Katherine 183

Hudson voyages 183

Huguenots $9,13,17,21,69,175,176,217$

Hume, Lord 273

Huyghen von Linschoten, Jan

Itinerario (1598) 73-74

Hunt Youngblut, Laura 17

Hyde, Edward, Earl of Clarendon $\quad 78$

Höfele, Andreas 17

Iberian Union 121

idolatry 131-32, 196

Ieyasu, Tokugawa $\quad 1^{1}$

Inca 143

India $37-38,42,75,56,125,132,143-44,150$, 193,216

as exotic and unknowable 143

as heathen 145,197

Mughal $36,53,99,141,155,277$

rude and barbarous 117

as a shorthand 144

trade 146,216

travellers in $263,268,271$

Indian, Indians $\quad 15,57$

as capacious descriptor $143-44,145$

commodities $144-45,147$

conversion of $74-76,79$

as Hindus 132

in England 146

as Romani 125

two Indies 144,145

Indian Ocean $\quad 52,53,55,155,203,208-09,274$

Indus 143

Inns of Court 227

Inquisition, Portuguese 165

Interregnum $\quad 28,233,236-37,248$

Ireland $28,128,150,151,177,192,218,236,25^{2}$,

253,274

armies in $177-78$

colonisation of, colonists in 13,218

English communities in $\quad 12,150-51$

Gaelic 218, 221

Irish 255

as English Catholic settlers $\quad 150-51$

as foreigners 110

as Gaelic 128, 221

as Gypsy $\quad 127$

as rogues 212

as uncivil 14,218

Iroquois 143

Isaiah, prophecy 70

Islam, Islamic $\quad 40,132,155,162,164,167-68,170$, $171,277,280$

as corrupt, counterfeit, heretical $\quad 168,264$

Christian converts from 40-1, 72-73, 172

conversions to $76-7,169,170,172,216,276$, 278,279 expansion of $\quad 177$

Ottoman Empire $\quad 271,276,278,282$

as threat $\quad 169$

see also Muslim

Israel $23,24,70,101-02,136,164$

ben Israel, Menasseh 165-66

see also Manuel Dias Soeiro

Israelites 157,163

Istanbul $98,204,225,228,264$

Italy $30,56,90,117,125,226,269,271,272$,

274

Ivan the Terrible $\quad 218$

ivory 43-44

see also materials

Iyengar, Sujata 17

Jahangir 140-41

Jamaica 166, 204, 210

James VI, king of Scotland and I of Eng-

land $24-45,31,32,71,84,91,97,112,118,189$,

205-06, 214, 240, 247-48, 274, 278, 288

plots against $255^{-5} 5^{6}$

James VII, king of Scotland and II of England 91, 106-07, 243, 249

Jamestown $\quad 55,58,108,115,15^{2}, 208,228$

Japan 141-42, 146, 151, 184, 210

Jenkinson, Anthony 118

Jesuits $70,71,84$

conversion rates 72,75

English 24, 45, 232, 237, 252

in Goa 263

in Mexico 45

in Peru 193

in Rome 274

Jewel, John $\quad 220$

Jews $136,157^{-166}$

as a nation 23

as pagans $\quad 196$

at the Ottoman court $\quad 106$

Ashkenazi 166

beauty of 162

crypto-Jews 159,160

in England 24

in Spain 158,159

Sephardi 106, 155, 166

see also Judaism

João IV, king of Portugal 114, 193

Johnson, Elizabeth 130

Jones, Inigo 48

Jonson, Ben 68

The Case is Altered (printed 16o9) 59

The devil is an asse (first performed 1616) 241-42

Epicoene or the Silent Woman (performed 1609) 241

The Gypsies Metamorphosed (1621) 129

'The Masque of Blackness' (1605) 48

Sejanus (c. 1603) 198

The Staple of News (performed 1625) 59

Jowitt, Claire 17,207 
Judaism $\quad 72,132,157,161,164,167$

crypto-Judaism $\quad 15^{8}$

see also Jews

Judas Iscariot $\quad 251$

Junius, Franciscus

Grammatica Hebraeae Linguae (1580) 164

jus soli $189,245-47$

Juvenal 57

Karl, Archduke of Austria $\quad 98$

Keechang, Kim 245

kern 127-28

de Kéroualle, Louise, Duchess of Portsmouth 47,242

Kershen, Anne 21-22

Khambhat 54

Khoekhoe 153

King, William 144

Kirkman, Francis

The Unlucky Citizen (1673) 68

Kitch, Aaron 162

Knapp, Jeffrey 286

Knivet, Anthony 60

Knolles, Richard $\quad 276,290$

Konkani $\quad 263$

von Koppenfels, Werner 17

Kupperman, Karen

Langland, William $\quad 267$

Piers Plowman $\quad 5^{1}$

languages

acquisition

of Algonquian $\quad 152-54,263$

of Arabic $\quad 154-55,171-172,264$

of English $\quad 45,146,153,154,221-22$

of French 231, 269

of Greek 154

of Hebrew 154

of Italian 191, 269, 272

of Konkani and Marathi $\quad 263$

of Persian 264

of South Asian languages $\quad 155,225$

through translation $148-50,171,263$, 265-56

tutors of foreign languages in

England 191, 260

bilingualism, multilingualism $\quad 97,149-50$

155-56, 178, 191, 222

Laud, William, Archbishop of Canter-

\section{bury $232,264,265$}

A Form of Penance and Reconciliation of a

Renegado or Apostate from the Christian

Religion to Turkism (1637) 172

Lee, Hugh 144, 184

migrants in England, legal status of

antinati 25,26

in Common Law $\quad 25,90,120,181,202,234,245$

deportations 45

free denizens $13,91,93,94,194$

incorporation of $65-67,69$ inheritance, rights of $\quad 26,88,91,190$

letters of denization $\quad 13,26,88,91-92,111,190$

merchandising $113,181-82$

naturalisation $\quad 25-26,28,54,88-89,91,94$, $97,111,190,192,247$

postnati $25,189,245-47$

taxation $12-13,21,89,90,92,120$

Lepanto, Battle of 177,278

de Léry, Jean $\quad 217$

the Levant $\quad 36-37,38,39,54,56,66,106,150$, $15^{2}, 173,184,225,230,265,283$

Levant Company $\quad 37-38,53,99,154,157,166$, $182,183,184,216,225,263264-5,277-78$

General Court 38

Levens, Peter

Manipulus Vocabulorum (1570) 51

Levine Melammed, Renee 158

Lisbon $35,96,121,158,182,184,255$

Lithgow, William $\quad 278-79$

Liverpool 109

Livorno 121,158

Lloyd, Ludovic $\quad 269$

loanwords 186

Locke, John 249

London livery companies $\quad 21,110,214,258$

Goldsmiths 66

Merchant Taylors 66

Weavers 66

Long, Benjamin $\quad 284$

Longcastle, Captain William 199

Loomba, Ania $\quad$ 10, 11, 43, 163

López, Ludovico 193

Lopez, Roderigo $\quad$ 159-60, 239, $25^{2}$

Lord, Henry $\quad 75,135$

Lord Mayor of London $\quad 113,214$

Louis XIV, king of France 242

Louvain 104

Low Countries $\quad 20,21,85,90,104,125,175,182$, 273-74

Lowe, Ben $\quad 287$

Luke 68,251

Lupton, Thomas 59

Luther, Martin $\quad$ 231-32

Luu, Lien 17

Lydgate, John The Fall of Princes (1431-1448) 96

Madagascar $\quad 210,289$

Madras 216

Madrid $31,34-36,85,105,248,273$

Magno, Alessandro $\quad 181$

Main Plot 256

Mainwaring, Henry 206

Malabari religion $\quad 132$

Malay 155

Malay-Javanese 150

Malintzin, La Malinche $\quad 55,154$

Mancall, Peter 17

Mandeville, Sir John Travels 143, 267 
Manila $\quad 151$

manumission 78-79

Manwaring, George 277

Marana, Giovanni Paolo 243

Marathi 263

Mariana, queen of Spain 34

Markham, Gervase

A health to the gentlemanly profession of servingmen (1598) 139

Marlowe, Christopher 12

The Jew of Malta (first performed 1592) 161-62

Tamburlaine (c. 1587) 280

Marrano $72,160-61$

Martyr, Peter $\quad 261$

Mary I, queen of England 22, 31, 159, 273

Mary, Queen of Scots 254

Maryland $65,79,115$

masque, masquing $\quad 48,84,126,282$

Massachusetts $104,107,108,134,263$

Massachusetts Bay 65,215

ben Messaoud, Abd el-Ouahed $\quad 41,280$

Massinger, Philip

The Renegado (1623-1624) 207, 281

Mataoaka 154

see also Pocahontas

Matar, Nabil 17

materials

calico 53

ceramics $\quad 187-88$

gold $10,51,59,79,130,146,162,205,283$

ivory $43-44$

silk $51,69,145,147,175$

Mather, Increase 104

Mather, Samuel 104

May Day 22, 197

Mecca 171

Mediterranean $41,53,75,77,114,126,177,186$ piracy in $203,204,208$

as Turkish, Ottoman $\quad 277,278,281$

Mehmed III, sultan of Ottoman Empire $\quad 161$

Mehmed IV, sultan of Ottoman Empire 99

Mendes, Álvaro $\quad 106$

de Mendoza, Bernardino:, 239

Merchant Adventurers of York 181

Metcalf, Alida 55

Methwold, William 134

Mexico 45, 55, 132, 154

the Middle Ages $\quad 40,51,63,67,90,267$

Middleton, Thomas $68,170,238$

The Game at Chess (1624) 34

The Spanish Gypsy (performed 1623) 129

The Triumphs of Truth (1613) 48

'Triumph of Honour and Industry' (1617) 162

middling classes $\quad 67,68,69,213$

Migell (Miguel) $\quad 15^{1}$

Mingo 49

Milton, John

Paradise Lost (1667) 35
Mir Jamal-ud-Din Husain 141

miscegenation 41,73

Misselden, Edward 208-o9

mobility, social $\quad 227-28$

Monck, George, Duke of Albemarle 243

Monmouth Rebellion 105

monsters 57, 144, 184, 255, 257

Montagu, Edward, Earl of Sandwich 36

Montague, Viscountess 231

de Montaigne, Michel 217

'Des Cannibales' (c. 1580) 6o, $15^{1}$

Essaies (1580) 259, 266

More, Anne $\quad 227$

More, Thomas $22,85,167$

A dialogue of comfort against tribulation (1535) 148

Utopia (1516) 268

Morgan, Jennifer L $\quad 46$

Morisco 40-41, 167

'Morisco tongue' 41

de Mornay, Philippe

Traicté de l'église (1578) 261

Morocco 73, 97, 99, 100, 106, 172, 177, 280

Moryson, Fynes $140,227,240$

Mughal

court $38,99,141,15^{2}$

diplomacy 100

emperor 177

empire 144,279

India $36,53,99,141,144,155,277$

law 77,173

shipping 209

Mulcaster, Richard $\quad 180-81$

Munday, Anthony 269-70

The Booke of Sir Thomas More (c. 1603-1604) 22

Mundt, Christopher $\quad 95-96$

Murad III, sultan of Ottoman Empire $\quad 265$

Muscovy Company 114

Muslims 40, 75, 131, 170-73, 196

of Al-Andalus $\quad 40,41,167$

Arab 40

Berber 40

converts to Protestantism $\quad 169$

converts to Catholicism 72

converts to Islam $\quad 77,172-73$

in England 280

hospitality $\quad 276$

'Mahometan', 'Musselman' 167

North African $41,167,277$

polities 134,277

Shi'a $\quad 169-70$

sub-Saharan 40

Sunni $169-70$

trade with 277

as Turks $\quad 276$

see also Islam

Nahigonsik 200

Nahua $\quad 55,154$ 
Nalson, John $\quad 257$

Nanawack 199

Nantes 158

Naples 121

Nashe, Thomas $\quad 68,133$

The Unfortunate Traveller (1594) 162, 272-73

Navarro, Abraham 155 see also Acts of Parliament

Nedham, Marchamont $\quad$ 242-43

Neoplatonism 133, 198

the Netherlands $32,102,105,119,239,272$ networks

artistic, patronage $\quad 86,97,261$

colonisation 10

commercial, merchant, trading $\quad 10,54,65$, $66,67,97,143,150,161,183$

correspondence 34,103

cross-cultural 17

diplomatic 54,86

intellectual 97

intelligence $106,225,227,229,238,241$, 243,244

religious 97,164

social, of sociability, friendship, kin, personal contacts $34,97,129,15^{\circ}$

Neville, Charles, sixth Earl of Westmor-

land 104, 253

New England

charters $\quad 92-93$

colonialism in 123,221

colonists born in 194, 200

English communities in 12

exile in $104,107,108$

war against Indigenous peoples 134

New England Company 74

New France $\quad 265$

New Jerusalem 134, 163

New Model Army 179

New Testament 198,263

Newfoundland 93, 206

Newport, Christopher $\quad 15^{2}$

Newton, Thomas 209

Nicholas, Thomas $\quad 185$

Nicholl, John

An houre-glasse of Indian newes (1607) 59-60

Nichols, Philip

Sir Francis Drake revived (1626) 208

Nisbet, Edward 255

Norden, John 59,251

Norfolk 110, 272

North-West Passage $\quad 265$

North-West Passage Company 183

Northleigh, John $\quad 98$

Norwich $\quad 65^{-66}$

Nubia, Onyeka 49

Oakley, William 204

Oath of Allegiance (1606:) 112

Odysseus 275

Ogborn, Miles 17
Old Testament $\quad 131,136,157,163,196$

Opecancanough 152

Osório, Jerónimo 174

Ottoman 132,169

barbarous 220

beauty 282

consumption 173

court $37,99,106,225,227-28$

culture and language $\quad 264-65,276,280$, 282-83

diplomacy $152,227,228,280$

Empire $36,73,77,99,125,167-69,177,276$, $277,281,290$

trade with $53,54,150,280,281$

English captivity in 59

espionage 243

female submission $\quad 281-82$

Islam $169,177,271,276,278,280,282$

Judaism 106, 165

moor 48

piracy 204

territories 36

'turning Turk' 76

visual differences $\quad 278,281$

warfare $161,167,178,278,279$

see also Turk

Ovid 197

Metamorphoses 101, 108

Ovington, John 100

Oxford University $\quad 31,202,227,265$

Painter, Thomas 122

Palatinate 77

Palavicino, Horatio $\quad 97,182$

Palmer, Thomas $\quad 269,270-71$

pantheism 196

Paris $31,85,105,232,243$

parishes $13,49,58,126,158,212,288-89$

authorities 29

banished, in exile from $\quad$ 102-03

in colonies 94

identity 103

legislation $\quad 285$

of London 44

migration between $109,125^{-27}$

records 43,47

rural 46

Parry, Clive 90,194

Parsi 75, 135

Passi, David 106

passports 211, 273-74

pastoral 217, 289

Patawamack 153

Paulet, Sir Amias 149

Peckham, George 58

Peele, George

The battell of Alcazar (1594) 177

A farewell Entitled to the famous and fortunate generalls of our English forces (1589) 208 
Pegu $\quad 5^{2}$

Pennsylvania 94

Penry, John 133

Pepys, Samuel 48-49

Pequot 134

Pera 184

de Peralta, Francisco 232

Perceval, Richard

Dictionarie in Spanish and English (1599) 41

Percy, George $\quad 58,145$

Pernambuco $166,193,194$

Persons, Robert $\quad 24,232,252$,

Peru 143, 144, 193, 195

Pestana, Carla 72

petitions $23,38,72,92,104-05,121,165,190$, 203-04, 229, 234, 246, 263

Petrarch 261

Pettegree, Andrew 17

Pettie, George

The civile conversation (1581) 222

Petty, William 56

persecution 20, 21, 22, 24, 103, 202

Persia, Persian $\quad 53,125,216,277$

coffee 173

diplomacy $32,37,99-100$

English diplomacy to Persia 118

interpreters 150,155

empire 169-70, 220

Persian Gulf 209

travel to $279-80$

Peterson, Robert 80

Pfister, Manfred $\quad 260$

Philip II, king of Spain $\quad 96,105,118,176,177$, 238,239

Philip III, king of Spain 73

Philip IV, king of Spain $\quad 34,86,114$

Philips, Edward 188

Phillips, Judith 130

Plantagenet, Beauchamp 200

plantations $45-46,60,72,115,146,192,194$, 206, 221, 234, 275

Committee of Trade and Plantations $\quad 165$

planters $49,74,115,152,194,235,289$

Plato 198

Pliny 57

Plymouth colony $\quad 134$

Plutarch

Moralia 259

Pocahontas $55,74-75,97,154$ see also Matoaka

Pococke, Edward 155, 264-65

Carmen Tograi (1661) $\quad 265$

Làmiyyat al-Ajam (1661) 265

Nature of the Drink Kauhi, or Coffee (1659) $\quad 265$

polytheism 131, 196

Poole, Robert $\quad 15^{2}$

pope $71,73,112,119,126,238,251,253,255$

Pope, Peter 75,146 de La Popelinière, Lancelot-Voisin

Dessein de l'histoire nouvelle des François (1571) 266

Pories see Purí

Porter, Endymion 86

portraiture $47,56,85,187,191,207,280$

Portugal $35,73,84,96,114,121,158,160,164$, 177,265

Pory, John 228-29, 230 translator of Leo Africanus 41, 46 A geographical historie of Africa (1600) 168

postnati $\quad 25,189,245-47$ see also migrants in England, legal status of

Poti, Potiguara chief 193-94 see also Camarão, António Filipe

Pread, John 28

Price, Polly J 246

Privy Council 45, 46, 92, 183, 190, 208, 214, 218,280

prostitutes $5^{1}$

Protestants 132, 134, 144

alien $27,29,181$

Dutch 138

English $21-24,70,78,121,133,135,176,177$, $178,197,218,222,235,282$

exiles, refugees $\quad 97,138,193,202,261$

Irish 104-05

strangers 29, 111

Protestantism 24, 54, 64, 65, 71-72, 117, 171, 176, $190,197,262,271,280$

Catholic threat 128

conversion to and from $72,76,79,102$, 172,173

as Company religion $\quad 77,157$

Luther as settler $\quad 231-32$

Muslim threat $\quad 167$

relationship to Judaism $\quad 163-65$

providentialism $71,134,246$

Prynne, William 14

Ptolemy 42, 126

Puerto Rico 144

Purchas, Samuel $40-41,123,131,134,184,197$, 220, 221

Purí 60

Puritans 14, 43, 59, 71, 86, 101-02, 103-04, 107, $123,134,163-5,174,199,200,240$

Puttenham, George 221-22 The arte of English poesie (1589) 222

de la Quadra, Álvaro 98

Quakers 78, 123

Quarasipsinca 6o

Quarles, Francis 233

Quran 167, 171, 172, 263

race

racial difference $10-11,17,42,49,73,74$

racial hybridity $\quad 73-74$

racialisation $\quad 40-42,234,281$ 
Rainold, Henry

'A Black-moor Maid Wooing a Fair Boy' $47-48$

Ralegh, Sir Walter $\quad 93,144,153,175,204-05,256$ The historie of the worlde (1614) 42 Lady Ralegh 44

Raman, Shankar 143

Rankins, William

The English ape, the Italian imitation, the foote-steppes of Fraunce (1588) 272

Rastell, John 120

Expositiones terminorum legume Angliea (1579) 88

Reconquista 40

Red Sea 209

the Reformation $59,70,71,79,136,157,164$,

175,211

Henrician $31,117,251$

post-Reformation England $24,64,111,131$, $163,167,179,197,218,238$

Restoration 91, 93, 212, 215, 233, 243, 254, 257

Rich, Robert, Earl of Warwick 46

Riche, Barnabe $\quad 151$

Richelieu, Cardinal 232

Rid, Samuel 126

rituals

diplomatic 32,35

heathen, pagan 131,198

Judaism 157, 278

xenia 138

Roberts, Lewes 66

Roe, Thomas $\quad 35-36,37-8,56,75,99,140-41$, $15^{2,}, 198$

Rolfe, John $\quad 74,15^{2-53}$

Romania 125

Rome $62,71,86,117,170,177,220,231,25^{2-53}$, 273,274

Romney, Rebecca 183

Romney, William 183

Ross, Thomas 264

Rouen 151

Royal African Company $\quad$ 9, 28, 46, 182 Factors 135

Royal Exchange, London $\quad 9,187$

royalists, royalist cause $38,107-08,174,178$, $206,215,241,242,254,257$ anti- 216

Rowley, William Fortune by Land and Sea (1607-1609) 207 The Spanish Gypsy (performed 1623) 129 The Travels of the Three English Brothers (1607) 170 see also Day, John; Heywood, Thomas

Rubens, Peter Paul 85

Rudd, Anthony $\quad 136$

Prince Rupert, Count Palatine of the Rhine 47,105

Russell, Edward, third Earl of Bedford $\quad 55-56$

Russia, Russians $\quad 57,132,220,290$

du Ryer, André $\quad 263$
Sackville, Thomas 82

Safavid $32,169,277$

Saltmarsh, John $\quad 25$

Salter, David 26-27

Sanderson, John 184

Sanderson, Thomas 59

Sandys, Edwin $\quad 152,199,214$

Sandys, George $\quad 108,162,168,276,282-83$

Saracens $143,168,171,283$

Sarmiento de Acuña, Diego, Count of Gondomar 33, 34, 240

Sarris, John 141,151

Savage, Thomas $15^{2}$

Scot, Thomas 240

Scotland $24,25,104,105,125,189,190,215,247$ Scottish 21, 24-26, 54, 64, 84, 88-9, 110-11, $120,189,212,218,247,263,264,278$

Scythia, Scythian 57

Sebastian I, king of Portugal 177

Sedgwick, George 229

Seaman, William $\quad 263,265$

Selden, John 264 see also Eutychius

Selwood, Jacob 17, 91, 110

van Senden, Caspar 45

sermons $71,104,133,246,261,267,276$

Settlement Act (1662) 288-89 see also Acts of Parliament

Settler 93-94, 107-08, 115, 192-95, 231-35, 274

Seville $115,158,182,231-32,277$

Sextus Pomponius 202

Sforza, Ludovico, Duke of Milan 30

Shah Abbas of Persia $\quad 32,170$

Shakespeare, William 48, 61, 81, 207

All's Well That Ends Well 149

As You Like It 145

Hamlet 213

King Lear $\quad 282$

Merchant of Venice 162

A Midsummer Night's Dream 143

Much ado about Nothing 218

Othello 48

The Tempest 61,145

Titus Andronicus 48, 197

The Tragedie of Antonie, and Cleopatra 130

Shapiro, James 17

Sherley, Anthony $170,177,277$

Sherley, Thomas, the younger $164,168-69,177$

Sherley, Robert $\quad 32,170$

Shirley, James

Changes, or Love in a maze (1632) 130

Shropshire 216

Shute, John $\quad 266$

Siam 54, 155

Sidney, Lady Mary 98

Sidney, Sir Philip 96, 164, 169, 207

Sidney-Herbert faction $\quad 261$

Sidney Herbert, Mary, Countess of

Pembroke 261

Le Sieur, Stephen 97 


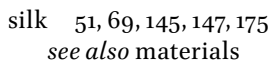

Singh, Jyotsna 17

Singhalese 193

slavery $9,42,45-47,49,172,214,287$

Smith, James 279

Smith, John $58,74-75,123,15^{2}$

Smith, Richard, planter 200

Smith, Richard, Catholic chaplain $\quad$ 231-32

Smith, Thomas 153

Smythe, John 177

smoking 49

see also tobacco

Solomon 20, 48, 236

Somerset, Duke of $\quad 287$

Somerset House 84

Sophonisba 122

South Sea 65

sovereignty $31-32,37,49,80,200,223,246$

Spain $32,35,51,84,86,90,96,118,190,214,220$ armed conflict with $\quad 45,119,176,182,204$, 238

colonialism 220

crusading 177

crypto-Judaism in 158

embassies in $30,35,248$

English in 232, 277

English commercial competition with 72 , $114,203,276$

exile from 102-03

expulsions from $73,15^{8}$

Catholic 72

exiles in 102

Muslim-occupied $\quad 167$

Romani in 125

Spaniards $\quad 45,140,195,198,204,238-39,277$

Spanish Armada $\quad 10,104,182,190,206,238$

Spanish Company $\quad 181,183$

Spanish Match 240

Speed, John 197

Spelman, Henry $\quad$ 152-53, 155

Spenser, Edmund

'Amoretti VI Ye tradefull Merchants that with weary toyle' 186

The Faerie Queene (1590) 144, 171

The shepheardes calender (1579) 96-97

'Sonnet XX' 218

spices $\quad 58,144-45,187$

Spitalfields 69

St Augustine 21

St Christopher's Island

see also St Kitt's Island

St Domingo 144

St Kitt's Island 26

St Lucia $\quad 59$

St Machor 21

St Paul 64,138

Stanley, Sir William $\quad 176$

Stapylton, Robert

Dido and Aeneas (1634) 259
Star Chamber 90

Starving Time $5^{8}$

States General $\quad 182$

Statute of Artificers (1563) $\quad 212$

Stephens, Thomas

Kristapurana (1616) $\quad 263$

Stephenson, Richard $\quad 185$

Stewert, Alan 89

Stile, John 30

Stockwood, John 72

Stow, John 65

Strachey, William

'True Reportory' (c. 1610) 61

Stratford-upon-Avon 12

Stubbe, Henry 172

Stubbes, Philip $\quad 284$

Stukeley, Thomas 253

The famous historye of the life and death of Captaine Thomas Stukeley (1605) 177, 207

Styward, Thomas

The pathwaie to martiall discipline (1582) 237

Sublime Porte $\quad 35,37,99,106,228,265$

Subrahmanyam, Sanjay 17

Sumatra 155

Surat $53,100,155,209$

Surinam 165, 275

Sutcliffe, Matthew 73

Swetnam, Joseph

The araignment of lewde, idle, forward, and unconstant women (1615) 240-41

Sylvester, Josuah $\quad 83$

Tahmasp I of Persia $\quad 118$

Tartary, Tatars 171,290

taxation $12-13,21,89,90,120,166,196$

Taylor, Becky $\quad 126$

Taylor, Jeremy

The Measures and Offices of Friendship (1657) 123

Taylor, John 140

Taylor, Robert 183

Taylor, Thomas

Commentarie upon the Epistle of S. Paul written to Titus (1612) 232

Tenison, Thomas, Archbishop of Canter-

bury 131,198

Terry, Edward $\quad 75,145-46,153,271$

Thirty Years' War $\quad 62,282$

Throckmorton plot 239

Tinoco, Manuel Luís 239

tobacco $46,49,145,186,188,266$

Thomas, Howard, Earl of Arundel $\quad 35,56,86$

Tonkin 54

Topkapı Palace $\quad 283$

Topsell, Edward

The historie of foure-footed beastes (1607) 217

Toulouse $\quad 158$ 


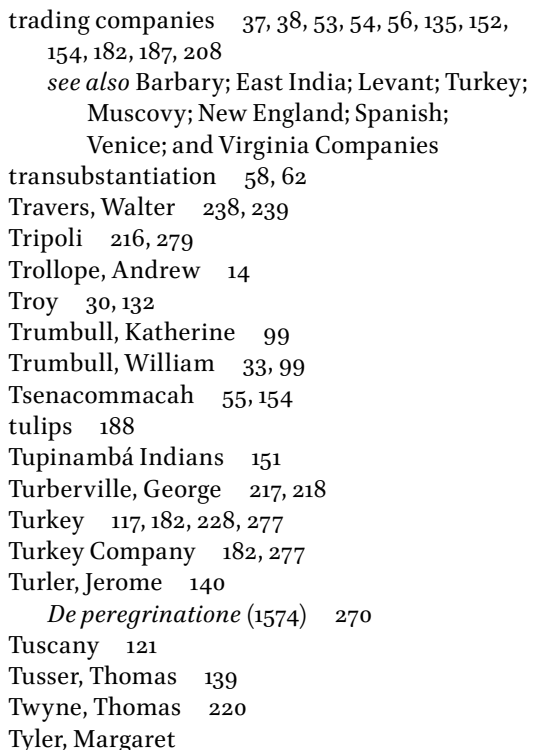

\section{Mirrour of Princely Deeds and Knighthood} (1578) 260

Tyndale, William 262

Tyrell, Anthony 71

Tyrone 104, 105

Ulpian 202

Ulster 104-05

Sultana Ümmühan 99

Union of the Crowns 25

usurers $51,180,187,286$

Varthema, Ludovico

Itinerario 132

Vaughan, John 233

Vaz de Camões, Luís Os Lusíadas (1572) 35

Venezuela 256

Venice $30,31,33,35,85,154,158,160,239$

Venice Company 277

de Vere, Edward, seventeenth Earl of

Oxford 274

Villani, Stefano 121

Villiers, George, Duke of Buckingham $\quad 56,85$, 129, 204

Virginia $74-75,115,144,152,155,227-28$ charter 92-93

English colonisation of 192,208

slave laws 49,79

Virginia Assembly 78

Virginia Company $\quad 74,183$

Vomero Santos, Kathryn 149

Wade, Thomas 239

Waite, Gary K 73

Wales 28, 110, 189, 269
Wandesford, Christopher 140

Waitaká 60

Walloon 66

Walsingham, Francis $82,128,159,224,226$, 238

Ward, John $\quad 162,169,278-79,281$

Ward, Joseph 17

Ward, Ned

Female policy detected (1695) 175

War of the Roses 24

Wataquazes see Waitaká

Watson, Thomas $\quad 251$

Webbe, Edward 279

Welden, Colonel Anthony 263

West Indies $\quad 26,57,144,146,206,214,220$

West, John 183

Whaw, Captain 118

Whetstone, George 43

whiteness 10, 40-41, 42-43, 47-49, 93, 126, 135, 235

Wickham, Richard 141

Willet, Andrew 24

William III, king of England $\quad$ 98, 105, 249 William and Mary 100

William the Conqueror $\quad 157$

Williams, Raymond Keywords A Vocabulary of Culture and Society (1976) 14-15

Williams, Roger 200

Williamson, Joseph $\quad 136$

Willoughby, Lord 273

Wilson, Arthur 79

Wilson, Robert

Three Ladies of London (printed 1584) 67, 161

The Three Lords and Three Ladies of London (1590) 12, 13, 112

Wilson, Thomas

Arte of Rhetorique (1553) 13

Winchester 158

Winterbottom, Anna 54

Winthrop, John 221

Wither, George $\quad 145$

Wolsey, Thomas 30

women 68-69

as ambassadresses, envoys, agents 34,55 , 98-99

as black $43,46,47,135$

as citizens $\quad 15$

as converts $74,78,135$

as English 107,132

enslaved $55,78,154$

Indigenous $\quad 55,97,154$

as intermediaries $\quad 55,97,135$

as interpreters 154

as investors 183

Jewish 16o, 162-63

Ottoman 281-82

as political brokers, influencers $\quad 56,122$

as migrants $29,46,69,107,109$ 
as spies $\quad 240-42$

as travellers $\quad 268,273$

as treasonous $\quad 253-54$

as wives $34,69,120,135,184-85,208,281$, 288

as writers $225,229,242,260$

Wood, Robert 223

Wotton, Henry $33,35,83,151,227,274$ Elements of Architecture (1624) 139

Wroth, Lady Mary 207

Urania (1621) 229

Wycliffe, John 20 xenophobia $\quad 22,29,110,178$

ben Yaesh, Salomon see Mendes, Álvaro

York 65

York, Archbishop of 232

Yorkshire 102

Young, Henry $\quad 76$

Zouch, Edward Lord $\quad 274$

Zurich 65 
What did it mean to be a stranger in sixteenth- and seventeenth-century England? How were other nations, cultures, and religions perceived? What happened when individuals moved between languages, countries, religions, and spaces? Keywords of Identity, Race, and Human Mobility analyses a selection of terms that were central to the conceptualisation of identity, race, migration, and transculturality in the early modern period. In many cases, the concepts and debates that they embody - or sometimes subsume - came to play crucial roles in the articulation of identity, rights, and power in subsequent periods. Together, the essays in this volume provide an invaluable resource for anyone interested in the development of these formative issues.

Nandini Das is a literary scholar and cultural historian, Professor of Early Modern Literature and Culture at the University of Oxford, Fellow of Exeter College, and Director of the ERC TIDE Project at the University of Oxford. João Vicente Melo is a JIN research fellow at Universidade Pablo de Olavide, Seville, and the Trade and Diplomacy lead on the TIDE project (2016-2020). Haig Z. Smith is a global historian and the Law and Governance lead on the TIDE project.

Lauren Working is an historian and literary scholar and the Religion and Ethnography lead on the TIDE project. 